\title{
\&o sustainability
}

Sustainability in

Food Consumption

and Food Security

\section{József H.c. Popp, Zoltán Lakner and Judit Oláh}

Printed Edition of the Special Issue Published in Sustainability 


\section{Sustainability in Food Consumption and Food Security}





\section{Sustainability in Food Consumption and Food Security}

Special Issue Editors

József Popp

Zoltán Lakner

Judit Oláh 
Special Issue Editors

József Popp

Szent István University;

Hungary;

TRADE Research Entity,

Faculty of Economic and

Management Sciences,

North-West University

South Africa

Editorial Office

MDPI

St. Alban-Anlage 66

4052 Basel, Switzerland
Zoltán Lakner

Szent István University

Hungary

Judit Oláh

University of Debrecen;

Hungary;

TRADE Research Entity,

Faculty of Economic and

Management Sciences,

North-West University

South Africa

This is a reprint of articles from the Special Issue published online in the open access journal Sustainability (ISSN 2071-1050) from 2019 to 2020 (available at: https://www.mdpi.com/journal/ sustainability/special_issues/Sustainability_Food_Consumption_Food_Security).

For citation purposes, cite each article independently as indicated on the article page online and as indicated below:

LastName, A.A.; LastName, B.B.; LastName, C.C. Article Title. Journal Name Year, Article Number, Page Range.

ISBN 978-3-03936-372-8 (Hbk)

ISBN 978-3-03936-373-5 (PDF)

(c) 2020 by the authors. Articles in this book are Open Access and distributed under the Creative Commons Attribution (CC BY) license, which allows users to download, copy and build upon published articles, as long as the author and publisher are properly credited, which ensures maximum dissemination and a wider impact of our publications.

The book as a whole is distributed by MDPI under the terms and conditions of the Creative Commons license CC BY-NC-ND. 


\section{Contents}

About the Special Issue Editors $\ldots \ldots \ldots \ldots \ldots \ldots \ldots$ vii

Preface to "Sustainability in Food Consumption and Food Security" $\ldots \ldots \ldots \ldots \ldots$ ix

Eszter Sugár, Nándor Fodor, Renáta Sándor, Péter Bónis, Gyula Vida and Tamás Árendás

Spelt Wheat: An Alternative for Sustainable Plant Production at Low N-Levels

Reprinted from: Sustainability 2019, 11, 6726, doi:10.3390/su11236726 . . . . . . . . . . . 1

Faheem Bukhari, Saima Hussain, Rizwan Raheem Ahmed, Dalia Streimikiene,

Riaz Hussain Soomro and Zahid Ali Channar

Motives and Role of Religiosity towards Consumer Purchase Behavior in Western Imported

Food Products

Reprinted from: Sustainability 2020, 12, 356, doi:10.3390/su12010356 . . . . . . . . . . . . .

Jana Majerova, Wlodzimierz Sroka, Anna Krizanova, Lubica Gajanova, George Lazaroiu and Margareta Nadanyiova

Sustainable Brand Management of Alimentary Goods

Reprinted from: Sustainability 2020, 12, 556, doi:10.3390/su12020556 . . . . . . . . . . . . . 3

József Tóth, Giuseppina Migliore, Giorgio Schifani and Giuseppina Rizzo

Sustainable Value Creation in the Food Chain: A Consumer Perspective

Reprinted from: Sustainability 2020, 12, 1438, doi:10.3390/su12041438 . . . . . . . . . . . . . 5

József Tóth and Giuseppina Rizzo

Search Strategies in Innovation Networks: The Case of the Hungarian Food Industry

Reprinted from: Sustainability 2020, 12, 1752, doi:10.3390/su12051752 . . . . . . . . . . . . . 69

Anna Walaszczyk and Barbara Galińska

Food Origin Traceability from a Consumer's Perspective

Reprinted from: Sustainability 2020, 12, 1872, doi:10.3390/su12051872 . . . . . . . . . . . . 87

\section{Dan Costin Nitescu and Valentin Murgu}

The Bioeconomy and Foreign Trade in Food Products-A Sustainable Partnership at the European Level?

Reprinted from: Sustainability 2020, 12, 2460, doi:10.3390/su12062460 . . . . . . . . . . . . 97

Dávid Szakos, László Ózsvári and Gyula Kasza

Perception of Older Adults about Health-Related Functionality of Foods Compared with Other Age Groups

Reprinted from: Sustainability 2020, 12, 2748, doi:10.3390/su12072748 . . . . . . . . . . . . . 117

\section{Zofia Utri and Dominika Głąbska}

Salmon Intake Intervention in the Vulnerable Group of Young Polish Women to Maintain Vitamin D Status during the Autumn Season Reprinted from: Sustainability 2020, 12, 2829, doi:10.3390/su12072829 . . . . . . . . . . . . . 135

\section{Chun-Chieh Ma, Han-Shen Chen and Hsiao-Ping Chang}

Crisis Response and Supervision System for Food Security: A Comparative Analysis between Mainland China and Taiwan

Reprinted from: Sustainability 2020, 12, 3045, doi:10.3390/su12073045 . . . . . . . . . . . . 150 
Gyula Kasza, Annamária Dorkó, Atilla Kunszabó and Dávid Szakos

Quantification of Household Food Waste in Hungary: A Replication Study Using the

FUSIONS Methodology

Reprinted from: Sustainability 2020, 12, 3069, doi:10.3390/su12083069

Kevin Serrem, Anna Dunay, Charlotte Serrem, Bridget Atubukha, Judit Oláh and

Csaba Bálint Illés

Paucity of Nutrition Guidelines and Nutrient Quality of Meals Served to Kenyan Boarding High

School Students

Reprinted from: Sustainability 2020, 12,3463, doi:10.3390/su12083463 . . . . . . . . . . . . . . 177

Alina Vysochyna, Natalia Stoyanets, Grzegorz Mentel and Tadeusz Olejarz

Environmental Determinants of a Country's Food Security in Short-Term and

Long-Term Perspectives

Reprinted from: Sustainability 2020, 12, 4090, doi:10.3390/su12104090

Dániel Fróna, János Szenderák and Mónika Harangi-Rákos

The Challenge of Feeding the World

Reprinted from: Sustainability 2019, 11, 5816, doi:10.3390/su11205816 . . . . . . . . . . . . . . 204

Ákos Mesterházy, Judit Oláh and József Popp

Losses in the Grain Supply Chain: Causes and Solutions

Reprinted from: Sustainability 2020, 12, 2342, doi:10.3390/su12062342 . . . . . . . . . . . . . . 222 


\section{About the Special Issue Editors}

József Popp is Professor and dean at Szent István University, Faculty of Economics and Social Sciences, Hungary. He is Professor at WSB University, Dąbrowa Górnicza, Poland and North-West University, South Africa. He is also an active member and chairman of several academic and professional organisations. Professor József Popp obtained his PhD of economics at the Hungarian Academy of Sciences and his Dr. Sc. oec. degree at the Humbold University, Berlin, Germany. $\mathrm{He}$ is a corresponding Member of the Hungarian Academy of Sciences. His research interests includes global food and energy security analysis, competitiveness of the food economy, rural development, supply chain management, renewable energy, bioeconomy and circular economy. Among the honors he has received are: Doctorem Honoris Causa Pannon University, Hungary, 2010 and "Honoris Causa Professorship", Delhi School of Professional Studies and Research, 2010. Award of the Hungarian Academy of Sciences in Recognition of Research Contributions, 2011. https: / / www.scopus.com/authid/detail.uri?authorId=56031677900.

Zoltán Lakner (1959). MS.c. (Food Eng.), Post-graduate diploma. (Management), Post-graduate diploma (Innovation Management), chartered accountant, Dr. univ. (food economics), Ph.D. (Agric. Econ.), habilitation (Agricultural Engineering), Doctor of Sciences (Agricultural Economics), professor (Szent Istán University), head of department (Food Chain Management). Jean Monet Chair. Interests: food system analysis; econometrics and mathematical modeling in food chain; food chain.

Judit Oláh is Associate Professor at the University of Debrecen, Faculty of Economics. She is Associate Professor at WSB University, Dąbrowa Gornicza, Poland and North-West University, South Africa. The main area of her scientific work is the food industry and the production of biofuels, risk management, food supply chain, bioenergy, logistics, Industry 4.0, and bioeconomy. https: / / www.scopus.com/authid/detail.uri?authorId=56016286600. 



\section{Preface to "Sustainability in Food Consumption and Food Security"}

The transformation of food chains towards sustainability in food consumption and food security is a global issue, connected with the global challenges of poverty reduction, employment and urbanization. Combating malnutrition-undernutrition and micronutrient deficiencies-as well as overweight and obesity is an increasing problem. Research can find sustainable solutions to challenges facing the global and national food systems relating to sustainable food consumption and food security. The integrative food systems approach encompasses all of the steps involved, from growing through to processing, transporting, trading, purchasing, consuming food, and disposing of or recycling food waste. Sustainability related to product standards and reactions of consumers to these standards are also of great importance.

This book discusses opportunities for and challenges to sustainable food systems from a food consumption and food security perspective by promoting healthy diets and increasing the focus on nutrition, with multiple implications for diet quality and vulnerable groups, reducing food loss and waste, agricultural transformation in the face of increasing competition for land use, responding to climate change and other environmental and social change, and introducing the bioeconomy concept to reduce the environmental impact of food production.

József Popp, Zoltán Lakner, Judit Oláh Special Issue Editors 



\title{
Article \\ Spelt Wheat: An Alternative for Sustainable Plant Production at Low N-Levels
}

\author{
Eszter Sugár, Nándor Fodor *, Renáta Sándor, Péter Bónis, Gyula Vida and Tamás Árendás \\ Agricultural Institute, Centre for Agricultural Research, Brunszvik u. 2, 2462 Martonvásár, Hungary; \\ sugar.eszter@agrar.mta.hu (E.S.); sandor.renata@agrar.mta.hu (R.S.); bonis.peter@agrar.mta.hu (P.B.); \\ vida.gyula@agrar.mta.hu (G.V.); arendas.tamas@agrar.mta.hu (T.A.) \\ * Correspondence: fodor.nandor@agrar.mta.hu; Tel.: +36-22-569-554
}

Received: 31 October 2019; Accepted: 21 November 2019; Published: 27 November 2019

\begin{abstract}
Sustainable agriculture strives for maintaining or even increasing productivity, quality and economic viability while leaving a minimal foot print on the environment. To promote sustainability and biodiversity conservation, there is a growing interest in some old wheat species that can achieve better grain yields than the new varieties in marginal soil and/or management conditions. Generally, common wheat is intensively studied but there is still a lack of knowledge of the competitiveness of alternative species such as spelt wheat. The aim is to provide detailed analysis of vegetative, generative and spectral properties of spelt and common wheat grown under different nitrogen fertiliser levels. Our results complement the previous findings and highlight the fact that despite the lodging risk increasing together with the $\mathrm{N}$ fertiliser level, spelt wheat is a real alternative to common wheat for low $\mathrm{N}$ input production both for low quality and fertile soils. Vitality indices such as flag leaf chlorophyll content and normalized difference vegetation index were found to be good precursors of the final yield and the proposed estimation equations may improve the yield forecasting applications. The reliability of the predictions can be enhanced by including crop-specific parameters which are already available around flowering, beside soil and/or weather parameters.
\end{abstract}

Keywords: wheat; spelt; sustainable plant production; $\mathrm{N}$-fertilisation; grain yield; vitality indices

\section{Introduction}

Climate-smart agriculture (CSA) strives for sustainable productivity, quality and economic viability while leaving a minimal foot print on the environment [1,2]. Despite the growing need for food and feed raw materials, crop yield is only one factor of the portfolio of the desired plant performances [3]. Plant genotypes developed on conventional tillage may not necessarily adapt to the changed cropping environment and new, specifically adapted genotypes may need to be developed [4]. To promote sustainability and biodiversity conservation, there is a growing interest in some old wheat species as well. Ruiz et al. [5] described some yield-related traits that have been identified as potential targets to achieve better grain yields of old wheat varieties in no-tillage and minimum tillage systems. Special attention is directed to the possible production of alternative cereals in organic production [6]. These species are nowadays rather produced for feed as alternatives to oats and barley. Ancient wheat genotypes that have the ability to maintain green leaf area ('stay green' traits) throughout grain filling are potential candidates for adapting and improving wheat for higher yield in arid and semi-arid regions. 'Stay green' is a vital characteristic associated with the capacity of the plant to maintain $\mathrm{CO}_{2}$ assimilation and photosynthesis [7]. Because of the more frequent and more severe extreme weather conditions, the 'stay green' characteristic is especially important for breeders in producing more drought and/or heat tolerant crop species.

Spelt wheat (Triticum aestivum ssp. spelta L.), the oldest known wheat species cultivated in ancient Egypt and Italy, was as a result of spontaneous crossings of wild grasses. Reviving of spelt 
wheat production has started in the hilly and mountainous region of Central Europe and North America at the end of the 20th century [8]. It is an alternative crop, growing without any special soil related and climatic demands [9]. Spelt has the potential for low input production and adaptation to harsh ecological conditions and resistance to diseases [10]. Owing to its hulled grain and genetic polymorphism of its population, spelt is resistant to pests and diseases and hence suitable for organic production [6]. Spelt wheat and its products could serve as an abundant source of protein and a great proportion of soluble fibre emerging in the final spelt wheat products [11].

The identification of those factors which are determining the adaptation and nitrogen $(\mathrm{N})$ utilization of spelt wheat is important for the successful introduction of the crop to a new environment in the comparison of non-fertilized and fertilized $\left(100 \mathrm{kgN} \mathrm{ha}^{-1}\right)$ circumstances [12]. Several studies compared the productivity of spelt and common wheat in particular years. Most of them reported substantially higher yield of common wheat. The difference in yield often was as great as $60 \%$ in favour of common wheat [13] comparing low $\left(6.8 \mathrm{~kg} \mathrm{ha}^{-1}\right)$ and high $\left(33.8 \mathrm{~kg} \mathrm{ha}^{-1}\right)$ phosphorus supply. In the study of Jablonskyté-Rašće et al. [14] the average common wheat yield was $28 \%$ higher than that of the spelt wheat using ecological fertilizers. Budzynski et al. [15] reported $2.55 \mathrm{t} \mathrm{ha}^{-1}$ higher yield potential average of common wheat than spelt in response to $\mathrm{N}$ rates. Some studies though reported that spelt was able to produce similar amount of yields as the common wheat (e.g., [16]). Probably because of the fact that climatic conditions of particular years, notably the climate $\times$ fertilisation interactions could significantly influence the grain yield of winter wheat [17]. However, there is still a lack of knowledge of the competitiveness of spelt grown at extensive or medium fertilisation levels.

Based on the results of Lazauskas et al. [18] we may assume that under low or moderate fertilisation inputs nitrogen will remain a major limiting factor for realizing high winter wheat yields in the coming decades. Nitrogen fertilisation directly or indirectly influences the LAI (leaf area index), degree of soil coverage by plants, leaf chlorophyll content, and other biophysical parameters, that can be characterized by vegetation indices, such as NDVI (normalized difference vegetation index) or SPAD (strongly correlated to chlorophyll content). Vegetation indices can be used as indicators of crop growth [19], nutrient status [20], and yield development [21]. Yield forecasting on the basis of vegetation indices acquired in the early stages of development can help farmers to make decisions about irrigation or additional fertilisation demand [22]. Normalized difference vegetation index have been widely used in agricultural remote sensing applications [22]. Leaf chlorophyll content (indexed e.g., by SPAD value) can be used as an accurate plant $\mathrm{N}$ status indicator. SPAD allows precise $\mathrm{N}$ fertilizer requirement calculations that are fundamental for enhancing $\mathrm{N}$ uptake efficiency [23,24]. A number of studies investigated the leaf growth of common wheat (e.g., $[25,26])$, but there are only a few data available regarding LAI changes of spelt wheat.

In addition for grain crops, harvest index (HI), the ratio of harvested grain to aboveground biomass, could be used as a measure of reproductive efficiency [27]. Although the effect of agronomical factors on $\mathrm{HI}$ of winter wheat was studied in a large number of works, there are just a few similar data for spelt wheat.

Because of the large inter-annual variability it is important to monitor the yield formation process of cereals in various years. More extensive data on yield formation of different wheat species may assist the spreading of production of alternative, even healthier cereals. The aim of this study is to provide a detailed analysis of vegetative, generative and spectral properties of spelt and common wheat grown under different $\mathrm{N}$ (from zero to moderate) levels.

\section{Materials and Methods}

The effect of nitrogen fertilisation on the yield and vitality parameters under various common and spelt winter wheat varieties was studied in parallel experiments in a split-plot design in four replications. The experiments were carried out in the years 2015/2016, 2017/2018 and 2018/2019 at the Agricultural Institute of the Centre for Agricultural Research in Martonvásár ( $\left.47^{\circ} 30^{\prime} \mathrm{N}, 18^{\circ} 82^{\prime} \mathrm{E}\right)$. The experiment was suspended for the 2016/2017 growing season, because of technical reasons. The $\mathrm{N}$ 
fertiliser doses (always applied in the form of ammonium-nitrate) were $0,40,80,120 \mathrm{~kg} \mathrm{ha}^{-1}$ (designated as N0, N40, N80 and N120, respectively) in the main plots. The same dose (120 kg ha $\left.{ }^{-1}\right)$ of phosphorus $(\mathrm{P})$ and potassium $(\mathrm{K})$ were given to every plot each year. Conventional tillage (no ploughing, only disk and cultivator use) was applied in the $0-20 \mathrm{~cm}$ soil layer after the PK fertilisation. By-products were always left on the field and incorporated in the soil. $\mathrm{N}$ fertiliser was applied in two splits: one-third before sowing (with PK) and two-third in early spring at tillering. Three genotypes of common wheat, Mv Kolo, Mv Marsall and Mv Kokárda, and spelt wheat, Mv Martongold, Franckenkorn and Mv Vitalgold, were sown in plots. All the genotypes except Franckenkorn (German origin) were breeded at Martonvásár. Around $9 \mathrm{~m}^{2}(1.44 \times 6 \mathrm{~m})$ plots were used for each $(\mathrm{N}$-level $\times$ variety) treatment. The chernozem soil of the experiment is non acidic loam with deep A horizon (Table 1).

Table 1. Main physical and chemical properties of the experimental plot at different layers at Martonvásár (Hungary) in 2018.

\begin{tabular}{cccc}
\hline Depth $(\mathrm{cm})$ & $0-30$ & $30-60$ & $60-90$ \\
Bulk density $\left(\mathrm{g} \mathrm{cm}^{-3}\right)$ & 1.47 & 1.49 & 1.49 \\
Soil organic matter (\%) & 2.82 & 2.02 & 1.39 \\
$\mathrm{pH}$ & 7.2 & 7.4 & 7.5 \\
Sand fraction (\%) & 27 & 26 & 24 \\
Silt fraction $(\%)$ & 40 & 41 & 44 \\
Clay fraction $(\%)$ & 33 & 33 & 32 \\
\hline
\end{tabular}

Owing to its favourable hydraulic properties (water holding capacity is $0.2 \mathrm{~cm}^{3} \mathrm{~cm}^{-3}$ ) and high soil organic matter content, based on the EU-SHG European Soil Database [28], the experiment site belongs to one of the most fertile regions of Central Europe.

Data of monthly precipitation and air temperature were recorded at the meteorological station at Martonvásár (Figure 1). The total amount of precipitation in the vegetative period (October-June) was $\sim 30 \%$ lower in 2018/2019 (350 mm) than in the other two years (475 $\mathrm{mm}$ in 2015/2016 and $495 \mathrm{~mm}$ in 2017/2018) and $\sim 16 \%$ lower than the 30 years' average (419 mm). The distribution of precipitation was less favourable for wheat owing to a prolonged dry period in March and April in 2015/2016 and 2018/2019, but the drought was compensated by high amount of precipitation (139 $\mathrm{mm}$ ) in May 2019 (around flowering). The mean temperature during the vegetative period was similar during the three experimental years $\left(8.6^{\circ} \mathrm{C}\right.$ in $2015 / 2016 ; 8.9^{\circ} \mathrm{C}$ in $2017 / 2018$ and $8.8^{\circ} \mathrm{C}$ in $2018 / 2019$ ) but considerably higher than the 30 years' average $\left(7.3^{\circ} \mathrm{C}\right)$. On the other hand, the course of the spring temperature was considerably different across the years especially in 2018 when the relatively cold February- March period $\left(4^{\circ} \mathrm{C}\right.$ colder than the other two years) was followed by a relatively $\left(3.5-4.5^{\circ} \mathrm{C}\right)$ warmer April-May period.

Planting took place on 17 October 2015, 26 October 2017, and 17 October 2018 and the plots were harvested in the first decade of July in each year. Grain yield was estimated from the harvested plot yields and were converted to tons per hectare. Harvest index was estimated from plant samples of 0.5-m long sections taken before harvest.

LAI was measured by a non-destructive method using AccuPAR ceptometer [29] at flowering stage. Eight measurements were made below the canopy, four parallel and four across to the rows in each plot. The parallel and perpendicular measurements were averaged. The maximum LAI (LAI max) values were measured in the third decade of May in each year. 


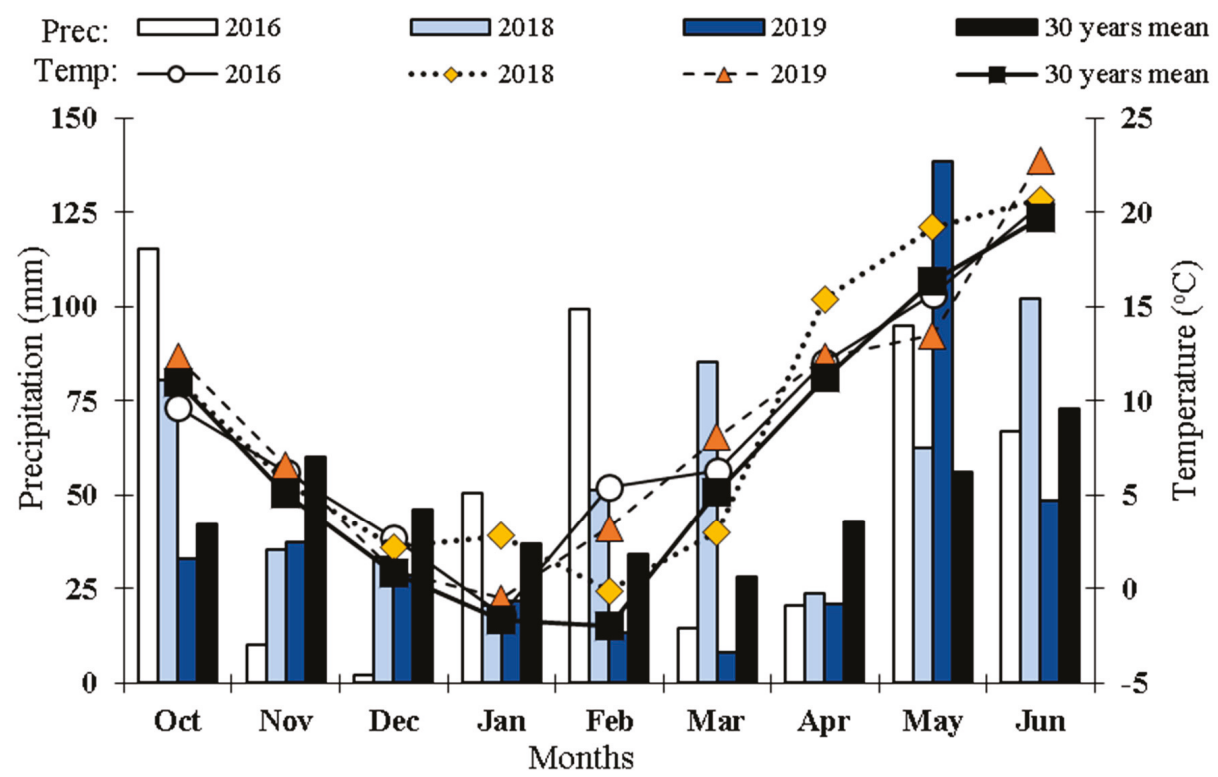

Figure 1. Monthly mean temperature and total precipitation at Martonvásár (Hungary) during the cropping seasons of 2015/2016, 2017/2018 and 2018/2019.

The chlorophyll content of the flag leaves at flowering was determined by using Minolta Chlorophyll Meter, SPAD-502 [30]. The measurements were made at the middle of the leaf lamina of 20 flag leaves. The SPAD values were converted to total chlorophyll values by using the conversion equation of Zhu et al. 2012 [31]. The 20 measurement results of each plot were averaged, and the mean values were used in the statistical analysis. NDVI was measured with a Trimble GreenSeeker ${ }^{\circledR}$ handheld crop sensor [32]. The measurements were made at flowering in sunny weather $\sim 80 \mathrm{~cm}$ above the crop canopy. Two measurements per plot were carried out. The two readings in each plot were averaged, and the mean values were used in the statistical analysis.

The performance of spelt and common wheat, the effects of the different $\mathrm{N}$ fertiliser levels as well as the performance of the different varieties were evaluated with paired sample $t$-tests [33]. A difference was regarded to be significant in case the corresponding $t$-test resulted in a smaller than 0.05 probability (p) value.

Based on crop vitality indices (LAI $\max , \mathrm{SPAD}$ and NDVI) as independent variables, a multivariable linear yield estimation equation (model) was constructed (1) for both wheat species. This Equation (1) can be applied for yield $(\mathrm{Y})$ forecast using data already available around flowering.

$$
\mathrm{Y}=\mathrm{a}+\mathrm{b} \times \mathrm{LAI}_{\max }+\mathrm{c} \times \mathrm{SPAD}+\mathrm{d} \times \mathrm{NDVI}
$$

where $a, b, c, d$ are fitting parameters, that were determined with regression analysis using the $\mathrm{lm}$ function of the stats v.3.6.1 R package [34].

From the 144 observed data record (Table A1 in the Appendix A) of the three years a random subset of 114 records were selected for determining/calibrating the parameters of the estimation equations (2). The remaining 30 records were used for validating the model. Estimated $\left(\mathrm{Y}_{\mathrm{e}}\right)$ and observed $\left(\mathrm{Y}_{\mathrm{o}}\right)$ yield data were compared using simple statistical indicators: Coefficient of determination $\left(R^{2}\right)$ and mean absolute error (MAE), where the mean function calculates the arithmetic average of the arguments and $n$ denotes the number of the estimated-observed data pairs. 


$$
\begin{gathered}
R^{2}=\frac{\left(\sum_{i=1}^{n}\left(Y_{o}^{i}-\operatorname{mean}\left(Y_{o}^{i}\right)\right)\left(Y_{e}^{i}-\text { mean }\left(Y_{e}^{i}\right)\right)\right)^{2}}{\sum_{i=1}^{n}\left(Y_{o}^{i}-\operatorname{mean}\left(Y_{o}^{i}\right)\right)^{2} \sum_{i=1}^{n}\left(Y_{e}^{i}-\text { mean }\left(Y_{e}^{i}\right)\right)^{2}} \\
M A E=\sum_{i=1}^{n} \frac{\left|Y_{o}-Y_{e}\right|}{n}
\end{gathered}
$$

\section{Results and Discussion}

All the observed data are presented in Table A1 in the Appendix A and summarized in Figures 2 and $\mathrm{A} 1$ in the Appendix A.

\subsection{Grain Yield}

When comparing the common and spelt wheat yields, statistically significant differences were found for each $\mathrm{N}$-fertilisation levels, though the difference was only marginal in favour of common wheat at $\mathrm{N}_{40}$ with a significance of $p=0.031$. When pooling together the $\mathrm{N}_{0}$ and $\mathrm{N}_{40}$ yields for the three years spelt wheat had significantly higher production $(p=0.033)$ having $0.24 \mathrm{t} \mathrm{ha}^{-1}$ higher average yield at this, low fertilisation level. At moderate fertilisation level $\left(\mathrm{N}_{80}\right.$ and $\mathrm{N}_{120}$ together) common wheat had $1.14 \mathrm{t} \mathrm{ha}^{-1}$ higher average yield that is a significant $(p \approx 0)$ surplus compared to spelt. This result confirms that spelt wheat is a real alternative to common wheat for low input production [10] even for sites with fertile soils. Both common wheat and spelt had the highest yield under the maximal $\mathrm{N}$ dose in 2019, despite the fact that this was the driest experimental year. The high yield might be the result of the large amount of precipitation in May $(\sim 140 \mathrm{~mm})$, that was $\sim 82 \%$ higher than the multi-year average of that month. This underlines the importance of timing of the precipitation that might be an even more important factor in yield formation than the precipitation amount in certain years.

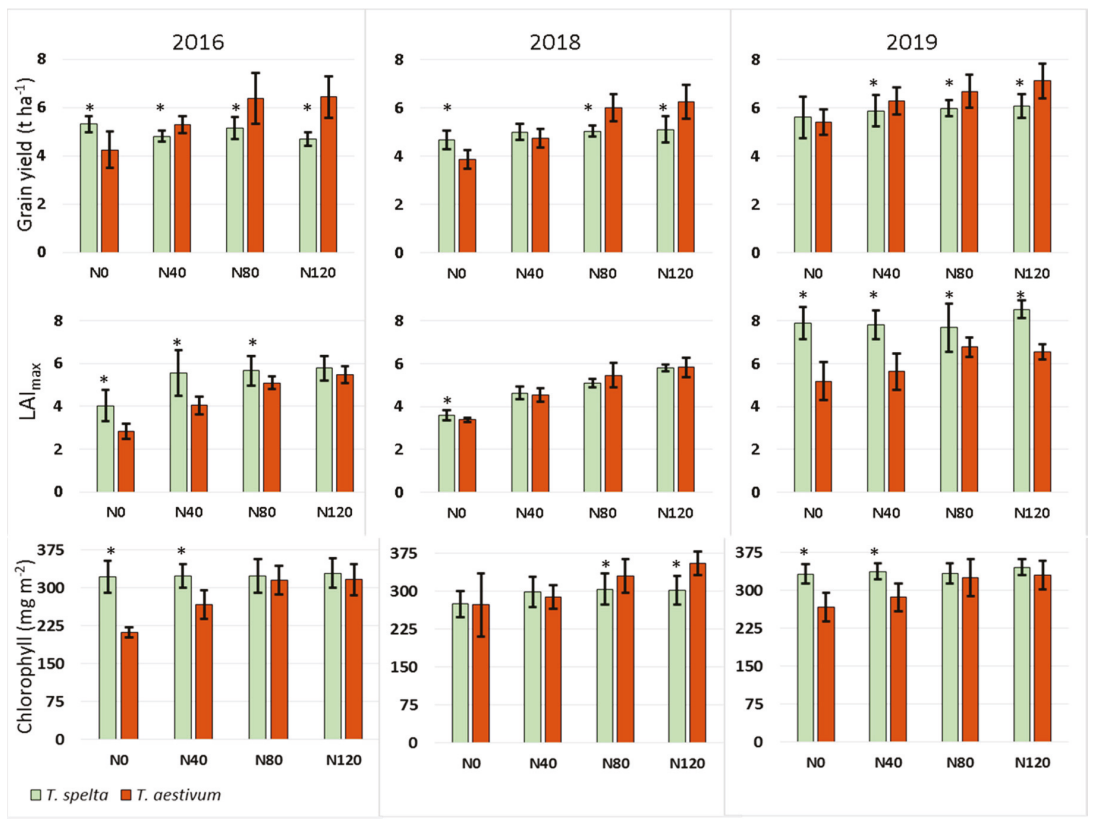

Figure 2. Harvested grain yield $\left(\mathrm{t} \mathrm{ha}^{-1}\right), \mathrm{LAI}_{\max }\left(\mathrm{m}^{2} \mathrm{~m}^{-2}\right)$ and chlorophyll content $\left(\mathrm{mg} \mathrm{m}^{-2}\right)$ of spelt (T. spelta) and common wheat (T. aestivum) across varieties under four different nitrogen fertilisation treatments $\left(0,40,80\right.$ and $\left.120 \mathrm{kgN} \mathrm{ha}^{-1}\right)$ at Martonvásár (Hungary) in 2016, 2018 and 2019. * indicates statistically significant difference between spelt and common wheat. 
The N-fertilisation significantly affected the grain yield (Figure 2) with a positive correlation between the $\mathrm{N}$ amount and the yield except for spelt in 2016. In 2016, high winds in June caused considerable lodging of growing degree with the increasing $\mathrm{N}$ fertilisation levels: 20, 45, 55 and $65 \%$ lodging at the $\mathrm{N}_{0}, \mathrm{~N}_{40}, \mathrm{~N}_{80}$ and $\mathrm{N}_{120}$ levels, respectively. Lodging made it very difficult for the harvester to properly harvest the plots resulting in uncertain and reduced yield results. In line with previous studies it is evident that lodging is clearly an issue in spelt production especially at higher $\mathrm{N}$ levels $[35,36]$. Common wheat showed much stronger reaction to the increasing fertiliser doses. Each increment in the $\mathrm{N}$ dose resulted in significantly higher yields. The $\mathrm{N}_{120}$ common wheat yields were $31-61 \%$ higher than that of the $\mathrm{N}_{0}$ yields. Even after excluding the 2016 data from the $t$-tests because of the lodging issue, spelt showed 8-9\% yield increase when the $\mathrm{N}_{120}$ yields were compared to the $\mathrm{N}_{0}$ yields when yield averaged across 2018 and 2019. This is a moderate fertiliser effect, though statistically significant ( $p=0.0068$ ). There was a significant yield increase between the $\mathrm{N}_{0}$ and $\mathrm{N}_{40}$ levels ( $p=0.0092$ ) but the further $\mathrm{N}$ increments were not associated with further significant yield growth. According to this result spelt wheat can close in its yield potential even at very low fertiliser levels (approx. $40 \mathrm{kgN} \mathrm{ha}^{-1} \mathrm{y}^{-1}$ ) on fertile soils. The variety selection had significant effect on the yield of both crops. Regarding the averaged N-treatments across the years, Mv Marsall, a common wheat variety had the highest yield $\left(6.09 \mathrm{t} \mathrm{ha}^{-1}\right)$ that was significantly higher than the average yields of the other two common wheat varieties. Mv Martongold and Mv Vitalgold spelt wheat varieties provided the highest average yields (5.37 and $5.3 \mathrm{t} \mathrm{ha}^{-1}$ ) that were significantly higher than the average yield of the Franckenkorn variety.

\subsection{Harvest Index (HI)}

The HI of the modern varieties of the intensively-cultivated grain crops is expected to fall within the range of 0.4 to 0.6 (40-60\%) [37-39]. Considerably lower HI values were observed in our experiment for both crops: 33.1 to $44.0 \%$ for common wheat and 28.4 to $36.4 \%$ for spelt (Figure A1 in the Appendix A). In agreement with White and Wilson [38], N-fertilisation significantly increased the common wheat harvest index. The $t$-test resulted in a $p=0.03$ probability value when $\mathrm{HI}$ of the $\mathrm{N}_{0}$ and $\mathrm{N}_{40}$ levels were compared to the $\mathrm{HI}$ values of the $\mathrm{N}_{80}$ and $\mathrm{N}_{120}$ levels. In contrary, $\mathrm{HI}$ of spelt was the highest in the control treatment every year. The difference in $\mathrm{HI}$ was significant between the $\mathrm{N}_{0}$ and $\mathrm{N}_{40}$ fertilisation levels $(p=0.039)$ and even between the $\mathrm{N}_{80}$ and $\mathrm{N}_{120}$ levels $(p=0.0001)$. On average every $10 \mathrm{~kg} \mathrm{ha}^{-1}$ increase in the $\mathrm{N}$ fertiliser dose decreased the $\mathrm{HI}$ of common wheat with $0.3 \%$. This result was in good agreement with previous findings that spelt is significantly more vigorous in tillering than standard bread wheat cultivars [13]. $\mathrm{LAI}_{\max }$ data (see Section 3.3) also confirms it.

\section{3. $L A I_{\max }$}

$\mathrm{LAI}_{\text {max }}$ values varied from 2.8 to 6.8 for common wheat and from 3.6 to 8.6 for spelt wheat (see Appendix A). Multi-year and multi-variety $\mathrm{LAI}_{\max }$ of spelt were 26.8, 22.8, 4.4 and 9.9\% higher than that of common wheat across $\mathrm{N}$ fertilizer levels. These significant differences (corresponding $p$ values were less than 0.027 ) clearly indicate the spelt is more vigorous in tillering, especially at low $\mathrm{N}$ levels. $\mathrm{LAI}_{\max }$ values grew significantly with the increasing $\mathrm{N}$ fertilisation level (Figure 2). Common wheat showed considerably more fertilisation-related $\mathrm{LAI}_{\max }$ growth. $\mathrm{LAI}_{\max }$ of the $\mathrm{N}_{120}$ treatment was $52 \%$ higher than that of the $\mathrm{N}_{0}$ treatment for common wheat while this difference was only $31 \%$ for spelt wheat. The observed LAI maximums of spelt wheat were considerably greater (even two times greater) than those reported in other studies [40], while the common wheat $\mathrm{LAI}_{\max }$ values were in good agreement with other studies $[25,41]$. Inter-annual variability could be a simple reason for this, as crop production could leave the so-called average range in certain years. Furthermore, results obtained at certain sites could be valid to other sites having different environmental conditions to a limited extent only. Thus, it is better to say that our results complement and do not contradict the previous findings on the maxima of spelt wheat leaf area index. 


\subsection{Chlorophyll Content of the Flag Leaf}

The measured SPAD values (see Table A1 in the Appendix A) and the corresponding leaf chlorophyll contents overlapped with the equivalent values of forty winter wheat varieties investigated in an independent experiment at two nitrogen levels $\left(\mathrm{N}_{0}\right.$ and $\left.\mathrm{N}_{120}\right)$ in three consecutive cropping seasons (2012/2013, 2013/2014 and 2014/2015) at Martonvásár, where the chlorophyll content ranged between 45 and $468 \mathrm{mg} \mathrm{m}^{-2}$ [42]. In our experiment the chlorophyll content of spelt and common wheat ranged between 227 and 338 and 195 and $451 \mathrm{mg} \mathrm{m}^{-2}$, respectively (Figure 2). Similarly to the yield, $\mathrm{N}$ fertilisation significantly increased the chlorophyll content of the flag leaf of both crops for every $\mathrm{N}$ dose increment with only one exception: the $\mathrm{N}_{40}-\mathrm{N}_{80}$ increment caused a non-significant increase in the spelt wheat chlorophyll content $(p=0.48)$. The chlorophyll content of common wheat showed a considerably stronger reaction to the increasing doses of $\mathrm{N}$ fertilisation. Spelt wheat chlorophyll contents were significantly higher than the common wheat chlorophyll contents in all three year at the $\mathrm{N}_{0}$ and $\mathrm{N}_{40}$ fertilisation levels. This again emphasizes the fact that spelt wheat has the capacity to use the resources of the soil more vigorously in limited environmental conditions.

\subsection{Normalized Difference Vegetation Index (NDVI)}

NDVI values (Table A1 and Figure A1 in the Appendix A), varied from 0.54 to 0.80 for common wheat and from 0.51 to 0.82 for spelt wheat, which were in good agreement with the measurements of Piekarczyk and Sulewska [22] who observed 0.72 and 0.71 average NDVI values for spelt and common wheat, respectively around flowering. Though there is a constant demand for deriving LAI data from NDVI, which is a standard component of remotely sensed datasets, the reality is that LAIs around and above $3 \mathrm{~m}^{2} \mathrm{~m}^{-2}$ are not distinguishable with NDVI data [43]. To make the issue even more complicated, according to our results, considerable interannual variable can be observed in the NDVI-LAI $I_{\max }$ correlation (Figure 3). The interannual difference is much more pronounced for spelt wheat, but the years 2016 and 2019 were considerably different for common wheat, as well. In general, there is certainly a positive correlation between the $\mathrm{LAI}_{\max }$ and the NDVI measured at flowering, but in certain years considerable deviations could be observed. If the 2016 and 2018 spelt wheat data are compared, similar $\mathrm{LAI}_{\max }$ values (5.2 and $4.8 \mathrm{~m}^{2} \mathrm{~m}^{-2}$; non-significant difference $p=0.35$ ) correspond to significantly different NDVI values $(0.54$ and 0,$72 ; p \approx 0)$. The difference between the two wheat species requires further investigation and highlights the fact that the NDVI-LAI interrelation is highly dependent on the plant species and probably on other environmental conditions as well.
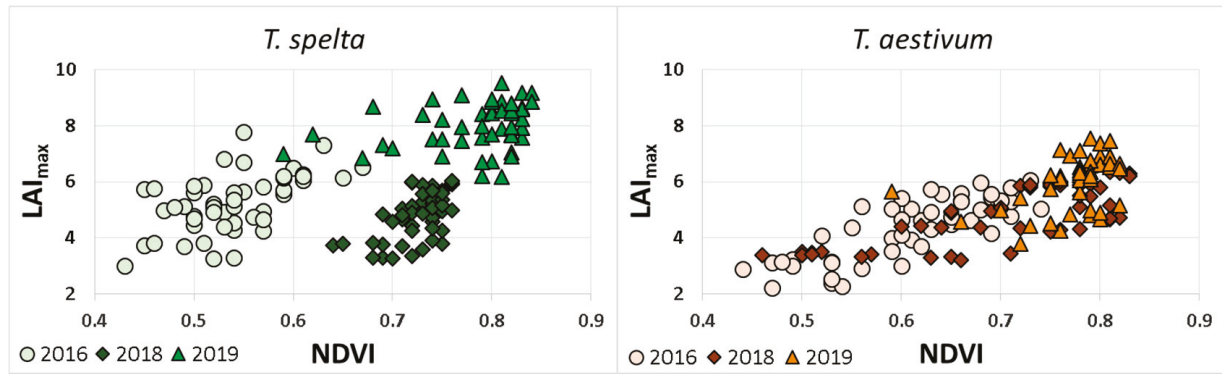

Figure 3. Correlation of leaf area index maximum ( $\left.\mathrm{LAI}_{\max }\right)$ and NDVI values for spelt (T.spelta, left) and common wheat (T. aestivum, right) at Martonvásár (Hungary) in 2016 (dots), 2018 (diamonds) and 2019 (triangles). 


\subsection{Multivariable Linear Yield Estimation Equation}

The linear regression (calibration) resulted in the following estimation equations for the two crops:

- Common wheat: $\mathrm{Y}=1.54155+0.63251 \times \mathrm{LAI}_{\max }+0.02549 \times \mathrm{SPAD}-0.19102 \times \mathrm{NDVI}\left(\mathrm{R}^{2}=0.5351\right)$.

- Spelt wheat: $\mathrm{Y}=0.01856+0.09132 \times \mathrm{LAI}_{\max }+0.07282 \times \mathrm{SPAD}+2.01997 \times \mathrm{NDVI}\left(\mathrm{R}^{2}=0.4399\right)$.

The equations were capable of estimating the yield with 0.64 and $0.37 \mathrm{t} \mathrm{ha}^{-1}$ mean absolute error, that correspond to $11.2 \%$ and $7.1 \%$ relative errors for common and spelt wheat, respectively. When the equations were applied to the validation datasets the results were more moderate:

- Common wheat: $\mathrm{R}^{2}=0.4557 ; \mathrm{MAE}=0.81 \mathrm{t} \mathrm{ha}^{-1}$.

- $\quad$ Spelt wheat: $\mathrm{R}^{2}=0.4099 ; \mathrm{MAE}=0.52 \mathrm{t} \mathrm{ha}^{-1}$.

These kind of equations could be useful extensions to yield forecasting applications such as AgrometShell [44], since they add crop-specific parameters to the estimation beyond the already incorporated soil and weather-specific parameters.

\section{Conclusions}

A detailed analysis of vegetative, generative and spectral properties of spelt and common wheat grown under zero and moderate $\mathrm{N}$ levels was carried out at Martonvásár, Hungary in three cropping seasons. Our results extend the findings of Caballero et al. [10] and highlight the fact that despite the lodging risk increasing together with $\mathrm{N}$ fertiliser level, spelt wheat is a real alternative to common wheat for low $\mathrm{N}$ input production both for low quality and fertile soils. Spelt may help promoting sustainable crop production at sites where low input management is carried out because of any reasons by producing more yield than common wheat. Vitality indices such as flag leaf chlorophyll content and NDVI showed significant and moderate reaction to the increasing $\mathrm{N}$ fertiliser doses for common and spelt wheat. It was demonstrated that spelt wheat has considerably more moderate requirements compared to common wheat regarding soil nitrogen supply. Vitality indices were found to be good precursors of the final yield for both crops and the proposed estimation equations may improve the yield forecasting applications that use soil and/or weather parameters only by including crop-specific parameters that are already available around flowering.

Author Contributions: Conceptualization, T.Á., P.B. and E.S.; methodology, E.S. and G.V.; software, R.S.; validation, N.F., R.S. and E.S.; formal analysis, R.S. and N.F.; investigation, E.S. and P.B.; resources, G.V., P.B. and T.Á.; data curation, P.B.; writing-original draft preparation, E.S., R.S. and N.F.; writing—review and editing, E.S., R.S. and N.F.; visualization, R.S.; supervision, T.Á.; project administration, N.F.; funding acquisition, N.F.

Funding: This research was funded by the Széchenyi 2020 programme, and the European Regional Development Fund and the Hungarian Government, grant number GINOP-2.3.3-15-2016-00028.

Conflicts of Interest: The authors declare no conflict of interest. 


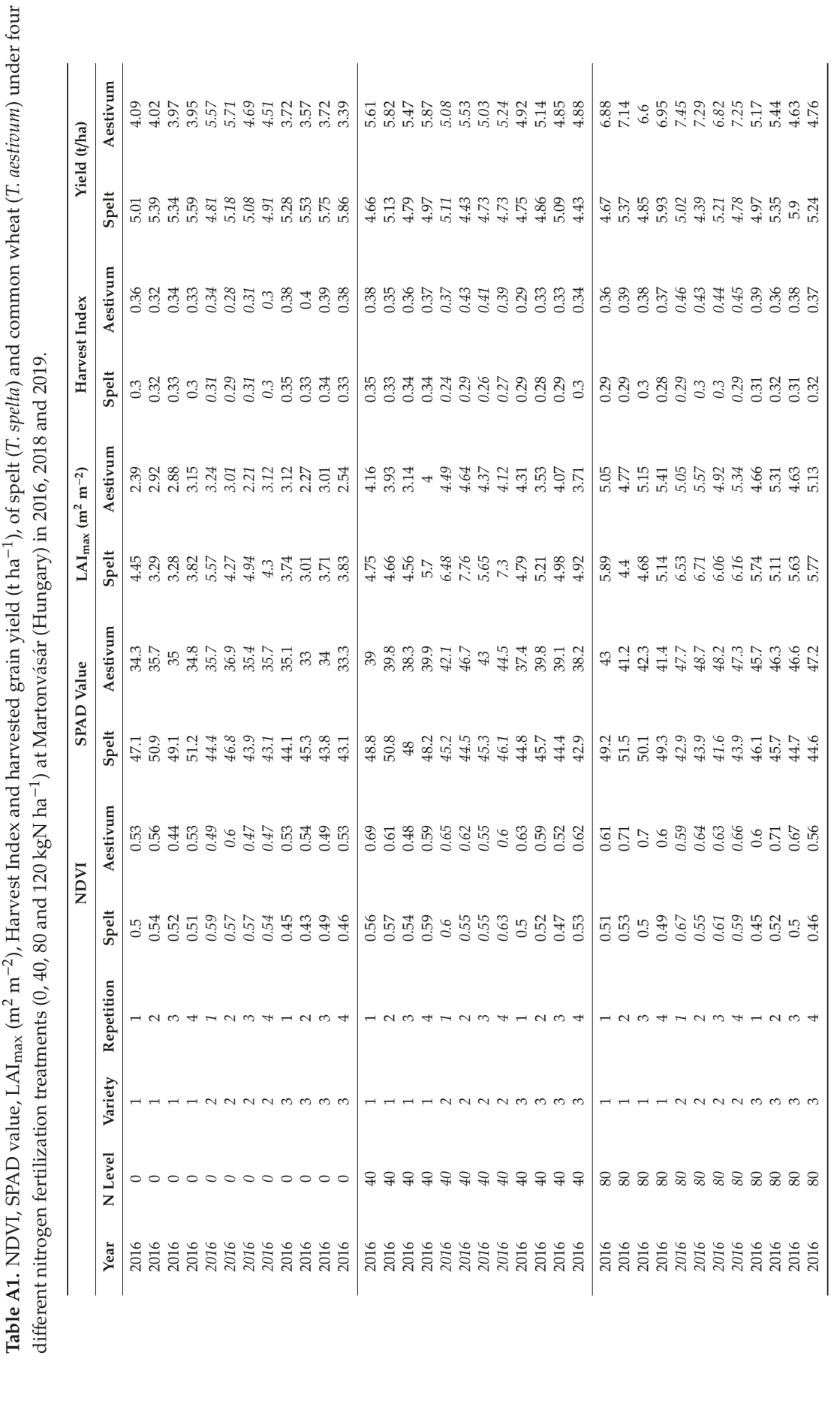




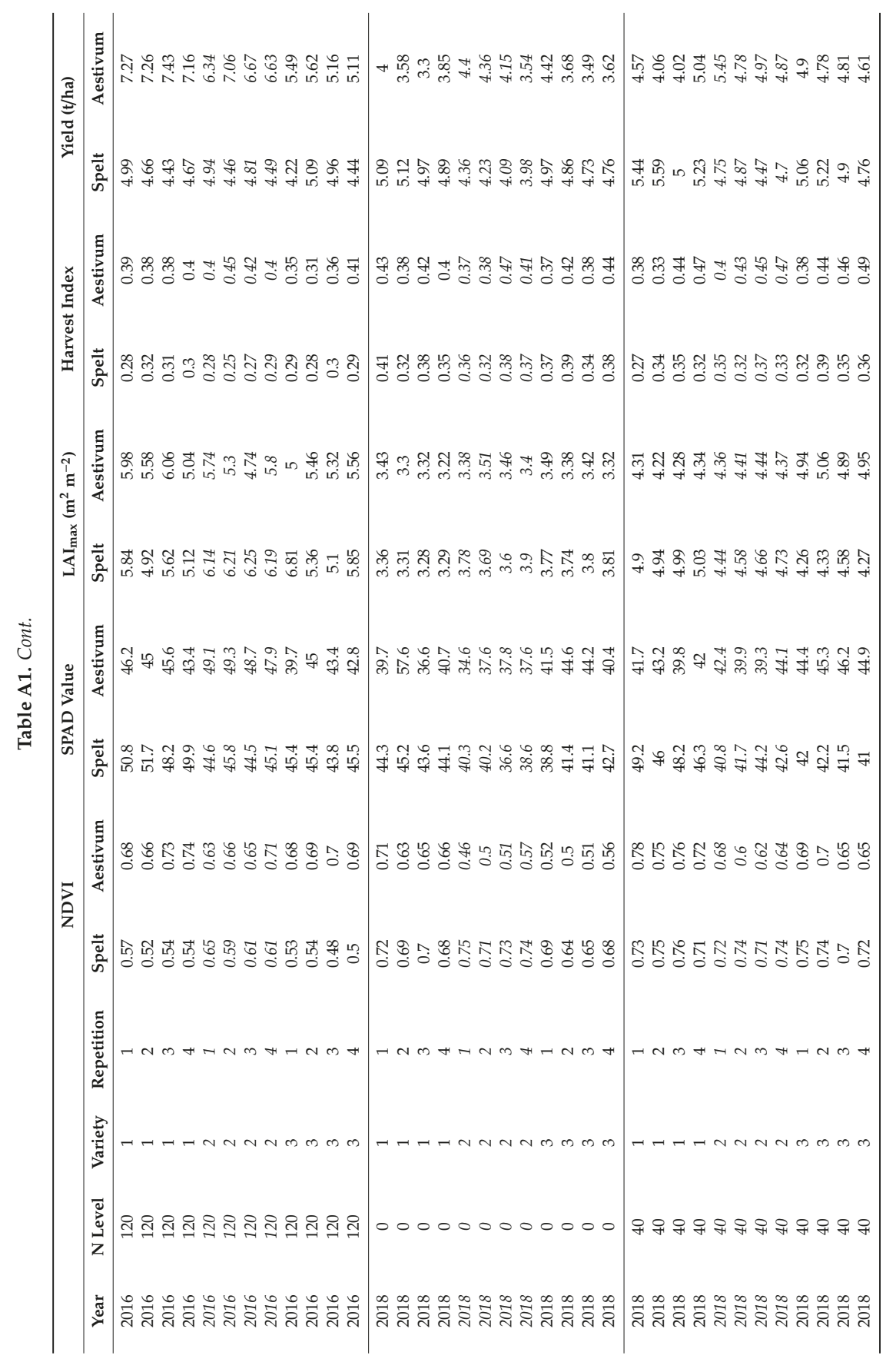




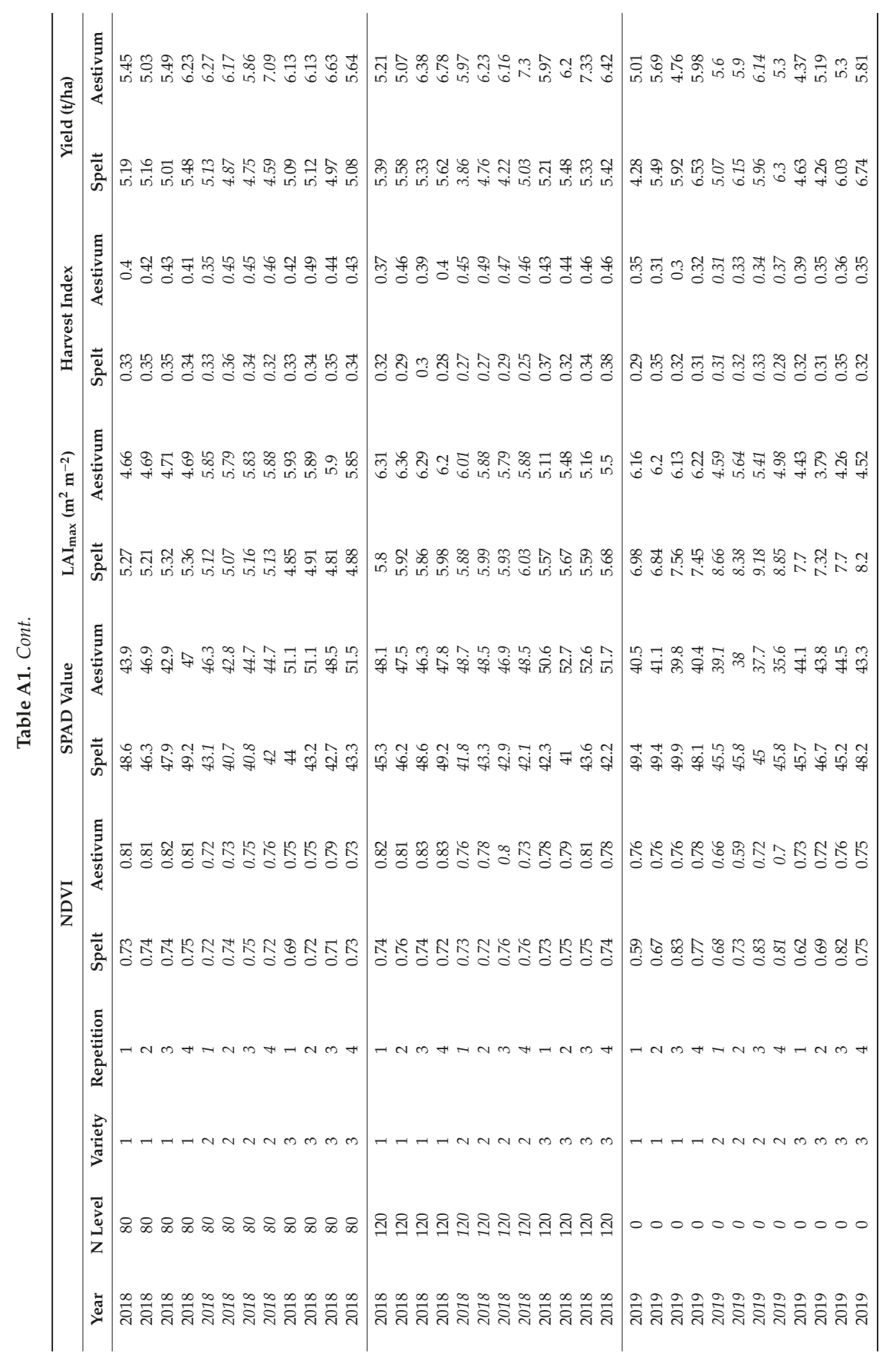




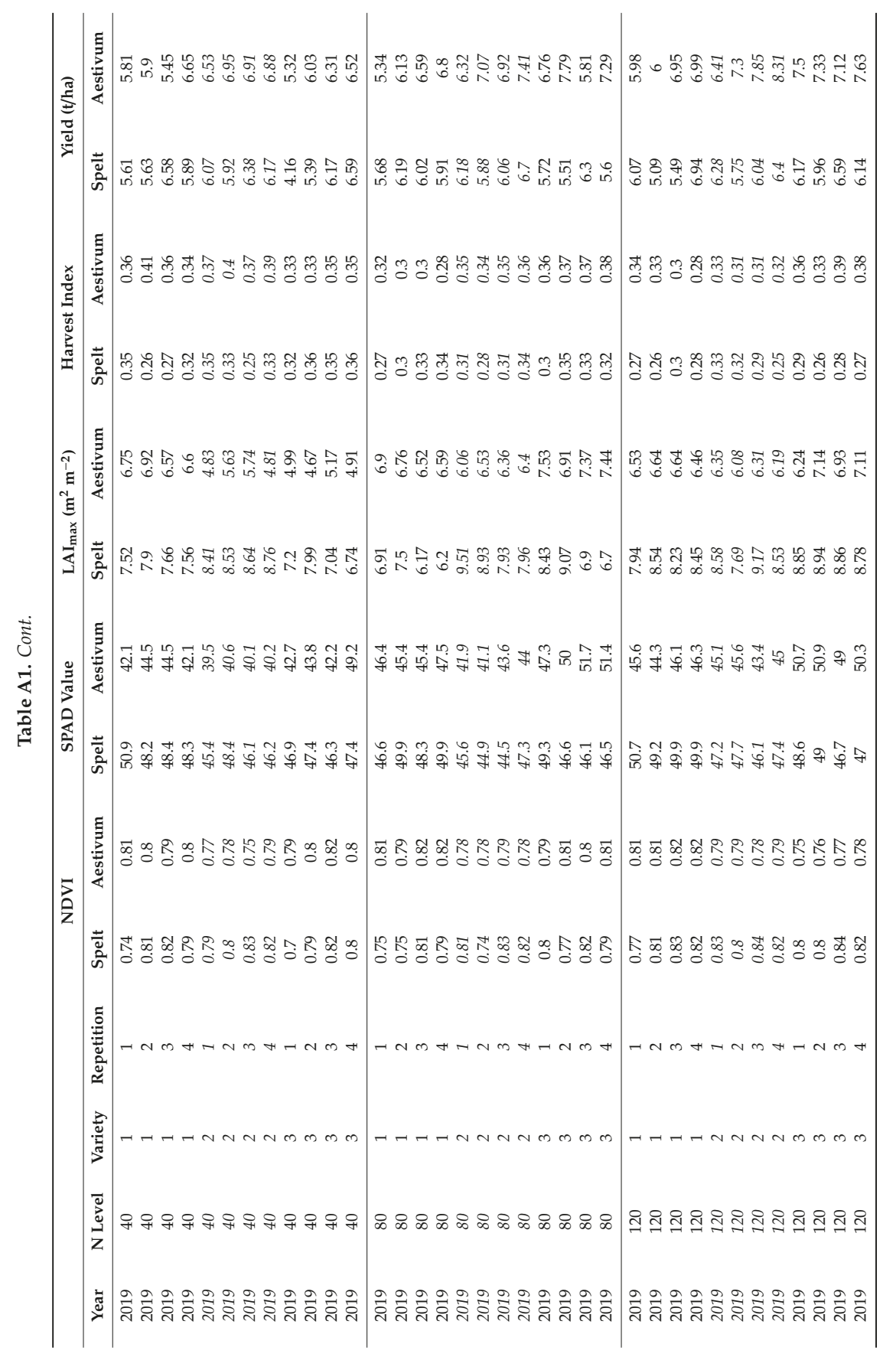




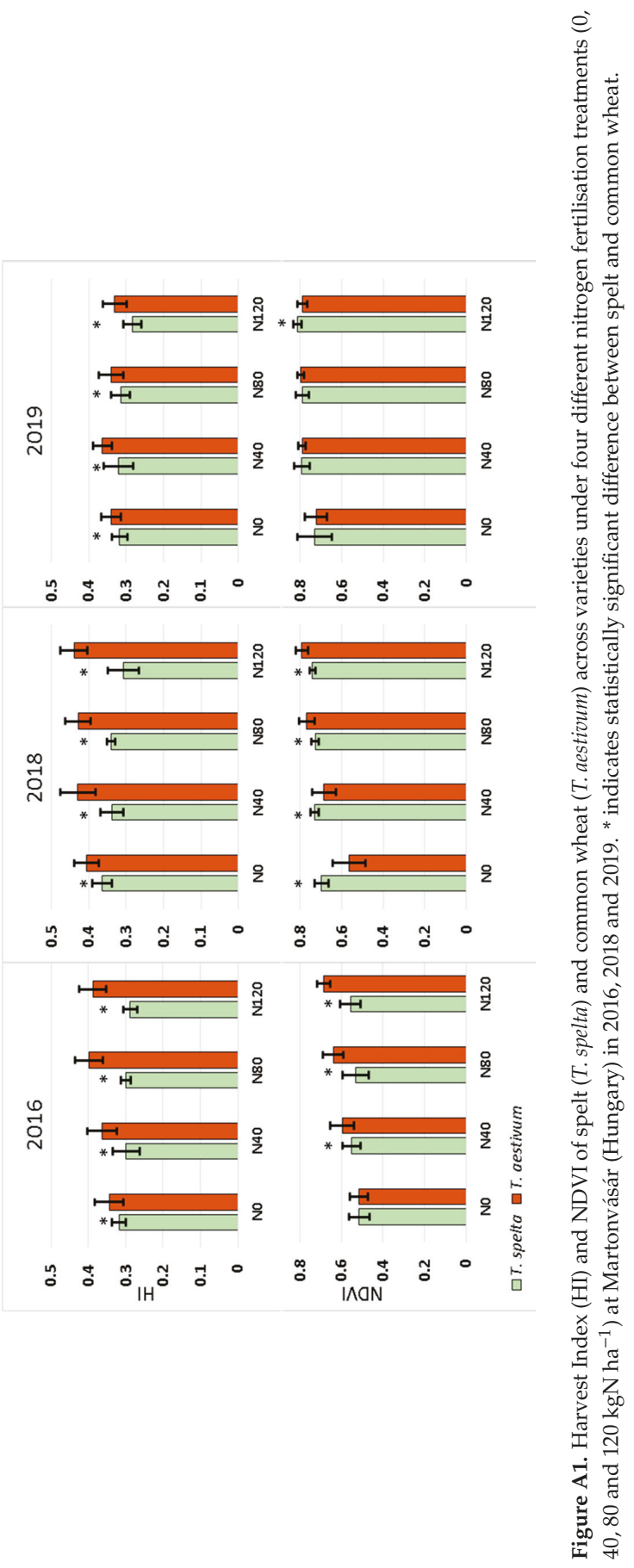




\section{References}

1. Lipper, L.; Thornton, P.; Campbell, B.M.; Baedeker, T.; Braimoh, A.; Bwalya, M.; Caron, P.; Cattaneo, A.; Garrity, D.; Henry, K.; et al. Climate-smart agriculture for food security. Nat. Clim. Change 2014, 4, 1068-1072. [CrossRef]

2. Gyalog, G.; Oláh, J.; Békefi, E.; Lukácsik, M.; Popp, J. Constraining factors in Hungarian carp farming: An econometric perspective. Sustainability 2017, 9, 2111. [CrossRef]

3. Ficiciyan, A.; Loos, J.; Sievers-Glotzbach, S.; Tscharntke, T. More than Yield: Ecosystem services of traditional versus modern crop varieties. Sustainability 2018, 10, 2834. [CrossRef]

4. Trethowan, R.M.; Reynolds, M.P.; Sayre, K.D.; Ortiz-Monasterio, I. Adapting wheat cultivars to resource conserving farming practices and human nutritional needs. Ann. Appl. Biol. 2005, 146, 404-413. [CrossRef]

5. Ruiz, M.; Zambrana, E.; Fite, R.; Sole, A. Yield and Quality Performance of Traditional and Improved Bread and Durum Wheat Varieties under Two Conservation Tillage Systems. Sustainability 2019, 11, 4522 [CrossRef]

6. Pospišil, A.; Pospišil, M.; Svečnjak, Z.; Matotan, S. Influence of crop management upon the agronomic traits of spelt (Triticum spelta L.). Plant Soil Environ. 2011, 57, 435-440. [CrossRef]

7. Adu, M.O.; Sparkes, D.L.; Parmar, A.; Yawson, D.O. 'Stay green' in wheat: Comparative study of modern bread wheat and ancient wheat cultivars. J. Agric. Biol. Sci. 2011, 6, 16-24.

8. Janković, S.; Ikanović, J.; Popović, V.; Rakić, S.; Kuzevski, J. Agro-ecological conditions and morpho-productive properties of spelt wheat. Biotechnol. Anim. Husb. 2013, 29, 547-554. [CrossRef]

9. Rüegger, A.; Winzeler, H.; Nösberger, J. Die Ertragsbildung von Dinkel (Triticum spelta L.) und Weizen (Triticum aestivum L.) unter verschiedenen Umweltbedingungen im Freiland. J. Agron. Crop Sci. 1990, 164, 145-152. [CrossRef]

10. Caballero, L.; Martin, L.M.; Alvarez, J.B. Genetic variability of the low-molecular-weight glutenin subunits in spelt wheat (Triticum aestivum ssp. spelta L. em Thell.). Theor. Appl. Genet. 2004, 108, 914-919. [CrossRef]

11. Bonifácia, G.; Galli, V.; Francisci, R.; Mair, V.; Skrabanja, V.; Kreft, I. Characteristics of spelt wheat products and nutritional value of spelt wheat-based bread. Food Chem. 2000, 68, 437-441. [CrossRef]

12. Koutroubas, S.D.; Fotiadis, S.; Damalas, C.A.; Papageorgiou, M. Grain-filling patterns and nitrogen utilization efficiency of spelt (Triticum spelta) under Mediterranean conditions. J. Agric. Sci. 2014, 152, 716-730. [CrossRef]

13. Evans, J.; Neeson, R.; Burnett, V.; Luckett, D.J.; Fettell, N.A. Phosphorus-use efficiency, growth and yield of spelt wheat (Triticum aestivum ssp. spelta) compared with standard wheat (Triticum aestivum ssp. vulgare) in south-eastern Australia. J. Org. Syst. 2014, 9, 63-78.

14. Jablonskyté-Raščé, D.; Maikšténiené, S.; Mankevičiené, A. Evaluation of productivity and quality of common wheat (Triticum aestivum L.) and spelt (Triticum spelta L.) in relation to nutrition conditions. Plant Soil Environ. 2013, 100, 45-56. [CrossRef]

15. Budzyński, W.S.; Bepirszcz, K.; Jankowski, K.J.; Dubis, B. The responses of winter cultivars of common wheat, durum wheat and spelt to agronomic factors. J. Agric. Sci. 2018, 156, 1163-1174. [CrossRef]

16. Burgos, S.; Stamp, P.; Schmid, J.E. Agronomy and physiological study of cold and flooding tolerance of spelt (Triticum spelta L.) and wheat (Triticum aestivum L.). J. Agron. Crop Sci. 2001, 187, 195-202. [CrossRef]

17. Babulicová, $\mathrm{M}$. The influence of fertilization and crop rotation on the winter wheat production. Plant Soil Environ. 2014, 60, 297-302. [CrossRef]

18. Lazauskas, S.; Povilaitis, V.; Antanaitis, Š.; Sakalauskaitè, J.; Sakalauskienè, S.; Pšibišauskienė, G.; Auškalnienè, O.; Raudonius, S.; Duchovskis, P. Winter wheat leaf area index under low and moderate input management and climate change. J. Food Agric. Environ. 2012, 10, 588-593.

19. Serrano, L.; Fillela, J.; Penuelas, J. Remote sensing of biomass and yield of winter wheat under different nitrogen supplies. Crop Sci. 2000, 40, 723-731. [CrossRef]

20. Zhao, D.; Reddya, K.R.; Kakania, V.G.; Reddyb, V.R. Nitrogen deficiency effects on plant growth, leaf photosynthesis, and hyperspectral reflectance properties of sorghum. Eur. J. Agron. 2005, 22, 391-403. [CrossRef] 
21. Plant, R.E.; Munk, D.S.; Roberts, B.R.; Vargas, R.N.; Travis, R.L.; Rains, R.W.; Hutmacher, R.B. Application of remote sensing to strategic questions in cotton management and research. J. Cotton Sci. 2001, 5, 30-41.

22. Piekarczyk, J.; Sulewska, H. Assessment of winter spelt and wheat growth and yield by ground spectral measurements. Acta Agrophysica 2010, 15, 371-381.

23. Peltonen, J.; Virtanen, A.; Haggrèn, E. Using a chlorophyll meter to optimize nitrogen fertilizer application for intensively-managed small-grain cereals. J. Agron. Crop Sci. 1995, 174, 309-318. [CrossRef]

24. Martínez, D.E.; Guiamet, J.J. Distortion of the SPAD 502 chlorophyll meter readings by changes in irradiance and leaf water status. Agronomy 2004, 24, 41-46. [CrossRef]

25. Bavec, M.; Vuković, K.; Grobelnik, S.; Rozman, Č.; Bavec, F. Leaf area index in winter wheat: Response on seed rate and nitrogen application by different varieties. J. Cent. Eur. Agric. 2007, 8, 337-342.

26. Nielsen, D.; Miceli-Garcia, J.J.; Lyon, D.J. Canopy cover and leaf area index relationships for wheat, triticale, and corn. Agron. J. 2012, 104, 1569-1573. [CrossRef]

27. Unkovich, M.J.; Baldock, J.A.; Forbes, M. Variability in harvest index of grain crops and potential significance for carbon accounting. Adv. Agron. 2010, 105, 173-219. [CrossRef]

28. Tóth, B.; Weynants, M.; Nemes, A.; Makó, A.; Bilas, G.; Tóth, G. New generation of hydraulic pedotransfer functions for Europe. Eur. J. Soil Sci. 2015, 66, 226-238. [CrossRef]

29. Meter Group. Canopy Interception and Leaf Area Index. Accurate Canopy Analysis in Realtime. Available online: https://www.metergroup.com/environment/products/accupar-lp-80-leaf-area-index/ (accessed on 25 October 2019).

30. Konica Minolta. Chlorophyll Meter SPAD-502. Easy and Damage-Free Chlorophyll Measurements on Plants. Available online: https://www5.konicaminolta.eu/en/measuring-instruments/products/colour-measurement/ discontinued-products/spad-502.html (assessed on 25 October 2019).

31. Zhu, J.; Tremblay, T.; Liang, Y. Comparing SPAD and atLEAF values for chlorophyll assessment in crop species. Can. J. Soil Sci. 2012, 92, 645-648. [CrossRef]

32. Trimble. Green Seeker Handheld Crop Sensor for Agriculture. Available online: https://www.trimble.com/ news/release.aspx?id=080612a/ (assessed on 25 October 2019).

33. Haynes, W. Student's t-Test. In Encyclopedia of Systems Biology; Dubitzky, W., Wolkenhauer, O., Cho, K.H., Yokota, H., Eds.; Springer: New York, NY, USA, 2013. [CrossRef]

34. RDocumentation 2019, the R Stats Package. Available online: https://www.rdocumentation.org/packages/ stats/versions/3.6.1 (accessed on 28 October 2019).

35. Koutroubas, S.D.; Fotiadis, S.; Damalas, C.A. Biomass and nitrogen accumulation and translocation in spelt (Triticum spelta) grown in a Mediterranean area. Field Crop Res. 2012, 127, 1-8. [CrossRef]

36. Andruszczak, S. Spelt wheat grain yield and nutritional value response to sowing rate and nitrogen fertilization. J. Anim. Plant Sci. 2018, 28, 1476-1484.

37. Hay, R.K.M. Harvest index: A review of its use in plant breeding and crop physiology. Ann. Appl. Biol. 1995, 126, 197-216. [CrossRef]

38. White, E.M.; Wilson, F.E.A. Responses of grain yield, biomass and harvest index and their rates of genetic progress to nitrogen availability in ten winter wheat varieties. Irish J. Agric. Food Res. 2006, 45, 85-101.

39. Dai, J.; Bean, B.; Brown, B.; Bruening, W.; Edwards, J.; Karow, R.; Lee, C.; Morgan, G.; Ottman, M.; Ransom, J.; et al. Harvest index and straw yield of five classes of wheat. Biomass Bioenergy 2016, 85, 223-227. [CrossRef]

40. Andruszczak, S.; Kwiecińska-Poppe, E.; Kraska, P.; Pałys, E. The influence of some plant protection chemical means on leaf area and their tip angle of some winter spelt wheat varieties (Triticum aestivum ssp. spelta L.). Prog. Plant Prot. 2012, 52, 163-166. [CrossRef]

41. Herrmann, I.; Pimstein, A.; Karnieli, A.; Cohen, Y. Ground level LAI assessment of wheat and potato crops by Sentinel-2 bands. Remote Sens. Environ. 2012, 115, 2141-2151. [CrossRef]

42. Monostori, I.; Árendás, T.; Hoffman, B.; Galiba, G.; Gierczik, K.; Szira, F.; Vágújfalvi, A. Relationship between SPAD value and grain yield can be affected by cultivar, environment and soil nitrogen content in wheat. Euphytica 2016, 211, 103-112. [CrossRef] 
43. Wang, Q.; Adiku, S.; Tenhunen, J.; Granier, A. On the relationship of NDVI with leaf area index in a deciduous forest site. Remote Sens. Environ. 2005, 94, 244-255. [CrossRef]

44. FAO 2019. AgrometShell: Software for Crop Yield Forecasting. Available online: http://www.fao.org/landwater/land/land-governance/land-resources-planning-toolbox/category/details/en/c/1026347/ (accessed on 28 October 2019).

(c) (1) BY

(C) 2019 by the authors. Licensee MDPI, Basel, Switzerland. This article is an open access article distributed under the terms and conditions of the Creative Commons Attribution (CC BY) license (http://creativecommons.org/licenses/by/4.0/). 


\title{
Motives and Role of Religiosity towards Consumer Purchase Behavior in Western Imported Food Products
}

\author{
Faheem Bukhari ${ }^{1}$, Saima Hussain ${ }^{2, *}$, Rizwan Raheem Ahmed ${ }^{3}$, Dalia Streimikiene ${ }^{4, *}$, \\ Riaz Hussain Soomro and Zahid Ali Channar ${ }^{6}$ \\ 1 Faculty of Business Administration, IQRA University, Defense view Shaheed-e-Millet Road (Ext), \\ Karachi 75500, Pakistan; faheembukhari@iqra.edu.pk \\ 2 Faculty of Management Sciences, Shaheed Zulfiqar Ali Bhutto Institute of Science and Technology, \\ SZABIST 90, Block 5, Clifton Karachi 75600, Pakistan \\ 3 Faculty of Management Sciences, Indus University, Karachi 75300, Pakistan; \\ rizwanraheemahmed@gmail.com \\ 4 Institute of Sport Science and Innovations, Lithuanian Sports University, Kaunas 44221, Lithuania \\ 5 Institute of Health Management, Dow University of Health Sciences, Karachi 74200, Pakistan; \\ riaz.soomro@duhs.edu.pk \\ 6 Department of Business Administration, Sindh Madressatul Islam University, Karachi 74000, Pakistan; \\ drzahidalic@gmail.com \\ * Correspondence: saima.hussain@szabist.edu.pk (S.H.); dalia@mail.lei.lt (D.S.)
}

Received: 11 November 2019; Accepted: 27 December 2019; Published: 2 January 2020

\begin{abstract}
The undertaken study examines the influence of the marketing mix, consumer attributes, and the role of religiosity towards consumer purchase behavior regarding western imported food products in Pakistan. The study has used the theory of planned behaviors as underpinning foundations for testing factors. In total, 1080 respondents from eight cities in Pakistan-Karachi, Lahore, Islamabad, Quetta, Peshawar, Hyderabad, Larkana, and Faisalabad-were part of this study. Path analysis performed through SEM (structural equation modeling). The result unveiled that product attributes, price, self-concept, brand trust, personality, and religiosity positively correlated with consumer's purchase intention in a Muslim country. The result of this study will also help potential future candidates for the food industry, especially those aimed at using the Asian consumer market. The penetration of western imported food may also bring convergence where the nation can feel upgraded and privileged. The study also adds to the academic literature on Muslim consumer behavior by combining numerous factors on a single model, grounded in the theory of planned behavior. Limited study has analyzed religiosity and other factors in context with a Muslim majority population. This study is a preliminary effort to understand the Muslim consumer food purchase behavior inadequately investigated by the consumer researcher.
\end{abstract}

Keywords: religiosity; western imported food; theory of planned behavior; Muslim consumers; consumer buying motive

\section{Introduction}

Religion is documented as an essential factor that profoundly influences consumer buying decisions [1]. Religion may serve to link consumers to a style of life that determines the pattern of consumption. Studies examining the effect or impact of religion on consumer behavior are based on two aspects: religious affiliation and religiosity [2,3]. The religious association mainly explored in comparison with the denominational association or the religious identification of a person (e.g., Catholic, Protestant, and Jewish). Although religiosity (in other words, religious commitment) 
is a significant construct to identify the effect of ethical behavior on a consumer's consumption and purchase behavior $[4,5]$.

Islam, as a religion, presents a comprehensive way of life and controls the behavior of Muslim buyers, to achieve satisfaction with this life and hereafter [6]. Religious beliefs (e.g., concerning halal food) are the best guiding principle to identify food consumption choices for Muslims who actively follow religious guidelines as these rules address the Islamic tenets of food consumption [7]. Over the next 40 years, Islam will grow more rapidly than any other dominant faith. If current trends persist, by 2050, there will be nearly as many Muslims as Christians in the world [8]. This rapid increase of the global Muslim population indicates an opportunity for researchers to investigate more about Islam and Muslim consumers' behavior in various contexts such as food consumption. Investigation of Islamic consumption patterns may add value to the academic literature on consumer behavior [9].

Among Muslim consumers, Islamic rules administer the culture, which assists as a direction in their daily lives. Muslims must spend their money for explicit purposes only such as for general living, education, health, and aiding the poor and those in need. Hence, the concept of moderation is encouraged and Muslims are told to base their usage on strict observance to this practice [10]. The Pakistani population is 97 percent Muslim with different religious beliefs as compared to the western part of the world [11]. In spite of these Islamic guidelines on appropriate food consumption and moderate spending, money spent on western imported food has been increasing in Pakistan [12]. Therefore, it is advantageous to know the consumer perception or motives behind the purchase of western imported food. Especially, as this is an increasing trend as the population grows and the general economy has developed so that there is increased discretional personal spending for the middle and upper classes in Pakistan [12,13].

Pakistani Muslim consumers may have different perceptions about western imported food products (concerning the marketing mix, personal, social, and cultural elements). Their religious commitment indeed expresses the intensity of their faith and is indicated in part through their consumption choices about western imported food products [14]. Hence, it is particularly interesting to investigate the Pakistani Muslim consumer's motives behind the purchase of western imported food products and the role of religiosity in determining their purchase behavior. The reasons for this behavior have scarcely been studied in prior research and yet there is an opportunity to explore the factors mentioned above for the western imported food products in a Muslim dominated country like Pakistan [15-19]. This research proposes an essential contribution to the field of Muslim consumer's behavior, and it also adds value to the literature on consumer behavior by employing a model wherein the single conceptual framework tests the elements, based on the theory of planned behavior. Religion is a critical element of Pakistani culture that directly affects the behavior of Pakistani consumers [20].

Furthermore, religion expressively governs cultural and social behaviors in Asian and Middle Eastern societies as compared to western nations. For these reasons, the level of religiosity needs research as an essential factor in shaping Muslim's purchasing behavior regarding western food items in Pakistan. This area is still under-researched and many studies have suggested exploring the influences of religiosity in defining Muslim consumer's purchase behavior in these regions in particular [21-24].

The national religion in Pakistan is Islam, in which $97 \%$ of the population is Muslim-numbering $207,774,520$ inhabitants [11]. Interestingly, the people of Pakistan spend $42 \%$ of their income on food-related items; the total trade and wholesale of $17 \%$ consists of food items [11]. Pakistan's middle and upper class spend money on imported western food items [25,26]. Throughout the first six months of the 2018 fiscal year, Pakistan spent US\$312.5 million on the importing of coffee, tea, beverage whiteners, and spices, the second-largest spending category in the food products sector [27]. Pakistan has spent US\$908.9 million on the import of animal or vegetable fats and oil products. In this period, the country also spent US\$500.9 million on imported oilseeds and 'oleaginous fruit', which is the part of a plant used to produce vegetable oil [27]. It can be a fruits (e.g., olive), seeds (e.g., sesame), or nuts 
(e.g., walnut) [27]. Pakistan is an emerging market for the consumption of imported food items [28]. The market context for the study discussed next with an explanation of its research objectives.

- To investigate factors affecting Muslim consumer's purchase behavior in western imported food products in Pakistan.

- To identify the relationships that exist between each of these factors and western imported food products purchase behavior.

- To determine the moderation of demographic profile on a relationship between contributory factors and consumer's purchase behavior.

\section{Integration of Theory of Planned Behavior}

The undertaken study employed the theory of planned behavior (TPB) to know the behavior intentions of Muslim consumers of western imported food products. This study is an attempt to comprehend the purchasing intention of food items consumers using the TPB model from a Pakistani perspective. According to Donald et al. [29] and Armitage and Conner [30], the TPB model mainly dominated by attitude, and several psychological new dimensions have studied with the TPB model. Such as in organic food products' research by Robinson and Smith [31] investigated self-congruity concerning environmental consumerism. Moral obligations are tested for organic food by Arvola et al. [32], Reviews by Armitage and Conner [30] explains that TPB framework accounts for $39-50 \%$ variations in intention leading to $27-36 \%$ of the difference in a consumer's behavior. However, Ajzen's [33] original model assumptions verified by several studies that antecedents potentially correlate with each other [34-36]. Hence, the present research has included constructs such as product attributes, price, promotion, brand loyalty, brand trust, customer satisfaction, religiosity, subjective norms, self-concept, personality, lifestyle, and social class besides the TPB factors for evaluating Muslims' customers' purchasing aim in the context of western imported food products. This study is an attempt to comprehend the consumers' purchase behavior employing the TPB framework in the Pakistani Muslim consumer's context. The element of religiosity is a combination of religious dimensions, which was described in Glock and Stark's [37] study. Since this study is based on Muslim consumer behavior in the context of western imported food, the combine notion of beliefs, practices, and knowledge about Islam and its linkage with food buying behavior is presented to explain how Muslim consumers take their food-related purchase decisions. New constructs added to TPB in prolific recent literature $[34,35,37]$ specific to various domains. Extensions of the Ajzen [33] model over a few years have proved an improvement in the explanatory power of the framework.

The rest of the paper organized as follows: Section 2 demonstrates the review of literature and hypotheses formulation, Section 3 deals with materials and methods, Section 4 comprises of results, Section 5 deals with discussions, and Section 6 presents the conclusion. Next, the study presents practical applications and followed by theoretical contributions. Lastly, limitations and future research directions have discussed.

\section{Literature Review and Hypotheses Development}

\subsection{Product Attributes}

Product attributes are the features of products through which brands recognized and distinguished. In other words, product attributes denoted to be the descriptive aspect of a marketing plan that characterizes the consumer's evaluative standards when selecting specific goods or services [38]. Product characteristics are discussed in terms of being either intrinsic or extrinsic. Intrinsic product attributes are specific to a product, unchangeable, and comprise features such as form, ingredients, flavor, color, and smell. Extrinsic characteristics are not a crucial part of the physical product such as value, brand name, and country of origin [39]. A study from Norway Torjusen et al. [40] reported that the traditional food quality aspects such as appearance, freshness, and taste, which they named 'observation traits', were important to all respondents. Most of the respondents were concerned about 
aspects related to food production and processing, they chose food with no harmful substances and the least possible additives. According to Dahm, Samonte, and Shows [41], the taste is as equally as an important attribute as quality, followed by price, appearance, and availability [42]. Knight [43] highlights the importance of factors like 'country of the producer' and 'product quality' and its impact on buying decision making in globally available product classes. The researchers reported that, when the imported goods are of a higher value, customers are willing to pay a higher price. Product attributes play a vital role in this research, which investigates these key attributes' influence on consumer buying behavior concerning western imported food. These have identified during the qualitative focused interviews as flavor, taste, nutritious value, and healthiness. Understanding these attributes from a consumer's perspective may assist the manufacturers in developing a refined marketing strategy. Thus, the above information leads to the development of the following hypothesis:

Hypothesis 1 (H1): Product attributes are positively associated with consumer's buying intention towards western food products.

\subsection{Price}

Price has always remained a cornerstone for any food item in every society; therefore, pricing strategy always considers segmentation, market condition, trade margins, competitors' price, and marketing and internal cost [43]. It is directed at distinct consumers alongside competitors [44]. Price is a major factor in determining consumers' choices. Even though many other factors unrelated to price are important in the literature, the price is the main determinant of the purchase decision for large segments of consumers across many countries $[45,46]$. Thus, the above information leads to the development of the following hypothesis:

Hypothesis 2 (H2): Price is positively associated with consumer's buying intention towards western food products.

\subsection{Promotion}

Marketing communication has a positive and vital impact on consumers' purchase intentions and companies' sales volumes. In particular, the advertising plan has an influence on the attitude and the purchase intention towards a brand [46]. Another study by Song, Safari and Mansori [47] reveals the effects of five marketing stimuli, which include marketing communication and promotion of the food items on the perceived value of consumers. Afterward, the effect of this perceived value on the actual purchase decision examined. The results showed a relationship between marketing communication and perceived customer value among organic food consumers of Malaysia. In contrast to the existing literature, findings for the same study revealed no relationship between sales promotion and product perceived value. $[43,45]$. Hence, the above information leads to the development of the following hypothesis:

Hypothesis 3 (H3): Promotion is positively associated with consumer's buying intention towards western food products.

\subsection{Personality}

Marketers accept the buyers experienced brands as a means to comprehend their personalities. We have taken a modified questionnaire in which we used the modified items for the brand personality from the previous study [48]. According to Banerjee [49], both individual and brand personalities have an important influence on brand preference in the consumer's mind. Consumer Preference implies that at the time of brand choice, consumers give prominence to individual personality and the personality of the chosen brand. In food products, such a relationship has also been found. According to Chang, 
Tseng, and Chu [50], few consumer traits lead to a positive consumer perception about food traceability, which means food items processing, production, and delivery to the consumers. The researchers used the Big Five Factor model to assess various traits of consumers and a 3M framework of motivation and personality (market, means, and motivation) for analyzing consumer's perceptions regarding food traceability $[47,50]$. Among elemental traits, it was found that openness, conscientious and extroverted personalities, combined with actual material and bodily needs, tend to be linked with compound traits such as health consciousness and the need for learning. These compound traits influence situational traits (consumer perceptions of food traceability and the concern for food value) and initiate the intention to purchase. Hence, the above information leads to the development of the following hypothesis:

Hypothesis 4 (H4): Personality is positively associated with consumer's buying intention towards western food products.

\subsection{Lifestyle}

The lifestyle to a certain extent defines patterns or trends of consumption. It is observed by looking at individuals' organization, space and time, leisure activities, working hours, housing, appearance, and other daily activities. In other words, lifestyle is one important variable, which expresses consumer's choices [51,52]. Ahaiwe et al. [53] reported several factors, which may influence consumers' buying behavior and their brand preferences for goods and services. Among these are cultural factors, social class, values and beliefs, interests, lifestyle, and personality. These factors jointly referred to as psychographic variables, which play a considerable role in consumers' preferences for products [54]. In a Chinese study comparing lifestyles and their impact on purchase intentions for domestic and imported food products, three groups identified which each had different behaviors: risk-takers, traditionalists, and experiencers. It was found that risk-takers and traditionalists were associated with purchasing imported fruits [55]. Another study suggests a food-related lifestyle model comprised of five components to explain consumption behavior: quality, methods to shopping, food consumption situation, manner of cooking, and purchasing motives [51,56]. Hence, the above information leads to the development of the following hypothesis:

Hypothesis 5 (H5): Lifestyle is positively associated with consumer's buying intention towards western food products.

\subsection{Family (Subjective Norms)}

A subjective norm generally explained as a person's awareness about what essential others consider the individual should comply with [57]. The association between subjective norms and attitudes towards behavior has been verified and tested. For example, researchers have established the pathway from subjective norms to attitudes towards behavior and found it significant [58]. Within the framework of subjective norms, reference groups somehow affect the values and behavior of others. Reference groups, particularly buyer groups of references-for example, institution and trade, professional institutions, social organizations, friends, family members-influence product selection and the choice of a specific brand. Most purchases influenced by the opinions of the groups of references, which include friends and professional institutions [59]. Parents have an impact on a person's purchase decision. Moreover, the dominance of the preference of the husband or the wife differs from the product category. Thus, in food items, the wife is predominantly the key decision-maker. However, children also influence at the time of purchasing [60]. Hence, the above information leads to the development of the following hypothesis: 
Hypothesis 6 (H6): Family is positively associated with consumer's buying intention towards western food products.

\subsection{Social Class}

Social class is used as a basis for market segmentation because members of different classes reflect different consumption patterns [61]. Especially in those countries where class differences exist, social class significantly impacts on consumer decisions [62]. When it comes to consumers' response to a new product, research indicates differences between the low and high socioeconomic classes. The low socioeconomic class is less likely to purchase a new product or one with new technologies. According to Majabadi et al. [63], there is a class difference in consumer preferences towards food products, prices, and concepts of value. This social class research has been investigated as an important factor to explore if it influences consumer's purchase behavior. Social class also is shown to connect with patterns of media usage, language patterns, source credibility, and spending behavior [56,62]. Social class is yet another important factor that needs to be studied in the context of food buying behavior. In a country such as Pakistan, with its complex history and deeply rooted perceptions of social class, social class may impact the purchase of western imported food products. Since this study based on the purchase behavior of western imported food in Pakistan, understanding the social classes in this context is a prerequisite. Hence, the above information leads to the development of the following hypothesis:

Hypothesis 7 (H7): Social class is positively associated with consumer's buying intention towards western food products.

\subsection{Self-Concept}

The congruence of brand personality and the consumer's self is a way to create an emotional attachment to the brand and other various brand-related outcomes [64]. Additionally, various research studies have posited a significant relationship between this congruity and a positive brand attitude, positive brand perception, and the intention to buy [65]. Another study also supports the view that consumers prefer those products, which match (somehow) with their self-concept [66]. Self-concept has been identified as playing a mediating role concerning the underdog brand effect and the intention to buy [67]. The research of Hoonsopon [68] also found and used the self-concept as a moderating variable in the relationship between consumer innovativeness and new product purchase intentions. Hence, it concluded that even in new product adoption, consumers have a unique self-concept, and there is a chance the new product will be adopted when it fits with the self-concept of the consumer. Regardless of the rising research regarding self-concept and consumer behavior, there are still areas in the literature, which need further exploration. Earlier researchers have not taken into account the self-concept and its influence on consumer's buying behavior for the food segment [65,68]. To fill this gap, this study expands on earlier research examining the role of the self-concept in consumer behavior by ascertaining its influence on buying behavior concerning western imported food. In the case of western imported food products, this self-concept is an important factor in the buyer's purchase decision. This includes the consumer's attitude and perception, and if both of these are positive towards the product, the consumer may end up finally deciding to purchase the product. Hence, the above information leads to the development of the following hypothesis:

Hypothesis 8 (H8): Self-concept is positively associated with consumer's buying intentions towards western food products.

\subsection{Brand Trust}

In the case of food purchase behavior, self-assurance in credence features, and could lead to brand trust. A food-related research study conducted by Chen and Lee [69] reported that brand trust plays 
an important role. There is an important relationship amid various kinds of trust and consumers' perceptions of safety concerning food items. The researchers specified two main types of trust: general and specific, specific trust further classified into supplier level, and industry-level trusts. Using the survey method in Beijing, results indicated an affirmative link amid consumer's brand trust in food producers and retailers with their perceptions of food safety. When marketers aim to increase specific trust, they should address the integrity and ability of producers [70]. Drescher et al. [71] studied Canadian households' perceptions of processed meat and their levels of trust. The research suggested customers with the highest level of brand trust spend more on processed meat than those with a low level. In the past literature, the importance of brand trust has highlighted along with its impact on creating highly valued relationships between consumers and firms. In this research, the element of brand trust has been added to determine the extent of consumers' brand trust in western imported food and if this is influencing their purchase behavior. Brand trust is essential for making sure that the consumer makes the purchase. In the case of western imported food products, brand trust is essential for purchase behavior to take place. Once the consumer trusts the brand, he or she is willing to pay higher prices to procure the western imported food product. Henceforth, the above information leads to the development of the following hypothesis:

Hypothesis 9 (H9): Brand trust is positively associated with consumer's buying intentions towards western food products.

\subsection{Religiosity}

The religious practices influence the imminence sited on attitudes and factual life towards possessing and consuming goods and services [72]. Religiosity, a central point of any religion, has a close association with consumer behavior. Thus, an exploration of religiosity allows in-depth investigation of consumer behavior [73]. Abundant literature is available regarding the association of religiosity and consumers' behavior. For example, in a practical study regarding consumers' intentions and religiosity amongst 602 typically Protestant customers. Rakrachakarn et al. [74] reported the noteworthy inference that religiosity influences numerous aspects of customers' lifestyles that ultimately reshape the selection behavior. In Vitell's [75] evaluation of religiosity and consumer behavior, one observation was prominent: that the number of academic studies has been inadequate in clarifying customers' norms and religious views. This was associated with the arguments of Hannah, Avolio, and May [76] who specified that norms and capabilities of views accounted for $20 \%$ of the difference in the behavior explained. Henceforth, the above information leads to the development of the following hypothesis:

Hypothesis 10 (H10): Religiosity is positively associated with consumer's buying intentions towards western food products.

\subsection{Purchase Intention}

Numerous factors influence purchase intention such as subjective norms, attitudes, and perceived behavioral control [77]. The consumers of imported food perceive these items as better quality compared to locally produced food brands and this positive attitude has affected their purchase intention [78]. Many previous studies further endorsed that factors such as subjective norms, health consciousness, and brand familiarity somehow influenced the purchase intention $[76,78]$. The results are consistent with several developed countries' literature in which perceived value was quite important and had an impact on the food buying behavior and consumers were willing to pay extra to avail the maximum benefits [79]. A perception of better quality was also one of the key aspects of shaping consumers' purchase intention. Those with a positive mindset concerning western food brands were likely to possess a positive intention to purchase it [80]. A positive attitude thus found to serve as an important 
stimulus and possibly influenced the consumers' purchase intention. However, in most of the cases and especially in food buying behavior, it has been noted that purchase intention is a primary indicator and a leading factor towards a final purchase behavior [78,81]. Henceforth, the above information leads to the development of the following hypothesis:

Hypothesis 11 (H11): Purchase intention is positively associated with consumer's buying behavior towards western food products.

Thus, the conceptual frame of the undertaken study is shown in Figure 1.

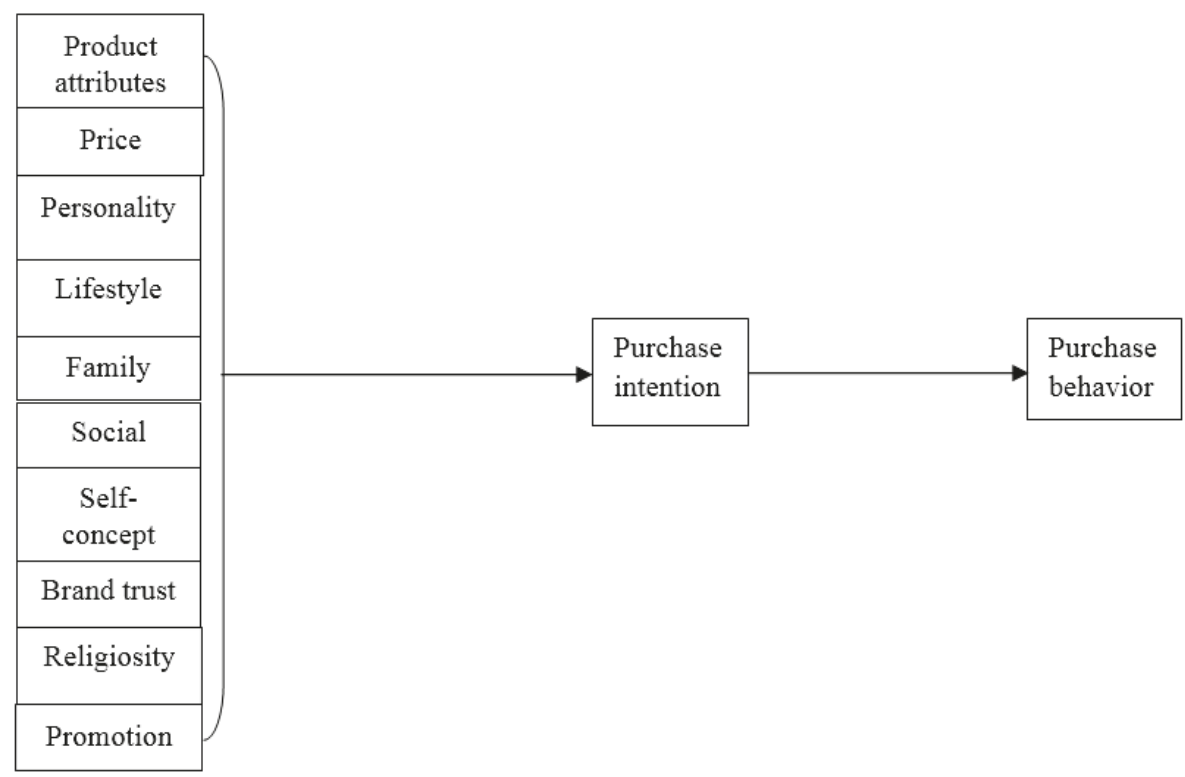

Figure 1. Conceptual framework.

\section{Materials and Methods}

A structured questionnaire has tested the model established in this study. The primary survey conducted in the eight metropolitan cities of Pakistan, Karachi, Lahore, Islamabad, Peshawar, Hyderabad, Faisalabad, Quetta, and Larkana which together cover four regions (Sindh, Punjab, Baluchistan, and Khyber Pakhtunkhwa). The main reason for selecting eight metropolitan cities of Pakistan was to ensure the sample represented the key Pakistani urban cities with diversified socio-economic classes and having the awareness and usage of western imported food, guaranteeing the generalizability of the research outcome [82]. The responses were collected online and in-person for the pilot study conducted in Karachi with a sample of 375 respondents. A pilot study has enhanced the precision of the survey instrument. A sample size of 375 deemed appropriate since there were 75 scale items and exploratory factor analysis requires a minimum of 5:1 ratio of respondents to items [83]. To run the factor analysis, a sample size smaller than 100 considered to be "dangerous", and sample sizes larger than 200 are considered safe for adequate conclusions [84,85]. The final survey administered to 1080 respondents through in-person and online media such as email and social media. The sample size was calculated based on the ratio of 20 respondents per item, which is the prescribed ideal sample size needed to conduct SEM $[85,86]$. Before inputting the data, the questionnaires checked for any missing data. This initial screening revealed that out of 1080 surveys, 927 filled in. Hence, the response rate was 86 percent. Data normality observed by reviewing residual 
plots, which appeared to be reasonable, and the skewness and kurtosis values were near zero. Thus, the notion of normality undisrupted.

\section{Measurement Scaling for Constructs and Items}

The data is collected from 927 respondents for the undertaken study by using a structured and modified questionnaire. We used adapted measurement scales for constructs and items from the previous literature such as modified items of product attributes are taken from previous studies [38-43], modified items for marketing mix such as price and promotion have been taken from the previous literature [43-46]. However, the adapted items of lifestyle and personality are considered from the previous studies [51-56]. The subjective norms of the family items have been modified from previous studies such as Al-Swidi et al. [57] and Kautonen et al. [59]. The adapted items for the social class have been taken from previous studies such as Rani [61], Durmaz and Taşdemir [62], and Majabadi et al. [63]. The modified items of self-concept are taken from previous literature [64-68]. The items for brand trust have taken from previous studies such as Chen and Lee [69] and Drescher et al. [71]. Religiosity is the most important variable in this research, we have taken adapted items from the previous literature [72-76]. We used modified items for purchase intention and purchase behavior constructs from previous studies [77-81].

\section{Results and Discussions}

The survey forms distributed to 1080 respondents from eight cities of Pakistan, Karachi, Hyderabad, Larkana, Lahore, Islamabad, Faisalabad, Quetta, and Peshawar. A sample of 927 individuals consisting of professionals, university students, and homemakers responded to the survey, which presented a response rate of 86 percent. The main demographic variables included in this study are gender, religious identity, and age, level of education, monthly income, marital status, and employment status. Table 1 exhibits the frequencies and corresponding percentages of each demographic variable.

Table 1. Demographics.

\begin{tabular}{|c|c|c|c|}
\hline Item & Characteristic & $\begin{array}{c}\text { No. of } \\
\text { Respondents }\end{array}$ & $\begin{array}{l}\text { Percentage } \\
\text { Response }\end{array}$ \\
\hline \multirow{2}{*}{ Gender } & Male & 542 & 58 \\
\hline & Female & 385 & 41 \\
\hline \multirow{5}{*}{ Age } & $18-24$ & 541 & 58 \\
\hline & $25-35$ & 313 & 34 \\
\hline & $36-45$ & 55 & 05 \\
\hline & $46-55$ & 17 & 18 \\
\hline & $55+$ & 03 & 01 \\
\hline \multirow{7}{*}{ Level of education } & Primary & 02 & 01 \\
\hline & Secondary or high school & 54 & 05 \\
\hline & Diploma/vocational education and training & 11 & 11 \\
\hline & Undergraduate (Bachelor) & 308 & 33 \\
\hline & Postgraduate (Masters) & 530 & 57 \\
\hline & $\mathrm{PhD}$ & 19 & 02 \\
\hline & Others & 03 & 01 \\
\hline \multirow{5}{*}{$\begin{array}{l}\text { Per month income } \\
\text { in Pak rupees }\end{array}$} & Less than 40,000 & 10 & 01 \\
\hline & 40,001-64,000 PKR & 448 & 48 \\
\hline & 64,001-150,000 PKR & 327 & 35 \\
\hline & 150,001-250,000 PKR & 81 & 08 \\
\hline & 250,001+ PKR & 61 & 07 \\
\hline \multirow{4}{*}{ Marital status } & Single & 659 & 71 \\
\hline & Married & 256 & 27 \\
\hline & Divorced & 06 & 01 \\
\hline & Others & 06 & 01 \\
\hline
\end{tabular}


Table 1. Cont.

\begin{tabular}{cccc}
\hline Item & Characteristic & $\begin{array}{c}\text { No. of } \\
\text { Respondents }\end{array}$ & $\begin{array}{c}\text { Percentage } \\
\text { Response }\end{array}$ \\
\hline \multirow{3}{*}{ Employment status } & Full time & 395 & 42 \\
& Part-time & 81 & 08 \\
& Self employed & 55 & 06 \\
& Unemployed & 396 & 42 \\
\hline \multirow{3}{*}{ City } & Karachi & 393 & 42 \\
& Hyderabad & 41 & 04 \\
& Larkana & 37 & 04 \\
& Lahore & 282 & 30 \\
& Islamabad & 30 & 03 \\
& Quetta & 23 & 02 \\
& Faisalabad & 73 & 08 \\
& Peshawar & 48 & 05 \\
\hline
\end{tabular}

As Table 1 indicates, of the 927 respondents, 542 were male, and 385 were females. The age group of 18 to 24 was the largest, with over half of the respondents 58 percent. About 48 percent had a monthly income between PKR 40,001-64,000 (equivalent to US\$310-497). Concerning academic qualifications, the majority had a postgraduate degree (57 percent). Most were single (71 percent), 42 percent were employed full time, and 42 percent resided in Karachi, followed by Lahore (with 30 percent).

\subsection{Factor Loading and Path Analysis}

The framework of this research tested in SPSS and AMOS 23.0 version. Analysis of a multi-stage SEM (structural equation modeling) process comprising of measurement and structural model conducted by path analysis $[85,86]$. Moreover, an exploratory factor analysis (EFA) test has explored several factors for this study. Almost forty factors recognized with the commonalities greater than 0.5 . Table 2 illustrates the results obtained through factor analysis. Furthermore, the sphericity and KMO tests recognized a significant relationship between the variables to authenticate the operationalization of factor analysis [86,87] as shown in Tables 3 and 4 .

Table 2. Component matrix with rotations.

\begin{tabular}{|c|c|c|c|c|c|c|c|c|c|c|c|c|}
\hline & \multicolumn{12}{|c|}{ Component } \\
\hline & 1 & 2 & 3 & 4 & 5 & 6 & 7 & 8 & 9 & 10 & 11 & 12 \\
\hline Product attribute & 0.620 & & & & & & & & & & & \\
\hline Product attribute & 0.712 & & & & & & & & & & & \\
\hline Product attribute & 0.656 & & & & & & & & & & & \\
\hline Price & & 0.504 & & & & & & & & & & \\
\hline Price & & 0.595 & & & & & & & & & & \\
\hline Price & & 0.500 & & & & & & & & & & \\
\hline Promotion & & & 0.862 & & & & & & & & & \\
\hline Promotion & & & 0.912 & & & & & & & & & \\
\hline Promotion & & & 0.833 & & & & & & & & & \\
\hline Promotion & & & 0.616 & & & & & & & & & \\
\hline Lifestyle & & & & 0.608 & & & & & & & & \\
\hline Lifestyle & & & & 0.889 & & & & & & & & \\
\hline Lifestyle & & & & 0.866 & & & & & & & & \\
\hline Personality & & & & & 0.806 & & & & & & & \\
\hline Personality & & & & & 0.910 & & & & & & & \\
\hline Personality & & & & & 0.922 & & & & & & & \\
\hline Personality & & & & & 0.884 & & & & & & & \\
\hline Family & & & & & & 0.828 & & & & & & \\
\hline Family & & & & & & 0.889 & & & & & & \\
\hline Family & & & & & & 0.866 & & & & & & \\
\hline
\end{tabular}


Table 2. Cont.

\begin{tabular}{|c|c|c|c|c|c|c|c|c|c|c|c|c|}
\hline & \multicolumn{12}{|c|}{ Component } \\
\hline & 1 & 2 & 3 & 4 & 5 & 6 & 7 & 8 & 9 & 10 & 11 & 12 \\
\hline Social-class & & & & & & & 0.535 & & & & & \\
\hline Social-class & & & & & & & 0.706 & & & & & \\
\hline Social-class & & & & & & & 0.630 & & & & & \\
\hline Social-class & & & & & & & 0.529 & & & & & \\
\hline Self-concept & & & & & & & & 0.747 & & & & \\
\hline Self-concept & & & & & & & & 0.891 & & & & \\
\hline Self-concept & & & & & & & & 0.760 & & & & \\
\hline Brand trust & & & & & & & & & 0.705 & & & \\
\hline Brand trust & & & & & & & & & 0.782 & & & \\
\hline Brand trust & & & & & & & & & 0.701 & & & \\
\hline Religiosity & & & & & & & & & & 0.845 & & \\
\hline Religiosity & & & & & & & & & & 0.798 & & \\
\hline Religiosity & & & & & & & & & & 0.648 & & \\
\hline Religiosity & & & & & & & & & & 0.592 & & \\
\hline PI & & & & & & & & & & & 0.550 & \\
\hline PI & & & & & & & & & & & 0.774 & \\
\hline PI & & & & & & & & & & & 0.801 & \\
\hline $\mathrm{PB}$ & & & & & & & & & & & & 0.738 \\
\hline $\mathrm{PB}$ & & & & & & & & & & & & 0.846 \\
\hline $\mathrm{PB}$ & & & & & & & & & & & & 0.773 \\
\hline
\end{tabular}

Table 3. KMO analysis Bartlett's sphericity test.

\begin{tabular}{ccc}
\hline \multicolumn{2}{c}{ KMO Measure of Sampling Adequacy } & $\mathbf{0 . 9 0 5}$ \\
\hline & Approx. Chi-square & 20295.022 \\
Bartlett's test of sphericity & Df & 1035 \\
& Sig. & 0.000 \\
\hline
\end{tabular}

Table 4. Total variances.

\begin{tabular}{cccc}
\hline \multirow{2}{*}{ Component } & \multicolumn{3}{c}{ Eigenvalues } \\
\cline { 2 - 4 } & Total & \% of Variance & Cumulative \% \\
\hline 1 & 11.594 & 21.47 & 21.47 \\
2 & 5.573 & 10.319 & 31.789 \\
3 & 3.389 & 6.275 & 38.064 \\
4 & 2.11 & 3.908 & 41.972 \\
5 & 1.849 & 3.424 & 45.396 \\
6 & 1.792 & 3.319 & 48.716 \\
7 & 1.682 & 3.115 & 51.83 \\
8 & 1.491 & 2.761 & 54.592 \\
9 & 1.368 & 2.534 & 57.126 \\
10 & 1.168 & 2.163 & 59.289 \\
11 & 1.089 & 2.017 & 61.306 \\
12 & 1.021 & 1.89 & 63.196 \\
\hline
\end{tabular}

\subsection{Structural Model}

The goodness of fit indices was fit for the model Chatfield [87] in Table 5. 
Table 5. Overall model fit indices.

\begin{tabular}{ccc}
\hline Indices & Reported Value & Recommended Value \\
\hline Chi-square/DF ratio (CMIN/DF) & 1.984 & $<3$ \\
GFI & 0.932 & 0.90 \\
AGFI & 0.920 & 0.90 \\
NFI & 0.921 & 0.90 \\
IFI & 0.959 & 0.90 \\
TLI & 0.954 & 0.90 \\
CFI & 0.959 & 0.90 \\
RMSEA & 0.033 & $<0.08$ \\
ECVI & 1.759 (Default model) & Default model should report \\
& 1.771 (Saturated model) & the smallest value \\
HOELTER & 18.964 (Independence model) & $>200$ at 0.01 level \\
\hline
\end{tabular}

The reported CMIN/DF (Chi-square $(\chi 2) / \mathrm{df}=1.984$ displays a good model fit since the value is less than 3 , which is a statistical benchmark. The remaining fit indices also report that the model fits the research data. CFI, IFI, and TLI values are above the minimum threshold level 0.9 indicating a good model fit. AGFI and GFI values are as per the minimum threshold, which is 0.90 . The RMSEA value is 0.033 which is $<0.08$ [88]. Besides, the ECVI indicates the smaller value, which presents that the model crosschecked by utilizing similar cases from the same target group. Lastly, the HOETLER figure of 527 at 0.01 level directed suitable sample suitability for the model; As per Hoelter [89], >200 would specify good sample appropriateness for the model. Hence, the figures deliver sufficient indication to support for a good model fit. Consequently, all the above-stated fit indices were acceptable well the above-suggested criteria.

\subsection{Validity and Reliability}

Reliabilities, factor loadings, and Average variance extracted (AVE) displayed in Table 6. Besides, the constructs' validity comprises 'convergent validity' and 'discriminant validity', and Table 6 has all values equal and above the prescribed threshold of 0.72 to 0.9 [90]. The criterion for convergent and discriminant validity is as per the benchmark suggested by [91] and henceforth established convergent validity, as mentioned in Table 6.

Table 6. Validity and reliability measures.

\begin{tabular}{|c|c|c|c|c|c|}
\hline Scales & Variable & $\begin{array}{c}\text { Factor } \\
\text { Loading }\end{array}$ & AVE & $\begin{array}{l}\text { Composite } \\
\text { Reliability }\end{array}$ & Cronbach's $\alpha$ \\
\hline Product attribute & \multirow{3}{*}{ Product attribute } & 0.681 & \multirow{3}{*}{0.555} & \multirow{3}{*}{0.788} & \multirow{3}{*}{0.711} \\
\hline Product attribute & & 0.807 & & & \\
\hline Product attribute & & 0.741 & & & \\
\hline Price & \multirow{3}{*}{ Price } & 0.704 & \multirow{3}{*}{0.500} & \multirow{3}{*}{0.749} & \multirow{3}{*}{0.715} \\
\hline Price & & 0.664 & & & \\
\hline Price & & 0.751 & & & \\
\hline Promotion & \multirow{4}{*}{ Promotion } & 0.794 & \multirow{4}{*}{0.689} & \multirow{4}{*}{0.898} & \multirow{4}{*}{0.834} \\
\hline Promotion & & 0.802 & & & \\
\hline Promotion & & 0.844 & & & \\
\hline Promotion & & 0.879 & & & \\
\hline
\end{tabular}


Table 6. Cont.

\begin{tabular}{|c|c|c|c|c|c|}
\hline Scales & Variable & $\begin{array}{c}\text { Factor } \\
\text { Loading }\end{array}$ & AVE & $\begin{array}{l}\text { Composite } \\
\text { Reliability }\end{array}$ & Cronbach's $\alpha$ \\
\hline Lifestyle & \multirow{3}{*}{ Lifestyle } & 0.927 & \multirow{3}{*}{0.750} & \multirow{3}{*}{0.900} & \multirow{3}{*}{0.784} \\
\hline Lifestyle & & 0.839 & & & \\
\hline Lifestyle & & 0.828 & & & \\
\hline Personality & \multirow{4}{*}{ Personality } & 0.794 & \multirow{4}{*}{0.679} & \multirow{4}{*}{0.894} & \multirow{4}{*}{0.897} \\
\hline Personality & & 0.841 & & & \\
\hline Personality & & 0.843 & & & \\
\hline Personality & & 0.817 & & & \\
\hline Family & \multirow{3}{*}{ Family } & 0.802 & \multirow{3}{*}{0.500} & \multirow{3}{*}{0.855} & \multirow{3}{*}{0.786} \\
\hline Family & & 0.793 & & & \\
\hline Family & & 0.847 & & & \\
\hline Social class & \multirow{4}{*}{ Social class } & 0.702 & \multirow{4}{*}{0.584} & \multirow{4}{*}{0.849} & \multirow{4}{*}{0.840} \\
\hline Social class & & 0.693 & & & \\
\hline Social class & & 0.744 & & & \\
\hline Social class & & 0.692 & & & \\
\hline Self-concept & \multirow{3}{*}{ Self-concept } & 0.711 & \multirow{3}{*}{0.515} & \multirow{3}{*}{0.761} & \multirow{3}{*}{0.737} \\
\hline Self-concept & & 0.722 & & & \\
\hline Self-concept & & 0.720 & & & \\
\hline Brand trust & \multirow{3}{*}{ Brand trust } & 0.772 & \multirow{3}{*}{0.620} & \multirow{3}{*}{0.830} & \multirow{3}{*}{0.870} \\
\hline Brand trust & & 0.752 & & & \\
\hline Brand trust & & 0.836 & & & \\
\hline Religiosity & \multirow{4}{*}{ Religiosity } & 0.591 & \multirow{4}{*}{0.552} & \multirow{4}{*}{0.737} & \multirow{4}{*}{0.731} \\
\hline Religiosity & & 0.618 & & & \\
\hline Religiosity & & 0.738 & & & \\
\hline Religiosity & & 0.616 & & & \\
\hline PI & \multirow{3}{*}{$\begin{array}{l}\text { Purchase } \\
\text { intention }\end{array}$} & 0.705 & \multirow{3}{*}{0.500} & \multirow{3}{*}{0.723} & \\
\hline PI & & 0.687 & & & 0.766 \\
\hline PI & & 0.655 & & & \\
\hline PB & & 0.831 & & & \\
\hline PB & behavior & 0.720 & 0.631 & 0.837 & 0.825 \\
\hline PB & & 0.831 & & & \\
\hline
\end{tabular}

The constructs stated in Table 7 fulfill the criterion of discriminant validity that is the square root of AVE > all possible squared correlations, as suggested by Hair et al. [85]. 
Table 7. Measurement model discriminant validity measures.

\begin{tabular}{|c|c|c|c|c|c|c|c|c|c|c|c|c|}
\hline Component & PA & PRC & PROMO & PER & LIFE & FAM & SC & SELF & BT & REL & PI & PB \\
\hline Product attribute & 0.745 & & & & & & & & & & & \\
\hline Price & 0.442 & 0.707 & & & & & & & & & & \\
\hline Promotion & 0.218 & 0.220 & 0.830 & & & & & & & & & \\
\hline Personality & 0.076 & 0.236 & 0.303 & 0.866 & & & & & & & & \\
\hline Lifestyle & 0.240 & 0.134 & 0.171 & 0.054 & 0.824 & & & & & & & \\
\hline Family & 0.182 & 0.200 & 0.348 & 0.422 & 0.098 & 0.707 & & & & & & \\
\hline Social class & 0.094 & 0.206 & 0.348 & 0.661 & 0.058 & 0.501 & 0.764 & & & & & \\
\hline Self-concept & 0.395 & 0.292 & 0.125 & 0.095 & 0.282 & 0.099 & 0.142 & 0.718 & & & & \\
\hline Brand trust & 0.500 & 0.403 & 0.129 & 0.199 & 0.206 & 0.173 & 0.213 & 0.417 & 0.787 & & & \\
\hline Religiosity & 0.135 & -0.029 & 0.163 & -0.055 & 0.270 & 0.125 & -0.038 & 0.099 & -0.007 & 0.743 & & \\
\hline Purchase intention & 0.496 & 0.453 & 0.192 & 0.205 & 0.310 & 0.229 & 0.232 & 0.424 & 0.564 & 0.084 & 0.707 & \\
\hline Purchase behavior & 0.471 & 0.427 & 0.164 & 0.179 & 0.291 & 0.190 & 0.195 & 0.387 & 0.568 & 0.102 & 0.704 & 0.794 \\
\hline
\end{tabular}

\subsection{Outcomes of Hypothesized Relationships}

Table 8 displays all relationships within independent, intervening, and dependent variables. The findings from the quantitative data analysis reveal that product attributes are positively associated with consumer purchase intentions for the sustenance of western imported food products, as exhibited in Table 8. It means that consumers give importance to product features at the time of purchase. The outcome of this hypothesis is also in line with the previous literature, for instance, Lian and Yoong [92] reported that product features such as taste, freshness, and packaging influenced consumers' attitudes to purchasing food products. It was further endorsed by Wee et al. [79] who found that product safety related to food brands had a significant influence on consumers' purchasing behavior of imported food products. Further research by Nasution and Rossanty [93] confirmed the long-established view that product labeling had an essential association with consumers' attitudes to the purchasing behavior of food products.

Table 8. Standardized regression weights and $p$-values.

\begin{tabular}{ccccc}
\hline Hypothesis & & & Estimates & $p$-Value \\
\hline Ha1 & Supported & Product attribute -> PI & 0.217 & $<0.001^{* * *}$ \\
Ha2 & Supported & Price - > PI & 0.204 & $<0.001^{* * *}$ \\
Ha3 & Not Supported & Promotion - PI & 0.012 & 0.704 \\
Ha4 & Supported & Personality - P PI & 0.108 & $0.001^{* * *}$ \\
Ha5 & Not Supported & Lifestyle - P PI & -0.018 & 0.745 \\
Ha6 & Not Supported & Family - P PI & -0.015 & 0.699 \\
Ha7 & Not Supported & Social class - P PI & 0.097 & 0.127 \\
Ha8 & Supported & Self-concept - PI PI & 0.066 & $0.091^{*}$ \\
Ha9 & Supported & Brand trust -> PI & 0.466 & $<0.001^{* * *}$ \\
Ha10 & Supported & Religiosity -> PI & 0.135 & $<0.001^{* * *}$ \\
Ha11 & Supported & PI-> purchase behavior & 0.91 & $<0.001^{* * *}$ \\
\hline Note: PI $=$ Purchase intention; ${ }^{*}$ Significant at $10 \%(p<0.1) ; * *$ Significant at $1 \%(p<0.01)$.
\end{tabular}

The second association investigated was between price and consumer purchase intention for western imported food. The quantitative data results illustrate a positive association between western imported food prices and consumer purchase intention. The previous literature has suggested that imported food products had a higher rate compared to local food products [46]. The main reasons offered were that these products perceived to have better overall quality, with quality ingredients, a country of origin, and an established product name [94,95]. Hence, consumers are eager to pay more price for such food brands due to the perception of their superior value $[96,97]$.

The next relationship investigated was between promotion and consumer purchase intention. Results from the quantitative findings indicate that promotion is not associated with consumer purchase intention, which differs from previous literature. Research conducted by Kazmi et al. [19] reported that product communication plays an imperative role in persuading consumers' attitudes to a 
product and thus adds brand recall and awareness about the food brands. Effective communication through various channels such as magazines, newspapers, social media, and television thus enhances food brand awareness, sustenance in the market, and purchase intention, particularly among young consumers [97].

The results showed that the impact of lifestyle does not have any effect on consumer's purchase intention, and showing no association between them. It suggests that Muslim consumer's lifestyles indirectly connected with the purchase intention in the context of western imported food products in Pakistan. On the contrary, the findings from the past literature revealed that consumers' health consciousness to food ingredients strongly motivate and influence consumers to engage in purchasing food brands manufactured outside the country. However, the overall quality and taste are also significant contributors to the purchase decision. Hence, elevating western imported food products [95].

The relationship between family and consumer purchase intention explored. Results indicated neither causal relationship nor any positive association between them. It contrasted with Tsang et al. [96] study which found a correlation between subjective norms and consumer food-buying behavior. Moreover, earlier research by Montano and Kasprzyk [36] endorsed the view that subjective criteria impact consumer food purchase behavior. The quantitative results of the current study of an absence of association can be due to different cultural and societal settings.

The construct of social class was also investigated, with no association found with the consumer buying intention for western imported food in Pakistan. This result differs from those of the literature. Durmaz and Taşdemir [62], for instance, reported that this factor had a substantial influence on customer buying behavior as this influence started throughout childhood, and the family shaped it. The researchers further stated that young people from the upper social class were more brands conscious and likely to seek information about the brand before making the final purchase decision as compared to their lower-class counterparts.

Brand trust was also investigated during the quantitative data analysis, indicating an affirmative corroboration between brand trust of organic food and consumer's intention to purchase. In past research, the construct of brand trust widely discussed, and similar findings revealed. The study conducted by Flavián and Guinaliu [98] reported that the trust element linked with the brand image which reduces the consumers' risk at the time of purchase. Therefore, a positive brand image leads to brand trust. Hence, the improved brand image of a company leads to positive and confident consumer behavior about that brand's products related to food. Other research findings have reinforced a positive association between the brand image of a company and a consumer's brand trust.

The construct of religiosity also tested and it discovered to have a positive association with the intentions of consumers' buying regarding organic food, which aligned with the past literature. Mathras et al. [14] reported that halal consciousness and product elements have considerably influenced Muslims' intention to purchase packaged food that is halal produced by Muslim or non-Muslim producers. Quantitative results confirm earlier research that in Muslim consumers, the religiosity behaves like an intervening factor within the different exogenous and endogenous variable [99]. Therefore, religious ethics perform integral in deciding consumer behavior. Religion guides Muslim consumers to take actions as per religious principles $[15,22,23]$. Thus, the quantitative analysis aligned with the previous literature wherein the connection of religiosity with consumer buying behavior well established.

Self-concept investigated, and results revealed it associated with the consumer purchase intention of western imported food, which aligns with the previous literature. Sirgy [100] reported that consumers preferred those products, which matched (somehow) with their self-concept. Self-concept identified as playing a mediating role concerning the brand effect and the intention to buy. Hoonsopon and Puriwat [101] also confirmed self-concept as a controlling variable for the innovative product purchase intentions. 


\subsection{Moderation Results}

The moderation analysis aimed to establish if gender, income, and city moderate the relationship and impact among independent and mediation, leading to dependent variables. Firstly, gender, income, and city coded as dummy variables. A correlation analysis performed between the dependent variable and dummy coded variables from gender, income, and city to establish which variables might be potential moderators. The only significant correlation obtained between PB and the dummy variable of Income Group 3, i.e., with an income between PKR 64,001-150,000 ( $r=0.065, p=0.047)$. Therefore, the dummy variable of Income Group 3 shortlisted as a potential moderator variable. First, a regression model (Block 1) fitted to predict PB using PI (purchase intention) and the dummy variable of Income Group 3. The regression model found to be significant $(r$-square $=0.586)$. The model coefficients are shown in Table 9; both the main effects of PI and the dummy variable of Income Group 3 were found to be significant.

Table 9. Block 1 regression model.

\begin{tabular}{ccccc}
\hline Model & B & Std. Error & T & Sig. \\
\hline (Constant) & 0.807 & 0.075 & 10.775 & $<0.001$ \\
PI & 0.772 & 0.021 & 36.072 & $<0.001$ \\
Dummy variable indicating that & 0.079 & 0.035 & 2.257 & 0.024 \\
INCOME = 3.0 (“64,001-150,000”). & & & & \\
\hline
\end{tabular}

Next, the interaction between PI and the dummy variable of Income Group 3 added to the Block 1 model, this constituted the Block 2 model. The regression model was found to be significant ( $\mathrm{r}$-square $=$ 0.586). The model coefficients shown in Table 10, after adding the interaction term, the main effect of PI was still substantial but the main impact of the dummy variable of Income Group 3 was not significant anymore. It indicates that the dummy variable of Income Group 3 moderates the relationship between PI and PB, but the main effect of PI is also substantial.

Table 10. Block 2 regression model.

\begin{tabular}{cccc}
\hline Model & & t & Sig. \\
\hline (Constant) & 0.812 & 9.615 & $<0.001$ \\
PI & 0.771 & 31.772 & $<0.001$ \\
Dummy variable indicating that INCOME =3.0 (“64,001-150,000”) & 0.058 & 0.318 & 0.751 \\
PI_X_Income_3 & 0.006 & 0.121 & 0.903 \\
\hline
\end{tabular}

\section{Conclusions}

Pakistan, as a developing country, has shown growth in imported food consumption while experiencing economic growth and stability. Comprehending the Pakistani Muslim consumer means understanding that Pakistan is a Muslim dominated society with 97 percent of its population. This study has examined the consumer motives behind the purchase of western imported food products. Even though prices are on the higher side compared to local food products, western imported food is making inroads into Pakistani food purchasing behavior. The findings concluded that product attributes are positively associated with consumer purchase intentions for the sustenance of western imported food products. The second association demonstrated a positive association between western imported food prices and consumer purchase intention. The study also revealed that promotion is not associated with consumer purchase intention. The results showed that the impact of lifestyle does not have any impact on consumer's purchase intention, and no association was found between them. It suggests that Muslim consumers' lifestyles are indirectly connected with the purchase intention in the context of western imported food products in Pakistan. However, the overall quality and taste are also important contributors to the purchase decision. The relationship between family and consumer 
purchase intention indicated neither causal relationship nor any positive association between them. The construct of social class also investigated, with no association found with the consumer buying intention for western imported food in Pakistan. The researchers further concluded that young people from the upper social class were more brands conscious and likely to seek information about the brand before making the final purchase decision as compared to their lower-class counterparts. The brand trust concluded an affirmative corroboration between brand trust of organic food and consumer's intention to purchase. Hence, the improved brand image of a company leads to positive and confident consumer behavior about that brand's products related to food. The construct of religiosity concluded a positive association with the intentions of consumers' buying regarding organic food. The study provides a holistic picture of cultural understanding, wherein religiosity was one of the central points of discussion to understand Pakistani Muslim consumers' purchase intentions about western imported food. Thus, it provides a strong empirical contribution to research in the context of a Muslim population in the sub-continent by identifying the factors stated above. From a demographic perspective, this study developed a profile of consumers of western imported food. This overall information adds value to the literature on consumer behavior. This profile can serve as a learning paradigm for future researchers interested in working on consumers' food purchasing patterns.

\section{Practical Implications}

The western world always seeks opportunities to export food products to emerging markets. With this strategic export vision, Asian consumer markets present great opportunities for many western food growers and businesses to explore [12]. Hence, this study may facilitate western food producers and exporters to understand Asian consumer behavior in particular western imported food products in Muslim Markets. They may then adjust their current marketing strategy, enabling them to export to such consumer markets. The outcome of this study brings in numerous opportunities for those western marketing practitioners interested in exploring and developing the Asian Muslim majority consumer market. Western food producers may differentiate their product offerings by emphasizing key attributes extracted from this study such as taste, quality, attractive packaging, and ingredients. Having a differentiated product may add a meaningful benefit which may enhance consumers' quality perception or may decrease the perceived risk associated with the use of western imported food products. The enhancement in product attributes may develop brand trust and justification of premium price charged by these western food producers. Since this research is based on a Muslim majority population country, western producers must consider the element of religiosity at the time of developing their marketing strategy. Incorporating the halal logo or stamp, which displays halal product authentication, is highly important for western imported food producers as this builds trust among Muslim consumers to purchase and consume such food. The findings witnessed a positive association with purchase intention towards western food items. Thus, this validates the importance of religiosity and, in particular, the halal authentication is the most important factor for the prospective consumer.

\section{Theoretical Contribution}

The theory of planned behavior once again verified as a powerful model for testing consumer purchase intention by combining several factors on a single model [30]. New constructs added in TPB to enhance the explanatory power $[32,34,35]$ in various domains. Thus, the present study has included marketing mix (product, price, and promotion); followed by consumer-related factors such as personality, social class, brand trust, and lifestyle; under the antecedents of attitude for family and friends; the antecedents of subjective norms such as self-concept and religiosity; and the antecedents of behavioral control. These tested concepts, for purchase intentions, are a strong contribution in this area of consumer behavior literature. The researchers have considered the above-stated factors as it plays an imperative role in food purchase intention. Therefore, understanding Muslim consumers' perception of western imported food products is significant. The undertaken study also provided the 
existence of religiosity as a dimension of behavioral control. Adding in this way to the stated theory in the Muslim context where religiosity impacts purchasing and, in particular, food buying choices.

\section{Limitations and Areas of Further Research}

This research mainly restricted to the eight urban metropolitan cities of Pakistan, and this results in a lack of reliability and credibility of the study outcome. In future studies, researchers can work on the number of cities and make a comparison between cities by utilizing the factors addressed in this study. A cross-country comparison among the cities would be a new area of investigation for researchers and an opportunity for marketers to alter their food product categories accordingly. There is a lack of concentration on a specific food category. This study-addressed consumers' motives behind the purchase of western imported food in general hence generalization to a specific food category is weak. Moving ahead, researchers can choose a specific category, for example, within fast-moving consumer goods (FMCG), a category of milk or any specific food item such as chocolates or biscuits explored. Within this category, a comparison study developed between the local and imported product categories. This research was limited to several consumer participants' groups such as homemakers, university students, and professionals. Pakistan represents many ethnic cultures by adding more participant ethnic groups in the future with specific race/ethnicity, which may provide a better insightful representation of consumer perception in the respective buying behavior as well as facilitate more reliable comparisons.

Author Contributions: Conceptualization, F.B. and S.H.; Methodology, R.R.A.; Software, R.H.S.; Validation, D.S., R.R.A., and Z.A.C.; Formal analysis, S.H.; Investigation, F.B.; Resources, D.S.; Data curation, R.H.S.; Writing-original draft preparation, F.B.; Writing—review and editing, Z.A.C.; Visualization, D.S.; Supervision, R.R.A.; Project administration, D.S. All authors have read and agreed to the published version of the manuscript.

Funding: This research received no external funding.

Acknowledgments: We acknowledge the support of IQRA University that provided during this project including administrative and technical support.

Conflicts of Interest: The authors declare no conflict of interest.

\section{References}

1. Forghani, M.H.; Kazemi, A.; Ranjbarian, B. Religion, peculiar beliefs and luxury cars' consumer behavior in Iran. J. Islam. Mark. 2019, 10, 673-688. [CrossRef]

2. Agarwala, R.; Mishra, P.; Singh, R. Religiosity and consumer behavior: A summarizing review. J. Manag. Spiritual. Relig. 2019, 16, 32-54. [CrossRef]

3. Choi, Y.; Paulraj, A.; Shin, J. Religion or religiosity: Which is the culprit for consumer switching behavior? J. Int. Consum. Mark. 2013, 25, 262-280.

4. Shukor, S.A.; Jamal, A. Developing scales for measuring religiosity in the context of consumer research. Middle-East. J. Sci. Res. 2013, 13, 69-74.

5. Quoquab, F.; Pahlevan, J.; Ramayah, T.M. Factors affecting consumers' intention to purchase a counterfeit product: An empirical study in the Malaysian market. Asia Pac. J. Mark. Logist. 2017, 29, 837-853. [CrossRef]

6. Swimberghe, K.; Flurry, L.A.; Parker, J.M. Consumer religiosity: Consequences for consumer activism in the United States. J. Bus. Ethics 2011, 103, 453-467. [CrossRef]

7. Asri, N.M.; Aziz, A.A. Halal Dietary Supplement Products in Malaysia. In Management of Shari'ah Compliant Businesses; Springer: Berlin/Heidelberg, Germany, 2019; pp. 133-138.

8. Hackett, C.; Lipka, M. The demographic factors that make Islam the world's fastest-growing major religious group. (The Religious and Ethnic Future of Europe). Scr. Inst. Donneriani Abo. 2018, 28, 11-14. [CrossRef]

9. Hackett, C.; Connor, P.; Stonawski, M.; Skirbekk, V. The Future of World Religions: Population Growth Projections, 2010-2050; Pew Research Center: Washington, DC, USA, 2015.

10. Al Harethi, A.R.S. The Role of The Islamic Economy in Rationalizing Consumer Behavior. J. Islam. Bus. Econ. Rev. 2019, 2, 13-17. 
11. Zahid, M.M.; Ali, B.; Ahmad, M.S.; Thurasamy, R.; Amin, N. Factors Affecting Purchase Intention and Social Media Publicity of Green Products: The Mediating Role of Concern for Consequences. Corp. Soc. Responsib. Environ. Manag. 2018, 25, 225-236. [CrossRef]

12. Hayat, N.; Hussain, A.; Yousaf, H. Food demand in Pakistan: Analysis and projections. South Asia Econ. J. 2016, 17, 94-113. [CrossRef]

13. Ramli, A.M.; Mirza, A.A.I. The Theory of Consumer Behavior: Conventional vs Islamic. In Proceedings of the 2nd Islamic Conference (iECONS2007); Faculty of Economics and Muamalat, Islamic Science University of Malaysia: Nilai, Malaysia, 2010.

14. Mathras, D.; Cohen, A.; Mandel, N.; Mick, D.G. The effects of religion on consumer behavior: A conceptual framework and research agenda. J. Consum. Psychol. 2016, 26, 298-311. [CrossRef]

15. Khalek, A.A.; Sharifah, H.S.; Hairunnisa, M.I. A study on the factors influencing young Muslims' behavioral intention in consuming halal food in Malaysia. J. Syariah 2015, 23, 79-102.

16. Bornemann, T.; Schöler, L.; Homburg, C. In the eye of the beholder? The effect of product appearance on shareholder value. J. Prod. Innov. Manag. 2015, 32, 704-715. [CrossRef]

17. Chamhuri, N.; Batt, P.J. Consumer perceptions of food quality in Malaysia. Br. Food J. 2015, 117, 1168-1187. [CrossRef]

18. Kazmi, S.A.Z.; Naarananoja, M.; Kytola, J. Harnessing new product development processes through strategic thinking initiatives. Int. J. Strateg. Decis. Sci. 2015, 6, 28-48. [CrossRef]

19. Kazmi, S.A.Z.; Naaranoja, M.; Kytola, J.; Kantola, J. Effective Corporate Communication: A Solution to Foster New Product Idea Generation Dynamics. In Advances in Human Factors, Business Management, Training, and Education; Springer: Cham, Gremany, 2017; pp. 1033-1045.

20. Shah, S.A.M.; Amjad, S. Investigating moral ideology, ethical beliefs, and moral intensity among consumers of Pakistan. Asian J. Bus. Ethics 2017, 6, 153-187. [CrossRef]

21. Yousaf, S.; Malik, M.S. Evaluating the influences of religiosity and product involvement level on the consumers. J. Islam. Mark. 2013, 4, 163-186. [CrossRef]

22. Wan Ismail, W.R.; Othman, M.; Rahman, R.A.; Kamarulzaman, N.H.; Ab Rahman, S.B. "Is sharing really caring?" The impact of eWoM on halal tolerance among Malay Muslim consumers. J. Islam. Mark. 2019, 10, 394-409. [CrossRef]

23. Hosseini, S.M.P.; Mirzaei, M.; Iranmanesh, M. Determinants of Muslims' willingness to pay for halal-certified food. J. Islam. Mark. 2019. [CrossRef]

24. Souiden, N.; Jabeur, Y. The impact of Islamic beliefs on consumers' attitudes and purchase intentions of life insurance. Int. J. Bank Mark. 2015, 33, 423-441. [CrossRef]

25. Ali, S.; Ullah, H.; Akbar, M.; Akhtar, W.; Zahid, H. Determinants of Consumer Intentions to Purchase Energy-Saving Household Products in Pakistan. Sustainability 2019, 11, 1462. [CrossRef]

26. Euro Monitor. Packaged Food in Australia 2018. 2018. Available online: https://www.euromonitor.com/ packaged-food-in-australia/report (accessed on 20 September 2019).

27. Khan, S.N.; Mohsin, M. The power of emotional value: Exploring the effects of values on green product consumer choice behavior. J. Clean. Prod. 2017, 150, 65-74. [CrossRef]

28. Ali, S.; Danish, M.; Khuwaja, F.M.; Sajjad, M.S.; Zahid, H. The Intention to Adopt Green IT Products in Pakistan: Driven by the Modified Theory of Consumption Values. Environments 2019, 6, 53. [CrossRef]

29. Donald, B.; Glasmeier, A.; Gray, M.; Lobao, L. Austerity in the City: Economic Crisis and Urban Service Decline? Camb. J. Reg. Econ. Soc. 2014, 7, 3-15. [CrossRef]

30. Armitage, C.J.; Conner, M. Efficacy of the theory of planned behaviour: A meta-analytic review. Br. J. Soc. Psychol. 2001, 40, 471-499. [CrossRef]

31. Robinson, R.; Smith, C. Psychosocial and demographic variables associated with consumer intention to purchase sustainably produced foods as defined by the Midwest Food Alliance. J. Nutr. Educ. Behav. 2002, 34, 316-325. [CrossRef]

32. Arvola, A.; Vassallo, M.; Dean, M.; Lampila, P.; Saba, A.; Lahteenmaki, L.; Shepherd, R. Predicting intentions to purchase organic food: The role of affective and moral attitudes in the Theory of Planned Behaviour. Appetite 2008, 50, 443-454. [CrossRef]

33. Ajzen, I. The theory of planned behavior. Organ. Behav. Hum. Decis. Process. 1991, 50, 179-211. [CrossRef]

34. Yadav, R.; Pathak, G.S. Young consumers' intention towards buying green products in a developing nation: Extending the theory of planned behavior. J. Clean. Prod. 2016, 135, 732-739. [CrossRef] 
35. Yadav, R.; Pathak, G.S. Determinants of consumers' green purchase behavior in a developing nation: Applying and extending the theory of planned behavior. Ecol. Econ. 2017, 134, 114-122. [CrossRef]

36. Montano, D.E.; Kasprzyk, D. Theory of Reasoned Action, Theory of Planned Behavior, and the Integrated Behavioral Model. Chapter 6 Health Behavior. In Theory, Research, and Practice Book, 5th ed.; Karen, G., Barbara, R., Viswanath, K., Eds.; Jossey-Bass: San Francisco, CA, USA, 2015; pp. 95-124.

37. Glock, C.; Stark, R. The New Denominationalism. Rev. Relig. Res. 1965, 7, 8-17.

38. Shamsher, R. Relationship between Store Characteristics and Store Loyalty: An Explorative Study. Int. J. Econ. Empir. Res. 2014, 2, 431-442.

39. Jamal, A.; Goode, M. Consumers, and brands: A study of the impact of self-image congruence on brand preference and satisfaction. Mark. Intell. Plan. 2001, 19, 482-492. [CrossRef]

40. Torjusen, H.; Lieblein, G.; Wandel, M.; Francis, C.A. Food system orientation and quality perception among consumers and producers of organic food in Hedmark County, Norway. Food Qual. Prefer. 2001, 12, $207-216$. [CrossRef]

41. Dahm, M.J.; Samonte, A.V.; Shows, A.R. Organic foods: Do eco-friendly attitudes predict eco-friendly behaviors? J. Am. Coll. Health 2009, 58, 195-202. [CrossRef]

42. Chen, Y.S.; Chang, C.H. Enhance green purchase intentions: The roles of green perceived value, green perceived risk, and green trust. Manag. Decis. 2012, 50, 502-520. [CrossRef]

43. Knight, B.A. Towards Inclusion of Students with Special Educational Needs in the Regular Classroom. SfL-NASEN 1999, 14, 3-7. [CrossRef]

44. Kotler, P.; Keller, K.L. Marketing Management Global, 14th ed.; Pearson Education Limited: London, UK, 2012.

45. Kotler, P. Marketing Management; Asia and North America Edition; Pearson Prentice Hall: New York, NY, USA, 2009.

46. Sharma, Y.; Nasreen, R.; Mishra, V. Impact of Consumer-Centric Marketing-Mix on Purchase Behavior of Non-Core Food Items: An Empirical Study of Urban Subsistence Marketplace. Asian J. Manag. Sci. 2017, 6, 28-41.

47. Song, B.L.; Safari, M.; Mansori, S. The marketing stimuli factors influencing consumers' attitudes to purchase organic food. Int. J. Bus. Manag. 2016, 11, 109-119.

48. Chryssochoidis, G.; Krystallis, A.; Perreas, P. Ethnocentric-beliefs and country-of-origin (COO) effect-Impact of country, product and product attributes on Greek consumers' evaluation of food products. Eur. J. Mark. 2007, 41, 1518-1544. [CrossRef]

49. Banerjee, S. Influence of consumer personality, brand personality, and corporate personality on brand preference: An empirical investigation of the interaction effect. Asia Pac. J. Mark. Logist. 2016, 28. [CrossRef]

50. Chang, A.; Tseng, C.H.; Chu, M.Y. Value creation from a food traceability system based on a hierarchical model of consumer personality traits. Br. Food J. 2013, 115, 1361-1380. [CrossRef]

51. Bolton, R.N.; Parasuraman, A.; Hoefnagels, A.; Kabadayi, S.; Gruber, T.; Loureiro, Y.K.; Solent, D. Understanding Generation $\mathrm{Y}$ and their use of Social Media: A Review and Research Agenda. J. Serv. Manag. 2013, 24, 245-267. [CrossRef]

52. Goddard, A.; Morrow, D. Assessing the impact of motivational interviewing via co-active life coaching on engagement in physical activity. Int. J. Evid.-Based Coach. Mentor. 2015, 13, 101-121.

53. Ahaiwe, E.; Onwumere, J.; Agodi, J. Analysis of determinants of Brand Preference for Cosmetics in Abia State, Nigeria. Int. J. Bus. Manag. 2015, 3, 244-250.

54. Qing, P.; Lobo, A.; Chongguang, L. The impact of lifestyle and ethnocentrism on consumers' purchase intentions of fresh fruit in China. J. Consum. Mark. 2012, 29, 43-52. [CrossRef]

55. Lassoued, R.; Hobbs, J. Consumer confidence in credence attributes: The role of brand trust. Food Policy 2015, 52, 99-107. [CrossRef]

56. Szakály, Z.; Szente, V.; Kövér, G.; Polereczki, Z.; Szigeti, O. The influence of lifestyle on health behavior and preference for functional foods. Appetite 2012, 58, 406-413. [CrossRef]

57. Al-Swidi, A.K.; Behjati, S.; Shahzad, A. Antecedents of Online Purchasing Intention among MBA Students: The Case of University Utara Malaysia Using the Partial Least Squares Approach. Int. J. Bus. Manag. 2012, 7, 35-49. [CrossRef]

58. Yazdanpanah, M.; Forouzani, M. Application of the Theory of Planned Behaviour to Predict Iranian Students' Intention to Purchase Organic Food. J. Clean. Prod. 2015, 107, 342-352. [CrossRef] 
59. Kautonen, T.; van Gelderen, M.W.; Fink, M. Behavior Robustness of the Theory of Planned in predicting entrepreneurial intentions and actions. Entrep. Theory Pract. 2015, 39, 655-674. [CrossRef]

60. Armstrong, E.A.; Hamilton, L.T.; Armstrong, E.M.; Seeley, J.L. "Good Girls”: Gender, Social Class, and Slut Discourse on Campus. Soc. Psychol. Q. 2014. [CrossRef]

61. Rani, P. Factors influencing consumer behaviour. Int. J. Curr. Res. Acad. Rev. 2014, 2, 52-61.

62. Durmaz, Y.; Taşdemir, A.A. Theoretical Approach to the Methods Introduction to International Markets. Int. J. Bus. Soc. Sci. 2014, 5, 47-54.

63. Majabadi, H.A.; Solhi, M.; Montazeri, A.; Shojaeizadeh, D.; Nejat, S.; Farahani, F.K.; Djazayeri, A. Factors Influencing Fast-Food Consumption Among Adolescents in Tehran: A Qualitative Study. Iran. Red Crescent Med. J. 2016, 18, e23890. [CrossRef]

64. Gonzalez-Jimenez, H. The self-concept life cycle and brand perceptions: An interdisciplinary perspective. AMS Rev. 2017, 7, 67. [CrossRef]

65. Sung, Y.; Choi, S.M. The influence of self-construal on self-brand congruity in the United States and Korea. J. Cross-Cult. Psychol. 2012, 43, 151-166. [CrossRef]

66. Lee, J. Universals and specifics of math self-concept, math self-efficacy, and math anxiety across 41 PISA 2003 participating countries. Learn. Individ. Differ. 2009, 19, 355-365. [CrossRef]

67. Tuškej, U.; Golob, U.; Podnar, K. The role of consumer-brand identification in building brand relationships. J. Bus. Res. 2013, 66, 53-59. [CrossRef]

68. Hoonsopon, D. The Moderating Effects of Self-Brand Concept and Reference Group on Consumer Innovativeness Toward Purchase Intention. In Marketing Challenges in a Turbulent Business Environment. Developments in Marketing Science: Proceedings of the Academy of Marketing Science; Groza, M., Ragland, C., Eds.; Springer: Cham, Gremany, 2016.

69. Chen, W.; Lee, K. Sharing, liking, commenting, and distressed? The pathway between Facebook interaction and psychological distress. Cyberpsychol. Behav. Soc. Netw. 2013, 16, 728-734. [CrossRef]

70. Su, J.; Tong, X. Brand personality, consumer satisfaction, and loyalty: A perspective from denim jeans brands. Fam. Consum. Sci. Res. J. 2016, 44, 427-446. [CrossRef]

71. Drescher, J.; Cohen-Kettenis, P.; Winter, S. Minding the body: Situating gender identity diagnoses in the ICD-11. Int. Rev. Psychiatry 2012, 24, 568-577. [CrossRef]

72. Shaharudin, M.R.; Pani, J.J.; Mansor, S.W.; Elias, S.J. Purchase Intention of Organic Food in Kedah, Malaysia; A Religious Overview. Int. J. Mark. Stud. 2010, 2, 96-103.

73. Chaudhry, S.; Razzaque, M.A. Religious Commitment and Muslim Consumers: A Model. to Study the Consumer Decision Making Process. In Proceedings of the 2010 Academy of Marketing Science (AMS) Annual Conference. Developments in Marketing Science: Proceedings of the Academy of Marketing Science; Deeter-Schmelz, D., Ed.; Springer: Cham, Gremany, 2015.

74. Rakrachakarn, V.; Moschis, G.P.; Ong, F.S.; Shannon, R. Materialism and life satisfaction: The role of religion. J. Relig. Health 2015, 54, 413-426. [CrossRef] [PubMed]

75. Vitell, S.J. The role of religiosity in business and consumer ethics: A review of the literature. J. Bus. Ethics 2009, 90, 155-167. [CrossRef]

76. Hannah, S.T.; Avolio, B.J.; May, D.R. Moral Maturation and Moral Conation: A Capacity Approach to Explaining Moral Thoughts and Action. Acad. Manag. Rev. 2011, 36. [CrossRef]

77. Vassallo, M.; Scalvedi, M.L.; Saba, A. Investigating psychosocial determinants in influencing sustainable food consumption in Italy. Int. J. Consum. Stud. 2016, 40, 422-434. [CrossRef]

78. Smith, S.; Paladino, A. Eating clean and green? Investigating consumer motivations towards the purchase of organic food. Australas. Mark. J. 2010, 18, 93-104. [CrossRef]

79. Wee, C.S.; Ariff, M.S.B.M.; Zakuan, N.; Tajudin, M.N.M. Consumers perception, purchase intention and actual purchase behavior of organic food products. Rev. Integr. Bus. Econ. Res. 2014, 3, 378-397.

80. Peter, J.P.; Olson, J.C. Consumer Behavior and Marketing Strategy, 8th ed.; McGraw-Hill, International Edition: Singapore, 2008; p. 400.

81. Krystallis, A.; Fotopoulos, C.; Zotos, Y. Organic Consumers' Profile and Their Willingness to Pay (WTP) for Selected Organic Food Products in Greece. J. Int. Consum. Mark. 2006, 19, 81-106. [CrossRef]

82. Gobo, G. Upside down. Reinventing research design. Chapter 5. In Handbook of Qualitative Data Collection; Flick, U., Ed.; Sage: London, UK, 2018; pp. 65-83. 
83. Hair, J.; Risher, J.; Sarstedt, M.; Ringle, C. When to use and how to report the results of PLS-SEM. Eur. Bus. Rev. 2019, 31, 2-24. [CrossRef]

84. Ahmed, R.R.; Streimikiene, D.; Berchtold, G.; Vveinhardt, J.; Channar, Z.A.; Soomro, R.H. Effectiveness of Online Digital Media Advertising as A Strategic Tool for Building Brand Sustainability: Evidence from FMCGs and Services Sectors of Pakistan. Sustainability 2019, 11, 3436. [CrossRef]

85. Hair, J.F., Jr.; Black, W.C.; Babin, B.J.; Anderson, R.E.; Tatham, R.L. Multivariate Data Analysis, 6th ed.; Prentice-Hall: Upper Saddle River, NJ, USA, 2006.

86. Ahmed, R.R.; Vveinhardt, J.; Štreimikiene, D. The direct and indirect impact of Pharmaceutical industry in Economic expansion and Job creation: Evidence from Bootstrapping and Normal theory methods. Amfiteatru Econ. 2018, 20, 454-469. [CrossRef]

87. Chatfield, C. Introduction to Multivariate Analysis; Routledge: New York, NY, USA, 2018.

88. Hair, J.F., Jr.; Hult, G.T.M.; Ringle, C.M.; Sarstedt, M. A Primer on Partial Least Squares Structural Equation Modeling (PLS-SEM), 2nd ed.; Sage Publications: Thousand Oaks, CA, USA, 2016.

89. Hoelter, J.W. The analysis of covariance structures: Goodness-of-fit indices. Sociol. Methods Res. 1983, 11, 325-344. [CrossRef]

90. Kline, T.J.B.; Sulsky, L.M.; Rever-Moriyama, S.D. Common method variance and specification errors: A practical approach to detection. J. Psychol. 2000, 134, 401-421. [CrossRef]

91. Fornell, C.; Larcker, D.F. Evaluating structural equation models with unobservable variables and measurement error. J. Mark. Res. 1981, 39, 39-50. [CrossRef]

92. Lian, S.B.; Yoong, L.C. Assessing the Young Consumers' Motives and Purchase Behavior for Organic Food: An Empirical Evidence from a Developing Nation. Int. J. Acad. Res. Bus. Soc. Sci. 2019, 9, 69-87. [CrossRef]

93. Nasution, M.D.T.P.; Rossanty, Y. Country of origin as a moderator of a halal label and purchase behaviour. J. Bus. Retail Manag. Res. 2018, 12, 194-201. [CrossRef]

94. Tomić, M.; Alfnes, F. Effect of Normative and Affective Aspects on Willingness to Pay for Domestic Food Products-A Multiple Price List Experiment. J. Food Prod. Mark. 2018, 24, 681-696. [CrossRef]

95. Nguyen, H.V.; Nguyen, N.; Nguyen, B.K.; Lobo, A.; Vu, P.A. Organic food purchases in an emerging market: The influence of consumers' personal factors and green marketing practices of food stores. Int. J. Environ. Res. Public Health 2019, 16, 1037. [CrossRef]

96. Tsang, M.M.; Ho, S.C.; Lian, T.P. Consumer attitudes toward mobile advertising: an empirical study. Int. J. Elec. Com. 2004, 8, 65-78. [CrossRef]

97. Cui, L.; Jiang, H.; Deng, H.; Zhang, T. The influence of the diffusion of food safety information through social media on consumers' purchase intentions: An empirical study in China. Data Technol. Appl. 2019, 53, 230-248. [CrossRef]

98. Flavián, C.; Guinaliu, M.; Torres, E. The influence of corporate image on consumer trust: A comparative analysis in traditional versus internet banking. Internet Res. 2005, 15, 447-470. [CrossRef]

99. Garg, P.; Joshi, R. Purchase intention of "Halal" brands in India: The mediating effect of attitude. J. Islam. Mark. 2018, 9, 683-694. [CrossRef]

100. Sirgy, M.J. Self-congruity theory in consumer behavior: A little history. J. Glob. Sch. Mark. Sci. 2018, 28, 197-207. [CrossRef]

101. Hoonsopon, D.; Puriwat, W. The effect of reference groups on purchase intention: Evidence in distinct types of shoppers and product involvement. Australas. Mark. J. 2016, 24, 157-164. [CrossRef]

(C) 2020 by the authors. Licensee MDPI, Basel, Switzerland. This article is an open access article distributed under the terms and conditions of the Creative Commons Attribution (CC BY) license (http://creativecommons.org/licenses/by/4.0/). 


\title{
Article
}

\section{Sustainable Brand Management of Alimentary Goods}

\author{
Jana Majerova ${ }^{1, *}$, Wlodzimierz Sroka ${ }^{2,3}$, Anna Krizanova ${ }^{1}$, Lubica Gajanova ${ }^{1}$, \\ George Lazaroiu ${ }^{4}$ and Margareta Nadanyiova ${ }^{1}$ \\ 1 Department of Economics, Faculty of Operation and Economics of Transport and Communications, \\ University of Zilina, Zilina 026 01, Slovakia; anna.krizanova@fpedas.uniza.sk (A.K.); \\ lubica.gajanova@fpedas.uniza.sk (L.G.); margareta.nadanyiova@fpedas.uniza.sk (M.N.) \\ 2 Management Department, WSB University, Dabrowa Gornicza 41-300, Poland; WSroka@wsb.edu.pl \\ 3 North-West University, Potchefstroom 2351, South Africa \\ 4 Department of Economic Sciences, Spiru Haret University, Bucharest 030045, Romania; \\ phd_lazaroiu@yahoo.com \\ * Correspondence: jana.majerova@fpedas.uniza.sk; Tel.: +421-41-513-3099
}

Received: 20 November 2019; Accepted: 9 January 2020; Published: 11 January 2020

\begin{abstract}
Sustainability of food production and consumption has become one of the most discussed topics of sustainable development in global context. Thus, traditional managerial patterns have to be revised according to the social request. The revisions that have been done so far are based on relevant specifics of production and have mostly general character. Moreover, traditional managerial postulates do not change; only their way of implementation is modified. These two facts are possible reason of the practical fails in sustainable management of alimentary goods. One of these traditional managerial concepts is brand. Within this context, it has been considered as a facilitator of CSR (corporate social responsibility) activities. But the situation has changed, and the suspicion that brand loyalty is not a facilitator but an obstacle to the sustainable management is high. Thus, the importance of research of brand loyalty in scope of sustainable management of alimentary goods is indisputable. According to the above mentioned, the main goal of the contribution is to identify relevant brand value sources of loyalty in scope of sustainable brand management of alimentary goods. To achieve this, the factor analysis has been applied to provide statistical evaluation of data obtained from our own questionnaire survey. We have found out that components of brand value sources do not vary when comparing brands and those without loyal consumers. Based on this, appropriate recommendations for the theory and practice of sustainable brand management of alimentary goods have been formulated.
\end{abstract}

Keywords: brand; branding; brand management; sustainability; alimentary goods; brand loyalty

JEL Classification: Q01; M11; M31

\section{Introduction and Current Situation Insight}

Contemporary scientific literature highlights the importance of corporate social responsibility in the sustainable management process, not only in general, but also regarding the sectoral specifics of production [1-3]. Thus, according to this trend, producers of alimentary goods should put moral pressure on their suppliers, and consumers should be more involved in their buying decision processes [4]. In order to achieve these changes in so far functioning stereotypes, the issue of brand and brand management should be highlighted. But the fact that alimentary goods are characterized by traditional habitual buying behavior creates a specific obstacle to such an approach, because the reason is that, in this type of buying behavior, consumer's loyalty is the leading motivation for purchase whether or not the brand is socially responsible on the market $[5,6]$. The above-mentioned fact can be considered as a real problem when seeking to achieve sustainability in scope of food production 
and consumption. The main reason for this is that brand managers of alimentary goods in case of brands subjectively perceived as valuable are not motivated enough to act responsibly towards society, and consumers are not motivated to play active role in the process of information searching [7]. In this case, socially responsible activities are not directly connected with desired effect, even if they are applied in accordance with contemporary state of knowledge. While the main theoretical attention is generally paid to the issue of facilitators of sustainable management, practice shows the need of application of an opposite approach - that is, a focus on possible obstacles to optimal implementation of managerial patterns. Thus, it is vital to change the approach and to focus not on the facilitators but on the contrary, also on the obstacles to sustainable development. Only when these barriers are identified will it be possible to manage them and to eliminate their negative impacts on the effectiveness of sustainable management. Thus, the irony is, on the one hand, the phenomenon of consumer loyalty can be considered as a stimulus, and on the other hand, as an obstacle to sustainable performance of brands on alimentary goods market. According to this fact, it is vital to analyze value sources of brands characterized by presence vs. absence of consumer loyalty and to apply a conscious and responsible approach to the consumer's loyalty as one of the leading buying behavior motivations.

Thus, this article focuses on the meaning of brand loyalty research in the scope of sustainable management of alimentary goods. The first part of the article analyses interactions between loyalty and sustainable brand management in general, as well as in case of alimentary goods. This is followed by a methodological part of the article where the main postulates of the article as well as factor analysis and relevant statistical tests are described. The next part synthetizes obtained results formulated on the basis of detected discrepancies in value sources of brands characterized by presence vs. absence of consumer's loyalty. The discussion is also an immanent part of the article and it is included in the same part as results of the research itself. The last part contains the summary of the main results and outcomes of research with implications for the future.

The conceptualization of the research is as follows: (1) literature review and current situation summary; (2) formulation of original presumptions of authors; (3) creation of the model of research based on questionnaire survey; (4) realization of the research itself; (5) statistical testing and evaluation of obtained data; (6) formulation of conclusions and managerial implications, and (7) critical consideration of framework conditions of applicability of the research outcomes, obstacles and limits of the research, and possible ways of further research in scope of sustainable brand management of alimentary goods. Doing all the mentioned activities while respecting the contemporary state of knowledge in the area of brand management, corporate social responsibility, strategic management, and statistics.

\section{Literature Review and Theoretical Background of Research Itself}

In recent decades, many researches in scope of the complex issue of corporate social responsibility have been carried out. However, it is still necessary to continue investigating its benefits and causalities in scope of marketing [8]. Thus, nowadays, it is crucial that the attention is paid to the impact of contemporary global trends on the practical aspects of managerial challenges stimulated by incorporation of the concept of corporate social responsibility. The reason is the assumption that it affects significantly the success of each company and its competitiveness by modifying traditional managerial patterns according to the postulates of corporate social responsibility [9]. Until now, the research has investigated this issue separately, without any deeper interactions with overall managerial framework. The representative example of such an approach is a huge scientific school focused on the analysis of supply chain management and its importance in sustainable management. It has been concluded that such an approach is insufficient, and formulated advices for managers should be revised according to the wider consequences of implementation of sustainable management [10]. Despite this fact, the importance of sustainable supply chain management as an immanent part of corporate social responsibility with significant impact on consumer buying behavior is indisputable. The reason is that consumers adapt supply chain practice to the real socially responsible behavior of the company and they perceive their own value across the prism of the market performance of the company and its 
transformation into real corporate citizenship [11]. So it is obvious that brands strongly affect overall sustainable development of the society as they can be considered as a powerful tool to create and maintain public opinion [12]. According to the above mentioned, brands are becoming parts of people's lives all over the world. They form an immanent part of human beings' reality and they co-act in the process of own value creation as they have strong interpretation power about their consumers [13]. Moreover, brands have become a very effective tool of communication. By these, consumers inform other members of their social group who they are and if they really belong to a specific social group. It is a way to communicate one's own social status and life values. Thus, once the brand starts to be perceived as valuable from the point of view of selected group of consumers, it is very likely that this group starts to be identified with this brand and all the group members will transform into loyal consumers who consider such a brand as subjectively valuable for them. A logical consequence of this situation is that there will be many benefits, like less price sensitivity, lower need of communication activities of such a brand, less critical approach towards quality, and so forth. Thus, a loyal consumer is a dream of each brand manager because only by personalizing a consumer with a brand, can brand management be considered as really effective. However, there is not only a one-way influence between brand and consumers. While, at the beginning, the brand is created by consumers, very shortly after creating a loyal consumer platform, consumers start to be modified by the brand. It means that the brand has potential to change social attitudes and life values and it is willing to be the real tool of social change leading to the sustainable development [14]. Thus, brands characterized by their environmental conformity can be transformed into a strong tool to learn who their consumers are. On the one hand, there is a huge amount of brands who are primarily focused on already environmentally oriented consumers, but on the other hand, there are many more brands (traditionally perceived as valuable and significant for selected social groups) that can change the environmental orientation of their consumers [15]. In scope of the above mentioned, it is vital to pay attention to the detailed segmentation of consumers. The reason is that the segment of socially responsible consumers can vary internally according to the highlighted green attitudes connected to brands. It means that there is at least a double construct of a socially responsible consumer: (1) a consumer who is really internally environmentally oriented and who prefers socially responsible brands when making a buying decision and (2) a consumer whose environmental attitudes are only derived and narrowly connected with the essence of his/her favorite brand. The main difference between these two types of consumers lies in the fact that, while in the first case, socially responsible orientation of the brand is the key attribute of its brand value building, in the second case, such a consumer does not prefer socially responsible brands automatically as it is only consequence of long-term subjectively perceived brand value and the main motive for brand value substitution would not be its replacement by a more environmentally friendly brand. Thus, it is vital to identify real internal attitudes of consumers and to discover if the subjectively perceived brand value is reason or consequence of its socially responsible market behavior [16]. So the main task for managers of not only formally but really sustainably manageable brands is to identify internal motives and brand value sources of their consumers and to co-act in the process of market education as one of the prerequisites of socially sustainable development [17].

One of possible tools to achieve this state is to apply a conscious and responsible approach to the consumer's loyalty and its creation through brand management [18]. The reason of such a postulate is that the traditional educational model of consumers (push model) has failed and thus, it is necessary to apply the opposite one (pull model). The main idea of such a model lies in identification of appropriate brand value sources of brands characterized by loyal and nonloyal attitudes and in subsequent usage of relevant brand loyalty sources (brand value sources in case of loyal brands) for purposes of sustainable management. Thus, subconscious consumers' education would be applied-that is, brands will affect consumer's environmental attitudes through existing brand value sources, and this change in attitudes will affect their general attitudes towards sustainable development of society. Unless this is done, the consumer's loyalty can be, in specific product categories, considered as a significant obstacle to the development of sustainable management and corporate social responsibility. That is why 
companies who are devoting significant resources to socially responsible activities, insights into the optimal formulation, implementation, and effectiveness estimation of socially responsible strategies are nowadays still on the crossroad [19].

Although the scientific literature clearly stated strong positive correlation between corporate social responsibility implementation into strategic management of the company and its positive image, the individual processes and mechanisms which are relevant from the point of view of this positive effect creation have not been analyzed in details so far [20]. Although the possible significant impact of psychographic characteristics of consumers on the process of a brand's positive image creation has been highlighted, there is a scientific gap lying in the need of the mechanisms of behavioral economics investigation [21]. In scope of the above mentioned, Song et al. focused on the identification of a relationship between selected structural associations and brand loyalty. They provided a case study on the example of coffee shop brands. As a result of the scientific effort of Song et al., it has been discovered that the phenomenon of so-called love brands is extremely effective in the process of brand loyalty creation and management [22]. Other researches have proven the significance of brand satisfaction and brand trust in the process of brand loyalty creation and maintenance [23,24]. On the other hand, not only the impact of selected subjectively perceived brand value sources on the brand loyalty has been investigated, but also the impact of brand loyalty and its value sources on the effectiveness of brand social responsibility has been analyzed. As a result, it has been concluded that brand loyalty is essential in the process of sustainable brand management implementation via systematic manipulation with (1) attitudinal loyalty, (2) expenditure level, and (3) intention to buy and recommend [25].

Since the very beginning of brand loyalty research, authors have examined separately purchase loyalty and attitudinal loyalty as two main aspects of brand loyalty. Recently, the first of them has been connected with factual brand performance, while the second one has been described as only a hypothetical construct of brand loyalty without significant impact on brand performance on the market [26]. This research rejected the original concept of dual structure of brand loyalty, which was constructed on the presumption of the meaning of attitudinal loyalty as a key issue in the pricing fences setting [27].

In addition to this dual approach to the brand loyalty research, also another one has been applied - brand as a way to build loyalty and loyalty as a way to build a brand. Bhattacharya and Sen have determined the conditions under which consumers enter into an emotional relationship with brands. Based on this, they have detected loyalty as one of the presumptions of subjectively perceived brand value. Thus, they have applied the opposite concept to the so far implemented. According to this, Bhattacharya and Sen doubt subjectively perceived brand value as an antecedent of brand loyalty creation [28]. Following this approach, Stocchi and Fuller identified brand loyalty with the main brand equity source, discussing different segments of consumers and different markets [29]. In their approach, we can see another dimension of brand loyalty research because they draw from the general approach and they also apply a diversified approach. They conclude that difference in ranking of individual brand value sources (not only its quantity but also quality) perceived by loyal and nonloyal consumers exists.

Thus, also the relationship between the sources of sustainable brand value management and brand loyalty is analyzed [30]. It has been found that there is a positive correlation between (1) sustainable brand management and brand attitude; (2) brand attitude and brand loyalty, and (3) brand loyalty and sustainable brand management [31]. This conclusion is essential as so far, the authors have mainly stated that sustainable management has a positive impact on perceived brand value. The key importance of brand loyalty in this process has not been detected until now. Moreover, it has been also highlighted that the concept of brand value and its patterns could vary across socio-cultural specifics of consumers. It means that the need of focusing on the consumers at the regional basis has been stated. According to this trend, contemporary research not only highlights the importance of consumer loyalty in the process of brand management in general, but authors also focus on identification of sources of brand loyalty across markets (in both product and regional prospective) [32,33]. 
Chatzipanagiotou et al. have applied a cross-cultural approach to the analysis of brand value sources [34]. They state that most of the so far created models of brand value building and managing are very simple and they do not take into account the complexity of relevant factors. As such a factor, it is identified also the consumer behavior and its individuality and difficult predictability due to the rejection of the traditional neoclassical concept of so-called Homo Oeconomicus. So, they have constructed regression model with significant factors affecting the final subjectively perceived brand value as well as they have identified critical points of this model implementation when applying it to cross-cultural environment. Regional specifics in perception of brand value sources with implications to brand loyalty have been discussed by Sukalova et al., Tamuliene and Pilipavicius, Rozgina, Jain and Zaman, and Christodoulides et al. These authors have verified the effectiveness of traditional Aaker's quadratic model of brand value sources in the wider perspective of unified European single market as well as individual national markets, formulating advices for the practice of international brand value management [35-39].

Not only regional but also sectoral specifics are relevant for the research of interactions between brand loyalty and sustainable management. Rather et al. focused in their research on sectoral specifics of brand loyalty using factor analysis [40]. They have developed an integrated model of brand loyalty building based on the consumer's perception of identified key brand value sources (brand commitment, brand trust and brand satisfaction).

Emotional attributes of brand loyalty in general (not respecting product or regional prospective but focusing on the pure nature of brand value sources in scope of consumer's characteristics) have been analyzed by Poushneh and Vasquez-Parraga [41]. On the one hand, they have removed the traditional heterogeneous approach, but on the other hand, they have incorporated another selective criterion-consumer typology. This approach follows the research which examined the changes in brand loyalty over time, a case study of plenty of product categories worldwide [42].

Since then, product categories have been analyzed mainly separately, focusing on these product categories where the loyalty can be considered as main motivation of buying behavior due to the capital demanding of the purchase [43]. Previously, customer satisfaction and image were priority proven as the main attributes of brand loyalty creation across product categorization. Unfortunately, only a few scientists have focused on their synergic effect and complex research of the mechanisms of causalities and correlations between customer satisfaction and image in the process of brand loyalty creation in the light and shadow of sustainable brand management [44]. One of these studies has formed the main premise for future research aimed to tourist services, as a significant subcategory of services where the decision-making process is based on rational pillars [45].

Similarly, the importance of brand loyalty in scope of corporate social responsibility has been analyzed in the banking sector. According to the results of this study, it has been proven that sustainable brand management directly influences brand image and brand value subjectively perceived by consumers. Moreover, dominant importance of brand loyalty in the process of sustainable brand management has been identified [46,47]. IT sector is another field where consumer's loyalty has been discussed as one of the pillars of CSR (corporate social responsibility) effectiveness [48]. Not only stating but also investigating the significance of consumer's loyalty has been the aim of the study provided in scope of luxury brands [49]. Generally, all above-mentioned researches focused on the identification of brand value sources relevant in scope of brand loyalty creation in a specific product category. The comparison of brand value sources in case of presence vs. absence of brand loyalty has not been done so far. However, contemporary trend in brand loyalty research indicate such an ideological change. On the contrary, research becomes more complex, trying to find common mechanisms in wider groups of brands.

Such a wider group of brands is also the category of so-called private label brands. Contemporary research of brand loyalty in case of this category escalates turbulently nowadays [50]. One of the trends identified in this field is the investigation of seasonality in brand loyalty, which has been detected by the practice of private label brands. Mainly in case of private label brands of alimentary goods 
has the observation of seasonality in consumer's preferences been really obvious [51]. This can be considered as a possible obstacle to sustainable brand management based on brand loyalty. This is because the variability in brand loyalty has not described in details so far, and thus, complex analysis of this phenomenon needs to be carried out [52]. Moreover, this fact partially rejects theoretical constructs based on presumption of positive effect of brand loyalty on the overall effectiveness of sustainable brand management. This is because such fluctuations in brand loyalty could affect negatively sustainable brand management activities. Thus, although many approaches to brand loyalty and its importance in sustainable management have been applied so far, there is still a scientific gap lying in the fact that brand loyalty is traditionally considered as a facilitator of corporate social responsibility while there are various indicators of the opposite- especially in the category of products characterized by habitual buying behavior.

In scope of the above mentioned, these research questions have been set:

(1) How are brand value sources of alimentary goods?

(2) What is the order of importance of these brand value sources and their components?

(3) Do these sources differ in case of brand loyalty absence vs. brand loyalty presence?

\section{Methodological Background}

According to the literature review above, the main aim of the article is to identify brand value sources of loyalty which are relevant to sustainable brand management of alimentary goods. To achieve this aim, we have used the data from our own research provided on the socio-demographically representative sample of 2000 respondents (sample without outliers and incompatible units was 697) during the first half of 2019. We conducted this research via a questionnaire survey in the form of computer-assisted web interviewing respecting the ICC/ESOMAR (International code on Market, Opinion and Social Research and Data Analytics). The questionnaire was administered in Slovak Republic among its inhabitants over 15 years of age who were asked to complete the questionnaire because of their legal working subjectivity. Thus, the main presumption of autonomous buying decision-making has been fulfilled. On the other hand, one of the limitations of general applicability of the research outcomes has been caused by this fact-that is, territorial applicability of the recommendations done on the basis of research outcomes only in scope of Slovak consumer's preferences. Thus, possible implementations of statements which result from research itself are applicable only in case of alimentary goods brands addressed to Slovak consumer (domestic or foreign). The questionnaire consisted of three parts with the following reasoning: (1) the first part covered the general socio-demographic profile of respondents; (2) the second part covered questions about perception of brand value sources generally, and (3) the third part covered questions about perception of brand value sources in details across the traditional typology of buying behavior and representative product categories.

To provide research of brand value sources in scope of buying behavior typology, the traditional quadratic typology of buying behavior has been used, where on the basis of the degree of engagement and differentiation, we can identify the following categories: (1) complex buying behavior (high involvement/significant differences between brands); (2) variety seeking behavior (low involvement/significant differences between brands); (3) dissonance-reducing buying behavior (high involvement/few differences between brands), and (4) habitual buying behavior (low involvement/few differences between brands) [53]. The last mentioned category is the category which is relevant for purposes of research of sustainable brand management of alimentary goods. Brand value sources are analyzed in their traditional structure defined by Aaker-that is, (1) imageries; (2) attitudes; (3) attributes, and (4) benefits. The components of brand value sources are set in accordance with provided literature review and with relevance to so far identified specifics of psychographic profile of Slovak consumers [54]. 
The model of brand value sources identified by Aaker was used in accordance with the provided literature review due to its general applicability regardless specifics of product categories formulated on the principle of typology of buying behavior. The reason is that the presented article is only a partial outcome of complex research aimed to verify the internal diversification in brand value sources, ranking in case of brand value presence vs. absence across four basic product categories. Brand value sources and their relevant components which have been, through the realized questionnaire survey, tested in scope of their importance across product categories relevant for the types of buying behavior are summarized in the Table 1 below.

Table 1. Coding of brand value sources and their components relevant to further research evaluation.

\begin{tabular}{|c|c|c|c|}
\hline \multirow{2}{*}{$\begin{array}{l}\text { Brand Value } \\
\text { Sources }\end{array}$} & \multirow{2}{*}{ Components of Brand Value Sources } & \multicolumn{2}{|c|}{ Code } \\
\hline & & Brand Loyalty Absence & Brand Loyalty Presence \\
\hline \multirow[t]{5}{*}{ imageries } & happiness & 2 & 4 \\
\hline & expectations & 3 & 5 \\
\hline & satisfaction & 1 & 1 \\
\hline & certainty & 5 & 2 \\
\hline & positive associations & 4 & 3 \\
\hline \multirow[t]{4}{*}{ attitudes } & I aim to buy branded products & 12 & 13 \\
\hline & $\begin{array}{c}\text { I am interested in branded products on a } \\
\text { regular basis }\end{array}$ & 13 & 12 \\
\hline & $\begin{array}{l}\text { branded products attract my attention } \\
\text { because I consider them better }\end{array}$ & 11 & 11 \\
\hline & $\begin{array}{l}\text { branded products attract my attention } \\
\text { because I consider them more prestigious }\end{array}$ & 14 & 14 \\
\hline \multirow[t]{5}{*}{ attributes } & quality & 19 & 19 \\
\hline & creativity of ad & 16 & 16 \\
\hline & popularity & 15 & 15 \\
\hline & availability & 17 & 17 \\
\hline & innovativeness & 18 & 18 \\
\hline \multirow[t]{5}{*}{ benefits } & branded product makes me happier & 10 & 10 \\
\hline & branded product increases my social status & 6 & 8 \\
\hline & $\begin{array}{l}\text { branded product makes it easier for me to } \\
\text { get friends }\end{array}$ & 7 & 6 \\
\hline & $\begin{array}{c}\text { branded product attracts the attention } \\
\text { of others }\end{array}$ & 8 & 7 \\
\hline & branded product belongs to my lifestyle & 9 & 9 \\
\hline
\end{tabular}

Source: Authors' own research, 2019.

Factor analysis has been chosen as the main statistical tool for evaluation of the consumer's perception of brand value sources in case of brand loyalty absence vs. brand loyalty presence. This analysis is one of the group of multidimensional statistical methods which are used to create so-called factors (previously unobservable variables) to reduce the amount of originally set attributes without losing the relevant information obtained inside the data set $[55,56]$. Recently, this statistical tool has been used with higher frequency in the social sciences due to the boom in information technology development and the need of reducing subjectivity. The definition of the relevant statistical model as well as the identification of rational assumptions is the base of this analysis. In the process of identification of relevant factors, it is primarily important to identify and test the dependence between originally defined variables through the correlation matrix. The basic presumption for the data reduction is the correlation of these variables verified by the correlation matrix creation as well as the fulfilment of the assumption that identified correlation exists as a consequence of less undetected hidden variables (factors). Based on this, it is possible to diversify originally defined variables into partial groups. In these groups, there are unified factors which internally correlate more inside the group than in comparison with other groups.

We assume that $\mathrm{x}$ is a $\mathrm{p}$-dimensional random vector of the considered variables with a vector of mean values $\mu$, a covariance matrix $C(X)=\Sigma$, and a correlation matrix of simple correlation coefficients $\mathrm{P}(\mathrm{X})=\mathrm{P}$. One of the basic assumptions of factor analysis is the existence of $\mathrm{R}$ common background 
factors $F_{1}, F_{2}, \ldots, F_{R}$; trying to have them as little as possible, preferably less than $p$. The P-dimensional random vector consists of the $j$-observable random variables $x_{j}, j=1,2, \ldots, p$; which can be expressed by Equation (1) as

$$
X_{j}=\mu_{j}+\gamma_{j 1} F_{1}+\gamma_{j 2} F_{2}+\ldots+\gamma_{j R} F_{R}+\varepsilon_{j},
$$

where $\varepsilon_{1}, \varepsilon_{2}, \ldots, \varepsilon_{p}$ are $\mathrm{p}$ stochastic error terms referred to as specific factors. If we write this in matrix, we get the Equation (2):

$$
x=\mu+\Gamma f+\varepsilon,
$$

where $\Gamma$ is a matrix of factors loadings type $\mathrm{p} \mathrm{R} ; f$ is R-member vector of common factors, and $\varepsilon$ is $\mathrm{p}$-member vector of specific factors. Factors loadings can be considered as regression coefficients $\mathrm{p}$ of observed variables on R nonobservable factors, and when certain conditions of solution are met, they are also covariance between the original and the new variables. Factors loadings can be interpreted as the contribution of the r-factor of the j-specified variable, when the same units of measurement are used. To determine the adequacy of the statistical sample, we use the KMO (Kaiser-Meyer-Olkin) Test Equation (3):

$$
K M O=\frac{\sum_{j \neq j^{\prime}}^{p} \sum_{j \neq j^{\prime}}^{p} r^{2}\left(x_{j}, x_{j^{\prime}}\right)}{\sum_{j \neq j^{\prime}}^{p} \sum_{j \neq j^{\prime}}^{p} r^{2}\left(x_{j}, x_{j^{\prime}}\right)+\sum_{j \neq j^{\prime}}^{p} \sum_{j \neq j^{\prime}}^{p} r^{2}\left(x_{j}, x_{j^{\prime}} . \text { other } x\right)}
$$

where $r^{2}\left(x_{j}, x_{j^{\prime}}\right)$ are simple correlation coefficients and $r^{2}\left(x_{j}, x_{j^{\prime}} \cdot\right.$ other $\left.x\right)$ are partial correlation coefficients under the condition of statically constant remaining p-2 variables. $\left(x_{1}, x_{2}, \ldots, x_{j-1}, x_{j+1}\right.$, $\left.\ldots, x_{j^{\prime}-1}, x_{j^{\prime}+1}, x_{p}\right)$.

Required value of KMO test should be higher than 0.6. By acquiring it, the adequacy of statistical sample is proved [57]. Required value of Barlett's test of sphericity should be lower than 0.05. By acquiring it, the dependence between variables is proved [58]. Required value of Cronbach's Alpha should be higher than 0.8. By acquiring it, the intrinsic consistency of the factors is proved [59]. Detection of the optimal values of these tests forms appropriate basis to the identification of the order of brand value sources in case of loyalty absence vs. loyalty presence. Thus, a set of advices formulated on the basis of factors identification and comparison of obtained results can be submitted to the practice of sustainable brand value building and managing of alimentary goods.

\section{Results and Discussion}

Provided KMO test (Kaiser-Meyer-Olkin test) has indicated the adequacy of the used statistical sample in case of brands with consumer's loyalty absence as well as in case of brands with consumer's loyalty presence $(>0.6)$. When testing the brand value sources in case of brand loyalty absence, the value of 0.902 has been reached, and in the case of brand loyalty presence, the value of 0.931 has been reached. Barlett's test of sphericity has proved the existence of dependence between variables by acquiring the resulting value at 0.00 in case of brands with consumer's loyalty absence as well as in case of brands with consumer's loyalty presence $(<0.05)$. We have also detected statistical relevance of four relevant factors in both cases.

The testimonial value of factor analysis in case of brand value sources research when brand loyalty is absent has reached a value of $76.552 \%$. (See Table 2 ) 
Table 2. Total variance explained—brand loyalty absence.

\begin{tabular}{|c|c|c|c|c|c|c|c|c|c|}
\hline \multirow[b]{2}{*}{ Code } & \multicolumn{3}{|c|}{ Initial Eigenvalues } & \multicolumn{3}{|c|}{ Extraction Sums of Squared Loadings } & \multicolumn{3}{|c|}{ Rotation Sums of Squared Loadings } \\
\hline & Total & $\begin{array}{c}\% \text { of } \\
\text { Variance }\end{array}$ & $\begin{array}{c}\text { Cumulative } \\
\%\end{array}$ & Total & $\begin{array}{c}\% \text { of } \\
\text { Variance }\end{array}$ & $\begin{array}{c}\text { Cumulative } \\
\%\end{array}$ & Total & $\begin{array}{c}\% \text { of } \\
\text { Variance }\end{array}$ & $\begin{array}{c}\text { Cumulative } \\
\%\end{array}$ \\
\hline 1 & 9.368 & 49.303 & 49.303 & 9.368 & 49.303 & 49.303 & 4.312 & 22.694 & 22.694 \\
\hline 2 & 2.595 & 13.660 & 62.963 & 2.595 & 13.660 & 62.963 & 3.871 & 20.374 & 43.068 \\
\hline 3 & 1.380 & 7.264 & 70.228 & 1.380 & 7.264 & 70.228 & 3.233 & 17.015 & 60.083 \\
\hline 4 & 1.202 & 6.325 & 76.552 & 1.202 & 6.325 & 76.552 & 3.129 & 16.469 & 76.552 \\
\hline 5 & 0.691 & 3.637 & 80.189 & & & & & & \\
\hline 6 & 0.494 & 2.598 & 82.787 & & & & & & \\
\hline 7 & 0.446 & 2.347 & 85.134 & & & & & & \\
\hline 8 & 0.374 & 1.967 & 87.101 & & & & & & \\
\hline 9 & 0.347 & 1.824 & 88.925 & & & & & & \\
\hline 10 & 0.307 & 1.614 & 90.539 & & & & & & \\
\hline 11 & 0.289 & 1.522 & 92.061 & & & & & & \\
\hline 12 & 0.280 & 1.472 & 93.534 & & & & & & \\
\hline 13 & 0.247 & 1.300 & 94.834 & & & & & & \\
\hline 14 & 0.206 & 1.082 & 95.916 & & & & & & \\
\hline 15 & 0.194 & 1.020 & 96.936 & & & & & & \\
\hline 16 & 0.184 & 0.967 & 97.903 & & & & & & \\
\hline 17 & 0.163 & 0.857 & 98.760 & & & & & & \\
\hline 18 & 0.132 & 0.693 & 99.454 & & & & & & \\
\hline 19 & 0.104 & 0.546 & 100.000 & & & & & & \\
\hline
\end{tabular}

Source: Authors' own research, 2019

In case of brand loyalty absence, the existence of four relevant factors with significant components has been proved. These factors are (1) imageries with five components where the value of Cronbach's Alpha has been 0.813 ; (2) benefits with five components where the value of Cronbach's Alpha has been 0.842 ; (3) attitudes with four components where the value of Cronbach's Alpha value has been 0.849 , and (4) attributes with five components where the value of Cronbach's Alpha has been 0.813. (See Table 3)

Table 3. Rotated component matrix—brand loyalty absence.

\begin{tabular}{|c|c|c|c|c|}
\hline \multirow{2}{*}{ Code } & \multicolumn{4}{|c|}{ Brand Value Source } \\
\hline & Imageries & Benefits & Attitudes & Attributes \\
\hline 1 & 0.855 & & & \\
\hline 2 & 0.825 & & & \\
\hline 3 & 0.790 & & & \\
\hline 4 & 0.790 & & & \\
\hline 5 & 0.784 & & & \\
\hline 6 & & 0.908 & & \\
\hline 7 & & 0.899 & & \\
\hline 8 & & 0.859 & & \\
\hline 9 & & 0.579 & 0.406 & \\
\hline 10 & 0.442 & 0.551 & & \\
\hline 11 & & & 0.798 & \\
\hline 12 & & & 0.785 & \\
\hline 13 & & 0.414 & 0.733 & \\
\hline 14 & & & 0.709 & \\
\hline 15 & & & & 0.798 \\
\hline 16 & & & & 0.784 \\
\hline 17 & & & & 0.739 \\
\hline 18 & & & & 0.664 \\
\hline 19 & 0.415 & & 0.421 & 0.594 \\
\hline
\end{tabular}

Source: Authors' own research, 2019. 
The creation of a rotated component matrix has allowed to rank the brand value sources in case of brand loyalty absence according to their priority in the impact on consumer's perception as follows: (1) imageries; (2) benefits; (3) attitudes; (4) attributes. (See Table 4)

Table 4. Brand value sources—brand loyalty absence.

\begin{tabular}{ccccc}
\hline Factors & $\begin{array}{c}\text { F1 } \\
\text { Imageries }\end{array}$ & $\begin{array}{c}\text { F2 } \\
\text { Benefits }\end{array}$ & $\begin{array}{c}\text { F3 } \\
\text { Attitudes }\end{array}$ & $\begin{array}{c}\text { F4 } \\
\text { Attributes }\end{array}$ \\
\hline N of Items & 5 & 5 & 4 & 5 \\
Cronbach's Alpha & 0.813 & 0.842 & 0.849 & 0.813 \\
\% of Variance & 49.303 & 13.660 & 7.264 & 6.325 \\
\hline
\end{tabular}

Source: Authors' own research, 2019.

The testimonial value of factor analysis in case of brand value sources research when brand loyalty is present has reached a value of $74.614 \%$. (See Table 5)

Table 5. Total variance explained—brand loyalty presence.

\begin{tabular}{|c|c|c|c|c|c|c|c|c|c|}
\hline \multirow[b]{2}{*}{ Code } & \multicolumn{3}{|c|}{ Initial Eigenvalues } & \multicolumn{3}{|c|}{ Extraction Sums of Squared Loadings } & \multicolumn{3}{|c|}{ Rotation Sums of Squared Loadings } \\
\hline & Total & $\begin{array}{c}\% \text { of } \\
\text { Variance }\end{array}$ & $\begin{array}{c}\text { Cumulative } \\
\%\end{array}$ & Total & $\begin{array}{c}\% \text { of } \\
\text { Variance }\end{array}$ & $\begin{array}{c}\text { Cumulative } \\
\%\end{array}$ & Total & $\begin{array}{c}\% \text { of } \\
\text { Variance }\end{array}$ & $\underset{\%}{\text { Cumulative }}$ \\
\hline 1 & 9.500 & 50.002 & 50.002 & 9.500 & 50.002 & 50.002 & 4.177 & 21.982 & 21.982 \\
\hline 2 & 2.080 & 10.949 & 60.951 & 2.080 & 10.949 & 60.951 & 3.941 & 20.741 & 42.723 \\
\hline 3 & 1.456 & 7.665 & 68.616 & 1.456 & 7.665 & 68.616 & 3.125 & 16.446 & 59.170 \\
\hline 4 & 1.140 & 6.001 & 74.617 & 1.140 & 6.001 & 74.617 & 2.935 & 15.448 & 74.617 \\
\hline 5 & 0.685 & 3.606 & 78.223 & & & & & & \\
\hline 6 & 0.480 & 2.527 & 80.751 & & & & & & \\
\hline 7 & 0.425 & 2.235 & 82.986 & & & & & & \\
\hline 8 & 0.413 & 2.171 & 85.157 & & & & & & \\
\hline 9 & 0.392 & 2.061 & 87.218 & & & & & & \\
\hline 10 & 0.359 & 1.889 & 89.106 & & & & & & \\
\hline 11 & 0.309 & 1.625 & 90.732 & & & & & & \\
\hline 12 & 0.294 & 1.547 & 92.279 & & & & & & \\
\hline 13 & 0.280 & 1.473 & 93.752 & & & & & & \\
\hline 14 & 0.261 & 1.372 & 95.124 & & & & & & \\
\hline 15 & 0.247 & 1.301 & 96.426 & & & & & & \\
\hline 16 & 0.222 & 1.169 & 97.595 & & & & & & \\
\hline 17 & 0.171 & 0.899 & 98.494 & & & & & & \\
\hline 18 & 0.151 & 0.797 & 99.291 & & & & & & \\
\hline 19 & 0.135 & 0.709 & 100.000 & & & & & & \\
\hline
\end{tabular}

Source: Authors' own research, 2019.

In case of brand loyalty presence, the existence of four relevant factors with significant components has been proved. These factors are (1) imageries with five components where the value of Cronbach's Alpha has been 0.854 ; (2) benefits with five components where the value of Cronbach's Alpha has been 0.837 ; (3) attitudes with four components where the value of Cronbach's Alpha value has been 0.841 and (4) attributes with five components where the value of Cronbach's Alpha has been 0.869. (See Table 6) 
Table 6. Rotated component matrix-brand loyalty presence.

\begin{tabular}{|c|c|c|c|c|}
\hline \multirow{2}{*}{ Code } & \multicolumn{4}{|c|}{ Brand Value Source } \\
\hline & Imageries & Benefits & Attitudes & Attributes \\
\hline 1 & 0.800 & & & \\
\hline 2 & 0.781 & & & \\
\hline 3 & 0.776 & & & \\
\hline 4 & 0.767 & & & \\
\hline 5 & 0.751 & & & \\
\hline 6 & & 0.880 & & \\
\hline 7 & & 0.860 & & \\
\hline 8 & & 0.850 & & \\
\hline 9 & & 0.604 & & \\
\hline 10 & 0.521 & 0.531 & & \\
\hline 11 & & & 0.812 & \\
\hline 12 & & & 0.784 & \\
\hline 13 & & & 0.762 & \\
\hline 14 & & 0.437 & 0.643 & \\
\hline 15 & & & & 0.784 \\
\hline 16 & & & & 0.752 \\
\hline 17 & & & & 0.747 \\
\hline 18 & & & & 0.586 \\
\hline 19 & 0.417 & & 0.411 & 0.559 \\
\hline
\end{tabular}

Source: Authors' own research, 2019.

The creation of a rotated component matrix has allowed ranking the brand value sources in case of brand loyalty presence according to their priority in the impact on consumer's perception as follows: (1) imageries; (2) benefits; (3) attitudes; (4) attributes. (See Table 7)

Table 7. Brand value sources—brand loyalty presence.

\begin{tabular}{ccccc}
\hline Factors & $\begin{array}{c}\text { F1 } \\
\text { Imageries }\end{array}$ & $\begin{array}{c}\text { F2 } \\
\text { Benefits }\end{array}$ & $\begin{array}{c}\text { F3 } \\
\text { Attitudes }\end{array}$ & $\begin{array}{c}\text { F4 } \\
\text { Attributes }\end{array}$ \\
\hline N of Items & 5 & 5 & 4 & 5 \\
Cronbach's Alpha & 0.854 & 0.837 & 0.841 & 0.869 \\
\% of Variance & 50.002 & 10.949 & 7.665 & 6.001 \\
\hline
\end{tabular}

Source: Authors' own research, 2019.

Thus, it is possible to make the conclusion that importance of factors does not vary across analyzed categories of brands of alimentary goods (i.e., brand loyalty absence vs. presence). For detailed information, see Table 8 .

Table 8. Ranking of groups of components in analyzed categories.

\begin{tabular}{ccc}
\hline \multirow{2}{*}{ Rank } & Brand Loyalty Absence & Brands \\
& Imageries & Imageries \\
2 & Benefits & Benefits \\
3 & Attitudes & Attitudes \\
4 & Attributes & Attributes \\
\hline
\end{tabular}

Source: Authors' own research, 2019.

As it is obvious, the brand value sources ranking created on the basis of their priority in the impact on consumer's perception in case of brands with consumer's loyalty absence is the same as in case of brands with consumer's loyalty presence. However, when analyzing groups of components deeply, we can see that differences exist. The internal ranking inside identified groups of components is equal only in case of the less important group of brand value sources-in case of attributes. All others brand value 
sources are internally different from the point of view of relevance of individual components of these groups of brand value sources. The most visible example can be seen in scope of imageries, where only one component of brand value sources has the same ranking in case of brand loyalty absence and in case of brand loyalty presence. Thus, in case of brand loyalty absence, the order is the following: (1) satisfaction; (2) happiness; (3) expectations; (4) positive associations, and (5) certainty, while in case of brand loyalty presence, the order is the following: (1) satisfaction; (2) certainty; (3) positive associations; (4) happiness, and (5) expectations. This finding indicates the need of a selective approach to brand value sources and implementation of so far defined patterns in the practice of brand management.

While in both cases satisfaction is considered a main component in case of brands of alimentary goods, complementary components should be used differently. In case of brand value absence (similarly in phase of brand value building), it is happiness and expectations which should be mainly used, while in case of brand value presence (similarly in phase of brad value managing), it is certainty and positive associations. In case of benefits, the order is also mixed - in case of brand loyalty absence, the most important component is the ability to increase social status, while in case of brand loyalty presence, it is the ability to make it easier to get friends. Based on these findings, it is crucial to unify the consumer's satisfaction (as a main component of the most important brand value source) with corporate social responsibility and to implement sustainable managerial tools focused on stimulation of the consumer's socially conformal behavior, mainly on the basis of this brand value source. For detailed information about internal order of components inside identified brand value sources of alimentary goods, see Table 9 as a modification of Table 1 .

Table 9. Brand value sources and components.

\begin{tabular}{|c|c|c|}
\hline \multirow{2}{*}{ Brand Value Sources } & \multicolumn{2}{|c|}{ Components of Brand Value Sources } \\
\hline & Brand Loyalty Absence & Brand Loyalty Presence \\
\hline imageries & $\begin{array}{c}\text { satisfaction } \\
\text { happiness } \\
\text { expectations } \\
\text { positive associations } \\
\text { certainty }\end{array}$ & $\begin{array}{c}\text { satisfaction } \\
\text { certainty } \\
\text { positive associations } \\
\text { happiness } \\
\text { expectations }\end{array}$ \\
\hline \multirow[t]{4}{*}{ benefits } & branded product increases my social status & $\begin{array}{l}\text { branded product makes it easier for me to get } \\
\text { friends }\end{array}$ \\
\hline & $\begin{array}{l}\text { branded product makes it easier for me to get } \\
\text { friends }\end{array}$ & $\begin{array}{l}\text { branded product attracts the attention of } \\
\text { others }\end{array}$ \\
\hline & $\begin{array}{c}\text { branded product attracts the attention of } \\
\text { others }\end{array}$ & branded product increases my social status \\
\hline & $\begin{array}{l}\text { branded product belongs to my lifestyle } \\
\text { branded product makes me happier }\end{array}$ & $\begin{array}{l}\text { branded product belongs to my lifestyle } \\
\text { branded product makes me happier }\end{array}$ \\
\hline \multirow[t]{4}{*}{ attitudes } & $\begin{array}{l}\text { branded products attract my attention } \\
\text { because I consider it better }\end{array}$ & $\begin{array}{l}\text { branded products attract my attention } \\
\text { because I consider it better }\end{array}$ \\
\hline & I aim to buy branded products & $\begin{array}{l}\text { I am interested in branded product on a } \\
\text { regular basis }\end{array}$ \\
\hline & $\begin{array}{l}\text { I am interested in branded products on a } \\
\text { regular basis }\end{array}$ & I aim to buy branded products \\
\hline & $\begin{array}{l}\text { branded products attract my attention } \\
\text { because I consider them more prestigious }\end{array}$ & $\begin{array}{l}\text { branded products attract my attention } \\
\text { because I consider them more prestigious }\end{array}$ \\
\hline \multirow[t]{5}{*}{ attributes } & popularity & popularity \\
\hline & creativity of ad & creativity of ad \\
\hline & availability & availability \\
\hline & innovativeness & innovativeness \\
\hline & quality & quality \\
\hline
\end{tabular}

Source: Authors' own research, 2019.

Another important dimension of these findings lies in the differences between the order of brand value sources which have been identified generally and in case of alimentary goods. In case of brand loyalty absence, both categories are characterized by imageries as a main brand value source, while in case of brand loyalty presence, imageries are the most important only for brands of alimentary goods. Generally, imageries have been replaced by benefits. Thus, the need of a selective approach to sustainable brand management across product categories which has been so far only assumed, has been definitely proved [45-50,52]. For detailed information, see Table 10. 
Table 10. Comparative ranking of grouped brand value components (in general/alimentary goods).

\begin{tabular}{|c|c|c|c|c|}
\hline \multirow{3}{*}{ Rank } & \multicolumn{4}{|c|}{ Brand Value Sources } \\
\hline & \multicolumn{2}{|c|}{ Brand Loyalty Absence } & \multicolumn{2}{|c|}{ Brand Loyalty Presence } \\
\hline & In General & Alimentary Goods & In General & Alimentary Goods \\
\hline 1 & Imageries & Imageries & Benefits & Imageries \\
\hline 2 & Attitudes & Benefits & Attributes & Benefits \\
\hline 3 & Benefits & Attitudes & Imageries & Attitudes \\
\hline 4 & Attributes & Attributes & Attitudes & Attributes \\
\hline
\end{tabular}

Practical implications of these results indicate that imageries are the leading brand value source in case of brand loyalty absence regardless of the category of product (i.e., in general or in case of alimentary goods). On the contrary, in case of brand loyalty presence, the leading brand value source with significant impact on brand value subjectively perceived by consumer is benefits, while in case of alimentary goods, imageries remain to be the most relevant brand value source. According to this fact, we can observe these main findings: (1) in general, brand value sources vary due to the phase of brand management, while in case of alimentary goods, brand value sources remain identical; (2) the position of brand loyalty is ambivalent when applying point of view of stimuli vs. point of view of obstacle to prospective sustainable brand management, and (3) traditional general patterns of sustainable brand management are inapplicable in case of brands of alimentary goods.

Thus, we can state that the process of brand value building and management in case of alimentary goods does not have to be selective if it is connected with the phase of brand value building or brand value management (taking brand value sources into account and not their components). This coherent approach facilitates the managerial practice of brands of alimentary goods, where it is enough to identify relevant components of imageries as the most important brand value sources (happiness, expectations, satisfaction, certainty, and positive associations) at the very beginning of the process of brand value building, and these components can be subsequently used during all the brand life cycle. A representative product which declares the applicability of this approach is Coca-Cola, which is systematically built on the basis of joy and happiness as the leading brand value pillars.

On the other hand, as it has not been identified the difference between brand value sources of alimentary goods regarding to the presence vs. absence of brand loyalty, we cannot conclude that its existence is vital in the process of sustainable brand management. It means that managers of brands of alimentary goods should not expect bigger receptivity of sustainable brand management activities by the customers in case of brand loyalty presence. In other words, if the transition to sustainable brand management is done and the consumer identifies that it is not in accordance with brand value source accented so far, the brand value could be harmed.

The fact that we have identified the difference between brand value sources in case of brand loyalty presence vs. brand loyalty absence among categories verifies the presumption that universal sustainable brand management patterns should not be applied, as individual product categories are specific, and the modification of formulated models and processes of sustainable brand management should be supported by further market, opinion, and social research to arrange optimal applicability and effective goal fulfilment in scope of sustainable brand management.

We have confirmed that the main task for managers of not only formally but really sustainably manageable brands is to identify internal motives and brand value sources of their consumers and to co-act in the process of market education as one of the prerequisites of socially sustainable development $[17,61]$. Similarly, we verified the importance of satisfaction-affected trust and brand loyalty in the category of alimentary goods [23,24]. On the other hand, we have rejected the theory which highlights the importance of emotional sources of brand value. Thus, the scientific gap lying in the need of the mechanisms of behavioral economics investigation has been disputed [21]. In scope of these facts, it is also disputable the phenomenon of so-called love brands and its effectiveness in the 
process of brand loyalty creation and management [22]. When analyzing these findings, it is possible to apply specific point of view based on the regional psychographic specifics of consumers [34-39]. It is because we have accepted theories from authors who investigated regionally closer markets, while the theories of other authors have been rejected. Such a specific attitude of Slovak consumers to the brands of alimentary goods can be the reason of the phenomenon of double quality of food, which is typical for Slovak market in comparison with other markets of neighbor countries (mainly Austria). Surprisingly, although double quality has been clearly proven by independent tests, Slovak consumers do not change their attitudes towards brands and they follow their buying habits. This fact is extremely dangerous in scope of sustainable brand management concept implementation because brands of alimentary goods which are subjectively perceived as valuable are not motivated enough to behave responsibly towards society, and consumers do not have motivation to be active in the process of information searching. Thus, it is extremely important to analyze value sources of brands characterized by presence vs. absence of consumer loyalty and to apply a conscious and responsible approach to the consumer's loyalty as to the one of the leading buying behavior motives. However, there are still possibilities for further research that should be focused in more detail on the specifics of consumer segmentation. A possible way to obtain brand management benefits in this case is the application of the generation approach. It is because we can suppose that the ranking of brand value sources and their components in case of alimentary goods varies if analyzing Generations $X, Y$, and $Z$.

\section{Conclusions}

Until now, the phenomenon of brand loyalty has not been analyzed in details connected with possible negative impact on sustainable development. Thus, the main aim of the article is to identify brand value sources of loyalty which are relevant to sustainable brand management of alimentary goods. To achieve this aim, we have used the data from our own research provided on the socio-demographically representative sample of 2000 respondents (sample without outliers, and incompatible units was 697) during the first half of the year 2019. We have realized this research via a questionnaire survey in the form of computer-assisted web interviewing. The questionnaire was administered in Slovak Republic among its inhabitants aged over 15 years who have been asked to fulfil the questionnaire because of their legal labor subjectivity. Thus, the main presumption of autonomous buying decision-making has been fulfilled. To provide research of brand value sources in scope of buying behavior typology, traditional quadratic typology of buying behavior has been used, where based on the degree of engagement and differentiation, obtained data were statistically evaluated by the factor analysis supported by relevant statistical tests (KMO Test, Barlett's test of sphericity, and calculation of Cronbach's Alpha). Based on this, it has been possible to identify relevant brand value sources of alimentary goods in case of brand loyalty absence as well as brand loyalty presence. It has not been proved the existence of significant difference between brand value sources ranking according to their priority in the impact on the consumer's perception in case of loyal and nonloyal consumers. The order of the brand value sources has been in both cases following (1) imageries; (2) benefits; (3) attitudes, and (4) attributes. However, when analyzing groups of components deeply, we can see that differences exist. The internal ranking inside identified groups of components is equal only in case of the less important group of brand value sources-in case of attributes. All others brand value sources are internally different from the point of view of relevance of individual components of these groups of brand value sources. The most visible example can be seen in scope of imageries, where only one component of brand value sources has the same ranking in case of brand loyalty absence and in case of brand loyalty presence. From a managerial point of view, these findings are even more important as they provide more details potentially used in scope of sustainable brand management of alimentary goods. Even though the conclusions formulated on the basis of provided research obtain useful information for the practice of sustainable brand management, there have been identified various relevant limitations of the research. The most important is the territorial validity of the research. These findings are fully applicable only in case of Slovak consumer, meaning that in case of entering Slovak company on 
foreign market, these findings have to be critically re-evaluated in scope of specifics of selected market. When respecting this fact, managers have to their disposal a very wide portfolio of information usable in all the portfolio of sustainable brand management implications. Not only valuable introspection into the previous practical successes and fails of brands is provided, but also the platform for optimal managerial decision-making in the future is created. In scope of the above mentioned, provided research offers the information relevant to appropriate setting of the content communicated with the consumers according to their identified preferences, demands, and expectations. The main managerial recommendation consists of the fact that "imageries" have been detected as a most valuable source of brand value from the consumer's point of view. This source consists of happiness, expectations, satisfaction, certainty, and positive associations as its relevant components. That is to say, these are the basic pillars of subjectively perceived brand value which should be systematically used in the process of sustainable brand management of alimentary goods in all its complexity. It means that there is no need to distinguish between the process of brand value building and the process of brand value management as the main brand value source does not change.

The outcomes of the research and subsequently formulated conclusions provide the understanding of overall complexity of internal and external factors which motivates consumers to be interested in strong and functional interaction with brand. These findings have already been partially outlined by various authors, but no clear and uniform statement has been formulated thus far in the scope of sustainable brand value management of alimentary goods and the individual brand value sources. We have mainly verified the importance of satisfaction affected by trust, and brand loyalty in the category of alimentary goods, but on the other hand, we have rejected existing theory which highlights the importance of emotional sources of brand value.

Regardless of the declared importance and usability of the research results, there are still many points of view which could enrich its managerial applicability. One of them is the consideration of generational stratification and critical discussion of specifics of the consumer's brand value perception in the light and shadow of sustainable brand management optimal implementation.

Author Contributions: J.M. and A.K. designed the experiments. M.N. and L.G. analysed the data. G.L. contributed analysis tools. J.K. and W.S. wrote the paper. All authors have read and agreed to the published version of the manuscript.

Funding: This contribution is a partial output of scientific project APVV-15-0505: Integrated model of management support for building and managing the brand value in the specific conditions of the Slovak Republic.

Conflicts of Interest: The authors declare no conflict of interest.

\section{References}

1. Oh, W.-Y.; Choi, K.J.; Chang, Y.K.; Jeon, M.-K. MNEs' Corporate Social Responsibility: An Optimal Investment Decision Model. Eur. J. Int. Manag. 2019, 13, 307-327. [CrossRef]

2. Popadic, I.; Borocki, J.; Radisic, M.; Stefanic, I.; Duspara, L. The Challenges While Measuring Enterprise Innovative Activities-The Case from a Developing Country. Teh. Vjesn. Tech. Gaz. 2018, 25, 452-459. [CrossRef]

3. Zvirgzdina, R.; Linina, I.; Vevere, V. Efficient Consumer Response (ECR) Principles and Their Application in Retail Trade Enterprises in Latvia. Eur. Integr. Stud. 2015, 9, 257-264. [CrossRef]

4. Gonzalez-Ramos, M.I.; Donate, M.J.; Guadamillas, F. An Empirical Study on the Link Between Corporate Social Responsibility and Innovation in Environmentally Sensitive Industries. Eur. J. Int. Manag. 2018, 12, 402-422. [CrossRef]

5. Bellucci, M.; Bini, L.; Giunta, F. Implementing Environmental Sustainability Engagement into Business: Sustainability Management, Innovation, and Sustainable Business Models. Innov. Strateg. Environ. Sci. 2020, 107-143. [CrossRef]

6. Demir, M.; Lenhart, S. Optimal sustainable fishery management of the Black Sea anchovy with food chain modeling framework. Nat. Resour. Modeling 2019, e12253. [CrossRef] 
7. Vafaei, S.; Bazrkar, A.; Hajimohammadi, M. The Investigation of the Relationship Between Sustainable Supply Chain Management and Sustainable Competitive Advantage According to the Mediating Role of Innovation and Sustainable Process Management. Braz. J. Oper. Prod. Manag. 2019, 16, 572-580. [CrossRef]

8. De los Salmones, M.D.G.; Crespo, A.H.; del Bosque, I.R. Influence of Corporate Social Responsibility on Loyalty and Valuation of Services. J. Bus. Ethics 2005, 61, 369-385. [CrossRef]

9. Ganushchak-Efimenko, L.; Shcherbak, V.; Nifatova, O. Assessing the Effects of Socially Responsible Strategic Partnerships on Building Brand Equity of Integrated Business Structures in Ukraine. Oeconomia Copernic. 2018, 9, 715-730. [CrossRef]

10. Zhulega, I.A.; Gagulina, N.L.; Samoylov, A.V.; Novikov, A.V. Problems of Corporate Economics and Sustainable Development in the Context of the Sanction World Order: Living Standards and Live Quality. Ekon. Manaz. Spektrum 2019, 13, 83-95. [CrossRef]

11. Gillespie, B.; Rogers, M.M. Sustainable Supply Chain Management and the End User: Understanding the Impact of Socially and Environmentally Responsible Firm Behaviors on Consumers' Brand Evaluations and Purchase Intentions. J. Mark. Channels 2016, 23, 34-46. [CrossRef]

12. Dumitriu, D.; Militaru, G.; Deselnicu, D.C.; Niculescu, A.; Popescu, M.A.M. A Perspective Over Modern SMEs: Managing Brand Equity, Growth and Sustainability Through Digital Marketing Tools and Techniques. Sustainability 2019, 11, 2111. [CrossRef]

13. Hu, D.; Wang, Y.D.; Yang, X. Trading Your Diversification Strategy for a Green One: How Do Firms in Emerging Economies Get on the Green Train? Organ. Environ. 2019, 32, 391-415. [CrossRef]

14. Lu, J.T.; Ren, L.C.; He, Y.F.; Lin, W.F.; Streimikis, J. Linking Corporate Social Responsibility with Reputation and Brand of the Firm. Amfiteatru Econ. 2019, 21. [CrossRef]

15. Drugau-Constantin, A. Emotional and Cognitive Reactions to Marketing Stimuli: Mechanisms Underlying Judgments and Decision Making in Behavioral and Consumer Neuroscience. Econ. Manag. Financ. Mark. 2018, 13, 46-50. [CrossRef]

16. Torres, A.; Bijmolt, T.H.A.; Tribo, J.A.; Verhoef, P. Generating Global Brand Equity through Corporate Social Responsibility to Key Stakeholders. Int. J. Res. Mark. 2012, 29, 13-24. [CrossRef]

17. Grubor, A.; Milovanov, O. Brand Strategies in the Era of Sustainability. Interdiscip. Descr. Complex. Syst. 2017, 15, 78-88. [CrossRef]

18. Riera, M.; Iborra, M. Corporate Social Irresponsibility: Review and Conceptual Boundaries. Eur. J. Manag. Bus. Econ. 2017, 26, 146-162. [CrossRef]

19. Bhattacharya, C.B.; Sen, S. Doing Better at Dong Good: When, Why, and How Consumers Respond to Corporate Social Initiatives. Calif. Manag. Rev. 2004, 47, 9-24. [CrossRef]

20. Hur, W.M.; Kim, H.; Woo, J. How CSR Leads to Corporate Brand Equity: Mediating Mechanisms of Corporate Brand Credibility and Reputation. J. Bus. Ethics 2014, 125, 75-86. [CrossRef]

21. Castro-Gonzalez, S.; Bande, B.; Fernandez-Ferrin, P.; Kimura, T. Corporate Social Responsibility and Consumer Advocacy Behaviors: The Importance of Emotions and Moral Virtues. J. Clean. Prod. 2019, 231, 846-855. [CrossRef]

22. Song, H.; Wang, J.; Han, H. Effect of Image, Satisfaction, Trust, Love, and Respect on Loyalty Formation for Name-brand Coffee Shops. Int. J. Hosp. Manag. 2019, 79, 50-59. [CrossRef]

23. Olah, J.; Karmazin, G.Y.; Farkasne Fekete, M.; Popp, J. An Examination of Trust as a Strategical Factor of Success in Logistical Firms. Bus. Theory Pract. 2017, 18, 171-177. [CrossRef]

24. Olah, J.; Sadaf, R.; Mate, D.; Popp, J. The Influence of the Management Success Factors of Logistics Service Providers on Firms' Competitiveness. Pol. Jounal Manag. Stud. 2018, 17, 175-193. [CrossRef]

25. Rivera, J.J.; Bigne, J.; Curras-Perez, R. Effects of Corporate Social Responsibility on Consumer Brand Loyalty. Rbgn-Rev. Bras. De Gest. De Neg. 2019, 21,395-415. [CrossRef]

26. Vevere, V.; Sannikova, A. Developing Intercultural Negotiations Skills to Meet Current Challenges of Diverse EU Business Environment as Part of University Social Responsibility. Eur. Integr. Stud. 2018, 12, 8-18. [CrossRef]

27. Chadhuri, A.; Holbrook, M.B. The Chain of Effects from Brand Trust and Brand Affect to Brand Performance: The Role of Brand Loyalty. J. Mark. 2001, 65, 81-93. [CrossRef]

28. Bhattacharya, C.B.; Sen, S. Consumer-company Identification: A Framework for Understanding Consumers' Relationships with Companies. J. Mark. 2003, 67, 76-88. [CrossRef] 
29. Stocchi, L.; Fuller, R. A Comparison of Brand Equity Strength Across Consumer Segments and Markets. J. Prod. Brand Manag. 2017, 26, 453-468. [CrossRef]

30. Curras-Perez, R.; Dolz-Dolz, C.; Sanchez-Garcia, I. How Social, Environmental, and Economic CSR Affects Consumer-Perceived Value: Does Perceived Consumer Effectiveness Make a Difference? Corp. Soc. Responsib. Environ. Manag. 2018, 25, 733-747. [CrossRef]

31. Yang, C.Y.; Yang, C.H. The Impact of Sustainable Environmental Management in the Food and Beverage Industry on Customer Loyalty: A View of Brand Attitude. Ekoloji 2019, 28, 965-972.

32. Abdullah, M.I.; Sarfraz, M.; Arif, A.; Azam, A. An Extension of the Theory of Planned Behavior Towards Brand Equity and Premium Price. Pol. J. Manag. Stud. 2018, 18, 20-32. [CrossRef]

33. Popp, J.; Olah, J.; Kiss, A.; Lakner, Z. Food Security Perspectives in Sub-Saharan Africa. Amfiteatru Econ. 2019, 21, 361-376. [CrossRef]

34. Chatzipanagiotou, K.; Christodoulides, G.; Veloutsou, C. Managing the Consumer-based Brand Equity Process: A Cross-cultural Perspective. Int. Bus. Rev. 2019, 28, 328-343. [CrossRef]

35. Sukalova, V.; Ceniga, P.; Janotova, H. Harmonization of Work and Family Life in Company Management in Slovakia. Procedia Econ. Financ. 2015, 26, 152-159. [CrossRef]

36. Tamuliene, V.; Pilipavicius, V. Research in Customer Preferences Selecting Insurance Services: A Case Study of Lithuania. Forum Sci. Oeconomia 2017, 5, 49-58. [CrossRef]

37. Rozgina, L. The Latvian Audit Services Market: Current Issues and Challenges. Forum Sci. Oeconomia 2018, 6, 7-21. [CrossRef]

38. Jain, T.; Zaman, R. When Boards Matter: The Case of Corporate Social Irresponsibility. Br. J. Manag. 2019. [CrossRef]

39. Christodoulides, G.; Cadogan, J.W.; Veloutsou, C. Consumer-based Brand Equity Measurement: Lessons Learned from an International Study. Int. Mark. Rev. 2015, 32, 307-328. [CrossRef]

40. Rather, R.A.; Tehseen, S.; Itoo, M.H.; Parrey, S.H. Customer Brand Identification, Affective Commitment, Customer Satisfaction, and Brand Trust as Antecedents of Customer Behavioral Intention of Loyalty: An Empirical Study in the Hospitality Sector. J. Glob. Sch. Mark. Sci. 2019, 29, 196-217. [CrossRef]

41. Poushneh, A.; Vasquez-Parraga, A.Z. Emotional Bonds with Technology: The Impact of Customer Readiness on Upgrade Intention, Brand Loyalty, and Affective Commitment through Mediation Impact of Customer Value. J. Theor. Appl. Electron. Commer. Res. 2019, 14, 90-105. [CrossRef]

42. Dawes, J.; Meyer-Waarden, L.; Driesener, C. Has Brand Loyalty Declined? A Longitudinal Analysis of Repeat Purchase Behavior in the UK and the USA. J. Bus. Res. 2015, 68, 425-432. [CrossRef]

43. Smith, A.; Stirling, A. Innovation, Sustainability and Democracy: An Analysis of Grassroots Contributions. J. Self-Gov. Manag. Econ. 2018, 6, 64-97. [CrossRef]

44. Brunner, T.A.; Stocklin, M.; Opwis, K. Satisfaction, Image and Loyalty: New Versus Experienced Customers. Eur. J. Mark. 2008, 42, 1095-1105. [CrossRef]

45. Alvarado-Herrera, A.; Bigne, E.; Aldas-Manzano, J.; Curras-Perez, R. A Scale for Measuring Consumer Perceptions of Corporate Social Responsibility Following the Sustainable Development Paradigm. J. Bus. Ethics 2017, 140, 243-262. [CrossRef]

46. Hafez, M. Measuring the Impact of Corporate Social Responsibility Practices on Brand Equity in the Banking Industry in Bangladesh the Mediating Effect of Corporate Image and Brand Awareness. Int. J. Bank Mark. 2018, 36. [CrossRef]

47. Long, C.Z.; Lin, J. The Impact of Corporate Environmental Responsibility Strategy on Brand Sustainability: An Empirical Study Based on Chinese Listed Companies. Nakai Bus. Rev. Int. 2018, 9, 366-394. [CrossRef]

48. Alcaide, M.A.; De La Poza, E.; Guadalajara, N. Assessing the Sustainability of High-Value Brands in the IT Sector. Sustainability 2019, 11, 1598. [CrossRef]

49. Pinto, D.C.; Herter, M.M.; Goncalves, D.; Savin, E. Can Luxury Brands Be Ethical? Reducing the Sophistication Liability of Luxury Brands. J. Clean. Prod. 2019, 233, 1366-1376. [CrossRef]

50. Tofighi, M.; Bodur, H.O. Social Responsibility and its Differential Effects on the Retailers' Portfolio of Private Label Brands. Int. J. Retail. Distrib. Manag. 2015, 43, 301-313. [CrossRef]

51. Lizbetinova, L. The Quality of Communication in the Context of Regional Development. Deturope-Cent. Eur. J. Reg. Dev. Tour. 2014, 6, 22-38.

52. Casteran, G.; Chrysochou, P.; Meyer-Waarden, L. Brand loyalty evolution and the impact of category characteristics. Mark. Lett. 2019, 30, 57-73. [CrossRef] 
53. Sukalova, V.; Ceniga, P. Customer Protection in the Field of Life Insurance. Lect. Notes Manag. Sci. 2017, 73, 17-22. [CrossRef]

54. Kolnhofer Derecskei, A. Relations between Risk Attitudes, Culture and the Endowment Effect. Eng. Manag. Prod. Serv. 2018, 10, 7-20. [CrossRef]

55. Berzakova, V.; Bartosova, V.; Kicova, E. Modification of EVA in Value Based Management. Procedia Econ. Financ. 2015, 26, 317-324. [CrossRef]

56. Lizbetinova, L.; Starchon, P.; Lorincova, S.; Weberova, D.; Prusa, P. Application of Cluster Analysis in Marketing Communications in Small and Medium-Sized Enterprises: An Empirical Study in the Slovak Republic. Sustainability 2019, 11, 2302. [CrossRef]

57. Tuffnell, C.; Kral, P.; Durana, P.; Krulicky, T. Industry 4.0-based Manufacturing Systems: Smart Production, Sustainable Supply Chain Networks, and Real-time Process Monitoring. J. Self-Gov. Manag. Econ. 2019, 7, 7-12. [CrossRef]

58. Popescu Ljungholm, D. Employee-employer Relationships in the Gig Economy: Harmonizing and Consolidating Labor Regulations and Safety Nets. Contemp. Read. Law Soc. Justice 2018, 10, 144-150. [CrossRef]

59. Svabova, L.; Kramarova, K.; Durica, M. Prediction Model of Firm'S Financial Distress. Ekon. Manaz. Spektrum 2018, 12, 16-29. [CrossRef]

60. Kliestikova, J.; Kovacova, M.; Krizanova, A.; Durana, P.; Nica, E. Quo Vadis Brand Loyalty? Comparative Study of Perceived Brand Value Sources. Pol. J. Manag. Stud. 2019, 19, 190-203. [CrossRef]

61. Krylov, S. Strategic Customer Analysis Based on Balanced Scorecard. Ekon. Manaz. Spektrum 2019, 13, 12-25. [CrossRef]

(C) 2020 by the authors. Licensee MDPI, Basel, Switzerland. This article is an open access article distributed under the terms and conditions of the Creative Commons Attribution (CC BY) license (http://creativecommons.org/licenses/by/4.0/). 
Article

\title{
Sustainable Value Creation in the Food Chain: A Consumer Perspective
}

\author{
József Tóth ${ }^{1,2, *}$, Giuseppina Migliore ${ }^{3}$, Giorgio Schifani ${ }^{3}$ and Giuseppina Rizzo ${ }^{3, *}$ \\ 1 Department of Agricultural Economics and Rural Development, Corvinus University of Budapest, \\ 1093 Budapest, Hungary \\ 2 Faculty of Economics, Socio-Human Sciences and Engineering, Sapientia Hungarian University of \\ Transylvania, 530104 Miercurea Ciuc, Piaţa Libertăţii nr. 1, Romania \\ 3 Department of Agricultural, Food and Forest Sciences, University of Palermo, 90128 Palermo, Italy; \\ giuseppina.migliore@unipa.it (G.M.); Giorgio.schifani@unipa.it (G.S.) \\ * Correspondence: jozsef.toth@uni-corvinus.hu (J.T.); giuseppina.rizzo03@unipa.it (G.R.); \\ Tel.: +36-30-555-9755 (J.T.); +39-320-041-5120 (G.R.)
}

Received: 24 January 2020; Accepted: 13 February 2020; Published: 14 February 2020

\begin{abstract}
The growth of diet-related diseases is becoming an important societal concern and a challenge for a more sustainable society. This has developed important trends in food consumption, including the increasing demand for food with a natural attribute and with health claims (e.g., enriched food). Consumers tend to evaluate these two attributes as superior ones and tend to pay a premium price for them. Accordingly, the value added by producers also will upturn if they take into consideration the consumers' preferences. However, to the best of our knowledge, consumer preference over the two types of products (natural and enriched) is not yet completely clear. The present study tries to contribute to reducing this gap by analyzing Hungarian consumer preferences for natural fruit juices over enriched ones and exploring the drivers which guide consumer choices for the two attributes. For this purpose, we analyze young consumers' willingness-to-pay (WTP) for natural and enriched fruit juices using a seemingly unrelated regression (SUR) to derive the two value-added activities. Our results show that the fruit juice with the natural attribute is preferred over the enriched one, and that there is a common feature behind the perception of the two attributes, namely the healthiness. Based on the natural fruit juice characteristic, these results open space for local production in gardens or in small-medium sized farms. This could have beneficial effects, both for sustainable development of rural areas and for the promotion of healthy food systems towards sustainability in food consumption.
\end{abstract}

Keywords: willingness to pay; enriched attribute; natural attribute; healthy attribute; seemingly unrelated regression (SUR); fruit juice; Hungary

\section{Introduction}

The growth of diet-related diseases is becoming an important societal concern and a challenge for a more sustainable society [1]. As a result, today, consumers are aware that their diet affects their health and so prefer to choose food that helps them to have a healthy lifestyle. [2,3]. This has contributed to the development of important trends in food consumption, which has seen, amongst others, the growing consumer interest towards foods with natural and health claims attributes [4]. The category of food with health claims includes food enriched with healthy components, such as polyphenols, vitamins, and other healthy components [2], while natural food is food without additives and human interventions, considered by consumers harmful for their health [5].

The Kampffmeyer Food Innovation Study [6] revealed that food naturalness is a decisive buying incentive and that the majority of the consumers perceived a strong connection between "natural" and 
"healthy." Furthermore, it has been demonstrated that consumers living in developed countries prefer natural foods over the conventional ones, as they are considered to have positive health effects [7]. Similarly, foods with health claims have registered a growing market success. According to the latest available data [8,9], 27\% of global respondents, on average, are very willing to pay a premium price for health claims. This percentage is slightly higher in western countries and particularly in the U.S., where the majority of consumers believe that health claim foods give real benefits in improving and maintaining overall health, and nearly $30 \%$ indicate that they buy products with health claims on the labels [10].

The growing consumers' interest towards these product characteristics has pushed the food industry to provide healthier products [11,12]. The use of health as a selection criterion has already been offering new possibilities to the food market and continues to provide new challenges for producers [13]. One of these challenges for the food industry is to give consumers product options with a natural and healthy image.

From a consumers perspective, interest shown towards these two attributes (natural and health claims) is due to the common will of consumers to improve or maintain their health, although the two attributes have different exceptions [14]. Health motivations as factors for purchasing natural and health claim products have already been investigated in several studies $[14,15]$. However, to the best of our knowledge, consumer preference over the two types of attributes is not yet completely clear.

The present study tries to reduce this gap, by analyzing consumer preferences for the attributes natural and health claim, and exploring the drivers affecting consumer choices for both attributes. Knowing which attribute is more valued by consumers could give important indications to the food industry more oriented to provide products with a health image. Furthermore, understanding the drivers behind consumer preference could be useful for planning successful marketing strategies for those enterprises oriented to satisfying those consumers' needs.

Based on these premises, three objectives have been set in this study: 1. to investigate which attribute, between natural and health claims, is more appreciated by consumers; 2 . to explore the drivers behind consumers' choice for both health attributes, and 3. to verify whether the price premium of two types of attributes is explained by common factors.

To answer these research questions, the present study used a laboratory experiment in order to derive the consumer's willingness to pay (WTP) for natural and enriched attributes. The remainder of the paper is organized as follows: after the introduction, Section 2 explains the theoretical framework and consumer choices on healthy products in Hungary; Section 3 shows the data collection and methods; Section 4 presents results and discussion and, finally, in Section 5, we conclude, and the study limitations are provided.

\section{Theoretical Framework}

Consumers consider the naturalness of foods as a highly valued quality characteristic [16]. They interpret the food naturalness as an indicator of the healthiness and quality of the product, derived from the 'integral integrity of the product' [17]. As a result, natural products are perceived as good for your health as they are free of additives and other synthetic substances, perceived to reduce the healthiness of food [18-21]. Furthermore, the idea of natural eating seems to generate a perception of physical and emotional well-being [22]. This is supported also by Rozin [18], according to whom natural food evokes a positive association in consumers' minds, following the idea that 'natural entities are inherently better than non-natural entities'. According to the literature, higher natural food consumption seems to be associated with the perception that processed food can cause high health risks $[20,23]$.

Similarly, health claim products have registered a faster market growing in the last few years, responding to consumers concerns on health and providing messages about specific benefits of products that potentially increase perceived wellbeing [24]. Indeed, enriched foods communicate their health-related benefits with the help of claims that may contain a bulk of information [25]. 
The typical elements that health claims may be built from are the components that trigger the function by generating physiological and psychological benefits [1]. Enriched food looks similar to conventional food and is consumed as part of a regular diet and has been shown to have health benefits and/or reduce the risk of chronic diseases beyond the basic nutritional functions of food [26].

However, how consumers respond to enriched food varies from product to product. From a consumer's perspective, enriched foods are not a homogenous category of products, and consumers' attitudes seem to affect the purchasing intention for various enriched products differently [15]. Moreover, some enriched foods are perceived as less natural, since the beneficial components which trigger the function are derived from technology-based enhancement, and they may include foods with chemical additives and preservatives.

Thus, consumer perception is influenced by both the health element that has been added in food and the process by which this addition happened [2]. Acceptance of food products depends on the health image of the product category or the ingredients [27], on the production method [1] and how the product was enriched and 'tampered with' [28]. According to Lähteenmäki [1], the familiarity with the product greatly influences the perception of the consumer. In fact, familiarity is a key factor in acceptance of enriched food [27]. However, although it may be thought that natural and enriched foods are contradictory (for example due to the difference in health-related message), there are several studies that indicate a link between the two concepts, because both are chosen by consumers to improve or maintain their health [29]. For example, Caracciolo and colleagues [30] investigated consumer preferences for the two attributes and their empirical findings revealed that consumers evaluate both attributes, natural and enriched, similarly.

Among the products having a health image, fruit juices are among the most recognizable, thanks to their natural contents of vitamins and minerals [31]. The fruit juice market is one of the most innovative and competitive segments of the food sector [31]. Manufacturers striving to expand sales are focusing on product diversification, developing fruit juices that go beyond the taste of the product and providing general health benefits. Since fruits are the primary source of ascorbic acid in the diet, the enrichment of fruit juices has been concerned mainly with this vitamin [32]. In this context, vitamin enrichments are more accepted by consumers compared to other types of fruit juice enrichment, for example with calcium, since the latter is perceived an unnatural type of enrichment [28,33]. This would position vitamin-enriched fruit juices closer to natural food, creating a more "holistic health image" [28]. Similarly, consumers are increasingly preferring fruit juices with the natural attribute, containing $100 \%$ in fruit. These drinks are free from added sugars and artificial colors or flavors, and they represent an opportunity for those companies that want to create a competitive advantage in the fruit juice market. Furthermore, to create a strong sense of community and add value to the product, the local origin of the ingredients is often emphasized and well specified in natural fruit juices. As a result, there is a growing consumer interest in local products that position these fruit juices as healthier and more sustainable than their conventional counterparts [31]. However, to date, it is not clear which type of attribute (enriched or natural) is more preferred by consumers in fruit juices. This information could be very helpful for those companies operating in those market segments where healthy products are becoming of primary importance in consumers' buying behavior. For this reason, we carried out an experimental study in Győr, Hungary, because this country is among those where consumers are starting to pay more attention to their health [34,35]. Indeed, in Hungary, alongside economic growth, the healthy diet and lifestyle are becoming increasingly important for consumers [36]. Literature reveals that health issues represent the main reason for purchasing health food and that health attributes have become as important as sensory ones, during the buying decision-making process [37]. For example, Balázs [38] in his study showed that more than half of the respondents were willing to pay an extra $10 \%$ for healthy products. Moreover, Balázs's findings showed that consumers of healthy food generally have higher levels of education and higher incomes, while their age ranged between young and middle-aged. Furthermore, according to the literature young consumers seem to exceed all prior generational expenditure [39], making a large direct contribution to the economy [40] and an even larger indirect 
economic impact, by influencing the majority of family purchase decisions [41]. In addition, young consumers have significant current and future impact on the Western economies and are accordingly considered the most powerful consumer group in the marketplace [42]. For this reason, we have focused our attention on the university student generation in Hungary, in order to understand which health attribute, enriched or natural, is preferred in fruit juices. Knowing the theoretical framework is fundamental to developing this research, which may contribute to better marketing design strategies and, successively, contribute to creating a competitive market advantage for food companies.

\section{Materials and Methods}

\subsection{Experimental Auctions}

The experiments were conducted over a two-week period, in autumn 2018, at the "Széchenyi István" University (Hungary). The consumers of this study were students, who were recruited randomly and informed they were participating in a consumer preference research study for different types of fruit juice. Using the Vickrey auction methodology [43], an experimental evaluation process was chosen, which is identified in the fifth-price auction. Ten 25-min experimental sessions involving ten people each were organized. The choice of the fifth-price auction allows, at the same time, the number of participants in the auction and their degree of involvement to be increased. Lusk et al. [44] showed that bidders would generally be more involved if at least half of them could potentially win the product at auction. In addition, participants were told that only one round and one product would be binding, to avoid reductions in demand and effects on wealth in subsequent rounds [45]. Each participant in the auction received 2000 Hungarian forints (HUF) (approximately $€ 5.50$ ) as a reward for his/her participation in the auction. All respondents rated the three fruit juices containing the same amount of information.

In the initial phase, participants were selected from among those who said they had been drinking fruit juice for the past two weeks. In the second phase, every individual received the monetary compensation and signed a consent form and a form committing him/her to buy the product in the case of a victory. In the third phase, the auction mechanism was explained, and in the fourth phase, a researcher described the three fruit juices' characteristics. The three products were (1) conventional fruit juice, used as a control product, compared to the other two types of fruit juices, (2) $100 \%$ natural fruit juice made from fruit straight from the garden, with no dilution and no concentrate and (3) fruit juice enriched with sea buckthorn to strengthen the immune system and with a high vitamin $C$ content. The three fruit juices were packaged in three white and unbranded packs, to avoid the effects of the brand and the label. In the fifth phase, the participants wrote their sealed bids on anonymous tickets. Finally, in the last phase, everyone completed a questionnaire and one fruit juice and one price (market price) were randomly extracted. Those participants who bid more for the auctioned fruit juice compared to the market price won the fruit juice, paying the extracted price for it.

\subsection{Questionnaire}

The questionnaire included two main sections. The first section collected information on consumers' socio-demographic characteristics (age, gender, number of household members and monthly net income), on their consumption frequency of fruit juice and the characteristics that are sought in the product (good taste and smell, vitamin and mineral content, geographical origin, nice appearance, calories content, free from artificial materials, price and brand name). The second section included three psycho-attitudinal scales: natural product interest (NPI), general health interest (GHI), and reward from using functional food (RFF). These scales are widely used in the literature [46,47]. More precisely, GHI and NPI scales were developed by Roininen, Lähteenmäki and Tuorila [48]; the first consists of eight articles that reveal the consumers' attitude towards healthy eating, while the second scale includes six articles aimed at capturing the consumers' attitude towards the consumption of unprocessed food. The RFF scale was proposed by Lähteenmäki [49] and includes seven items that explain the declaration 
of gratitude deriving from the use of enriched foods. These validated GHI, NPI and RFF attitude scales were collected by means of 7-point Likert scales, where 1 corresponds to totally disagree and 7 to totally agree.

\subsection{Statistical Analysis}

The data collected were processed in four distinct phases, using the STATA 15.0 (Budapest, Hungary) integrated statistical software. In the first phase, the socio-demographic characteristics of the sample were defined, through descriptive analyses; in the second phase, the psycho-attitudinal scales were interpreted, checking their internal consistency (alpha-coefficient) and calculating the average of each item. In the third part, a description of the WTPs detected for the three types of fruit juices was made; in addition, by means of parametric (t-test) and non-parametric tests (Wilcoxon tests), it was verified whether the three WTPs were significantly different, and therefore, two deltas (premium prices) were calculated. The two premium prices were obtained, one at a time, by first calculating the difference between the WTP for natural and conventional fruit juices and then the difference between WTP for enriched and conventional fruit juice:

$$
\begin{aligned}
& \Delta W T P_{N A T}=\left(W T P_{N A T}-W T P_{C O N V}\right) \\
& \Delta W T P_{E N R}=\left(W T P_{E N R}-W T P_{C O N V}\right)
\end{aligned}
$$

Later, the seemingly unrelated regressions (SUR) [50] were presented, together the Breusch-Pagan test of independence, to measure how the price premium of the two fruit juices can be influenced and, at the same time, to verify whether the price premium of the two types of juices is explained by common attributes.

This stochastic model may be expressed by the following relationship:

$$
y=X \beta+u
$$

where $y$ and $u$ are vectors with n elements, $X$ is a matrix with n rows and $k+1$ columns (with $k$ the explanatory variables +1 for the constant) and $\beta$ is the vector containing $k+1$ unknown coefficients.

\section{Results and Discussion}

\subsection{Sample Description}

The consumers participating in the experiment were 100 students of the "Széchenyi István" University of Győr (Hungary), including 29 males and 71 females, between 18 and 28 years of age (mean age $=22$; S.D. $=2.23$ ). The number of family members the students had ranged from 1 to 5 , where 1 indicates that the student lives alone and 5 indicates that he/she lives with more than 4 people. The average number of members per family was 3 people. Finally, the monthly net income was in a range from "below 60 thousand" and "more than 350 thousand", with an average of about 120 thousand HUF (about $€ 360$ ). The socio-demographic characteristics of the participants are shown in Table 1.

Table 1. Socio-demographic characteristics of the sample.

\begin{tabular}{ccccc}
\hline Variables & Mean & Std. dev. & Min & Max \\
\hline Gender $^{1}$ & 0.29 & 0.50 & 0 & 1 \\
Age $^{2}$ & 21.65 & 2.23 & 18 & 28 \\
Family Members $^{3}$ & 2.77 & 1.12 & 1 & 5 \\
Monthly Income $^{4}$ & 1.81 & 0.64 & 1 & 3 \\
\hline
\end{tabular}

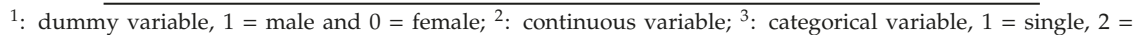
two members, 3 = three members, $4=$ four members, $5=$ family with more than 4 members; ${ }^{4}$ categorical variable, $1=<60$ thousand HUF; $2=60-120$ thousand HUF; $3=121-220$ thousand HUF; $4=221-350$ thousand HUF; $5=>350,000$. 


\subsection{Psycho-Attitudinal Scales}

Attitudes have been shown to have a great effect during the consumers' decision-making process, and for this reason, they were used in the present study to explain consumers' food choices, through appropriate attitudinal scales [51]. In particular, the GHI scale was chosen because it is expected to correlate positively with attitudes towards enriched foods [48]; the NPI scale is hypothesized to have a positive correlation with natural product consumption [48], while the RFF is expected to have a positive correlation with the consumer's willingness to feed himself/herself with enriched foods in order to improve or maintain a state of health [52,53]. Furthermore, for those items with negative meaning, Likert scale scores were reversed to improve the attitude scales' readability.

The Cronbach's alpha value was 0.85 for natural product interest, 0.83 for general health interest and 0.89 for reward from using functional food, indicating a good internal reliability (Table 2).

Table 2. Internal reliability of the scales.

\begin{tabular}{cc}
\hline Scale & Cronbach's Alpha \\
\hline GHI & 0.83 \\
NPI & 0.85 \\
RFF & 0.89 \\
\hline
\end{tabular}

The results show a high awareness of consumers about the health consequences of their food choices. Indeed, the higher GHI item scores were: "The healthiness of food has little impact on my food choices" (reversed mean $=5.00$ ) and "I am very careful about the healthiness of food I eat" (mean $=4.51$ ). Concerning NPI, the items with the highest scores were: "Foods containing artificial flavor enhancers are not harmful to health" (reversed mean $=5.98$ ) and "Organically grown vegetables are no healthier than others" (reversed mean $=6.10$ ). The items with the highest values for RFF were: "I get pleasure from eating functional foods" (mean $=5.77$ ) and "The idea that I can take care of my health by eating functional foods gives me pleasure" (mean $=6.01$ ).

Finally, correlation coefficients were computed and the presence of a positive and statistically significant correlation was found among all the three scales (Table 3).

Table 3. Correlation coefficients of the scales.

\begin{tabular}{cccc}
\hline & GHI & NPI & RFF \\
\hline GHI & 1.0000 & & \\
NPI & 0.5890 & 1.0000 & \\
RFF & 0.6601 & 0.4233 & 1.0000 \\
\hline
\end{tabular}

The descriptive statistics of individual items composing the three scales are shown in Tables 4-6.

Table 4. Items' statistics of general health interest (GHI) scale.

\begin{tabular}{|c|c|c|c|c|c|}
\hline & General Health Interest (GHI) & Mean & S.D. & Min & Max \\
\hline GHI_1 & $\begin{array}{l}\text { The healthiness of food has little impact on my food } \\
\text { choices. }\end{array}$ & 5.00 & 1.6 & 1 & 7 \\
\hline GHI_2 & $\begin{array}{c}\text { I am very particular about the healthiness of food I } \\
\text { eat. }\end{array}$ & 4.51 & 1.39 & 1 & 7 \\
\hline GHI_3 & $\begin{array}{c}\text { I eat what I like, and I do not worry much about the } \\
\text { healthiness of food. }\end{array}$ & 4.06 & 1.67 & 1 & 7 \\
\hline GHI_4 & It is important for me that my diet is low in fat. & 3.53 & 1.40 & 1 & 7 \\
\hline GHI_5 & I always follow a healthy and balanced diet. & 3.85 & 1.54 & 1 & 7 \\
\hline GHI_6 & $\begin{array}{l}\text { It is important for me that my daily diet contains a } \\
\text { lot of vitamins and minerals. }\end{array}$ & 4.67 & 1.49 & 1 & 7 \\
\hline GHI_7 & The healthiness of snacks makes no difference to me. & 3.64 & 1.94 & 1 & 7 \\
\hline GHI_8 & $\begin{array}{l}\text { I do not avoid foods, even if they may raise my } \\
\text { cholesterol. }\end{array}$ & 3.78 & 1.66 & 1 & 7 \\
\hline
\end{tabular}


Table 5. Items' statistics of natural product interest (NPI) scale.

\begin{tabular}{|c|c|c|c|c|c|}
\hline \multicolumn{2}{|c|}{ Natural Product Interest (NPI) } & \multirow{2}{*}{$\begin{array}{c}\text { Mean } \\
3.98\end{array}$} & \multirow{2}{*}{$\begin{array}{l}\text { S.D. } \\
1.70\end{array}$} & \multirow{2}{*}{$\begin{array}{c}\text { Min } \\
1\end{array}$} & \multirow{2}{*}{$\frac{\text { Max }}{7}$} \\
\hline NPI_1 & $\begin{array}{l}\text { I try to eat foods that do not } \\
\text { contain additives. }\end{array}$ & & & & \\
\hline NPI_2 & $\begin{array}{l}\text { I do not care about additives in } \\
\text { my daily diet. }\end{array}$ & 4.33 & 1.72 & 1 & 7 \\
\hline NPI_3 & $\begin{array}{l}\text { I do not eat processed foods, } \\
\text { because I do not know what they } \\
\text { contain. }\end{array}$ & 3.42 & 1.83 & 1 & 7 \\
\hline NPI_4 & $\begin{array}{l}\text { I would like to eat only } \\
\text { organically grown vegetables. }\end{array}$ & 5.59 & 1.56 & 1 & 7 \\
\hline NPI_5 & $\begin{array}{c}\text { In my opinion, artificially flavored } \\
\text { foods are not harmful for my } \\
\text { health. }\end{array}$ & 5.98 & 1.16 & 1 & 7 \\
\hline NPI_6 & $\begin{array}{l}\text { In my opinion, organically grown } \\
\text { foods are no better for my health } \\
\text { than those grown conventionally. }\end{array}$ & 6.10 & 1.37 & 1 & 7 \\
\hline
\end{tabular}

Table 6. Items' statistics of reward from using functional food (RFF) scale.

\begin{tabular}{|c|c|c|c|c|c|}
\hline \multicolumn{2}{|c|}{ Reward from using Functional Food (RFF) } & \multirow{2}{*}{$\begin{array}{c}\text { Mean } \\
5.77\end{array}$} & \multirow{2}{*}{$\begin{array}{l}\text { S.D. } \\
1.35\end{array}$} & \multirow{2}{*}{$\frac{\text { Min }}{1}$} & \multirow{2}{*}{ Max } \\
\hline RFF_1 & $\begin{array}{l}\text { I get pleasure from eating } \\
\text { functional foods. }\end{array}$ & & & & \\
\hline RFF_2 & $\begin{array}{l}\text { The idea that I can take care of my } \\
\text { health by eating functional foods } \\
\text { gives me pleasure. }\end{array}$ & 6.01 & 1.17 & 1 & 7 \\
\hline RFF_3 & $\begin{array}{l}\text { Functional foods make me feel } \\
\text { more energetic. }\end{array}$ & 5.12 & 1.43 & 1 & 7 \\
\hline RFF_4 & $\begin{array}{l}\text { Functional foods help to improve } \\
\text { my mood. }\end{array}$ & 4.69 & 1.53 & 1 & 7 \\
\hline RFF_5 & $\begin{array}{l}\text { My performance improves when I } \\
\text { eat functional foods. }\end{array}$ & 4.81 & 1.43 & 1 & 7 \\
\hline RFF_6 & $\begin{array}{l}\text { I actively seek out information } \\
\text { about functional foods. }\end{array}$ & 4.27 & 1.57 & 1 & 7 \\
\hline RFF_7 & $\begin{array}{l}\text { I willingly try even unfamiliar } \\
\text { products if they are functional. }\end{array}$ & 4.04 & 1.63 & 1 & 7 \\
\hline
\end{tabular}

\subsection{Willingness to Pay (WTP)}

Consumer bids describe how much participants are willing to pay for conventional, natural and enriched fruit juice. The estimated average WTPs were the following: $646.76 \mathrm{HUF}$ (about $€ 1.93$ ) for the conventional fruit juice, 794.09 HUF (about €2.37) for the enriched fruit juice, and 957.93 (about €2.86) for the natural fruit juice (Table 7).

Table 7. Consumers' willingness to pay.

\begin{tabular}{ccccc}
\hline & Mean & S. D. & Min & Max \\
\hline$W T P_{C O N}$ & 646.76 & 322.32 & 50 & 1800 \\
$W T P_{E N R}$ & 794.09 & 369.98 & 100 & 2000 \\
$W T P_{N A T}$ & 957.93 & 489.08 & 200 & 2500 \\
$\Delta W T P_{E N R}$ & 147.32 & 178.91 & -500 & 1050 \\
$\Delta W T P_{N A T}$ & 311.17 & 287.97 & -270 & 1400 \\
\hline
\end{tabular}

By means of a t-test and Wilcoxon test, it was possible to verify that there are statistically significant differences between the two attributes and that the natural attribute was preferred to the enriched attribute. Indeed, $\triangle W T P_{N A T}$, that is the differential value between the natural fruit juice and the conventional one, has an average value of 311.17 HUF (about $0.93 €$ ), while $\triangle W T P_{E N R}$, which is the 
differential value between the enriched fruit juice and the conventional one, has an average value of 147.32 HUF (about €0.44) (Table 7).

\subsection{Drivers Behind Consumers' WTP for Both Attribute}

It is clear that consumer choice depends on many factors [48]. By performing a SUR between the two WTP for natural and enriched fruit juices and the other variables collected through the questionnaire, such as the consumer characteristics and psycho-attitudinal scales, it was possible to understand which are the drivers affecting consumer WTP for the two attributes. In Table 8 drivers behind consumers' WTP for both enriched and natural attributes, and the estimated coefficients as well as their statistical significance, are shown.

Table 8. Drivers behind consumers' willingness to pay.

\begin{tabular}{ccccc}
\hline Equation & Obs & Parms & “R-sq" & $p$ \\
\hline$\Delta W T P_{E N R}$ & 95 & 4 & 0.1675 & 0.0007 \\
$\Delta W T P_{N A T}$ & 95 & 4 & 0.1093 & 0.0201 \\
\hline$\Delta W T P_{\text {ENR }}$ & Coef. & Std. Err. & $\mathbf{z}$ & $\mathbf{z} \mid$ \\
\hline GHI & -61.76 & 23.05 & -2.68 & 0.007 \\
NPI & -0.56 & 21.35 & -0.03 & 0.979 \\
RFF & 70.81 & 19.62 & 3.61 & 0.000 \\
INCOME & 37.01 & 15.02 & 2.46 & 0.014 \\
\hline$\Delta W T P_{N A T}$ & Coef. & Std. Err. & $\mathbf{z}|\mathbf{z}|$ \\
\hline GHI & -21.24 & 38.34 & -0.55 & 0.580 \\
NPI & -16.61 & 35.50 & -0.47 & 0.640 \\
RFF & 72.22 & 32.64 & 2.21 & 0.027 \\
INCOME & 60.09 & 24.97 & 2.41 & 0.016 \\
\hline
\end{tabular}

Breusch-Pagan test of independence: $\operatorname{ch} 2(1)=63.129, \operatorname{Pr}=0.0000$.

For the section on consumers' WTP for vitamin-enriched fruit juice as a dependent variable, the results showed that the participants' preference is mainly affected by participants' attitude towards healthy eating (through their importance attributed to the items of the general interest scale for health (GHI)), towards the reward from using enriched foods (RFF) and consumers' monthly net income. Looking at this in more detail, RFF attitude and the monthly net income are positively correlated with the dependent variable; therefore, as the value of these independent variables increases, the average of the WTP for the enriched fruit juice tends to increase. On the contrary, the negative coefficient of GHI attitude suggests that as they increase, the dependent variable tends to decrease. This means that the attitude towards healthy eating negatively affects the preference for the enriched fruit juice. This research is in line with other studies that describe the choice for the two attributes to improve or maintain a state of health $[14,54,55]$.

Relatively to the consumers' WTP for the natural fruit juice, the results show that, contrary to what was showed by Caracciolo and colleagues' study, the preference for natural fruit juice is not explained by the NPI attitude. According to the results, the WTP values for natural fruit juice seem to be also affected by RFF attitudes, which in this case is related to the rewards from using natural fruit juice rich in vitamins. This suggests the interest for both attributes (enriched and natural) seems to be affected by common drivers, that is, rewards from using fruit juices richer in vitamins compared to the conventional one. Differences in results, compared to other research findings, may depend on consumers familiarity with the product [1], suggesting, in line with Urala and Lähteenmäki's study [15], that effects on consumer choice have to be studied not as one homogenous group of product, but rather as separate products within the various food categories. Furthermore, monthly net income positively affects consumers' WTP for both products. This is in line with Bruchi and colleagues' study [50] 
showing how as the level of monthly net income increases, the WTP for natural and enriched fruit juice increases.

\section{Conclusions}

The present study had multiple objectives: to investigate the preferences for natural and enriched products and to understand which drivers affect their preference and if there are common drivers between the two WTP. To respond to these research questions, consumers' preferences for enriched and natural attributes were measured via an experimental auction on fruit juices. Outcomes point out that consumers prefer natural fruit juice more than the enriched ones, but the motivations underlying consumers' preferences for both products are the same (the perceived reward from consuming fruit juices richer in vitamins compared to the conventional one).

These results can help us to understand how much and how consumers accept innovations in the food market, and therefore, help companies put their products on the markets.

Our analysis also reveals the primacy of natural fruit juice against the enriched fruit juices at WTP level. Regarding the participants' cohort and the way the juice was produced (fresh apples direct from the garden/local farms, without burdening the environment) we can also conclude that producers along the food chain may create additional value if they consider the consumer preferences of the younger generation.

Furthermore, the preference for natural fruit juice opens space for local production in gardens or in small-medium sized farms. This could have beneficial effects, on one hand for sustainable development of the rural area due to the resulting lower $\mathrm{CO} 2$ emissions from short-distance transportation and the recirculation of financial capital in rural areas. On the other hand, the preference for the natural attribute could be a leverage for the promotion of healthy and sustainable food systems more oriented towards sustainability in food consumption. This direction is very much in line with the sustainability requirements of the globe. The study carries significant implications for consumer research on the preference of sustainable fruit juices, as well as practical management implications. Regarding the former, our study is one of the first to analyze consumer behavior towards fruit juices with health attributes, thus enriching extant literature on the willingness to pay a premium price for health attributes, and reinforcing business literature, which supports that consumers have a positive attitude towards sustainable products. In addition, our results corroborate the importance of consumer attitudinal characteristics in explaining the purchasing decision process for products with sustainable characteristics. As for the managerial perspective, our results offer entrepreneurs suggestions to differentiate their product offerings. In fact, considering the growing awareness, among consumers, of the importance of healthy food consumption, the Hungarian fruit juices industry is called upon to develop effective marketing strategies that will help consumers identify and distinguish fruit juices on the market. From this point of view, the ability of industries to develop innovations in this direction, which could boost the competitive performance of companies, is particularly important.

Although the study offers much food for thought, it has some limitations, such as having used a non-representative sample; thus, the generalizability of the results is limited. Furthermore, the RFF attitude in explaining the preference for both attributes in fruit juices opens space for further analysis in order to validate the results of the present study or overcome its limitations. Therefore, further studies have to take into account statistically representative samples in order to capture a full picture of consumers' preferences for healthy fruit juices. Moreover, further research could be repeated in different markets also for comparison. This would offer cross-cultural insights and help adapt marketing strategies to the individual and/or global perspectives.

Author Contributions: Conceptualization, J.T. and G.R.; methodology, J.T. and G.S.; formal analysis, investigation and writing-original draft preparation, G.R.; writing—review and editing, J.T. and G.M. All authors have read and agree to the published version of the manuscript.

Funding: This research was funded by National Research, Development and Innovation Office (NKFI), Hungary, grant number OTKA-120563 
Conflicts of Interest: The authors declare no conflicts of interest. The funders had no role in the design of the study; in the collection, analyses, or interpretation of data; in the writing of the manuscript, or in the decision to publish the results.

\section{References}

1. Lähteenmäki, L. Claiming health in food products: Ninth Pangborn Sensory Science Symposium. Food Qual. Prefer. 2013, 27, 196-201. [CrossRef]

2. Grunert, K.G. Consumer Trends and New Product Opportunities in the Food Sector; Academic Publishers: Wageningen, The Netherlands, 2017.

3. Goetzke, B.; Nitzko, S.; Spiller, A. Consumption of organic and functional food. A matter of well-being and health? Appetite 2014, 77, 96-105. [CrossRef] [PubMed]

4. Willer, H.; Schaack, D.; Lernoud, J. Organic farming and market development in Europe and the European Union. In The World of Organic Agriculture. Statistics and Emerging Trends; Research Institute of Organic Agriculture FiBL and IFOAM-Organics International: Bonn, Germany, 2019; pp. 217-254. Available online: https://shop.fibl.org/chde/2020-organic-world-2019.html (accessed on 10 November 2019).

5. Asioli, D.; Aschemann-Witzel, J.; Caputo, V.; Vecchio, R.; Annunziata, A.; Næs, T.; Varela, P. Making sense of the "clean label" trends: A review of consumer food choice behavior and discussion of industry implications. Food Res. Int. 2017, 99, 58-71. [CrossRef] [PubMed]

6. GoodMills Innovation. Available online: http://goodmillsinnovation.com/sites/kfi.kampffmeyer. faktor3server.de/files/attachments/1_pi_kfi_cleanlabelstudy_english_final.pdf/ (accessed on 15 October 2016).

7. Roman, S.; Sánchez-Siles, L.M.; Siegrist, M. The importance of food naturalness for consumers: Results of a systematic review. Trends Food Sci. Technol. 2017, 67, 44-57. [CrossRef]

8. Nielsen Company. Available online: https://www.nielsen.com/wp-content/uploads/sites/3/2019/04/healthwellness-report-feb-2017.pdf (accessed on 7 December 2019).

9. Nielsen Company. Available online: https:/www.nielsen.com/wpcontent/uploads/sites/3/2019/04/ Nielsen20Global20Health20and20Wellness20Report20-20January202015-1.pdf (accessed on 12 October 2018).

10. Sloan, E.; Adams Hutt, C. Beverage trends in 2012 and beyond. Agro. FOOD Ind. Hi Tech. 2012, 23, 8-12.

11. Nguyen, H.V.; Nguyen, N.; Nguyen, B.K.; Lobo, A.; Vu, P.A. Organic Food Purchases in an Emerging Market.: The Influence of Consumers' Personal Factors and Green Marketing Practices of Food Stores. Int. J. Environ. Res. Public Health 2019, 16, 1037. [CrossRef]

12. Seiders, K.; Ross, D.P. Obesity and the Role of Food Marketing: A Policy Analysis of Issues and Remedies. J. Public Policy Mark. 2004, 23, 153-169. [CrossRef]

13. Casey, D.K. Three Puzzles of Private Governance: Global GAP and the Regulation of Food Safety and Quality. UCD Working Papers in Law, Criminology \& Socio-Legal Studies. United Kingdom. 2009. Available online: http://dx.doi.org/10.2139/ssrn.1515702 (accessed on 1 November 2019).

14. Aschemann-Witzel, J.; Maroscheck, N.; Hamm, U. Are organic consumers preferring or avoiding foods with nutrition and health claims? Food Qual. Prefer. 2013, 30, 68-76. [CrossRef]

15. Urala, N.; Lähteenmäki, L. Reasons behind consumers' functional food choices. Nutr. Food Sci. 2003, 33, 148-158. [CrossRef]

16. Rozin, P.; Spranca, M.; Krieger, Z.; Neuhaus, R.; Surillo, D.; Swerdlin, A.; Wood, K. Preference for natural: Instrumental and ideational/moral motivations, and the contrast between foods and medicines. Appetite 2004, 43, 147-154. [CrossRef]

17. Kahl, J.; Załęcka, A.; Ploeger, A.; Bügel, S.; Huber, M. Functional food and organic food are competing rather than supporting concepts in Europe. Agriculture 2012, 2, 316-324. [CrossRef]

18. Rozin, P. The meaning of "natural" process more important than content. Psychol. Sci. 2005, 16, 652-658. [CrossRef]

19. Migliore, G.; Borrello, M.; Lombardi, A.; Schifani, G. Consumers' willingness to pay for natural food: Evidence from an artefactual field experiment. Agric. Food Econ. 2018, 6, 21. [CrossRef]

20. Dickson-Spillmann, M.; Siegrist, M.; Keller, C. Attitudes toward chemicals are associated with preference for natural food. Food Qual. Prefer. 2011, 22, 149-156. [CrossRef]

21. Evans, G.; de Challemaison, B.; Cox, D.N. Consumers' ratings of the natural and unnatural qualities of foods. Appetite 2010, 54, 557-563. [CrossRef] [PubMed] 
22. Moscato, E.M.; Machin, J.E. Mother natural: Motivations and associations for consuming natural foods. Appetite 2018, 121, 18-28. [CrossRef] [PubMed]

23. Lockie, S.; Lyons, K.; Lawrence, G.; Grice, J. Choosing organics: A path analysis of factors underlying the selection of organic food among Australian consumers. Appetite 2004, 43, 135-146. [CrossRef]

24. Nocella, G.; Kennedy, O. Food health claims-What consumers understand. Food Policy 2012, 37, 571-580. [CrossRef]

25. Annunziata, A.; Vecchio, R. Functional foods development in the European market: A consumer perspective. J. Funct. Foods 2011, 3, 223-228. [CrossRef]

26. Falguera, V.; Aliguer, N.; Falguera, M. An integrated approach to current trends in food consumption: Moving toward functional and organic products? Food Control 2012, 26, 274-281. [CrossRef]

27. Lähteenmäki, L.; Lampila, P.; Grunert, K.; Boztug, Y.; Ueland, Ø.; Åström, A.; Martinsdóttir, E. Impact of health-related claims on the perception of other product attributes. Food Policy 2010, 35, 230-239. [CrossRef]

28. Siro, I.; Kápolna, E.; Kápolna, B.; Lugasi, A. Functional food. Product development, marketing and consumer acceptance-A review. Appetite 2008, 55, 456-467. [CrossRef] [PubMed]

29. Verbeke, W. Consumer acceptance of functional foods: Socio-demographic, cognitive and attitudinal determinants. Food Qual. Prefer. 2005, 16, 45-57. [CrossRef]

30. Caracciolo, F.; Vecchio, R.; Lerro, M.; Migliore, G.; Schifani, G.; Cembalo, L. Natural versus enriched food: Evidence from a laboratory experiment with chewing gum. Food Res. Int. 2019, 122, 87-95. [CrossRef]

31. Priyadarshini, A.; Priyadarshini, A. Market dimensions of the fruit juice industry. In Fruit Juices Fruit Juices, Extraction, Composition, Quality and Analysis; Rajauria, G., Tiwari, B., Eds.; Academic Press; Elsevier: Dublin, Ireland, 2018; Volume 19, pp. 15-32.

32. Bunnell, R.H. Enrichment of fruit products and fruit juices. J. Agric. Food Chem. 1968, 16, 177-183. [CrossRef]

33. Verbeke, W.; Scholderer, J.; Lähteenmäki, L. Consumer appeal of nutrition and health claims in three existing product concepts. Appetite 2009, 52, 684-692. [CrossRef]

34. Oláh, J.; Virglerova, Z.; Popp, J.; Kliestikova, J.; Kovács, S. The Assessment of Non-Financial Risk Sources of SMES in the V4 Countries and Serbia. Sustainability 2019, 11, 4806. [CrossRef]

35. Lakner, Z.; Kiss, A.; Merlet, I.; Oláh, J.; Máté, D.; Grabara, J.; Popp, J. Building Coalitions for a Diversified and Sustainable Tourism: Two Case Studies from Hungary. Sustainability 2018, 10, 1090. [CrossRef]

36. Nagy-Pércsi, K.; Fogarassy, C. Important Influencing and Decision Factors in Organic Food Purchasing in Hungary. Sustainability 2019, 11, 6075. [CrossRef]

37. Lee, H.J.; Yun, Z.S. Consumers' perceptions of organic food attributes and cognitive and affective attitudes as determinants of their purchase intentions toward organic food. Food Qual. Prefer. 2015, 39, $259-267$. [CrossRef]

38. Balázs, B. Local Food System Development in Hungary. Int. J. Sociol. Agric. Food 2012, 19, 403-421.

39. O'Donnell, J. Gen Y sits on top of consumer food chain; they're savvy shoppers with money and influence. USA Today 2006, 11, 322-358.

40. Yang, Z.; Lu, W.; Long, Y.; Bao, X.; Yang, Q. Assessment of heavy metals contamination in urban topsoil from Changchun City, China. J. Geochem. Explor. 2011, 108, 27-38. [CrossRef]

41. Bucic, T.; Harris, J.; Arli, D. Ethical consumers among the millennials: A cross-national study. J. Bus. Ethics 2012, 110, 113-131. [CrossRef]

42. Ferris, G.R.; Berkson, H.M.; Harris, M.M. The recruitment interview process: Persuasion and organization reputation promotion in competitive labor markets. Hum. Resour. Manag. Rev. 2002, 12, 359-375. [CrossRef]

43. Vickrey, W. Counter speculation, auctions, and competitive sealed tenders. J. Financ. 1961, 16, 8-37. [CrossRef]

44. Lusk, J.L.; Alexander, C.; Rousu, M.C. Designing experimental auctions for marketing research: The effect of values, distributions, and mechanisms on incentives for truthful bidding. Rev. Mark. Sci. 2007, 5. [CrossRef]

45. Shogren, J.F.; Shin, S.Y.; Hayes, D.J.; Kliebenstein, J.B. Resolving differences in willingness to pay and willingness to accept. Am. Econ. Rev. 1994, 30, 255-270.

46. Onwezen, M.C.; Reinders, M.J.; van der Lans, I.A.; Sijtsema, S.J.; Jasiulewicz, A.; Guardia, M.D.; Guerrero, L. A cross-national consumer segmentation based on food benefits: The link with consumption situations and food perceptions. Food Qual. Prefer. 2012, 24, 276-286. [CrossRef]

47. Zandstra, E.H.; De Graaf, C.; Van Staveren, W.A. Influence of health and taste attitudes on consumption of low- and high-fat foods. Food Qual. Prefer. 2001, 12, 75-82. [CrossRef] 
48. Roininen, K.; Lähteenmäki, L.; Tuorila, H. Quantification of consumer attitudes to health and hedonic characteristics of foods. Appetite 1999, 33, 71-88. [CrossRef] [PubMed]

49. Lähteenmäki, L.; Lyly, M.; Urala, N. Consumer attitudes towards functional foods. Underst. Consum. Food Prod. 2004, 412-427. [CrossRef]

50. Cameron, A.C.; Trivedi, P.K. Microeconometrics, Methods and Applications; Cambridge University Press: New York, NY, USA, 2005; ISBN 13 978-0-521-84805-3.

51. Tuorila, H. Attitudes as determinants of food consumption. In Encyclopedia of Human Biology, 2nd ed.; Academic Press: San Diego, CA, USA, 1997; Volume 1.

52. Bruschi, V.; Teuber, R.; Dolgopolova, I. Acceptance and willingness to pay for health-enhancing bakery products-Empirical evidence for young urban Russian consumers. Food Qual. Prefer. 2015, 46, 79-91. [CrossRef]

53. Rizzo, G.; Borrello, M.; Dara Guccione, G.; Schifani, G.; Cembalo, L. Organic Food Consumption: The Relevance of the Health Attribute. Sustainability 2020, 12, 595. [CrossRef]

54. Apaolaza, V.; Hartmann, P.; D'Souza, C.; López, C.M. Eat organic-Feel good? The relationship between organic food consumption, health concern and subjective wellbeing. Food Qual. Prefer. 2018, 63, 51-62. [CrossRef]

55. Barauskaite, D.; Gineikiene, J.; Fennis, B.M.; Auruskeviciene, V.; Yamaguchi, M.; Kondo, N. Eating healthy to impress: How conspicuous consumption, perceived self-control motivation, and descriptive normative influence determine functional food choices. Appetite 2018, 131, 59-67. [CrossRef]

(C) 2020 by the authors. Licensee MDPI, Basel, Switzerland. This article is an open access article distributed under the terms and conditions of the Creative Commons Attribution (CC BY) license (http://creativecommons.org/licenses/by/4.0/). 


\title{
Article \\ Search Strategies in Innovation Networks: The Case of the Hungarian Food Industry
}

\author{
József Tóth ${ }^{1,2, *}$ and Giuseppina Rizzo ${ }^{3, *}$ \\ 1 Department of Agricultural Economics and Rural Development, Corvinus University of Budapest, \\ 1093 Budapest, Hungary \\ 2 Faculty of Economics, Socio-Human Sciences and Engineering, Sapientia Hungarian University of \\ Transylvania, 530104 Miercurea Ciuc, Piaţa Libertăţii nr. 1, Romania \\ 3 Department of Agricultural, Food and Forest Sciences, University of Palermo, 90128 Palermo, Italy \\ * Correspondence: jozsef.toth@uni-corvinus.hu (J.T.); giuseppina.rizzo03@unipa.it (G.R.); \\ Tel.: +36-30-555-9755 (J.T.); +39-320-041-5120 (G.R.)
}

Received: 5 February 2020; Accepted: 25 February 2020; Published: 26 February 2020

\begin{abstract}
In the food sector, open innovation has become of particular interest. This paper considers open innovation search strategies in the food and beverages industry and examines the probability of using different innovation sources with respect to the type of innovation. Although the information search for new ideas, tools and solutions in the innovation process regarding the scope and depth is well explored and interpreted in the literature, the probability of using the different sources with respect to type of innovation is rarely investigated. To answer these questions, first a probit, then OLS regression model is adopted, in order to understand the chance of a specific source of information being chosen, and then, to verify how much of these sources are selected in different types of innovation. Findings show that food companies use several kinds of information sources during their product, process, organization and market innovation development processes and apply different sourcing strategies based on innovation type. The study concludes that managers have to take into consideration the type of innovation when they formulate their innovation search strategies. Moreover, if they would like to strive on the European, or even more on the world market, they necessarily have to cooperate with universities and research institutes. Our recommendation for policymakers is that they should encourage the food companies in creation of a viable information network with their business, scientific and professional partners. It is also important that they help the food producers in their continuous innovation activities as well as in expanding their business to European, or even more, to world level.
\end{abstract}

Keywords: innovation network; innovation sourcing strategy; policy implication; food industry; Hungary

\section{Introduction}

Innovation is one of the main economic activities that lead the company to organizational success and high results, independently of its size and the sector in which it operates [1]. It brings a positive change within the enterprise and it is led by many factors such as, for example, competition and customer demand. For this reason, every company must adapt its behavior to external demands, in order to maintain or raise the level of its performance [2]. Over time, innovation has also gained interest in the agri-food sector, where the open type of innovation is very much appreciated in the recent decades [3,4]. Open innovation is an effective driving force to promote innovation performance $[5,6]$. It is based on obtaining technical resources and market information, to increase the company's internal resources, thus improving the original level [7]. It is possible to distinguish four types of open innovation [8]: product innovation (which concerns a good or a service); process innovation (which 
involves a new production method); marketing innovation (which refers to a new marketing method, such as changes in product packaging, product promotion or prices); and organizational innovation (which involves improvements in the organization of work or in the company's external relations).

Among the main advantages of open innovation, we can list the improvement of business efficiency [9], which makes late companies keep up with the technological development of the reference market [10]. On the other hand, open innovation can lead the company to a reduction in marginal returns, caused by the time spent on search [11] and by collaborative activities with other entrants or companies [12], which require significant coordination efforts [13].

The openness assumes that firms construct several ties with business, science and professional partners in order to create bi- and multilateral connections for acquiring innovation ideas, making development progress, as well as promoting and marketing new products and services $[3,14]$. Indeed, companies that want to innovate, can turn to external sources of information for innovation, in order to seek specific knowledge useful for their purpose [15]. In particular, four specific sources of external knowledge sources have been identified in the literature [16], including suppliers [17], customers [18], competitors [19] and universities [20]. Through these relations the in- and outflow of information related to innovation can more efficiently and smoothly be managed [21]. The effectiveness of open innovation activities, as well as creating links with the external environment is now consolidated [22]. It is clear that sourcing needs resources (financial, managerial and specific knowledge) and that each of them competes with other possible uses. This rivalry of resources for recruiting outside information should be explored, as, net of our knowledge, the topic has received scant attention in the existing literature. In addition, using too many information sources can lead to management problems [23]. Consequently, our research question focuses on the information acquiring strategy of the firm. We are interested, from which directions it is appropriate that information arrives to the company and how much information is really needed. Our assumption is that this strategy differs based on the type of innovation. Therefore, the present study positions a double research question: 1 . What is the chance that a specific source of information is selected in relation to the type (product, process, organization and market) of the innovation? and, 2. By grouping the sources into three different ones (business, science and professional), how many of them are selected in different types of innovation? In order to answer the two research questions, we use the Community Innovation Survey-2012 Hungary data [24] filtering for the Nace. Rev 10-12 categories (food, beverages and tobacco industries-more precise breakdown is not possible within this database). We apply probit and OLS regression for exploring our answer. Hungary is an interesting case from an innovation point of view, because according to the European Innovation Scoreboard (2017) report [25], Hungary's summarized innovation score is 67.4 against the EU28 average of 102. This implies that the Hungarian economy has got rather serious disadvantages in the EU community. This statement is more pronounced in case of the food industry. From an innovation point of view, food industry is seen as a slow one, which is lagging behind the technology pushed possibilities, but sometimes behind the customers' desires and requirements as well. One possible way of boosting the food economy is, therefore, to speed up the innovation.

The remaining part of this paper is structured as follows: first we shed light on some basic theoretical concepts and empirical findings in the related fields. Next, we introduce our data and methodology. After that, we comprise the results. At the end, we discuss, conclude and draw the limitations of our findings.

\section{Theoretical Considerations and Empirical Evidences}

Open innovation can be defined as "the use of inflows and outflows of knowledge that improve internal innovation and at the same time widen the markets for the external use of innovation" [26]. It involves the use of multiple internal and external sources, integrating this activity with company resources and exploiting these opportunities through multiple channels [27]. Indeed, based on the theories of inter-organizational knowledge flows and organizational learning, many authors [28-33] have stated that the use of a limited number of external channels facilitates the performance of the 
innovative company. This approach refers to the depth of the research strategy [34], according to which the term "depth of open research" indicates from how many intense channels the company gets ideas for innovation.

The incremental nature of innovation is a realistic hypothesis in the case of the food industry, because the fundamental attributes of the food we eat today are only slightly different from what humanity ate a hundred years ago. For this reason, previous researches e.g., [21,32,35] have shown that organizations that do not use current external knowledge, do not have the means to be effective competitors. Therefore, companies often establish collaborations with other actors in the supply chain, such as suppliers, customers in the public and private sector, competitors, universities, professional and sector associations for self-improvement [1]. Suppliers and industry associations are an important source of knowledge, and collaboration is usually an opportunity to get more information about the competition. At the same time, consumers and universities are valuable sources of knowledge as they know the product better than the manufacturer [36].

However, the increase in external collaborations entails higher costs for the company, while the advantages of this open innovation system may only be observable in the long term [37], connecting this scheme to strategic thinking. The costs of selecting suitable partners are also likely to increase, leading to the need for supplementary resources. In addition, companies must pay attention to balancing external and internal research activities as otherwise, they will have negative consequences for their innovative performance [11] and their costs of coordination, management and control of partner activities involved will increase [38]. Furthermore, in transition to an open research and development system, the company's internal research and development structure requires a fundamental transformation, as its role shifts "from the generation of discovery as a primary activity to the design and integration of systems as a function key" [26].

Open innovation concept has sparked the interest of both academics and practitioners, as illustrated by the multiple studies on this topic. In this vein, many debates have developed in managerial literature and several studies have investigated the innovating company's methods of accessing knowledge from external channels. Although these empirics and theories touch and sometimes describe the different ways of information acquisition for certain types of innovation, they do not develop applicable information search strategies. For illustrating this shortcoming, we summarize the main findings of several papers from the last one and a half decade.

In 2006, Cassiman and Veugelers [39] analyzed complementarity between internal research, development and external knowledge acquisition, suggesting that they are complementary innovation activities, but the degree of complementarity is sensitive to other elements of the firm's strategic environment. In the same year, Emden and colleagues [40] developed the process theory of partner selection for collaboration, using a theory development approach. Laursen and Salter [11] studied the effect of open research strategies with other companies that rely on the product life cycle theory. They used data from the UK's Innovation Survey and found that the more important the innovation is, the deeper the influence of external research on the company's innovative performance will be.

In 2007, Perkmann and Walsh [41] analyzed links between university and industry and they have emphasized how important the collaboration is between companies and the scientific sector. Subsequently, Knudsen [36] analyzed the employment of inter-organizational relationships in product innovation by European manufacturing in the food sector. It appeared that all the companies interviewed had collaborated with at least one other organization in order to increase their production. $\mathrm{He}$ also has found that these companies preferred to collaborate with customers, suppliers and competitors rather than with public/private research organizations or consultants, preferably in the phase of initial research rather than during the development of the innovations acquired.

Gumusluoglu and Ilsev [42] found that transformational leadership positively affects organizational innovation in small businesses.

In 2010, Dahlander and Gann [43] studied the advantages and disadvantages of innovation in the procurement and acquisition processes, creating a guideline for the development of the research agenda. 
In the same year, Zhou and $\mathrm{Wu}[44]$ supported the argument that technological capability has an inverted U-shaped relationship with exploration. That is, a high level of technological capability prevents exploratory innovation. Capitanio and co-workers [45] stressed that the ability to build relationships on product markets is a key factor in successfully developing and introducing product innovation.

In 2013, Xiaobao and co-authors [21] analyzed the effect the size of a company has on innovation, using data from a survey of 420 innovative SMEs in China from the point of view of social networks. Garcia Martinez and collaborators [34] studied the impact of companies' open behavior on their performance, considering the breadth and depth of collaboration. Subsequently, Bayona-Saez and colleagues [46] wanted to extend our knowledge on the relationship between open innovation and the company's innovative performance. In particular, the authors aimed to determine whether the benefits of open innovation practices are different for food businesses than for other industries.

Ferraris, Santoro and Dezi [47] verified the positivity of using moderate external knowledge. This means that branches with superior Knowledge Management are more capable of managing external information, improving their innovative performance. Giacosa, Ferraris and Monge [48] in their study concerning an Italian company, stated that the company's competitiveness is the result of a balanced management of innovation and tradition.

In 2019, Török, Tóth and Balogh [49] studied how external impulses and internal knowledge resources influenced the development of innovation in the Hungarian agri-food sector, finding that tacit knowledge is more important than explicit knowledge.

Apparently, there are many studies that take into consideration the different channels of information acquisition and their methods of attainment. Although in the field of open innovation there are different research findings and empirical results, we could get convinced that there were no investigations which linked the type of innovation with the search strategy.

Understanding these dynamics is therefore essential for the development of specific programs for the promotion of each type of innovation.

Table 1 comprises all the studies mentioned in the section. 


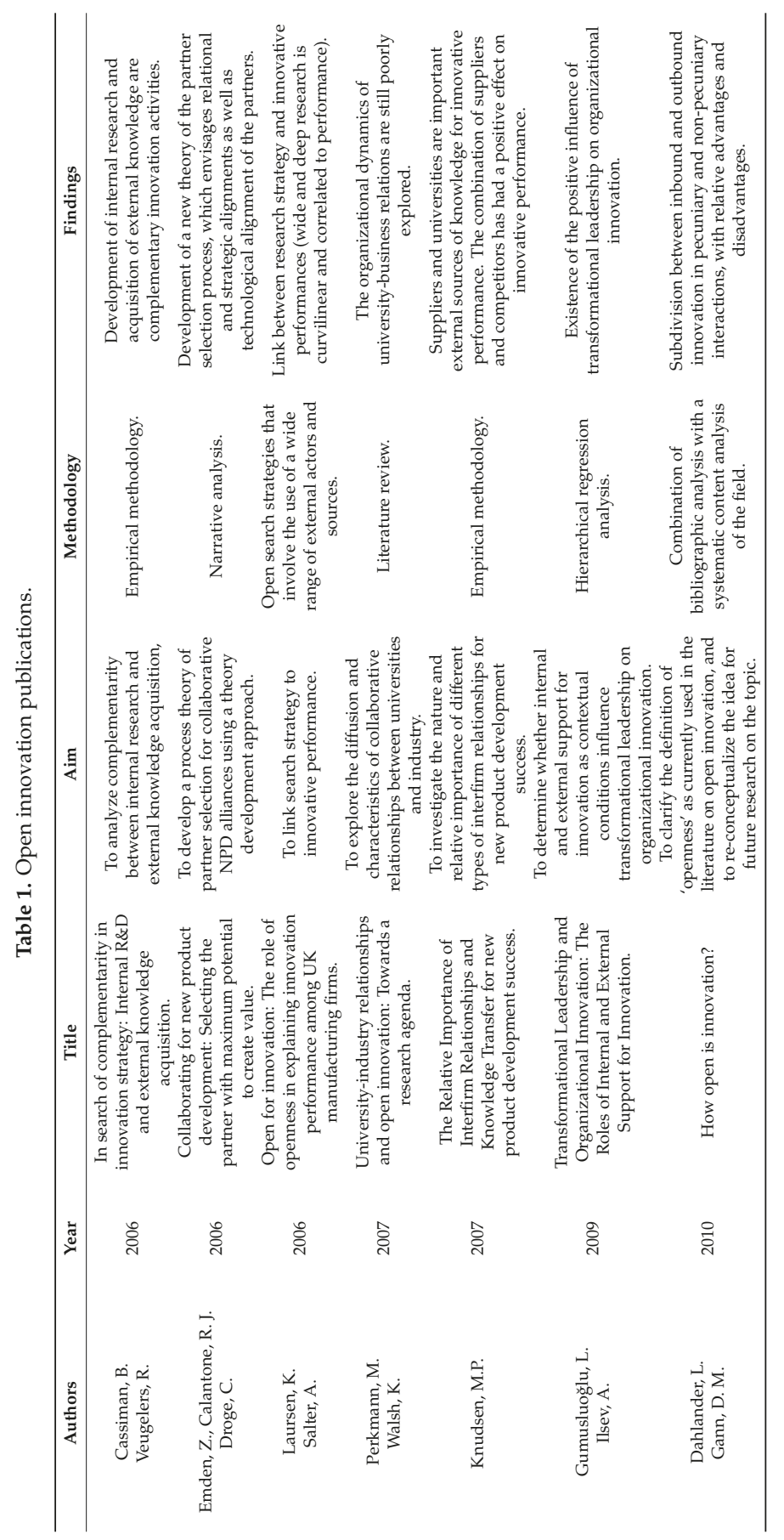




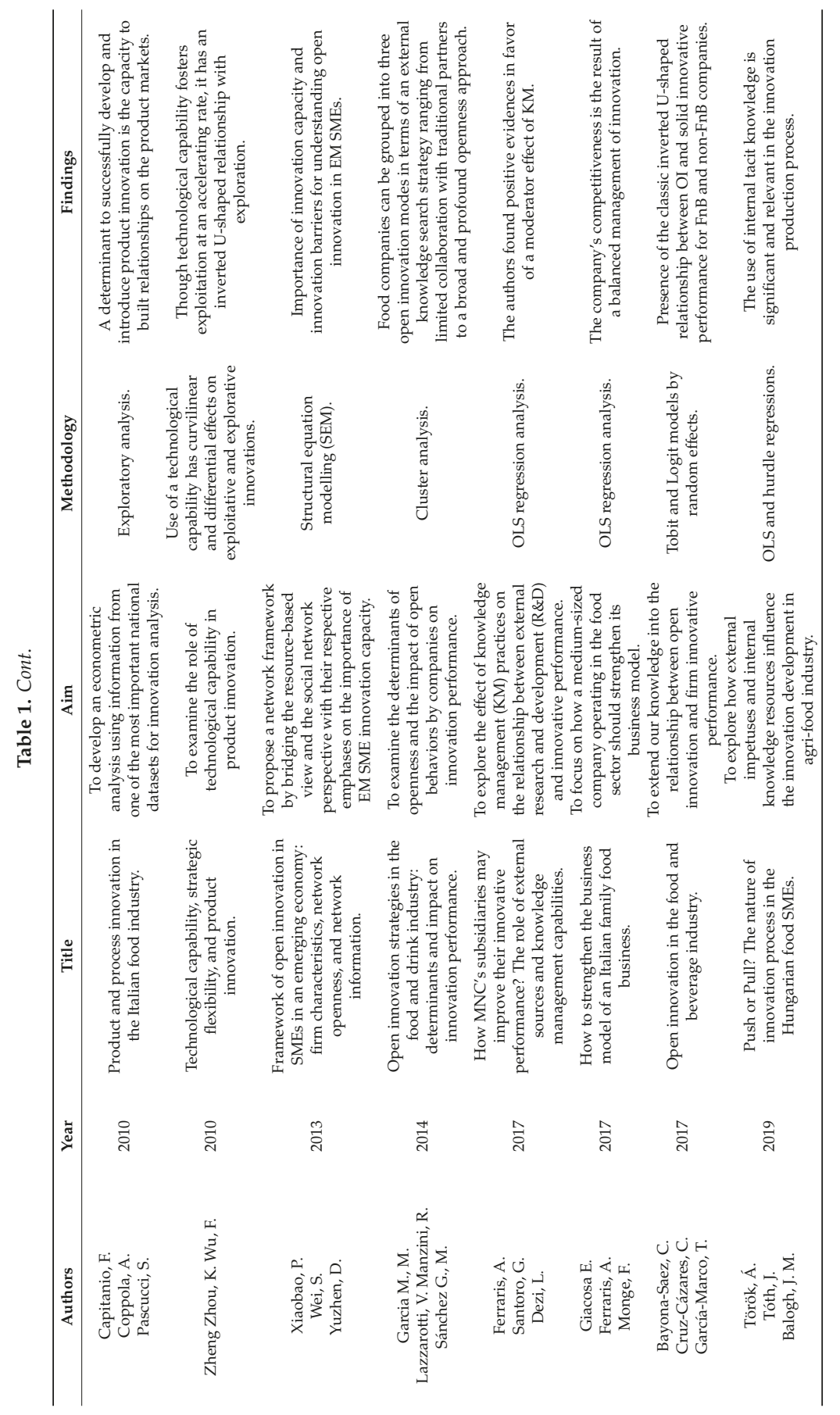




\section{Data and Empirical Strategy}

The empirical analysis in this paper is based on data from Community Innovation Survey (CIS-2012) [24], filtering for the Nace. Rev 10-12 categories (food, beverages and tobacco industries-more detailed breakdown is not possible within this database). We use the openness of firms to European and global markets and continuous innovation activity as control variables. This is because the European food companies are mainly SMEs, and they usually do not have enough resources for doing their own serious R\&D activities. However, the openness and past innovation activities force them to be innovative in the present.

This survey covers 6317 Hungarian firms that are distributed across all major sectors of economic activity. Out of them, there are 440 companies which belong to food, beverage and tobacco industries. The questionnaire includes three main sections: general information about the enterprise, type of innovation and source of information.

In particular, we have twelve types of innovation, which are divided into four groups according to the questionnaire (Table 2).

Table 2. Types of innovation

\begin{tabular}{clc}
\hline Type of Innovation & Acronym & Group \\
\hline New or significantly improved goods & INPDGD & Product innovation \\
New or significantly improved services & INPDSV & Process innovation \\
New or significantly improved methods of manufacturing & INPSPD & Organization innovation \\
New or significantly improved logistics & INPSL & INPSSU \\
\hline New business practices for organizing procedures & ORGBUP & ORGWKP \\
New methods of organizing work responsibilities & ORGEXR & MKTDGP \\
New methods of organizing external relations with other firms & MKTPDP & Marketing innovation \\
Significant changes to the aesthetic design & MKTPRI & \\
New media or techniques for product promotion & & \\
New methods of pricing goods or services & &
\end{tabular}

In addition, we considered ten sources supporting the innovation activities which, by factor analysis, are being grouped into three major sets: business, science and profession (Table 3).

Table 3. Innovation activities sources.

\begin{tabular}{ccc}
\hline Information Sources of Innovation Activities & Acronym & Groups \\
\hline Suppliers of equipment, materials, components, or software & SSUP & \\
Clients or customers from the private sector & SCLPR & Business \\
Clients or customers from the public sector & SCLPU & \\
Competitors or other enterprises in your industry & SCOM & \\
Consultants and commercial labs & SINS & \\
Universities or other higher education institutions & SUNI & Science \\
Government, public or private research institutes & SGMT & \\
Conferences, trade fairs, exhibitions & SCON & \\
Scientific journals and trade/technical publications & SJOU & Profession \\
Professional and industry associations & SPRO & \\
\hline
\end{tabular}

In order to understand what is the possibility of choosing a specific source of information regarding the type of innovation, and then, to verify how much of a source is selected in different types of innovation, the data collected through the questionnaire were processed in three distinct phases, using the STATA 16.0 integrated statistical software. In the first phase, the descriptive analysis of the data were conducted in order to define the socio-demographic characteristics of the sample; in the second 
phase, a probit regression was made between source of information, type of innovation and two control variables (ongoing innovation and openness to European and world markets); in the final part, after doing a Factor Analysis in order to group information sources into three large groups, the three new variables were used as dependent variables for an OLS regression with type of innovation and control variables.

\section{Descriptive Statistics}

The sample consists of 440 small- and medium-sized Hungarian enterprises, with data from Community Innovation Survey (CIS-2012) [24]. The mean enterprise employed 135.52 people and had a turnover of $€ 68,594.9$. The average of enterprise employees, who in 2012 had a tertiary degree, was 1.657 .

Table 4 shows the data set characteristics in terms of turnover, size, and percentage of enterprise employees having a tertiary degree. Table 5 displays the innovation types and control variables, and Table 6 illustrates the quantity of information sources.

Table 4. Data set characteristics.

\begin{tabular}{cccccc}
\hline Variable & Obs & Mean & Std.Dev. & Min & Max \\
\hline Turnover $(€)$ & 440 & $68,594.9$ & 178,000 & 290.407 & $1,710,000$ \\
Size (number of & 440 & 135.523 & 157.703 & 10 & 500 \\
employees) & 440 & 1.657 & 1.24 & 0 & 6 \\
\hline of tertiary degree * & &
\end{tabular}

${ }^{*}$ Categorical variable, $0=0 \%, 1=1-4 \%, 2=5-9 \%, 3=10-24 \%, 4=25-49 \%, 5=50-74 \%, 6=75-100 \%$.

Table 5. Innovation Types.

\begin{tabular}{cccccc}
\hline Variable & Obs & Mean & Std.Dev. & Min & Max \\
\hline Product innovation & 440 & 0.195 & 0.414 & 0 & 2 \\
Process innovation & 440 & 0.166 & 0.475 & 0 & 3 \\
Organizational innovation & 440 & 0.266 & 0.629 & 0 & 3 \\
Market Innovation & 440 & 0.659 & 1.106 & 0 & 4 \\
Openness * & 440 & 0.927 & 0.845 & 0 & 2 \\
Ongoing innovation ** & 440 & 0.1 & 0.3 & 0 & 1
\end{tabular}

* Categorical variable, $0=$ Domestic, $1=$ European, $2=$ world market; ${ }^{* *}$ Dummy variable, $1=$ Yes and 0 No.

Table 6. Information sources.

\begin{tabular}{cccccc}
\hline Variable & Obs & Mean & Std.Dev. & Min & Max \\
\hline Business & 440 & 0.695 & 1.363 & 0 & 4 \\
Science & 440 & 0.359 & 0.858 & 0 & 3 \\
Professional & 440 & 0.527 & 1.08 & 0 & 3 \\
\hline
\end{tabular}

\section{Results}

In order to comprise the results, we have used the coefplot [50] procedure of STATA for graphical interpretation. The first six charts show the coefficients of individual information source contingencies (Figures 1-6), while the other six analyze the quantity of information sources applied in innovation activities (Figures 7-12). In all Figures, the horizontal axis shows the value of the estimated parameters, while " $p$ " denotes the significance level.

We summarize the probit and OLS coefficients and significances in the Appendix A-Table A1.

We have explored the role of 10 different information sources in innovation with regard to the Hungarian food and beverage processing companies. Using the CIS 2012 data [24], we have learned that 
search strategies applied by food companies are greatly different depending on the type of innovation in question. The results can be discussed at two connecting, but distinct layers. First, we evolve the strategy orientation, which relies on whether the chance of being selected is significant in case of the particular information source. Then, we have estimated the number of information sources used by companies in three appropriate groups of sources: business, science and profession, which refers to the quantity of information.

According to these two layers, we can postulate the findings below:

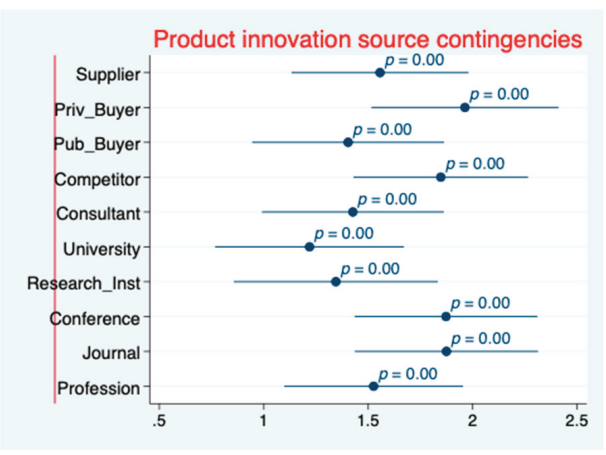

Figure 1. Product information source contingencies.

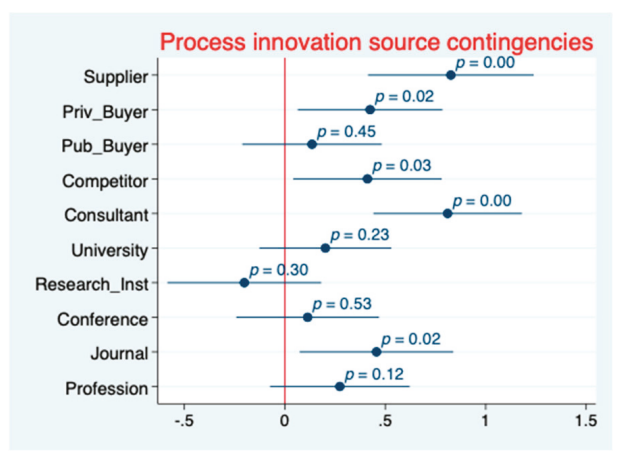

Figure 2. Process information source contingencies.

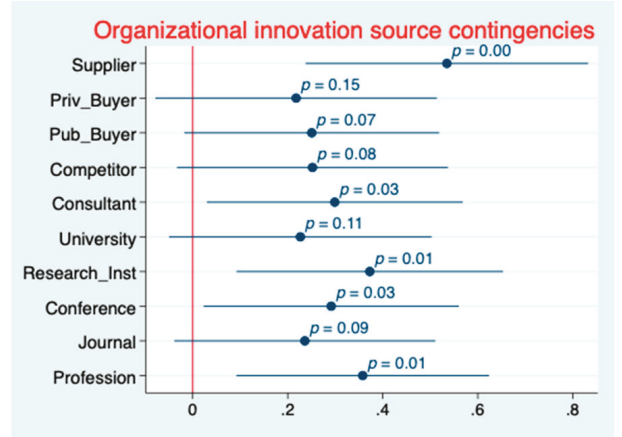

Figure 3. Organ. information source contingencies. 


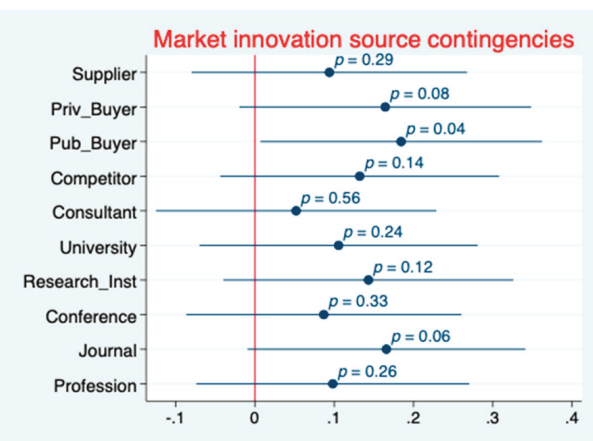

Figure 4. Market information source contingencies.

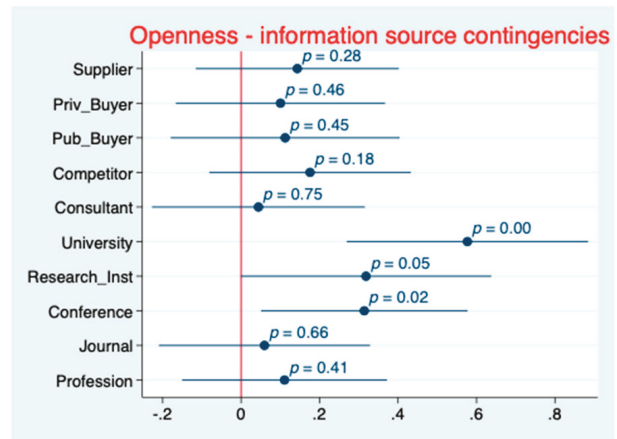

Figure 5. Openness information source contingencies.

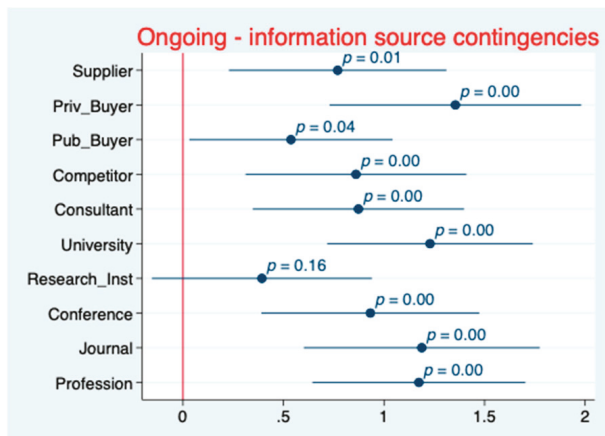

Figure 6. Ongoing information source contingencies. 


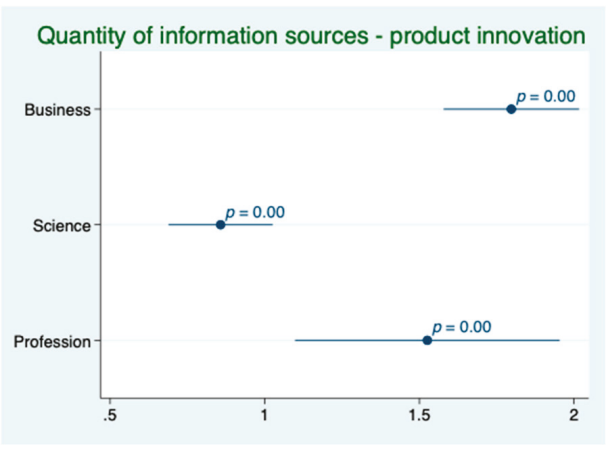

Figure 7. Product innovation.

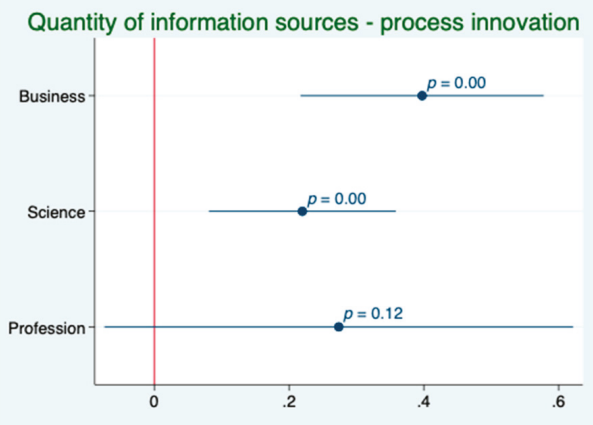

Figure 8. Process innovation.

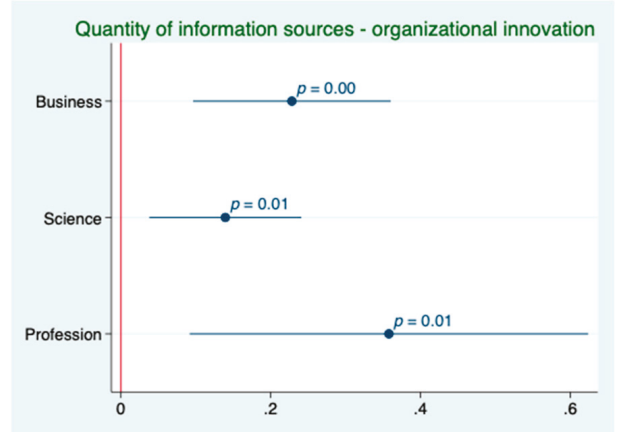

Figure 9. Organizational innovation. 


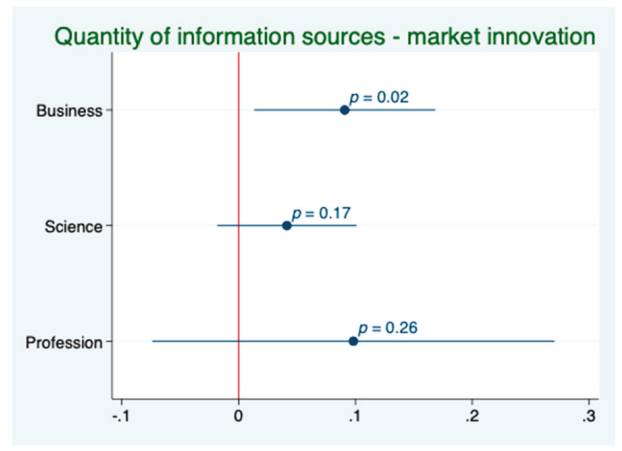

Figure 10. Market innovation.

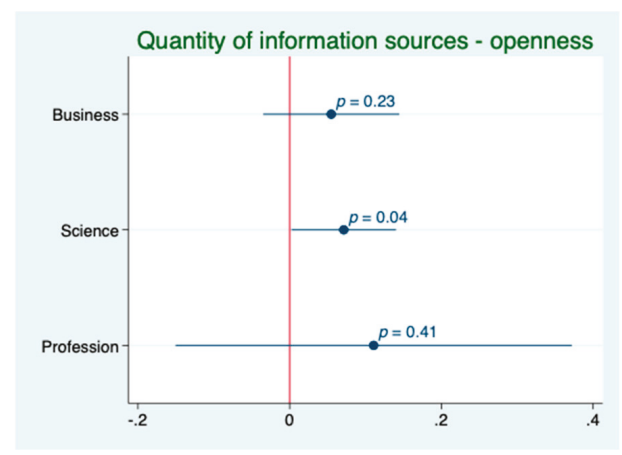

Figure 11. Openness-information quantity.

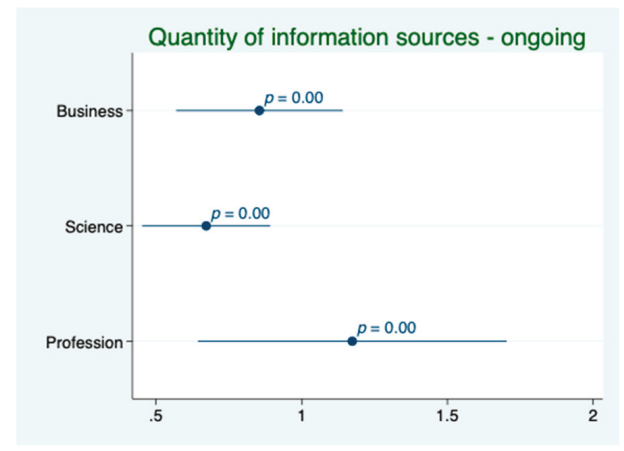

Figure 12. Ongoing-information quantity.

\subsection{Strategy Orientation}

- For product innovators, the chance for an individual innovation source being used in the innovation development process is equally positive and significant for all sources. It is very much in line with the open attribute of innovation which derives basically from the SMS nature of the Hungarian food manufacturing companies.

- For companies concentrating on process innovation, mainly business sources (extended with some professional information) have the possibility of becoming information source. These firms do not rely on science. 
- Organizational innovators orient mainly towards professional sources and some business inputs.

- For market innovating firms, the probability of becoming an appropriate innovation information source is given almost exclusively for the information coming from the downstream partners. This is very articulate, because they necessarily need to trust in their buyers' opinion and recommendations.

- Companies with more openness to European and world markets align themselves with information for innovation originating from the scientific world. This is because they need to compete with global challenges. Therefore, they have to follow the latest trends, achievements and results of the science in order to sound on the European, or even on the global market.

- Those enterprises, which have been carrying out innovations for a long time, expect new ideas and hints from everywhere to successful completion of the ongoing innovation projects. Therefore, any kind of sources-except the research institutes—-may become a springboard for innovation.

\subsection{Quantity of Sources/Information}

- In case of product innovation, each of the sourcing groups are relevant, significant and positive: the more product innovation the firms proceed with, the more sources they use from each of the sourcing partner groups.

- The picture is different with process innovation: the application of business and science sources' quantity is positively related to the process innovation. However, the professional sources' connection is not significant.

- The organizational innovation shows the same picture as product innovation: positively and significantly relates to each information source group; consequently, the more organizational innovation a company can accomplish, the more sources it acquires from any source group.

- The market innovation confirms our previous ascertainment that companies are looking at marketing innovation as a very confidential one, therefore, they are not willing even to consult with their partners, except the business ones.

- The openness proves also in this case, that if the firms are more exposed to global market contests, they use more scientific information sources in their innovation process.

- The more continuous innovation activity is running within the frame of the company, the more information sources will be applied, independently from the type of information source groups.

\section{Discussion and Conclusions}

In line with Rosa, Chimendes and Amorim [51], we can claim that an open innovation model guides companies towards opportunities in a more interactive way, seeking the integration of knowledge between them. Companies need to innovate constantly, faster and more original than competing companies [31], and this makes communication, networking and collaboration between knowledge producers and users fundamental [52].

The present study aimed to investigate the probability of using different sources with respect to the type of innovation, since through the analysis of these relationships it is possible to manage the inand outflow of information related to innovation in a more efficient and easier way [21]. To answer our research questions, Hungary's data on Community Innovation Survey have been used, and probit as well as OLS regressions were applied.

The above examination unequivocally supports our perception of the different nature of innovation source strategies based on the type of innovation. We can derive that food companies in Hungary use different types of sources of innovation during their product, process, organization and market development processes. It has also been shown that at least two different, but connecting layers are formulating the sourcing strategy, namely (a) orientation and (b) quantity decision. Based on the analysis, food companies can compile their search strategies according to the nature of their planned innovation activities. They can also use the results related to open innovating companies: if they want 
to engage on the European market, or even on the world market, they must necessarily cooperate with universities and research institutes.

Our results follow the footsteps of studies already present in the literature, which have shown that collaboration is a worthy way for improving the innovation capacity of companies [41,53-56].

With regard to product innovation, previous literature argues that collaboration with other external sources plays a fundamental role, provided the resources necessary for business success are not available within the company $[57,58]$. In addition, our contribution discovers that in this specific case, the more the desired product innovation is, the greater quantity of information from each sourcing group is used.

It happens partly differently for process and organization innovations, where business sources are preferred. In particular, process innovation favors the use of just a few sources, the organizational innovation evolves more or less in the same way as product innovation. These results find their basis of reasoning in the study of Gumusluoglu and Ilsev [42], Dressler and Paunovic [59], Amit and Zott, [60] and Capitanio and colleagues [45], which highlight the importance of external support in organizational and process innovation.

In accordance with Storbacka and Nenonen [61], we finally found that market innovation prefers to turn to a few, mainly downstream sources, as this represents a complex, delicate and confidential division of a company.

A very important aspect to consider in relation to innovation is that of sustainability, too [62,63]. Sustainable partnerships encourage companies to adopt practices that offer environmental, economic and social benefits to their wider communities [64]. Once companies understand that innovating is likely to offer private economic benefits in terms of lower input costs or better business results, they will make the economic decisions to carry them out. However, the community's interest should prioritize those innovation practices with the greatest environmental benefits to improve the overall sustainability [59]. If the Hungarian food companies follow the strategical sourcing recommendations developed in this study, they really can contribute to better economic sustainability of the society, but they are also supposed to prefer those innovations, which have more environmental and social benefits.

We deem this study has important implications for the Hungarian market, which is now struggling to innovate. We suggest to policymakers that it is worth considering support and encouraging companies in their creation and maintaining good networks with commercial, scientific and professional partners in order to help companies' progress for private, social and environmental advantage. It is also important to help companies in continuous innovation activities by different means (e.g., tax reduction). We also believe that our results can help the politics of inspiring food companies to cooperate with their competitors on the world market rather than locally, thus managing to improve innovation adequately.

However, despite the gap-filling nature of our study, there are mainly two limitations that affect the validity of our results. The first is that there is a geographical boundary which should be dissolved by extending the survey to other countries which are included in the CIS system. The second limitation is given by the time constraint which ought to be reduced. Although the data of CIS 2014 are available, these do not contain data on the sources of information on innovation. It would therefore be interesting to see how the sourcing strategy changes over time. Based on the above, an interesting future research area could be to extend the analysis to other sectors of the economy as well, and make a comparison between "slow" (such as food and agriculture) and "fast"(like IT) industries. Furthermore, it may be useful to make a further comparison with the markets of the more or less developed countries compared to Hungary, to see the significant differences.

Author Contributions: All authors have read and agree to the published version of the manuscript. Conceptualization, J.T.; methodology, J.T.; software, G.R.; validation, J.T. and G.R.; formal analysis, J.T.; investigation, J.T.; resources, J.T.; data curation, J.T. and G.R.; writing-original draft preparation, G.R.; writing-review and editing, J.T. and G.R.; visualization, G.R.; supervision, J.T.; project administration, J.T.; funding acquisition, J.T. 
Funding: This research was funded by National Research, Development and Innovation Office (NKFI), Hungary, grant number OTKA-120563.

Conflicts of Interest: The authors declare no conflict of interest.

\section{Appendix A}

Table A1. Probit Regression (Information source contingencies).

\begin{tabular}{|c|c|c|c|c|c|c|c|c|c|c|}
\hline & \multicolumn{2}{|c|}{ Supplier } & \multicolumn{2}{|c|}{ Private Buyer } & \multicolumn{2}{|c|}{ Public Buyer } & \multicolumn{2}{|c|}{ Competitor } & \multicolumn{2}{|c|}{ Consultant } \\
\hline & Coef. & Sig. & Coef. & Sig. & Coef. & Sig. & Coef. & Sig. & Coef. & Sig. \\
\hline Product innovation & 1.556 & $* * *$ & 1.963 & $* * *$ & 1.404 & $* * *$ & 1.847 & $* * *$ & 1.426 & $* * *$ \\
\hline Process innovation & 0.826 & $* * *$ & 0.424 & ** & 0.135 & & 0.411 & ** & 0.810 & $* * *$ \\
\hline $\begin{array}{l}\text { Organizational } \\
\text { innovation }\end{array}$ & 0.535 & $* * *$ & 0.218 & & 0.251 & * & 0.252 & * & 0.299 & $* *$ \\
\hline Market innovation & 0.094 & & 0.164 & * & 0.184 & ** & 0.132 & & 0.052 & \\
\hline $\begin{array}{l}\text { Openness-information } \\
\text { source }\end{array}$ & 0.143 & & 0.100 & & 0.112 & & 0.176 & & 0.044 & \\
\hline $\begin{array}{l}\text { Ongoing-information } \\
\text { source }\end{array}$ & 0.769 & $* * *$ & 1.355 & $* * *$ & 0.537 & $* *$ & 0.860 & $* * *$ & 0.873 & $* * *$ \\
\hline CONSTANT & -2.164 & $* * *$ & -2.089 & $* * *$ & -2.517 & $* * *$ & -2.137 & $* * *$ & -2.168 & $* * *$ \\
\hline \multirow[t]{3}{*}{ Pseudo $R^{2}$} & \multicolumn{2}{|c|}{0.577} & \multicolumn{2}{|c|}{0.616} & \multicolumn{2}{|c|}{0.454} & \multicolumn{2}{|c|}{0.579} & \multicolumn{2}{|c|}{0.536} \\
\hline & \multicolumn{2}{|c|}{ University } & \multicolumn{2}{|c|}{$\begin{array}{l}\text { Research } \\
\text { Institutes }\end{array}$} & \multicolumn{2}{|c|}{ Conference } & \multicolumn{2}{|l|}{ Journal } & \multicolumn{2}{|c|}{ Profession } \\
\hline & Coef. & Sig. & Coef. & Sig. & Coef. & Sig. & Coef. & Sig. & Coef. & Sig. \\
\hline Product innovation & 1.219 & $* * *$ & 1.345 & $* * *$ & 1.872 & $* * *$ & 1.874 & *** & 1.526 & $* * *$ \\
\hline Process innovation & 0.202 & & -0.202 & & 0.114 & & 0.456 & ** & 0.274 & \\
\hline $\begin{array}{c}\text { Organizational } \\
\text { innovation }\end{array}$ & 0.227 & & 0.373 & $* * *$ & 0.291 & $* *$ & 0.236 & * & 0.358 & $* * *$ \\
\hline Market innovation & 0.106 & & 0.143 & & 0.087 & & 0.166 & * & 0.098 & \\
\hline $\begin{array}{c}\text { Openness-information } \\
\text { source }\end{array}$ & 0.577 & $* * *$ & 0.318 & * & 0.314 & ** & 0.060 & & 0.111 & \\
\hline $\begin{array}{l}\text { Ongoing_information } \\
\text { source }\end{array}$ & 1.229 & $* * *$ & 0.393 & & 0.932 & $* * *$ & 1.188 & $* * *$ & 1.173 & $* * *$ \\
\hline CONSTANT & -2.873 & $* * *$ & -2.824 & $* * *$ & -2.304 & $* * *$ & -2.155 & $* * *$ & -2.168 & $* * *$ \\
\hline Pseudo $R^{2}$ & \multicolumn{2}{|c|}{0.522} & \multicolumn{2}{|c|}{0.415} & \multicolumn{2}{|c|}{0.556} & \multicolumn{2}{|c|}{0.596} & \multicolumn{2}{|c|}{0.526} \\
\hline
\end{tabular}

${ }^{*}$ Significant at $1 \%$ level; ${ }^{* *}$ Significant at $5 \%$ level; ${ }^{* * *}$ Significant at $10 \%$ level .

\section{References}

1. Bigliardi, B.; Galati, F. Models of adoption of open innovation within the food industry. Trends Food Sci. Technol. 2013, 13, 495-522. [CrossRef]

2. Damanpour, F.; Schneider, M. Characteristics of innovation and innovation adoption in public organizations: Assessing the role of managers. J. Public Adm. Res. Theory 2008, 19, 495-522. [CrossRef]

3. Van Lancker, J.; Wauters, E.; Van Huylenbroeck, G. Open Innovation in Public Research Institutes-Success and Influencing Factors. Int. J. Innov. Manag. 2019, 19, 50-64. [CrossRef]

4. Bresciani, S. Open, networked and dynamic innovation in the food and beverage industry. Br. Food J. 2017, 119, 2290-2293. [CrossRef]

5. Caridi-Zahavi, O.; Carmeli, A.; Arazy, O. The influence of CEOs' visionary innovation leadership on the performance of high-technology ventures: The mediating roles of connectivity and knowledge integration. $J$. Prod. Innov. Manag. 2016, 33, 356-376. [CrossRef]

6. Jin, H.K.; Kim, S.; Kim, K. The Role of Learning Capability in Market-Oriented Firms in the Context of Open. J. Prod. Innov. Manag. 2016, 33, 356-376.

7. Clauss, T. Measuring business model innovation: Conceptualization, scale development, and proof of performance. RD Manag. 2017, 47, 385-403. [CrossRef] 
8. Rebelo, J.; Muhr, D. Innovation in wine SMEs: The Douro Boys informal network. Stud. Agric. Econ. 2012, 114, 111-117. [CrossRef]

9. McMillan, G.S.; Mauri, A.; Casey, D.L. The Scientific Openness Decision Model: "Gaming" the Technological and Scientific Outcomes. Technol. Forecast. Soc. Chang. 2014, 86, 132-142. [CrossRef]

10. Chen, Y.; Chen, J. The Influence of Openness to Innovation Performance. Stud. Sci. Sci. 2008, 26, 419-426. [CrossRef]

11. Laursen, K.; Salter, A. Open for Innovation: The Role of Openness in Explaining Innovation Performance among U.K. Manufacturing Firms. Strateg. Manag. J. 2006, 27, 131-150. [CrossRef]

12. Bader, K.; Enkel, E. Understanding a Firm's Choice for Openness: Strategy as Determinant. Int. J. Technol. Manag. 2014, 66, 156-182. [CrossRef]

13. Ben Letaifa, S.; Rabeau, Y. Too Close to Collaborate? How Geographic Proximity Could Impede Entrepreneurship and Innovation. J. Bus. Res. 2013, 66, 2071-2078. [CrossRef]

14. Sun, Y.; Liu, J.; Ding, Y. Analysis of the relationship between open innovation, knowledge management capability and dual innovation. Technol. Anal. Strateg. Manag. 2020, 32, 15-28. [CrossRef]

15. Albers, A.; Miller, S. Open innovation in the automotive industry. RD Manag. 2010, 40, 246-255.

16. West, J.; Gallagher, S. Challenges of open innovation: The paradox of firm investment in open-source software. RD Manag. 2006, 36, 319-331. [CrossRef]

17. Schiele, H. Early supplier integration: The dual role of purchasing in new product development. RD Manag. 2010, 40, 138-153. [CrossRef]

18. Grimpe, C.; Sofka, W. Search patterns and absorptive capacity: Low-and high-technology sectors in European countries. Res. Policy 2009, 38, 495-506. [CrossRef]

19. Lim, K.; Chesbrough, H.; Ruan, Y. Open Innovation and Patterns of R\&D Competition. Ph.D. Thesis, Institute of Australia Alan Gilbert Building, The University of Melbourne, Parkville, VIC, Australia, 2008.

20. Serrano-Bedia, A.M.; López-Fernández, M.C.; García-Piqueres, G. Complementarity between innovation knowledge sources: Does the innovation performance measure matter? BRQ Bus. Res. Q. 2018, 21, 53-67. [CrossRef]

21. Xiaobao, P.; Wei, S.; Yuzhen, D. Framework of open innovation in SMEs in an emerging economy: Firm characteristics, network openness, and network information. Int. J. Technol. Manag. 2013, 62, 223-225. [CrossRef]

22. Menrad, K. Innovations in the food industry in Germany. Res. Policy 2004, 33, 845-878. [CrossRef]

23. Franke, N.; Lüthje, C. User Innovation Oxford Research Encyclopedia, Business and Management. In Oxford Research Encyclopedia of Business and Management; Oxford University Press: Oxford, UK, 2020.

24. CIS (2012): Data of Community Innovation Survey of the European Union. Conducted in Hungary; Eurostat, European Union: Brussels, Belgium, 2012.

25. Rethinking the European Innovation Scoreboard. A New Methodology. 2017. Available online: http: /www.merit-unimass.nl (accessed on 25 November 2019).

26. Chesbrough, H.; Vanhaverbeke, W.; West, J. Open Innovation: Researching a New Paradigm; Oxford University Press on Demand: Oxford, UK, 2006.

27. de Oliveira, R.T.; Indulska, M.; Steen, J.; Verreynne, M.L. Towards a framework for innovation in retailing through social media. J. Retail. Consum. Serv. 2019. [CrossRef]

28. Habanabakize, T.; Meyer, D.F.; Oláh, J. The Impact of Productivity, Investment and Real Wages on Employment Absorption Rate in South Africa. Soc. Sci. 2019, 8, 330. [CrossRef]

29. Kiss, A.; Popp, J.; Oláh, J.; Lakner, Z. The Reform of School Catering in Hungary: Anatomy of a Health-Education Attempt. Nutrients 2019, 11, 716. [CrossRef]

30. Popp, J.; Oláh, J.; Kiss, A.; Temesi, Á.; Fogarassy, C.; Lakner, Z. The socio-economic force field of the creation of short food supply chains in Europe. J. Food Nutr. Res. 2018, 58, 31-41.

31. Henttonen, K.; Ritala, P. Search far and deep: Focus of open search strategy as driver of firm's innovation performance. Int. J. Innov. Manag. 2013, 17, 134-146. [CrossRef]

32. Chen, J.; Chen, Y.; Vanhaverbeke, W. The influence of scope, depth, and orientation of external technology sources on the innovative performance of Chinese firms. Technovation 2011, 31, 362-373. [CrossRef]

33. Chiang, Y.H.; Hung, K.P. Exploring open search strategies and perceived in- novation performance from the perspective of inter-organizational knowledge flows. RD Manag. 2010, 40, 292-299. [CrossRef] 
34. Garcia Martinez, M.; Lazzarotti, V.; Manzini, R.; Sánchez García, M. Open innovation strategies in the food and drink industry: Determinants and impact on innovation performance. Int. J. Technol. Manag. 2014, 66, 2012-2242. [CrossRef]

35. Desouza, K.C.; Awazu, Y.; Jasimuddin, S. Utilizing external sources of knowledge. KM Rev. 2005, 8, 16-19.

36. Knudsen, M.P. The relative importance of interfirm relationships and knowledge transfer for new product development success. J. Prod. Innov. Manag. 2007, 24, 117-138. [CrossRef]

37. Ardito, L.; Messeni Petruzzelli, A.; Albino, V. Investigating the antecedents of general purpose technologies: A patent perspective in the green energy field. J. Eng. Technol. Manag. 2016, 39, 81-100. [CrossRef]

38. Gulati, R.; Singh, H. The architecture of cooperation: Managing coordination costs and appropriation concerns in strategic alliances. Adm. Sci. Q. 1998, 43, 781-814. [CrossRef]

39. Cassiman, B.; Veugelers, R. In search of complementarity in innovation strategy: Internal R\&D and external knowledge acquisition. Manag. Sci. 2006, 52, 68-82. [CrossRef]

40. Emden, Z.; Calantone, R.J.; Droge, C. Collaborating for new product development: Selecting the partner with maximum potential to create value. J. Prod. Innov. Manag. 2006, 23, 330-341. [CrossRef]

41. Perkmann, M.; Walsh, K. University-industry relationships and open innovation: Towards a research agenda. Int. J. Manag. Rev. 2007, 9, 259-280. [CrossRef]

42. Gumusluoğlu, L.; Ilsev, A. Transformational leadership and organizational innovation: The roles of internal and external support for innovation. J. Prod. Innov. Manag. 2009, 26, 264-277. [CrossRef]

43. Dahlander, L.; Gann, D.M. How open is innovation? Res. Policy 2010, 39, 699-709. [CrossRef]

44. Zhou, K.Z.; Wu, F. Technological capability, strategic flexibility, and product innovation. Strateg. Manag. J. 2009. [CrossRef]

45. Capitanio, F.; Coppola, A.; Pascucci, S. Product and process innovation in the Italian food industry. Agribusiness 2010, 26, 503-518. [CrossRef]

46. Bayona-Saez, C.; Cruz-Cázares, C.; García-Marco, T. Open innovation in the food and beverage industry. Manag. Decis. 2017, 55, 526-546. [CrossRef]

47. Ferraris, A.; Santoro, G.; Dezi, L. How MNC's subsidiaries may improve their innovative performance? The role of external sources and knowledge management capabilities. J. Knowl. Manag. 2017, 21, 540-552. [CrossRef]

48. Giacosa, E.; Ferraris, A.; Monge, F. How to strengthen the business model of an Italian family food business. Br. Food J. 2017, 119, 2309-2324. [CrossRef]

49. Török, Á.; Tóth, J.; Balogh, J.M. Push or Pull? The nature of innovation process in the Hungarian food SMEs. J. Innov. Knowl. 2019, 4, 234-239. [CrossRef]

50. Jann, B. Plotting regression coefficients and other estimates. Stata J. 2014, 14, 708-737. [CrossRef]

51. Rosa, A.C.M.; Chimendes, V.C.G.; Amorim, G.F. Measuring open innovation practices in small companies at important Brazilian industrial centers. Technol. Forecast. Soc. Chang. 2020, 151, 119805. [CrossRef]

52. Nieto, M.J.; Santamaría, L. The importance of diverse collaborative networks for the novelty of product innovation. Technovation 2007, 27, 367-377. [CrossRef]

53. Miotti, L.; Sachwald, F. Co-operative R\&D: Why and with whom? An integrated framework of analysis. Res. Policy 2003, 32, 1481-1499.

54. Becker, W.; Dietz, J. R\&D cooperation and innovation activities of firms-evidence for the German manufacturing industry. Res. Policy 2004, 33, 209-223.

55. Faems, D.; Van Looy, B.; Debackere, K. Interorganizational collaboration and innovation: Toward a portfolio approach. J. Prod. Innov. Manag. 2005, 22, 238-250. [CrossRef]

56. Rybnicek, R.; Königsgruber, R.J. What makes industry-university collaboration succeed? A systematic review of the literature. J. Bus. Econ. 2019, 89, 221. [CrossRef]

57. Belderbos, R.; Carree, M.; Lokshin, B. Cooperative R\&D and firm performance. Res. Policy 2004, 33, 1477-1492.

58. Das, T.K.; Teng, B.S. A resource-based theory of strategic alliances. J. Manag. 2000, 26, 31-61. [CrossRef]

59. Dressler, M.; Paunovic, I. Towards a conceptual framework for sustainable business models in the food \& beverage industry: The case of German wineries. Br. Food J. 2019. [CrossRef]

60. Amit, R.; Zott, C. Creating value through business model innovation. MIT Sloan Manag. Rev. 2012, 12, 140-151. 
61. Storbacka, K.; Nenonen, S. Learning with the market: Facilitating market innovation. Ind. Mark. Manag. 2015, 44, 73-82. [CrossRef]

62. Lubell, M.; Fulton, A. Local policy networks and agricultural watershed management. J. Public Adm. Res. Theory 2008, 18, 673-696. [CrossRef]

63. Wejnert, B. Integrating models of diffusion of innovations: A conceptual framework. Annu. Rev. Sociol. 2002, 28, 297-326. [CrossRef]

64. Lubell, M.; Hillis, V.; Hoffman, M. Innovation, cooperation, and the perceived benefits and costs of sustainable agriculture practices. Ecol. Soc. 2011, 16, 296-310. [CrossRef]

(C) 2020 by the authors. Licensee MDPI, Basel, Switzerland. This article is an open access article distributed under the terms and conditions of the Creative Commons Attribution (CC BY) license (http://creativecommons.org/licenses/by/4.0/). 


\title{
Article \\ Food Origin Traceability from a Consumer's Perspective
}

\author{
Anna Walaszczyk* and Barbara Galińska \\ Faculty of Management and Production Engineering, Lodz University of Technology, 90-924 Lodz, Poland; \\ barbara.galinska@p.lodz.pl \\ * Correspondence: anna.walaszczyk@p.lodz.pl
}

Received: 30 January 2020; Accepted: 28 February 2020; Published: 2 March 2020

\begin{abstract}
The awareness of food origin in the consumers' perspective has gradually become more significant not only in reference to consumers from highly developed countries but also from emerging ones, which are already on their way from a developing to developed economy. The purpose of the paper is to answer the research question by verifying four hypotheses formulated in the research process. The research question is: "Do the variables which characterize consumers of food products in Poland, including gender, age, education and financial status, affect the aspects related to food traceability, such as identification of the producer, importance of food product features when shopping, importance of the information given on food product packaging and influence of the shopping place and frequency on tracing the food origin?" The paper presents the results, analysis, and conclusions from the study in reference to the four assumed hypotheses related to the above-mentioned research question. The study was carried out on a group of 500 consumers of food products in Poland. The study topic selection is justified by the assumed significance of tracing back a food product's origin for a consumer who functions in a globalization-based economy; this was confirmed by the subject literature presented in the paper.
\end{abstract}

Keywords: traceability; food; consumer; consumption; behavior; security

\section{Introduction}

Food traceability, defined as the possibility to trace back the history of a food product, is a very important process from the point of view of ensuring food safety for consumers all over the world. The safety of produced food can be maintained only when full traceability of raw materials, semi-finished products, and processes are ensured on all stages of the food chain [1-5]. Adequate organization of the market of food products is difficult considering the size of the market and the strict legal requirements in force. Despite stringent control of the market by authorized control units, every week the Rapid Alert System for Food and Feed (RASFF) registers several dozen alerts in Europe, regarding food launched in the market that has been labeled dangerous for human life and health (RASFF was introduced by means of EC regulation No. 178/2002 of the European Parliament and the Council on 29 January 2002).

The literature on food safety presents different definitions of the term "traceability" [6]. The term originally appeared back in 1996 in the international ISO 8402 standard concerning quality management and quality assurance. According to the definition in the standard, traceability stands for the ability to trace the history, application, or location of a unit by way of an analysis of records allowing its identification [7]. The publication by Moe (1998) entitled "Perspectives on Traceability in Food Manufacture" contains a wider definition stating that traceability stands for the ability to trace a batch of products and its history throughout the entire production chain or part of it, from harvesting through to transport, storage, processing, distribution, and sales (this is known as the traceability chain) or internally-in a single step of the production chain (this is known as the internal traceability 
chain) [8]. According to the Efficient Consumer Response (ECR) strategy enforced in 2004, the essence of traceability lies in the possibility of monitoring the handling and origin of a reference product (production batch) in each stage of the supply chain, by all companies in the food sector (ECR Europe 2004). The ECR integrates producers, suppliers, and sellers in the supply chain to build a cost-effective system which responds to specific needs of a consumer; consequently, the total cost of the system and stock level are reduced with a simultaneous increase in value for the end customer [9]. Identification is an intrinsic element of traceability, determining its success in relation to tracing the history of products [10]. Schwagele defines traceability through the concept of identification and states that identification enables the acquisition of data from a previous stage of the chain (what was received and from whom) and the provision of information for the following stage (what was sent and to whom) [11]. In the opinion of Rabade and Alfaro, traceability stands for the registration and tracing of processes and materials used in production [12]. A definition of the concept of traceability can also be found in the first international standard-ISO 22005 of 2007-applying to food safety management in the context of tracing its history. The standard contains the following definition: "traceability stands for the ability to trace the flow (movement) of feed or food through specific production stage(s), processing and distribution; movement can refer to the origin of materials (raw materials), history of processing and distribution of feed or food" $[13,14]$.

Gradually more attention was paid to scientific research carried out not only in Europe but also globally on the consumers' perception of food origin tracing. Recently such research was conducted in China [15], Japan [16], and Brazil [17]. The general conclusion from the research, which either applies to a particular country or compares the issue of consumers' approach to food traceability in different countries [18], is that consumers want information regarding where a product comes from, what production methods were used, whether production was certified, and if information on the packaging is complete and reliable $[19,20]$. Consumers have become highly concerned about the safety of their food and so the speed of obtaining information about contamination and diseases transmitted by food, effective risk management, and efficient management of non-compliant products' withdrawal from the market, have become more important [21]. Consumers' concerns about food safety are also related to genetic modification of food [22]. In order to face the challenge of an increasingly demanding process of food product traceability, China uses extensive and advanced food origin tracing methods based on DNA [23], whereas in reference to food origin tracing management, an additional consumer fee, called WTP (Willingness To Pay), is used for information about the food [24].

Regulation No. 178/2002 issued in January 2002, sets out the general rules and requirements of food law; the establishment of the European Food Safety Authority and procedures concerning food safety are fundamental for the food laws of communities (including Poland, on which the research was based). Article 18 of the Regulation obliges all EU member states to establish and implement traceability procedures as of 1 January 2005. The core of traceability is in tracing the path of a finished product "forwards" and "backwards" [25]. Backward traceability helps to identify the cause and sources of a hazard (e.g., via data by the producer or number of product batches). Forward traceability involves withdrawing a finished product from the market owing to identification of the location where a non-compliant batch was delivered. The trade quality of products in Poland is supervised by two bodies: the Trade Inspectorate (retail) and the Inspectorate for Trade Quality of Agricultural and Food Products (producers). Moreover, in the food supply chain, there is no continuous exchange of information about the course of each measure taken by subsequent actors, which impairs the traceability of products. The growth of a company in the food sector and the adaptation of the internal and external traceability system to ensure food safety, are possible if the traceability system is treated as a subsystem whose presence is necessary to manage product quality $[26,27]$. This is because traceability is indispensable to ensuring the quality of production and the product itself [28].

This study's research problem, formulated based on the subject literature review, is expressed as a research question, the answers to which are the paper's objective. The research question is as follows: "Do the variables which characterize consumers of food products in Poland, including gender, age, 
education and financial status, affect the aspects related to food traceability, such as identification of the producer, importance of food product features when shopping, importance of the information given on food product packaging and influence of the shopping place and frequency on tracing the food origin?".

The validity of the research issue to be verified is justified by the fact that under current globalization-based economic conditions, food origin is of paramount importance. Consumers in highly developed and developing countries have a wide variety of food product criteria (including origin) to choose from [29]. Observations of consumer behavior revealed that people want to know more about the food they buy. Knowledge of the food origin, and as a conscious choice in this respect, contributes to the consumer's self-assurance about food safety [30-33]. The issue of the requirements that particular consumer groups establish for particular food products is also very important for food producers and developers of production-related processes. Clients' requirements are the key requirements to be faced by producers because a consumer is the key stakeholder for a conscious producer [34].

In order to assign a quantitative dimension to the research issue, which can be confirmed by statistical indicators, four research hypotheses were formulated and verified in the study:

1. H1. There is a relationship between the identified groups of consumers and the kind of food producer they choose, as regards market coverage.

2. H2. There are significant differences in the ranking of the validity of aspects taken into account when people from the identified consumer groups buy food.

3. H3. There are significant differences in the way that people from the identified consumer groups rank the validity of information on food packaging.

4. H4. There are significant differences in the way that people from the identified consumer groups rank the significance of a food product's origin.

The presented hypotheses determined the use of the following study methods.

\section{Materials and Methods}

The study was carried out in the first half of 2017 in Poland on a population of 500 consumers. It was a pilot study in which $50 \%$ of the studied group of respondents were men and $50 \%$ were women. The integrity of the study sample was the only parameter of purposeful selection of the study subject matter. Other selection conditions of consumers participating in the study were randomized and comprised of:

- respondents in four age brackets (20-30 years, 31-40 years, $41-50$ years, and over 60 years);

- four levels of education (primary or lower secondary education, vocational education, secondary education, and university education);

- $\quad$ size of private household in terms of number of persons included (1 person, 2 people, 3-4 people, more than 5 people);

- place of residence presented in four categories (countryside, city up to 50,000 people, city with $50,000-100,000$ inhabitants, and city with a population above 100,000);

- per capita gross income in the household (up to 400 EUR, 401-600 EUR, 601-950 EUR, over 950 EUR).

Following a demographic analysis of the respondents taking part in the study, regarding their sex, age, education and income, some similarities and relationships were observed between the characteristics. An analysis of concentrations was performed in order to group the respondents 
according to uniform or highly similar characteristics [35]. Grouping was intended to focus attention on the groups of consumers participating in the study, which could become representative groups from the point of view of the conclusions drawn from the study. A two-step concentration analysis was applied to divide the study participants into four groups. The Bayesian information criterion (BIC) was used to separate the subgroups, while the distance between the study participants was measured with a credibility logarithm. The two-step concentration analysis facilitated the identification of the following four groups; most homogeneous within a specific group and also most diversified as compared to other groups, based on such variables as sex, age, education, and income:

- $\quad$ men of all ages, with a secondary degree, medium income

- $\quad$ people aged 31-60, with a university degree, medium income

- women of all ages, with a secondary degree, medium income

- $\quad$ younger people (20-30 years old), with a university degree, medium and higher income.

Table 1 presents the quantitative characteristics of the identified groups.

Table 1. Profiles of the four identified groups of respondents.

\begin{tabular}{|c|c|c|c|c|c|c|c|c|c|}
\hline & & \multicolumn{8}{|c|}{ Concentration Number in Two-Step Grouping } \\
\hline & & \multicolumn{2}{|c|}{1} & \multicolumn{2}{|c|}{2} & \multicolumn{2}{|c|}{3} & \multicolumn{2}{|c|}{4} \\
\hline & & $n$ & $\%$ & $n$ & $\%$ & $n$ & $\%$ & $n$ & $\%$ \\
\hline \multirow{5}{*}{ Age } & $20-30$ & 39 & 32.5 & & & 10 & 6.0 & 50 & 47.2 \\
\hline & $31-40$ & 11 & 9.2 & 3 & 2.9 & 45 & 26.8 & 40 & 37.7 \\
\hline & $41-50$ & 2 & 1.7 & 52 & 51.0 & 34 & 20.2 & 11 & 10.4 \\
\hline & $51-60$ & 24 & 20.0 & 21 & 20.6 & 49 & 29.2 & 5 & 4.7 \\
\hline & $60+$ & 44 & 36.7 & 26 & 25.5 & 30 & 17.9 & & \\
\hline \multirow{2}{*}{ Sex } & Male & 120 & 100.0 & 85 & 83.3 & & & 43 & 40.6 \\
\hline & Female & & & 17 & 16.7 & 168 & 100.0 & 63 & 59.4 \\
\hline \multirow{4}{*}{ Education } & $\begin{array}{c}\text { Primary/lower } \\
\text { secondary }\end{array}$ & & & 12 & 11.8 & & & & \\
\hline & Vocational & & & 36 & 35.3 & 39 & 23.2 & & \\
\hline & Secondary & 120 & 100.0 & 10 & 9.8 & 128 & 76.2 & & \\
\hline & Tertiary & & & 44 & 43.1 & 1 & 0.6 & 106 & 100.0 \\
\hline \multirow{3}{*}{ Income } & 401-600 EUR & 6 & 5.0 & 2 & 2.0 & 6 & 3.6 & & \\
\hline & 601-950 EUR & 83 & 69.2 & 98 & 96.1 & 136 & 81.0 & 54 & 50.9 \\
\hline & over 950 EUR & 31 & 25.8 & 2 & 2.0 & 26 & 15.5 & 52 & 49.1 \\
\hline
\end{tabular}

Source: data developed based on our own study.

A proprietary questionnaire consisting of eight main questions and six identification questions concerning sex, age, education, household size, and income of the respondents (based on the analysis of concentrations, household size and place of residence did not matter from the point of view of respondent grouping) was the study tool. Among the main questions there were six multiple-choice questions and two questions where one needed to assign rank on a 1-6 and 1-5 scale. "1" meant most important, and "5" or "6" least important. The ranked questions concerned those factors most important for consumers when they buy food. They involved such aspects as knowledge of the brands, guarantee of product quality and freshness, low price, best before date, product origin, and ingredients. Moreover, the questions touched upon information that in the consumers' opinions should be placed on food packaging (i.e., information about the producer, the product's energy value, best before date, detailed information about raw materials, and product ingredients).

Collection of empirical materials by means of an interview questionnaire developed by the authors was justified by the specificity of the research and the necessity to reach a wide range of respondents. 
A focused group interview (i.e., a focus group), composed of representatives of academic staff and entrepreneurs was involved in the study in order to:

- $\quad$ use the opinions of the focus group members (as one of the factors) to formulate four study hypotheses (presented in the introduction of the paper) and to develop an interview questionnaire; - extend the interpretation of the obtained results of the study.

The study used both direct tools (proprietary interviews) and indirect tools (e-mails and Google surveys). The data from the study were collected in an Excel spreadsheet and then summarized and analyzed quantitatively using Statistica (a statistical data-processing software). The following statistical measures were used to analyze the results of the study:

- Chi-squared test of cross tabulation;

- Cramer's V test, effect size;

- non-parametric Mann-Whitney U test;

- non-parametric Kruskal-Wallis test.

The majority of analyses in the study were based on data in the form of ranks or ordinal variables. Therefore, referring to the characteristics of each statistical measure, when testing hypotheses mentioning different distributions of ranks in different groups, the Kruskal-Wallis test was used. Pearson's Chi-squared test was used for verification of the presence of relationships between the variables according to the hypotheses. The following symbols were used for presenting the study results:

- $\mathrm{M}$-arithmetic mean

- $\quad \mathrm{SD}$ - standard deviation (the lower the value, the more focused the observations around M)

- $\quad$ MR-mean range (non-parametric equivalent of M)

- Mdn-median (value of a characteristic above and below which the number of observations $\mathrm{N}$ is the same)

- $\quad \mathrm{N}-$ number of observations

- $\quad " p "$-relevance, for the value $<0.05$ we have over $95 \%$ certainty that there is a relationship between classifications and the selected variable (i.e., that the observed relationship is not incidental)

- $\quad \chi^{2}$-general statistics for the reference analysis, based on which " $p$ " is calculated

- Cramer's r, V-effect size: it gives information about the size of the relationship between two variables (up to 0.30 the effect is assumed to be weak; between 0.30 and 0.50 the effect is assumed to be medium, while over 0.50 the effect is assumed to be strong)

- Z Z general statistics for the reference analysis, based on which " $p$ " and "r" are calculated.

\section{Results of the Study}

The first hypothesis assumed there would be a relationship between the identified consumer groups and the food producers they chose for their market coverage. An analysis performed with a Chi-squared test of cross tabulations revealed the presence of a strong relationship between the identified groups and their preferred producers. Details of the study results in this respect are presented in Table 2.

The second hypothesis assumed there would be significant differences in the ranking of the validity of aspects, which the representatives of the four identified groups of consumers took into account when buying food. Analysis using the Kruskal-Wallis test revealed that differences in the ranking of validity occurred in three (brand, best before date, and product ingredients) out of six analyzed aspects, which included brand, quality guarantee, price, best before date, origin, and ingredients. Details of the study results in this respect are presented in Table 3. 
Table 2. First hypothesis results.

\begin{tabular}{|c|c|c|c|c|c|c|c|c|c|}
\hline & & & \multicolumn{4}{|c|}{ Most often You Choose Producers among: } & \multirow{2}{*}{$x^{2}$} & \multirow{2}{*}{$p$} & \multirow{2}{*}{ Cramer's V } \\
\hline & & & $\begin{array}{l}\text { Global } \\
\text { Market } \\
\text { Leaders }\end{array}$ & $\begin{array}{l}\text { Domestic } \\
\text { Producers }\end{array}$ & $\begin{array}{l}\text { Regional } \\
\text { Producers }\end{array}$ & $\begin{array}{l}\text { It does not } \\
\text { Matter to Me }\end{array}$ & & & \\
\hline \multirow{8}{*}{$\begin{array}{l}\text { Group } \\
\text { number }\end{array}$} & \multirow{2}{*}{1} & $\mathrm{~N}$ & 51 & 52 & 10 & 7 & \multirow{8}{*}{20.78} & \multirow{8}{*}{$<0.05$} & \multirow{8}{*}{0.12} \\
\hline & & $\%$ & $42.5 \%$ & $43.3 \%$ & $8.3 \%$ & $5.8 \%$ & & & \\
\hline & \multirow{2}{*}{2} & $\mathrm{~N}$ & 49 & 50 & 1 & 2 & & & \\
\hline & & $\%$ & $48.0 \%$ & $49.0 \%$ & $1.0 \%$ & $2.0 \%$ & & & \\
\hline & \multirow{2}{*}{3} & $\mathrm{~N}$ & 65 & 82 & 19 & 2 & & & \\
\hline & & $\%$ & $38.7 \%$ & $48.8 \%$ & $11.3 \%$ & $1.2 \%$ & & & \\
\hline & \multirow{2}{*}{4} & $\mathrm{~N}$ & 51 & 42 & 12 & 1 & & & \\
\hline & & $\%$ & $48.1 \%$ & $39.6 \%$ & $11.3 \%$ & $0.9 \%$ & & & \\
\hline
\end{tabular}

Source: data developed based on our own study.

Table 3. Second hypothesis results.

\begin{tabular}{|c|c|c|c|c|c|c|c|c|c|}
\hline Question & $\begin{array}{l}\text { Group } \\
\text { Number }\end{array}$ & $\mathbf{N}$ & MR & $\mathbf{M}$ & Mdn & SD & $x^{2}$ & $p$ & $\begin{array}{c}\text { Significant } \\
\text { Differences }\end{array}$ \\
\hline \multirow{4}{*}{$\begin{array}{l}\text { How } \\
\text { important is } \\
\text { the brand? }\end{array}$} & 1 & 120 & 221.52 & 2.50 & 3.00 & 1.34 & \multirow{4}{*}{12.56} & \multirow{4}{*}{$<0.01$} & \multirow{4}{*}{$1<4$} \\
\hline & 2 & 102 & 245.48 & 2.72 & 3.00 & 1.22 & & & \\
\hline & 3 & 168 & 248.51 & 2.76 & 3.00 & 1.26 & & & \\
\hline & 4 & 106 & 281.93 & 3.07 & 3.00 & 1.17 & & & \\
\hline \multirow{4}{*}{$\begin{array}{l}\text { How } \\
\text { important is } \\
\text { the best } \\
\text { before date? }\end{array}$} & 1 & 120 & 282.14 & 2.47 & 2.00 & 1.66 & \multirow{4}{*}{11.74} & \multirow{4}{*}{$<0.01$} & \multirow{4}{*}{$1>3 ; 1>4$} \\
\hline & 2 & 102 & 247.41 & 1.94 & 1.50 & 1.24 & & & \\
\hline & 3 & 168 & 239.65 & 1.93 & 1.00 & 1.36 & & & \\
\hline & 4 & 106 & 225.50 & 1.80 & 1.00 & 1.29 & & & \\
\hline \multirow{4}{*}{$\begin{array}{c}\text { How } \\
\text { important } \\
\text { are the } \\
\text { ingredients? }\end{array}$} & 1 & 120 & 208.39 & 3.88 & 4.00 & 1.01 & \multirow{4}{*}{13.47} & \multirow{4}{*}{$<0.01$} & \multirow{4}{*}{$\begin{array}{c}1<2 ; 1<3 ; 1 \\
<4\end{array}$} \\
\hline & 2 & 102 & 260.32 & 4.34 & 4.00 & 1.25 & & & \\
\hline & 3 & 168 & 262.68 & 4.38 & 4.00 & 1.30 & & & \\
\hline & 4 & 106 & 260.06 & 4.38 & 4.00 & 1.32 & & & \\
\hline
\end{tabular}

Source: data developed based on our own study. N, number of observations; MR, mean range; M, arithmetic range; Mdn, mean; SD, standard deviation.

The third hypothesis assumed there would be significant differences in the ranks assigned by the representatives of the identified consumer groups to the validity of information given on food packaging. A quantitative analysis revealed that the assumed differences did not actually occur. Details of the study results in this respect are presented in Table 4.

In the last (fourth) research hypothesis, it was assumed that significant differences existed in the ranks that the identified groups of consumers assigned to food product origin. The variables included the place of food purchase (Table 5) and the frequency of shopping (Table 6). The results of the performed analysis did not confirm the hypothesis. 
Table 4. Third hypothesis results.

\begin{tabular}{|c|c|c|c|c|c|c|c|c|c|}
\hline Questions & Group No. & $\mathbf{N}$ & MR & $\mathbf{M}$ & Mdn & SD & $x^{2}$ & $p$ & $\begin{array}{l}\text { Significant } \\
\text { Differences }\end{array}$ \\
\hline \multirow{4}{*}{$\begin{array}{l}\text { How important is } \\
\text { information about } \\
\text { the producer? }\end{array}$} & 1 & 120 & 253.81 & 5.13 & 5.00 & 0.84 & \multirow{4}{*}{1.72} & \multirow{4}{*}{0.63} & \multirow{4}{*}{-} \\
\hline & 2 & 102 & 243.72 & 5.06 & 5.00 & 0.87 & & & \\
\hline & 3 & 168 & 240.32 & 5.04 & 5.00 & 0.83 & & & \\
\hline & 4 & 106 & 260.06 & 5.16 & 5.00 & 0.86 & & & \\
\hline \multirow{4}{*}{$\begin{array}{l}\text { How important is } \\
\text { information about } \\
\text { the energy value? }\end{array}$} & 1 & 120 & 251.33 & 2.29 & 2.00 & 0.46 & \multirow{4}{*}{2.47} & \multirow{4}{*}{0.48} & \multirow{4}{*}{-} \\
\hline & 2 & 102 & 242.22 & 2.25 & 2.00 & 0.44 & & & \\
\hline & 3 & 168 & 257.24 & 2.32 & 2.00 & 0.47 & & & \\
\hline & 4 & 106 & 237.49 & 2.24 & 2.00 & 0.43 & & & \\
\hline \multirow{4}{*}{$\begin{array}{l}\text { How important is } \\
\text { information about } \\
\text { the best before date? }\end{array}$} & 1 & 120 & 245.67 & 2.71 & 3.00 & 0.46 & \multirow{4}{*}{2.47} & \multirow{4}{*}{0.48} & \multirow{4}{*}{ - } \\
\hline & 2 & 102 & 254.78 & 2.75 & 3.00 & 0.44 & & & \\
\hline & 3 & 168 & 239.76 & 2.68 & 3.00 & 0.47 & & & \\
\hline & 4 & 106 & 259.51 & 2.76 & 3.00 & 0.43 & & & \\
\hline \multirow{4}{*}{$\begin{array}{l}\text { How important is } \\
\text { information about } \\
\text { the raw materials the } \\
\text { product is made of? }\end{array}$} & 1 & 120 & 242.48 & 5.00 & 5.00 & 0.77 & \multirow{4}{*}{1.11} & \multirow{4}{*}{0.77} & \multirow{4}{*}{ - } \\
\hline & 2 & 102 & 257.92 & 5.09 & 5.00 & 0.77 & & & \\
\hline & 3 & 168 & 243.74 & 5.01 & 5.00 & 0.80 & & & \\
\hline & 4 & 106 & 253.79 & 5.07 & 5.00 & 0.73 & & & \\
\hline \multirow{4}{*}{$\begin{array}{l}\text { How important is } \\
\text { information about } \\
\text { ingredients? }\end{array}$} & 1 & 120 & 248.15 & 4.88 & 5.00 & 0.84 & \multirow{4}{*}{3.20} & \multirow{4}{*}{0.36} & \multirow{4}{*}{ - } \\
\hline & 2 & 102 & 245.35 & 4.85 & 5.00 & 0.80 & & & \\
\hline & 3 & 168 & 261.22 & 4.95 & 5.00 & 0.82 & & & \\
\hline & 4 & 106 & 231.77 & 4.77 & 5.00 & 0.81 & & & \\
\hline
\end{tabular}

Source: data developed based on our own study.

Table 5. Product origin vs. place of purchase.

\begin{tabular}{ccccccccc}
\hline & $\begin{array}{c}\text { Where do You } \\
\text { Buy Food } \\
\text { Most Often? }\end{array}$ & N & MR & M & Mdn & SD & $\chi^{2}$ & $p$ \\
\hline \multirow{2}{*}{$\begin{array}{c}\text { How important is } \\
\text { product origin? }\end{array}$} & Supermarket & 103 & 237.03 & 5.09 & 5.00 & 0.84 \\
\cline { 2 - 7 } & Mini market & 279 & 253.37 & 5.18 & 5.00 & 0.83 & \multirow{2}{*}{1.22} & 0.75 \\
\cline { 2 - 8 } & Grocer's & 89 & 251.61 & 5.19 & 5.00 & 0.78 \\
\hline
\end{tabular}

Source: data developed based on our own study.

Table 6. Product origin vs. frequency of doing shopping.

\begin{tabular}{|c|c|c|c|c|c|c|c|c|}
\hline & $\begin{array}{l}\text { Frequency of Doing } \\
\text { Shopping }\end{array}$ & $\mathbf{N}$ & MR & $\mathbf{M}$ & Mdn & SD & $x^{2}$ & $p$ \\
\hline \multirow{4}{*}{$\begin{array}{l}\text { How important is } \\
\text { product origin? }\end{array}$} & Every day & 55 & 251.27 & 5.16 & 5.00 & 0.83 & \multirow{4}{*}{1.37} & \multirow{4}{*}{0.71} \\
\hline & Several times a week & 107 & 237.54 & 5.12 & 5.00 & 0.75 & & \\
\hline & Once a week & 318 & 254.39 & 5.18 & 5.00 & 0.84 & & \\
\hline & Once or twice a month & 20 & 255.83 & 5.05 & 5.00 & 1.19 & & \\
\hline
\end{tabular}

Source: data developed based on our own study.

\section{Analysis of Results and Discussion}

In reference to the four hypotheses made at the beginning of the study, only two were confirmed; there are relationships between the identified groups of consumers and the kind of producer they chose as regards market coverage $(\mathrm{H} 1)$, and there are significant differences in the ranking of the validity 
of aspects taken into account when representatives of the four identified groups of consumers buy food (H2).

As for the first hypothesis, women of all ages (no age diversification), with secondary education and medium income, were the ones who chose products from "global market leaders" least often (group 3). Global brand products were most often chosen by people aged 31-60, with higher education and medium income (group 2), and by younger people (aged 20-30) with higher education and medium or higher income (group 4). Consumers from group 2 tended to buy products from domestic producers as often as products from global market leaders, while regional producers were the least popular in the group. This can be justified by the maturity of this group of consumers, as exemplified by their age and education, and hence greater confidence in a producer operating on a global market and having a more extended control system of the food produced.

Confirmation of the second hypothesis reveals that males of any age, medium income, and secondary education (group 1) ranked the significance of a brand much lower than younger people (aged 20-30) with higher education, and medium and higher income (group 4). Additionally, the same men ranked the significance of the product ingredients lower than any other identified group. They considered the best before date as a much more important factor than people from group 3 (women of any age, secondary education, and medium income) and group 4 (younger people aged 20-30, higher education, of medium and higher income). From the point of view of the aim of the study, product ingredients form the most important aspect for food traceability. The study revealed that this mattered to all consumers participating in the study, but it was least important for men with secondary education and medium income. Such a result can be justified by the fact that medium income does not always give consumers the freedom to choose food with the ingredients they would prefer, and secondary education may be indicative of a lack of knowledge on how to analyze the ingredients of a food product correctly. In addition to the above, men typically pay less attention to more pragmatic issues, such as best before dates or prices, than the product's composition/ingredients. The reasons for this behavior could form the subject of a sociological or psychological enquiry.

Two hypotheses were not confirmed in the course of the study. They included H3: there are important differences in the rank assigned by representatives of the identified consumer groups to the validity of information given on food packaging, and H4: there are significant differences in the rank assigned by the identified groups of consumers to the aspect of food product origin. Referring to $\mathrm{H} 3$, it should be pointed out that the identified groups of consumers were quite unanimous about the significance of information on the raw materials that the product is made of (which is a positive result from the point of view of the importance of traceability for consumers). The greatest discrepancies in answers were observed in relation to information about the product composition/ingredients (the greatest differences were observed between groups 3 and 4). It can be concluded that all studied information on food packaging, including identification of the producer, energy value of the product, best before date, raw materials used for production, and composition/ingredients are of equal importance for men and women, regardless of age, education, or income.

In reference to $\mathrm{H} 4$, assuming significant differences in the assessment of the validity of food origin, it turned out that differences in the answers given by different consumers were so small that they could be considered unanimous as for the significance of product origin vs. the following two variables: place of doing shopping and frequency of doing shopping. This suggests that food traceability is important for all study participants, regardless of the frequency or location of doing shopping.

Referring to the research question posed, the results of the study showed that the origin of food products mattered to consumers, regardless of the analyzed conditions. Differences in relation to the identified groups of consumers were noticeable in the following respect: some aspects of traceability were approached in a different way and have a different significance priority assigned to them. Perhaps it would be worth analyzing the issue of specific information that should-in the consumers' opinion-be placed on food products and reviewing if the scope of data complies with the 
current legal requirements. Identification of how far back the process of backward traceability of food should reach from the point of view of consumers could form an interesting focus for further studies.

\section{Conclusions}

The results of the study on food traceability from a consumer's perspective, carried out on a group of 500 randomly selected representatives in Poland and presented here, revealed that the issue of food traceability in Poland is important. This is evidenced by the fact that of all the aspects available in the study for selection, the one that consumers paid most attention to was food origin, while the presence of information about producers was considered necessary for food packaging.

Food traceability by consumers is an interesting and diversified phenomenon, which strongly affects the organization of a food chain. Consumer requirements are conditioned by organizational and management decisions by food suppliers on different levels of production, especially when their decisions apply to food safety. The research constraints, which could be used as an idea for subsequent consumer research related to food traceability include:

- a lack of comparison with other research results conducted worldwide, pertaining to similar research topics;

- a lack of initial in-depth verification of the knowledge of the traceability notion among the responders.

Author Contributions: Conceptualization, A.W. and B.G.; methodology, A.W.; software, A.W.; validation, A.W. and B.G.; formal analysis, A.W.; investigation, A.W.; resources, A.W. and B.G.; data curation, A.W.; writing—original draft preparation, A.W.; writing—review and editing, B.G.; visualization, A.W.; supervision, A.W. and B.G.; project administration, B.G.; funding acquisition, B.G.. All authors have read and agreed to the published version of the manuscript.

Funding: This research received no external funding.

Conflicts of Interest: The authors declare no conflicts of interest.

\section{References}

1. Skilton, P.F.; Robinson, L.J. Traceability and normal accident theory: How does supply network complexity influence the traceability of adverse events? J. Supply Chain Manag. 2009, 45, 40-53. [CrossRef]

2. Adrian, A.M.; Norwood, S.H.; Mask, P.L. Producers' perceptions and attitudes toward precision agriculture technologies. Comput. Electron. Agric. 2005, 48, 256-271. [CrossRef]

3. Hoorfar, J.; Jordan, K.; Butler, F.; Prugger, R. Food Chain Integrity: A Holistic Approach to Food Traceability, Safety, Quality and Authenticity; Woodhead Publishing Limited: Sawston, UK; Cambridge, UK, 2011.

4. Bennet, G.S. Food Identity Preservation and Traceability: Safer Grains; CRC Press: Boca Raton, FL, USA, 2009.

5. Bosona, T.; Gebresenbet, G. Food traceability as an integral part of logistics management in food and agricultural supply chain. Food Control 2013, 33, 32-48. [CrossRef]

6. Olsen, P.; Borit, M. How to define traceability. Trends Food Sci. Technol. 2013, 29, 142-150. [CrossRef]

7. ISO 8402:1994-Quality Management and Quality Assurance-Vocabulary. British Standards Institution, London, 1994. Available online: https://www.iso.org/standard/20115.html (accessed on 20 March 2019).

8. Moe, T. Perspectives on tracebility in food manufacture. Trends Food Sci. Technol. 1998, 9, 211-214. [CrossRef]

9. ECR Europe (Efficient Consumer Response). Using Traceability in the Supply Chain to Meet Consumer Safety Expectations. ECR Europe, 2004. Available online: https://www.ecr-community.org/publications/ (accessed on 15 June 2015).

10. Beulens, A.J.M.; Broens, D.F.; Folstar, P.; Hofstede, G.J. Food safety and transparency in food chains and networks: Relationships and challenges. Food Control 2005, 16, 481-486. [CrossRef]

11. Schwagele, F. Traceability from a European Perspective. Meat Sci. 2005, 71, 164-173. [CrossRef] [PubMed]

12. Rabade, L.A.; Alfaro, J.A. Buyer-supplier relationship's influence on traceability implementation in the vegetable industry. J. Purch. Supply Manag. 2006, 12, 39-50. [CrossRef] 
13. ISO 22005:2007-Traceability in the Feed and Food Chain-General Principles and Basic Requirements for System Design and Implementation. European Committee for Standardization, CEN 2007. Available online: https://www.iso.org/standard/36297.html (accessed on 29 February 2020).

14. Shengnan, S.; Xinping, W. Promoting traceability for food supply chain with certification. J. Clean. Prod. 2019, 217, 658-665.

15. Kendall, H.; Kuznesof, S.; Dean, M.; Chan, M.-Y.; Frewer, L. Chinese consumer's attitudes, perceptions and behavioural responses towards food fraud. Food Control 2019, 95, 339-351. [CrossRef]

16. Jin, S.; Zhou, L. Consumer interest in information provided by food traceability systems in Japan. Food Quality and Preference 2014, 36, 144-152. [CrossRef]

17. Matzembacher, D.E.; Stangherlin, I.; Slongo, L.A.; Cataldi, R. An integration of traceability elements and their impact in consumer's trust. Food Control 2018, 92, 420-429. [CrossRef]

18. Rijswijk, W.; Frewer, L.J.; Menozzi, D.; Faioli, G. Consumer perceptions of traceability: A cross-national comparison of the associated benefits. Food Qual. Prefer. 2008, 19, 452-464. [CrossRef]

19. Smith, I. Meeting Customer Needs; Routledge: London, UK, 2012.

20. Smith, I.; Furness, A. Improving Traceability in Food Processing and Distribution; Woodhead Publishing: Sawston, UK; Cambridge, UK, 2006.

21. Astill, J.; Dara, R.A.; Campbell, M.; Farber, J.M.; Yada, R.Y. Transparency in food supply chains: A review of enabling technology solutions. Trends Food Sci. Technol. 2019, 91, 240-247. [CrossRef]

22. Boccia, F.; Covino, D.; Sarnacchiaro, P. Genetically modified food versus knowledge and fear: A Noumenic approach for consumer behaviour. Food Res. Int. 2018, 111, 682-688. [CrossRef] [PubMed]

23. Zhao, J.; Xu, Z.; You, X.; Zhao, Y.; Yang, S. Genetic traceability practices in a large-size beef company in China. Food Chem. 2019, 277, 222-228. [CrossRef] [PubMed]

24. Liu, R.; Gao, Z.; Nayga, R.M.; Snell, H.A.; Ma, H. Consumers'valuation for food traceability in China: Does trust matter? Food Policy 2019, 88, 101768. [CrossRef]

25. Council of the European Union. Regulation (EC) No. 178/2002 of the European Parliament and of the Council; Council of the European Union: Brussels, Belgium, 2002.

26. Coff, C.; Barling, D.; Korthals, M.; Nielsen, T. Ethical Traceability and Communicating Food; Springer Science \& Business Media: Dordrecht, The Netherlands, 2008; Volume 15, pp. 1-18.

27. Eckschmidt, T. The Little Green Book of Food Traceability: Concepts and Challenges; Booksurge Publishing: Charleston, SC, USA, 2009.

28. Bertolini, M.; Bevilacqua, M.; Massini, R. FMECA approach to product traceability in the food industry. Food Control 2006, 17, 137-145. [CrossRef]

29. Galińska, B. Changes in Supply Chains in the Light of Emerging Market Procurement. In Proceedings of the 19th International Scientific Conference Business Logistics in Modern Management (BLMM2019), Osijek, Croatia, 10-11 October 2019; pp. 533-545.

30. Wales, C.; Harvey, M.; Warde, A. Recuperating from BSE: The shifting UK institutional basis for trust in food. Appetite 2006, 47, 187-195. [CrossRef] [PubMed]

31. Montserrat, E.; Santaclara, F.J. Advances in Food Traceability Techniques and Technologies: Improving Quality Throughout the Food Chain; Woodhead Publishing Limited: Sawston, UK; Cambridge, UK, 2016.

32. Resende-Filho, M.A.; Terrance, M. Hurley, Information asymmetry and traceability incentives for food safety. Int. J. Prod. Econ. 2012, 139, 596-603.

33. Lees, M. Food Authenticity and Traceability; Woodhead Published Limited: Sawston, UK; Cambridge, UK, 2003.

34. ISO 9001:2015-Quality Management System. Requirements. ISO 2015. Available online: https://www.iso. org/standard/62085.html (accessed on 29 February 2020).

35. Everitt, B.S.; Landau, S.; Leese, M. Cluster Analysis; Oxford University Press: New York, NY, USA, 2001. 
Article

\title{
The Bioeconomy and Foreign Trade in Food Products-A Sustainable Partnership at the European Level?
}

\author{
Dan Costin Nițescu * and Valentin Murgu \\ Bucharest University of Economic Studies, Faculty of Finance and Banking, Department of Money and Banking, \\ 010961 Bucharest, Romania; valentin_murgu@hotmail.com \\ * Correspondence: dan.nitescu@fin.ase.ro
}

Received: 10 February 2020; Accepted: 17 March 2020; Published: 20 March 2020

\begin{abstract}
This research addresses the problem of the synergistic relationship between the sustainable development of the green economy (bioeconomy) at the European level and the commercial flows with food. Mainly, two components were analyzed and integrated: A qualitative one, on the perspective of the development of the bioeconomy at the European level, and a quantitative one, on the study of the nature of the inter-correlation between the exogenous indicators of foreign food trade (exports and imports) and the relevant endogenous indicators (the labor force, gross added value of agriculture, forestry and fisheries, research and development expenditure, forest area, fossil fuel energy consumption, and renewable energy consumption), for 24 European countries over a 22 year period. Exports and imports of food products are positively influenced by the added value of the agricultural sector and by the share of research and development expenditures, both in the short and long term. Renewable energy consumption influences exports in the short term, but in the long term, the forest area has a significant positive impact. Imports are negatively influenced by renewable energy consumption. The findings of this research can provide support for the future mix of policies.
\end{abstract}

Keywords: sustainability; bioeconomy; foreign trade in food products; agriculture; labor force; research and development; renewable energy; European Union

\section{Introduction}

Due to the technological developments, behavioral changes, and the recent orientation towards "green" projects and sectors, currently, the European economy is facing significant changes. In this context, the production, commercialization, and trade of food products at the level of the European countries, interconnected with the renewable energy resources used for food production, together with their transport and distribution routes, create the premises for development of sustainable communities.

Sustainability (sustainable development) is not a new concept. In 1987, the World Commission on Environment and Development (WCED) published the report "Our Common Future" [1], which developed the concept of sustainable development, which involves people's relations with the environment and the responsibilities of present generations to future generations. At the European level, investment programs have been developed to support innovation and research and to provide solutions to the challenges facing national and global food systems, with respect to food consumption and ensuring food security. An overall deterioration of the state of food security at the global level is being witnessing, generated by the emergence of major risk factors, both structural (increasing world population, global warming, degradation of water resources and land with agricultural potential, etc.), and short term (adoption of inadequate policies, erosion of the political-economic role of the states, proliferation of poverty, etc.). To the extent that the current manifestation trends do not change, 
there are premises for a serious global food crisis, which entails adverse implications for all of the coordinates of global and, implicitly, national and individual security [2]. The gradual transition from linear economy to bioeconomy (the bioeconomy encompasses those parts of the economy that use renewable resources from land and sea, such as crops, forests, fish, animals, and microorganisms, to produce food, materials, and energy [3]) is a strategic goal at the European level. The notion of bioeconomy has grown in importance, both in the research environment, in the public debate, and at the level of political decision-makers, as it is considered as an alternative solution for a different set of problems; strategies/studies were developed as a basis for the construction of a unitary vision on the development, sustainability, and implications of the transition to the bioeconomy. From the European Commission's perspective, the bioeconomy represents an "economy that includes the production of renewable biological resources and their transformation into food, biological, and bioenergy products. This includes the gross added value of agriculture, forestry and fisheries, food, cellulose, and paper production, as well as parts of the chemical, biotechnological, and energy industry" [4]. Other considerations of the bioeconomy are highlighted in certain sectors (e.g., biofuels [5]; biotechnologies [6]; reduced emissions and use of fossil fuels [7]). The studies that were conducted synthesize some views on the bioeconomy, which are included in the following table (Table 1).

Table 1. Key features of the visions regarding the bioeconomy.

\begin{tabular}{|c|c|c|c|}
\hline & $\begin{array}{l}\text { The Vision of } \\
\text { Bio-Technologies }\end{array}$ & The Vision of Bio-Resources & The Vision of Bio-Ecology \\
\hline Purposes and goals & $\begin{array}{l}\text { Economic growth and } \\
\text { job creation }\end{array}$ & $\begin{array}{l}\text { Economic growth and } \\
\text { sustainability }\end{array}$ & $\begin{array}{l}\text { Sustainability, biodiversity, } \\
\text { conservation of ecosystems, } \\
\text { avoiding soil degradation }\end{array}$ \\
\hline Creation of value & $\begin{array}{c}\text { Applications of } \\
\text { biotechnology, } \\
\text { commercialization of } \\
\text { research and technology }\end{array}$ & $\begin{array}{l}\text { Conversion and upgrade of } \\
\text { bioresources (process orientation) }\end{array}$ & $\begin{array}{l}\text { Development of integrated } \\
\text { production systems and } \\
\text { high-quality products with } \\
\text { territorial identity }\end{array}$ \\
\hline $\begin{array}{l}\text { Catalyst and mediators } \\
\text { of innovation }\end{array}$ & $\begin{array}{c}\text { Research and } \\
\text { Development, patents, } \\
\text { Technology Transfers } \\
\text { Officers, research and } \\
\text { funding councils (focus } \\
\text { on science, linear model) }\end{array}$ & $\begin{array}{l}\text { Interdisciplinarity, optimization of } \\
\text { land use, inclusion of degraded } \\
\text { land in biofuel production, use } \\
\text { and availability of bioresources, } \\
\text { waste management, engineering, } \\
\text { science and market (interactive } \\
\text { and network production mode) }\end{array}$ & $\begin{array}{l}\text { Identification of favorable } \\
\text { organic agro-ecological practices, } \\
\text { ethics, risk, interdisciplinary } \\
\text { sustainability, ecological } \\
\text { interactions, re-use and } \\
\text { re-circulation of waste, land use } \\
\text { (circular and self-sustainable } \\
\text { production mode) }\end{array}$ \\
\hline Space focus & $\begin{array}{l}\text { Global clusters/central } \\
\text { regions }\end{array}$ & $\begin{array}{c}\text { Rural/ } \\
\text { peripheral regions }\end{array}$ & $\begin{array}{c}\text { Rural/ } \\
\text { peripheral regions }\end{array}$ \\
\hline
\end{tabular}

The remaining part of this paper is structured in five sections. Section 1 provides a literature review on bioeconomy and foreign trade in food, focusing on EU countries. Section 2 explains the research methodology of the calculation and presents the econometric methodology, specifically the database, variable, and quantitative methods. The third and fourth sections show the discussion and results of the quantitative findings of the study, and the final section provides concluding remarks and policy recommendations.

\section{Literature Review}

The European Organization for Cooperation and Development (OECD) emphasizes a vision based on bio-technologies (reflected in the vision on bioecology-focused bioeconomy) [9]. From the perspective of the European Commission (2017), a significant variety of research and innovation priorities related to the bioeconomy at the level of the European regions/countries have been identified. Most countries/regions use a mix of thematic areas, from the perspective of both the focus on bioresources and the orientation towards energies obtained from bioresources. At the European level [10], several bioeconomic development initiatives, including with regional orientation, have 
been identified. The need for each nation to build a competitive advantage (supported by a localized territorial process and allowing it to differentiate from the other nations) has allowed the emphasis on the competitiveness of a nation through its ability to innovate and on the ability to create and assimilate knowledge [11]. Other approaches [12] consider that the focus on the bioeconomy stems from the need to cover the food requirements of a growing population, related to lower yields of agricultural production, or from the need to ensure energy and food security as well as economic prosperity in the face of some new challenges-climate change. The transition to the bioeconomy involves concerted efforts, both on the part of the authorities and on the part of the society, as such a transformation involves substantial changes in the market through the impact of technological development on industrial processes, ultimately affecting the production and consumption patterns. The success of the bioeconomy is dependent on the active involvement of the authorities in the creation of an adequate legislative framework, taking into account that the advanced bioeconomy will become a reality only if the intensification of the research and development efforts will be reflected in the subsequent implementation of the technologies. The bioeconomy can reflect the direct link between innovation and economic growth [10], in the sense that increasing productivity by maximizing the efficiency of the resources used in counterpoint with limiting the impact on the environment can be achieved only through technological research and development. It is worth mentioning that innovation must be accepted by each participant in the economic chain as well as by the society as a whole. Identifying the stimulating factors of the transition to the bioeconomy is a difficult and complex process, given their diversity. The analysis carried out in 2018 by the FAO (Food and Agriculture Organization, a specialized agency of the UN, with the aim to eliminate world hunger, as well as to improve the food, by coordinating the activities of the governments in the field of agriculture, forestry, and the fishing industry [13]) reflects the contribution of the bioeconomy to a country's economic growth. Although the implementation of this concept requires a harmonization with the particularities and priorities of each state, in a general framework, however, certain aspects essential to the development of the bioeconomy can be identified (see Figure 1).

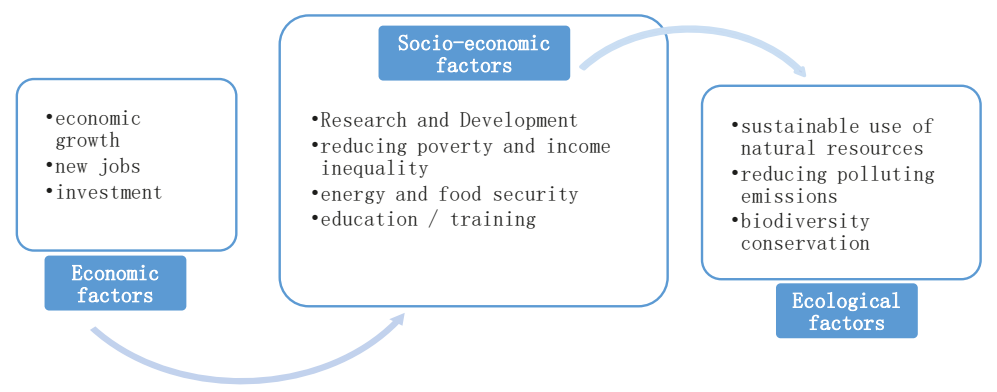

Figure 1. Essential factors for the development of a sustainable bioeconomy. Source: [13].

An empirical study [14] on the EU component states has shown that Finland and Sweden have the lowest levels of environmental pollution due to the rigorous ecological awareness of the population; the focus in these countries is on education and vocational training, with a basis of solid knowledge. In addition, the two states are among the most innovative countries in the EU and are based on rich and diverse natural resources. Denmark, Ireland, the Netherlands, and the UK have similarities in terms of innovation capacity supported by a developed economy, but natural assets are narrower than in the two Nordic countries (much of the countries' areas are used for agriculture, as forests are restricted as a surface), and the quality of the environment is above average. At the opposite end, these states are noted: Bulgaria, Croatia, Cyprus, Czech Republic, Greece, Hungary, Italy, Latvia, Lithuania, Poland, Portugal, Romania, Slovakia, and Spain. Although they have the largest agricultural sectors, innovation activity is relative low, which results in a low employment rate in the technological field. In these 
countries, the public authorities are less dedicated to education and training, and the population is not so concerned about the environment. According to the studies, the historical, geographical, and cultural factors influence the pro-bioeconomic behaviors adopted by the citizens. The size of the socio-economic context highlighted the most visible differences between countries, leading us to the conclusion that the countries of Central and Eastern Europe are in different stages of development [15].

The economic literature has developed progressively, encompassing the issues of bioeconomy and sustainability, as well as the determining elements that influence the economic growth.

In this section of the research, relevant aspects of some studies and research were analyzed, which include the issue of the sustainability of economic growth, the analysis of its components, analysis of the developments of bioeconomy at the European level, research on the six macroeconomic indicators included in the empirical study, and their correlations. Foreign trade, both export and import, continued to be one of the fundamental factors of economic growth contributing to the growth of national economies. The value of foreign agri-food trade is relevant, considering that, in 2018, the EU maintained its position as a world leader in the global export of agri-food products, with EU exports reaching 138 billion EUR in 2018. The top five destinations for food products exported by the European Union continue to be the United States, China, Switzerland, Japan, and Russia, which account for $40 \%$ of EU exports. The EU's common agricultural policy has become increasingly market-oriented, thus contributing to the EU's success in agricultural trade [16]. In 2018, the EU became the second largest importer of agri-food products in the world, the value of its imports amounting to 116 billion EUR, bringing the EU trade balance for this sector to a net positive result of 22 billion EUR. The EU mainly imports three types of products: Products not produced in the EU (or are produced only to a small extent, such as tropical fruits, coffee, and fresh or dried fruits), representing $23.4 \%$ of EU imports, products that are intended for animal feed (accounting for $10.8 \%$ of EU imports), and products used as ingredients in further processing [16]. Although agri-food trade is shown to benefit from a positive global climate assessment from 2019 [16], substantial future risks remain for trade developments [16]. The biggest threats to trade developments include protectionist political approaches (which are increasingly important for economies), more frequent trade disputes, and possible trade unrest linked to Britain's decision to leave the EU. On the positive side, global demand for food is likely to increase, correlated with population growth, income growth, middle-class expansion, and changes in consumer preferences [17].

Figures 2 and 3 respectively show the evolution of exports and food imports at the level of the 24 countries included in the empirical study, highlighted distinctly by the two groups (countries of Western and Northern Europe, considered countries with developed economies, and countries of Central and Eastern Europe, considered countries with emerging/developing economies).

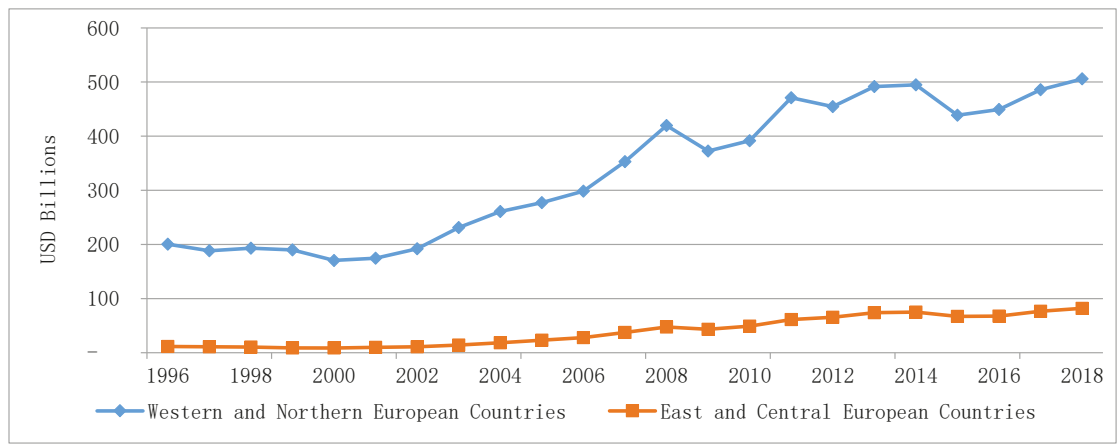

Figure 2. The evolution of total food exports in the countries included in the empirical analysis. Source: Own processing, data are sourced from the World Bank database [18]. 


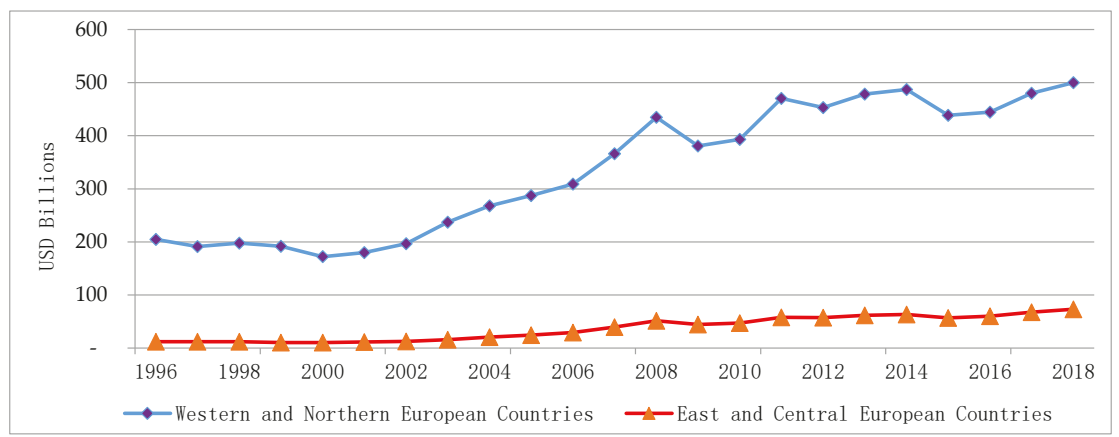

Figure 3. The evolution of total food imports in the countries included in the empirical analysis. Source: Own processing, data are sourced from the World Bank database [18].

Thus, it is observed that, in the case of countries with emerging/developing economies, the variations of exports and imports are more pronounced compared to those registered with the countries with developed economies, which can absorb the impacts of the influence factors. The economic literature analyzes the effects of imports and exports on private research and development expenditures in the food-processing sector. The empirical results [19] reflect that increasing the level of import intensity leads to reductions in private spending on research and development, while increasing the level of export intensity promotes higher private spending on research and development. These results imply that the effects of reducing the research and development activity of imports offset the effects of improving export research and development. Other studies examine the impact of EU enlargement on export performance of agri-food products in 12 new EU Member States and five new independent states on EU markets, covering the period 1999-2007 [20]. A longer duration for agri-food exports from the new EU member states was identified. The results confirm the gains from the eastern enlargement of the EU in terms of export growth and a longer duration for the export of specialized foods, with a higher added value for consumers and more competitive niche agri-food products [20].

\section{Materials and Methods}

This research applies scientific tests, uses specific estimators and statistical-econometric techniques, investigates data sets and collections, and assesses the most appropriate methods of investigation in order to provide accurate results. The activity of foreign trade in foodstuffs, transposed in the external balance of a country, can make a significant contribution to the economic (sustainable) growth of the respective country. Especially in the context of the transition to the green economy, a strategic vision must include the factors that achieve a significant influence. It is also necessary to integrate and study the behavioral evolution, habits/preferences and attitudes of consumption, and the degree of adoption and use of technologies along the value chain from plant culture/animal growth to food processing/distribution.

As regards the selected countries (presented in Table 2), on the one hand, the founding countries of the European Union were included; on the other, countries in Central and Eastern Europe, representative in terms of structural changes in the economy, were also included. The countries in Central and Eastern Europe are affected by processes of transition from a centralized economy to a market economy, or are even in the early stages of reforms, such as in Macedonia, Former Yugoslav Republic (FYR), a candidate country for EU accession. The authors opted for a split into two groups of countries based on the criteria: Geographical and economic development. The division into two groups of countries based on their level of development was made taking into consideration similar approaches to be found in the field's literature, such as the ones cited in this article. Additionally, a division into three groups would make the groups very unequal with respect to the volume of the sample, with advanced economies having much more representation than the developing or the emerging ones; consequently, 
the representativeness of such results would be far lower than in the present situation (lower accuracy). Similar divisions of the European countries are to be found in [21,22]. With respect to the criteria of economic development, in practice, international bodies also operate with the same classifications: 1. economically advanced countries and developing and emerging countries [23]; 2. developed markets, emerging markets, and border markets [24]; 3. developed economies and economies in transition [25].

Table 2. List of countries according to their grouping by level of development.

\begin{tabular}{ccc}
\hline $\begin{array}{c}\text { Western and Northern European } \\
\text { Countries Advanced Economies }\end{array}$ & $\begin{array}{c}\text { East and Central European Countries Emerging } \\
\text { and Developing Economies }\end{array}$ \\
\hline 1 & Austria & Bulgaria \\
\hline 2 & Belgium & Croatia \\
\hline 3 & Denmark & Czech Republic \\
\hline 4 & France & Estonia \\
\hline 5 & Germany & Hungary \\
\hline 6 & Italy & Latvia \\
\hline 7 & Luxemburg & Lithuania \\
\hline 8 & Holland & Macedonia, Former Yugoslav Republic (FYR) \\
\hline 9 & Norway & Poland \\
\hline 10 & Spain & Romania \\
\hline 11 & Sweden & Slovak Republic \\
\hline 12 & United Kingdom & Slovenia \\
\hline & & Source: Authors' own processing.
\end{tabular}

In the empirical study, to determine the inter-correlation with the exogenous indicators of foreign food trade, six relevant endogenous indicators were selected, including from the perspective of the bioeconomy/sustainable development: Labor force, added value of agriculture, forestry and fisheries, research and development expenses, forest area, fuel consumption based on fossils, and renewable energy consumption:

- Labor force includes all persons who are available to provide labor for the production of goods and services over a certain period of time, whether they are employed or unemployed. In emerging countries, the problem of disguised unemployment (includes low productivity, poorly paid jobs) can be solved by transferring the labor force affected by this phenomenon to the industrial sector in order to support production and, implicitly, export development. [18]. The economic literature shows a statistically significant reduction in employment in the forestry sector and a simultaneous increase in labor productivity due to the increasing use of technological equipment [26]. The analysis focused on the Czech Republic, but the results can be applied to other European countries as well [26]. A significant decrease in employment leads to instability in the forestry sector.

- Added value from agriculture, forestry, and fisheries. This is represented by the net production of a sector after all of the results have been gathered and the intermediate inputs have decreased. It is calculated without making deductions for the depreciation of manufactured assets or the depletion and degradation of natural resources. [18];

- Expenditure on research and development, a notion aimed at a marketable application in practice of an invention or an integration of the invention into the economic-social practice. The usual method of measuring innovation is based on the use of indirect indicators: Data on research and development (that measure parts of the inputs to the innovation process, indicate resources 
spent) and data on patents for invention (granted for inventive technologies with marketing prospects) [18].

- The forest area, which is represented by the land under natural trees or under planted trees, but excludes tree stands from agricultural production systems and trees from urban parks and gardens [18].

- Fossil fuel energy consumption. Fossil fuels are non-renewable resources from coal, oil, and oil and natural gas products; they take millions of years to form and reserves are depleted much faster than new ones are made [18].

- Renewable energy consumption is calculated as the share of renewable energy in the total final energy consumption [18]. Accordingly [26], the large-scale renewable energy implementation plans should include strategies for integrating renewable sources into coherent energy systems influenced by energy saving and efficiency measures. In the case of Denmark, the authors of [27] discussed the problems and prospects of converting the current energy systems into a $100 \%$ renewable energy system. Renewable energy sources are used in the context of further technological improvements; the renewable energy system can be implemented in a sustainable manner.

Through a quantitative mix of instruments, the nature of the inter-correlations between these indicators was studied in order to provide certain answers to the fundamental question of this research: Which of the indicators analyzed at the level of the 24 European economies, over a period of 22 years, has a positive impact on the determination/influence, in a relevant way, of the evolution of food exports and imports? To answer this question for the present analysis, a series of six working hypotheses has been constructed, which will be tested using the multiple regression model; the first of these is methodological in nature:

- H1. The Pooled Mean Group (PMG) estimator is best suited for modeling the relationships between variables. Judging from the fact that the countries included in the panel belong to the European area, it is expected to be characterized by a common long-term trend, but at the same time, to present short-term differences, considering the internal conditions specific to each state.

- H2. The labor force directly impacts both exports and imports. This hypothesis is because exports contribute to economic growth, and one of the most important sources of economic growth is the labor force. Thus, a direct relationship between the two variables is expected. The more the labor force is developed, the greater the ability of a country to export. As for imports, if the labor force grows, the availability of money on the market will increase, as well as its remuneration. Thus, the demand for products will increase, some of them being covered by imports; their value will also increase.

- H3. The added value of the agricultural sector positively influences exports, but negatively influences imports. A high added value in the agricultural sector implies a high productivity, which will increase the value of exports. Moreover, increasing productivity in the agricultural sector will lead to better coverage of domestic needs from their own production, which will decrease the value of food imports.

- H4. Research and development expenditure leads to an increase in the value of exports, but also of imports. Rising spending on research and development implies a development of this sector, which will increase the added value of the economy. This is because the final product of innovation is one with high gross added value, as it is intensive in innovation, knowledge, and capital. Thus, if part of the innovation process is carried out in the food sector, it will lead to an increase in exports of this sector. As in the case of the labor force, the increase of the expenditure with the research and development brings financial resources to the society, which positively impacts the imports.

- H5. Energy consumption is higher in countries with higher food exports and lower in countries with higher imports. Countries with large exports consume more energy, while importing countries will consume less energy; 
- H6. Renewable energy consumption is inversely correlated with food exports and directly correlated with imports. Countries with important renewable energy sectors are more developed countries, which export products other than food, but mainly import this type of product because they do not have a highly developed agricultural sector.

The purpose of the present research is to link the foreign trade of foodstuffs, estimated both by exports (EXP) and by imports (IMP), with the following factors:

- labor force (LABOR),

- the gross added value of agriculture, forestry, and fisheries (AGRI),

- $\quad$ expenditure on research and development (RD).

In the preliminary stage of the actual modeling of the relation between the dependent variables and the main determinants considered in the present analysis, it is necessary to investigate the statistical properties of the series of variables. Following this examination, the most appropriate statistical-econometric techniques are decided to model the link between the variables included in the study. Moreover, before the start of the statistical analysis, all of the variables considered were respectively logarithmized for a possible normalization of their distribution for an easier interpretation of the associated coefficients in the form of elasticities. To determine whether the series of variables are stationary in the level or first difference, the Fisher-Phillips Perron unit root test developed by Choi [28] was applied. The main advantage of this test is that it can be applied to both balanced and unbalanced panel data. Thus, considering the series of our variables that sometimes have missing values, it was considered that the application of this test is the most appropriate. First, in the analysis of stationarity for the level of variables, it was included in the equation for both the constant and the trend. Considering that series of macroeconomic variables most often have a certain tendency, including the trend in the equation increases the accuracy of the results. Secondly, for the first difference of the series, only the constant in the equation was included, since the differentiation of the series leads, in most cases, to the elimination of a possible tendency. Moreover, to correct for potential data persistence, both equations are aggregated with a lag.

The results of the stationarity test presented in Table 3 suggest that both dependent variables, i.e., exports and imports, have a unit root (they are integrated with an order of one - I (1)); the p-value associated with the statistics calculated for the level of the variables is higher than the significance thresholds of $1 \%$ and $5 \%$, thus leading to the acceptance of the null hypothesis that the series are characterized by the unit root. In contrast, for the first difference of the variables, the p-value associated with the calculated statistics is lower even than the significance thresholds of $1 \%$, leading to the rejection of the null hypothesis and the acceptance of the alternative one, according to which the series are stationary.

Regarding the exogenous (independent) variables, the results are mixed, as the variables are both integrated by the first order and stationary at the level. Taking into account the characteristics of the series of variables included in this analysis-namely that the dependent variables are I(1), and the independent variables are both $\mathrm{I}(1)$ and $\mathrm{I}(0)$-for modeling the relation between them, a dynamic model was considered, namely an ARDL (Autoregressive Distributed Lag) data panel. The mathematical form of the dynamic model for the ARDL panel data (p, q_1 ... q_k) [29] is as follows:

$$
Y_{i t}=\sum_{j=1}^{p} \partial_{i j} Y_{i, t-j}+\sum_{j=0}^{q} \gamma_{i j}^{\prime} X_{i, t-j}+\mu_{i}+\varepsilon_{i t},
$$

where $i=\overline{1, N}$ represents the countries analyzed, and $t=\overline{1, T}$ denotes the number of years included in the study (the period analyzed). $Y_{i t}$ is the dependent variable, and $X_{i t}(k \times 1)$ represents the vector of explanatory variables with the vector of associated coefficients $\gamma_{i j}(k \times 1)$. 
Table 3. Test of stationarity (unit root).

\begin{tabular}{|c|c|c|c|c|}
\hline \multirow{3}{*}{$\begin{array}{c}\text { Test/ } \\
\text { VAriable }\end{array}$} & \multicolumn{4}{|c|}{ Fisher-Type unit-Root Test } \\
\hline & \multicolumn{2}{|c|}{ Level (Constant and Trend) } & \multicolumn{2}{|c|}{$\Delta$ (Constant) } \\
\hline & Inverse Chi-Square & p-Value & Inverse Chi-Square & p-Value \\
\hline \multicolumn{5}{|c|}{ Dependent variable } \\
\hline EXP & 22.9662 & $(0.9992)$ & $260.7056^{* * *}$ & $(0.0000)$ \\
\hline IMP & 16.6480 & $(1.0000)$ & $272.1349 * * *$ & $(0.0000)$ \\
\hline \multicolumn{5}{|c|}{ Independent variable } \\
\hline LABOR & 31.0687 & $(0.9724)$ & $356.7083 * * *$ & $(0.0000)$ \\
\hline AGRI & $87.9761 * * *$ & $(0.0004)$ & - & - \\
\hline $\mathrm{RD}$ & 10.4846 & $(1.0000)$ & $250.6373^{* * *}$ & $(0.0000)$ \\
\hline FOREST & $67.7993 * *$ & $(0.0314)$ & - & - \\
\hline ENG & $70.6167 * *$ & $(0.0184)$ & - & - \\
\hline RENEW & $72.9023 * *$ & $(0.0117)$ & - & - \\
\hline
\end{tabular}

Source: own processing. Note: The null hypothesis (H0): All panels contain unit roots, and the alternative hypothesis (H1): At least one panel is stationary. For the stationary variables at a level of significance of $1 \%$ and $5 \%$, the first difference of the series was not analyzed. ${ }^{* * *}$ and ${ }^{* *}$ indicate statistical significance at a threshold of $1 \%$ and $5 \%$. In the above table, the following abbreviations were used: Exports (EXP), imports (IMP), labor force (LABOR), gross added value of agriculture, forestry, and fisheries (AGRI), expenditure on research and development (RD), forest area (FOREST), fossil fuel energy consumption (ENG), and renewable energy consumption (RENEW).

In our case, the dependent variable is represented by the exports; the imports of food products, and as their main determinants, the labor force, the added value of agriculture, forestry and fisheries, and the expenditure for research and development were respectively considered. Moreover, $\mu \_i$ and $\varepsilon \_$it indicate the country-specific fixed effects and the error term, respectively.

The above Equation (1) can be rewritten in the form of a panel data error correction model if it is assumed that the variables are non-stationary and co-integrated. Thus, the equation incorporating both long-term and short-term coefficients, together with the error correction term Equation (2), has the following form:

$$
\Delta Y_{i t}=\phi_{i}\left(Y_{i t-1}-\lambda_{i}^{\prime} X_{i t}\right)+\sum_{j=1}^{p-1} \partial_{i j}^{*} \Delta Y_{i t-j}+\sum_{j=0}^{q-1} \gamma_{i j}^{\prime *} \Delta X_{i t-j}+\mu_{i}+\varepsilon_{i t}
$$

where:

$$
\begin{gathered}
\phi_{i}=-\left(1-\sum_{j=1}^{p} \partial_{i j}\right), \\
\lambda_{i}=\sum_{j=0}^{q} \gamma_{i j} /\left(1-\sum_{k} \partial_{i k}\right), \\
\partial_{i j}^{*}=-\sum_{m=j+1}^{p} \partial_{i m}, \\
\gamma_{i j}^{*}=-\sum_{m=j+1}^{q} \gamma_{i m},
\end{gathered}
$$

and $\Delta$ represents the difference operator.

In order to confirm the long-term relationship between the variables, the coefficient associated with the error correction term, namely $\phi_{i}$ must be negative and statistically significant, and its values must be between $[-1 ; 0]$. Moreover, it helps us evaluate whether the model is specified correctly and to determine the speed of adjustment of the system to long-term equilibrium following an exogenous shock. First, it should be noted that one advantage of the ARDL technique on panel data is the accuracy (consistency) of the estimated coefficients when the dependent variable is I(1) and the independent variables have different integration orders of $(\mathrm{I}(0)$ and $\mathrm{I}(1))$. Secondly, another advantage is given by the flexibility of the estimated coefficients, in the sense that it allows us to evaluate the influence of the independent variables on the dependency in both the long term and in the short term. 
Considering all of the results related to the evaluation of the characteristics of the analyzed variables, an ARDL model (1.1) was estimated, including one lag for the dependent variable and, respectively, one lag for the independent ones. The decision to include a lag in the model is closely linked to the value of the Akaike Information Criterion (AIC) and the total number of panel-level observations. Considering that $\mathrm{N}=24$ and $\mathrm{T}=21(\mathrm{~N} * \mathrm{~T}=504)$, the inclusion of several lags in the model significantly reduces the number of observations; the ARDL model is sensitive in this respect. It should be mentioned that the main analysis was started for a group of 24 countries in Europe (Austria, Belgium, Bulgaria, Croatia, Czech Republic, Denmark, Estonia, France, Germany, Hungary, Italy, Latvia, Lithuania, Luxembourg, North Macedonia, Netherlands, Norway, Poland, Romania, Slovak Republic, Slovenia, Spain, Sweden, and United Kingdom) for the period 1996-2017. The choice of the analysis period was strictly determined by the availability of data and, respectively, by the variable of expenditure on research and development, for which the values stop in 2017. The ARDL model (1.1) is estimated using three specific estimators, namely the Dynamic Fixed Effects (DFE), Pooled Mean Group (PMG), and Mean Group (MG). Then, the Hausman test helps us determine if the PMG estimator or the MG is best suited to model the evaluated data. It should be noted that the DFE estimator considers that both the short-term and long-term coefficients, together with the error correction term, are identical for all panel members (for the analyzed countries) only the constant is different, depending on the country. On the other hand, the MG estimator assumes the exact opposite (the short-term and long-term coefficients, together with the error correction term, are different for all panel members), and the PMG estimator is the intermediate version between the two, considering a common long-term trend for all countries, with a respective short-term heterogeneity between coefficients. The final step in the analysis was the validation of the final models by evaluating their robustness. For this purpose, three variables (related to both the agricultural sector and the size of sustainable development) were introduced in the analysis, taking into account the continuous discussions at the international level related to the problem of natural resources and their diminution. For the present analysis, the following variables were considered as control variables:

- forest area (FOREST),

- fossil fuel energy consumption (ENG), and

- renewable energy consumption (RENEW),

These were used to check if the relationships found in the main regressions remain stable in the presence of environmental and long-term sustainability factors, i.e., FOREST, ENG, and RENEW.

\section{Results}

Hypothesis $\mathrm{H} 1$ was first evaluated in order to determine the appropriate final model for the data sample used. In Tables 4 and 5 are presented the estimations of the ARDL model (1.1) through the three estimators for exports (EXP) and imports (IMP). In the basic vector, the variables of labor force (LABOR), the added value of agriculture, forestry, and fisheries (AGRI), and the expenditure of research and development $(\mathrm{RD})$ were considered as factors influencing the exports/imports.

Table 4. Estimation of the Autoregressive Distributed Lag (ARDL) model (1.1) for exports.

\begin{tabular}{|c|c|c|c|}
\hline & DFE & PMG & MG \\
\hline \multicolumn{4}{|c|}{ The dependent variable: $\Delta \mathrm{EXP}$} \\
\hline \multicolumn{4}{|c|}{ Long-term coefficients } \\
\hline LABOR & $\begin{array}{c}-2.7674 * * * \\
(0.7793)\end{array}$ & $\begin{array}{c}-1.6328^{* * *} \\
(0.2483)\end{array}$ & $\begin{array}{c}-9.7459 \\
(10.1587)\end{array}$ \\
\hline AGRI & $\begin{array}{c}0.7217^{* * *} \\
(0.2761)\end{array}$ & $\begin{array}{c}0.1591 * * * \\
(0.0881)\end{array}$ & $\begin{array}{c}0.5002 \text { ** } \\
(0.2095)\end{array}$ \\
\hline $\mathrm{RD}$ & $\begin{array}{c}1.0087^{* * *} \\
(0.1336)\end{array}$ & $\begin{array}{c}1.1345^{* * *} \\
(0.0448)\end{array}$ & $\begin{array}{c}1.3584 \text { ** } \\
(0.6856)\end{array}$ \\
\hline
\end{tabular}


Table 4. Cont.

\begin{tabular}{cccc}
\hline & DFE & PMG & MG \\
\hline \multicolumn{4}{c}{ Short-term coefficients } \\
\hline ECT & $-0.1297^{* * *}$ & $-0.1882^{* * *}$ & $-0.4012^{* * *}$ \\
& $(0.0189)$ & $(0.0404)$ & $(0.0506)$ \\
$\Delta$ LABOR & 0.2795 & -0.0688 & -0.6799 \\
& $(0.3959)$ & $(0.4027)$ & $(0.4416)$ \\
$\Delta$ AGRI & $0.2634^{* * *}$ & $0.2589^{* * *}$ & 0.0813 \\
& $(0.0392)$ & $(0.0463)$ & $(0.0719)$ \\
$\Delta$ RD & $0.2762^{* * *}$ & $0.3132^{* * *}$ & $0.2191 * * *$ \\
& $(0.0459)$ & $(0.0680)$ & $(0.0754)$ \\
Constant & $3.5616^{* *}$ & $3.7360^{* * *}$ & $-14.6986^{* *}$ \\
& $(1.4659)$ & $(0.8157)$ & $(6.3261)$ \\
\hline Log Likelihood & - & 637.0791 & - \\
No. of countries & 24 & 24 & 24 \\
No. of observations & 493 & 493 & 493 \\
\hline
\end{tabular}

Source: own processing. Note: Hausman test: MG vs. PMG: Since the $p$-value $=0.4865$ is greater than all significance thresholds, the null hypothesis that the PMG estimator is the preferred model to form the relationship between variables was accepted. ${ }^{* * *}$ and ${ }^{* *}$ indicate statistical significance at a threshold of $1 \%$ and $5 \%$. In the above table, the following abbreviation were used: Dynamic fixed effects (DFE), pooled mean group (PMG), mean group (MG), exports (EXP), labor force (LABOR), gross added value of agriculture, forestry, and fisheries (AGRI), expenditure on research and development $(\mathrm{RD})$, and error correction term (ECT).

Table 5. Estimation of the ARDL model (1.1) for imports.

\begin{tabular}{|c|c|c|c|}
\hline & DFE & PMG & MG \\
\hline \multicolumn{4}{|c|}{ The dependent variable: $\Delta \mathrm{IMP}$} \\
\hline \multicolumn{4}{|c|}{ Long-term coefficients } \\
\hline LABOR & $\begin{array}{l}-0.6142 \\
(0.7179)\end{array}$ & $\begin{array}{c}0.2027 \\
(0.1405)\end{array}$ & $\begin{array}{c}1.9127 \\
(1.9953)\end{array}$ \\
\hline AGRI & $\begin{array}{c}0.4032 \\
(0.2708)\end{array}$ & $\begin{array}{c}0.3155^{* * *} \\
(0.0366)\end{array}$ & $\begin{array}{c}0.5320 * * \\
(0.2155)\end{array}$ \\
\hline $\mathrm{RD}$ & $\begin{array}{c}0.8464^{* * *} \\
(0.1303)\end{array}$ & $\begin{array}{c}0.8605^{* * *} \\
(0.0211)\end{array}$ & $\begin{array}{c}0.5569 * * * \\
(0.2047)\end{array}$ \\
\hline \multicolumn{4}{|c|}{ Short-term coefficients } \\
\hline ECT & $\begin{array}{c}-0.1073^{* * *} \\
(0.0202)\end{array}$ & $\begin{array}{c}-0.2529^{* * *} \\
(0.0547)\end{array}$ & $\begin{array}{c}-0.4740^{* * * *} \\
(0.0515)\end{array}$ \\
\hline$\triangle \mathrm{LABOR}$ & $\begin{array}{c}0.3294 \\
(0.3281)\end{array}$ & $\begin{array}{l}-0.0733 \\
(0.3773)\end{array}$ & $\begin{array}{l}-0.4728 \\
(0.4393)\end{array}$ \\
\hline$\triangle \mathrm{AGRI}$ & $\begin{array}{c}0.2559 * * * \\
(0.0325)\end{array}$ & $\begin{array}{c}0.1876^{* * *} \\
(0.0485)\end{array}$ & $\begin{array}{c}0.0570 \\
(0.0479)\end{array}$ \\
\hline$\Delta \mathrm{RD}$ & $\begin{array}{c}0.3688 \text { *** } \\
(0.0376)\end{array}$ & $\begin{array}{c}0.3607^{* * *} \\
(0.0701)\end{array}$ & $\begin{array}{c}0.2765 * * * \\
(0.0616)\end{array}$ \\
\hline Constant & $\begin{array}{c}0.5509 \\
(1.2108)\end{array}$ & $\begin{array}{c}-1.5650^{* * *} \\
(0.3585)\end{array}$ & $\begin{array}{l}-9.0339 \\
(5.4557)\end{array}$ \\
\hline Log Likelihood & - & 702.2978 & - \\
\hline No. of countries & 24 & 24 & 24 \\
\hline No. of observations & 495 & 495 & 495 \\
\hline
\end{tabular}

Source: own processing. Note: Hausman test: MG vs. PMG: Since the $p$-value $=0.7162$ is greater than all significance thresholds, the null hypothesis that the PMG estimator is the preferred model to form the relationship between variables was accepted. ${ }^{* *}$ and ${ }^{* *}$ indicate statistical significance at a threshold of $1 \%$ and $5 \%$.In the above table, the following abbreviation were used: Dynamic fixed effects (DFE), pooled mean group (PMG), mean group (MG), imports (IMP), labor force (LABOR), gross added value of agriculture, forestry and fisheries (AGRI), expenditure on research and development (RD), and error correction term (ECT).

First of all, it was noticed that the Error Correction Term (ECT) is negative and strongly significant for all models. Thus, the modeling technique is justified and the specification of the models is validated. Moreover, for the export equation, the associated coefficient varies between about 0.13 and 0.4, 
suggesting a low adjustment rate (similarly to the case for the import equation, where the adjustment rate varies between about 0.11 and 0.47 ). Second, the Hausman test, by which we discriminated between the estimator MG and PMG, suggests that the most appropriate of these is the PMG estimator for both the dependent variable exports and imports ( $\mathrm{p}$-value $=0.486$ for exports, $\mathrm{p}$-value $=0.716$ for imports). Consequently, the working hypothesis H1 is accepted: The PMG estimator is the preferred one for modeling the relationships between variables. Countries have a common long-term tendency with respective short-term heterogeneities. The common long-term trend can be explained by the efforts of all states to increase trade openness, ultimately stimulating the economic growth. For example, at the European Union level, trade policies focus on coordinating states towards a common trajectory, which involves increasing the trade flow. In tandem, the heterogeneities in the short term can be given by the differences in the commercial structures of the countries, both in terms of exports and imports of food products, or respectively of the national macroeconomic policies. As stated in the methodological section, to evaluate the validity of the other working hypotheses, the results of the PMG estimator were analyzed. Regarding the export model, the following were observed:

1. The labor force has a negative long-term and strongly significant effect on the value of food exports in the countries analyzed. Thus, with an increase of $1 \%$ of the labor force, the value of exports decreases by approximately $1.6 \%$. The second working hypothesis, $\mathrm{H} 2$, is invalidated for exports.

2. Both the added value of agriculture, forestry, and fisheries and the expenditure on research and development positively influence the value of exports in the long term. Moreover, as with the labor force case, the associated coefficients are strongly significant at a significance threshold of $1 \%$ ( $\mathrm{p}$-value $<1 \%$ ). In addition, the magnitude of the coefficients suggests that an increase of $1 \%$ in the added value of agriculture, forestry, and fisheries and in expenditure on research and development causes an increase of approximately $0.16 \%$ and $1.13 \%$, respectively, in the value of exports. The working hypotheses $\mathrm{H} 3$ and $\mathrm{H} 4$ are accepted for exports.

3. In the short term, the variable LABOR does not have statistical significance, and AGRI and RD contribute significantly to increasing the value of food exports in the analyzed countries.

The results of the import model show the following:

1. The labor force does not have a statistically significant impact on the value of food imports because of the lack of significance of the associated coefficient. This result invalidates $\mathrm{H} 2$ on the import side, as there is no relationship between the two variables.

2. On the other hand, as in the case of exports, the added value of agriculture, forestry, and fisheries and the expenditure on research and development help to stimulate the value of imports. The difference that appears is related to the magnitude of the coefficients associated with these variables compared to those of the export model. For example, the coefficient associated with the variable AGRI is approximately double for the model of imports, and suggests that, with a $1 \%$ increase in the added value of agriculture, forestry, and fisheries, the value of imports increases by about $0.32 \%$. On the other hand, when the RD increases by $1 \%$, the value of the imports of food products increases by about $0.86 \%$ (the magnitude of the coefficient being smaller in comparison with that of the expenditure for research and development in the case of the export model). The results invalidate $\mathrm{H} 3$ on the import side and accept $\mathrm{H} 4$.

3. In the short term, the coefficients associated with the variables AGRI and RD are statistically significant, having a positive impact on the value of food imports.

The robustness analysis of the basic model of exports and imports was made by introducing the three additional variables closely related to the concept of sustainable development (environmental quality); namely, the forest area (FOREST), the energy consumption of fossil fuels as a share of total energy (ENG), and the renewable energy consumption (RENEW). Considering that the ARDL technique provides consistent results for mixed independent variables (i.e., first order (I(1)), as well as 
stationary $(\mathrm{I}(0))$, no prior analysis of the stationarity of these factors (additional ones included in the study) is required. However, it should be mentioned that due to the availability of data, the analysis period of the models that include the FOREST variable is 1996-2016, and for the other two variables, the analyzed period is 1996-2015. The results of the models estimated through the PMG estimator are presented in Tables 6 and 7. The additional independent variables were included one at a time in the vector of the basic variables, so that finally, in the last column (column (4)) of the two tables, all of the independent variables are considered. On the one hand, for the export model, it was observed that ECT is negative and strongly significant in all models, validating once again the chosen technique and specification of the models. Moreover, its magnitude is comparable from one model to another, also indicating a relatively low rate of adjustment to long-term equilibrium (see Table 6). Regarding the independent variables, overall, it can be observed that the statistical significance and the signs of the coefficients of the variables in the basic vector do not change with the inclusion of the additional factors. Moreover, if the last model, where all of the exogenous factors were included (see column (4) of Table 6), is considered, it is to be noticed that the additional factors have a positive impact on exports in the long term. In contrast, in the short term, it is to be mentioned that only the consumption of energy and renewable energy significantly influences exports, the first variable in the positive sense and the second in the negative sense. Hypothesis H5 is accepted for exports in both the short and long terms. Hypothesis $\mathrm{H} 6$ is invalidated at the level of the analyzed sample, highlighting a direct link between the renewable energy consumption and exports. On the other hand, for the model of imports, the associated coefficient of ECT is also strongly statistically and negatively significant, suggesting once again that the model is well specified and has a high accuracy. Contrary to the main model, it is observed that the inclusion of the variable of forest area or the inclusion of all variables in the equation (see column (1) and column (4) of Table 7) brings a significant gain to the long-term coefficient associated with the variable of labor force (the sign of the associated coefficient is positive). In addition, if the most complete model is analyzed (see column (4) in Table 7), it must be noted that the variables of the main vector (AGRI and RD) keep their positive sign for the associated coefficient and, respectively, the high statistical significance. In addition, the FOREST variable has a positive influence on imports, while RENEW has a negative impact on the value of imports. For the ENG variable, the associated coefficient does not have statistical significance. In the case of imports, both working assumptions related to sustainability factors are rejected ( $\mathrm{H} 5$ and $\mathrm{H} 6)$. The short-term coefficients are statistically significant for the variables AGRI, RD, and ENG, and the positive sign illustrates that all of these macroeconomic factors contribute to the increase of the value of imports. In total, for the models of both exports and imports, the inclusion of additional factors in the main equation does not significantly affect the results of the initial models, so it can be said that that they have a high robustness.

Table 6. Estimation of the ARDL model (1.1) for exports-robustness analysis.

\begin{tabular}{|c|c|c|c|c|}
\hline The Dependent Variable: $\Delta$ EXP & (1) & (2) & (3) & (4) \\
\hline \multicolumn{5}{|c|}{ Long-term coefficients } \\
\hline LABOR & $\begin{array}{c}-2.6293^{* * *} \\
(0.3809)\end{array}$ & $\begin{array}{c}-4.2200 * * * \\
(0.5559)\end{array}$ & $\begin{array}{c}-2.3602 \text { *** } \\
(0.2952)\end{array}$ & $\begin{array}{c}-1.8319 \text { *** } \\
(0.3317)\end{array}$ \\
\hline AGRI & $\begin{array}{c}0.4649 * * * \\
(0.0988)\end{array}$ & $\begin{array}{c}0.6135^{* * *} \\
(0.0534)\end{array}$ & $\begin{array}{c}0.4354^{* * *} \\
(0.1098)\end{array}$ & $\begin{array}{c}0.7151^{* * *} \\
(0.0625)\end{array}$ \\
\hline $\mathrm{RD}$ & $\begin{array}{c}0.8934^{* * *} \\
(0.0574)\end{array}$ & $\begin{array}{c}0.9876^{* * *} \\
(0.0314)\end{array}$ & $\begin{array}{c}1.0177^{* * * *} \\
(0.0611)\end{array}$ & $\begin{array}{c}0.8004 \text { *** } \\
(0.0438)\end{array}$ \\
\hline FOREST & $\begin{array}{c}1.8069 * * * \\
(0.4867)\end{array}$ & & & $\begin{array}{c}2.5942 * * * \\
(0.6370)\end{array}$ \\
\hline ENG & & $\begin{array}{c}0.9073^{* * *} \\
(0.1266)\end{array}$ & & $\begin{array}{c}1.3878^{* * * *} \\
(0.1590)\end{array}$ \\
\hline RENEW & & & $\begin{array}{c}0.0567 \\
(0.0417)\end{array}$ & $\begin{array}{c}0.2954^{* * *} \\
(0.0518)\end{array}$ \\
\hline
\end{tabular}


Table 6. Cont.

\begin{tabular}{ccccc}
\hline The Dependent Variable: $\Delta$ EXP & $\mathbf{( 1 )}$ & $\mathbf{( 2 )}$ & $\mathbf{( 3 )}$ & $\mathbf{( 4 )}$ \\
\hline & Short-term coefficients & & \\
\hline ECT & $-0.2266^{* * *}$ & $-0.1782^{* * *}$ & $-0.2105^{* * *}$ & $-0.2935^{* * *}$ \\
& $(0.0514)$ & $(0.0443)$ & $(0.0447)$ & $(0.0554)$ \\
$\Delta$ LABOR & 0.0867 & 0.1496 & -0.2014 & $0.5162^{* * *}$ \\
& $(0.4107)$ & $(0.4242)$ & $(0.4082)$ & $(0.3156)$ \\
AGRI & $0.1939^{* * *}$ & $0.1716^{* *}$ & $0.1965^{* * *}$ & 0.0851 \\
& $(0.0551)$ & $(0.0683)$ & $(0.0556)$ & $(0.0705)$ \\
$\Delta$ RD & $0.2766^{* * *}$ & $0.2951^{* * *}$ & $0.3284^{* * *}$ & $0.2001^{* *}$ \\
& $(0.0843)$ & $(0.0984)$ & $(0.0689)$ & $(0.0851)$ \\
$\Delta$ FOREST & 13.5043 & & & 3.0714 \\
& $(13.2621)$ & & & $(13.6067)$ \\
$\Delta$ EENG & & $0.3288^{* *}$ & & $0.3317^{* *}$ \\
& & $(0.1293)$ & & $(0.1574)$ \\
Constant & & & $0.0250^{* * *}$ & $-0.0966^{* *}$ \\
& $3.2907^{* * *}$ & $7.1126^{* * *}$ & $(0.0515)$ & $(0.0479)$ \\
& $(0.7605)$ & $(1.7842)$ & $(1.2187)$ & $(1.5790)$ \\
\hline Log Likelihood & 633.3564 & 606.3407 & 586.0194 & 656.261 \\
No. of countries & 24 & 24 & 24 & 24 \\
No. of observations & 468 & 441 & 447 & 439 \\
\hline
\end{tabular}

Source: Own processing. Standard error in round brackets. ${ }^{* *}$ and ${ }^{* *}$ indicate statistical significance at a threshold of $1 \%$ and $5 \%$. In the above table, the following abbreviation were used: Exports (EXP), labor force (LABOR), gross added value of agriculture, forestry, and fisheries (AGRI), expenditure on research and development (RD), forest area (FOREST), fossil fuel energy consumption (ENG) and renewable energy consumption (RENEW), and error correction term (ECT).

Table 7. Estimation of the ARDL model $(1,1)$ for imports-robustness analysis.

\begin{tabular}{|c|c|c|c|c|}
\hline The Dependent Variable: $\Delta \mathrm{IMP}$ & (1) & (2) & (3) & (4) \\
\hline \multicolumn{5}{|c|}{ Long-term coefficients } \\
\hline LABOR & $\begin{array}{c}0.2607 \\
(0.1406)\end{array}$ & $\begin{array}{l}-0.0293 \\
(0.2018)\end{array}$ & $\begin{array}{l}-0.0791 \\
(0.1831)\end{array}$ & $\begin{array}{c}0.6177 * * \\
(0.2443)\end{array}$ \\
\hline AGRI & $\begin{array}{c}0.3826^{* * *} \\
(0.0472)\end{array}$ & $\begin{array}{c}0.3961^{* * *} \\
(0.0434)\end{array}$ & $\begin{array}{c}0.3964^{* * *} \\
(0.0438)\end{array}$ & $\begin{array}{c}0.6869 * * * \\
(0.0655)\end{array}$ \\
\hline $\mathrm{RD}$ & $\begin{array}{c}0.8105^{* * *} \\
(0.0277)\end{array}$ & $\begin{array}{c}0.8556^{* * *} \\
(0.0242)\end{array}$ & $\begin{array}{c}0.8561 \text { *** } \\
(0.0246)\end{array}$ & $\begin{array}{c}0.7026^{* * *} \\
(0.0409)\end{array}$ \\
\hline FOREST & $\begin{array}{c}0.8985^{* *} \\
(0.3789)\end{array}$ & & & $\begin{array}{c}5.7577^{* * *} \\
(1.2851)\end{array}$ \\
\hline ENG & & $\begin{array}{c}-0.1517^{* *} \\
(0.0724)\end{array}$ & & $\begin{array}{c}0.0036 \\
(0.1189)\end{array}$ \\
\hline RENEW & & & $\begin{array}{c}0.0104 \\
(0.0195)\end{array}$ & $\begin{array}{c}-0.2249^{* * *} \\
(0.0626)\end{array}$ \\
\hline \multicolumn{5}{|c|}{ Short-term coefficients } \\
\hline ECT & $\begin{array}{c}-0.3123^{* * *} \\
(0.0566)\end{array}$ & $\begin{array}{c}-0.2799 * * * \\
(0.0568)\end{array}$ & $\begin{array}{c}-0.2897^{* * *} \\
(0.0515)\end{array}$ & $\begin{array}{c}-0.2591 * * * \\
(0.0498)\end{array}$ \\
\hline$\triangle \mathrm{LABOR}$ & $\begin{array}{l}-0.1696 \\
(0.4113)\end{array}$ & $\begin{array}{l}-0.2139 \\
(0.4697)\end{array}$ & $\begin{array}{l}-0.5791 \\
(0.4352)\end{array}$ & $\begin{array}{l}-0.4609 \\
(0.5869)\end{array}$ \\
\hline$\triangle \mathrm{AGRI}$ & $\begin{array}{c}0.1445^{* * *} \\
(0.0504)\end{array}$ & $\begin{array}{c}0.1438^{* * *} \\
(0.0518)\end{array}$ & $\begin{array}{c}0.1394 \text { *** } \\
(0.0477)\end{array}$ & $\begin{array}{c}0.0861 \\
(0.0461)\end{array}$ \\
\hline$\Delta \mathrm{RD}$ & $\begin{array}{c}0.3153^{* * *} \\
(0.0737)\end{array}$ & $\begin{array}{c}0.3636^{* * *} \\
(0.0846)\end{array}$ & $\begin{array}{c}0.3853^{* * *} \\
(0.0714)\end{array}$ & $\begin{array}{c}0.4164^{* * *} \\
(0.0943)\end{array}$ \\
\hline$\triangle$ FOREST & $\begin{array}{c}-1.4857 \\
(13.4565)\end{array}$ & & & $\begin{array}{l}-12.5173 \\
(17.9804)\end{array}$ \\
\hline$\triangle \mathrm{ENG}$ & & $\begin{array}{c}0.2821 * * * \\
(0.0911)\end{array}$ & & $\begin{array}{c}0.3724 * * * \\
(0.1224)\end{array}$ \\
\hline$\triangle$ RENEW & & & $\begin{array}{c}0.0393 \\
(0.0726)\end{array}$ & $\begin{array}{c}0.0239 \\
(0.0701)\end{array}$ \\
\hline Constant & $\begin{array}{c}-5.1475 * * * \\
(0.9681)\end{array}$ & $\begin{array}{c}-0.6655 \text { *** } \\
(0.1670)\end{array}$ & $\begin{array}{c}-1.0976^{* * *} \\
(0.2242)\end{array}$ & $\begin{array}{c}-18.8824 \text { *** } \\
(3.7615)\end{array}$ \\
\hline
\end{tabular}


Table 7. Cont.

\begin{tabular}{|c|c|c|c|c|}
\hline The Dependent Variable: $\Delta \mathrm{IMP}$ & (1) & (2) & (3) & (4) \\
\hline Log Likelihood & 695.4414 & 663.4577 & 660.5005 & 706.2197 \\
\hline No. of countries & 24 & 24 & 24 & 24 \\
\hline No. of observations & 470 & 443 & 449 & 441 \\
\hline
\end{tabular}

Source: Own processing. Standard error in round brackets. ${ }^{* * *}$ and ${ }^{* *}$ indicate statistical significance at a threshold of $1 \%$ and $5 \%$. In the above table, the following abbreviation were used: Imports (IMP), labor force (LABOR), gross added value of agriculture, forestry, and fisheries (AGRI), expenditure on research and development (RD), forest area (FOREST), fossil fuel energy consumption (ENG) and renewable energy consumption (RENEW), and error correction term (ECT).

\section{Discussion}

The analysis identified and presented, mainly within the literature review section, a significant variety of research and studies related to the bioeconomy, reflecting the complexity of the transition process and its substantial transformations. Several studies approached a smaller number of countries for a shorter period of time. The focus within those studies was on one or two indicators. A study on bioeconomy [13] reflected the essential factors for the development of a sustainable bioeconomy, describing and linking economic factors, socio-economic factors, and ecological factors. The present analysis selects factors from each of the three mentioned categories, as per the study [13], identifies data, uses instruments to research the inter-linkages between the factors, tests hypotheses, and provides conclusions.

This study advances the reader's understanding of the research problem by considering for analysis a larger number of countries over a longer period of time. The focus of the study is on six indicators, significantly larger than in other related studies.

At the level of the sample of analyzed European countries, there is a tendency of long-term convergence in this area. The estimated models highlight the existence of a significant common long-term trend and an adjustment speed. These characteristics are due to the economic policies that exist not only at the level of the European Union, but also through the economic treaties it has with other European countries, which are meant to open up the trade and trade flows. Obviously, in the short term, heterogeneities are highlighted because they depend on the internal conditions and the structural specificity of the national economy of each country in the sample.

The study advances the reader's understanding by presenting the diversity of financial instruments, explaining the importance of financial mechanisms and financial resources as well as their risks and vulnerabilities, and the connection with bioeconomy and with the analyzed factors.

Considering the results of the empirical study, it is necessary to anchor them in the context of allocating/ensuring adequate financial support. In order to strategically orient the European economy towards the bioeconomy, there are needed financial resources, allocated through European programs, but also alternatives: Private and public financial resources to co-finance and support this transition process, the results of which will be reflected in the long term. The bioeconomy, by building a strategic vision and translating it at the regional level, can be the driving factor of societal changes. According to the European Commission [10], 67\% of regions used European Structural and Investment Funds (ESIF) as a source of funding to support bioeconomic activities and access cooperation programs (for cooperation between regions: Joint Programming Initiatives; for other programs to promote the bioeconomy: Interreg, LIFE +, CIP/COSME, ERASMUS+, Intelligent Energy Europe) [10]. Specific mechanisms for granting ESIF funds to synergistic projects have been developed at the levels of several countries and regions (Italy, Czech Republic, Spain, France) together with public-private partnerships for the diversification of funding sources. The investment dimension is significantly larger than the capacity of the public sector. The European Commission estimates an additional annual investment requirement to reach the current targets set for 2030, in terms of climate and energy, of approximately 260 billion EUR, or, respectively, 1.5\% of the GDP of 2018 [30]. It is also necessary to mobilize national budgets and private capital. In order to support the bioeconomic processes, it is appropriate to 
approach the issues related to sustainability, the sustainable financing of the European economy, and sustainable banking activities at European level in a convergent way.

Among the risks and uncertainties that may affect the bioeconomic processes, the following must be mentioned:

- the short-term orientation, the need for short-term financial results;

- non-integrated financial instruments/programs to provide the financing;

- the low degree of educational promotion/transparency regarding the sustainable impact of investments in bioeconomic activities, including for retail customers who could buy "green bonds" (EU Green Bonds) [31];

- the limited contributions of banks, insurance companies, institutional investors on the capital market, and entrepreneurs for re-orienting financial resources towards bioeconomic activities;

- the reduced promotion of scoring systems/standards accepted at the level of funders for better scoring of projects that support the bioeconomy;

- the low degree of connection of financial programs/resources offering specialized consultancy for the support of bioeconomic activities;

- the low level of education of the participants and lack of information and understanding about the impact of bioeconomic activities for each individual and for the European society as a whole.

The European Commission has set up a High-Level Expert Group (HLEG on Sustainable Finance) [32] with a mandate to propose changes to the investment chain in order to build a sustainable financing strategy for the European Union economy (to "achieve economic prosperity in the long term, increasing social inclusion and reducing dependence on the exploitation of finite resources and the natural environment" [10]). The objective proposed by the mandate is ambitious, but realistic: Transforming Europe into the main pole for low-carbon global investments, resource efficiency, and circular economy; in conjunction with this are the two strategic objectives: The adoption of the 2030 Agenda for Sustainable Development [33] and the Paris Agreement 2015/16, which regulates measures to reduce carbon dioxide emissions [34].

At the European banking level [35] a number of proposals have been formulated that will stimulate and contribute to the debate of European institutions, regulators, and banks on how to increase sustainable activities, mobilize and redirect private financial flows to support such activities, develop new tools, and increase the number of eligible projects. A specific element in the proposals made is the recommendation of the development of a "sustainable finance support factor" [33,36] as part of the legislation on bank capital requirements in the European Union. It has been proposed that the EBA (European Banking Authority) should explore the possibility of introducing a justification factor for certain assets that are classified as sustainable under the EU taxonomy. Europe has identified an annual financial gap of over 180 billion EUR to finance the policies and investments needed to maintain global temperatures [33] in line with the objectives of the Paris Agreement. It is more than obvious that, without the private sector, this funding gap cannot be closed. Because about two-thirds of the European economy is bank-financed, banks play-and will continue to play-a key role in the transition to a sustainable future, acting as investors, capital providers, and capital intermediaries for "green packaging" of some projects, in order to be eligible for funding through:

- Bank financing for "green projects" with the development of specific indicators or rating models. Due to the consistent role of the banking system in financing the European economy, in accordance with the results of the empirical study and with the theme of research-bioeconomy and foreign food trade-some relevant considerations from the perspective of sustainable banking activities were added. According to the report by the GABV (Global Alliance for Banking on Values) [36], sustainable banks consistently deliver products, services and social, environmental, and financial "profits" to support the real economy. The focus of sustainable banks is simultaneously on three components: People, environment, and prosperity. They are anchored in the communities in which they operate, establish long-term relationships with customers, and manage long-term risks. 
The products and services of sustainable banks are mainly oriented toward supporting smalland medium-sized enterprises (SMEs) and microfinance, agriculture (food production, organic farms, rural, and agro-finance), financing energy efficiency (green energy, innovative technologies, alternative energy), financing eco-housing and social housing, and financing of educational and cultural programs (schools, kindergartens, theatres, museums). It is to be mentioned that the development and knowledge of activities/principles promoted by sustainable banks, together with other alternative financing instruments and mechanisms (crowdfunding platforms [37], specialized private energy investment funds, innovative institutional investors specializing in innovative products) could contribute synergistically to the developed programs of authorities and the orientation of financial and educational resources towards supporting bioeconomy at the European level.

- The technical support offered to obtain financing through capital markets, through the issuance of variable/fixed income securities for the financial support of "green projects".

Associations between international financial institutions, development banks, international banks, and local banks in the form of international networks-for example, the SBN (Sustainable Banking Network) operating in over 38 countries, with members of financial-banking institutions with assets of approximately 43 trillion USD [38] — lead to the promotion of sustainable financing as a global priority and to the transformation of the financial sectors/markets in which they operate. In addition, the efforts of coagulation and convergence in order to support the gradual transition to the bioeconomy were also made at the level of central banks, regulators, and supervisors. The Network for Greening the Financial Sector (NGFS) [39], which includes 46 members-central banks and financial supervisory authorities-emphasizes, at the level of the portfolios held, making socially responsible investments, managing the ESG risks (Environment, Social, Governance) related to the transition to the bioeconomy, and the development of scoring systems/new indicators that reflect the transition to a sustainable economy. The partnership between the bioeconomy and foreign trade with food products within the "green economy", together with the entire value chain that contributes to obtaining food, harmonized with the new technological context, must also be supported at the microeconomic level. Regional cooperation, especially in the agricultural field, between investment funds and small entrepreneurs, family associations, and authorized individuals contributes to the transformation of life and work, enhancing the connection between them, increasing the degree of innovation, and increasing social inclusion [40].

The future evolution of the bioeconomy will influence and will be influenced by public support and attitudes in the process of change [41]. The synergistic co-interest of all "actors" through harmonized, individual, and collective contributions can lead to the implementation and realization of this complex process of transition from the linear economy to the bioeconomy at the level of Europe.

This study adds to the existing literature by connecting the analysis of macroeconomic policies with the results of the empirical study and with potential guidelines for future policies. The study presents results and various influences between the analyzed factors in the short term, providing explanations and correlations for the long term trends as well.

This study advances the understanding in the complex topic of bioeconomy, providing an integrated approach for the reader. The approach explains and presents the relationships between the components of foreign trade in food products and macroeconomic variables, the various forms of financial support and mechanisms, and the newest established networks of financial institutions, focused on supporting the development of bioeconomy and its essential factors. Those correlations, together with the presentation of risks that may affect bioeconomic processes, offer a better understanding of the future mix of policies developed by authorities. The references included in the study offer a broad, up-to-date perspective with high relevance for the object of the research. 


\section{Conclusions}

This research aimed to identify the factors with the highest capacity to stimulate the trade in food products, starting from a data panel over a limited time horizon (1996-2017), which included 24 European countries. The econometric results, statistically relevant, together with the qualitative aspects presented, highlighted that the bioeconomy and foreign trade in food products are in a sustainable partnership at the European level. All six independent variables analyzed act positively on the dependent variables; the main direct influencers of foreign food trade are the gross added value of the agricultural sector and the research and development expenses, both in the short and long term.

Sustainable bioeconomy can represent a strategic catalyst for economic growth at the European level and a beneficiary thereof; for all three visions of the bioeconomy included in the research, the main objectives are growth and sustainability. For future research, it is necessary to study the consumption habits, the behaviors regarding the food products, the modalities of their distribution at the regional level, and the connection with financing solutions, which will ensure the entire value chain necessary for the production, marketing, and promotion of the food products. A key point is to gather the cooperation and contributions of authorities, regulators, academic environment/researchers, investors, and financial-banking actors to harmonize the instruments in order to support the transition to the bioeconomy and make the partnership sustainable in the long term.

Author Contributions: D.C.N. and V.M. designed and implemented the research, analyzed the data and the results, and wrote and revised the manuscript together; both authors contributed equally (50\%) for each task. All authors have read and agreed to the published version of the manuscript.

Funding: This research received no external funding.

Conflicts of Interest: The authors declare no conflict of interest.

\section{Abbreviations}

The following abbreviations are used in this manuscript:

\begin{tabular}{ll} 
EU & European Union \\
WCED & World Commission on Environment and Development \\
OECD & European Organization for Cooperation and Development \\
FAO & Food and Agriculture Organization \\
UN & United Nations \\
ARDL & Autoregressive Distributed Lag \\
PMG & Pooled Mean Group \\
DFE & Dynamic Fixed Effects \\
MG & Mean Group \\
ECT & Error Correction Term \\
EXP & Food exports \\
IMP & Food imports \\
LABOR & Labor force, total \\
AGRI & Agriculture, forestry, and fishing, value-added \\
RD & Research and development expenditure \\
FOREST & Forest area \\
ENG & Fossil fuel energy consumption \\
RENEW & Renewable energy consumption GDP Gross Domestic Product \\
ESIF & European Structural and Investment Funds \\
HLEG & High Level Expert Group \\
EBA & European Banking Authority \\
GABV & Global Alliance for Banking on Values \\
SME & Small- and medium-sized enterprises \\
SBN & Sustainable Banking Network \\
NGFS & Network for Greening the Financial Sector \\
ESG & Environment, Social, Governance \\
& \\
\hline
\end{tabular}




\section{References}

1. Brundtland at 25. Available online: https://greenblue.org/brundtland-at-25/ (accessed on 14 January 2020).

2. Dinu, V. Food Security. Amfiteatru Econ. 2019, 22, 281-283.

3. European Commission. What Is the Bioeconomy? Available online: https://ec.europa.eu/research/ bioeconomy/index.cfm (accessed on 14 January 2020).

4. European Commission. Innovating for Sustainable Growth: A Bioeconomy for Europe; Publication Office of the European Office: Luxembourg, 2012.

5. Scarlat, N.; Dallemand, J.F.; Monforti-Ferrario, F.; Nita, V. The role of biomass and bioenergy in a future bioeconomy: Policies and Facts. Environ. Dev. 2015, 15, 3-34. [CrossRef]

6. OECD. The Bioeconomy to 2030. Designing a Policy Agenda; Organisation for Economic Co-Operation and Development (OECD): Paris, France, 2009.

7. Poltronieri, P. Alternative energies and fossil fuels in the bioeconomy era: What is needed in the next five years for real change. Challenges 2016, 7, 11. [CrossRef]

8. Bugge, M.M.; Hansen, T.; Klitkou, A. What is the bioeconomy? A review of the literature. Sustainability 2016, 8, 691. [CrossRef]

9. Staffas, L.; Gustavsson, M.; Mccormick, K. Strategies and policies for the bioeconomy and bio-based economy: An analysis of official national approaches. Sustainability 2013, 5, 2751-2769. [CrossRef]

10. European Commission. Research and Innovation Plans \& Strategies for Smart Specialisation (RIS3) on Bioeconomy; European Commission: Brussels, Belgium, 2017; p. 5.

11. Porter, M. The Competitive Advantage of Nations; Free Press: New York, NY, USA, 1990.

12. McCormick, K.; Kautto, N. The Bioeconomy in Europe: An overview. Sustainability 2013, 5, 2589-2608. [CrossRef]

13. Food and Agriculture Organization of the United Nations. Assessing the Contribution of Bioeconomy to Countries' Economy: A Brief Review of National Frameworks; Food and Agriculture Organization of the United Nations: Rome, Italy, 2018.

14. Urmetzer, S.; Pyka, A. Varieties of Knowledge-Based Bioeconomies; University of Hohenheim: Stuttgart, Germany, 2014; pp. 91-2014.

15. Pașnicu, D.; Ghența, M.; Matei, A. Transition to Bioeconomy: Perceptions and behaviours in Central and Eastern Europe. Amfiteatru Econ. 2019, 21, 9-23.

16. European Commission. Agri-Food Trade in 2018. Available online: https://ec.europa.eu/info/sites/info/files/ food-farming-fisheries/news/documents/agri-food-trade-2018_en.pdf (accessed on 14 January 2020).

17. European Commission. EU Agri-Food Trade Surplus Hits Record Levels in September 2019. Available online: https://ec.europa.eu/info/news/eu-agri-food-trade-surplus-hits-record-levels-september-2019-2019dec-17_en (accessed on 15 January 2020).

18. World Bank Data. Available online: https://data.worldbank.org/indicator?tab=all (accessed on 14 January 2020).

19. Pascal, L. Assessing the Effects of International Trade on Private RED Expenditures in the Food-Processing Sector; Department of Economics, University of Lethbridge: Lethbridge, AB, Canada, 2002; pp. 349-369.

20. Bojnec, Š.; Fertő, I. Does EU Enlargement Increase Agro-Food Export Duration? World Econ. 2012, 35, 609-631. [CrossRef]

21. Dragos, S.; Mare, C.; Dragoș, C.M. Institutional drivers of life insurance consumption: A dynamic panel approach for European countries. Geneva Pap. Risk Insur.-Issues Pract. 2019, 44, 36-66. [CrossRef]

22. Dragos, S.L.; Mare, C.; Dragota, I.M.; Dragos, C. M, Muresan G.M. The nexus between the demand for life insurance and institutional factors in Europe: New evidence from a panel data approach. Econ. Res.-Ekon. Istraz. 2017, 30, 1477-1496.

23. International Monetary Fund (IFM). World Economic Outlook update January 2020. Available online: http://www.imf.org/en/publications/weo/issues/2020 (accessed on 21 January 2020).

24. Morgans Stanley Capital International (MSCI). Market Classification. Available online: https://www.msci. com/market-classification (accessed on 19 January 2020).

25. United Nations. World Economic Situation and Prospects 2020. Available online: https://www. un.org/development/desa/dpad/publication/world-economic-situation-and-prospects-2020 (accessed on 19 January 2020). 
26. Toth, D.; Maitah, M.; Maitah, K. Development and Forecast of Employment in Forestry in the Czech Republic. Sustainability 2019, 11, 6901. [CrossRef]

27. Lund, H. Elsevier Global Right; Aalborg Universitet: Aalborg, Denmark, 2007; Volume 32, pp. 912-919.

28. Choi, I. Unit root tests for panel data. J. Int. Money Financ. 2001, 20, 249-272. [CrossRef]

29. Pesaran, H.M.; Shin, Y.; Smith, R.P. Pooled mean group estimation of dynamic heterogeneous panels. J. Am. Stat. Assoc. 1999, 94, 621-634. [CrossRef]

30. European Commission. The European Green Deal; European Commission: Brussels, Belgium, 2019.

31. Green Bonds. Mobilising the Debt Capital Markets for a Low-Carbon Transition. Bloomberg. Philantropies. 2015. Available online: https://www.oecd.org/environment/cc/Green $\% 20$ bonds $\% 20 \mathrm{PP} \% 20 \% 5 \mathrm{Bf3} \% 5 \mathrm{D} \% 20 \%$ 5Blr\%5D.pdf (accessed on 5 February 2020).

32. European Commission. Final Report of the High-Level Expert Group on Sustainable Finance; European Commission: Brussels, Belgium, 2018; Available online: https:/ec.europa.eu/info/publications/180131sustainable-finance-report_en (accessed on 19 January 2020).

33. The 2030 Agenda for Sustainable Development. Available online: https://sustainabledevelopment.un.org/ content/documents/21252030\%20Agenda\%20for\%20Sustainable\%20Development $\% 20$ web.pdf (accessed on 15 January 2020).

34. The Paris Agreement. Available online: https://unfccc.int/process-and-meetings/the-paris-agreement/theparis-agreement (accessed on 15 January 2020).

35. European Banking Federation-Press Release from 9 December 2019. Available online: https://www.ebf.eu/ sustainable-finance/banks-present-proposals-to-scale-up-sustainable-finance/ (accessed on 12 December 2019).

36. Global Alliance for Banking on Values (GABV). Strong, Straightforward and Sustainable Banking. A Report on Financial Capital and Impact Metrics of Values Based Banking; Global Alliance for Banking on Values: Zeist, The Netherlands, 2012.

37. Crowdfunding the European Transition to Renewable Energy. 2016. Available online: http://www. crowdfundres.eu/index.html@p=695.html (accessed on 4 February 2020).

38. Sustainable Banking Network, International Finance Corporation. Global Progress Report of the Sustainable Banking Network; Sustainable Banking Network, International Finance Corporation: Washington, DC, USA, 2019.

39. Network for Greening the Financial System. A Sustainable and Responsible Investment Guide for Central Banks' Portfolio Management; Network for Greening the Financial System: Paris, France, 2019.

40. European Fund for Southeast Europe. Impact Report 2018. Cultivating Entrpreneurship; European Fund for Southeast Europe: Luxembourg, 2019.

41. Dinu, V. The Transition to Bioeconomy. Amfiteatru Econ. 2019, 21, 5-7.

(C) 2020 by the authors. Licensee MDPI, Basel, Switzerland. This article is an open access article distributed under the terms and conditions of the Creative Commons Attribution (CC BY) license (http://creativecommons.org/licenses/by/4.0/). 


\title{
Perception of Older Adults about Health-Related Functionality of Foods Compared with Other Age Groups
}

\author{
Dávid Szakos *, László Ózsvári and Gyula Kasza \\ Department of Veterinary Forensics an Economics, University of Veterinary Medicine Budapest, 1078 Budapest, \\ Hungary; ozsvari.laszlo@univet.hu (L.Ó.); kasza.gyula@univet.hu (G.K.) \\ * Correspondence: szakos.david@univet.hu; Tel.: +36-30-618-8530
}

Received: 13 March 2020; Accepted: 28 March 2020; Published: 1 April 2020

\begin{abstract}
The proportion of older adults in the population is significantly growing in the EU, therefore, wellbeing of the older population has become a social challenge. Functional foodstuffs are food products with nutritional composition that may reduce the risk of diet-related diseases or enhance physiological functions. Therefore, they could play an important role in prevention and mitigation of health-related problems, and in promotion of healthy ageing. The aim of this study is to present the impact of age on consumer preferences about functionality of foods, covering attitude aspects, nutrition claims, possible carriers, some particular health problems and expectations about sustainable production. The results are based on a representative quantitative survey. Findings highlight statistically significant $(p<0.05)$ differences in preferences of older adults compared to other age segments. They generally accept functional foods, especially when functionality is attached to increased vitamin, protein, and fiber content. Older adults also prefer products with lower salt and sugar content, which were less relevant for other age groups. Products of fruit and vegetable origin are distinguished as carriers of functional traits. Compared to other segments, older adults accept products of animal origin (especially milk products) and even breakfast products on a higher level. The paper provides details about particular health issues that could be addressed by functional foods based on actual consumer concerns.
\end{abstract}

Keywords: functional food; consumer survey; nutrition claims; health claims; older adults; healthy diet; healthy ageing

\section{Introduction}

The relationship between health and nutrition has come to the forefront of scientific research due to global health trends and lifestyle changes. According to WHO data, chronic non-communicable diseases (CNDs) are the leading cause of death worldwide [1]. In 2016, they were responsible for $71 \%$ (41 million) of the 57 million deaths which occurred globally, and $94 \%$ of the number of deaths in Hungary. Major CNDs are cardiovascular diseases (44\% of all CND deaths), cancers (22\%), chronic respiratory diseases $(9 \%)$, and diabetes $(4 \%)$, all of which are strongly connected to dietary factors, among others [2]. Therefore, $\mathrm{WHO}$ formed a guideline for healthy diet to prevent chronic diseases worldwide, and national level health prevention programs also emerged [3-5]. Demographic statistics related to ageing shows that life expectancy (LE) and proportion of older adults in the population are increasingly growing both at global and EU level. Between 2000 and 2016, global LE at birth increased by 5.5 years, from 66.5 to 72.0 years [6]. In the EU, almost one fifth of the population (19.7\%) was over the age of 65 in 2018, and the relative share of the population is projected to reach $28.5 \%$ until 2050 [7]. According to the latest country reports of the European Health \& Life Expectancy Information System (EHLEIS) based on 2015 data, Hungarian LE was 18.2 years (21.2 for women 
and 17.9 for men) at the age 65 [8]. This index, compared to LE at birth, give better estimation to older adults, but do not give information about the quality of those years. The same report presents another indicator: the healthy life years (HLY, also called healthy life expectancy or disability-free life expectancy), which was 5.9 years in Hungary at the age 65, so 68\% of elderly years (approximately 12 years) are usually spent with disabilities. LE at birth in Hungary was 75.7 years in 2015, which was nearly 5 years below the EU average, mainly due to higher death rates from cardiovascular diseases and cancer [9]. The same study highlights that only slightly more than half (56\%) of Hungarians consider themselves to be in good health, which is one of the lowest rates in the EU. Besides new ways in the investigation of health-related issues [10-12], sustainability of food consumption (including food security) is also becoming an increasingly prominent topic for the scientific community [13-16]. Furthermore, the harmonization of a balanced and sustainable diet opened a new research regime [17].

Nowadays, a rising number of consumers follow a special or consciously composed diet because of health issues or lifestyle decisions, which have opened new opportunities for food business operators. During the last decades, a special focus was given to the health-related functionality of foodstuffs [18]. Functional foods with high added value have become the fastest growing area of the food industry, although the market share varies greatly from country to country, and there is not one generally accepted definition of functional foods in the industry, so different market data are available due to different interpretations of the category $[18,19]$. A study reviewed over one hundred different definitions to determine the boundaries of functional food better [20]. One even argued that functional foods might not be handled as a well-definable separate product category [21]. Although the definitions help scientific and professional dialogues, they do not have a particularly significant role from the perspective of consumers. Instead of legal definitions, consumers receive information about the functional properties of food through advertisements and labels. Regarding labels, nutrition and health claims in the EU may appear on products by following the indications of Regulation (EC) No. 1924/2006 [22] and Regulation (EU) 432/2012 [23] based on the scientific advice of the European Food Safety Authority (EFSA) [24,25].

The increasing importance of the functionality of foodstuffs was recognized even before the turn of the millennium by the food industry, which has accelerated the development of new products. However, new products had a high failure rate on the market in the 1990s, because most of them were not preceded by a deeper exploration of consumer needs $[19,26]$. Developing functional food is often a far more complex issue than introducing a new variation of generalized food products, which was realized by researchers and company experts in the 2000s. Many consumer-related studies emerged about functional foods from that time. The first consumer studies related to functional foods tried to explore the effect of socio-demographics factors [27-29], attitudinal profiles and motivations [21,30-34], and reactions connected to health and nutrition claims [35-38]. Based on the results of the studies that focused on the concept of functional foods in general, later studies targeted more specific product categories and novel concepts [39-44]. It also means that the focus shifted to market-related surveys and product development aspects.

The relatively few consumer-related articles, which focus on older European consumers, also follow a marketing approach, and they are connected to protein-enriched functional foods majorly [45-47]. In Eastern Europe, a Polish study, based on a nationwide representative consumer survey in 2009, found significant differences between age groups in functional food consumption, awareness, and perceived barriers to health improvement. Qualitative consumer studies that support the food product development for older adults have also been published [48,49]. In Hungary, however, a few consumer studies have recently emerged on the relationship between health and food consumption [50-52], and the perspective of older adults on functional foods have not been analyzed yet.

Based on the previous findings, physical and psychological wellbeing of the older population has become a globally significant social challenge. The aim of this study is to give an overall picture about the impact of age on consumer expectations about the functionality of foods, which covers attitude, health-related lifestyle factors, nutrition claims, carriers, health problems, and known diseases as well. 
It was also an important goal of our study to investigate the most common sustainability markers used on food products.

\section{Materials and Methods}

The results of this study are based on a quantitative consumer survey conducted between 11 July and 14 August in 2018 with 1002 respondents. For data collection, personal sampling method was used with a questionnaire designed to be suitable for self-administered completion. Research was conducted at crowded traffic junctions in different Hungarian cities: Budapest, Dombóvár, Eger, Füzesabony, Győr, Kiskunfélegyháza, Miskolc, Siófok, Szeged, Székesfehérvár, Szolnok, and Veszprém. In terms of sex, age, and geographical distribution (NUTS-2) of the respondents, the sample is representative of the total adult population of Hungary, based on the latest census [53] at the time of the data collection (Table 1). To ensure representativeness, we employed quota sampling. During the research design, besides general socio-demographic characteristics, we aimed to collect data on some further particular conditions that may affect food consumption directly according to literature [29] (Table 2).

In the beginning of the interview, the respondents were informed about the aim of the research and the management of anonymous data. If the respondents were willing to participate, before the research questions were asked, the quota parameters (age, sex, geographical location) had been recorded, that allowed the quota numbers to be tracked by the interviewers to ensure an appropriate level of representability. Although the questionnaire was designed to be self-administered, interviewers provided help to fill the questionnaire, which was important in the case of older respondents.

The questionnaire contained 288 variables, from attitude-related questions through to nutritional claims and carrier foods to questions focusing on diseases. The questionnaire employed closed-form questions predominantly. Many questions were measured on five-point Likert scale, where grade 1 meant "strongly disagree" and grade 5 meant "strongly agree." Table A1 in Appendix A shows the content of the questionnaire in terms of all variables used in this study.

Statistical analysis of the data was carried out by IBM SPSS Statistics 22.0 software package. Beyond descriptive analysis, Kruskal-Wallis test and Pearson's chi-square test (CI: 95\%) were used to analyze data on ordinal scale when the distribution of data did not meet the criteria for normal distribution [54]. Factor analysis (principal component analysis-PCA) was used to explore overlaps and to combine correlated variables [55].

Table 1. Representative socio-demographic characteristics of the sample ( $\%$ of respondents, $n=1002)$.

\begin{tabular}{cccc}
\hline \multicolumn{2}{c}{ Socio-demographic Categories } & Sample & Population * \\
\hline \multirow{2}{*}{ Sex } & Female & 53.19 & 53.07 \\
& Male & 46.81 & 46.93 \\
\hline \multirow{2}{*}{ Age } & $18-29$ & 17.96 & 17.59 \\
& $30-39$ & 16.97 & 17.04 \\
& $40-59$ & 34.53 & 33.83 \\
& $>60$ & 30.54 & 31.54 \\
\hline \multirow{2}{*}{ distribution (NUTS-2) } & Central Hungary & 31.04 & 30.75 \\
& Central Transdanubia & 10.78 & 10.80 \\
& Western Transdanubia & 10.18 & 10.03 \\
& Northern Transdanubia & 8.68 & 9.13 \\
& Northern Great Plain & 11.48 & 11.62 \\
& Southern Great Plain & 15.07 & 14.90 \\
& & 12.77 & 12.78 \\
\hline
\end{tabular}

* Latest census data of Hungarian Central Statistical Office to adult Hungarian population [53]. 
Table 2. Further socio-demographic characteristics of the sample (valid \% of respondents).

\begin{tabular}{|c|c|c|}
\hline \multicolumn{2}{|c|}{ Socio-demographic Categories } & \multirow{2}{*}{$\begin{array}{c}\% \\
15.49\end{array}$} \\
\hline \multirow{3}{*}{ Place of living } & Village & \\
\hline & Another city & 61.54 \\
\hline & Capital city & 22.98 \\
\hline \multirow{3}{*}{$\begin{array}{l}\text { Highest accomplished } \\
\text { qualification }\end{array}$} & Primary and vocational school & 11.46 \\
\hline & High school (graduated) & 33.37 \\
\hline & Higher education & 55.17 \\
\hline \multirow{3}{*}{$\begin{array}{l}\text { Income level (subjective } \\
\text { estimation) }\end{array}$} & Below average & 13.11 \\
\hline & Average & 68.16 \\
\hline & Above average & 17.17 \\
\hline \multirow{6}{*}{ Economic status } & Active worker & 54.64 \\
\hline & Entrepreneur & 6.25 \\
\hline & Retiree & 27.12 \\
\hline & Job seeker & 1.51 \\
\hline & Homemaker & 1.41 \\
\hline & Student & 9.07 \\
\hline \multirow{2}{*}{$\begin{array}{l}\text { Children under } 15 \text { years of age in } \\
\text { the household }\end{array}$} & Yes & 20.04 \\
\hline & No & 79.96 \\
\hline \multirow{5}{*}{$\begin{array}{l}\text { Number of persons living in the } \\
\text { household }\end{array}$} & 1 & 16.48 \\
\hline & 2 & 40.88 \\
\hline & 3 & 17.83 \\
\hline & 4 & 14.18 \\
\hline & 5 or more & 10.63 \\
\hline \multirow{4}{*}{ Special dietary needs } & Respondent & 49.50 \\
\hline & Another person in the family & 10.68 \\
\hline & No & 34.53 \\
\hline & Did not respond & 5.29 \\
\hline
\end{tabular}

\section{Results}

\subsection{Attitudes and Lifestyle Factors toward Nutrition}

At the beginning of the survey, attitude-related 1-5 Likert questions were listed in order to characterize different age groups based on their opinion about health and age-related aspects of nutrition (Table 3).

Table 3. Attitudes toward nutrition in different age groups (level of agreement, 1-5 Likert scale).

\begin{tabular}{|c|c|c|c|c|c|c|}
\hline \multirow{2}{*}{ Variables } & Total Sample & $18-29$ & $30-39$ & $40-59$ & $>60$ & \multirow{2}{*}{ Sig. } \\
\hline & \multicolumn{5}{|c|}{ M (SD) } & \\
\hline $\begin{array}{l}\text { Nutrition has a direct } \\
\text { impact on health }\end{array}$ & $4.60(0.783)$ & $4.51(0.897)$ & $4.60(0.751)$ & $4.61(0.744)$ & $4.64(0.773)$ & 0.362 \\
\hline $\begin{array}{l}\text { Healthy diet has great } \\
\text { impact on the } \\
\text { prevention of diseases } \\
\text { in older adults }\end{array}$ & $4.50(0.822)$ & 4.57 (0.703) & $4.43(0.868)$ & $4.50(0.830)$ & $4.49(0.852)$ & 0.534 \\
\hline $\begin{array}{l}\text { For older adults, diet } \\
\text { has a more important } \\
\text { role in health }\end{array}$ & $4.31(0.976)$ & $4.34(0.871)$ & $4.16(1.046)$ & $4.28(0.971)$ & $4.42(0.976)$ & 0.003 \\
\hline $\begin{array}{l}\text { Healthy diet is } \\
\text { important for me }\end{array}$ & $4.28(0.885)$ & $4.05(0.878)$ & $4.16(0.879)$ & $4.31(0.827)$ & $4.45(0.920)$ & $<0.0001$ \\
\hline
\end{tabular}

According to the results, each age group perceived strong connection between nutrition and health. While all age groups agreed that "healthy diet has a great impact on the prevention of diseases 
in older adults," the oldest group attached significantly more importance to "for older adults, diet has a more important role in health" compared to other age groups. The importance of a healthy diet increases with age according to the responses.

The questionnaire also contained lifestyle-related multiple choice questions, which allowed further differentiation of age groups (Table 4).

Table 4. Perception of health-related lifestyle factors in different age groups.

\begin{tabular}{|c|c|c|c|c|c|c|}
\hline \multirow{2}{*}{ Variables } & Total Sample & $18-29$ & $30-39$ & $40-59$ & $>60$ & \multirow{2}{*}{ Sig. } \\
\hline & \multicolumn{5}{|c|}{$\%$} & \\
\hline I feel healthy in general & 59.96 & 67.05 & 57.23 & 57.85 & 59.72 & 0.184 \\
\hline $\begin{array}{l}\text { I want to lose weight, } \\
\text { and I do something } \\
\text { about this }\end{array}$ & 41.63 & 38.07 & 39.76 & 44.77 & 41.13 & 0.461 \\
\hline I exercise regularly & 37.64 & 48.30 & 43.03 & 35.17 & 30.85 & 0.001 \\
\hline $\begin{array}{l}\text { I have a stressful } \\
\text { lifestyle }\end{array}$ & 36.02 & 36.93 & 49.40 & 43.60 & 18.37 & $<0.0001$ \\
\hline I do not sleep enough & 33.75 & 31.82 & 40.96 & 39.53 & 23.67 & $<0.0001$ \\
\hline I do not exercise enough & 32.57 & 32.39 & 34.34 & 38.19 & 24.82 & 0.005 \\
\hline $\begin{array}{l}\text { I pay more attention to } \\
\text { my diet than average }\end{array}$ & 30.03 & 22.73 & 34.34 & 28.78 & 33.57 & 0.049 \\
\hline $\begin{array}{l}\text { I use dietary } \\
\text { supplements }\end{array}$ & 25.70 & 22.16 & 28.92 & 27.33 & 24.03 & 0.400 \\
\hline $\begin{array}{c}\text { I can spend only a little } \\
\text { time on eating and } \\
\text { cooking }\end{array}$ & 19.09 & 33.52 & 25.90 & 19.19 & 6.01 & $<0.0001$ \\
\hline I smoke every day & 15.17 & 20.45 & 21.08 & 16.57 & 6.71 & $<0.0001$ \\
\hline $\begin{array}{l}\text { I try to consume less } \\
\text { alcohol }\end{array}$ & 17.44 & 21.59 & 17.47 & 16.57 & 15.90 & 0.431 \\
\hline
\end{tabular}

Significant difference between age groups was not found in terms of self-estimation of health, the need for weight loss, use of dietary supplements, and alcohol consumption habits. Younger respondents exercise more often, although they still tend to think it is below the required level. Stressful lifestyle and not enough sleep are the most common problems reported by the middle-aged groups. Older adults rarely smoke and this group has significantly more time to eat and cook than the younger respondents. Consumers between 30 and 39 years and over 60 years state that they pay more attention to diet compared to the average.

\subsection{Nutrition Claims}

The questionnaire contained 39 nutrition claims in total, covering all options listed by the Regulation (EC) No. 1924/2006. In some cases, claims were presented through an example, such as "source of calcium," while others used a generalized form, for instance, "source of vitamins." EU and national level food law allow the use of the terms salt and sodium as synonyms in labelling, so both terms were included in the questionnaire. Besides the claims listed in the regulation, some other elements were also included (for example, prebiotic, contains antioxidants, etc.). Respondents expressed their opinion on 1-5 Likert scale about their preference of the listed nutrition claims shown in Figure 1. For better interpretation, PCA was used to reduce 39 items to 8 well-distinguishable nutrition claim categories (Table 5). As expected on the basis of previous relevant studies, the created categories highlighted that consumers did not perceive significant differences between multiple level claims $[40,56]$. Accordingly, the categories give a robust representation for multiple level claim groups (for instance, with no added sugar, low in sugar, sugar-free, within the factor named sugar). 


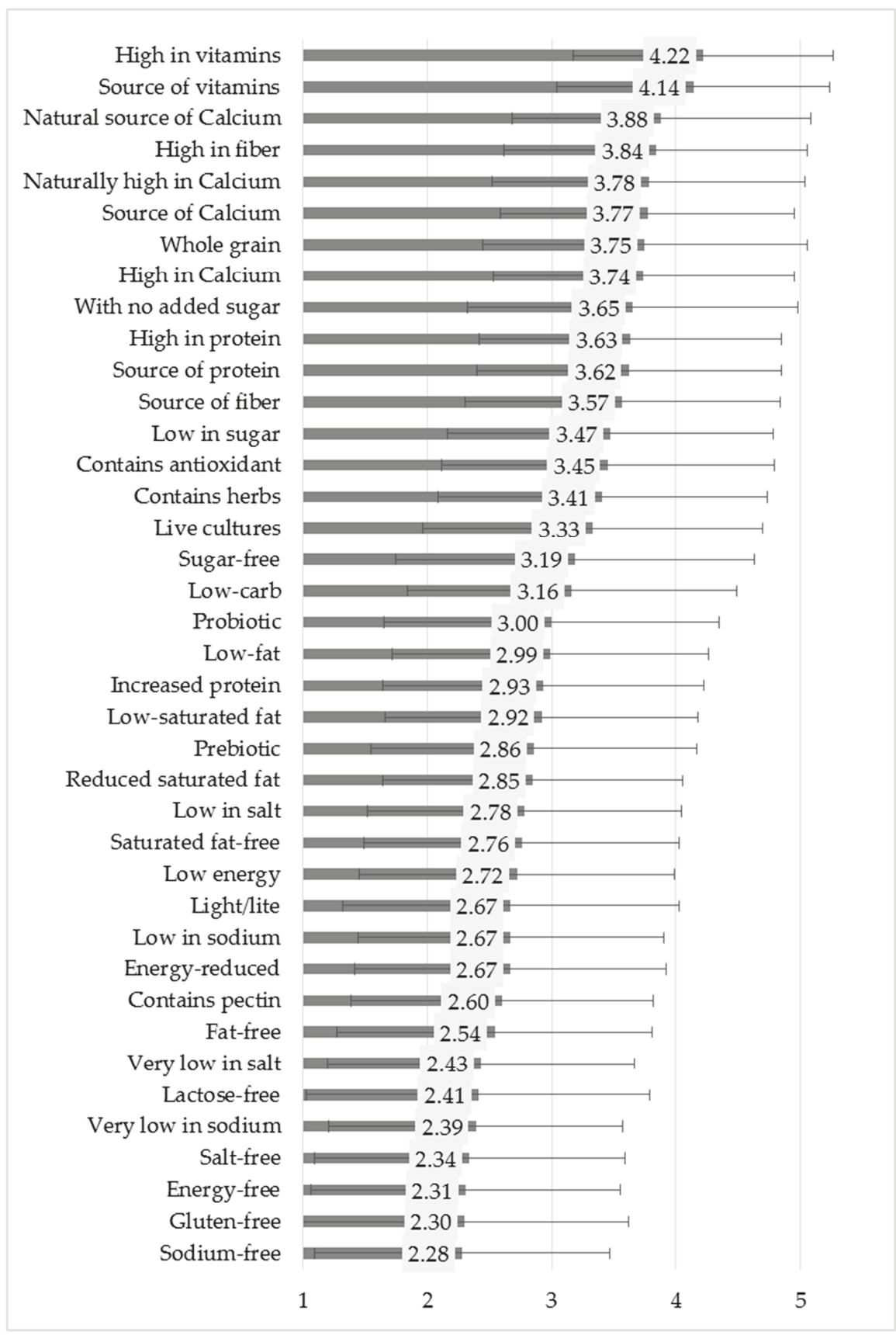

Figure 1. Preference of nutrition claims on food (1-5 Likert scale, where 5 means the highest level of preference). 
Table 5. Nutrition claims factor categories based on PCA (Rotation method: Varimax; KMO: 0.944; Bartlett: <0.0001).

\begin{tabular}{|c|c|c|c|}
\hline \multirow{2}{*}{ Factor Names } & \multirow{2}{*}{ Included Variables } & \multicolumn{2}{|c|}{ Total Variance Explained } \\
\hline & & $\%$ of Variance & Cumulative $\%$ \\
\hline Vitamins and minerals & $\begin{array}{c}\text { High in vitamins } \\
\text { Source of vitamins } \\
\text { Natural source of Calcium } \\
\text { Naturally high in Calcium } \\
\text { Source of Calcium } \\
\text { High in Calcium }\end{array}$ & 13.469 & 13.469 \\
\hline Salt & $\begin{array}{c}\text { Low in salt } \\
\text { Low in sodium } \\
\text { Very low in salt } \\
\text { Very low in sodium } \\
\text { Salt-free } \\
\text { Sodium-free }\end{array}$ & 13.353 & 26.822 \\
\hline Not listed claims & $\begin{array}{l}\text { Whole grain } \\
\text { Contains antioxidant } \\
\text { Contains herbs } \\
\text { Live cultures } \\
\text { Probiotic } \\
\text { Prebiotic } \\
\text { Contains pectin }\end{array}$ & 11.714 & 38.536 \\
\hline Light & $\begin{array}{l}\text { Low energy } \\
\text { Light/lite } \\
\text { Energy-reduced } \\
\text { Energy-free }\end{array}$ & 9.601 & 48.137 \\
\hline Sugar & $\begin{array}{l}\text { With no added sugar } \\
\text { Low in sugar } \\
\text { Sugar-free } \\
\text { Low-carb }\end{array}$ & 8.451 & 56.588 \\
\hline Fat & $\begin{array}{c}\text { Low-fat } \\
\text { Low-saturated fat } \\
\text { Reduced saturated fat } \\
\text { Saturated fat-free } \\
\text { Fat-free }\end{array}$ & 8.108 & 64.697 \\
\hline Protein and fiber & $\begin{array}{l}\text { High in fiber } \\
\text { High in protein } \\
\text { Source of protein } \\
\text { Source of fiber } \\
\text { Increased protein }\end{array}$ & 7.369 & 72.065 \\
\hline Free from & $\begin{array}{l}\text { Lactose-free } \\
\text { Gluten-free }\end{array}$ & 4.693 & 76.758 \\
\hline
\end{tabular}

In general, nutrition claims related to vitamins and minerals received the highest preference scores. Protein, fiber and sugar content also seem to be important for the respondents. Claims related to fat content, energy, and salt can typically be found in the middle section of the list. PCA analysis clearly indicated a group constituted by those claims that are not listed in the Regulation (EC) No. 1924/2006 (Table 5). Lactose-free and gluten-free are at the bottom of the list. In terms of salt and sodium, the former one is more preferred by the consumers, although both terms indicate the same nutritional element (Figure 1).

Figure 2 shows the differences between age groups in regard to the nutrition claims categories composed with PCA. 


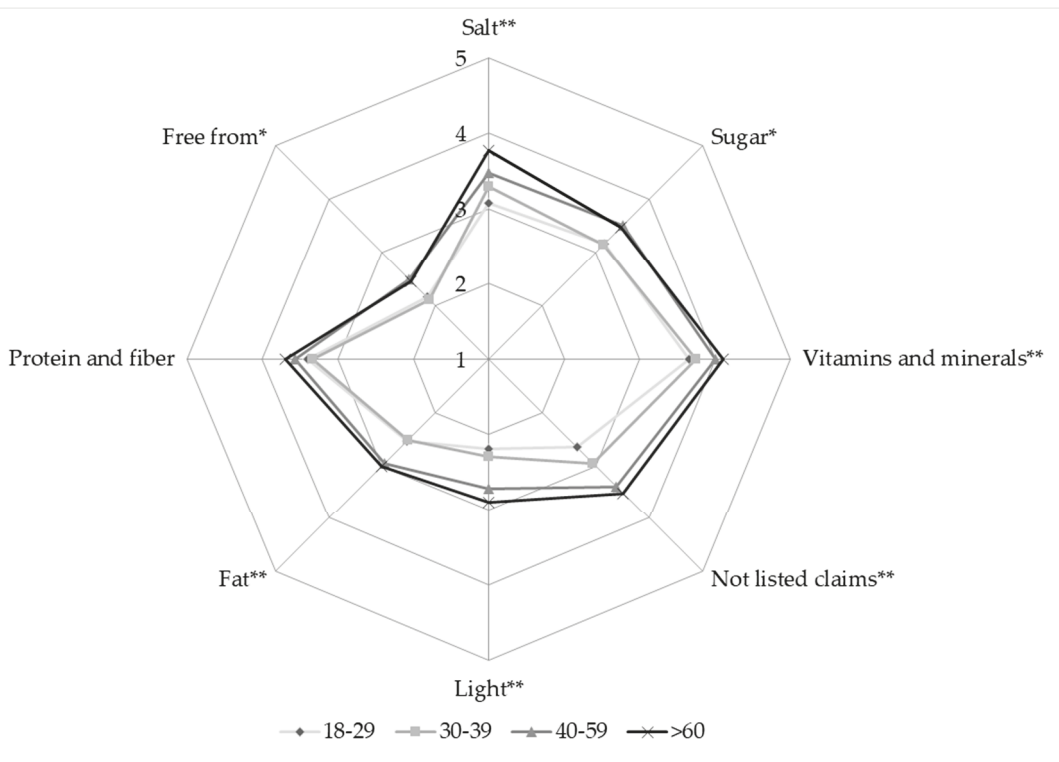

Figure 2. Preference of nutrition claims categories composed with PCA, between different age groups $\left({ }^{*} p<0.05 ;{ }^{* *} p<0.01\right)$.

Differences between preferences of age groups are significant in all cases, except nutrition claims related to protein and fiber. Respondents over 60 years typically have stronger preference of the listed claims than the younger age groups. The most significant difference was found in the case of saltrelated claims.

\subsection{Carrier Foods}

Previous studies highlighted the importance of the type of carrier food products regarding acceptance of health benefits by consumers [30,40,57,58]. During data collection, respondents could express their health-related preference about 25 types of foods on 1-5 Likert scale (Figure 3). Table 6 shows the 5 carrier categories composed by PCA.

Eating fruits and vegetables is the best way for keeping a healthy diet according to the respondents. "Fruits and vegetables" form an independent group by PCA, which contains processed products and mushrooms, too. The following categories are "meat, fish, and egg," "natural products," and "dairy products." "Natural products" is a heterogeneous group compared to the others. It contains juice; honey; tea; nuts and other oily seeds, muesli; and herbal products. "Breakfast products," namely fruit jam, bakery products, and margarine are at the end of the preference list.

Figure 4 shows the differences between age groups connected to carrier categories composed with PCA.

Differences between preferences of age groups are significant in cases of "dairy products," "breakfast products," and "meat, fish, and eggs." "Fruits and vegetables" and "natural products" are fairly important for all age groups. Older adults preferred "dairy products" and "breakfast products" to a greater extent than others. 


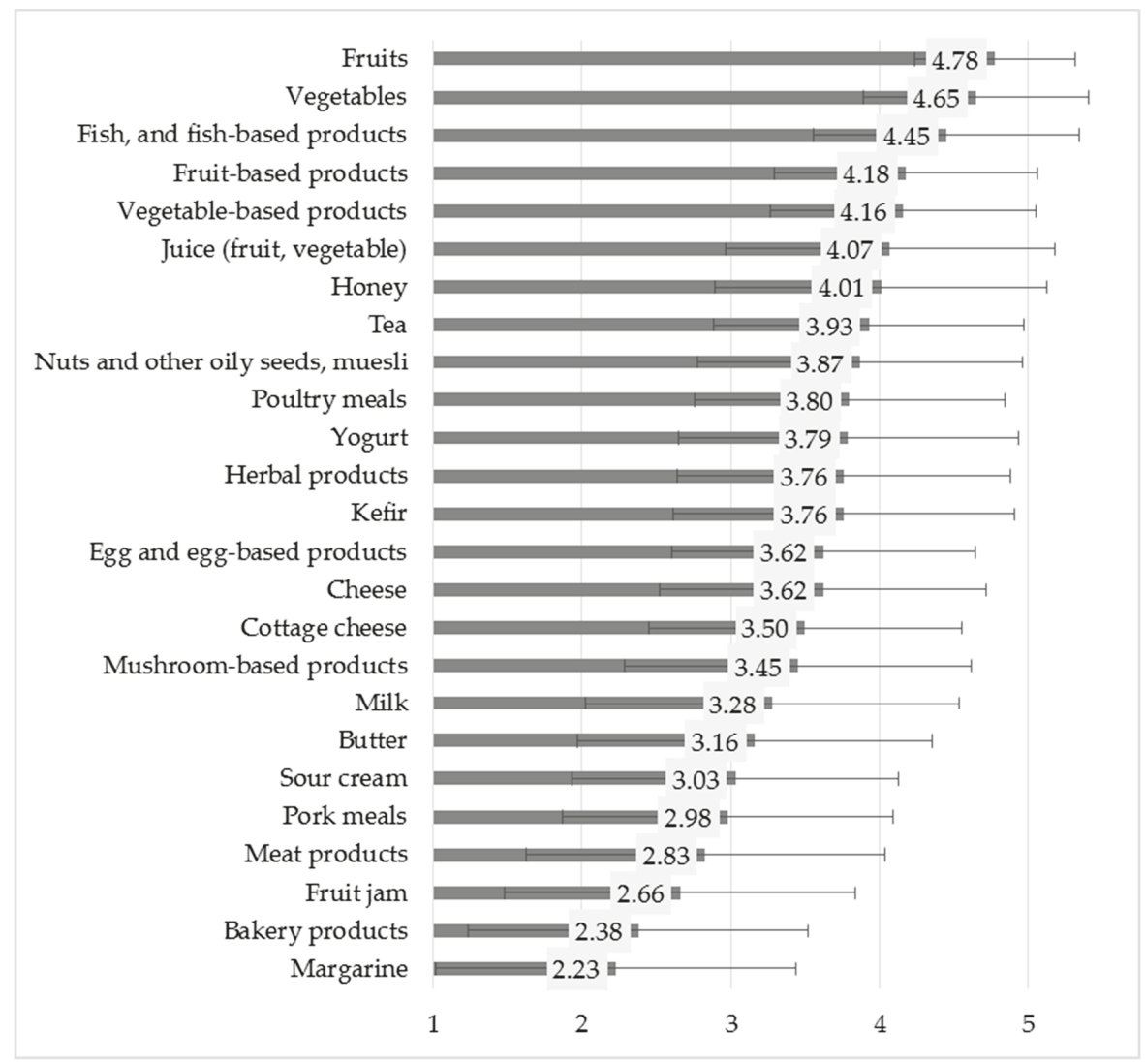

Figure 3. Preference of different food carriers (1-5 Likert scale, where 5 means the highest level of preference).

Table 6. Carrier factor categories based on PCA (Rotation method: Varimax; KMO: 0.848; Bartlett: $<0.0001)$.

\begin{tabular}{|c|c|c|c|}
\hline \multirow{2}{*}{ Factor Names } & \multirow{2}{*}{ Included Variables } & \multicolumn{2}{|c|}{ Total Variance Explained } \\
\hline & & $\%$ of Variance & Cumulative \% \\
\hline Dairy products & $\begin{array}{c}\text { Yogurt } \\
\text { Kefir } \\
\text { Cheese } \\
\text { Cottage cheese } \\
\text { Milk } \\
\text { Butter } \\
\text { Sour cream }\end{array}$ & 14.541 & 14.541 \\
\hline Breakfast products & $\begin{array}{c}\text { Margarine } \\
\text { Bakery products } \\
\text { Fruit jam }\end{array}$ & 10.256 & 24.797 \\
\hline
\end{tabular}


Table 6. Cont.

\begin{tabular}{|c|c|c|c|}
\hline \multirow{2}{*}{ Factor Names } & \multirow{2}{*}{ Included Variables } & \multicolumn{2}{|c|}{ Total Variance Explained } \\
\hline & & $\%$ of Variance & Cumulative \% \\
\hline Fruits and vegetables & $\begin{array}{c}\text { Fruits } \\
\text { Vegetables } \\
\text { Fruit-based products } \\
\text { Vegetable-based products } \\
\text { Mushroom-based products }\end{array}$ & 10.038 & 34.835 \\
\hline Meat, fish, and eggs & $\begin{array}{l}\text { Fish and fish-based products } \\
\text { Poultry meals } \\
\text { Egg and egg-based products } \\
\text { Pork meals } \\
\text { Meat products }\end{array}$ & 9.783 & 44.619 \\
\hline Natural products & $\begin{array}{c}\text { Juice (fruit, vegetable) } \\
\text { Honey } \\
\text { Tea } \\
\text { Nuts and other oily seeds, } \\
\text { muesli } \\
\text { Herbal products }\end{array}$ & 9.349 & 53.967 \\
\hline
\end{tabular}

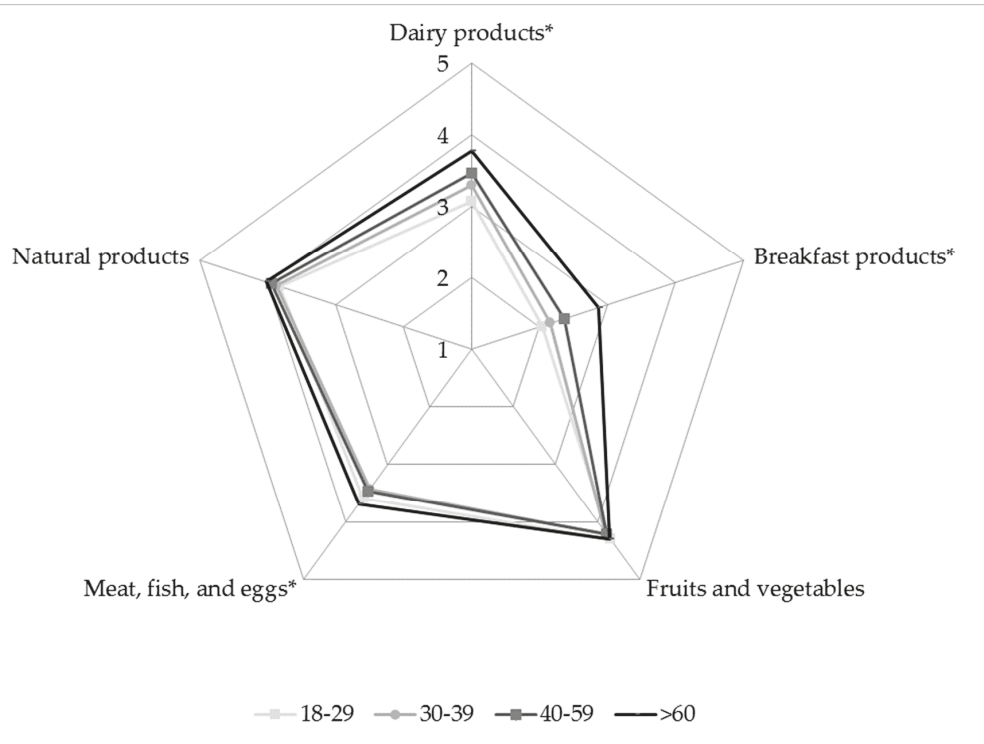

Figure 4. Preference of food carrier categories composed with PCA, between different age groups $\left({ }^{*} p<0.05\right)$.

\subsection{Health problems and acceptance of functional foods}

The main health problems people are most affected by and worried about compared to the acceptance of mitigation and prevention with functional foods are shown in Figure 5. 


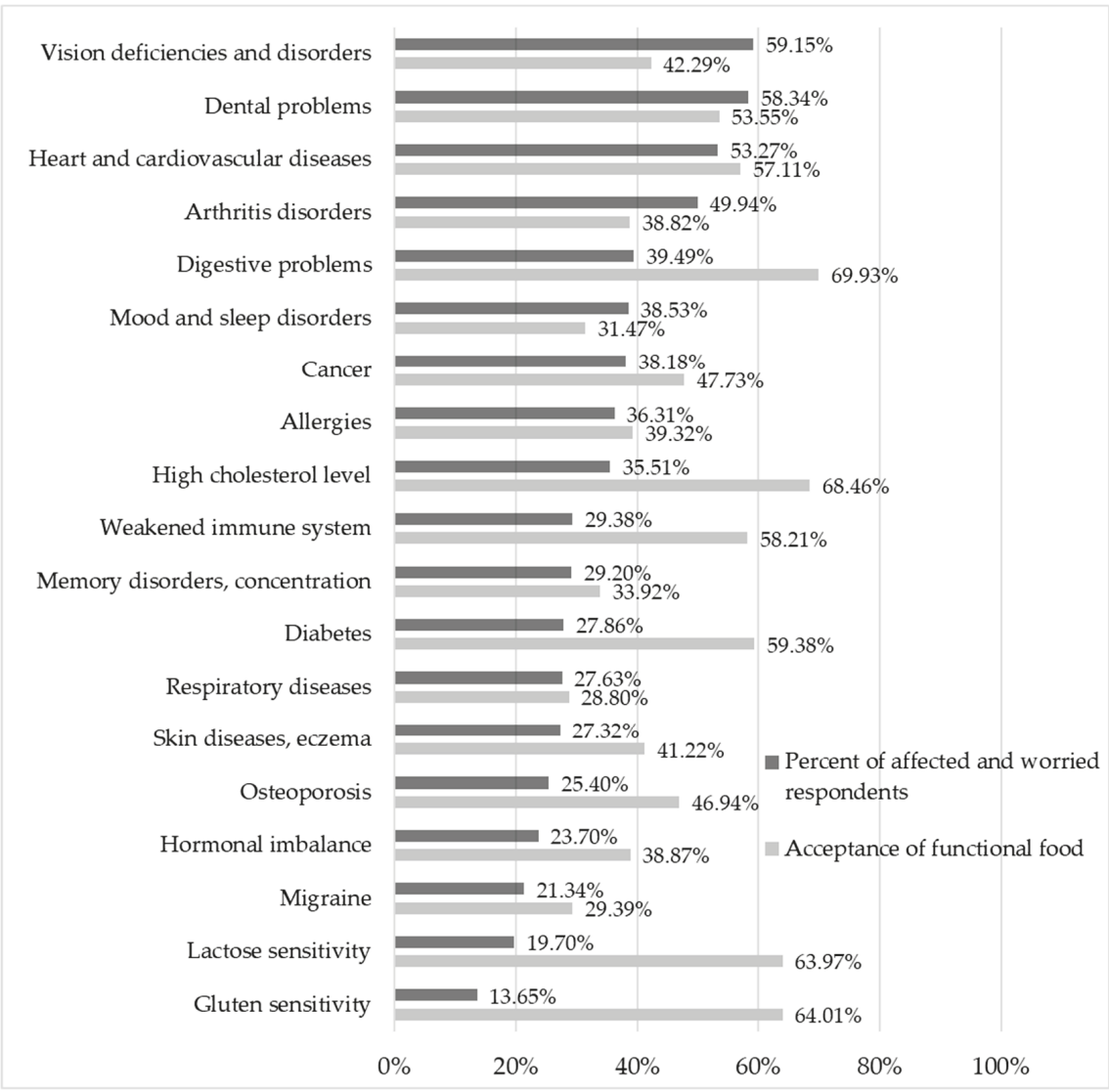

Figure 5. Consumer concerns in regard to certain health problems and the perceived suitability of functional foods to prevent or mitigate these problems.

According to the results, the Hungarian population is mainly concerned/worried about the following health problems: vision deficiencies and disorders, dental problems, and heart and cardiovascular diseases. Results also highlight that diets containing functional foods for the mitigation and prevention of health problems are mainly related to digestive problems, high cholesterol level, lactose sensitivity, and gluten sensitivity according to the opinion of the respondents.

In the case of several health problems, the age of respondents has been a significant factor, shown in Table 7.

In the vast majority of cases where significant differences were detected, older adults are more affected or worried about the certain health problems. The only exception is migraine, which worries and affects younger people more. 
Table 7. Presence of particular health concerns in different age groups.

\begin{tabular}{|c|c|c|c|c|c|}
\hline \multirow{2}{*}{ Health Problem } & $18-29$ & $30-39$ & $40-59$ & $>60$ & \multirow{2}{*}{ Sig. } \\
\hline & \multicolumn{4}{|c|}{$\%$} & \\
\hline $\begin{array}{c}\text { Vision deficiencies and } \\
\text { disorders }\end{array}$ & 46.06 & 43.04 & 64.57 & 72.97 & $<0.0001$ \\
\hline Dental problems & 40.85 & 57.86 & 65.91 & 61.21 & $<0.0001$ \\
\hline $\begin{array}{c}\text { Heart and } \\
\text { cardiovascular } \\
\text { diseases }\end{array}$ & 27.53 & 45.24 & 48.86 & 54.93 & $<0.0001$ \\
\hline Arthritis disorders & 27.11 & 37.34 & 53.97 & 69.70 & $<0.0001$ \\
\hline Digestive problems & 29.45 & 35.67 & 45.00 & 42.36 & 0.0063 \\
\hline High cholesterol level & 19.88 & 31.45 & 34.56 & 51.60 & $<0.0001$ \\
\hline $\begin{array}{l}\text { Memory disorders, } \\
\text { concentration }\end{array}$ & 23.49 & 26.42 & 28.19 & 38.02 & 0.0142 \\
\hline Diabetes & 17.58 & 26.58 & 29.77 & 34.50 & 0.0033 \\
\hline Osteoporosis & 13.25 & 20.13 & 27.65 & 36.79 & $<0.0001$ \\
\hline Migraine & 22.42 & 25.16 & 24.91 & 10.86 & 0.0017 \\
\hline
\end{tabular}

Figure 6 shows the proportion of affected/worried consumers in the age groups, who would accept food as a solution to prevent and/or mitigate the particular health problem.

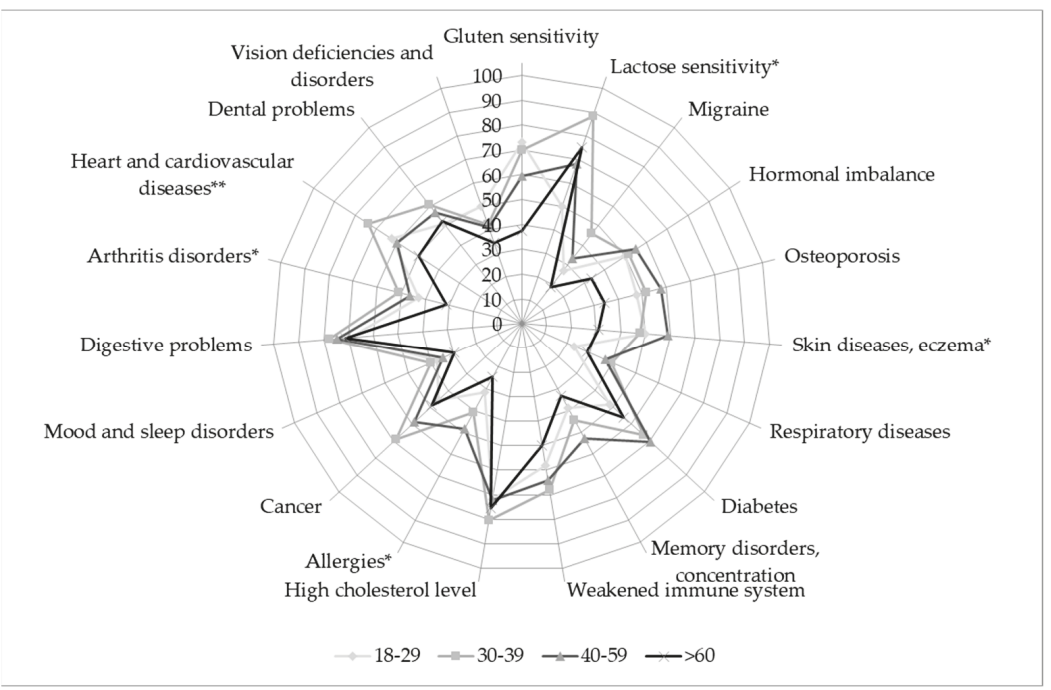

Figure 6. Proportion of affected/worried consumers in the age groups, who accepted food as a solution to prevent and/or mitigate a particular health problem $\left({ }^{*} p<0.05 ; * *<0.01\right)$.

Among the affected/worried consumers, significant differences were detected between age groups in the case of heart and cardiovascular diseases, arthritis disorders, allergies, skin diseases and eczema, and lactose sensitivity. In the majority of these cases, older adults are characterized by a lower level of acceptance than the younger ones. In general, affected young adults and middle-aged adults show the highest level of acceptance of functional food products: younger adults particularly accept these in 
case of heart and cardiovascular diseases, and lactose sensitivity, while middle-aged adults would prefer functional food to prevent/mitigate the effect of skin diseases and eczema and allergies.

\subsection{Sustainability Factors}

In the context of functional food preferences, the possible value-added characteristics of certain sustainability factors were also analyzed. It gives an opportunity to identify further consumer expectations about "healthy" food products. Results about consumer perceptions are presented in Table 8.

Table 8. Preference of certain sustainability factors in regard to functional food products in different age groups.

\begin{tabular}{|c|c|c|c|c|c|c|}
\hline \multirow{2}{*}{ Variables } & Total Sample & $18-29$ & $30-39$ & $40-59$ & $>60$ & \multirow{2}{*}{ Sig. } \\
\hline & \multicolumn{5}{|c|}{$\mathrm{M}(\mathrm{SD})$} & \\
\hline Domestic product & $3.85(1.213)$ & $3.24(1.370)$ & $3.86(1.086)$ & $3.85(1.170)$ & $4.21(1.085)$ & $<0.0001$ \\
\hline Small-scale production & $3.77(1.215)$ & $3.06(1.289)$ & $3.71(1.224)$ & $3.92(1.105)$ & $4.05(1.125)$ & $<0.0001$ \\
\hline $\begin{array}{l}\text { Animal welfare } \\
\text { considerations }\end{array}$ & $3.73(1.228)$ & $3.51(1.403)$ & $3.77(1.179)$ & $3.73(1.150)$ & $3.83(1.220)$ & 0.143 \\
\hline Traditional product & $3.53(1.159)$ & $2.87(1.257)$ & $3.43(1.257)$ & $3.64(1.067)$ & $3.87(0.981)$ & $<0.0001$ \\
\hline Organic product & $3.47(1.281)$ & $3.08(1.379)$ & $3.29(1.291)$ & $3.61(1.203)$ & $3.65(1.246)$ & $<0.0001$ \\
\hline $\begin{array}{l}\text { Produced with modern } \\
\text { technology }\end{array}$ & $2.93(1.212)$ & $2.52(1.178)$ & $2.69(1.231)$ & $2.95(1.225)$ & $3.29(1.217)$ & $<0.0001$ \\
\hline
\end{tabular}

According to the preference of the consumers, domestic origin is the most prominent aspect, followed by small-scale production and animal welfare considerations. Except in the case of animal welfare, differences between age groups were proven to be significant by using a confidence interval of $95 \%$. All listed sustainability factors were more preferred by consumers over the age of 60 , which indicates that the combination of sustainability labels (especially in regard to domestic origin) and health and nutrition claims on the package could bear a recognized value for senior conscious consumers.

\section{Discussion}

This paper aims to give an overall picture on the impact of age on consumer expectations about the functionality of foods based on a nationwide representative consumer survey. Besides a description of significant differences between age groups about health-related attitudes and lifestyle factors, our study analyzes the most important aspects of functionality of foods through quantification of consumer expectations and preferences.

A special focus was placed on older consumers in the analysis. The importance of the wellbeing of older adults is increasing, as their social representation grows. While there is a big variety of functional foodstuffs on the market already, their contribution to disability-free life years also depends on consumer choice. The combination of functional foods with scientifically proven health and nutrition claims and appropriate consumer perception would deliver significant social benefits.

Thirty-eight nutrition claims and 25 carrier food types were categorized with PCA to identify the most prominent decision points of older adults compared to other age groups. Respondents expressed their involvement and concerns about 19 health problems, and also gave their opinion about the appropriateness of food as a solution to prevent and/or mitigate the particular health problem. Our study also investigated the preference of the most common sustainability markers for functional foods.

Significant differences were found between age groups in consumer preferences about the functionality of foods. Results are harmonizing with previous studies, which pointed out that older adults have a more positive attitude toward functionality of foods in general [33,59-61].

"Vitamins and minerals," "protein and fiber," and claims related to sugar content were found to be the most preferred nutrition claims. Differences between preferences of age groups were significant in 
all cases, except nutrition claims related to protein and fiber. Respondents over 60 years typically prefer the listed claims more than younger age groups. The most important significant difference was found about salt-related claims. A recent Italian study with similar methodology also identified significant differences between age groups in regard to the preference of nutrition claims, and found similarly that claims related to vitamins are the most preferred ones by the consumers [62]. The same study found a lower level of preference about salt-related claims, which can be explained by country differences described in previous cross-country research [36]. Moreover, previous studies indicated a connection between health status and the importance people attach to nutrition and health claims [33,35]. In this case, it is important to mention that the proportion of death caused by cardiovascular diseases-where the reduction of salt intake would be one of the most important dietetic factors-is four times higher in Hungary than in Italy [63].

Based on the opinion of respondents, the following food categories are the most suitable for a healthy diet: "fruits and vegetables," "meat, fish, and egg," "natural products," (e.g., juices, tea, honey), and "dairy products." Older adults preferred the "dairy products" and "breakfast products" significantly more than the younger respondents. Related studies mostly analyzed carrier food products combined with some particular claims that contributed for product development in a more direct manner $[30,40,57,58]$. These studies concluded that the type of the carrier had a greater effect on the acceptance of health benefits by consumers than the type of claim. Furthermore, consumers showed higher acceptance toward the functionality of foods, where the functional ingredient was inherently contained to some extent [30,40].

A Dutch study, which analyzed health claims, pointed out that health claims related to physiological health problems (e.g., heart and cardiovascular diseases, osteoporosis, cancer) are of greater importance among such claims stated on the labels of foodstuffs than those related to psychological problems (e.g., stress, fatigue), which are in line with our results [35]. A recent Hungarian study which examined the effect of socio-demographic factors in the case of functional foods also highlighted the importance of age regarding to health problems [50]. Our results indicate that the Hungarian population is mainly concerned about the following health problems: vision deficiencies and disorders, dental problems, and heart and cardiovascular diseases. According to the respondents, functional foods are most suitable for the mitigation and prevention of digestive problems, high cholesterol level, lactose sensitivity, and gluten sensitivity. In the vast majority of cases where significant differences are detected, older adults are more affected or worried about health problems. After filtering the sample only for the affected/worried consumers, less significant differences between age groups were detected. Where significant differences were found, younger and middle-aged adults are more likely to accept food as a solution to prevent and/or mitigate the particular health problem.

In terms of key health-related sustainability factors of food products, domestic origin played the most important role, followed by small-scale production and animal welfare, which are in line with previous studies [64]. Animal welfare was the only factor found to be universally appreciated, while other factors are preferred by the older adults to a higher extent.

The results of this quantitative study highlighted the importance of considering the wellbeing of older adults during product development. The investigation proven that significant differences in attitudes and preferences do exist and might be used for product differentiation. The paper contains a detailed data set about possible carrier food and functionality combinations that might be used for subsequent academic studies and for field experts as well. However, it is important to consider country-level differences that might be reflected in the preference of carrier food and functionality combinations. In this survey, we have collected a representative sample of the Hungarian population that served the purpose of demographical comparison well, and was also able to deliver some health status specific results according to the most frequent problems. This investigation was limited to respondents in relatively good health conditions, due to the methodology of data collection, which was performed at crowded traffic junctions. To reach older adults who are affected by serious health problems, investigations must be expanded to retirement homes and hospitals. However, during 
our research, the main focus was on disability-free life years, which required the answers of persons with seemingly normal health conditions. The research was conducted in summer, and seasonality may effect consumer preference on foodstuffs - especially in terms of locally produced fruits and vegetables-according to certain studies [65]. However, questions were aimed to measure general attitudes. Additionally, seasonality tends to be less important in the last decades, especially in the urbanized population of economically developed countries.

This explorative study can be used as a basis for a subsequent research focusing on the ageing consumers to provide an in-depth insight into their food consumption behavior and perception of the link between nutrition and health. It must be considered for further research that a larger sample size of older adults would allow the use of sophisticated multivariate statistics methods, such as cluster analysis and structural equation modelling. By this investigation, further segmentation could be conducted to identify possible gaps in education, availability of expected health-promoting products and innovation areas. This research can also reveal behavioral reasons behind health-related food consumption habits of older adults, which, besides fostering product development, could lay the foundations of social and health-related policy actions as well.

Author Contributions: D.S. and G.K. conceived and designed the experiments; D.S. analyzed the data; D.S., L.Ó. and G.K. contributed to conceptualization and writing the paper. All authors have read and agreed to the published version of the manuscript.

Funding: The Project was supported by the European Union and co-financed by the European Social Fund: (1) EFOP-3.6.1-16-2016-00024 'Innovations for Intelligent Specialization on the University of Veterinary Science and the Faculty of Agricultural and Food Sciences of the Széchenyi István University Cooperation'; (2) EFOP-3.6.2-16-2017-00012 'Development of a product chain model for functional, healthy and safe foods from farm to fork based on a thematic research network'; and (3) EFOP-3.6.3-VEKOP-16-2017-00005 'Strengthening the scientific replacement by supporting the academic workshops and programs of students, developing a mentoring process'.

Conflicts of Interest: The authors declare no conflicts of interest.

\section{Appendix A}

Table A1. Summary of the questionnaire for all variables used in this study.

\begin{tabular}{|c|c|c|}
\hline Questions & Set of Values & Listed Variables \\
\hline $\begin{array}{l}\text { To what extent do you agree with the following } \\
\text { statements? }\end{array}$ & 1-5 Likert scale & $\begin{array}{l}\text { Attitude factors presented in } \\
\text { Table } 3\end{array}$ \\
\hline $\begin{array}{l}\text { Which of the following lifestyle statements are } \\
\text { relevant for you? }\end{array}$ & Multiple choice & $\begin{array}{c}\text { Lifestyle factors presented in } \\
\text { Table } 4\end{array}$ \\
\hline $\begin{array}{l}\text { To which extent do you prefer the following } \\
\text { nutrition claims while shopping? }\end{array}$ & 1-5 Likert scale & $\begin{array}{l}\text { Nutrition claims presented in } \\
\text { Figure } 1\end{array}$ \\
\hline $\begin{array}{l}\text { How much do you think the consumption of } \\
\text { the following foods contribute to your health? }\end{array}$ & 1-5 Likert scale & Carrier foods presented in Figure 3 \\
\hline $\begin{array}{l}\text { How important is it for you that a "healthy } \\
\text { food" has the following properties? }\end{array}$ & 1-5 Likert scale & $\begin{array}{c}\text { Sustainability factors presented in } \\
\text { Table } 8\end{array}$ \\
\hline Which health problems do you worry about? & $\begin{array}{l}\text { Not concerned/ } \\
\text { Concerned }\end{array}$ & $\begin{array}{l}\text { Health-related problems presented } \\
\text { in Figure } 5\end{array}$ \\
\hline $\begin{array}{l}\text { Would you choose "healthier foods" to prevent } \\
\text { or mitigate the following health problems? }\end{array}$ & Yes/No & \\
\hline \multicolumn{3}{|c|}{ Socio-demographic parameters presented in Tables 1 and 2.} \\
\hline
\end{tabular}




\section{References}

1. World Health Organization. Noncommunicable Diseases Country Profiles 2018. Available online: https: //www.who.int/nmh/publications/ncd-profiles-2018/en/ (accessed on 18 February 2020).

2. World Health Organization Global Health Estimates 2016: Death by Cause, Age, Sex, by Country and by Region, 2000-2016. Geneva. Available online: https://www.who.int/healthinfo/global_burden_disease/ estimates/en/index1.html (accessed on 18 February 2020).

3. World Health Organization Diet, Nutrition, and the Prevention of Chronic Diseases: Report of a Joint WHO/FAO Expert Consultation. Available online: https://www.who.int/dietphysicalactivity/publications/ trs916/en/ (accessed on 18 February 2020).

4. Jankovic, N.; Geelen, A.; Streppel, M.T.; de Groot, L.C.P.G.M.; Orfanos, P.; van den Hooven, E.H.; Pikhart, H.; Boffetta, P.; Trichopoulou, A.; Bobak, M.; et al. Adherence to a Healthy Diet According to the World Health Organization Guidelines and All-Cause Mortality in Elderly Adults From Europe and the United States. Am. J. Epidemiol. 2014, 180, 978-988. [CrossRef] [PubMed]

5. Kiss, A.; Popp, J.; Oláh, J.; Lakner, Z. The Reform of School Catering in Hungary: Anatomy of a Health-Education Attempt. Nutrients 2019, 11, 716. [CrossRef] [PubMed]

6. World Health Organization. World health statistics 2019: Monitoring Health for the SDGs, Sustainable Development Goals. Available online: https://www.who.int/gho/publications/world_health_statistics/2019/ en/ (accessed on 18 February 2020).

7. OECD/European Observatory on Health Systems and Policies (2017), Hungary: Country Health Profile 2017, State of Health in the EU, OECD Publishing, Paris/European Observatory on Health Systems and Policies, Brussels. Available online: http://dx.doi.org/10.1787/9789264283411-en (accessed on 18 February 2020).

8. Eurostat Healthy Life Years statistics-Statistics Explained. Available online: https://ec.europa.eu/eurostat/ statistics-explained/index.php?title=Healthy_life_years_statistics\#Healthy_life_years_at_birth (accessed on 18 February 2020).

9. Eurostat. Ageing Europe —Looking at the Lives of Older People in the EU, Statistical books, 2019th ed.; Publications Office of the European Union: Luxembourg, 2019; ISBN 978-92-76-09815-7.

10. Barabási, A.-L.; Menichetti, G.; Loscalzo, J. The unmapped chemical complexity of our diet. Nat. Food 2019, 1, 33-37. [CrossRef]

11. Jacobs, D.R.; Tapsell, L.C. Food synergy: The key to a healthy diet. Proc. Nutr. Soc. 2013, 72, 200-206. [CrossRef] [PubMed]

12. Giacalone, D.; Wendin, K.; Kremer, S.; Frøst, M.B.; Bredie, W.L.P.; Olsson, V.; Otto, M.H.; Skjoldborg, S.; Lindberg, U.; Risvik, E. Health and quality of life in an aging population - Food and beyond. Food Qual. Prefer. 2016, 47, 166-170. [CrossRef]

13. Vermeir, I.; Verbeke, W. Sustainable Food Consumption: Exploring the Consumer "Attitude - Behavioral Intention" Gap. J. Agric. Environ. Ethics 2006, 19, 169-194. [CrossRef]

14. Reisch, L.; Eberle, U.; Lorek, S. Sustainable food consumption: An overview of contemporary issues and policies. Sustain. Sci. Pract. Policy 2013, 9, 7-25. [CrossRef]

15. Popp, J.; Oláh, J.; Kiss, A.; Lakner, Z. Food Security Perspectives in Sub-Saharan Africa. Amfiteatru Econ. J. 2019, 21, 361-376. [CrossRef]

16. Benedetti, I.; Laureti, T.; Secondi, L. Choosing a healthy and sustainable diet: A three-level approach for understanding the drivers of the Italians' dietary regime over time. Appetite 2018, 123, 357-366. [CrossRef]

17. EAT-Lancet Commission. Food Planet Health - Healthy Diets from Sustainable Food Systems. Available online: https://eatforum.org/eat-lancet-commission/eat-lancet-commission-summary-report/ (accessed on 18 February 2020).

18. Siró, I.; Kápolna, E.; Kápolna, B.; Lugasi, A. Functional food. Product development, marketing and consumer acceptance-A review. Appetite 2008, 51, 456-467.

19. Menrad, K. Market and marketing of functional food in Europe. J. Food Eng. 2003, 56, 181-188. [CrossRef]

20. Bigliardi, B.; Galati, F. Innovation trends in the food industry: The case of functional foods. Trends Food Sci. Technol. 2013, 31, 118-129. [CrossRef]

21. Urala, N.; Lähteenmäki, L. Reasons behind consumers' functional food choices. Nutr. Food Sci. 2003, 33, 148-158. [CrossRef] 
22. European Commission. Regulation (EC) No 1924/2006 of the European Parliament and of the Council of 20 December 2006 on Nutrition and Health Claims Made on Foods. Available online: https://eur-lex.europa.eu/ legal-content/EN/TXT/PDF/?uri=CELEX:02006R1924-20141213 (accessed on 18 February 2020).

23. European Union. Commission Regulation (EU) No 432/2012 of 16 May 2012 Establishing a List of Permitted Health Claims Made on Foods, other than Those Referring to the Reduction of Disease Risk and to Children's Development and Health. Available online: https://eur-lex.europa.eu/legal-content/EN/TXT/HTML/?uri= CELEX:32012R0432\&from=EN (accessed on 18 February 2020).

24. Verhagen, H.; Vos, E.; Francl, S.; Heinonen, M.; van Loveren, H. Status of nutrition and health claims in Europe. Arch. Biochem. Biophys. 2010, 501, 6-15. [CrossRef]

25. Verhagen, H.; van Loveren, H. Status of nutrition and health claims in Europe by mid 2015. Trends Food Sci. Technol. 2016, 56, 39-45. [CrossRef]

26. Hilliam, M. The Market for Functional Foods. Int. Dairy J. 1998, 8, 349-353. [CrossRef]

27. Gilbert, L.C. The functional food trend: What's next and what Americans think about eggs. J. Am. Coll. Nutr. 2000, 19, 507S-512S. [CrossRef]

28. Childs, N.M. Functional foods and the food industry: Consumer, economic and product development issues. J. Nutraceuticals Funct. Med. Foods 1997, 1, 25-43. [CrossRef]

29. Verbeke, W. Consumer acceptance of functional foods: Socio-demographic, cognitive and attitudinal determinants. Food Qual. Prefer. 2005, 16, 45-57. [CrossRef]

30. Bech-Larsen, T.; Grunert, K.G. The perceived healthiness of functional foods: A conjoint study of Danish, Finnish and American consumers' perception of functional foods. Appetite 2003, 40, 9-14. [CrossRef]

31. Landström, E.; Hursti, U.-K.K.; Becker, W.; Magnusson, M. Use of functional foods among Swedish consumers is related to health-consciousness and perceived effect. Br. J. Nutr. 2007, 98, 1058-1069. [CrossRef] [PubMed]

32. Niva, M. 'All foods affect health': Understandings of functional foods and healthy eating among health-oriented Finns. Appetite 2007, 48, 384-393. [CrossRef] [PubMed]

33. Urala, N.; Lähteenmäki, L. Consumers' changing attitudes towards functional foods. Food Qual. Prefer. 2007, 18, 1-12. [CrossRef]

34. Szakály, Z.; Szente, V.; Kövér, G.; Polereczki, Z.; Szigeti, O. The influence of lifestyle on health behavior and preference for functional foods. Appetite 2012, 58, 406-413. [CrossRef]

35. Van Kleef, E.; van Trijp, H.C.; Luning, P. Functional foods: Health claim-food product compatibility and the impact of health claim framing on consumer evaluation. Appetite 2005, 44, 299-308. [CrossRef]

36. Van Trijp, H.C.; Van der Lans, I.A. Consumer perceptions of nutrition and health claims. Appetite 2007, 48, 305-324. [CrossRef]

37. Behrens, J.H.; Villanueva, N.D.; Da Silva, M.A. Effect of nutrition and health claims on the acceptability of soyamilk beverages. Int. J. Food Sci. Technol. 2007, 42, 50-56. [CrossRef]

38. Urala, N.; Arvola, A.; Lähteenmäki, L. Strength of health-related claims and their perceived advantage. Int. J. Food Sci. Technol. 2003, 38, 815-826. [CrossRef]

39. Banovic, M.; Arvola, A.; Pennanen, K.; Duta, D.E.; Brückner-Gühmann, M.; Lähteenmäki, L.; Grunert, K.G. Foods with increased protein content: A qualitative study on European consumer preferences and perceptions. Appetite 2018, 125, 233-243. [CrossRef]

40. Verbeke, W.; Scholderer, J.; Lähteenmäki, L. Consumer appeal of nutrition and health claims in three existing product concepts. Appetite 2009, 52, 684-692. [CrossRef]

41. Wortmann, L.; Enneking, U.; Daum, D. German Consumers' Attitude towards Selenium-Biofortified Apples and Acceptance of Related Nutrition and Health Claims. Nutrients 2018, 10, 190. [CrossRef] [PubMed]

42. Micale, R.; Giallanza, A.; Russo, G.; La Scalia, G. Selection of a Sustainable Functional Pasta Enriched with Opuntia Using ELECTRE III Methodology. Sustainability 2017, 9, 885. [CrossRef]

43. Sagan, A.; Blicharz-Kania, A.; Szmigielski, M.; Andrejko, D.; Sobczak, P.; Zawiślak, K.; Starek, A. Assessment of the Properties of Rapeseed Oil Enriched with Oils Characterized by High Content of $\alpha$-linolenic Acid. Sustainability 2019, 11, 5638. [CrossRef]

44. Annunziata, A.; Vecchio, R. Consumer perception of functional foods: A conjoint analysis with probiotics. Food Qual. Prefer. 2013, 28, 348-355. [CrossRef]

45. van der Zanden, L.D.; van Kleef, E.; de Wijk, R.A.; van Trijp, H.C. Knowledge, perceptions and preferences of elderly regarding protein-enriched functional food. Appetite 2014, 80, 16-22. [CrossRef] 
46. van der Zanden, L.D.; van Kleef, E.; de Wijk, R.A.; van Trijp, H.C. Understanding heterogeneity among elderly consumers: An evaluation of segmentation approaches in the functional food market. Nutr. Res. Rev. 2014, 27, 159-171. [CrossRef]

47. van der Zanden, L.D.; van Kleef, E.; de Wijk, R.A.; van Trijp, H.C. Examining heterogeneity in elderly consumers' acceptance of carriers for protein-enriched food: A segmentation study. Food Qual. Prefer. 2015, 42, 130-138. [CrossRef]

48. Doma, K.M.; Farrell, E.L.; Leith-Bailey, E.R.; Soucier, V.D.; Duncan, A.M. Older Adults' Awareness and Knowledge of Beans in Relation to Their Nutrient Content and Role in Chronic Disease Risk. Nutrients 2019, 11, 2680. [CrossRef]

49. Collins Orla; Bogue Joe Designing health promoting foods for the ageing population: A qualitative approach. Br. Food J. 2015, 117, 3003-3023. [CrossRef]

50. Plasek, B.; Lakner, Z.; Kasza, G.; Temesi, Á. Consumer Evaluation of the Role of Functional Food Products in Disease Prevention and the Characteristics of Target Groups. Nutrients 2020, 12, 69. [CrossRef]

51. Temesi, Á.; Bacsó, Á.; Grunert, K.G.; Lakner, Z. Perceived correspondence of health effects as a new determinant influencing purchase intention for functional food. Nutrients 2019, 11, 740. [CrossRef] [PubMed]

52. Dávid Szakos; Ózsvári László; Kasza Gyula Consumer demand analysis in the Hungarian functional food market focused on the main health problems. Gradus 2020, 7, 62-66.

53. Hungarian Central Statistical Office (HCSO). Hungarian Census Data 2016. Available online: https: //www.ksh.hu/mikrocenzus2016/kotet_3_demografiai_adatok (accessed on 18 February 2020).

54. Clason, D.L.; Dormody, T.J. Analyzing data measured by individual Likert-type items. J. Agric. Educ. 1994, 35, 4. [CrossRef]

55. Grafen, A.; Hails, R. Modern Statistics for the Life Sciences, 2002nd ed.; Oxford University Press: Oxford, UK, 2002; Volume 351.

56. Hooker, N.H.; Teratanavat, R. Dissecting Qualified Health Claims: Evidence from Experimental Studies. Crit. Rev. Food Sci. Nutr. 2008, 48, 160-176. [CrossRef] [PubMed]

57. Ares, G.; Gámbaro, A. Influence of gender, age and motives underlying food choice on perceived healthiness and willingness to try functional foods. Appetite 2007, 49, 148-158. [CrossRef]

58. Williams, P.; Ridges, L.; Batterham, M.; Ripper, B.; Hung, M.C. Australian consumer attitudes to health claim—food product compatibility for functional foods. Food Policy 2008, 33, 640-643. [CrossRef]

59. Urala, N.; Lähteenmäki, L. Attitudes behind consumers' willingness to use functional foods. Food Qual. Prefer. 2004, 15, 793-803. [CrossRef]

60. Bimbo, F.; Bonanno, A.; Nocella, G.; Viscecchia, R.; Nardone, G.; De Devitiis, B.; Carlucci, D. Consumers' acceptance and preferences for nutrition-modified and functional dairy products: A systematic review. Appetite 2017, 113, 141-154. [CrossRef]

61. Messina, F.; Saba, A.; Turrini, A.; Raats, M.; Lumbers, M. Older people's perceptions towards conventional and functional yoghurts through the repertory grid method: A cross-country study. Br. Food J. 2008, 110, 790-804. [CrossRef]

62. Cavaliere, A.; Ricci, E.C.; Banterle, A. Nutrition and health claims: Who is interested? An empirical analysis of consumer preferences in Italy. Food Qual. Prefer. 2015, 41, 44-51. [CrossRef]

63. European Hearth Network European Cardiovascular Disease Statistics 2017. Available online: http: //www.ehnheart.org/cvd-statistics.html (accessed on 18 February 2020).

64. Grunert, K.G.; Hieke, S.; Wills, J. Sustainability labels on food products: Consumer motivation, understanding and use. Food Policy 2014, 44, 177-189. [CrossRef]

65. Wilkins, J.L. Seasonality, food origin, and food preference: A comparison between food cooperative members and nonmembers. J. Nutr. Educ. 1996, 28,329-337. [CrossRef]

(C) 2020 by the authors. Licensee MDPI, Basel, Switzerland. This article is an open access article distributed under the terms and conditions of the Creative Commons Attribution (CC BY) license (http://creativecommons.org/licenses/by/4.0/). 


\title{
Salmon Intake Intervention in the Vulnerable Group of Young Polish Women to Maintain Vitamin D Status during the Autumn Season
}

\author{
Zofia Utri and Dominika Głąbska * \\ Department of Dietetics, Institute of Human Nutrition Sciences, Warsaw University of Life \\ Sciences (SGGW-WULS), 159c Nowoursynowska Street, 02-776 Warsaw, Poland; zofia_utri@mail.sggw.pl \\ * Correspondence: dominika_glabska@sggw.pl; Tel.: +48-22-593-71-26
}

Received: 1 March 2020; Accepted: 30 March 2020; Published: 2 April 2020

\begin{abstract}
Fish products are the main dietary source of vitamin D, but due to a low fish intake in the majority of European countries, an inadequate vitamin D intake is common, especially in the vulnerable group of young women for whom it is essential for the osteoporosis prevention. The aim of the presented study was to assess the possibility of applying salmon intake intervention for maintaining vitamin D status in young Polish women during the autumn season, in which in Poland there is not enough sunshine exposure to generate skin synthesis. The dietary intervention within VISA Study (Vitamin D In Salmon) comprised eight weeks of daily consumption of $50 \mathrm{~g}$ of Atlantic salmon and was conducted in a group of 47 women aged 20-30 years. Within the study, their changes of total serum 25-hydroxyvitamin $\mathrm{D}(25(\mathrm{OH}) \mathrm{D})$ levels were analyzed and the effectiveness of the intervention depending on age, body mass index (BMI), and baseline $25(\mathrm{OH}) \mathrm{D}$ were assessed. Until the 4th week, 25(OH)D in the studied group decreased from $57.1 \mathrm{nmol} / \mathrm{L}$ to $39.9 \mathrm{nmol} / \mathrm{L}$ $(p<0.0001)$, but afterward it increased until the 8 th week to $54.1 \mathrm{nmol} / \mathrm{L}(p=0.0005)$, contributing to results not differing from the baseline $(p=0.7964)$. At the same time, the share of respondents characterized by an inadequate vitamin D status increased until the 4th week, but afterward, it decreased until the 8 th week $(p=0.0002)$. Neither the age (in the assessed range), nor the BMI influenced $25(\mathrm{OH}) \mathrm{D}$ during the study, but only the baseline $25(\mathrm{OH}) \mathrm{D}$ was correlated with the BMI $(p=0.0419 ; \mathrm{R}=-0.2980)$. The baseline $25(\mathrm{OH}) \mathrm{D}$ was associated with its levels during the intervention, as well as with $25(\mathrm{OH}) \mathrm{D}$ change from the baseline values $(p<0.0001)$. It may be concluded that, in spite of the initial decline of the $25(\mathrm{OH}) \mathrm{D}$ observed (probably connected to the starting time of the study), afterward the salmon intake intervention contributed to its increase, while the baseline $25(\mathrm{OH}) \mathrm{D}$ status was an important determinant of the intervention effectiveness during the autumn season.
\end{abstract}

Keywords: vitamin D; dietary intake; dietary intervention; fish intake; salmon; 25-OH-cholecalciferol; 25-hydroxyvitamin D; 25(OH)D; young women

\section{Introduction}

Vitamin D is of the highest importance for the skeletal system, promoting calcium and phosphorus absorption in the gut, maintaining their adequate concentrations, and for bone growth and remodeling by osteoblasts and osteoclasts [1]. Studies also suggest an association between vitamin D status or intake and various diseases and disorders. Recent meta-analyses show that vitamin D deficiency is associated with a higher risk of sleep disorders [2] and may be related to autoimmune thyroid disease [3], whereas high vitamin D serum levels have a protective effect on breast cancer in premenopausal women [4]. They also indicate that vitamin D supplementation significantly reduces cancer mortality [5], as well as the rate of asthma exacerbations [6]. Taking it into account, scientists agree that vitamin D goes beyond influencing bone health only $[7,8]$. 
However, vitamin D status is a global problem. Based on protocols of the Vitamin D Standardization Program (VDSP) by National Institutes of Health (NIH) [9], the analysis of data for 14 European countries indicated the prevalence of vitamin D deficiency of 13\% [10], while defined by the United States (US) Institute of Medicine (IoM) and the United Kingdom National Osteoporosis Society (NOS) as serum 25-hydroxyvitamin D (25(OH)D) level lower than $30 \mathrm{nmol} / \mathrm{L}$ (12 ng/mL, $1 \mathrm{nmol} / \mathrm{L}=0.4 \mathrm{ng} / \mathrm{mL})$ [11,12]. At the same time, for the alternate threshold for vitamin D deficiency of serum 25(OH)D level lower than $50 \mathrm{nmol} / \mathrm{L}$, which is suggested by the US Endocrine Society [13], European Food Safety Authority (EFSA) [14] and Polish recommendations [15], the prevalence was 40.4\% [10]. Among healthy adolescents, the prevalence of vitamin D deficiency $(25(\mathrm{OH}) \mathrm{D}$ level lower than $50 \mathrm{nmol} / \mathrm{L}$ ) sometimes reaches even $42 \%$ [16] and in teenage girls living in northern Europe, in the winter season, even $92 \%$ [17]. In young women aged 18-29 years living in France, the prevalence of vitamin D deficiency $(25(\mathrm{OH}) \mathrm{D}$ level lower than $50 \mathrm{nmol} / \mathrm{L})$ amounts to $48.4 \%$ and is the highest among female groups [18].

The main source of vitamin $D$ is the skin synthesis of cholecalciferol from 7-dehydrocholesterol [19] as a result of UVB radiation (290-320 nm) from sunshine exposure, which depends on the latitude, the season, and the time of the day [7]. In countries such as Poland, which are situated in a moderate climate, endogenous vitamin D synthesis is possible from April to October only [20]. The other source of vitamin D is dietary intake - mainly from animal products, especially from fatty fish [21]. However, the vitamin D content in fish species differs significantly—in Poland, from $30 \mu \mathrm{g} / 100 \mathrm{~g}$ for eel, $19 \mu \mathrm{g} / 100 \mathrm{~g}$ for herring, and $13 \mu \mathrm{g} / 100 \mathrm{~g}$ for salmon to $1 \mu \mathrm{g} / 100 \mathrm{~g}$ for cod and $0.8 \mu \mathrm{g} / 100 \mathrm{~g}$ for flounder [22].

Due to a low fish intake in most European countries [23], inadequate vitamin D intake has been observed for years [19]. In Poland, it has been reported that for women the average vitamin $\mathrm{D}$ intake is $3.3 \mu \mathrm{g}$ [24], whereas the most prominent recommendations indicate at least $10 \mu \mathrm{g}$ as the reference intake of vitamin $\mathrm{D}$ for adults $[11,25,26]$. The problem of inadequate vitamin $\mathrm{D}$ intake is most serious when it comes to women under 30 years of age, since this is the group in which the intake of vitamin D is the lowest according to the 2003-2006 National Health and Nutrition Examination Survey (NHANES) [27]. Moreover, until the age of 30, the maximum bone density and peak bone mass are reached [28], which is influenced by vitamin D, so obtaining adequate vitamin D intake and status would be especially important in that vulnerable group of young women.

In recent years, intervention studies with the aim of improving vitamin D status through fish intake increase have been conducted in various European countries [29]. Their efficacy differed depending on the studied group, the type of intervention (fish species, dose, frequency), and intervention duration. However, no effective and recommended intervention has been defined in order to improve vitamin D intake and status in young women. Taking this into account, the aim of the presented study was to assess the efficacy of salmon intake intervention on vitamin D status in young Polish women during autumn.

\section{Materials and Methods}

\subsection{Ethical Statement}

The VISA Study (Vitamin D In Salmon) was conducted according to the guidelines of the Declaration of Helsinki and it was approved by the Ethics Committee of the Faculty of Human Nutrition and Consumer Sciences of the Warsaw University of Life Sciences (No 27/2018).

\subsection{Studied Group}

The studied group of young women was recruited in a procedure of convenience sampling, with the snowball effect, while announced in university social media. The inclusion criteria were as follows:

- females,

- Caucasian, 
- $\quad$ aged 20-30 years,

- living in Warsaw or its surroundings (necessary to visit Dietetic Outpatient Clinic of the Department of Dietetics, Warsaw University of Life Sciences (WULS-SGGW) once a week for 8 weeks of the study duration),

- $\quad$ providing written informed consent to participate in the study.

The exclusion criteria were as follows:

- pregnancy,

- lactation,

- $\quad$ obesity, defined based on the criteria of the World Health Organization [30] as body mass index (BMI) $\geq 30 \mathrm{~kg} / \mathrm{m}^{2}$,

- fish and/or seafood allergy,

- following any diet with fish consumption restriction (e.g., vegetarian diet),

- $\quad$ vitamin D supplementation use up to 3 weeks before beginning of study and/or planned during study time,

- $\quad$ diseases and/or use of medicines changing vitamin D metabolism,

- $\quad$ planned travels to countries below the 40th parallel (countries with adequate sun exposure to obtain cutaneous vitamin D synthesis during study time),

- $\quad$ planned solarium use during study time.

In total, 51 individuals met the criteria and were included in the study and in this group the salmon intake intervention was conducted.

\subsection{Dietary Intervention}

The intervention study was designed to assess the efficacy of daily Atlantic farmed smoked salmon intake intervention on serum 25(OH)D level. All participants were enrolled in and finished the study at the same time. The fish intake intervention lasted from October 24, 2018 to December 18, 2018. The period of intervention was planned because from other studies it is known that in countries such as Poland, skin synthesis of vitamin D, which is the major source of the vitamin, is only possible from April to October [20], so it was decided to conduct the study directly after this period.

Atlantic farmed smoked salmon was chosen in the intervention as a source of vitamin D that is possible to be applied in practice, for numerous reasons. Salmon contains significant amounts of vitamin D $(17.1 \mu \mathrm{g} / 100 \mathrm{~g}$ for smoked salmon, based on United States Department of Agriculture-USDA food composition tables [31]) and is widely available on the Polish market, independently from the region of the country [32]. Moreover, Atlantic farmed salmon is a species that contains very little mercury $(\leq 0.1 \mu \mathrm{g} / \mathrm{g})$ and dioxins $(0.5-4 \mathrm{pg}$ Toxic Equivalent (TEQ)/g), so it is classified to the first and second group respectively when it comes to the smallest content of those contaminants [33]. The very high content of eicosapentaenoic acid (EPA) and docosahexaenoic acid (DHA) (>15 mg/g) also contributes to the Food and Agriculture Organization (FAO) of the United Nations and the World Health Organization (WHO) [33] recommending salmon as a fish species having much more benefits than risks.

The Atlantic farmed smoked salmon that was used for the study was obtained from one producer, one of the leading salmon sellers in Poland (Suempol Polska Ltd.), and for all the participants, the provided salmon was obtained from the same batch, in identical sliced tray modified atmosphere packaging.

Studies show a large variation in the content of vitamin D in salmon [34], therefore its content was measured in the smoked Atlantic salmon used in the study by a leading vitamin laboratory in Europe - Eurofins Vitamin Testing Denmark (EN 12821: 2009-08, LC-DAD, accredited methodology no. 581). The measured content of vitamin D was $21.3 \pm 5.55 \mu \mathrm{g} / 100 \mathrm{~g}$, which is higher than the value typical for smoked salmon, like the one shown in the Polish Food Composition Tables [22]. 
The daily intake was planned as $50 \mathrm{~g}$, so it was attributed to around $10.65 \mu \mathrm{g}$ of vitamin $\mathrm{D}$, which covers the recommended $10 \mu \mathrm{g}[11,25,26]$. Atlantic farmed smoked salmon was packed in $50 \mathrm{~g}$ portions to facilitate consuming 1 portion $(50 \mathrm{~g})$ each day. Participants were given 7 packages $(7 \times 50 \mathrm{~g})$ of smoked salmon once a week, for 8 weeks of the study duration. To increase adherence to intervention, participating women were asked to report their intake daily. Participants were asked to incorporate the given salmon in their daily food intake substituting it for other products such as meat, cheese, or eggs. They were not recommended to exclude other fish products from their diet, so if they had previously consumed them, they were recommended not to change this habit.

Participants had their serum 25(OH)D level measured three times: before the dietary intervention (at baseline ( $\mathrm{t} 0)$ ), after 4 weeks of dietary intervention ( $\mathrm{t} 4$ ), and after 8 weeks of intervention (after the study (t8)). The study course is shown in Figure 1.

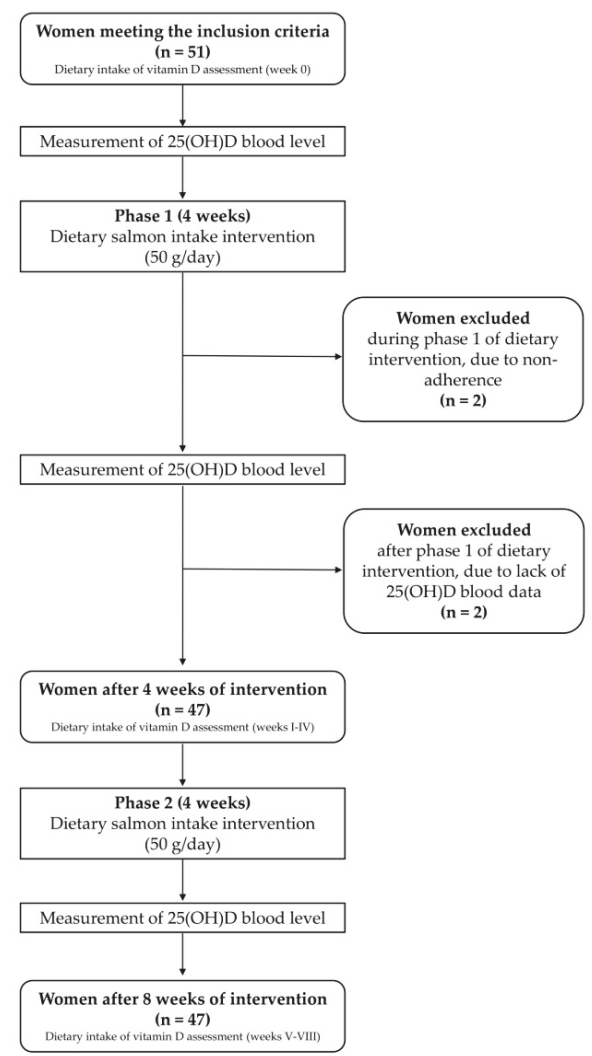

Figure 1. Study design and number of participants.

\subsection{Measurements}

Anthropometric measurements included body mass and height. Body mass was assessed using a calibrated weighing scale with an accuracy of $\pm 0.1 \mathrm{~kg}$ and body height was assessed using a stadiometer with an accuracy of $\pm 0.5 \mathrm{~cm}$. The measurements were conducted by a professional nutritionist, according to the recommended procedure [35]. Afterward, the BMI was calculated, based on the Quetelet equation and interpreted to verify the exclusion criteria [30].

Vitamin D status was assessed based on the total serum 25(OH)D level at baseline ( $\mathrm{t} 0)$, after 4 weeks of dietary intervention ( $t 4)$, and after 8 weeks of intervention ( $t 8)$. For the analysis, venous blood samples were drawn by a qualified nurse in a certified medical analysis laboratory in Warsaw, 
Poland; participants did not have to be in a fasting state before blood collection. Total serum 25(OH)D level tests were performed on BS Mindray BS-200 Chemistry Analyzer using Diazyme EZ Vitamin D assay and the dual vial liquid stable (latex enhanced immunoturbidimetric) method, which enabled determination of total 25(OH)D in the range of 19.0-369.5.8 nmol/L. For this method, a comparison of the EZ Vitamin D assay (y) using samples measured with LC-MS (liquid chromatography-mass spectrometry)/MS in the validation gave the following correlation: $y=1.0297 x-0.813$ for $R^{2}=0.9622$ and a comparison of the EZ Vitamin D assay using samples measured with a commercially available $25(\mathrm{OH}) \mathrm{D}$ immunoassay in the validation gave the following correlation: $\mathrm{y}=1.1537 \mathrm{x}-1.2321$ for $\mathrm{R}^{2}=0.9716$. The assay precision for the method is defined by percent coefficient of variation (\%CV) lower than $5 \%$ at $75 \mathrm{nmol} / \mathrm{L}$. The method is certified by the Centers for Disease Control and Prevention within the Vitamin D Standardization-Certification Program (CDC VDSCP) and meets the performance target set by the Vitamin D External Quality Assessment Scheme (DEQAS) advisory panel.

Each sample was assessed by the same person, in the same conditions, with the same equipment, and using exactly the same methodology, for each sample within 1 hour from drowing the blood samples. The obtained results of total serum $25(\mathrm{OH}) \mathrm{D}$ level were compared to the following reference values: $<50 \mathrm{nmol} / \mathrm{L}$-inadequate, 50-250 nmol/L_adequate, $>250 \mathrm{nmol} / \mathrm{L}$-potentially toxic $[11,25,36,37]$.

In order to provide the necessary safety precautions, during the whole experiment, participants had their vitamin $\mathrm{D}$ intake and blood pressure controlled. As the intervention comprised additional intake of vitamin D, the total vitamin D intake was controlled throughout the experiment, using the Vitamin D Estimation Only-Food Frequency Questionnaire (VIDEO-FFQ), which was previously validated in a group of Polish women aged 20-30 years [38]. Afterward, the obtained vitamin D intake was compared with the upper intake level (UL) of $100 \mu \mathrm{g}$ [14]. At the same time, because of high salt content in smoked salmon $(1.5 \mathrm{~g} / 50 \mathrm{~g})$, the blood pressure of participants was controlled throughout the experiment (once a week), using Omron Healthcare BP 710N blood pressure monitor, according to the recommended procedure [39]. The observed systolic and diastolic blood pressure values were compared with the standard reference values of $140 \mathrm{mmHg}$ and $90 \mathrm{mmHg}$, respectively, and the increase of blood pressure above the recommended values observed during two following weeks was decided to be interpreted as a reason to suspend participation in the experiment. Neither for vitamin D intake, nor for blood pressure were the excessive values stated, so it was interpreted as obtaining the required safety of dietary intervention.

\subsection{Statistical Analysis}

The distribution of the obtained values was verified using Shapiro-Wilk test. The groups were compared using the t-Student test (for parametric distributions), the Mann-Whitney U test, and the Kruskal-Wallis Analysis of Variance (ANOVA) with multiple comparisons (for non-parametric distributions), as well as the chi ${ }^{2}$ test. The correlations were verified using Pearson correlation coefficient (for parametric distributions) and Spearman rank correlation coefficient (for non-parametric distributions).

The accepted level of significance was $p \leq 0.05$. The following software was used: Statistica 8.0 (Statsoft Inc., Tulsa, OK, USA), Statgraphics Plus for Windows 4.0 (Statgraphics Technologies Inc., The Plains, VA, USA).

\section{Results}

The characteristics of the studied group and vitamin D status throughout the intervention are presented in Table 1. While comparing the serum 25(OH)D level, it was stated that the results differed throughout the study ( $p=0.0001$; Kruskal-Wallis ANOVA), but for multiple comparisons, it was stated that the results after 8 weeks of intervention did not differ from the results at baseline $(p=0.7964)$. However, during phase I of the study (weeks I-IV), a significant decrease of serum 25(OH)D level was observed ( $p<0.0001$ for the comparison of $\mathrm{t} 0$ and $\mathrm{t} 4$ results), whereas during phase II (weeks V-VIII), a significant increase was noted ( $p=0.0005$ for the comparison of $t 4$ and $t 8$ results). 
Table 1. Characteristics of the studied group accompanied by vitamin D status throughout the study.

\begin{tabular}{cccc}
\hline & Variables & Mean \pm SD & Median (Min-Max) \\
\hline \multirow{2}{*}{ Characteristics } & Age $($ years $)$ & $22.9 \pm 1.6$ & $23.0 *(20.0-28.0)$ \\
& BMI $\left(\mathrm{kg} / \mathrm{m}^{2}\right)$ & $21.43 \pm 2.49$ & $21.27(16.92-27.96)$ \\
\multirow{2}{*}{ Serum level } & 25(OH)D for t0 $(\mathrm{nmol} / \mathrm{L})$ & $58.4 \pm 20.2$ & $57.1(19.7-93.1)$ \\
& 25(OH)D for t4 $(\mathrm{nmol} / \mathrm{L})$ & $41.2 \pm 14.1$ & $39.9 *(15.1-90.3)$ \\
Change of serum level & 25(OH)D for t8 $(\mathrm{nmol} / \mathrm{L})$ & $52.5 \pm 11.4$ & $54.1(25.6-72.9)$ \\
& 25(OH)D change from t0 to t4 $(\mathrm{nmol} / \mathrm{L})$ & $-17.2 \pm 13.9$ & $-16.7(-44.5-11.4)$ \\
& 25(OH)D change from t4 to t8 $(\mathrm{nmol} / \mathrm{L})$ & $11.3 \pm 12.2$ & $8,8 *(-18.5-38.8)$ \\
& 25(OH)D change from t0 to t8 $(\mathrm{nmol} / \mathrm{L})$ & $-6.0 \pm 16.1$ & $-8.1(-36.8-24.2)$ \\
\hline
\end{tabular}

* non-parametric distribution (verified using Shapiro-Wilk test; $p \leq 0.05$ ); 25(OH)D-25-hydroxyvitamin D;

t0 - baseline; $\mathrm{t} 4$-after 4 weeks of intervention; t 8 -after 8 weeks of intervention.

The dietary vitamin D intake in the studied group throughout the study is presented in Table 2. It was observed that, at baseline, the dietary intake of vitamin D was significantly lower than those assessed after four weeks of intervention $(p<0.0001)$, as well as after eight weeks of intervention $(p<0.0001)$. At the same time, the dietary intakes of vitamin D assessed after four weeks of intervention and those assessed after eight weeks of intervention did not differ $(p=0.5758)$.

Table 2. Dietary vitamin D intake in the studied group throughout the study.

\begin{tabular}{lcccc}
\hline \multicolumn{2}{c}{ Variables } & Mean \pm SD & $\begin{array}{c}\text { Median } \\
\text { (Min-Max) }\end{array}$ & $p$ \\
\hline \multirow{3}{*}{ Intake for $\mathrm{t} 0(\mu \mathrm{g})$} & Total & $3.02 \pm 1.36$ & $2.79 *(1.04-7.74)$ & - \\
& $25(\mathrm{OH}) \mathrm{D}<50 \mathrm{nmol} / \mathrm{L}$ & $3.02 \pm 1.63$ & $2.66 *(1.04-7.74)$ & 0.7510 \\
& $25(\mathrm{OH}) \mathrm{D} \geq 50 \mathrm{nmol} / \mathrm{L}$ & $3.02 \pm 1.20$ & $2.90 *(1.09-5.99)$ & - \\
Intake for $\mathrm{t} 4(\mu \mathrm{g})$ & Total & $10.08 \pm 1.34$ & $9.82 *(7.84-13.91)$ & - \\
& $25(\mathrm{OH}) \mathrm{D}<50 \mathrm{nmol} / \mathrm{L}$ & $9.88 \pm 1.26$ & $9.73 *(7.84-13.15)$ & 0.0515 \\
& $25(\mathrm{OH}) \mathrm{D} \geq 50 \mathrm{nmol} / \mathrm{L}$ & $10.73 \pm 1.46$ & $10.65 *(8.62-13.91)$ & - \\
Intake for $\mathrm{t} 8(\mu \mathrm{g})$ & Total & $9.85 \pm 1.96$ & $9.71 *(1.81-13.82)$ & - \\
& $25(\mathrm{OH}) \mathrm{D}<50 \mathrm{nmol} / \mathrm{L}$ & $9.44 \pm 2.43$ & $9.59 *(1.81-13.82)$ & 0.3411 \\
\hline & $25(\mathrm{OH}) \mathrm{D} \geq 50 \mathrm{nmol} / \mathrm{L}$ & $10.11 \pm 1.60$ & $9.89 *(6.77-12.78)$ & \\
\hline
\end{tabular}

* non-parametric distribution (verified using Shapiro-Wilk test; $p \leq 0.05$ ); t0—baseline; t4-after 4 weeks of intervention; t8-after 8 weeks of intervention.

The assessment of the adequacy of vitamin D status throughout the study is presented in Table 3. While comparing the share of participants characterized by adequate and inadequate serum $25(\mathrm{OH}) \mathrm{D}$ level, it was stated that it did not differ between baseline assessment and assessment after eight weeks of intervention ( $p=1.0000, \mathrm{chi}^{2}$ ). At the same time, the share of respondents characterized by inadequate serum 25(OH)D levels increased during phase I of the study ( $p=0.0002$ for the comparison of $\mathrm{t} 0$ and $\mathrm{t} 4$ shares, $\left.\mathrm{chi}^{2}\right)$, but decreased during phase II ( $p=0.0002$ for the comparison of $\mathrm{t} 4$ and $\mathrm{t} 8$ shares, $\left.\mathrm{chi}^{2}\right)$.

Table 3. Assessment of adequacy of vitamin D status throughout the study while compared with the reference values.

\begin{tabular}{|c|c|c|c|}
\hline & \multicolumn{3}{|c|}{ Serum 25-hydroxyvitamin D level } \\
\hline & $\begin{array}{c}\text { Inadequate } \\
(<50 \mathrm{nmol} / \mathrm{L}) *\end{array}$ & $\begin{array}{c}\text { Adequate } \\
(50-250 \mathrm{nmol} / \mathrm{L}) \text { * }\end{array}$ & $\begin{array}{l}\text { Potentially Toxic } \\
(>250 \mathrm{nmol} / \mathrm{L}) \text { * }\end{array}$ \\
\hline Before intervention & $18(38 \%)$ & $29(62 \%)$ & $0(0 \%)$ \\
\hline After 4 weeks of intervention & $36(77 \%)$ & $11(23 \%)$ & $0(0 \%)$ \\
\hline After 8 weeks of intervention & $18(38 \%)$ & $29(62 \%)$ & $0(0 \%)$ \\
\hline
\end{tabular}

${ }^{*}$ reference values of $50 \mathrm{nmol} / \mathrm{L}$ and $250 \mathrm{nmol} / \mathrm{L}[11,25,36,37]$. 
The analysis of correlations between age or BMI and vitamin D status throughout the study are presented in Table 4. It was stated that neither age nor BMI influenced 25(OH)D level during the study, as well as its changes, apart from the baseline $25(\mathrm{OH}) \mathrm{D}$ level which was significantly correlated with $\operatorname{BMI}(p=0.0419 ; \mathrm{R}=-0.2980)$.

Table 4. Analysis of correlations between age, or BMI, and vitamin D status throughout the study.

\begin{tabular}{cccccc}
\hline \multirow{2}{*}{ Variables } & \multicolumn{2}{c}{ Age } & \multicolumn{2}{c}{ BMI } \\
\cline { 3 - 6 } & & $p$ & $\mathbf{R}$ & $p$ & R \\
\hline \multirow{3}{*}{ Serum level } & 25(OH)D for t0 (nmol/L) & 0.0880 & -0.2512 & $0.0419 *$ & -0.2980 \\
& 25(OH)D for t4 (nmol/L) & $0.5753 *$ & -0.0838 & $0.0663 *$ & -0.2701 \\
Change of & 25(OH)D for t8 (nmol/L) & 0.2300 & -0.1786 & $0.4038^{*}$ & -0.1247 \\
serum level & 25(OH)D change from t0 to t4 (nmol/L) & 0.4630 & 0.1096 & $0.3604 *$ & 0.1364 \\
& 25(OH)D change from t4 to t8 (nmol/L) & $0.4387 *$ & 0.1157 & $0.4776 *$ & 0.1062 \\
& 25(OH)D change from t0 to t8 (nmol/L) & 0.2010 & -0.1897 & $0.1362 *$ & 0.2206 \\
\hline
\end{tabular}

* Spearman rank correlation coefficient for non-parametric distributions (for parametric distribution Pearson correlation coefficient applied); $25(\mathrm{OH}) \mathrm{D}$-25-hydroxyvitamin $\mathrm{D}$; t0-baseline; 4 -after 4 weeks of intervention; t8-after 8 weeks of intervention.

The analysis of correlations between vitamin D status before the intervention and its later levels and changes throughout the study is presented in Table 5. It was stated that the $25(\mathrm{OH}) \mathrm{D}$ level before the intervention was associated with its levels during the intervention $(p<0.0001)$. It was also associated with $25(\mathrm{OH}) \mathrm{D}$ changes from the baseline values $(p<0.0001)$, but not with the following changes (from $t 4$ to $\mathrm{t} 8$ ).

Table 5. Analysis of correlations between vitamin D status before intervention and its later levels and changes throughout the study.

\begin{tabular}{cccc}
\hline & Variables & $p$ & $\mathbf{R}$ \\
\hline \multirow{2}{*}{ Serum level } & 25(OH)D for t4 $(\mathrm{nmol} / \mathrm{L})$ & $<0.0001^{*}$ & 0.7474 \\
& 25(OH)D for t8 $(\mathrm{nmol} / \mathrm{L})$ & $<0.0001$ & 0.6089 \\
\multirow{3}{*}{ Change of serum level } & $<5(\mathrm{OH})$ D change from t0 to t4 $(\mathrm{nmol} / \mathrm{L})$ & $<0.0001$ & -0.7154 \\
& 25(OH)D change from t4 to t8 $(\mathrm{nmol} / \mathrm{L})$ & $0.1257^{*}$ & -0.2265 \\
& 25(OH)D change from t0 to t8 $(\mathrm{nmol} / \mathrm{L})$ & $<0.0001$ & -0.8274 \\
\hline
\end{tabular}

* Spearman rank correlation coefficient for non-parametric distributions (for parametric distribution Pearson correlation coefficient applied); $25(\mathrm{OH}) \mathrm{D}$-25-hydroxyvitamin $\mathrm{D}$; t0 - baseline; t4-after 4 weeks of intervention; t8 - after 8 weeks of intervention.

The comparison of the vitamin D status throughout the study between subgroups characterized by various baseline statuses is presented in Table 6 .

For the serum 25(OH)D level, all differences were statistically significant $(p \leq 0.05)$ and higher levels were observed for participants characterized by adequate baseline status. However, for the serum $25(\mathrm{OH}) \mathrm{D}$ level, for participants characterized by inadequate baseline status, lower decreases from $\mathrm{t} 0$ to $t 4$ and higher increases from $t 4$ to $t 8$ were noted, when compared to participants with adequate baseline status. 


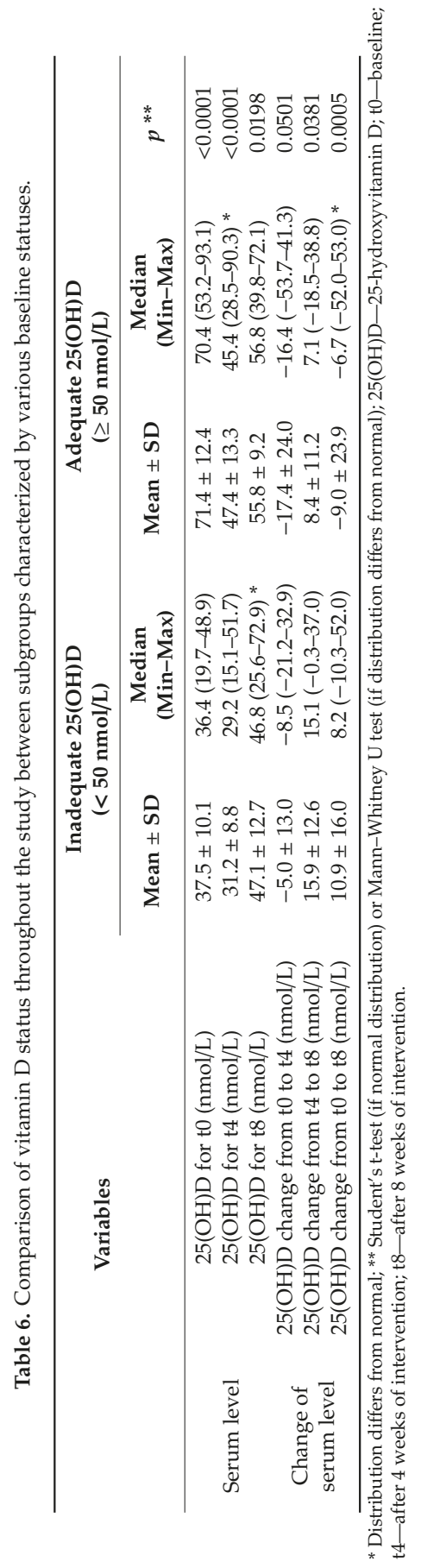




\section{Discussion}

In the presented study, it was stated that the baseline $25(\mathrm{OH}) \mathrm{D}$ level had a profound impact on the changes observed after the intervention, so it may be concluded that the efficacy of the applied dietary intervention of daily salmon intake depends on the baseline $25(\mathrm{OH}) \mathrm{D}$ level. In the total studied group, the median change after eight weeks of intervention was $-8.1 \mathrm{nmol} / \mathrm{L}$. Taking into consideration only the participants with adequate $25(\mathrm{OH}) \mathrm{D}$ level $(\geq 50 \mathrm{nmol} / \mathrm{L})$, it was also a drop $($ median $=-6.7 \mathrm{nmol} / \mathrm{L})$, whereas in participants with inadequate $25(\mathrm{OH}) \mathrm{D}$ level $(<50 \mathrm{nmol} / \mathrm{L})$ after eight weeks of intervention, a median rise of $8.2 \mathrm{nmol} / \mathrm{L}$ was observed.

While comparing the obtained results with studies by other authors, it may be supposed that it is a general association - in groups with lower baseline $25(\mathrm{OH}) \mathrm{D}$ levels, a higher effect of intervention may be observed, so it may confirm that the baseline $25(\mathrm{OH}) \mathrm{D}$ blood level plays an important role. In a similar intervention study, lasting eight weeks, conducted in wintertime in Iceland, Spain, and Ireland, in which its participants (mean baseline 25(OH)D blood level $61.9 \mathrm{nmol} / \mathrm{L}$ ) consumed around $450 \mathrm{~g}$ of salmon per week (compared to $350 \mathrm{~g}$ per week in our study), the mean rise of 25(OH)D was $8.4 \mathrm{nmol} / \mathrm{L}$ [40]. In another study conducted in Finland, on participants with a much higher mean baseline $25(\mathrm{OH}) \mathrm{D}$ level of $124.0 \mathrm{nmol} / \mathrm{L}$, no significant increase in $25(\mathrm{OH}) \mathrm{D}$ was noted when consuming 300-600 g of fatty fish (including salmon) per week after eight weeks of intervention [41]. However, most studies of this type are small intervention studies with a limited number of participants, therefore comparing the obtained results with the conclusions from a meta-analysis summarizing the most essential results may be helpful. According to a meta-analysis of Lehmann et al. [29], the mean change in 25(OH)D for interventions lasting 4-8 weeks was $3.8 \mathrm{nmol} / \mathrm{L}$; whereas in intervention groups with an inadequate mean $25(\mathrm{OH}) \mathrm{D}$ baseline $(<50 \mathrm{nmol} / \mathrm{L})$, the change was $6.1 \mathrm{nmol} / \mathrm{L}$; and in groups with adequate $(\geq 50 \mathrm{nmol} / \mathrm{L}) 25(\mathrm{OH}) \mathrm{D}$ blood levels at baseline, the change was only $3.9 \mathrm{nmol} / \mathrm{L}$. Taking into account the results of various studies, presented above, it may be confirmed that the most important factor for the efficacy may be the baseline 25(OH)D level.

However, in the presented study in the total study group, a decrease of $25(\mathrm{OH}) \mathrm{D}$ level after four weeks of intervention (phase I) was stated and later on (phase II), an increase (compared to the level after four weeks) was observed. The decline is very surprising, as salmon is known to be a good source of vitamin D [22,26], and in numerous studies, an increase in 25(OH)D was shown, also only after a four-week-long intervention of salmon intake in the winter [29]. Nevertheless, a recent intervention study conducted in Norway indicated that even a weekly consumption of $750 \mathrm{~g}$ (compared to $350 \mathrm{~g}$ in the presented study) of salmon for eight weeks was not sufficient to prevent the $25(\mathrm{OH}) \mathrm{D}$ decrease [42]. In that study, 25(OH)D decreased both in the salmon intervention and the control group, however, the decline was significantly lower in the salmon group compared to the control group.

What should be underlined is that the intervention period in the referred study [42] was from August/September to October/November, whereas in the presented study it was later-from October to December. Therefore, the decline seen in the presented study from week 0 to week 4 may correspond to the one observed in the Norwegian study (after eight weeks of intervention). In the presented study, the amount of salmon consumed was more than two times less than in the Norwegian one, and still in the second part of the intervention (from week four to week eight) an increase in $25(\mathrm{OH}) \mathrm{D}$ was observed. Unfortunately, to our best knowledge, the reason why such high amounts of dietary vitamin $\mathrm{D}$ from fish do not contribute to an immediate increase of $25(\mathrm{OH}) \mathrm{D}$ is not yet described or well known. There are only some hypotheses that could be listed.

The decrease may be attributed to a lack of adequate sunshine exposure to cause skin vitamin D synthesis during the time of intervention. From other studies, it is known that in countries such as Poland, skin synthesis of vitamin D is observed only from April to October (if the sunshine exposure is adequate) [20]. According to a recent Polish study [43], the highest levels of 25(OH)D in Poland are observed in August and the lowest in January, which could be explained by insolation and 25(OH)D synthesis during summer and the mobilization of vitamin D stored in the body (during the summer months) in the winter. 
This hypothesis corresponds to the initial decrease of 25(OH)D levels in the presented study, which was performed from October to December. Therefore, it may be assumed that in phase I (until week four), not dietary vitamin $\mathrm{D}$, but rather previously stored vitamin $\mathrm{D}$ had been used by the organism causing the constant decrease of $25(\mathrm{OH}) \mathrm{D}$ blood level, but in phase II (from week five to week eight), in which not enough vitamin D was stored in the body anymore, the daily intake of $50 \mathrm{~g}$ of fish and dietary vitamin D provided must have been intensively stored and metabolized to improve its status. Other studies also emphasize that it is the vitamin D storage from sun exposure and its release from fat tissues in winter that is the major factor contributing to $25(\mathrm{OH}) \mathrm{D}$ levels throughout the year [44], and dietary vitamin $\mathrm{D}$ is associated with $25(\mathrm{OH}) \mathrm{D}$ mainly in the winter and spring [45], in which perhaps not that much vitamin $\mathrm{D}$ is left in fat tissue and, therefore, the body must depend on vitamin $\mathrm{D}$ from food sources. This could also be the reason for the observed impact of baseline vitamin $\mathrm{D}$ status (adequate or inadequate) on $25(\mathrm{OH}) \mathrm{D}$ changes throughout the study, since in participants with inadequate vitamin D status, a lower decrease in phase I and a higher increase in phase II were seen, compared to participants with adequate vitamin D status at baseline.

Another possible explanation could be the difference in dietary vitamin D intake throughout the study. The statistical comparison of participants with inadequate $(<50 \mathrm{nmol} / \mathrm{L})$ and adequate $(\geq 50 \mathrm{nmol} / \mathrm{L}) 25(\mathrm{OH}) \mathrm{D}$ levels at baseline showed that at week four $(\mathrm{t} 4)$ participants with adequate $(\geq 50 \mathrm{nmol} / \mathrm{L}) 25(\mathrm{OH}) \mathrm{D}$ levels had a close to significant $(p=0.0515)$ higher vitamin $\mathrm{D}$ intake (median $=10.65 \mu \mathrm{g}$ ) in the first part of the intervention ( $\mathrm{t} 0$ to $\mathrm{t} 4$ ) compared to the ones with inadequate $(<50 \mathrm{nmol} / \mathrm{L}) 25(\mathrm{OH}) \mathrm{D}$ levels (median intake $=9.73 \mu \mathrm{g})$. What should be noted is that the dietary vitamin $D$ intake of participants with adequate $(\geq 50 \mathrm{nmol} / \mathrm{L}) 25(\mathrm{OH}) \mathrm{D}$ levels covered the recommended $10 \mu \mathrm{g}[11,25,26]$, which was also assumed in the study. Therefore, the possible reason for having an adequate $25(\mathrm{OH}) \mathrm{D}$ level at week four could be the higher (covering the recommended $10 \mu \mathrm{g}$ ) intake of vitamin $\mathrm{D}$ in the preceding time (from t0 to 4 ). At week eight, the vitamin $\mathrm{D}$ intakes did not differ significantly between groups $(p=0.3411)$, therefore the influence of vitamin D intake on different outcomes at that time remains unclear.

There are also other possible explanations, such as levels of other nutrients, that are related to the metabolism of vitamin D [46]. It may have been influenced by a decreased calcium level prior to the study [47]. This level was not assessed in the presented study, but if this level is lowered, it may influence not only the $25(\mathrm{OH}) \mathrm{D}$ level, but also the $1,25(\mathrm{OH}) 2 \mathrm{D}$ level, and the activity of $25(\mathrm{OH}) \mathrm{D}$ 1- $\alpha$-hydroxylase [47].

Therefore, it may be hypothesized that apart from baseline $25(\mathrm{OH}) \mathrm{D}$ levels, it is the starting time of intervention and the dietary intake of vitamin D and other nutrients that play a big role in the outcomes of such short-term fish intake interventions. Other hypothetical possible explanations to such intervention outcomes could be that the digestive system needs to adjust to utilize vitamin D from the smoked salmon. Another could be that the metabolism and storage of vitamin D are faster in the case of high dietary supply (intervention) while the levels of vitamin D stored from the summer exposure are also high, which might lead to lower $25(\mathrm{OH}) \mathrm{D}$ levels because the whole consumed amount of vitamin D is converted to other metabolites in a dynamic way. Last but not least, the vitamin D metabolism might have other various pathways depending on the baseline level, exposure, dietary intake, and applied intervention, which we are not yet aware of.

Based on the meta-analysis of Lehmann et al. [29], it may be indicated that the length of the intervention also plays a key role-short-term studies (4-8 weeks) revealed a mean difference of $3.8 \mathrm{nmol} / \mathrm{L}$ and long-term studies (around six months) revealed $8.3 \mathrm{nmol} / \mathrm{L}$ [29]. If the interventions last longer, there is more time for a change of $25(\mathrm{OH}) \mathrm{D}$. Therefore, it may be supposed that prolonging the conducted intervention would have resulted in a higher increase of $25(\mathrm{OH}) \mathrm{D}$ in the studied group. It may be hypothesized especially for participants with an adequate $25(\mathrm{OH}) \mathrm{D}$ level for whom after eight weeks of intervention a lower $25(\mathrm{OH}) \mathrm{D}$ serum level (median $56.8 \mathrm{nmol} / \mathrm{L}$ ) than at baseline (median $70.4 \mathrm{nmol} / \mathrm{L}$ ) was still observed, but higher than after four weeks of intervention (median $45.4 \mathrm{nmol} / \mathrm{L}$ ), so a progressive increase may be supposed. 
In spite of a number of arguments for choosing salmon as a vitamin D source in diet, namely its availability, as well as the content of nutrients and other components, the price of this product is quite high [48], contributing to low consumption in Poland (in 2017: $0.63 \mathrm{~kg} /$ person/year) [48]. There are other much cheaper (and therefore consumed more often) fish species available in Poland with significant vitamin D and combined EPA and DHA content, as well as low mercury and dioxin levels, that should be recommended, such as herring and rainbow trout. Both those species have very high $(>15 \mathrm{mg} / \mathrm{g})$ combined EPA and DHA content, low $(\leq 0.1 \mu \mathrm{g} / \mathrm{g})$ mercury levels, as well as quite low $(0.5-4 \mathrm{pg}$ TEQ/g) dioxin content, so according to the FAO and WHO [32] similarly as in the case of farmed Atlantic salmon, consuming them has more benefits than risks. Their prices in Poland are lower than salmon and they are as follows: rainbow trout-23.62 PLN/kg (approx. 5.42 €/kg) and herring-16.03 PLN/kg (approx. $3.68 € / \mathrm{kg}$ ), compared to $57.90 \mathrm{PLN} / \mathrm{kg}$ for salmon (approx. 13.28 €/kg) [48].

Moreover, herring and rainbow trout contain significant amounts of vitamin D: $19.00 \mu \mathrm{g}$ and $13.50 \mu \mathrm{g} / 100 \mathrm{~g}$, respectively [22]. There were some single intervention studies in which participants consumed $750 \mathrm{~g} /$ week of herring for six weeks [49] or 400-600 g/week of fatty fish including herring and rainbow trout for eight weeks [42] which did not reveal any significant effect of the applied dietary intervention on total $25(\mathrm{OH}) \mathrm{D}$. What should be pointed out is that the study groups consisted of only 32 [49] and 11 participants [41]. Therefore, similar intervention studies with herring or rainbow trout should be conducted in larger study groups in order to explore the influence of consumption of those species on $25(\mathrm{OH}) \mathrm{D}$ blood levels. If they also have a positive influence on vitamin $\mathrm{D}$ status, it could have a greater impact on Polish people to recommend them to eat more of those fish species, as they can afford and already consume them in higher amounts than salmon (herring 2.56, trout $0.50 \mathrm{~kg} /$ person/year in 2017) [48].

According to the American Heart Association [50], as well as the Polish National Food and Nutrition Institute [51], the recommended fish (especially fatty fish) intake is at least two times a week. Fatty fish include the fish species mentioned above such as salmon, herring, and rainbow trout, which are good sources of vitamin D, and should not be reduced from the diet, as they contain less mercury and dioxins than other species. From other studies, it is known that fish intake is the most influential food source contributor to vitamin D intake [52,53], and there may be a strong correlation between fatty fish intake and 25(OH)D levels [54]. A recent cross-sectional Norwegian study revealed that for a median vitamin D intake of $10.3 \mu \mathrm{g}$, the mean $25(\mathrm{OH}) \mathrm{D}$ level was $64.0 \mathrm{nmol} / \mathrm{L}$, while the prevalence of deficiency (defined as $25(\mathrm{OH}) \mathrm{D}<50 \mathrm{nmol} / \mathrm{L}$ ) was only $24.7 \%$; in such a situation, a low vitamin D deficiency prevalence was observed, even in winter [55]. This suggests that with an adequate vitamin $\mathrm{D}$ intake (at least $10 \mu \mathrm{g} /$ day) it is possible to achieve an adequate 25(OH)D level, maybe even in seasons with limited sunshine exposure such as the autumn and winter seasons in Poland. It corresponds with the obtained results, as even as short a period as eight weeks of dietary intervention of adequate vitamin D intake influenced the $25(\mathrm{OH}) \mathrm{D}$ levels and was revealed to be a promising option.

The novelty of the study is the fact that it was the first fish intake intervention study to asses 25(OH)D levels in a Polish population. Moreover, it is one of the first fish intake intervention studies in which a decrease in $25(\mathrm{OH}) \mathrm{D}$ was observed despite high salmon intake. The hypothetical explanations for that are listed above. Nevertheless, this indicates that this matter needs further study.

Although the presented study was the first fish intervention study conducted in Poland to access the efficacy of such intervention on $25(\mathrm{OH}) \mathrm{D}$ serum levels, limitations of the study should be indicated. The most important issue is associated with the fact that in the presented study there was no control group with no dietary intervention, which makes it more challenging to draw conclusions. However, this study is not the first one to analyze the influence of fish intake intervention on vitamin D status (measured as total 25(OH)D). Similar studies were conducted in other countries (but not in Poland), such as one in Iceland, Spain, and Ireland [39], with similar dietary intervention and similar results. Thus, it can be hypothesized that in the present study, the reason for the recovery of $25(\mathrm{OH}) \mathrm{D}$ was also due to fish intake and the presented study is of great importance, despite the lack of a control group. 
Taking it into account, it must be stated that this matter needs further study, as there are not many studies conducted on that topic, and, what has to be underlined, there were no such studies in Poland, so far. Finally, the studies conducted in other countries are frequently carried out on very specific participants such as prisoners [56], sex offenders [57], overweight individuals following a low-calorie diet [39], and 8-9-year-old children [58], therefore, there is a great need for similar intervention studies (conducted using various, but defined fish species) on larger, homogenous study groups covering various ages for both male and female participants.

\section{Conclusions}

Although in the presented intervention study an initial decline of $25(\mathrm{OH}) \mathrm{D}$ blood level was observed (probably connected to the starting time of the study), afterward the daily salmon intake contributed to its increase. Based on the observed results, it may be stated that the baseline $25(\mathrm{OH}) \mathrm{D}$ status is an important determinant of the intervention effectiveness during the autumn season, as it is more effective in participants with inadequate vitamin D status. It may be concluded that an increase in farmed Atlantic salmon intake may be a good way to improve vitamin D status, especially in vitamin D-deficient individuals.

Author Contributions: D.G. made conception; Z.U. and D.G. performed the research; Z.U. and D.G. analyzed the data; and Z.U. and D.G. wrote the paper. All authors have read and agreed to the published version of the manuscript.

Funding: This research was funded by the Polish Ministry of Science and Higher Education within funds of the Institute of Human Nutrition Sciences, Warsaw University of Life Sciences (WULS), for scientific research. The experiment was financed by Suempol Polska Ltd.

Conflicts of Interest: The funders had no role in the design of the study; in the collection, analyses, or interpretation of data; in the writing of the manuscript; or in the decision to publish the results. None of the authors declare any conflict of interest.

\section{References}

1. Lips, P.; van Schoor, N.M. The effect of vitamin D on bone and osteoporosis. Best Pract. Res. Clin. Endocrinol. Metab. 2011, 25, 585-591. [PubMed]

2. Gao, Q.; Kou, T.; Zhuang, B.; Ren, Y.; Dong, X.; Wang, Q. The Association between Vitamin D Deficiency and Sleep Disorders: A Systematic Review and Meta-Analysis. Nutrients 2018, 10, 1395.

3. Wang, J.; Lv, S.; Chen, G.; Gao, C.; He, J.; Zhong, H.; Xu, Y. Meta-analysis of the association between vitamin $\mathrm{D}$ and autoimmune thyroid disease. Nutrients 2015, 7, 2485-2498. [PubMed]

4. Estébanez, N.; Gómez-Acebo, I.; Palazuelos, C.; Llorca, J.; Dierssen-Sotos, T. Vitamin D exposure and Risk of Breast Cancer: A meta-analysis. Sci. Rep. 2018, 8, 9039.

5. Keum, N.; Lee, D.H.; Greenwood, D.C.; Manson, J.E.; Giovannucci, E. Vitamin D supplementation and total cancer incidence and mortality: A meta-analysis of randomized controlled trials. Ann. Oncol. 2019, 30, 733-743.

6. Wang, M.; Liu, M.; Wang, C.; Xiao, Y.; An, T.; Zou, M.; Cheng, G. Association between vitamin D status and asthma control: A meta-analysis of randomized trials. Respir. Med. 2019, 150, 85-94.

7. Christakos, S.; Dhawan, P.; Verstuyf, A.; Verlinden, L.; Carmeliet, G. Vitamin D: Metabolism, Molecular Mechanism of Action, and Pleiotropic Effects. Physiol. Rev. 2016, 96, 365-408.

8. Caprio, M.; Infante, M.; Calanchini, M.; Mammi, C.; Fabbri, A. Vitamin D: Not just the bone. Evidence for beneficial pleiotropic extraskeletal effects. Eat. Weight Disord. Stud. Anorex. Bulim. Obes. 2017, 22, $27-41$. [CrossRef]

9. Durazo-Arvizu, R.A.; Tian, L.; Brooks, S.P.J.; Sarafin, K.; Cashman, K.D.; Kiely, M.; Merkel, J.; Myers, G.L.; Coates, P.M.; Sempos, C.T. The Vitamin D Standardization Program (VDSP) Manual for Retrospective Laboratory Standardization of Serum 25-Hydroxyvitamin D Data. J. AOAC Int. 2017, 100, 1234-1243. [CrossRef] 
10. Cashman, K.D.; Dowling, K.G.; Škrabáková, Z.; Gonzalez-Gross, M.; Valtueña, J.; De Henauw, S.; Moreno, L.; Damsgaard, C.T.; Michaelsen, K.F.; Mølgaard, C.; et al. Vitamin D deficiency in Europe: Pandemic? Am. J. Clin. Nutr. 2016, 103, 1033-1044. [CrossRef]

11. National Academies Press (US). Institute of Medicine (US) Committee to Review Dietary Reference Intakes for Vitamin D and Calcium. In Dietary Reference Intakes for Calcium and Vitamin D; Ross, A.C., Taylor, C.L., Yaktine, A.L., Del Valle, H.B., Eds.; The National Academies Collection: Reports funded by National Institutes of Health; National Academies Press (US): Washington, DC, USA, 2011.

12. Aspray, T.J.; Bowring, C.; Fraser, W.; Gittoes, N.; Javaid, M.K.; Macdonald, H.; Patl, S.; Selby, P.; Tanna, N.; Francis, R.M. National Osteoporosis Society Vitamin D Guideline Summary. Age Ageing 2014, 43, 592-595. [PubMed]

13. Holick, M.F.; Binkley, N.C.; Bischoff-Ferrari, H.A.; Gordon, C.M.; Hanley, D.A.; Heaney, R.P.; Murad, M.H.; Weaver, C.M. Evaluation, Treatment, and Prevention of Vitamin D Deficiency: An Endocrine Society Clinical Practice Guideline. J. Clin. Endocrinol. Metab. 2011, 96, 1911-1930.

14. EFSA Panel on Dietetic Products. N. and A. (NDA) Dietary reference values for vitamin D. EFSA J. 2016, 14, e04547. [CrossRef]

15. Rusińska, A.; Płudowski, P.; Walczak, M.; Borszewska-Kornacka, M.K.; Bossowski, A.; Chlebna-Sokół, D.; Czech-Kowalska, J.; Dobrzańska, A.; Franek, E.; Helwich, E.; et al. Vitamin D Supplementation Guidelines for General Population and Groups at Risk of Vitamin D Deficiency in Poland-Recommendations of the Polish Society of Pediatric Endocrinology and Diabetes and the Expert Panel with Participation of National Specialist Consultants and Representatives of Scientific Societies-2018 Update. Front. Endocrinol. 2018, 9, 246.

16. Gordon, C.M.; DePeter, K.C.; Feldman, H.A.; Grace, E.; Emans, S.J. Prevalence of Vitamin D Deficiency among Healthy Adolescents. Arch. Pediatr. Adolesc. Med. 2004, 158, 531-537.

17. Andersen, R.; Mølgaard, C.; Skovgaard, L.T.; Brot, C.; Cashman, K.D.; Chabros, E.; Charzewska, J.; Flynn, A.; Jakobsen, J.; Kärkkäinen, M.; et al. Teenage girls and elderly women living in northern Europe have low winter vitamin D status. Eur. J. Clin. Nutr. 2005, 59, 533-541.

18. ENNS: Étude Nationale Nutrition Santé /Enquêtes et Etudes/Nutrition et Santé/Maladies Chroniques et Traumatismes /Dossiers Thématiques /Accueil. Available online: http://invs.santepubliquefrance.fr/Dossiersthematiques/Maladies-chroniques-et-traumatismes/Nutrition-et-sante/Enquetes-et-etudes/ENNS-etudenationale-nutrition-sante (accessed on 25 June 2019).

19. Calvo, M.S.; Whiting, S.J.; Barton, C.N. Vitamin D Intake: A Global Perspective of Current Status. J. Nutr. 2005, 135, 310-316.

20. Webb, A.R.; Kline, L.; Holick, M.F. Influence of season and latitude on the cutaneous synthesis of vitamin D3: Exposure to winter sunlight in Boston and Edmonton will not promote vitamin D3 synthesis in human skin. J. Clin. Endocrinol. Metab. 1988, 67,373-378.

21. Schmid, A.; Walther, B. Natural Vitamin D Content in Animal Products. Adv. Nutr. 2013, 4, 453-462. [PubMed]

22. Kunachowicz, H.; Przygoda, B.; Nadolna, I.; Iwanow, K. Tabele Składu i Wartości Odżywczej Żywności; Wydawnictwo Lekarskie PZWL: Warsaw, Poland, 2017.

23. National Food Institute. European Nutrition and Health Report 2009; Elmadfa, I., Ed.; Karger: Basel, Switzerland; New York, NY, USA, 2009.

24. Flynn, A.; Hirvonen, T.; Mensink, G.B. Intake of selected nutrients from foods, from fortification and from supplements in various European countries. Food Nutr. Res. 2009, 12, 2038.

25. Nordiska Ministerrådet. Nordic Nutrition Recommendations 2012. Part 3: Vitamins A, D, E, K, Thiamin, Riboflavin, Niacin, Vitamin B6, Folate, Vitamin B12, Biotin, Pantothenic acid and Vitamin C; Nordisk Ministerråd: Copenhagen, Denmark, 2014.

26. SACN Vitamin D and Health Report. Available online: https://www.gov.uk/government/publications/sacnvitamin-d-and-health-report (accessed on 20 May 2019).

27. Bailey, R.L.; Dodd, K.W.; Goldman, J.A.; Gahche, J.J.; Dwyer, J.T.; Moshfegh, A.J.; Sempos, C.T.; Picciano, M.F. Estimation of Total Usual Calcium and Vitamin D Intakes in the United States. J. Nutr. 2010, 140, 817-822. [CrossRef] [PubMed]

28. Benjamin, R.M. Bone health: Preventing osteoporosis. J. Am. Diet. Assoc. 2010, 110, 498. [CrossRef] [PubMed] 
29. Lehmann, U.; Gjessing, H.R.; Hirche, F.; Mueller-Belecke, A.; Gudbrandsen, O.A.; Ueland, P.M.; Mellgren, G.; Lauritzen, L.; Lindqvist, H.; Hansen, A.L.; et al. Efficacy of fish intake on vitamin D status: A meta-analysis of randomized controlled trials. Am. J. Clin. Nutr. 2015, 102, 837-847. [CrossRef] [PubMed]

30. Body Mass Index-BMI. Available online: http:/www.euro.who.int/en/health-topics/disease-prevention/ nutrition/a-healthy-lifestyle/body-mass-index-bmi (accessed on 24 July 2019).

31. United States Department of Agriculture, Agricultural Research Service. Available online: https://fdc.nal. usda.gov/fdc-app.html\#/food-details/337771/nutrients (accessed on 24 March 2020).

32. Fish and Seafood Market in Poland. 2018. Available online: https://gain.fas.usda.gov/Recent\%20GAIN\% 20Publications/2017\%20Fish\%20and\%20Seafood\%20Market\%20in\%20Poland_Warsaw_Poland_2-21-2018. pdf (accessed on 19 August 2019).

33. FAO/WHO. Report of the Joint FAO/WHO Expert Consultation on the Risks and Benefits of Fish Consumption: Rome, 25-29 January 2010; FAO: Rome, Italy, 2011.

34. Jakobsen, J.; Smith, C.; Bysted, A.; Cashman, K.D. Vitamin D in Wild and Farmed Atlantic Salmon (Salmo Salar)—What Do We Know? Nutrients 2019, 11, 982. [CrossRef] [PubMed]

35. International Society for Advancement of Kinanthropometry. International Standards for Anthropometric Assessment; International Society for the Advancement of Kinanthropometry: Potchefstroom, South Africa, 2001.

36. Reference Values DACH-Referenzwerte. Available online: http://www.sge-ssn.ch/grundlagen/lebensmittelund-naehrstoffe/naehrstoffempfehlungen/dachreferenzwerte/ (accessed on 2 August 2019).

37. Jarosz, M.; Rychlik, E.; Stoś, K.; Wierzejska, R.; Wojtasik, A.; Charzewska, J.; Mojska, H.; Szponar, L.; Sajór, I.; Kłosiewicz-Latoszek, L.; et al. Normy Żywienia dla Populacji Polski; Instytut Żywności i Żywienia: Warszawa, Poland, 2017.

38. Głąbska, D.; Guzek, D.; Sidor, P.; Włodarek, D. Vitamin D Dietary Intake Questionnaire Validation Conducted among Young Polish Women. Nutrients 2016, 8, 36. [CrossRef]

39. Ogedegbe, G.; Pickering, T. Principles and techniques of blood pressure measurement. Cardiol. Clin. 2010, 28, 571-586. [CrossRef]

40. Lucey, A.J.; Paschos, G.K.; Cashman, K.D.; Martínéz, J.A.; Thorsdottir, I.; Kiely, M. Influence of moderate energy restriction and seafood consumption on bone turnover in overweight young adults. Am. J. Clin. Nutr. 2008, 87, 1045-1052. [CrossRef]

41. Erkkilä, A.T.; Schwab, U.S.; de Mello, V.D.F.; Lappalainen, T.; Mussalo, H.; Lehto, S.; Kemi, V.; Lamberg-Allardt, C.; Uusitupa, M.I.J. Effects of fatty and lean fish intake on blood pressure in subjects with coronary heart disease using multiple medications. Eur. J. Nutr. 2008, 47, 319-328. [CrossRef]

42. Bratlie, M.; Hagen, I.V.; Helland, A.; Midttun, Ø.; Ulvik, A.; Rosenlund, G.; Sveier, H.; Mellgren, G.; Ueland, P.M.; Gudbrandsen, O.A. Five salmon dinners per week was not sufficient to prevent the reduction in serum vitamin D in autumn at $60^{\circ}$ north latitude: A randomised trial. Br. J. Nutr. 2019, 123, 1-21. [CrossRef]

43. Smyczyńska, J.; Smyczyńska, U.; Stawerska, R.; Domagalska-Nalewajek, H.; Lewiński, A.; Hilczer, M. Seasonality of vitamin D concentrations and the incidence of vitamin D deficiency in children and adolescents from central Poland. Pediatr. Endocrinol. Diabetes Metab. 2019, 25, 54-59. [CrossRef]

44. Diffey, B.L. Modelling vitamin D status due to oral intake and sun exposure in an adult British population. Br. J. Nutr. 2013, 110, 569-577. [CrossRef] [PubMed]

45. Macdonald, H.M.; Mavroeidi, A.; Barr, R.J.; Black, A.J.; Fraser, W.D.; Reid, D.M. Vitamin D status in postmenopausal women living at higher latitudes in the UK in relation to bone health, overweight, sunlight exposure and dietary vitamin D. Bone 2008, 42, 996-1003. [CrossRef] [PubMed]

46. Dale, M.M.; Haylett, D.G. Rang and Dale's Pharmacology Flashcards; Churchill Livingstone Elsevier: London, UK, 2014.

47. Kumar, R. The metabolism and mechanism of action of 1,25-dihydroxyvitamin D3. Kidney Int. 1986, 30, 793-803. [CrossRef]

48. Rynek Ryb [Fish Market]. Available online: https://www.ierigz.waw.pl/publikacje/analizy-rynkowe/rynekryb/20873,3,3,0,nr-26-2017-rynek-ryb.html (accessed on 16 August 2019).

49. Scheers, N.; Lindqvist, H.; Langkilde, A.M.; Undeland, I.; Sandberg, A.-S. Vitamin B12 as a potential compliance marker for fish intake. Eur. J. Nutr. 2014, 53, 1327-1333. [CrossRef] [PubMed]

50. Fish and Omega-3 Fatty Acids. Available online: https://www.heart.org/en/healthy-living/healthy-eating/ eat-smart/fats/fish-and-omega-3-fatty-acids (accessed on 19 August 2019). 
51. Piramida Zdrowego Żywienia i Aktywności Fizycznej [Food and Physical Activity Pyramid]. Available online: http://www.izz.waw.pl/attachments/article/7/Piramida\%20Zdrowego\%20\%C5\%BBywienia\%20i\% 20Aktywno\%C5\%9Bci\%20Fizycznej\%20Broszura.pdf (accessed on 19 August 2019).

52. Becker, W.; Pearson, M.; Metod Och Resultatanalys. Livsmedelsverket, Uppsala, Sverige, Riksmaten 1997-1998. Available online: https://www.livsmedelsverket.se/globalassets/matvanor-halsa-miljo/ kostrad-matvanor/matvaneundersokningar/riksmaten-1997-1998-resultat-och-metodrapport.pdf (accessed on 19 August 2019).

53. Pietinen, P.; Paturi, M.; Reinivuo, H.; Tapanainen, H.; Valsta, L.M. FINDIET 2007 Survey: Energy and nutrient intakes. Public Health Nutr. 2010, 13, 920-924. [CrossRef] [PubMed]

54. Van der Meer, I.M.; Boeke, A.J.P.; Lips, P.; Grootjans-Geerts, I.; Wuister, J.D.; Devillé, W.L.J.M.; Wielders, J.P.M.; Bouter, L.M.; Middelkoop, B.J.C. Fatty fish and supplements are the greatest modifiable contributors to the serum 25-hydroxyvitamin D concentration in a multiethnic population. Clin. Endocrinol. Oxf. 2008, 68, 466-472. [CrossRef]

55. Petrenya, N.; Lamberg-Allardt, C.; Melhus, M.; Broderstad, A.R.; Brustad, M. Vitamin D status in a multi-ethnic population of northern Norway: The SAMINOR 2 Clinical Survey. Public Health Nutr. 2019, 1-15. [CrossRef]

56. Hansen, A.L.; Dahl, L.; Bakke, L.; Frøyland, L.; Thayer, J.F. Fish consumption and heart rate variability: Preliminary results. J. Psychophysiol. 2010, 24, 41-47. [CrossRef]

57. Hansen, A.L.; Dahl, L.; Olson, G.; Thornton, D.; Graff, I.E.; Frøyland, L.; Thayer, J.F.; Pallesen, S. Fish Consumption, Sleep, Daily Functioning, and Heart Rate Variability. J. Clin. Sleep Med. 2014, 10, 567-575. [CrossRef]

58. Vuholm, S.; Teisen, M.N.; Buch, N.G.; Stark, K.D.; Jakobsen, J.; Mølgaard, C.; Lauritzen, L.; Damsgaard, C.T. Is high oily fish intake achievable and how does it affect nutrient status in 8-9-year-old children? The FiSK Junior trial. Eur. J. Nutr. 2019, 59, 1205-1218. [CrossRef]

(C) 2020 by the authors. Licensee MDPI, Basel, Switzerland. This article is an open access article distributed under the terms and conditions of the Creative Commons Attribution (CC BY) license (http://creativecommons.org/licenses/by/4.0/). 


\title{
Article
}

\section{Crisis Response and Supervision System for Food Security: A Comparative Analysis between Mainland China and Taiwan}

\author{
Chun-Chieh Ma ${ }^{1}$, Han-Shen Chen ${ }^{2,3}$ and Hsiao-Ping Chang ${ }^{2,3, *}$ \\ 1 Department of Public Administration and Management, National University of Tainan, No.33, Sec. 2, \\ Shu-Lin St., Tainan 70005, Taiwan; ccma@mail.nutn.edu.tw \\ 2 Department of Health Diet and Industry Management, Chung Shan Medical University, No.110, Sec. 1, \\ Jianguo N. Rd., Taichung City 40201, Taiwan; allen975@csmu.edu.tw \\ 3 Department of Medical Management, Chung Shan Medical University Hospital, No. 110, Sec. 1, \\ Jianguo N. Rd., Taichung City 40201, Taiwan \\ * Correspondence: pamela22@csmu.edu.tw; Tel.: +886-4-2473-0022 (ext. 12197)
}

Received: 16 February 2020; Accepted: 28 March 2020; Published: 10 April 2020

\begin{abstract}
In Mainland China, major food security incidents have occurred with high frequency, of which the number and degree of harm are both increasing. At the same time, Taiwan's food security crisis has also been spreading. For these reasons, this article makes a comparative analysis of food security issues between Mainland China and Taiwan from a legal point of view and identifies the blind spots of the legal system and supervision using official documents and research papers regarding the most typical incidents in the period of 2008-2019. The results indicate that, compared with Mainland China, Taiwan has a better food security supervision system, and its experience with the supervision system, specific rules, social supervision, and responsibility is worth investigating. However, while there are loopholes in criminal law in Mainland China, which has not formed a complete system, criminal law in Taiwan is also weak in terms of regulation of food security incidents. Based on the results, this article puts forward suggestions with the expectation that, in the face of an increasingly severe food security crisis, Mainland China and Taiwan will strengthen their cooperation in constructing legal systems for food security supervision and inspection, exchange experience, cooperate in inspection, and share food security information to avoid rumors of food insecurity circulating in popular science. It is expected that the results and suggestions of this study will be helpful in the crisis response, as well as in the supervision systems in Mainland China and Taiwan for guarding food security. Although the comparative analysis is specific to the two regions, its characteristics are typical of food security globally, especially in Asia.
\end{abstract}

Keywords: crisis response; supervision system; food security; Mainland China; Taiwan

\section{Introduction}

With the rapid development of the social economy under globalization, various kinds of public emergencies in traditional and nontraditional fields have become increasingly prominent, which has become an important hidden threat to national security and people's property and life security [1]. Frequent food security incidents have resulted in the repeated questioning of the credibility of the government [2]. Researchers have found that an effective emergency system can reduce accident losses to less than $6 \%$ compared to a situation without an emergency system [3]. In view of this, in the process of dealing with crisis events, the appropriateness of the emergency response system has become the focus of researchers.

In recent years, major food security incidents have occurred frequently in Mainland China, the number and degree of harm of which are both increasing. Food security has attracted more attention 
from all walks of life than ever before, resulting in a crisis of public confidence in food security [4]. In terms of recent food security incidents, poisonous milk powder incidents broke out in March 2008, but due to the preparation for the Olympic Games, the local government of Hebei did not deal with these in time. The poisonous milk powder incident continued until the New Zealand government reported the incident to China in September. This incident affected China's foreign trade and seriously damaged China's international image [5]. This incident caused social unrest because the melamine mixed in the infant milk powder caused kidney lesions in infants [5]. In view of the importance of food security issues, the Food Security Law of Mainland China regulates scientific and effective supervision measures with a clear and systematic division of responsibilities for food security supervision, which provides a legal guarantee to resolve the current prominent food security issues in a proper and orderly manner. However, due to the unique and complex market environment of Mainland China, food security supervision will still face multiple dilemmas with respect to the system and technology [6].

Taiwan's food security crisis has also been spreading [7]. From the "plasticizer" to the "Datong Tainted Oil" incidents, food security issues have also been emerging in Taiwan one after the other. The emergence of the poisonous starch incident in 2013 in Taiwan set off a panic in Taiwanese society. The official poisonous compound in the starch was maleic anhydride. It was originally used as a food packaging material and adhesive, but some practitioners mixed it into edible starch to increase the viscosity and elasticity of the starch. This substance was illegally added and may cause kidney damage. In April 2013, seven county and municipal health bureaus, such as New Taipei City, began to investigate the manufacturers using the poisonous starch closely. In May, the New Taipei City Health Bureau found that Mingji tofu contained the toxic starch elements, and its raw material was procured from Sanjin Powder Trading Company, located in Tainan; therefore, the Health Bureau of Tainan City continued to investigate the incident. In order to eliminate the circulation of the toxic starch in the market and require the raw material manufacturers of the starch to start providing security certificates from the downstream manufacturers, pitchmen, and food practitioners starting in June, the Health Department launched the "0527 Food Security Project". The "0527 Food Security Project" was a project for food safety control initiated by the resolution of the Conference on Research and Strategies organized by the Ministry of Health and Welfare, which invited experts from food management, science and technology, and public health and medical fields in order to solve the food safety problem caused by the malicious addition of maleic anhydride to starch. It was launched by the Health Department to check all starch manufacturers in Taiwan. Because the poisonous starch incident was a significant issue, it brought food security issues to the public's attention, as well as governmental actions on food security issues [4].

Mainland China and Taiwan are facing a major impact from food security issues. In the face of many major food security incidents in Mainland China and Taiwan over the years and in view of the fact that food security affects people's lives and health, this article performs a comparative study of food security in the two regions, which should help governments and nongovernmental organizations to learn from each other's progress at the levels of food supervision and the legal system and to establish an effective food supervision mechanism and rigorous legal system to protect consumers' rights and interests. Taking advantage of the promotion of the "Food Security Law" in Mainland China, this study explores the legal system of food security supervision, which should have theoretical and practical significance to solve food security problems effectively [8]. A comparative analysis of the current situation of food security in Taiwan could be helpful in implementing a cross-strait food security agreement, enhancing food security communication and mutual trust in Mainland China and Taiwan, thereby ensuring the security and health of local citizens [9]. 


\section{Literature Review}

\subsection{Concept of Food Security}

The precise concept of food security was first proposed by the Food and Agriculture Organization of the United Nations (FAO) at the World Food Conference in November 1974. The FAO believes that food security is a fundamental right of people that includes their subsistence rights. At this conference, the FAO defined food security as "guaranteeing that everyone can get what they need for survival and health everywhere."

In the 1980s, the Food and Agriculture Organization of the United Nations gave a new definition of food security in response to food shortages in developing countries: "The ultimate goal of food security is to ensure that all people can buy and afford any food they need at any time." After the 1990s, with the improvement of the economy and the increase in material consumption, the quality and nutrition of food became the theme of food security. In 1991, the International Conference on Nutrition gave a new definition of food security: "Everyone can get safe and nutritious food at any time to maintain a healthy and active life" [10].

\subsection{Crisis Response and Supervision System for Food Security}

Crises often occur in our daily lives. Especially in the modern era of rapid technological change, the impact of a crisis becomes more and more important. Fink described a crisis as a watershed, "turning point", or "deterioration" of an event, which is a key time point or opportunity for decision making. The time and situation during the occurrence of the incident are not stable, thus demanding immediate decisions [11]. Coombs suggested that no organization can be free from crisis [12], so when a crisis occurs, if policymakers can respond appropriately, implement corresponding prevention/mitigation measures for the crisis incident in stages, prepare for response, advanced recovery, and other management behaviors, and cooperate with all relevant stakeholders with good communication channels, they can defuse the crisis and transform the organization from being in crisis to becoming a model for crisis management [13]. Therefore, in the modern era of academic debate, how to respond to a crisis has become an important issue [14].

Among the numerous crises from the past to the present, food security incidents have emerged one after the other in recent years and have attracted great attention from society. With regard to food security, Yeung and Morris [15] found that the main influencing factor of consumer behavior was consumers' own perception of the food security crisis, rather than the risk of food security incidents. Therefore, previous literature has argued that the potential harms caused by food security incidents may be far less than the exaggerated crisis [16]. Smith [17] further pointed out that the public would first use their usual information channels to understand the situation in the face of the crisis. At the beginning of the event, they would be more sensitive to the information they first received and would more easily believe the information. Therefore, at the moment of the crisis, the first response is very important in influencing the public's perception.

With the improvement of the economy and the standard of living, the public attach more and more importance to food security issues. In a multirisk society, when facing a potential food security crisis, the public collects information about new crises mainly through the media. After receiving such information, people internalize their awareness of the crisis and its risks. With modern science and technology, the circulation of information becomes easier, and the public can have a deeper and more confident understanding of the crisis [18]. According to the analysis of a study conducted by Palenchar and Heath [18], in the face of a crisis, community residents can achieve self-protection through the relevant norms of crisis response and are willing to adopt other contingency measures to make them feel more in control of the crises. Jacob et al. [19] also found that uncertainty in crisis information increases people's fear and cognitive bias. It is important to inform consumers about the risks so that they can choose the right strategy that reflects their demand for information, their morals, and their values [20]. 
From those studies, the public must deal with an abundance of information in order to manage their own risk profile connected to nourishment and possibly place trust in various expert systems delivering the information in order to overcome anxiety in approaching food-related crises [21,22]. Since different groups of actors-governments or institutions on the one hand and private commercial enterprises on the other-influence decision making about food, often conflicting with each other and enhancing the anxiety in food choices [23], the public's fear or aversion about food security could be contained through both information provided by expert systems and adequate communication to trigger positive emotional responses [24].

Moreover, most public opinion concerns derive from problems with food safety and government supervision, coupled with a slow or lacking action by the government, resulting in aggravated negative public sentiment and a decrease in the credibility of the government. Therefore, the government must start from the source, from research experiments to market entry, and further improve the system at each level to strengthen approval and supervision. For these reasons, it is important to be open and transparent in policy formulation and to give people an opportunity to express their demands while using the media and other forces to increase information disclosure, actively address popular science rumors, guide the public in rational discussions, effectively protect the public's rights, and enhance the credibility of the government [25].

Accordingly, because of the increase in the risk to food security, the governments of various countries should rethink their current response programs to establish suitable food security management systems and adequate communication features. Under such a situation, priority should be given to establishing adequate norms for the crisis response to lead the execution of the related orders, as well as implementing supervision systems to reduce damage during the crisis [26]. Based on the studies, suitable norms for the crisis response can improve the public's sense of control over a crisis of food security, and a better supervision system, specific rules, social supervision, and responsibility investigation will also be helpful to prevent as well as mitigate crises in food security.

\section{Methods: Comparative Analysis Approach and Qualitative Research Method}

Comparative political and social research is generally defined in two ways: Either on the basis of its supposed core subject, which is almost always defined at the level of political and social systems [27], or by means of descriptive features that claim to enhance knowledge about politics and society as a process [28]. These descriptions are generally considered to differentiate the comparative approach from other approaches within political and social sciences.

Since the food security crises depicted in this study were the first major emergencies to occur in Mainland China and Taiwan after the enforcement of food security systems comprehensively adopted at that time, by adopting a comparative analysis approach, the observation of the crisis responses in these two regions could show the descriptive features of two systems so as to enhance knowledge regarding food security policies, the food security situation, and supervision issues.

Additionally, based on qualitative research, this study performs a holistic exploration of social phenomena using various data collection methods in the natural environment. The practical induction method was used to analyze data and formation theory. This is an activity to gain an explanatory understanding of the behavior and meaning construction of the research object through interaction with the research object [29]. Hence, this study also chose a qualitative research method for exploration and collected data in the period of 2008-2019, both in Mainland China and Taiwan, so as to avoid any subjective judgment and to make more objective judgments and a comparative study.

This paper takes the legal norms of food security in Mainland China and Taiwan as the research scope and identifies the blind spots of the legal system and supervision through comparative analysis using official documents and research papers regarding the two regions. It also puts forward suggestions with the expectation that Mainland China and Taiwan will learn from each other and make improvements in their responses to food security crises. 


\section{Food Security Situation and Supervision Issues in Mainland China}

\subsection{Situation of Food Security in Mainland China}

In recent years, many major food security incidents have occurred frequently in Mainland China, as shown in Table 1. For this reason, food security has attracted more attention from all domains than ever before, resulting in a crisis of public confidence in food security [4].

Table 1. Situation of food security in Mainland China.

\begin{tabular}{l} 
Situation \\
\hline $\begin{array}{l}\text { The security situation of agricultural products and } \\
\text { poultry products is worrying. }\end{array}$ \\
\hline There are potential security hazards in the \\
production, processing, and marketing of agricultural \\
products, which can easily cause secondary food \\
poisoning and foodborne diseases.
\end{tabular}

\section{Description}

Harmful residues, such as fertilizers and pesticides, antibiotics, and other harmful substances, excessive heavy metals, etc., exist in agricultural products. Due to inadequate supervision, production,
processing, and marketing places often become the transmission centers of infectious diseases.

1. The "Sanlu poisonous milk powder" incident in 2008 that resulted in 14 newborns suffering from urolithiasis;

2. The "Shuanghui lean meat powder" incident in 2011;

Food poisoning and foodborne diseases occur from time to time.
3. The "Vitamin C Yinqiao tablets of Guangzhou Pharmaceuticals containing highly toxic substances" case in 2013.

4. According to the statistics of the National Health and Family Planning Commission, the frequent occurrence of food poisoning and foodborne diseases poses a serious threat to food security in 2019.

The key detection technologies of foodborne hazards and food security control technologies in Mainland China are lagging behind those in developed areas such as Taiwan.
The technological achievements and technical reserves of food security are inadequate.

\subsection{Issues for Food Security Supervision in Mainland China}

Mainland China currently implements a multisectoral and phased supervision system [30]. In detail, before the reform, the highest coordinating body for food security in Mainland China was the Commission on Food Security of the State Council, which served as a high-level deliberative and coordinating body for food security work under the State Council. It comprised the Commission Office on Food Security of the State Council (referred to as the Food Security Office of the State Council) as the body handling daily affairs of the Commission. According to the institutional reform and functional transformation plan of the State Council approved in March 2013, the relevant organizations and affiliations will be adjusted and merged into the National Health and Family Planning Commission and the State Food and Drug Administration.

Continuing the above, the food security supervision system in Mainland China can be visualized as in Figure 1. This supervision system seems to be comprehensive, but its biggest drawback is that it is prone to unclear powers and responsibilities, overlapping functions, inefficiency, and shirking of responsibilities by the food supervision departments. Moreover, more than 10 supervision departments, including agriculture, industry and commerce, quality inspection, health, and food and medicine, are involved in various links closely related to production, processing, circulation, and consumption. If a certain link is broken and the connection is not good, the whole food supervision system will have problems [31,32]. 


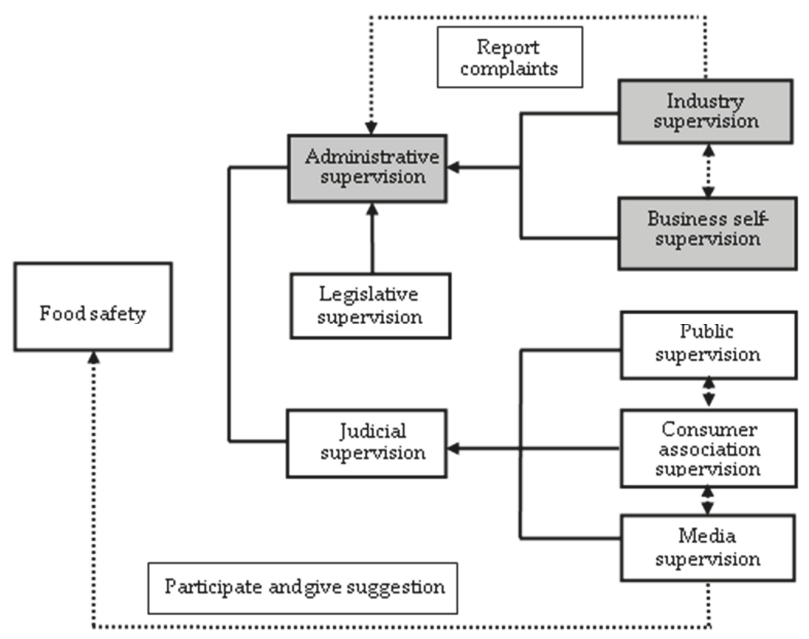

Figure 1. Food security supervision system in Mainland China.

Apart from the power and responsibility problems, in the actual operation process, the supervision system also has the problem of inadequate supervision [33,34]. Consumers often abandon attempts at solving food security problems through judicial procedures because of the high cost of safeguarding rights, which leads to the failure of mass supervision. Media supervision and consumer association supervision mainly rely on the reports of those whose rights and interests have been damaged, but because of consumers' apprehension, the effect of supervision will be greatly weakened. Enterprise self-supervision and industry supervision mainly depend on the morality and conscience of the enterprise itself, and once in conflict with economic interests, food manufacturers are likely to choose to pursue maximum benefits and market share. These two kinds of supervision are also difficult to achieve.

As in administrative supervision, information about the food supply chain is not open and transparent, so consumers can only passively believe the information issued by third-party government departments when they want to buy products manufactured by enterprises. Not only are they unable to respond to the government's supervision, but they also have little information exchange with food enterprises. For certain reasons, the government may not provide all of the real information to consumers [35]. This kind of one-way government trust very easily causes crises. Although government departments will invest much money in monitoring food security risks, as long as food security incidents occur, "government supervision is not in place" must be one of the reasons for the occurrence of food security incidents [36,37].

At the technical level, the food security standards in Mainland China are lagging behind, and the means of inspection and detection are relatively undeveloped. Therefore, it is difficult to guarantee the scientific rigor and authority of the test results [38]. Current food security supervision urgently needs to solve the technical problems such as the immature means of the evaluation and detection of food security risks [39].

\section{Food Security Situation and Supervision Issues in Taiwan}

\subsection{Situation of Food Security in Taiwan}

Taiwan attaches great importance to food security. It not only formulates relatively complete laws and regulations, but also has a complete process supervision and guarantee system from farm to dining table, as shown in Table 2. In 2011, Taiwan responded decisively and quickly to the plasticizer incident, which took only three months to subside. However, in 2013, a series of food security incidents 
broke out, such as "organic rice mixing with low-price imported rice", "poisonous starch", "tainted oil", and "poisonous milk", which also shook the Taiwanese people's confidence in their food security.

Table 2. Situation of food security in Taiwan.

\begin{tabular}{ll}
\hline \multicolumn{1}{c}{ Situation } & \multicolumn{1}{c}{ Description } \\
\hline $\begin{array}{l}\text { Responded decisively and quickly to the } \\
\text { plasticizer incident. }\end{array}$ & $\begin{array}{l}\text { Taiwan responded decisively and quickly to the } \\
\text { plasticizer incident, which took only three months to } \\
\text { subside in 2011. }\end{array}$ \\
\hline A series of food security incidents broke out. & $\begin{array}{l}\text { "Organic rice mixing low-price imported rice", } \\
\text { "poisonous starch", "tainted oil", and "poisonous milk" } \\
\text { also shook Taiwanese people's confidence in their food } \\
\text { security in 2013. }\end{array}$ \\
\hline
\end{tabular}

\subsection{Issues for Food Security Supervision in Taiwan}

Compared with that of Mainland China, Taiwan's food security supervision is mainly the responsibility of three government departments: Council of Agriculture, Executive Yuan, Ministry of Health and Welfare, Executive Yuan, and Bureau of Standards, Metrology, and Inspection, Ministry of Economic Affairs. Among them, the Council of Agriculture, Executive Yuan is mainly responsible for the supervision of the production of raw food materials, including raw material management for agricultural products, animal husbandry, and aquatic products, and assisting in the work of the Ministry of Health and Welfare, Executive Yuan. The Ministry of Health and Welfare, Executive Yuan and its subordinate health agencies are responsible for the supervision of food market circulation under the leadership of Executive Yuan. The Bureau of Standards, Metrology, and Inspection, Ministry of Economic Affairs (MOEA) is responsible for entry and exit food inspection and entrusted inspection. Only food inspected up to the standard can be circulated in the market [40]. Finally, food security and quality certification based on the Food Security and Health Management Law is the Good Manufacturing Practice (GMP) Smile Mark promoted by the Industrial Development Bureau, MOEA, and the Certified Agricultural Standards (CAS) Mark of the Council of Agriculture, Executive Yuan [41]. Taiwan's food security supervision system is shown in Figure 2.

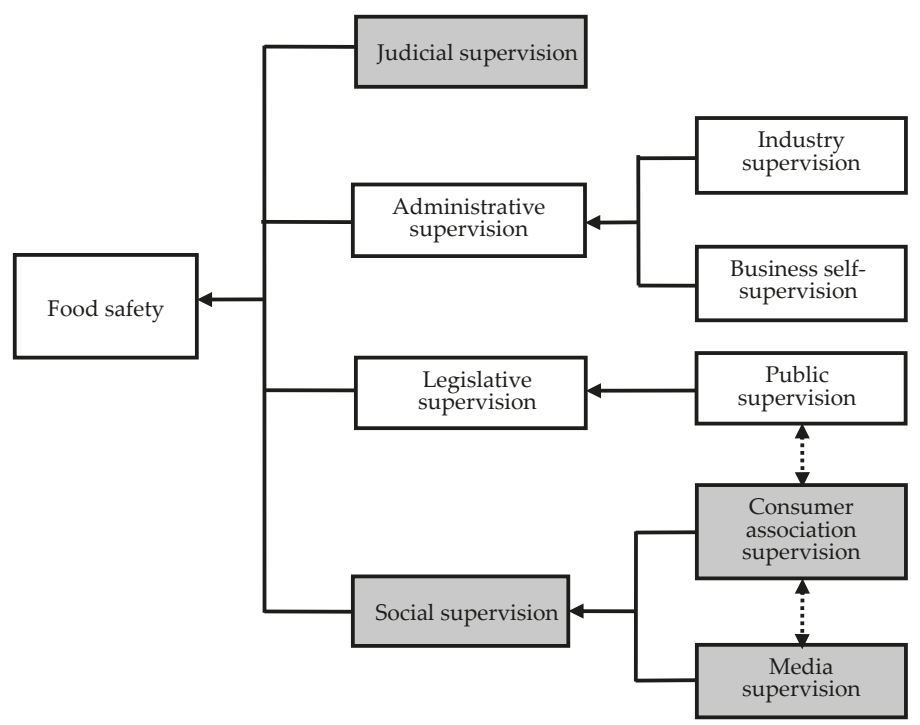

Figure 2. Taiwanese food security supervision departments and their duties. 


\section{Comparison of Food Security Status and Supervision Issues in Mainland China and Taiwan}

From the food security supervision system in Mainland China and Taiwan, we can deduce the food security responses relative to the system, as shown in Table 3. The legal construction on food security issues in Mainland China has not only such problems as a lack of system, integrity, and deterrence in supervision laws and regulations, duplicated multidepartment enforcement, repeated enforcement, conflict of laws and regulations, a discrepancy of technical standards, and imperfect enforcement measures [42], but also supervision blind spots, such as imperfect legislation, content lags, discoordination between laws, the insufficient force of legal penalties, and even the weak legal awareness of the general public.

Table 3. Comparisons of food security issues in Mainland China and Taiwan.

\begin{tabular}{ll}
\hline \multicolumn{1}{c}{ Difference } & \multicolumn{1}{c}{ Mainland China } \\
\hline $\begin{array}{l}\text { Time point of food } \\
\text { security accidents }\end{array}$ & $\begin{array}{l}\text { The problem was found only when } \\
\text { patients appeared. Food security } \\
\text { accidents resulted in bad effects and } \\
\text { serious consequences. }\end{array}$ \\
\hline Penalty intensity & $\begin{array}{l}\text { The criminal law of the mainland is more } \\
\text { stringent and the penalties heavier, but for } \\
\text { the administrative penalty, enterprise } \\
\text { food security information is not disclosed. }\end{array}$ \\
\end{tabular}

Public response

Scope of problem

Social and economic conditions

Social system

Inspection and testing measures
It is relatively difficult for public opinion to create pressure.

Since the beginning of the 21st century, food security issues have been widespread, with numerous categories and a high frequency of outbreaks.

Mainland China is currently a developing region, with economic development as the central task, so it is inevitable that some manufacturers with low social morality will only care about their interests, regardless of risk to life.

As it implements the socialist system with Chinese characteristics, it is vulnerable to the impact of the market economy, which leads to money-oriented food producers and processors.

The legislative branch is the National People's Congress (NPC). The establishment of new laws and the revision of old laws take a long time, which hinders the thorough eradication of food security issues.

Food security testing systems are duplicated, the testing system is not perfect, and the testing standards are confusing (provincial, prefectural, and municipal standards are different).

Informers do not receive corresponding personal security protection.
Taiwan

Poisonous and harmful food was reported by the public before it caused serious casualties.

Taiwan's criminal law has not been amended and does not meet the requirements of the times. The level of penalty is too light, and there is collusion between the government and businesses.

The public response is intense and can generate strong public opinion pressure, but social network and social media rumors spread.

Food security incidents have occurred frequently in the last decade, but the severity is much lower than in Mainland China.

Taiwan is relatively developed with a relatively better quality of life and fewer food security incidents than Mainland China.

With the implementation of the capitalist social system, utilitarianism is rampant, and companies are easily driven by profits.

The legislative branch is the Legislative Yuan; the law-passing rate and number have greatly increased recently, but the law on food security still needs to be amended.

CAS Good Food System, GMP

Certification System, Processed Food

Traceability System, Food

Consumption Traffic Light System, Food Recycling System.

The government helps informers of illegal acts by keeping their identities secret, protecting their personal security through legislation, and through an incentive system to encourage consumers to report substandard food actively. 
Compared with that of Mainland China, Taiwan's food security management is under the jurisdiction of the "Ministry of Health and Welfare, Executive Yuan" and the "Industrial Development Bureau, MOEA". Relevant laws and regulations are also incorporated in the food hygiene management law, food hygiene standards, and regulations to promote industrial upgrading. This model has its own unique features, but it also has many unsatisfactory defects. The more noticeable ones are: (1) Political mafias are often involved in food security incidents, and some public opinion representatives arbitrarily carry out "lobbying" in judicial cases. There is a suspicion of collusion between officials and businessmen, resulting in difficult judgment in major cases and obstacles for law enforcement and inspection, which makes food practitioners act with impunity. (2) Taiwan's criminal law has a weak effect in the punishment of food security felonies to achieve its proper purpose. (3) Taiwan's administrative punishment is too light, which may lead to disguised incentives for economic crime and social network and social media rumors.

Comprehensive research and analysis has shown that the fundamental reason for the frequent occurrence of food security accidents in China lies in the more humanistic supervision mode, under which most departmental managers often act on their own will, regardless of the regulations. To change this dependence on the bad paths of free-riding, weak government rules, abuse of power, and buck-passing, we must change the supervision mode of food security from the rule-of-man mode of supervision to supervision based on rules and regulations [43]. The inherent reason for the frequent occurrence of food security accidents lies in the unequal interests among all levels of the regulatory bodies and food enterprises caused by information asymmetry. Based on incentive compatibility theory, improving food security supervision in China should start with clarifying the responsibility of food security supervision at all levels and increasing the punishment of enterprises violating regulations [44]. In contrast, Taiwan should promote the basic law on food security, starting from reviewing and revising its existing cumbersome and decentralized food security regulations [45]. The primary task is to strengthen the promotion of third-party inspection, the "production resumé" system, food security knowledge advocacy, moral education, information provision, etc. [20].

\section{Discussion and Suggestions}

As food security is the focus of the whole society, it is of great importance. The legal system of supervision is the source of food security problems and thus is the most important of aspect of food security. Based on the comparative study of Mainland China and Taiwan, it was found that there were similarities and differences in the legal system of food security supervision between Mainland China and Taiwan. In view of this, the researchers put forward the following opinions and suggestions about the current legal system of food security supervision in Mainland China and Taiwan.

\subsection{Suggestions for Food Security in Mainland China}

In view of the current food security problems in Mainland China, this paper considers that it should establish a scientific, rational, advanced, and sound food security supervision system, learn from Taiwan's "product-management-oriented, stage-management-supplemented" food security supervision model, and change the current situation of unclear powers and responsibilities of various departments, different divisions of labor, and low efficiency of supervision [45-47].

(1) One suggestion is to deepen and refine relevant food security laws, such as clarifying the relevant unclear legal interpretation in the Food Security Law.

(2) In order to inform people, it could be a good idea to realize a specific international system for the rigorous evaluation of human health and environmental consequences [21]. This entails standardizing food security certification activities, improving the food recall system, establishing a food security liability insurance system, and formulating strict food security standards, which could be strictly implemented with reference to Taiwanese or European and American standards.

(3) Another suggestion is to foster diversified food security intermediary organizations with powerful supervision, improve their legal status, strengthen their supervision and restraint mechanisms, 
improve their role of social supervision, and form a four-in-one supervision system involving government, enterprises, intermediaries, and individuals.

(4) Another suggestion is to formulate strict punishment measures, increase the intensity of punishment, and combine fines and corporal punishment, with multiple and more severe penalties for more serious offenses.

(5) Another suggestion is to establish an incentive system to encourage consumers to report illegal acts, bring out public enthusiasm to participate in food security, and give full play to their supervisory role.

(6) Civil education cultivated appropriately would enforce civil awareness, as well as public cognition of crisis prevention [20,48], providing moral education to food companies and raw material suppliers and popularizing and advocating food security knowledge among consumers to solve food security problems in a two-pronged way [21].

\subsection{Suggestions for Food Security in Taiwan}

In view of the abovementioned food security problems in Taiwan and the analysis results, this paper considers that the key point of response to these problems is to formulate the basic laws for the promotion of food security, review and revise Taiwan's existing cumbersome and decentralized food security regulations, and integrate them into a set of transparent, consistent, and comprehensive food security regulations $[45,49,50]$.

(1) Food security legislation must cover every stage of food production and should be extended to the scope of animal feed. This is because only by ensuring feed security can it guarantee the security of livestock and poultry products, and also indirectly guarantee the security of consumers. Regulations should clearly specify that during the process of food production and marketing, suppliers of each production and marketing supply chain should bear the responsibility for the security of the food or raw materials they provide. Illegal food suppliers should be severely penalized and exposed to severe criminal liability.

(2) A special administrative body should be set up to coordinate all food security businesses so as to take effective food security management measures to safeguard public health and restore consumers' confidence in the security of food sold in Taiwan; for example, further integrating food security and hygiene regulatory bodies to centralize the power of food security and hygiene supervision, establishing the Food and Drug Administration, and reclaiming the business of imported food inspection from the Label Inspection Authority.

(3) Introduce third-party inspection: Inspection fees of all of the food on the shelves can be paid by consumers themselves to transfer the inspection fee to consumers by means of increasing the prices of commodities by the inspection cost, so that consumers can buy assurance and producers cannot counterfeit it.

(4) Improve and strictly control the food "production resumé" policy: The so-called "production resumé" system refers to the establishment of a "traceability system" to track the information of raw material ingredients, production, processing, circulation, sale, date, and other stages of food and to mark related information on the products. After the establishment of this system, on the one hand, consumers can understand the relevant ingredients and service life of the food; on the other hand, once the food has problems, we can immediately identify the crux of the problem from relevant information and deal with it properly, which will play an important role in ensuring food security in Taiwan.

(5) The government should strengthen food knowledge regarding security education advocacy and moral education, help to teach food producers at basic levels to follow good farming practices, help food processors to abide by good operation practices and instructions, and help food cooks to follow good hygienic practices and habits [20]. Food security knowledge, education, and training should be provided to producers at each stage of the food supply chain in order to prevent the generation of harmful residues during the food production process and avoid harm to consumers' health and the environment [21,22]. 


\subsection{Implications}

In recent years, food problems have been occurring in Mainland China and Taiwan. In order to ensure food security and considering the fact that food security is directly related to people's lives, the public's rights, and the credibility of the government, the relevant departments in Mainland China and Taiwan have realized the importance of responding to the food security crisis and signed the preliminary "Agreement on Food Security in Mainland China and Taiwan" to safeguard the rights and interests of consumers in Mainland China and Taiwan [25]. Furthermore, in the face of increasingly severe food security crises, governments shall strengthen cooperation in constructing legal systems on food security supervision and inspection, exchange experience, and cooperate in inspection (for example, when dealing with the international food security problem of imported poisonous milk powder, Mainland China can refer to strict inspection practices, such as "Food GMP Certification" and the high import standard requirements and policy means implemented in Taiwan over the years, starting from the source management of food security, so as to prevent the entry of problematic foreign food). Finally, because, in general, the more unfamiliar things are, the more they are perceived as risky, and avoidance and fear are the consequences [21,22], to avoid the occurrence of hygienic hazards of food, governments should establish adequate communication, be open and transparent in policy formulation, provide consumers with more information about how to fill the gap in food security knowledge, and share food security information to avoid rumors of food insecurity circulating in popular science $[20,24,25]$. It is expected that the results and suggestions of this study will be helpful in crisis response, as well as to the supervision system in Mainland China and Taiwan to guard food security. Although the comparative analysis was specific to the two regions, its characteristics are typical of food security globally, especially in Asia.

Author Contributions: Writing-review, analysis \& interpretation of data, C.-C.M.; Writing - review \& editing, H.-S.C.; Writing-review, editing \& Project administration, H.-P.C. All authors have read and agreed to the published version of the manuscript.

Funding: This research received no external funding.

Conflicts of Interest: The authors declare no conflict of interest.

\section{References}

1. Wang, H.T. Crisis Communication of the Government: A Case Study of the Ba-zhang Creek Event. Master's Thesis, University of Shih Hsin, Taipei, Taiwan, 2010, unpublished. Available online: https: //hdl.handle.net/11296/6xnbhw (accessed on 23 November 2019).

2. Luo, S.T. The Media Agenda and Government Agenda in China's Food Safety Crisis. Master's Thesis, Southwest University of Political Science and Law, Chongqing, China, 2012, unpublished.

3. Tan, Y.H. Effectiveness evaluation of emergency response plan. Sci. Technol. Manag. Res. 2010, 24, 56-59.

4. Li, Y.Z. Harmony for Chaos, Food Safety, No Small Matter. Available online: http://shipin.people.com.cn/GB/ 86164/363431/index.html (accessed on 20 May 2013).

5. Chiou, W.W. The Development and Challenge of the Food Safety Institution in the PRC: On the Case of China's Poisoned-Milk Scandal. Master's Thesis, Nanhua University, Chiayi, Taiwan, 2010, unpublished.

6. China Economic Net. 2012 Food Safety Confidence Index Research Report. Available online: http: //www.ce.cn/cysc/ztpd/12/xcz/xxzs/201206/15/t20120615_21179342.shtml (accessed on 15 June 2012).

7. China Food Safety Rule Network. Food Safety and Hygiene in Taiwan. Available online: http://foodlaw.cn/ lawhtml/ywjy/109.shtml (accessed on 18 June 2010).

8. Zhang, F. The development and improvement of China's modern food safety supervision legal system. Polit. Law 2007, 5, 18-23.

9. Xia, Y.J. Food safety supervision system in Taiwan and its enlightenment. J. Wuhan Univ. Technol. (Soc. Sci. Ed.) 2013, 26, 163-168.

10. Wang, K.Y. Non-conventional security and reforms of Taiwan's military strategy. Taiwan Int. Stud. Q. 2010, $6,1-43$.

11. Fink, S. Crisis Management: Planning for the Inevitable; AMACOM: New York, NY, USA, 1986. 
12. Coombs, W.T. Ongoing Crisis Communication; Sage: London, UK, 1999.

13. Howitt, A.M.; Leonard, H.B.; Giles, D. (Eds.) Managing Crises; Sage: New York, NY, USA, 2009.

14. Wang, H.Z. Comparative study on the background of Chinese and American food safety legislation. Reform Open. 2010, 8, 13-14.

15. Yeung, R.W.; Morris, J. Consumer perception of food risk in chicken meat. Nutr. Food Sci. 2001, 31, $270-279$. [CrossRef]

16. Chen, K.L. Food Safety Issues and Risk Perception of Public: A Situational Theory of Problem Solving. Master's Thesis, University of Shih Hsin, Taipei, Taiwan, 2012, unpublished. Available online: https: //hdl.handle.net/11296/4s75j9 (accessed on 12 October 2019).

17. Smith, R.D. Responding to global infectious disease outbreaks. Public Relat. Rev. 2006, 33, 120-129.

18. Palencher, M.J.; Heath, R.L. Strategic risk communication: Adding value to society. Public Relat. Rev. 2007, 33, 120-129. [CrossRef]

19. Jacob, C.; Mathiasen, L.; Powell, D. Designing effective messages for microbial food safety hazards. Food Control 2010, 21, 1-6. [CrossRef]

20. Xu, R.; Wub, Y.; Luan, J. Consumer-perceived risks of genetically modified food in China. Appetite 2020, 147, 104520. [CrossRef]

21. Boccia, F.; Covino, D.; Sarnacchiaro, P. Genetically modified food versus knowledge and fear: A Noumenic approach for consumer behaviour. Food Res. Int. 2018, 111, 682-688. [CrossRef] [PubMed]

22. Boccia, F. Fear of Genetically Modified Food and the Role of Knowledge for Consumer Behavior: The New Noumenic Approach. EC Nutr. 2019, 14, 205-207.

23. Baker, G.A. Food safety and fear: Factors affecting consumer response to food safety risk. Int. Food Agribus. Manag. Rev. 2003, 6.

24. Eiser, J.R.; Miles, S.; Frewer, L.J. Trust, perceived risk, and attitudes toward food technologies 1. J. Appl. Soc. Psychol. 2002, 32, 2423-2433. [CrossRef]

25. Li, Y.; Gao, X.; Du, M.; He, R.; Yang, S.; Xiong, J. What Causes Different Sentiment Classification on Social Network Services? Evidence from Weibo with Genetically Modified Food in China. Sustainability 2020, 12, 1345. [CrossRef]

26. MA, C.C. Responding in Crises: A Comparative Analysis of Disaster Responses between Mainland China and Taiwan. J. Homel. Secur. Emerg. 2012, 9, 1. [CrossRef]

27. Keman, H. Comparative research methods. Comp. Polit. 2014, 3, 47-59.

28. Pennings, P.; Keman, H.; Kleinnijenhuis, J. The comparative approach: Theory and method. In Meaning and Use of the Comparative Method: Research Design; Sage Publications: London, UK; Thousand Oaks, CA, USA, 1999.

29. Chen, X.M. Qualitative Research Methods and Social Science Research; Educational Science Publishing House: Beijing, China, 2000.

30. Overseas Agricultural Product Regulations. Mainland China Food Regulations Food Additives. Available online: http://foodadd.cas.org.tw/ (accessed on 2 November 2017).

31. Zhang, H. On Perfecting the Food Safety Legal System. Port Health Control 2006, 3, 4-5.

32. Luo, J.; Ren, D.P.; Yang, Y.X. The loopholes and improvement of food security regulation system in China. Food Sci. 2006, 7, 250-253.

33. Xie, S.F. A study on product liability insurance system in food industry-Inspiration from China's Taiwan food industry compulsory insurance legislation. Econ. Manag. 2011, 25, 83-87.

34. Jiang, X.F. On the crime of producing and selling toxic and harmful food. Leg. Syst. Soc. 2012, 36, 278-279.

35. Zhou, H.A. Comparative Study of Criminal Law Protection of Food Safety across the Taiwan Straits. Master's Thesis, Nanjing Normal University, Nanjing, China, 2010, unpublished. Available online: https: //max.book118.com/html/2014/0329/7056505.shtm (accessed on 8 November 2019).

36. Kai, Z.; Fanfan, H.; Kui, Y.; Xueqiong, R.; Si, C.; Xiaojing, L.; Lixia, G. Current situation, problems, challenges and countermeasures of food safety risk communication in China. Chin. J. Food Hygiene 2012, 6, 19.

37. Fan, S.; Brzeska, J. Feeding more people on an increasingly fragile planet: China's food and nutrition security in a national and global context. J. Integr. Agric. 2014, 13, 1193-1205. [CrossRef]

38. Marucheck, A.; Greis, N.; Mena, C.; Cai, L. Product safety and security in the global supply chain: Issues, challenges and research opportunities. J. Oper. Manag. 2011, 29, 707-720. [CrossRef] 
39. Pei, X.; Tandon, A.; Alldrick, A.; Giorgi, L.; Huang, W.; Yang, R. The China melamine milk scandal and its implications for food safety regulation. Food Policy 2011, 36, 412-420. [CrossRef]

40. Bi, B. Taiwan's food safety supervision legal system and its reference significance. J. Anhui Agric. Sci. 2013, 41, 2261-2265.

41. Guo, W.; Zhou, W.; Wang, W.Z.; Nie, X.M.; Li, L.; Chu, X.G. Introduction to Taiwan food safety supervision system and quality certification. Chin. Agric. Sci. B 2009, 25, 79-83.

42. Chen, L.F.; Zhao, F.J. Analysis on the construction of China's food safety legal system. J. Anhui Agric. Sci. 2008, 10, 4275-4277.

43. Liu, P. Tracing and periodizing China's food safety regulation: A study on China's food safety regime change. Regul. Gov. 2010, 4, 244-260. [CrossRef]

44. Zhou, Y.H.; Song, Y.L.; Yan, B.J. Compatible-incentive Mechanism Design of Food Safety Supervision in China. Commer. Res. 2013, 1, 4-11.

45. Zhou, J. A Study on Punitive Compensation System of Food Safety Law. Master's Thesis, Tianjin Polytechnic University, Tianjin, China, 2010, unpublished.

46. Yu-li, S.H.A.N. The Motives, Measures, Achievements and Enlightenment of Three Rural Land Reforms in Taiwan. Taiwan Res. J. 2010, 3, 8.

47. Lu, J.H. The status quo and enlightenment of Taiwan agricultural product safety retrospect. Straits Sci. 2012, 9, 33-35.

48. Useem, M.; Kunreuther, H.; Michel-Kerjan, E. Leadership Dispatches: Chile's Extraordinary Comeback from Disaster; Stanford University Press: Palo Alto, CA, USA, 2015.

49. Wei, G.; Yu, Z.; Wenzhi, W.; Xuemei, N.; Li, L.; Xiaogang, C. Introduction of Food Safety Supervision System and Quality Certification in Taiwan. Chinese Agric. Sci. B. 2010, 18.

50. Chang, C.F. Constructing the Process Model for the Traceability of Rice Producing and Distribution. Master's Thesis, Tatung University, Taipei, Taiwan, 2007, unpublished. Available online: https://hdl.handle.net/11296/ ucb5w4 (accessed on 10 April 2020).

(C) 2020 by the authors. Licensee MDPI, Basel, Switzerland. This article is an open access article distributed under the terms and conditions of the Creative Commons Attribution (CC BY) license (http://creativecommons.org/licenses/by/4.0/). 


\title{
Quantification of Household Food Waste in Hungary: A Replication Study Using the FUSIONS Methodology
}

\author{
Gyula Kasza ${ }^{1, *}$, Annamária Dorkó ${ }^{1}$, Atilla Kunszabó ${ }^{1}$ and Dávid Szakos ${ }^{2}$ \\ 1 Risk Management Directorate, National Food Chain Safety Office, 1024 Budapest, Hungary; \\ dorkoa@nebih.gov.hu (A.D.); kunszaboa@nebih.gov.hu (A.K.) \\ 2 Department of Veterinary Forensics and Economics, University of Veterinary Medicine Budapest, \\ 1078 Budapest, Hungary; szakos.david@univet.hu \\ * Correspondence: kaszagy@nebih.gov.hu; Tel.: +36-20-454-8418
}

Received: 15 March 2020; Accepted: 8 April 2020; Published: 11 April 2020

\begin{abstract}
Household food waste accounts for the most significant part of total food waste in economically developed countries. In recent times, this issue has gained recognition in the international research community and policy making. In light of the Sustainable Development Goals of FAO, mandatory reporting on food waste has been integrated into European legislation, as a basis of preventive programs. The paper presents the results of research that aimed to quantify the food waste generated by Hungarian households. Research methodology was based on the EU compliant FUSIONS recommendations. In total, 165 households provided reliable data with detailed waste logs. Households were supported by kitchen scales, measuring glasses, and a manual. Based on the extrapolation of the week-long measurement, the average food waste was estimated to be $65.49 \mathrm{~kg}$ per capita annually, of which the avoidable part represented $48.81 \%$. Within the avoidable part, meals, bakery products, fresh fruits and vegetables, and dairy products are accountable for $88 \%$ of the mass. This study was a replication of the first Hungarian household food waste measurement conducted in 2016 with the same methodology. Between the two periods, a 4\% decrease was observed. The findings, for instance the dominant share of meals in food waste, should be put in focus during preventive campaigns. National level food waste measurement studies using the FUSIONS methodology should be fostered by policy makers to establish the foundations of effective governmental interventions and allow for the international benchmarking of preventive actions.
\end{abstract}

Keywords: household food waste; food waste measurement; food waste composition; sustainable consumption; consumer research; consumer behavior

\section{Introduction}

In recent times, food wastage has become a frequently investigated issue. In countries with developed economic status, the largest quantities of food waste are generated at the consumer level [1]. The ratio of household food waste in the EU is estimated to be about $53 \%$ of the amount produced within the entire food chain, which equals $92 \mathrm{~kg}$ per capita annually [2]. Reported numbers are mainly originating from calculations based on general waste databases of the member countries. In the last ten years, research activity has been accelerated in this field, delivering a variety of-sometimes contradictory-results. The greatest research activity in the field is focusing on Northern and Western Europe (prominently Denmark, Finland, Germany, Italy, Norway, UK) [3], but there are several examples outside the continent as well (USA, China, Canada) [4].

The majority of the variation in reported empirical data can be explained by the wide range of methods used by the studies. There are quite a few direct research methods that can be applied in 
research practice to acquire primary data on the extent of household food waste [5,6]. Several reports used questionnaires, where the focus is on self-reporting [7-10]. Physical measurements, such as diaries or composition analysis, are also widely used methods [11-17]. Nevertheless, we must take into consideration that these methods entail a great deal of uncertainty [18]. For instance, separately collected organic stream could contain other biological waste besides food (flowers, green waste from the garden or the street), while other elements could be missing (food put in general domestic waste, poured into the sink, or fed to animals) [19]. A significant gap can be detected between the amounts resulted from physical measurements and self-report surveys $[17,20,21]$. Self-reported numbers tend to be significantly lower than physically measured values. Physical measurements, however, require a serious commitment from family members and a great amount of trust invested in the researchers. Moreover, gathering an appropriate sample size in physical measurement surveys is a very challenging endeavor. Despite the known hindrances of the discussed research methods, it must be noted that acquiring reliable and detailed information on household food waste is of great importance [22]. A recent study argues that physical measurements for data collection instead of self-reporting are preferred [23], because of their higher reliability.

In the case of Hungary, the only study based on the physical measurement of household food waste was conducted in 2016 [24]. The measurement involved 100 households during a one-week period. Besides solid food items, liquid waste was also measured, which was later considered to be an essential element of food waste accounting [6]. Based on the results of this study, $68.04 \mathrm{~kg}$ of food were wasted in average by a Hungarian person annually, and out of it $33.14 \mathrm{~kg}$ would have been avoidable. Similar results have been found by a Greek study, involving 101 urban households [15]. After the 14-day measurement period, the assessment of the total per capita food waste resulted in $76.1 \mathrm{~kg}$, of which $25.9 \mathrm{~kg}$ considered as avoidable. The proportion of the avoidable part was proven to be relevant in Finland too, $23 \mathrm{~kg}$ per person annually [12]. The differentiation between avoidable and unavoidable food waste is recommended and applied in the vast majority of measurements $[11,12,16,17,23,25,26]$.

The composition of household food waste varies from country to country. However, it is found that generally the most perishable food items are thrown away the most frequently [27]. With respect to the avoidable category, these food items include fresh fruits and vegetables, bakery products, and dairy products. According to the previous Hungarian study, the main types were meals, bakery products, fresh vegetables, dairy products, and fresh fruits [24]. In Serbia, though in reverse order, bakery products and ready-to-eat food items were on the top of the list as well [28]. Bread and bakery products were observed to have the highest ratio in Norway as well, based on a waste composition analysis [14]. Contrastively, fresh vegetables and drinks have been found to be the most prevalent types in the UK [11]. Vegetables were observed to be the most commonly wasted food items in Denmark, Greece, and Israel $[13,15,16]$.

In order to reach the Sustainable Development Goal 12.3, halving the amount of food waste by 2030 [29], it would be essential to determine the magnitude of the problem that we face. According to a recent study, $15-16 \%$ of the total environmental impact of the food supply chain is derived from food waste [30]. It can also be stated that food wastage is in constant increase (especially in developed countries), and the actual quantity of food waste seems to be twice the amount of the results from previous global estimates [31]. Physical measurements, especially in households-a sector that accounts for the most significant part of food waste in the food chain - play a central role in refining national statistics [24]. However, this poses a particular challenge, since the lifestyle, consumption trends, and purchasing habits are in continuous change [32].

Recently, the importance of food waste measurement has become a major concern also at the European Union legislative level. Until 2020, the member states have to integrate a food waste reduction strategy into the national waste reduction plan. Furthermore, food waste prevention campaigns have to be established at the national level [33]. The European Commission has recently issued a decision establishing a common methodology and determining the minimum quality requirements for food waste data collection $[34,35]$. The national food waste reduction strategies should be based on the 
actual numbers, which have to be updated every four years. Measures aiming at food waste reduction may pose an elevated health risk to consumers (for instance eating expired food or offering it to charity, feeding potentially infectious food to livestock or companion animals). Therefore, communication campaigns, governmental institutions, and business organizations should handle food safety questions as a priority during food waste reduction efforts [36].

The aim of this research was to estimate the amount of food waste that an average Hungarian household generates based on a one-week period. This investigation was a replication of a household food waste measurement conducted in 2016 with the same methodology, within the boundaries of the Wasteless (Maradék nélkül) food waste prevention campaign, organized by the National Food Chain Safety Office in Hungary.

\section{Materials and Methods}

\subsection{Theoretical Background}

Household food waste measurement is an important step in the global efforts to reduce food losses [37]. However, a sound theoretical background, experience in practical organization, and comparable research data are scarce in this field. From the 1990s, a methodological evolution can be observed in this field, which allowed us to apply a standardized research methodology in 2016 and in our actual study (Figure 1).

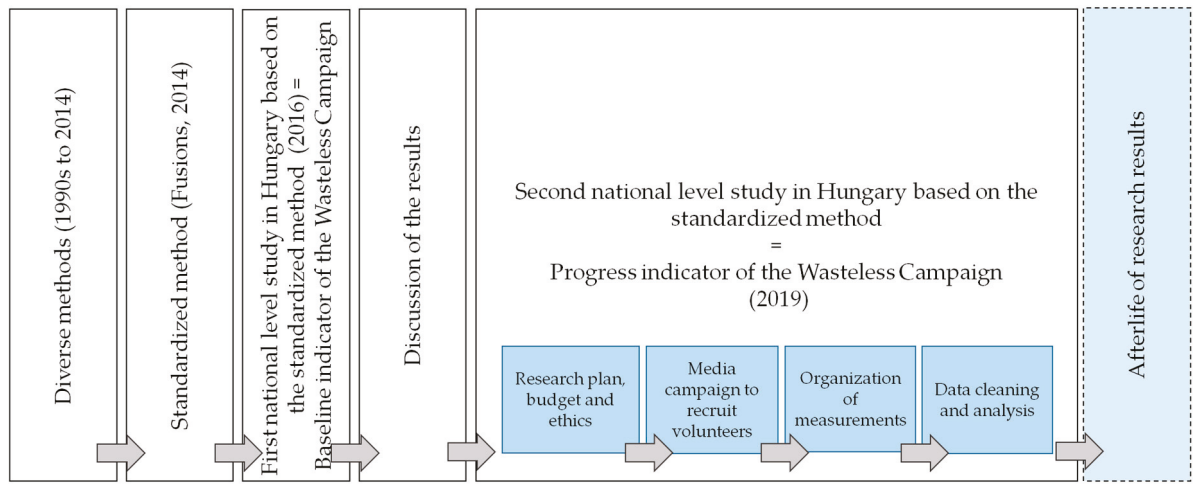

Figure 1. Theoretical framework and organization of the study.

2.1.1. Diverse Methods (1990s to 2014)

Despite the growing number of studies carried out to investigate the quantity of household food waste, the diversity of methodological approaches that different researchers applied limited the comparability of most of the findings, dating back to the 1990s [18], which might have resulted in different interpretations of the research data. The following methods were used most frequently [38]:

- Questionnaire-based survey

- Food waste diary

- Waste composition analysis

- Interview

- Mass and energy balance

- Statistics from authorities or waste management companies

Besides the basic methodological approach itself, a further significant bias resulted from small differences in the considerations applied by the research teams. For instance, the recorded material streams and their classification were also divergent. Typical differences found in the literature: 
- Inedible part of foodstuffs are recorded / not recorded [3]

- Differences in the definition of the avoidable (in some studies: edible) food waste category [16]

- Potentially avoidable food waste is classified / not classified as an individual category [26]

- Liquids are measured / not measured $[12,15,17]$

- Food waste going to a valorization stream (e.g., composting, feed) are not recorded / recorded [5, $12,17]$

- Food made for human consumption but ultimately fed to animals is classified / not classified as food waste [39]

- The part of food eaten that exceeds physiological nutritional needs of a person is recorded / not recorded as food waste [40]

- $\quad$ Food packaging is recorded / not recorded [41]

- Different measurement tools and units that could not be reliably converted to mass units $[42,43]$

- Different observation units (e.g., per person, per household) $[13-15,17,20,24]$

\subsubsection{Standardized Method (FUSIONS, 2014)}

Considering these barriers, the FUSIONS project, funded by the European Commission recognized the importance of establishing a standard for measurement methodology. Between 2012 and 2016, FUSIONS consulted researchers, industrial stakeholders, and governments about the harmonization of food waste monitoring. One of the most significant deliverables of FUSIONS was a well-balanced, widely accepted standardized methodology (that we refer to as FUSIONS methodology) to measure food waste [38], which provides the opportunity to compare country-level data. The most important considerations for household food waste measurement studies, according to the FUSIONS methodology, are the following:

- Food waste should be recorded in a diary by household members

- A description of the food or drink waste should be given in the diary

- The amount of waste should be measured and recorded

- Throughout the fieldwork, it is suggested that the researcher maintains regular contact with each household to resolve any issues, encourage participation, and ensure the accurate completion of the diary

- The sample needs to include at least a few hundred households

\subsubsection{First National-Level Study in Hungary Based on the FUSIONS Methodology}

In 2015 the National Food Chain Safety Office of Hungary (Nébih) started a public awareness campaign on household food waste prevention, called "Wasteless", which received support in 2016 from the LIFE Framework program of the EU. Influential European food waste prevention projects were: the EU-FP7 funded FUSIONS and Horizon 2020 funded "Refresh", the "Love Food Hate Waste" campaign by WRAP, and the "Every Crumb Counts" campaign organized by different entities from the industry, academics, and NGOs. Wasteless aimed to decrease avoidable food waste in Hungarian households. In order to measure the efficiency of the communication efforts, a baseline was set based on the FUSIONS recommendations. This has been the first empirical study carried out with this methodology in the Central and Eastern European region [24]. Focus group interviews and a preliminary, representative quantitative consumer survey covering 1000 respondents were conducted to receive research insights before the first household study.

\subsubsection{Discussion of the Experiences of the First Study}

The results of the survey were published in national and international academic journals and discussed at national and international platforms (including the EU Platform on Food Losses and Food Waste, operated by the Directorate-General for Health and Food Safety of the EU Commission) 
and scientific conferences $[24,37,44-47]$. Public dissemination activities through the Wasteless communication campaign were also conducted, presenting the results to consumers. Until 2018 the campaign managed to achieve a reach of almost 50 million via different media platforms [37], and the research results are widely cited by journalists even today.

\subsubsection{Second National-Level Study in Hungary Based on the FUSIONS Methodology}

A second study for household food waste measurement using the FUSIONS methodology took place in 2019. The research was organized to deliver comparable data to monitor changes in food waste quantities and composition. According to the analysis of the literature, this study has most probably been the first one to repeat a previous measurement based on the FUSIONS methodology. Although the research was not conducted as a validation action, its experiences are still valuable to indicate the replicability of the methodology.

The research was advertised in a media campaign in October 2019. The households were selected on the basis of voluntary registration. The advertisement included radio interviews (6); television interviews (3); press releases (7); online press releases (45). In total, 200 households applied to participate in the research. The sampling was conducted in November and December of 2019. The sampling period avoided all national and religious holidays.

During the measurement period, households received a kitchen scale (accuracy in grams) and a measuring glass from the research team. The measuring glass served for liquid wastes. Participants were also provided with a manual which described the scope of the research and explained clearly the difference between avoidable and unavoidable food waste. The following definitions were used for avoidable, unavoidable, and potentially avoidable food waste [11]:

- Avoidable-food and drink thrown away that was, at some point prior to disposal, edible (e.g., slice of bread, apples, meat)

- Unavoidable - waste arising from food or drink preparation that is not, and has not been, edible under normal circumstances (e.g., meat bones, egg shells, pineapple skin, tea bags)

- Potentially avoidable: food and drink that some people eat and others do not (e.g., bread crusts), or that can be eaten when a food is prepared in one way but not in another

For the whole duration of the investigation, e-mail and telephone support was provided to the participants. Attention was paid to reduce bias by explaining participants that the data collection was conducted anonymously, which impeded the identification of the household. The data was administered into a unified waste log. Participating households could use an online platform or a printed sheet for this purpose. The weight and exact type of each unit of food waste had to be recorded for one week (seven days). This time frame is assumed to be long enough to reduce influences caused by the participants' compulsion to conform, originating from the fact of observation. Data on solid and liquid waste were documented in mass (grams). Weighing had to be performed prior to disposal.

A supporting unit was set up to help participants of the household measurement study taking care of:

- Procurement of the tools for the measurement (scales and measuring glasses)

- Compilation of the questionnaire and log-book structure, maintaining the online platform for online data registration, and printing the hard copy version of the diary

- Receiving volunteer applications and answering the questions of the prospective households

- Distributing measurement tools, guides, and diaries to the participants

- Operating a call center for the participants to resolve any issues that arose during the measurement

- Online messages to keep contact with participants and maintain motivation

A total of 200 households applied for participation in the survey during the media campaign, but only 165 households provided a reliable and complete data set for the analysis. The most common reasons for excluding households were interrupted communication, logs not returned by 
the participants, an inappropriate or non-consecutive data recording period, missing data in the logs, or inadequate details on food types that made the classification impossible.

Although there have been several studies on the topic with similar or even smaller sample sizes ([15] $n=101 ;[16] n=192 ;[19] n=61 ;[41] n=61 ;[48] n=13)$, a post-hoc calculation was performed to determine the power of the test, for which data from the previous Hungarian study [24] served as basis. The power of the test proved to be $87.5 \%$, which meets the criterion of being above $80 \%$ [49-51].

Based on the household data, a detailed classification was made by the research team (e.g., meals, bakery products, fresh vegetables, etc.). Each item had to be recorded by the participants as accurately as possible (e.g., not 'bread' but 'bread crust', not 'chicken' but 'chicken skin', etc.). Avoidable and unavoidable food waste units were recorded separately by the households. Subsequently to the measurement, the research team conducted a post-hoc validation of the categorization performed by the consumers.

After data cleaning, the analysis was conducted for each household. Data on food waste per person were calculated in each food waste category. The results were extrapolated to one year by multiplying the results of the one week by 52 .

\subsubsection{Afterlife of Research Results}

Planning the afterlife of the research data has been a part of the theoretical framework This inspection is considered to be an element in a time series study, with the objective of providing information to policy makers on a regular basis and also helping to optimize public awareness-raising activities. Since the reporting on the food waste situation became a compulsory activity of all EU member states [35], the study will also serve to deliver national level data to the EU Commission with respect to Hungarian households. Experiences with the FUSIONS methodology are still scarcely available, and therefore sharing the findings of this research may help other research teams to start their own activities in this field.

\subsection{Sample Description}

The socio-demographic characteristics were collected by an initial questionnaire at the households (Table 1). This characterization covered the geographical location, the size and level of income of the household, and the age, sex, and qualification of the respondent. The income level of the household had to be estimated subjectively by the inhabitants, compared to the average income level in Hungary. A total of 200 households applied, and 165 households provided appropriate data sets. These 165 households represented 452 consumers in total.

Table 1. Socio-demographic composition of the sample.

\begin{tabular}{cc}
\hline Sex of respondents generally responsible for food purchasing & Sample \\
\hline Female & $83.03 \%$ \\
Male & $16.97 \%$ \\
\hline Regions (NUTS1) & \\
\hline Central Hungary & $42.42 \%$ \\
Transdanubia & $32.73 \%$ \\
Great Plain and North & $24.85 \%$ \\
\hline Geographical location & \\
\hline Capital city (Budapest) & $27.88 \%$ \\
Other city & $55.76 \%$ \\
Village & $16.36 \%$ \\
\hline
\end{tabular}


Table 1. Cont.

\begin{tabular}{cc}
\hline Household size & \\
\hline 1 & $13.94 \%$ \\
2 & $33.94 \%$ \\
3 & $26.06 \%$ \\
4 & $17.58 \%$ \\
$\geq 5$ & $8.48 \%$ \\
Average household size & 2.7 people \\
\hline Age of the person generally responsible for food purchasing & \\
\hline Under 30 years & $11.52 \%$ \\
Between 30 and 39 years & $20.61 \%$ \\
Between 40 and 59 years & $50.91 \%$ \\
Above 60 years & $16.97 \%$ \\
\hline Qualification of the person generally responsible for food & \\
purchasing & $6.0 \%$ \\
\hline Elementary & $38.2 \%$ \\
High school graduation & $61.2 \%$ \\
\hline Higher education & $1.21 \%$ \\
\hline Income level of the household & $14.55 \%$ \\
Low & $65.45 \%$ \\
Below average & $16.97 \%$ \\
Average & $1.82 \%$ \\
\hline Above average &
\end{tabular}

Number of households: 165; Total participants: 452.

\section{Results}

During the measurement period, the 165 participant households generated $532.76 \mathrm{~kg}$ of food waste (Table 2). After extrapolation of the one week data per capita, the total per capita food waste was estimated to be $65.49 \mathrm{~kg}$ annually (Table 3).

Table 2. Quantity of food waste categories.

\begin{tabular}{cccc}
\hline \multirow{2}{*}{ Food Waste Categories } & \multicolumn{2}{c}{ Amount of Waste of $\mathbf{1 6 5}$ Households during the One-Week Period (kg) } \\
\cline { 2 - 4 } & Solid & Liquid & Total = Solid + Liquid \\
\hline Unavoidable food waste & 239.33 & 7.19 & 246.52 \\
Potentially avoidable food waste & 17.40 & 3.27 & 20.67 \\
Avoidable food waste & 218.27 & 47.29 & 265.56 \\
\hline Total food waste & 475.00 & 57.75 & 532.75 \\
\hline
\end{tabular}

Table 3. Estimation of annual household food waste generation per capita.

\begin{tabular}{cccc}
\hline \multirow{2}{*}{ Food Waste Categories } & \multicolumn{2}{c}{ Extrapolated Data for One Year per Capita (kg) } \\
\cline { 2 - 4 } & Solid & Liquid & Total = Solid + Liquid \\
\hline Unavoidable food waste & $29.91(51.08 \%)$ & $0.90(12.99 \%)$ & $30.81(47.04 \%)$ \\
Potentially avoidable food waste & $2.30(3.93 \%)$ & $0.42(6.06 \%)$ & $2.72(4.16 \%)$ \\
Avoidable food waste & $26.35(45.00 \%)$ & $5.61(80.95 \%)$ & $31.97(48.81 \%)$ \\
\hline Total food waste & $58.56(100.00 \%)$ & $6.93(100.00 \%)$ & $65.49(100.00 \%)$ \\
\hline
\end{tabular}

The proportion of the avoidable fraction (which means the real wastage) was the highest, with $48.81 \%$ ( $31.97 \mathrm{~kg}$ annually) of the total food waste. The unavoidable food waste category 
accounted for $47.04 \%$ (30.81 $\mathrm{kg}$ annually). The most prevalent food types within this category were coffee grounds, inedible fruit and vegetable parts (inedible peels such as banana peels, citrus fruit peels, onion peels, and inedible stalk, woody parts, seeds, shell of nuts, etc.), bones, eggshell, and teabags. The potentially avoidable part, such as edible fruit and vegetable peels (e.g., apple, pear, cucumber, tomato, mushroom, zucchini), chicken skin, bread crust, greasy pieces of meat, pickling liquid, juices of canned food, and oil of canned fish represented the smallest proportion, with $4.16 \%$ ( $2.72 \mathrm{~kg}$ annually). Liquid food, such as soft drinks, coffee, tea, and soup appeared in the logs in significantly lower amounts compared to solid foodstuffs (Table 3).

Eighteen different food categories were defined based on the recorded elements within avoidable food waste. Results suggest that consumers discard perishable foodstuffs more frequently and in larger quantities than durable products. Table 4 shows the mass and proportion of the established food waste categories.

Table 4. Quantity and proportion of food categories within avoidable food waste based on the one-week measurement in 165 households.

\begin{tabular}{ccc}
\hline Avoidable Food Waste & Total Weight & Proportion (\%) \\
\hline Meals (home-made and ready-to-eat) & 118.80 & 44.74 \\
Bakery products & 46.79 & 17.62 \\
Fresh vegetables & 26.55 & 10.00 \\
Dairy products & 21.12 & 7.95 \\
Fresh fruits & 20.03 & 7.54 \\
Mineral water, soft drinks, coffee, tea & 6.93 & 2.61 \\
Canned foods, pickles & 5.37 & 2.02 \\
Processed animal products & 4.77 & 1.80 \\
Grain products (flour, semolina, oat) & 4.25 & 1.60 \\
Raw meat & 4.06 & 1.53 \\
mayonnaise) & 2.87 & 1.08 \\
Marmalades, jams & 1.37 & 0.52 \\
Confectionery, snacks & 1.20 & 0.45 \\
Eauces, toppings (ketchup, mustard, salad dressings) & 0.77 & 0.29 \\
Erost, muesli, corn flakes, raisins, puffed rice, baking mixtures & 0.49 & 0.19 \\
Frozen meats, vegetables & 0.10 & 0.04 \\
Fats (butter, margarine, lard, etc.) & 0.08 & 0.03 \\
Packed spices (rosemary, marjoram, parsley, etc.) & 0.01 & 0.01 \\
\hline Total & 265.56 & 100.00 \\
\hline
\end{tabular}

Meals (including homemade and ready-to-eat) account for the highest proportion (44.74\%) of the total avoidable food waste. Bakery products (typically breads and bread rolls) are the second most common food items in this category (17.62\%). Fresh vegetables and fresh fruits have also significant proportions, $10.00 \%$ and $7.54 \%$, respectively. Dairy products ranked in the fourth place of the list (7.95\%). These five product categories altogether represent almost $88 \%$ of the total avoidable food waste.

Based on the actual data collected from the households, the quantity of annual avoidable wastage in the particular food categories has been estimated with extrapolation (Figure 2). 


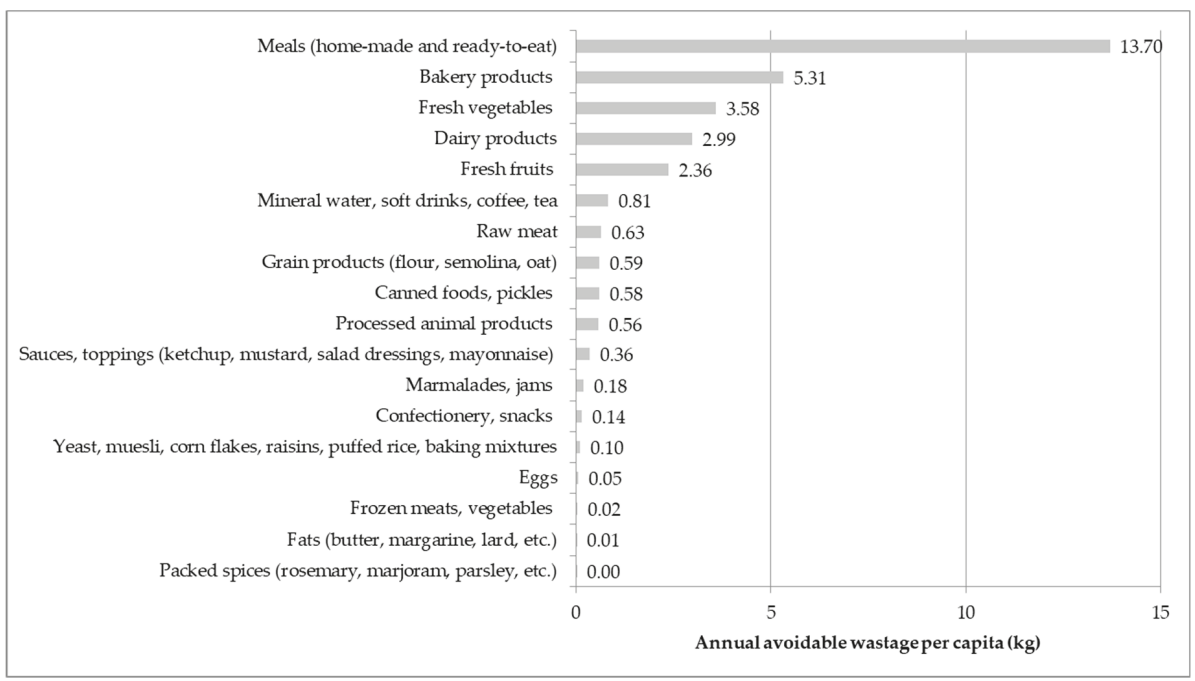

Figure 2. Annual avoidable wastage in different food categories per capita.

\section{Discussion}

Due to the role of consumers in food wastage in economically developed countries, gathering actual data on food waste generation from households is a major issue and a prerequisite for successful prevention campaigns [22]. Since the reliability of physical measurements is higher [23], our research placed the focus on determining the exact quantities of food waste that Hungarian households generate. The study illustrates several similarities and also some contradictions when compared to the international literature.

The actual study is a replication of the first Hungarian measurement-based research conducted in 2016 [24], which we regarded as a baseline for comparison. A decrease of $4 \%$ in the annual food waste per capita estimation was observed between the two periods $(65.49 \mathrm{~kg}$ compared to $68.04 \mathrm{~kg}$ from 2016). The constitution of food waste in the households was found to be very similar, indicating a dominant rate of avoidable food waste (an actual share of $48.82 \%$ compared to $48.70 \%$ in 2016), followed by the unavoidable part (47.05\% compared to $47.13 \%$ in 2016). Potentially avoidable food waste remained under $5 \%$ in both periods. (Table 5). Although the second household food waste measurement study was not organized and not suitable to be a validation of the replicability of the FUSIONS methodology [38], the results suggest that it might deliver reliable data for decision makers.

Table 5. Proportion of food waste categories (actual data compared to the findings of the 2016 study [24]).

\begin{tabular}{ccc}
\hline Food Waste Categories & $\mathbf{2 0 1 9}$ & $\mathbf{2 0 1 6}$ \\
\hline Unavoidable food waste & $47.05 \%$ & $47.13 \%$ \\
Potentially avoidable food waste & $4.15 \%$ & $4.16 \%$ \\
Avoidable food waste & $48.82 \%$ & $48.70 \%$ \\
\hline Total food waste & $\mathbf{1 0 0 . 0 0 \%}$ & $\mathbf{1 0 0 . 0 0 \%}$ \\
\hline
\end{tabular}

As already discussed, a number of methodological differences can be observed in the international literature that limits the comparability of the studies $[16,26]$. The proportion of avoidable food waste observed by the two Hungarian studies is higher than in Greece, where $25.9 \mathrm{~kg}$ from the total $76.1 \mathrm{~kg}$ household food waste $(n=101)$ was reported based on the diary method [15]. In Finland, a significantly lower amount of avoidable food waste was also found (23 kg in total) [12]. Similarly, a lower proportion 
$(35 \%)$ of avoidable waste was noted in Sweden, as a result of a waste composition analysis with 486 households [52], in which the number of individual consumers remained unknown. The differences might partially be explained by the fact that the Hungarian studies have also recorded liquids besides solid food waste, and their contribution to the avoidable part was found to be significant. However, an Italian study-applying the diary method with 388 families—demonstrated that a person generates $27.5 \mathrm{~kg}$ of avoidable food waste annually in Italy, including liquids [17]. They also pointed out that, based on the studies that they had reviewed, the average mass of edible food waste was between 27.5 and $33 \mathrm{~kg}$. The diary method was also employed in the UK, in a one-week measurement survey involving 13 households [48]. The study revealed that the total measured food waste (including liquids) was $0.199 \mathrm{~kg}$ per person per day. This would be equal to $72.63 \mathrm{~kg}$ annually, which is higher, but still similar to our results. In Israel $573 \mathrm{~g} /$ day per capita of food waste was measured involving 192 households, based on a new method of physical measurement [16]. Scaling up this outcome to one year, we would get $209 \mathrm{~kg}$, which is much higher compared to the above-mentioned studies. A further hindrance to comparing international food waste research data are the units that researchers use to present their results. While some studies-including the present paper-provide the amount of generated food waste "per person" [12,15-17,48], others presented their results "per household" [13,14,17,20,41]. The one-week long household food waste measurement study in Israel, applying waste sorting analysis, resulted in $3.012 \mathrm{~kg}$ avoidable food waste per household per week (without liquids) [20]. In Denmark, the outcomes of a waste composition analysis (involving 1474 households) showed that a household generates $183 \mathrm{~kg}$ of food waste, of which the avoidable food waste was $103 \mathrm{~kg}$ per household per year [13].

Parfitt et al. made the general observation that perishable food items are the most frequently discarded ones [27], which has been confirmed by this paper as well. Results indicate that meals, bakery products, fresh vegetables, dairy products, and fresh fruits are the most frequently discarded food types within the avoidable part. This also correlates with the outcomes of the first Hungarian study [24], which indicated the same order. However, the share of meals appeared to be higher $(44.73 \%)$ than in the previous study $(40.08 \%)$, which suggests that Hungarian consumers' cooking habits and leftover storage practices should be addressed in food waste prevention awareness campaigns. Similarly to our study, bakery products and ready-to-eat food items were found to be the most prevalent food waste types in Serbia [28]. In contrast, fresh vegetables were on the top of the list in the UK, Greece, Denmark, and Israel $[11,13,15,16,52]$. The discovered differences in the composition of household food waste may be explained by the eating habits of different nations. It has been assumed that the season when the survey period is conducted also affects the composition of discarded food types [24].

Concerning the limitations of the general interpretation of the data, it has to be mentioned that the recruitment of households was challenging, as well as achieving participant engagement and constant activity, even for a period as short as seven days. An additional potential source of error is the fact that, since the research team was not capable of offering a financial incentive, enthusiastic participants with a more conscious behavior regarding food handling were more likely to get involved in the study [12]. However, we assume that the other family members compensated this behavior to some extent. Furthermore, in the measurement period, participants might have changed their general wasting behavior and become more conscious, knowing that they were being observed, which could have resulted in lower amounts of weighed total food waste [15]. It could also have happened that, due to the compulsion to conform, originating from the fact of observation, some participants did not record all of the discarded food items. On the other hand, the duration of the survey could be long enough to alleviate this phenomenon to some extent. An additional limitation of the study was that income level is difficult to assess, compared to other socio-demographic parameters [53]. Asking the respondents' income directly would have been indiscreet, and therefore a subjective ordinal scale was applied in the questionnaire. All of the mentioned limitations could result in an underestimation of the actual food waste amount generated in the household. However, by the application of the 
standardized methodology developed by FUSIONS, research data from different countries could be compared, and the possibility to observe tendencies in the different countries was also provided.

The importance of a common methodology is especially highlighted by the recent changes in EU legislation. According to the latter, all member states should conduct food waste measurements in the food chain covering agriculture, food processing, retail, catering, and households from 2020. Considering the major contribution of households to the total food waste production, this subject is expected to be a focus area in most of the countries during the next years. The EU Platform on Food Losses and Food Waste made the recommendation that in implementing national strategies to prevent food waste, member states should make full use of the latest findings of behavioral science research [37]. The experiences of the first academic studies in this field have certainly provided important input for the officers responsible for national level food waste measurements and preventive campaigns. Even more importantly, time series studies will help decision makers and communication experts to measure the performance of public awareness campaigns within a few years.

As a conclusion, the results of this research point out that a very significant part of food waste could be avoided. It is too early to reliably estimate the results of public campaigns before having longer time series data, but the first replication study using the FUSIONS methodology provided promising results. The $4 \%$ drop in avoidable food waste in a three-year period is notable, especially in a period of economic expansion. However, the fact that the list is still dominated by meals (incorporating the highest level of energy and natural resources amongst all food types) suggests that future public awareness campaigns should aim at this subject more efficiently.

Based on the results, some policy recommendations could be also formulated. Fostering national-level food waste measurement research with standardized methodologies is essential to establish the fundamentals of effective governmental interventions and to allow for the international benchmarking of preventive actions. It is also clear that food waste is a problem, which will persist for a long period in developed countries. A very intense campaign, which was observed in Hungary between the dates of the two studies, could contribute to a $4 \%$ drop in food waste, with all its novelty to society. While awareness raising should be continued, a major effort has to be placed on the integration of food waste prevention principles into children education. To be sure, we will never reach a zero level of avoidable food waste, but changing the habits of the new generation of food consumers can bring profound and long-lasting changes.

Author Contributions: G.K. and D.S. conceived the study; A.D. contributed to the data curation and formal analysis; G.K. contributed to funding acquisition; A.D. and A.K. contributed to the investigation, G.K. and D.S. contributed to the methodology and the supervision; G.K., A.D., and A.K. wrote the original draft; D.S. contributed to the review and editing of the manuscript. All authors have read and agreed to the published version of the manuscript.

Funding: The research was funded by the European Union's LIFE programme (LIFE15 GIE/HU/001048 project of the National Food Chain Safety Office of Hungary).

Conflicts of Interest: The authors declare no conflicts of interest.

\section{References}

1. Food and Agricultural Organization. Global Food Losses and Food Waste. 2011. Available online: http://www.fao.org/3/a-i2697e.pdf (accessed on 14 February 2020).

2. FUSIONS. Estimates for European Food Waste Level. 2016. Available online: https://www.eufusions.org/ phocadownload/Publications/Estimates\%20of\%20European \%20ood\%20waste\%20levels.pdf (accessed on 14 February 2020).

3. Schneider, F. Review of food waste prevention on an international level. Waste Res. Manag. 2013, 166, 187-203. [CrossRef]

4. Do Carmo Stangherlin, I.; de Barcellos, M.D. Drivers and barriers to food waste reduction. Br. Food J. 2018, 120, 2364-2387. [CrossRef]

5. Quested, T.E.; Parry, A.D.; Easteal, S.; Swannell, R. Food and drink waste from households in the UK. Nutr. Bull. 2011, 36, 460-467. [CrossRef] 
6. Corrado, S.; Caldeira, C.; Eriksson, M.; Hanssen, O.J.; Hauser, H.E.; van Holsteijn, F.; Liu, G.; Östergren, K.; Parry, A.; Secondi, L.; et al. Food waste accounting methodologies: Challenges, opportunities, and further advancements. Glob. Food Secur. 2019, 20, 93-100. [CrossRef]

7. Jorissen, J.; Priefer, C.; Brautigam, K.R. Food waste generation at household level: Results of a survey among employees of two European research centers in Italy and Germany. Sustainability 2015, 7, 2695-2715. [CrossRef]

8. Lorenz, B.A.S.; Hartmann, M.; Langen, N. What makes people leave their food? The interaction of personal and situational factors leading to plate leftovers in canteens. Appetite 2017, 116, 45-56. [CrossRef]

9. Ponis, S.T.; Papanikolaou, P.A.; Katimertzoglou, P.; Ntalla, A.C.; Xenos, K.I. Household food waste in Greece: A questionnaire survey. J. Clean. Prod. 2017, 149, 1268-1277. [CrossRef]

10. Stefan, V.; van Herpen, E.; Tudoran, A.A.; Lähteenmäki, L. Avoiding food waste by Romanian consumers: The importance of planning and shopping routines. Food Qual. Prefer. 2013, 28, 375-381. [CrossRef]

11. Quested, T.; Johnson, H. Household Food and Drink Waste in the UK; Final Report. WRAP: Banbury, UK, November 2009. Available online: www.wrap.org.uk/sites/files/wrap/Household_food_and_drink_waste_i n_the_UK_-_report.pdf (accessed on 14 February 2020).

12. Koivupuro, H.K.; Hartikainen, H.; Silvennoinen, K.; Katajajuuri, J.M.; Heikintalo, N.; Reinikainen, A.; Jalkanen, L. Influence of socio-demographical, behavioural and attitudinal factors on the amount of avoidable food waste generated in Finnish households. Int. J. Consum. Stud. 2012, 36, 183-191. [CrossRef]

13. Edjabou, M.E.; Petersen, C.; Scheutz, C.; Astrup, T.F. Food waste from Danish households: Generation and composition. Waste Manag. 2016, 52, 256-268. [CrossRef]

14. Hanssen, O.J.; Syversen, F.; Stø, E. Edible food waste from Norwegian households—Detailed food waste composition analysis among households in two different regions in Norway. Resour. Conserv. Recycl. 2016, 109, 146-154. [CrossRef]

15. Abeliotis, K.; Lasaridi, K.; Boikou, K.; Chroni, C. Food waste volume and composition in households in Greece. Glob. Nest J. 2019, 21, 399-404. [CrossRef]

16. Elimelech, E.; Ofira, A.; Eyal, E. What gets measured gets managed: A new method of measuring household food waste. Waste Manag. 2018, 76, 68-81. [CrossRef]

17. Giordano, C.; Alboni, F.; Falasconi, L. Quantities, determinants, and awareness of households' food waste in Italy: A comparison between diary and questionnaires quantities. Sustainability 2019, 11, 3381. [CrossRef]

18. Bräutigam, K.R.; Jörissen, J.; Priefer, C. The extent of food waste generation across EU-27: Different calculation methods and the reliability of their results. Waste Manag. Res. 2014, 32, 683-694. [CrossRef]

19. Parizeau, K.; von Massow, M.; Martin, R. Household-level dynamics of food waste production and related beliefs, attitudes, and behaviours in Guelph. Ontario. Waste Manag. 2015, 35, 207-217. [CrossRef]

20. Elimelech, E.; Ert, E.; Ayalon, O. Exploring the Drivers behind Self-Reported and Measured Food Wastage. Sustainability 2019, 11, 5677. [CrossRef]

21. Van Herpen, E.; van der Lans, I.A.; Holthuysen, N.; Nijenhuis-de Vries, M.; Quested, T.E. Comparing wasted apples and oranges: An assessment of methods to measure household food waste. Waste Manag. 2018, 88, 71-84. [CrossRef]

22. Corrado, S.; Sala, S. Food waste accounting along global and European food supply chains: State of the art and outlook. Waste Manag. 2018, 79, 120-131. [CrossRef]

23. Schanes, K.; Dobernig, K.; Gözet, B. Food waste matters-A systematic review of household food waste practices and their policy implications. J. Clean. Prod. 2018, 182, 978-991. [CrossRef]

24. Szabó-Bódi, B.; Kasza, G.; Szakos, D. Assessment of household food waste in Hungary. Br. Food J. 2018, 120, 625-638. [CrossRef]

25. Schneider, F.; Obersteiner, G. Food waste in residual waste of households-Regional and socio-economic differences. In Proceedings of the Eleventh International Waste Management and Landfill Symposium, Sardinia, Italy, 1-5 October 2007; pp. 469-470.

26. Lebersorger, S.; Schneider, F. Discussion on the methodology for determining food waste in household waste composition studies. Waste Manag. 2011, 31, 1924-1933. [CrossRef]

27. Parfitt, J.; Barthel, M.; MacNaughton, S. Food waste within food supply chains: Quantification and potential for change to 2050. Philos. Trans. R. Soc. B Biol. Sci. 2010, 365, 3065-3081. [CrossRef]

28. Djekic, I.; Miloradovic, Z.; Djekic, S.; Tomasevic, I. Household food waste in Serbia-Attitudes, quantities and global warming potential. J. Clean. Prod. 2019, 229, 44-52. [CrossRef] 
29. United Nations. Transforming Our World: The 2030 Agenda for Sustainable Development; United Nations: New York, NY, USA, 2015.

30. Scherhaufer, S.; Moates, G.; Hartikainen, H.; Waldron, K.; Obersteiner, G. Environmental impacts of food waste in Europe. Waste Manag. 2018, 77, 98. [CrossRef]

31. van den Bos Verma, M.; de Vreede, L.; Achterbosch, T.; Rutten, M.M. Consumers discard a lot more food than widely believed: Estimates of global food waste using an energy gap approach and affluence elasticity of food waste. PLoS ONE 2020, 15, e0228369. [CrossRef]

32. Oláh, J.; Zéman, Z.; Balogh, I.; Popp, J. Future challenges and areas of development for supply chain management. LogForum 2018, 14, 127-138. [CrossRef]

33. European Union. Directive (EU) 2018/851 of the European Parliament and of the Council of 30 May 2018 Amending Directive 2008/98/EC on Waste. Available online: https://eur-lex.europa.eu/legal-content/EN/TXT /PDF/?uri=CELEX:32018L0851\&from=EN (accessed on 14 February 2020).

34. European Commission. Commission Delegated Decision (EU) 2019/1597 of 3 May 2019 Supplementing Directive 2008/98/EC of the European Parliament and of the Council as Regards a Common Methodology and Minimum Quality Requirements for the Uniform Measurement of Levels of Food Waste. Available online: https://eur-lex.europa.eu/legal-content/EN/TXT/PDF/?uri=CELEX:32019D1597\&from=en (accessed on 14 February 2020).

35. European Commission. Commission Implementing Decision (EU) 2019/2000 of 28 November 2019 Laying Down a Format for Reporting of Data on Food Waste and for Submission of the Quality Check Report in Accordance with Directive 2008/98/EC of the European Parliament and of the Council. Available online: https://eur-lex.europa.eu/legal-content/EN/TXT/PDF/?uri=CELEX:32019D2000\&from=EN (accessed on 14 February 2020).

36. Kasza, G.; Szabó-Bódi, B.; Lakner, Z.; Izsó, T. Balancing the desire to decrease food waste with requirements of food safety. Trends Food Sci. Technol. 2019, 84, 74-76. [CrossRef]

37. Caldeira, C.; De Laurentiis, V.; Sala, S. Assessment of Food Waste Prevention Actions: Development of an Evaluation Framework to Assess the Performance of Food Waste Prevention Actions; Publications Office of the European Union: Luxembourg, 2019; ISBN 978-92-76-12388-0. [CrossRef]

38. FUSIONS. Report on Review of (Food) Waste Reporting Methodology and Practice. 2014. Available online: http://www.eu-fusions.org/index.php/download?download=7\%3Areport-on-review-of-food-wast e-reporting-methodology-and-practice (accessed on 14 February 2020).

39. Food Loss + Waste Protocol. Available online: https://flwprotocol.org/ (accessed on 3 April 2020).

40. Blair, D.; Sobal, J. Luxus consumption: Wasting food resources through overeating. Agric. Hum. Values 2006, 23, 63-74. [CrossRef]

41. Williams, H.; Wilkström, F.; Ottebring, T.; Löfgren, M.; Gustaffson, A. Reasons for household food waste with special attention to packaging. J. Clean. Prod. 2012, 24, 141-148. [CrossRef]

42. Van Dooren, C.; Janmaat, O.; Snoek, J.; Schnirijnen, M. Measuring food waste in Dutch households: A synthesis of three studies. Waste Manag. 2019, 94, 153-164. [CrossRef] [PubMed]

43. Van Geffen, L.E.J.; van Herpen, E.; van Trijp, H. Quantified Consumer Insights on Food Waste: Pan-European Research for Quantified Consumer Food Waste Understanding. 2017. Available online: https://eu-refresh.org/sites/default/files/REFRESH\%202017\%20Quantified\%20consumer\%20insight s\%20on\%20food\%20waste\%20D1.4_0.pdf (accessed on 2 April 2020).

44. Kunszabó, A.; Szakos, D.; Kasza, G. Food waste-A general overview and possible solutions. Hung. Agric. Res. 2019, 28, 14-19.

45. Szakos, D.; Szabó-Bódi, B.; Kasza, G. Consumer awareness campaign to reduce household food waste based on PLS-SEM behavior modeling. In Proceedings of the 7th International Conference on Sustainable Solid Waste Management, Heraklion Crete Island, Greece, 26-29 June 2019.

46. Doma, E.; Szakos, D.; Kasza, G.; Szabó-Bódi, B.; Bognár, L. Food waste measurement and prevention in Hungarian households. In Proceedings of the 17th Annual STS Conference, Graz, Austria, 7-8 May 2018.

47. Kunszabó, A.; Szabó-Bódi, B.; Szakos, D.; Doma, E.; Kasza, G. Education campaign based on household food waste measurement study. In Proceedings of the Reduce Food Waste Conference on Food Waste Prevention and Management, Vienna, Austria, 25-26 April 2019. 
48. Langley, J.; Yoxall, A.; Heppel, G.; Rodriguez, E.M.; Bradbury, S.; Lewis, R.; Luxmoore, J.; Hodzic, A.; Rowson, J. Food for Thought? A UK pilot study testing a methodology for compositional domestic food waste analysis. Waste Manag. Res. 2010, 28, 220-227. [CrossRef] [PubMed]

49. Kane SP. Post. ClinCalc. Available online: https://clincalc.com/stats/Power.aspx (accessed on 31 March 2020).

50. Rosner, B. Fundamentals of Biostatistics, 7th ed.; Brooks/Cole: Boston, MA, USA, 2011; ISBN 978-0-538-73349-6.

51. Levine, M.; Ensom, M.H. Post hoc power analysis: An idea whose time has passed? Pharmacotherapy 2001, 21, 405-409. [CrossRef]

52. Schott, A.B.S.; Andersson, T. Food waste minimization from life-cycle perspective. J. Environ. Manag. 2015, 147, 219-226. [CrossRef]

53. Patten, M.L. Questionnaire Research: A Practical Guide; Routledge: Abingdon, UK, 2017; ISBN 1936523310.

(C) 2020 by the authors. Licensee MDPI, Basel, Switzerland. This article is an open access article distributed under the terms and conditions of the Creative Commons Attribution (CC BY) license (http://creativecommons.org/licenses/by/4.0/). 


\title{
Paucity of Nutrition Guidelines and Nutrient Quality of Meals Served to Kenyan Boarding High School Students
}

\author{
Kevin Serrem ${ }^{1}$, Anna Dunay ${ }^{1}$, Charlotte Serrem ${ }^{2}$, Bridget Atubukha ${ }^{3}$, Judit Oláh ${ }^{4,5, *}$ and \\ Csaba Bálint Illés ${ }^{1}$ \\ 1 Institute of Business Economics, Leadership and Management, SzentIstván University, \\ 2100 Gödöllő, Hungary; kevin.serrem@phd.uni-szie.hu (K.S.); dunay.anna@gtk.szie.hu (A.D.); \\ illes.b.csaba@gtk.szie.hu (C.B.I.) \\ 2 Department of Consumer Sciences, School of Agriculture and Biotechnology, University of Eldoret, \\ Eldoret 1125-30100, Kenya; charlottejes@gmail.com \\ 3 Faculty of Bioscience Engineering, Katholieke Universitiet Leuven, 3001 Leuven, Belgium; \\ Bridget.atubukha@student.kuleuven.be \\ 4 Institute of Applied Informatics and Logistics, Faculty of Economics and Business, University of Debrecen, \\ 4032 Debrecen, Hungary \\ 5 TRADE Research Entity, Faculty of Economic and Management Sciences, North-West University, \\ Vanderbijlpark 1900, South Africa \\ * Correspondence: olah.judit@econ.unideb.hu; Tel.: +36-20-286-9085
}

Received: 14 March 2020; Accepted: 22 April 2020; Published: 24 April 2020

\begin{abstract}
Adequate nutrition is vital for the optimal growth, development, and general well-being of adolescents. A lack of nutritional guidelines for school meals poses a major challenge in the provision of nutritious meals to students in Kenyan boarding high schools. The aim of the study was to investigate the nutrient quality and portion sizes of meals served to students and the adequacy of the meals in meeting students' health requirements. A cross-sectional study was carried out among 50 catering or kitchen managers of 50 high schools in Kenya. Data were obtained through researcher-assisted questionnaires. It was established that menus were simplistic in nature, lacked variety, and were repetitive. With regard to nutrients, menus offered to students were excessively highin dietary fiber, containing three or five times more than the recommended daily intake. In most cases, students were underfed on nutrients such as carbohydrates, vitamin A, folic acid, potassium, calcium, proteins, and vitamins B1-12, resulting in low energy provision. It is concluded that a majority ofthe Kenyan high schools studied do not provide nutritionally adequate meals. The government of Kenya should have nutrition guidelines to ensure that schools provide diets with high foodand nutrient quality to students.
\end{abstract}

Keywords: adolescents; high schools; nutrition guidelines; meals; Kenya

\section{Introduction}

The burden of malnutrition, which includesunder- and over-nutrition, is an emerging crisis in developing countries. Adequate nutrition is vital for optimal growth, development, and general well-being, particularly of children and adolescents [1]. Availability of adequate nutrition, either at home or through the education system, contributes to thereduction of malnutrition, especially among children who attend school [2]. There is evidence that educational institutions in developing countries are grappling with malnutrition that could have far-reaching effects on the health of school-goers, ultimately compromising an entire generation's health. For example, in Africa chronic and acute under-nutrition and micronutrient deficiency of iron, iodine, zinc, and vitamin A persist among 
children and adolescents, according to Gegios et al. [3]. Additionally, overweight and obesity have increasingly become epidemics in most countries [4]. All forms of malnutrition negatively impact the ability of children to stay in school and learn throughout the year, and affect health by creating deficiency diseases such as protein energy malnutrition, as well as predisposing children to chronic lifestyle diseasesin adulthood [5,6].

Schools provide a perfect opportunity for the prevention of malnutrition, as they provide the best access to a large number of people, including family and community members, school staff, and young people. In most developed countries with well-established school feeding programmes, such as Britain, France, the USA, and Italy, school meals and school feeding have been used as an effective mechanism to address child nutrition, education enrolment, school retention, and hygiene issues [7]. Additionally, they provide income-generation, employment, and economic integration benefits to the communities in which they are implemented [8]. This demonstrates that provision of food in the right portion sizes translates into improved nutrition, nutrition education, and adoption of health measures for the sustained provision of adequate quality, quantity, and composition of the meals and snacks provided [9]. Hence, there is a need for country-specific guidelines and menu designs thataddress the nutrition priorities of the target populations, and the objectives of the feeding programs [9].

In Kenya, students in boarding high schools are a vulnerable group as they depend on meals provided by the school as the main source of all their nutrient needs. Studies carried out in Kenya show that there are nolegislated or advised nutrition guidelines for use in school feeding programmes [10].Therefore, school feeding programmes in the country are guided by other factors, not necessarily nutrition guidelines. For example, onecurrent school feeding programme geographically targets regions with the highest poverty rates, the lowest education achievement rates, or the highest numbers ofchildren residing in highly marginalized areas, for provision of free food [10]. This is unfortunate because Kenya faces numerousnutrition deficienciesdue to inadequate protein, vitamin A, and iron intake [11] among children and adolescents. Eventually these mayinfluence children's cognitive development, lower school performance, limit adult productivity, reduce immunity, and eventually contribute to a high burden of morbidity and mortality [10].

The lack of an adequate school feeding policy and nutrition guidelines indicatesthe lack of adequate knowledge and precise benchmarking with regard to food rations, nutrient content, and feeding patterns when administering food to children and adolescents who attend school. Additionally it implies compromise in the provision of quality nutritious meals to school-going adolescents. Hence, there is a heavy reliance on the World Health Organization's (WHO's) recommendeddaily allowance (RDA) as itis an internationally accepted standard [11]. Therefore, the study investigated the nutrient quality, portion size, and suitability to meet health requirements of meals offered to students in Kenyan boarding high schools.

\section{Materials and Methods}

\subsection{Study Area and Target Population}

A cross-sectional study was conducted in May through to July 2019, to assess the portion size and composition of meals offered to Kenyan boarding high school students aged 15 to 18 years, on a daily and weekly basis. The target population was catering managers or head cooks who were in charge of kitchens in high schools. The study was conducted in eight counties, namely Nakuru, UasinGishu, Nandi, Kakamega, Nairobi, Kisumu, Laikipia, and ElgeyoMarakwet, where 50 selected boarding high schools categorized by the Kenyan Ministry of Education as national, extra county, county, and private, were included.

\subsection{Sampling Design}

Purposive judgmental sampling was used to select eight out of the 47 counties, and 50 out of over 3000 high schools in Kenya were selected toparticipate in the study. This was done based on 
preliminary knowledge of the various counties and the number of schools they had in each of the Ministry of Education school categories. One catering manager/head cook from each of the 50 schools was interviewed.

\subsection{Food Frequency Questionnaire}

Food frequency questionnaires were used to collect dietary information from the school catering managers or cooks about the school menus and meals that were provided to students in the high schools. This information was based on the types of foods and meals offered to the students on both a daily and a weekly basis, the frequency of food provision, and the portion size of meals offered to students, all based on the school menus. This was necessary to establish the types of meals offered in the high schools, and the meal frequency and portion sizes served to students to provide nutrients in comparison to the WHO's 2006 guidelines for RDA.

\subsection{Ethical Approval}

Approval for conducting the study was granted by the National Commission for Science, Technology and Innovation (NACOSTI) in Kenya, under permit number NACOSTI/P/1981086/28440. Permission was also granted by the education sections of all the participating counties and the head teachers of each of the 50 schools. Informed consent was also obtained from the respondents, whose participation was voluntary after assurances of anonymity and confidentiality.

\subsection{Data Analysis}

NutriSurvey Software for Windows (2007) was used to generate dietary intake data. Many of the foods in the school menus were native Kenyan local foods; therefore, additional nutrient composition was obtained from the Kenya Food Composition Tables 2018, compiled by the FAO/Government of Kenya [12], which has a collection of the foods consumed. The nutrient profile of each food was then added from the Food Composition Tables into the nutrient database of NutriSurvey Software for Windows. Additionally, Minitab 18 Statistical Software for analysis was used to separate the means ANOVA, as the data being analyzed had more than two groups from which comparison was to be made. The level of significance was $p<0.05$.

\section{Results}

\subsection{Mean Quantity of Each Food Consumed Daily among School Categories}

The results in Table 1 show the quantities of each type of food provided daily to individual students in the different school categories. Githeri (a mixture of maize and beans) was providedin the highest (377 g) quantities in county schools, while private schools providedthe least. The highest (166 g) provision of ugali (stiff porridge) was by national schools, while private schools servedthe least. Compared to all other school types the highest $(278 \mathrm{~g})$ amount of rice was servedby the private schools. Legume servicewas highest $(90 \mathrm{~g})$ in county schools and lowest in private schools, and vegetables were provided most $(121 \mathrm{~g})$ in county schools and least in private schools. Bread and potatoes were servedacross all school types. The least providedfoods were spreads, tea, coffee, and milk. Animal-source foods such as eggs, sausage, and beef mainly appeared in the menus of private schools compared to other school types. 
Table 1. The mean amounts in grams of the foods provided daily to students aged 15-18 years in the selected high schools.

\begin{tabular}{|c|c|c|c|c|c|}
\hline Categories & Main Foods (g) & $\begin{array}{c}\text { Extra County } \\
\text { Schools }\end{array}$ & $\begin{array}{l}\text { National } \\
\text { Schools }\end{array}$ & $\begin{array}{l}\text { Private } \\
\text { Schools }\end{array}$ & $\begin{array}{l}\text { County } \\
\text { Schools }\end{array}$ \\
\hline \multirow{7}{*}{$\begin{array}{l}\text { Starchy } \\
\text { Staples }\end{array}$} & Rice & $158.57 \pm 51.9$ & $173.25 \pm 39.3$ & $277.61 \pm 121.9$ & $225 \pm 45.5$ \\
\hline & Potatoes & $7.95 \pm 18.4$ & $44.91 \pm 41.8$ & $35.31 \pm 29.6$ & $19 \pm 26.2$ \\
\hline & Chapatti & 0.00 & $22.50 \pm 45.0$ & $15.61 \pm 29.6$ & 0 \\
\hline & ${ }^{1}$ Githeri & $335.79 \pm 172.2$ & $375.43 \pm 197.6$ & $123.75 \pm 51.0$ & $377 \pm 48.5$ \\
\hline & ${ }^{2}$ Ugali & $146.56 \pm 46.0$ & $166.61 \pm 66.4$ & $78.36 \pm 14.1$ & $141 \pm 2.02$ \\
\hline & Bread & $61.07 \pm 38.6$ & $100.00 \pm 0.0$ & $100.00 \pm 0.0$ & $100 \pm 0.0$ \\
\hline & Scones & $27.57 \pm 50.6$ & 0.00 & $17.86 \pm 35.7$ & 0 \\
\hline \multirow{5}{*}{ Beverages } & White tea & $109.00 \pm 48.5$ & $150.00 \pm 0.0$ & $132.86 \pm 64.2$ & $201 \pm 30.3$ \\
\hline & Black tea & $58.57 \pm 77.58$ & 0.00 & $0.00 \pm 0.0$ & 0 \\
\hline & Cocoa & $2.43 \pm 4.9$ & $5.71 \pm 6.6$ & $3.04 \pm 6.1$ & 0 \\
\hline & ${ }^{3} \mathrm{Uji}$ & $111.43 \pm 105.0$ & 0.00 & $87.50 \pm 71.5$ & $36 \pm 50.5$ \\
\hline & Coffee & 0.00 & $3.04 \pm 6.0$ & $4.29 \pm 4.9$ & 0 \\
\hline Dairy & Milk & 0.00 & $26.79 \pm 53.57$ & $0.00 \pm 0.0$ & 0 \\
\hline \multirow{3}{*}{$\begin{array}{l}\text { Fruits and } \\
\text { Vegetables }\end{array}$} & Fruit & $0.70 \pm 0.78$ & $0.50 \pm 0.6$ & $1.75 \pm 0.9$ & 0 \\
\hline & Cabbage & $40.50 \pm 29.8$ & $42.29 \pm 48.9$ & $35.96 \pm 15.3$ & $121 \pm 71.7$ \\
\hline & Kales & $47.15 \pm 25.6$ & $52.00 \pm 66.17$ & $8.34 \pm 16.69$ & 0 \\
\hline \multirow{2}{*}{ Legumes } & Green grams & 0.00 & 0.00 & $15.00 \pm 17.4$ & $16 \pm 22.7$ \\
\hline & Beans & $71.74 \pm 54.8$ & $78.21 \pm 13.1$ & $29.57 \pm 34.7$ & $64 \pm 90.9$ \\
\hline \multirow{2}{*}{ Meat } & Beef & $12.17 \pm 10.6$ & $13.79 \pm 13.1$ & $16.07 \pm 14.48$ & $8.0 \pm 1.0$ \\
\hline & Sausage & 0.00 & 0.00 & $2.86 \pm 3.3$ & 0 \\
\hline Eggs & Egg & $0.50 \pm 1.5$ & $6.25 \pm 4.8$ & $30.00 \pm 40.0$ & 0 \\
\hline \multirow[t]{2}{*}{ Spreads } & Spreads & 0.00 & 0.00 & $15.00 \pm 0.0$ & 0 \\
\hline & Total & 1191 & 1261 & 1030 & 1308 \\
\hline
\end{tabular}

Figures are means \pm standard deviation; ${ }^{1}$ githeri is a meal prepared from a stewed mixture of dry maize and beans;

2 ugali is stiff porridge prepared from maize meal; ${ }^{3}$ uji is a drinking porridge prepared from maize or millet meal.

\subsection{Food Groups Provided by the Different Categories of High Schools}

Foods appearing in the school menu were classified into eightfood groups (Table 2). Results showed that the most providedgroup was the starchy staples which contributed 64 to $68 \%$ of the total diet. The highest servers of the staples were county schools $(898 \mathrm{~g})$ and the lowest were private schools. Dairy products (milk) were only served in national schools. Private schools were the leading providers of fruits, while county schools' menus did not feature fruits. Legumes were the main source of proteins across all the school types, with a high of $6 \%$ of the diet, except for the private schools, which included more animal proteins in their menus than all the other school types.

Table 2. The mean amount in grams of the food groups served daily to students aged 15-18 years old in different school types and their percentage contributions to the total dietary intake ( $\mathrm{g} / \mathrm{student} /$ day).

\begin{tabular}{ccccc}
\hline Food Group & Extra County Schools & National Schools & Private Schools & County Schools \\
\hline Starchy Staples & $849 \pm 47(68.69)$ & $883 \pm 61(67.66)$ & $736 \pm 35(64.50)$ & $898 \pm 26(68.65)$ \\
Beverages & $170 \pm 25(13.75)$ & $159 \pm 1(12.18)$ & $52 \pm 21(4.56)$ & $201 \pm 30(15.37)$ \\
Dairy & $0(0)$ & $27 \pm 54(2.07)$ & $0(0)$ & $0(0)$ \\
Fruits & $80 \pm 92(6.47)$ & $60 \pm 69(4.60)$ & $200 \pm 105(17.53)$ & $0(0)$ \\
Vegetables & $88 \pm 16(7.12)$ & $78 \pm 9(5.98)$ & $44 \pm 12(3.86)$ & $121 \pm 21(9.25)$ \\
Legumes & $36 \pm 29(2.91)$ & $78 \pm 13(5.98)$ & $45 \pm 36(3.94)$ & $80 \pm 68(6.12)$ \\
Meat & $12 \pm 11(0.97)$ & $14 \pm 13(1.07)$ & $19 \pm 17(1.67)$ & $8 \pm 1(0.61)$ \\
Eggs & $1 \pm 2(0.08)$ & $6 \pm 5(0.46)$ & $30 \pm 40(2.63)$ & $0(0)$ \\
Spreads & $0(0)$ & $0(0)$ & $15 \pm 10(1.31)$ & $0(0)$ \\
\hline Total & $1236(100)$ & $1305(100)$ & $1141(100)$ & $1308(100)$ \\
\hline
\end{tabular}

Values are means \pm standard deviations. Values in parenthesis are percentage contributions to total dietary intake. 


\subsection{Mean Amount of Nutrients Provided by the Diet}

Table 3 shows an estimate of the mean amount of nutrients providedby the diet for each student in the four school categories. Results indicate that protein intake is highest in national schools (62 g) and lowest in private schools. Retinol and Vitamin A intake were significantly higher in private schools compared with other school types. Retinol intake was lowest $(26 \mu \mathrm{g})$ in extra county schools while vitamin A provision in extra county and county schools ranged from 114 to $40 \mu \mathrm{g}$. The highest $(8.15 \mu \mathrm{g})$ intake of vitamin $B_{1}$ was in county schools, which also exceeded the required daily intake, compared to the lowest intake in extra county schools, which hadan almost eight-times lower intake. Vitamin $\mathrm{B}_{12}$ provision is highest in private schools $(1.55 \mu \mathrm{g})$ and lowest in county schools $(0.7 \mu \mathrm{g})$. Its provision in extra county schools and private schools was significantly different.

Table 3. The mean amount of nutrients provided daily by the total diet of the high-school students in the sampled schools.

\begin{tabular}{|c|c|c|c|c|c|}
\hline \multirow[b]{2}{*}{ Nutrients } & \multirow[b]{2}{*}{ Units } & \multicolumn{4}{|c|}{ School Type } \\
\hline & & $\begin{array}{l}\text { Extra County } \\
\text { Schools }\end{array}$ & $\begin{array}{l}\text { National } \\
\text { Schools }\end{array}$ & $\begin{array}{l}\text { Private } \\
\text { Schools }\end{array}$ & $\begin{array}{l}\text { County } \\
\text { Schools }\end{array}$ \\
\hline Energy & K Cal & $1453.1^{a} \pm 267.3$ & $1729.0^{\mathrm{a}} \pm 309.0$ & $1494.0^{\mathrm{a}} \pm 294$ & $1576.0^{a} \pm 201$ \\
\hline Minerals & $\mathrm{g}$ & $12.46^{\mathrm{ab}} \pm 2.8$ & $13.95^{\mathrm{a}} \pm 3.5$ & $9.73^{b} \pm 0.9$ & $13.40^{\mathrm{ab}} \pm 2.12$ \\
\hline Proteins & $\mathrm{g}$ & $52.98^{a} \pm 9.4$ & $61.80^{\mathrm{a}} \pm 12.9$ & $44.80^{\mathrm{a}} \pm 7.2$ & $56.35^{\mathrm{a}} \pm 11.9$ \\
\hline Fat & $\mathrm{g}$ & $27.38^{\mathrm{a}} \pm 5.9$ & $37.27^{\mathrm{a}} \pm 12.8$ & $38.80^{a} \pm 16.7$ & $28.75^{\mathrm{a}} \pm 2.9$ \\
\hline Carbohydrates & $\mathrm{g}$ & $227.8^{a} \pm 40.9$ & $264.8^{\mathrm{a}} \pm 35.3$ & $228.8^{a} \pm 33.7$ & $249.0^{\mathrm{a}} \pm 26.3$ \\
\hline Dietary fiber & $\mathrm{g}$ & $45.83^{\mathrm{a}} \pm 11.9$ & $48.63^{a} \pm 13.1$ & $26.13^{\mathrm{ab}} \pm 3.6$ & $45.80^{\mathrm{ab}} \pm 10.0$ \\
\hline Retinol & $\mu g$ & $26.08^{b} \pm 10.6$ & $66.10^{\mathrm{b}} \pm 31.9$ & $191.6^{\mathrm{a}} \pm 129.0$ & $35.40^{\mathrm{b}} \pm 4.5$ \\
\hline Vitamin A & $\mu g$ & $114.6^{\mathrm{b}} \pm 43.8$ & $169.8^{\mathrm{ab}} \pm 148.5$ & $253.2^{\mathrm{a}} \pm 160.4$ & $39.5^{\mathrm{b}} \pm 4.74$ \\
\hline$\beta$-Carotene & $\mathrm{mg}$ & $882^{\mathrm{a}} \pm 488$ & $975^{\mathrm{a}} \pm 1205$ & $167^{\mathrm{a}} \pm 310$ & $33.75^{\mathrm{a}} \pm 4.88$ \\
\hline Vitamin $B_{1}$ & $\mathrm{mg}$ & $0.80^{c} \pm 0.2$ & $0.97^{b c} \pm 0.3$ & $7.55^{\mathrm{a}} \pm 8.0$ & $8.15^{\mathrm{ab}} \pm 10.2$ \\
\hline Vitamin $B_{2}$ & $\mathrm{mg}$ & $0.56^{\mathrm{a}} \pm 0.0$ & $0.75^{\mathrm{a}} \pm 0.2$ & $0.6^{\mathrm{a}} \pm 0.2$ & $0.6^{\mathrm{a}} \pm 0.1$ \\
\hline Vitamin $\mathbf{B}_{12}$ & $\mu g$ & $0.74^{b} \pm 0.5$ & $1.12^{\mathrm{ab}} \pm 0.8$ & $1.55^{\mathrm{a}} \pm 0.9$ & $0.7^{\mathrm{ab}} \pm 0.1$ \\
\hline Vitamin $B_{6}$ & $\mathrm{mg}$ & $0.21^{\mathrm{C}} \pm 0.1$ & $0.43^{\mathrm{ab}} \pm 0.2$ & $0.48^{a} \pm 0.2$ & $0.15^{b c} \pm 0.0$ \\
\hline Folic acid & $\mu g$ & $32.89^{b} \pm 14.2 \mathrm{~s}$ & $38.13^{b} \pm 15.6$ & $68.50^{\mathrm{a}} \pm 34.9$ & $19.95^{\mathrm{b}} \pm 3.9$ \\
\hline Vitamin C & $\mathrm{mg}$ & $67.74^{\mathrm{a}} \pm 26.8$ & $44.5^{\mathrm{a}} \pm 37.6$ & $63.0^{\mathrm{a}} \pm 17.9$ & $31.60^{\mathrm{a}} \pm 6.6$ \\
\hline Sodium & $\mathrm{mg}$ & $1631.0^{\mathrm{a}} \pm 471$ & $1851.0^{\mathrm{a}} \pm 430$ & $1592.9^{a} \pm 179.3$ & $1978.0^{\mathrm{a}} \pm 195$ \\
\hline Potassium & $\mathrm{mg}$ & $1542.0^{\mathrm{a}} \pm 610$ & $1863.0^{\mathrm{a}} \pm 537$ & $1279^{a} \pm 345$ & $1657^{\mathrm{a}} \pm 345$ \\
\hline Calcium & $\mathrm{mg}$ & $455.4^{\mathrm{a}} \pm 91.8$ & $474.0^{\mathrm{a}} \pm 233$ & $254.9^{b} \pm 29.6$ & $292.8^{\mathrm{ab}} \pm 56.4$ \\
\hline Magnesium & $\mathrm{mg}$ & $295.3^{a} \pm 67.5$ & $330.2^{\mathrm{a}} \pm 80.4$ & $210.9^{b} \pm 25.2$ & $290.1^{\mathrm{ab}} \pm 43.5$ \\
\hline Phosphorus & $\mathrm{mg}$ & $1336.0^{\mathrm{a}} \pm 351$ & $1551.0^{\mathrm{a}} \pm 399$ & $900.6^{b} \pm 116.7$ & $1456.0^{\mathrm{ab}} \pm 254$ \\
\hline Iron & $\mathrm{mg}$ & $19.52^{\mathrm{a}} \pm 8.0$ & $19.55^{\mathrm{a}} \pm 7.4$ & $12.00^{\mathrm{a}} \pm 4.0$ & $14.25^{\mathrm{a}} \pm 1.9$ \\
\hline Zinc & $\mathrm{mg}$ & $8.32^{\mathrm{ab}} \pm 1.4$ & $9.55^{\mathrm{a}} \pm 1.9$ & $6.78^{\mathrm{b}} \pm 1.0$ & $8.80^{\mathrm{ab}} \pm 1.7$ \\
\hline
\end{tabular}

Values are means \pm standard deviation; values with the same letter (a to c) superscript on the same row are not significantly different at $p<0.05$ as assessed by Fisher's least significant difference.

Intake of vitamin $\mathrm{B}_{6}$ and folic acid were significantly higher in private schools compared to all other school categories, whilenational schools had the highest calcium and magnesium intakes. Only the private schools' phosphorous intake was very low- $900.6 \mathrm{mg}$ - when compared to other schools. There was a significant difference in zinc provision between national and private schools at 9.55 and $6.8 \mathrm{mg}$, respectively (Table 3).

\subsection{Percentage Fulfillment of Different Nutrients}

The percentage fulfillment of the recommended daily allowance of nutrients for students in the four categories of schools is shown in Table 4. Results show that school meals did not meet $100 \%$ of the energy needs of the students. Carbohydrates, proteins, and fats provided 57.6, 11.8, and 30.5\% of energy requirements, respectively. The meals met more than $75 \%$ of the nutritional requirements for proteins, fats, and carbohydrates. The diets fell short in vitamins $A, C$, and $B_{12}$. In terms of minerals, calcium was the nutrient for which the requirements were least fulfilled (3-37\%). Themineral requirements that were adequately fulfilled were phosphorous, iron, and zinc. 
Table 4. Percentage fulfilment of the different nutrients according to school type.

\begin{tabular}{ccccccc}
\hline & Units & $\begin{array}{c}\text { Recommended } \\
\text { Value/Day }\end{array}$ & \multicolumn{4}{c}{ Percentage (\%) Fulfilment } \\
\cline { 4 - 7 } & & & $\begin{array}{c}\text { Extra County } \\
\text { Schools }\end{array}$ & $\begin{array}{c}\text { National } \\
\text { Schools }\end{array}$ & $\begin{array}{c}\text { Private } \\
\text { Schools }\end{array}$ & $\begin{array}{c}\text { County } \\
\text { Schools }\end{array}$ \\
\hline Energy & $\mathrm{kCal}$ & 2036.3 & 71.35 & 84.91 & 73.37 & 77.40 \\
Proteins & $\mathrm{g}$ & 60.1 & 88.15 & 102.83 & 74.54 & 93.76 \\
Fat & $\mathrm{g}$ & 69.1 & 39.62 & 53.94 & 56.15 & 41.61 \\
Carbohydrates & $\mathrm{g}$ & 290.7 & 78.36 & 91.09 & 78.71 & 85.66 \\
Dietary fiber & $\mathrm{g}$ & 30 & 152.77 & 162.10 & 87.10 & 152.67 \\
Vitamin A & $\mu \mathrm{g}$ & 1000 & 11.46 & 16.98 & 25.32 & 3.95 \\
Vitamin $\mathbf{B}_{\mathbf{1}}$ & $\mathrm{mg}$ & 1.15 & 69.57 & 84.35 & 656.52 & 708.70 \\
Vitamin $\mathbf{B}_{\mathbf{2}}$ & $\mathrm{mg}$ & 1.35 & 41.48 & 55.56 & 44.44 & 44.44 \\
Vitamin $\mathbf{B}_{\mathbf{1 2}}$ & $\mu \mathrm{g}$ & 3 & 24.67 & 37.33 & 51.67 & 23.33 \\
Vitamin $\mathbf{B}_{\mathbf{6}}$ & $\mathrm{mg}$ & 1.4 & 15.00 & 30.71 & 34.29 & 10.71 \\
Folic acid & $\mu \mathrm{g}$ & 400 & 8.22 & 9.53 & 9.53 & 4.99 \\
Vitamin C & $\mathrm{mg}$ & 100 & 67.74 & 44.50 & 63.00 & 31.60 \\
Sodium & $\mathrm{mg}$ & 2000 & 81.55 & 92.55 & 79.65 & 98.90 \\
Potassium & $\mathrm{mg}$ & 3500 & 44.06 & 53.23 & 36.54 & 47.34 \\
Calcium & $\mathrm{mg}$ & 1200 & 37.95 & 3.95 & 21.24 & 24.40 \\
Magnesium & $\mathrm{mg}$ & 375 & 78.75 & 88.05 & 56.24 & 77.36 \\
Phosphorus & $\mathrm{mg}$ & 1250 & 106.88 & 124.08 & 72.00 & 116.48 \\
Iron & $\mathrm{mg}$ & 13.5 & 144.59 & 144.81 & 88.89 & 105.56 \\
Zinc & $\mathrm{mg}$ & 8.5 & 97.88 & 112.35 & 79.76 & 103.53 \\
\hline
\end{tabular}

${ }^{1}$ WHO, [11].

\section{Discussion}

\subsection{Diversity of Foods Provided}

The low diversity of food items in the schools categories other than private schools may be a result of limited government funding in public schools, while the more diverse foods in private school menus might be influenced by the purchasing power of the parents, who pay higher school fees. A study by Zuilkowski et al. [13] on primary schools in Nairobi showed that low-cost private schools (LCPS) spent an average of Ksh 1962 per annum on school meals, while public schools spent almost half of this. This can be extrapolated to secondary schools, which are guided by the same document, i.e., the National School Meals and Nutrition Strategy 2017-2022 [14]. Furthermore, studies show that parents with students in private schools are more likely to pay more money to ensure that their children are well-fed [13]. This may be the reason for the increased diversity of school meals in private schools. Additionally, private schools have been shown to have better autonomy to make decisions regarding the foods that should appear in school menus compared to public schools [9].Private schools alsoserved the lowest amount of starchy staples such as ugali and githeri. Their main source of carbohydrates is rice. This could be explained by the high amount of energy required to cook maize and beans, making it expensive, hence their preference to cook rice.

\subsection{Food Groups Provided}

The starchy staples, which contributed more than $60 \%$ of the entire diet, have been found to be the major foods fed to school children in developing countries [15] because they are easilyavailable and are a cheap source of energy compared to other food groups. Thompson and Amoroso [16] indicate a shift from a varied diet rich in micronutrients to one derived from predominantly high-carbohydrate starchy staples. Animal-source foods arethe least provided foods in school menus because they are expensive, in the context of school feeding in developing countries. A study by Cornelsen et al. [17] in Kenya found that price was the most frequently reported barrier to the provision of animal-source Foods (ASF), therefore affordability is the main hindrance to their service. Additionally, the study revealed that milk was providedonly by the national schools because they reared dairy animals in their school farms and therefore had a constant supply of milk. Azzarri et al. [18] suggest that livestock 
ownership confers on households more opportunities to increase the consumption of animal-source food as it translates into cheaper or more reliable access to animal-source food supplies. A study by Kabunga et al. [19] showed that the adoption of improved dairy cow breeds at farm level led to increased consumption of milk in Ugandan households and translated to improved dietary quality among young children. Meat and eggs, the least-provided foods, contributed an estimated $2 \%$ to the total dietary intake among the high-school students. The major source of proteins were legumes, which are known to have lower protein quality compared to animal sources [16]. From the foregoing, school feeding policies should advocate for boarding schools to rear animals for milk, eggs, and meat for the cheaper supply of high-quality protein.

The provision of fruitsin private schools and not at all in county schools may be explained by the purchasing ability of the parents of children attending private schools, compared to those attending county schools. Fruits are known to be an expensive source of energy and therefore this could be the reason for the high intake in private schools. Review studies on the determinants of fruit and vegetables consumption among adolescents consistently show that high income levels largely influence fruit intake, often because of affordability [20-22].

The high provision of vegetables in county schools could be attributed to the parents who sometimes supply vegetables from their farms as a form of school fees payment, since most of these types of schools are commonly found in rural areas. A review on the determinants of vegetable consumption among adolescents by Rasmussen et al. [20] showed that availability of vegetables is one of the determinants that greatly influence vegetable intake, which may be true in this study. Furthermore, low vegetable provision in private schools could be attributed to the children'slack of engagement in school gardening activities owing to limited land sizes in private schools. Despite epidemiological evidence by He et al. [23] for the health benefits of a diet rich in fruits and vegetables, such as reduced risk of chronic diseases later in life, large numbers of adolescents do not meet the WHO requirement of a daily intake of at least $400 \mathrm{~g}$ (roughly equivalent to five servings per day) of fruits and vegetables [24]. A study by Peltzer and Pengpid [25] in seven African countries, including Kenya, found that most adolescents $(77.5 \%)$ did not consume the recommended daily servings of vegetables. Similar results to this have been reported by Doku et al. [26], who found that $56 \%$ and $48 \%$ of adolescents in Ghana rarely consumed fruits and vegetables. According to South African dietary guidelines, it is recommended that adolescents consume at least one fruit and/or vegetable in a meal [24]. This recommendation was not met in this study. This could be due to the limited variety of fruits (banana and orange) and vegetables (kale and cabbage) that appear on most of the school menus. This study is in agreement with other studies that fruit and vegetable consumption is consistently low in many low middle income countries [27].This implies that nutrition guidelines for school feeding in Kenya should recommend the minimum fruit and vegetable portions that should be provided to students.

\subsection{The Mean Amount of Nutrients Provided Daily from the Total Diet}

The higher consumption of proteins by the national compared to private schools may be explained by the fact that the major sources of proteins in the diets are cereals and legumes. The low values reported in private schools could be due to their low service of these grains. Private schools provided more rice and potatoes, which are poor sources of protein. However, they provided more beef, eggs, and sausages than the other schools-implying that though their protein intake is low, it is of higher quality, since it comes from animal sources.

The national schools' diet had high mineral content, probably because most of the meals served were wholemeal, and therefore the presence of bran in the foods leads to a high mineral content in the diet. In contrast, most of the foods servedin private schools such as rice, chapatti, and potatoes have low mineral content, and are processed with husks removed. For example, the processing of maize by dry milling and fractionation results in the removal of bran, which is the major constituent of the pericarp, and which contains B-vitamins and minerals [28]. Cornbran contains more iron, zinc, 
and phosphorous than corn starch [29]. This shows that the micronutrient content of cereals is greatly reduced after processing, and therefore serviceof processed foods provides a small proportion of the daily requirements for most vitamins and minerals. Nutrition guidelines should emphasize the use of whole grain for food and food products in adequate portions in school meals to contribute to mineral provision.

The service of higher amounts of fruits, and also spreads on bread that are fortified with vitamin A, to students in private schools may have resulted in their intake of higher amounts of retinol and vitamin A than the other types of school. Margarine has been found to be one of the most suitable vehicles for vitamin A [30]. A study involving Filipino pre-school children who consumed $27 \mathrm{~g}$ of vitamin A-fortified margarine per day for a period of six months showed that there was a reduced prevalence of low serum retinol from $26 \%$ to $10 \%$, hence consumption of the margarine significantly improved the vitamin A status of the children [31]. Foods high in vitamin A should be deliberately included among those in school menus based on Kenyan nutrition guidelines.

Furthermore, the significantly higher vitamins $\mathrm{B}_{12}, \mathrm{~B}_{6}$, and folic acid in private school menus compared to the other school types may be attributed to the higher service of animal-source foods such as eggs and beef. In contrast, the lowcalcium, phosphorous, and magnesium provision in private schools compared to other school types may be explained bythe low serviceof cereals and legumes, which are rich sources of magnesium and phosphorous [32]. The low intake of milk and milk products could further explain the low calcium levels in the students' diets. In national schools the provision of zinc was higher compared to private schools. This could be explained by the fact that they were served with more beans compared to other schools. They were also provided with milk, which is a rich source of zinc.

\subsection{Fulfillment of the Different Nutrients}

The study's findings showed that school meals did not meet 100\% of the energy needs of the students. This findings contradict those of Buluku [7] who found that energy was adequately met in the diets of girls in selected boarding schools in Nairobi, Kenya. However, this finding concurs with that of Nhlapo et al. [33] who found that the meals served under a South African school feeding scheme did not meet the energy needs of school children aged 11-18 years. Carbohydrates, proteins, and fats provided $57.6 \%, 11.8 \%$, and $30.5 \%$ of energy, respectively. According to the School Food Trust [34], a minimum of 50\% of the energy provided should be sourced from carbohydrates, less than $35 \%$ should be met from fats and the rest from proteins. The results of this study indicate that the meals provided met the recommendations regarding the contributions of the three macronutrients to the energy needs of the high school students. This finding is similar to that of Charrondiere et al. [35] on numerous food items from different countries in which the total carbohydrate content supplied $50-80 \%$ of energy, and $7-11 \%$ of energy was from protein. Nutrition guidelines should recommend portion sizes for energy-providing foods that enable students in boarding high schools to meet all their energy requirements.

The ability of national schools to meet the required protein intake while the other school types fell short may be attributed to the provision of more food groups rich in proteins, and that this was the only school type that served milk. Protein is important in adolescent nutrition as it provides structure for the body and major components of the bones, blood, muscle, cell membranes, enzymes, and immune factors [32].

The high intake of dietary fiber in the public schools may be explained by the provision of starchy unrefined grains and pulses in meals such as githeri (a stewed mixture of maize and beans), wholemeal ugali, and vegetables such as kale, which are rich in fiber. This is an advantage, as high-fiber diets have a low glycemic index, therefore keeping students full for a longer time, which reduces the rate of hunger. For instance, a study by Ye et al. [36] showed that consumption of dietary fiber decreased hunger and increased satiety hormones in humans when ingested with a meal. This implies that that the students can concentrate in class for longer without feeling hungry. However, high-fiber diets 
tend to be rich in phytates, and therefore could bind key mineral elements such as calcium and also reduce absorption of minerals such as iron and zinc [37]. Private schools reported a low intake of fiber compared to the other schools because of the low provision of githeri, ugali, and kale, and the provision of potatoes, which are low in fiber as stated earlier.

The percentage fulfillment of Vitamin A was high in private schools and lowin county schools due to the high intake of fruits, and Vitamin A-fortified spreads on bread. The low value reported in county schools is a result of the non-provision of fruits and spreads. This finding is similar to that of Buluku [7] on Kenyan boarding school meals that did not meet the nutrient requirements for adolescent girls. Vitamin A is a key micronutrient in adolescent nutrition. Vitamins play important roles in the body such as aiding vision, immunity (vitamin A), calcium absorption (vitamin D), and anti-oxidative protection in cell membranes (vitamin E) [32].

Calcium intake was highest in the national schools probably because of milk provision to students in national schools, compared to private schools, which did not providemilk. The ability of most school types to fully meet their phosphorous, zinc, and iron requirements in most school types could be attributed to the consumption of cereals and pulses, which are rich sources of these minerals [32]. The intake of iron and zinc appears to be overestimated because the diet was mainly composed of cereals and pulses. These minerals were mostly found in githeri, ugali, millet porridge, maize porridge, beans, and green grams, which were frequentlyprovided.

However, cereals and legumes contain phytates which chelate with minerals and metals such as calcium, magnesium, zinc, and iron, forming insoluble salts that are not easily absorbed by humans [38]. Phytates particularly form complexes which can severely impair the availability of zinc and iron [39]. Furthermore, most schools took beverages in the form of tea, coffee, or cocoa, which may also contain tannins that could further bind the minerals [40]. Deficiencies of iron and zinc are a public health problem in developing countries, particularly among adolescents and women of reproductive age. A systematic review to evaluate iron and zinc intakes in adolescents from Ethiopia, Kenya, Nigeria and South Africa concluded that diet-related anaemia and zinc deficiencies are problems of public health significance [41]. Zinc is important in adolescence because of its critical function in growth and sexual maturation [42]. However, adolescents are at high risk of deficiency, often related to the consumption of plant-based diets, which have low zinc and iron bioavailability reported by Gibson et al. [43], which are similar to the diets providedin this study. From the forgoing it is noted that the studyonly focused on whatschools provided to their students and did not consider how much the adolescents consumed.

\section{Conclusions}

Kenyan high schools fail to provide students with adequate nutritious foods. In comparison to the FAO [9], which acts as the worldwide benchmark for the development of school dietary guidelines, the study notes that none of the high schools in Kenya adequately meet the nutritional requirements of meals served to school-goers. Meal menus lack variation in food options, and are very repetitive and simplistic in nature. It observed that the foods most providedin schools are highfiber foods, githeri (a mixture of maize and beans), and starchy foods such as ugali (stiff porridge) and rice, while the least-consumed food are fruits, proteins_especially during breakfasts—and vegetables. National schools consume the highest quantities of dietary fiber and starch in comparison to other high schools whilst county schools consume the highest quantities of vegetables. Private schools consume the highest quantities of breakfast proteins, while county schools consume the highest quantities of legumes. The majority of Kenyan high schools fail to attain nutrient requirements in meals offered to students, while in some cases schools surpass the recommended amount, such as for dietary fiber, where schools offer three times more than the recommended amounts. The Kenyan government should work with various stakeholders to ensure the development of an adequate school feeding policy to develop and implement nutrition guidelines in the county. Additionally, an area of further research would be how much food the adolescents in Kenyan high schools consumed. 
Author Contributions: Conceptualization by C.B.I. and K.S.; methodology designed by C.B.I., K.S. and A.D.; Data compilation by K.S. and C.S.; Data analysis by K.S. and B.A.; validation by C.B.I., A.D. and J.O.; original draft prepared by K.S.; review and editing by K.S., C.B.I., A.D. and J.O. All authors have read and agreed to the published version of the manuscript.

Funding: This research received no external funding.

Conflicts of Interest: The authors declare that there is no conflict of interest.

\section{References}

1. Afoakwa, E.O. Enhancing the Quality of School Feeding Programmes in Ghana-Developments and Challenges; University of Ghana: Accra, Ghana, 2005; Available online: http://www.academia.edu/download/52162306/ fulltext_stamped.pdf (accessed on 20 February 2020).

2. Essuman, E.; Walker, L.R.; Maziasz, P.J.; Pint, B.A. Oxidation behaviour of cast Ni-Cr alloys in steam at $800{ }^{\circ}$ C. Mater. Sci. Technol. 2013, 29, 822-827. [CrossRef]

3. Gegios, A.; Amthor, R.; Maziya-Dixon, B.; Egesi, C.; Mallowa, S.; Nungo, R.; Gichuki, S.; Mbanaso, A.; Manary, M.J. Children consuming cassava as a staple food are at risk for inadequate zinc, iron, and vitamin A intake. Plant Foods Hum. Nutr. 2010, 65, 64-70. [CrossRef]

4. Muthuri, S.K.; Wachira, L.-J.M.; Leblanc, A.G.; Francis, C.E.; Sampson, M.; Onywera, V.O.; Tremblay, M.S. Temporal trends and correlates of physical activity, sedentary behaviour, and physical fitness among school-aged children in Sub-Saharan Africa: A systematic review. Int. J. Environ. Res. Public Health 2014, 11, 3327-3359. [CrossRef]

5. Crookston, B.T.; Schott, W.; Cueto, S.; Dearden, K.A.; Engle, P.; Georgiadis, A.; Lundeen, E.A.; Penny, M.E.; Stein, A.D.; Behrman, J.R. Postinfancy growth, schooling, and cognitive achievement: Young Lives. Am. J. Clin. Nutr. 2013, 98, 1555-1563. [CrossRef]

6. Nyaradi, A.; Li, J.; Hickling, S.; Foster, J.; Oddy, W.H. The role of nutrition in children's neurocognitive development, from pregnancy through childhood. Front. Hum. Neurosci. 2013, 7, 97. [CrossRef]

7. Buluku, E. An Assessment of the Adequacy of School Meals in Meeting the Nutritional Requirements of Girls in Boarding Secondary Schools in Nairobi; Kenyatta University: Nairobi, Kenya, 2012; Available online: http://ir-library.ku.ac.ke/handle/123456789/2516 (accessed on 20 February 2020).

8. Moriset, B. Building new places of the creative city: The rise of coworking spaces. Territ. Mov. J. Geogr. Plan. 2017. [CrossRef]

9. FAO. Nutrition Guidelines and Standards for School Meals: A Report from 33 Low and Middle-Income Countries; Food and Agriculture Organization of the United Nations: Rome, Italy, 2019; pp. 10-11. Available online: http://www.fao.org/3/CA2773EN/ca2773en.pdf (accessed on 20 February 2020).

10. Kisa, S.; Zeyneloğlu, S.; Yilmaz, D.; Güner, T. Quality of sexual life and its effect on marital adjustment of Turkish women in pregnancy. J. Sex Marital. Ther. 2014, 40, 309-322. [CrossRef]

11. WHO. Adolescent Nutrition: A Review of the Situation in Selected South-East Asian Countries; WHO Regional Office for South-East Asia: New Delhi, India, 2006; Available online: https://apps.who.int/iris/handle/10665/204764 (accessed on 20 February 2020).

12. FAO/Government of Kenya. Food Composition Tables. Government of Kenya, Nairobi; The Food and Agriculture Organization of the United Nations, The Ministry of Health, Republic of Kenya and The Ministry of Agriculture and Irrigation, Republic of Kenya: Kenya, Africa, 2018; pp. 12-56. Available online: http: //www.fao.org/3/I8897EN/i8897en.pdf (accessed on 20 February 2020).

13. Zuilkowski, S.S.; Piper, B.; Ong'ele, S.; Kiminza, O. Parents, quality, and school choice: Why parents in Nairobi choose low-cost private schools over public schools in Kenya's free primary education era. Oxf. Rev. Educ. 2018, 44, 258-274. [CrossRef]

14. Ministry of Education; Ministry of Health; Ministry of Agriculture, LAF. National School Meals and Nutrition Strategy 20172-022; Ministry of Education; Ministry of Health Ministry of Agriculture, Livestock and Fisheries: Nairobi, Republic of Kenya, 2018; pp. 1-64. Available online: https://planipolis.iiep.unesco. org/sites/planipolis/files/ressources/kenya_school_meals_nutrition_strategy_20172--022.pdf (accessed on 20 February 2020).

15. Kennedy, G.L.; Pedro, M.R.; Seghieri, C.; Nantel, G.; Brouwer, I. Dietary diversity score is a useful indicator of micronutrient intake in non-breast-feeding Filipino children. J. Nutr. 2007, 137, 472-477. [CrossRef] 
16. Thompson, B.; Amoroso, L. Combating Micronutrient Deficiencies: Food-Based Approaches; CABI: Wallingford, UK, 2011. [CrossRef]

17. Cornelsen, L.; Alarcon, P.; Häsler, B.; Amendah, D.D.; Ferguson, E.; Fèvre, E.M.; Grace, D.; Dominguez-Salas, P.; Rushton, J. Cross-sectional study of drivers of animal-source food consumption in low-income urban areas of Nairobi, Kenya. BMC Nutr. 2016, 2, 70. [CrossRef]

18. Azzarri, C.; Cross, E.; Haile, B.; Zezza, A. Does livestock ownership affect animal source foods consumption and child nutritional status? Evidence from rural Uganda. J. Dev. Stud. 2014, 51, 1034-1059. [CrossRef]

19. Kabunga, N.S.; Ghosh, S.; Webb, P. Does ownership of improved dairy cow breeds improve child nutrition? A pathway analysis for Uganda. PLoS ONE 2017, 12, e0187816. [CrossRef] [PubMed]

20. Rasmussen, M.; Krølner, R.; Klepp, K.-I.; Lytle, L.; Brug, J.; Bere, E.; Due, P. Determinants of fruit and vegetable consumption among children and adolescents: A review of the literature. Part I: Quantitative studies. Int. J. Behav. Nutr. Phys. Act. 2006, 3, 22. [CrossRef] [PubMed]

21. Kiss, A.; Popp, J.; Oláh, J.; Lakner, Z. The reform of school catering in hungary: Anatomy of a health-education attempt. Nutrients 2019, 11, 716. [CrossRef] [PubMed]

22. Kiss, A.; Pfeiffer, L.; Popp, J.; Oláh, J.; Lakner, Z. A blind man leads a blind man? Personalised nutrition-related attitudes, knowledge and behaviours of fitness trainers in Hungary. Nutrients 2020, 12, 663. [CrossRef]

23. He, F.; Nowson, C.; Lucas, M.; MacGregor, G. Increased consumption of fruit and vegetables is related to a reduced risk of coronary heart disease: Meta-analysis of cohort studies. J. Hum. Hypertens. 2007, 21, 717-728. [CrossRef]

24. Kimmons, J.; Gillespie, C.; Seymour, J.; Serdula, M.; Blanck, H.M. Fruit and vegetable intake among adolescents and adults in the United States: Percentage meeting individualized recommendations. Medscape J. Med. 2009, 11, 26.

25. Peltzer, K.; Pengpid, S. Fruits and vegetables consumption and associated factors among in-school adolescents in seven African countries. Int. J. Public Health 2010, 55, 669-678. [CrossRef]

26. Doku, D.; Koivusilta, L.; Raisamo, S.; Rimpelä, A. Socio-economic differences in adolescents' breakfast eating, fruit and vegetable consumption and physical activity in Ghana. Public Health Nutr. 2013, 16, 864-872. [CrossRef]

27. Darfour-Oduro, S.A.; Buchner, D.M.; Andrade, J.E.; Grigsby-Toussaint, D.S. A comparative study of fruit and vegetable consumption and physical activity among adolescents in 49 low-and-middle-income countries. Sci. Rep. 2018, 8, 1-12. [CrossRef]

28. Gwirtz, J.A.; Garcia-Casal, M.N. Processing maize flour and corn meal food products. Ann. N. Y. Acad. Sci. 2014, 1312, 66. [CrossRef] [PubMed]

29. USDA. Food Composition Databases; USA Department of Agriculture Agricultural Research Service: Washington, DC, USA, 2018. Available online: https://ndb.nal.usda.gov/ (accessed on 20 February 2020).

30. Dary, O.; Mora, J.O. Food fortification to reduce vitamin A deficiency: International Vitamin A Consultative Group recommendations. J. Nutr. 2002, 132. [CrossRef] [PubMed]

31. Solon, F.; Solon, M.; Mehansho, H.; West, J.K.; Sarol, J.; Perfecto, C.; Nano, T.; Sanchez, L.; Isleta, M.; Wasantwisut, E. Evaluation of the effect of vitamin A-fortified margarine on the vitamin A status of preschool Filipino children. Eur. J. Clin. Nutr. 1996, 50, 720-723. [PubMed]

32. Morris, E.; Whitney, E.N.; Cataldo, C.B. Understanding normal and clinical nutrition. Am. J. Nurs. 1984, 84, 146. [CrossRef]

33. Nhlapo, N.; Lues, R.J.; Kativu, E.; Groenewald, W.H. Assessing the quality of food served under a South African school feeding scheme: A nutritional analysis. South Afr. J. Sci. 2015, 111, 1-9. [CrossRef]

34. School Food Trust. A Guide to Introducing the Government's Food-Based and Nutrient-Based Standards for School Lunches; School Food Trust: London, UK, 2013; Available online: https://sheu.org.uk/content/ guide-introducing-governments-food-based-and-nutrient-based-standards-school-lunches-0 (accessed on 20 February 2020).

35. Charrondiere, U.; Chevassus-Agnes, S.; Marroni, S.; Burlingame, B. Impact of different macronutrient definitions and energy conversion factors on energy supply estimations. J. Food Compos. Anal. 2004, 17, 339-360. [CrossRef]

36. Ye, Z.; Arumugam, V.; Haugabrooks, E.; Williamson, P.; Hendrich, S. Soluble dietary fiber (Fibersol-2) decreased hunger and increased satiety hormones in humans when ingested with a meal. Nutr. Res. 2015, 35, 393-400. [CrossRef] 
37. Prosky, L. Dietary Fiber | Effects of Fiber on Absorption; Elsevier: Oxford, UK, 2003; pp. 1838-1844.

38. Al Hasan, S.M.; Hassan, M.; Saha, S.; Islam, M.; Billah, M.; Islam, S. Dietary phytate intake inhibits the bioavailability of iron and calcium in the diets of pregnant women in rural Bangladesh: A cross-sectional study. BMC Nutr. 2016, 2, 24. [CrossRef]

39. Murphy, K.J.; Marques-Lopes, I.; Sánchez-Tainta, A. Cereals and legumes. In The Prevention of Cardiovascular Disease Through the Mediterranean Diet; Sánchez-Villegas, A., Sánchez-Tainta, A., Eds.; Academic Press: Cambridge, UK, 2018; Chapter 7; pp. 11-132.

40. Delimont, N.M.; Haub, M.D.; Lindshield, B.L. The impact of tannin consumption on iron bioavailability and status: A narrative review. Curr. Dev. Nutr. 2017, 1,1-12. [CrossRef]

41. Harika, R.; Faber, M.; Samuel, F.; Mulugeta, A.; Kimiywe, J.; Eilander, A. Are low intakes and deficiencies in iron, vitamin A, zinc, and iodine of public health concern in Ethiopian, Kenyan, Nigerian, and South African children and adolescents? Food Nutr. Bull. 2017, 38, 405-427. [CrossRef]

42. Kawade, R. Zinc status and its association with the health of adolescents: A review of studies in India. Glob. Health Action 2012, 5. [CrossRef] [PubMed]

43. Gibson, R.S.; Raboy, V.; King, J.C. Implications of phytate in plant-based foods for iron and zinc bioavailability, setting dietary requirements, and formulating programs and policies. Nutr. Rev. 2018, 76, 793-804. [CrossRef] [PubMed]

(C) 2020 by the authors. Licensee MDPI, Basel, Switzerland. This article is an open access article distributed under the terms and conditions of the Creative Commons Attribution (CC BY) license (http://creativecommons.org/licenses/by/4.0/). 


\title{
Article
}

\section{Environmental Determinants of a Country's Food Security in Short-Term and Long-Term Perspectives}

\author{
Alina Vysochyna ${ }^{1}$, Natalia Stoyanets ${ }^{2}$, Grzegorz Mentel ${ }^{3, *}$ and Tadeusz Olejarz ${ }^{4}$ \\ 1 Department of Accounting and Taxation, Sumy State University, 40000 Sumy, Ukraine; \\ a.vysochyna@uabs.sumdu.edu.ua \\ 2 Faculty of Economics and Management, Sumy National Agrarian University, 40000 Sumy, Ukraine; \\ natalystoyanez@gmail.com \\ 3 Department of Quantitative Methods, The Faculty of Management, Rzeszow University of Technology, \\ 35-959 Rzeszow, Poland \\ 4 Department of Management Systems and Logistics, The Faculty of Management, Rzeszow University of \\ Technology, 35-959 Rzeszów, Poland; olejarz@prz.edu.pl \\ * Correspondence: gmentel@prz.edu.pl
}

Received: 10 April 2020; Accepted: 14 May 2020; Published: 16 May 2020

\begin{abstract}
About 10\% of the world population suffered from hunger in 2018. Thereby, the main objective of this research is the identification of environmental drivers and inhibitors of a country's food security in the short and long run. The Food Security Index (FSI) was constructed from 19 indicators using Principal Component Analysis. Identification of the short- and long-run relationships between the FSI and environmental factors was realized with the pooled mean-group estimator for 28 post-socialistic countries for 2000-2016. Empirical research results showed that a country's food security in the short run is affected by greenhouse gas emissions but boosted by the increase of renewable energy production. Reduction of carbon dioxide emissions, electrification of rural populations, access to clean fuels, renewable energy production, arable land, and forest area growth might be essential tasks in order to ensure countries' food security in the long-run.
\end{abstract}

Keywords: food security; food availability; food access; food stability; food utilization; environmental determinants; sustainable development

\section{Introduction}

Global economic development at the end of the XX century led to the boosting of industrial and technological development. However, these processes also triggered numerous destructive trends, especially for the environment. In turn, the scale of the environmental problems needed cooperation of the global community to solve them, so the Agenda 21 and, recently, the Millennium Development Goals were developed in order to coordinate the efforts of different countries on the way to elimination of global damages and implementation of sustainable development. At the Millennium Summit in 2000, eight Millennium Development Goals were developed, aimed at poverty, hunger and child mortality reduction, decrease of different diseases, expansion of education, banning of gender inequality, triggering of cooperation of local community, and promotion of sustainable environment development. All of these goals have quantitative measures that needed to be achieved in order to fulfill the goals. Global community cooperation during the last decades allowed the partial fulfilment of these goals. Nevertheless, considering such achievements and newly appeared damages in 2015 at the United Nations General Assembly, the 17 Sustainable Development Goals by 2030 were introduced [1]. It is worth noting that most of the Sustainable Development Goals focus on food security or environmental issues that clarify their urgency and importance both at national (local) and supranational levels. 
Elimination of hunger and different forms of malnutrition in order to overcome food insecurity continues to be an urgent global task because of the insufficient economic growth dynamics in different countries, climate change, existence of war conflicts and political instability zones, etc. Namely, according to the Food and Agriculture Organization of the United Nations (FAO) report [2] in 2000, there were 792 million people in 98 countries who met food insecurity problems, while, in 2018 [3], more than 820 million people were still suffering from hunger. Such a situation proves the extreme urgency of the need for the global community's cooperation in order to fulfill the Zero Hunger goal by 2030. Moreover, it is also essential to continue scientific research aiming at clarification of factors strengthening or worsening country food security. That might help to develop a more well thought out and scientifically grounded economic policy at both national and supranational levels.

Particularly, according to the FAO [4], nowadays, "food security exists when all people, at all times, have physical and economic access to sufficient, safe, and nutritious food that meets their dietary needs and food preferences for an active and healthy life". Moreover, in terms of the FAO approach, food security has four dimensions, namely food availability, food access, food stability, and food utilization. Food availability is about physical existence of foodstuffs of appropriate quality that might be supplied to the population. Food access characterizes the possibility of getting food considering legal, political, economic, and social conditions. Food utilization illustrates rationality and effectiveness of consumption, sanitation, and water access conditions. Food stability is about ensuring foodstuff provision at any time range, even in cases of insufficient economic situations or realization of some other risks [4]. As it becomes evident from the essence of the food security perspectives, some of them mostly dependent on economic conditions, but the majority of pillars are reliant on environmental preconditions. Consequently, environmental determinants play a crucial role in foodstuff production, distribution, and the quality of its consumption. However, the functioning of food-producing enterprises is quite often (especially in developing countries) accompanied by numerous adverse environmental effects (air pollution, soil degradation, elimination of certain species of flora and fauna, reduction of forest area, greenhouse gas emissions increase, etc.). On the contrary, spurring environmental problems would likely lead to an increase in food insecurity and disruption of sustainability of the national economy.

It should be noted that there is plenty of research that specifies the influence of social, economic, and environmental factors on a country's food security as a whole and on its perspectives separately, but they sometimes contradict each other. In addition, different groups of scientists focused on various environmental aspects and food security pillars, so it might be hard to see the situation comprehensively. Therefore, from both theoretical and empirical points of view, it is crucial to identify the impact of environmental (ecological) factors on a country's food security in the short-run and long-run perspectives using up-to-date data and scientific approaches. Specifically, this research aimed at clarifying several important issues:

(1) Identification of the relevant environmental factors that influence a country's food security (we used to think that some environmental problems might damage foodstuff production, distribution, and consumption value, but the existence of contradictory empirical research results about such an impact reveals the necessity of further theoretical and empirical findings in this direction);

(2) Comprehensiveness: As a rule, empirical research is narrow and focused on the clarification of influence of some certain environmental determinant on a country's food security or its pillars; however, we try to consider the vast majority of potential environmental factors mentioned in previous empirical research; this approach might be useful from the regulatory perspective because it could help to identify the priorities of environmental, economic, and social government policy (to some extent);

(3) Clarification of the short- and long-run impacts of environmental factors on a country's food security (basically, most of the empirical research is based on classical regression analysis and aimed at confirmation or rejection of some empirical hypothesis, but it should be taking into 
consideration that environmental factors likely have no immediate influence on a country's food security; thus, it is by far more valuable to clarify this impact in different time perspectives).

Moreover, the food security concept originated in 1974 during the World Food Conference, but gained its modern features in 1996 at the World Food Summit [4]. Despite the conceptual clarification from the mid-1990s of the XX century, the possibility of tracking countries' progress in terms of food security appeared only in 2012 with the launching of the Global Food Security Index. Thus, there is no considerable amount of similar research results aimed at testing the influence of the environmental factors on a proxy of countries' food security, especially in different time perspectives.

Consequently, this research might have significant theoretical and empirical value both in terms of development of countries' environmental and food security policies and tracking of changes the environmental determinants of countries' food security.

\section{Literature Review}

In order to fulfill the task of comprehensiveness of the research, it is necessary to generalize potential environmental determinants influencing a country's food security (alternatively, foodstuff production, agribusiness performance, etc.) that were previously mentioned by scientists. Basically, some theoretical and empirical findings confirm the hypothesis about social, economic, or environmental factors' impacts on countries' food security as a whole or its particular perspective.

It should be noted that there is a set of scientific research that, in general terms, supports the hypothesis about the influence of environmental factors on a country's food security or its proxies. Namely, Musová, Musa, and Ludhova [5], Dwikuncoro and Ratajczak [6], and Vasa [7] researched factors influencing food purchasing (food utilization) in the Slovak Republic, Poland, and Hungary. They found out that consumer behavior is mostly driven by economic factors (quality and prices of products, household income). However, environmental factors also matter- $69 \%$ of respondents mentioned that they prefer environmentally friendly goods. Moreover, Jakubowska and Radzymińska [8] found out that Czech students, who participated in the research, declare environmental motives as dominant in their consumer choices. Dabija, Bejan, and Dinu [9] also identified that consumers of Generation Z prefer green suppliers. In turn, Gadeikienè, Dovalienè, Grase, and Banytė [10], Arslan [11], Olasiuk and Bhardwaj [12], and Ahmad [13] reveal that environmental preconditions and comprehensive nutrition knowledge play an important role in ensuring sustainable consumption. Thus, this group of scientists supports the idea that environmental image and responsibility are impactful for food consumption (food utilization proxy of a country's food security).

In terms of discussing the impact of environmental determinants on the performance of food producers and foodstuff trade, i.e., food availability and partial food access, Morkūnas, Volkov, and Pazienza [14], Morkūnas et al. [15], and Tomchuk et al. [16] mentioned that economic and environmental factors have an impact for resilience of agricultural enterprises. Similarly, Handayani, Wahyudi, and Suharnomo [17], Mikhaylova et al. [18], Akhtar [19], Kheyfets and Chernova [20], Stjepanović, Tomić, and Škare [21], Cismas et al. [22], Jayasundera [23], and Harold [24] proved that green innovations positively influence business performance, sustainability of agriculture, and food security. Haninun, Lindrianasari, and Denziana [25] mentioned that environmental performance has an effect on financial performance. Ortikov, Smutka, and Benešován [26] reveal that increase of innovativeness and eco-friendliness might be among essential preconditions of an increase of competitiveness of Uzbekistan's agrarian foreign trade. However, Shuquan [27] empirically proved the existence of the relationship between international trade and countries' environmental performance (case of China). In turn, Smutka, Maitah, and Svatoš [28], Falkowski [29], and Kadochnikov and Fedyunina [30] pointed out that, in the case of Russian foodstuff imports, not environmental, but economic and political factors matter. However, in the case of Russia's exports to EU countries, political and environmental determinants play a more significant role. This block of research supports the idea that eco-friendliness and environmental responsibility are not just influencing consumers' motives, but also argue that agricultural enterprises are also driven by environmental motives. Nevertheless, these researches 
also allow us to conclude that environmental factors play a prior role in foodstuff trade in developed countries, but a secondary role in developing countries.

The third set of researches is mainly focused on clarification of state regulations' influence on a country's food security. In turn, Krajnakova, Navickas, and Kontautiene [31] mentioned that environmental regulation might be a trigger of a country's competitiveness and sustainability. Similarly, Grenčíková et al. [32], Bilan et al. [33-36], Lyulyov et al. [37], Akhmadeev et al. [38], Bhandari [39], Bello, Galadima, and Jibrin [40], Sokolenko, Tiutiunyk, and Leus [41], Lizińska, Marks-Bielska, and Babuchowska [42], Vacca and Onishi [43], Kostyuchenko et al. [44], and Popp et al. [45] found out that different environment-related institutional factors significantly influence countries' sustainability and food security.

Previous parts of the literature review proved the hypothesis that environmental (ecological) factors, in general terms, do influence a country's food security and its perspectives. Moreover, this allows the revelation that environmental responsibility is triggered by regulatory and institutional preconditions and is an essential determinant of consumer choice and agricultural business performance. Thus, it creates a background for more in-depth analysis regarding the identification of specific environmental factors that have impacts on a country's sustainable development and food security. In this perspective, it should be mentioned that Vasylyeva and Pryymenko [46], Mekhum [47], Lu et al. [48], Androniceanu and Popescu [49], Lyeonov et al. [50], Abdimomynova et al. [51], and Mentel et al. [52] clarify renewable energy production and consumption as among key environmental determinants. Additionally, Aitkazina et al. [53] pointed out that an increase in greenhouse gas emissions by agrarian enterprises and expansion of use of chemical fertilizers create threats for sustainable development and, consequently, a country's food security. Similarly, Sibanda and Ndlela [54], Dkhili and Dhiab [55], Mačaitytè and Virbašiūte [56], and Odermatt [57] also argue that increase of carbon emissions negatively influences company performance, countries' food security, and sustainability. In turn, Vasylieva [58] mentioned that a country's food security is dependent on yields, rational land use, development of innovations, and infrastructure. However, Aliyas, Ismail, and Alhadeedy [59] supposed that a country's food security and agricultural sustainability are based on environmental friendliness, decrease of chemical fertilizers, and effective ecological state policy.

Consequently, a comprehensive analysis of the theoretical and empirical research results aimed at clarifying factors affecting countries' food security leads to the conclusion that economic factors are still among key determinants of foodstuff consumption (it mostly depends on prices of goods and household income) and agribusiness performance (as a key sphere of food production and distribution). At the same time, there is a considerable block of research proving that the influence of ethical, institutional, and specific environmental factors on a country's food security become more significant. In turn, among major environmental determinants affecting a country's food security, scientists mention water and soil usage, energetic issues (expansion of renewable and traditional energy production and consumption), greenhouse gas emission, fertilizer usage, etc. Nevertheless, the influence of these factors on a country's food security is revealed, but scientists have no unified position about the scale and character of such an impact, so it might be valuable, from both theoretical and practical perspectives, to identify which factors are more influential in the long run and which in the short run.

\section{Materials and Methods}

Previous studies [60] were mainly related to primary empirical research. Specifically, they allowed the identification of the potential blocks of environmental determinants affecting a country's food security, such as: (1) Measures concerning natural resource availability and usage; (2) energy production and consumption items; (3) fertilizer usage; (4) greenhouse gas emissions by agricultural enterprises; (5) parameters of agribusiness yield. In turn, as a result of this literature review, a set of 37 environmental determinants was collected from the World Bank DataBank [61] and the United Nations Environment Program Data Explorer [62]. Correlation analysis helped to select the most influential 
factors and eliminate multicollinearity problems. It allowed the choosing of 14 out of 37 environmental factors. Additionally, two of these 14 variables were eliminated because they had negative influences on regression model quality parameters. Therefore, previous research [60] helped to clarify a set of environmental factors that do have an impact on a country's food security.

The realization of this research task implied the need for several stages: (1) Construction of the comprehensive food security indicator; (2) identification of certain ecological factors influencing food security in the short and long run.

In general terms, the research was based on data collected from public sources (the World Bank DataBank [61], the United Nations Environment Programme Data Explorer [62], and the Food and Agriculture Organization of the United Nations database (FAOSTAT) [63]) for 28 post-socialistic countries (Albania, Armenia, Azerbaijan, Belarus, Bosnia and Herzegovina, Bulgaria, Croatia, Czech Republic, Estonia, Georgia, Hungary, Kazakhstan, Kyrgyz Republic, Latvia, Lithuania, Macedonia, Moldova, Montenegro, Poland, Romania, Russia, Serbia, Slovak Republic, Slovenia, Tajikistan, Turkmenistan, Ukraine, and Uzbekistan) from 2000 to 2016.

As for the first stage, it might be noted that The Economist in cooperation with the FAO have developed the Global Food Security Index, which consists of 28 measurement indicators of affordability, availability, quality, and safety of food. Nevertheless, this index has been calculated from 2012, which is too small a period for gaining reliable modeling results. That is why the Food Security Index (FSI) was constructed. The FSI consists of 19 indicators of food availability, food access, food stability, and food utilization. The FAO officially identifies these parameters as measures of food security. The descriptions of the indicators used for the FSI's construction are in Table 1.

Table 1. Measurement indicators of the Food Security Index (FSI).

\begin{tabular}{cl}
\hline Perspective of Food Security & \multicolumn{1}{c}{ Indicators of Food Security Measurement } \\
\hline \multirow{3}{*}{ Food availability } & Average dietary energy supply adequacy, \% (ADESA); \\
& Average value of food production, USD per capita (FoodProd); \\
& Share of dietary energy supply derived from cereals, roots, and tubers, \% (CRT); \\
& Average protein supply, gr/capita/day (Protein); \\
& Average supply of proteins of animal origin, gr/capita/day (AnProt). \\
\hline \multirow{3}{*}{ Food access } & Rail line density, total route in km per 100 square km of land area (Railway); \\
& GDP per capita, USD (GDPpc); \\
& Prevalence of undernourishment, $\%$ (Under); \\
& Depth of the food deficit, kcal/capita/day (FoodDef). \\
& Cereal import dependency ratio, \% (Cereals); \\
& Percentage of arable land equipped for irrigation, \% (Irrig); \\
& Value of food imports over total merchandise exports, \% (ImEx); \\
& Political stability and absence of violence, index (PolStab); \\
& Per capita food production variability, thousand USD (FPV); \\
& Per capita food supply variability, kcal/capita/day (FoodSup). \\
\hline \multirow{3}{*}{ Food stability } & Percentage of population with access to improved drinking water sources, \% (ImWater); \\
& Percentage of population with access to sanitation facilities, \% (Sanit); \\
& Prevalence of obesity in the adult population (18 years and older), \% (Obesity); \\
& Prevalence of anemia among women of reproductive age (15-49 years), \% (Anemia). \\
\hline \multirow{2}{*}{ Food utilization } &
\end{tabular}

The FAO does not clarify a certain algorithm for aggregation of food availability, food access, food stability, and food utilization indicators. Therefore, the Principal Component Analysis (PCA) in Stata software was used to realize this particular task. Namely, the eigenvalues of the first principal component were used as weighted coefficients for the FSI's construction. It is worth noting that we use the PCA method rather than the Analytic Hierarchy Process (AHP) because it is a rather complicated task for realizing pairwise judgments to prioritize measures of food security on a scale of 1 to 9 . Thus, we decided to apply not a subjective, but a more objective method (PCA), which aimed at clarification of data trends and identification of weight coefficients based on them [64]. In addition, before applying the PCA, all of the above-mentioned indicators were primarily normalized considering their stimulating or unstimulating influence on the state of countries' food security. The normalization process allows us to arrange them from 0 to 1. 
In turn, the second stage of the research is focused on the identification of environmental determinants influencing a country's food security in short- and long-run perspectives. As the research sample includes rather huge number of observations, both in terms of periods, countries, and independent variables (panel data sample), a pooled mean-group (PMG) estimator, developed by Pesaran, Shin, and Smith [65], was used. Traditionally, in research based on panel data with a large number of cross-sections but a small number of time observations, fixed effects are applied, as well as random effects estimators or generalized method of moments. However, an increase in the number of time observations might result in non-stationarity. As this research covers a rather large number of cross-sectional observations and time observations, it is better to apply the PMG estimator. Moreover, this research method allows us to manage the problem of non-stationarity and better fits heterogeneous panels. In addition, the PMG estimator considers both pooling and averaging approaches (it allows short-run coefficients to differ across countries, but long-run coefficients might be equal for the whole panel). Thus, it helps to mix some technical aspects from the mean group estimator and fixed effects estimator [66].

The PMG estimator allows testing of the hypothesis about the existence of influence on food security (specifically, the FSI) in the long-term and short-term perspectives of the following environmental indicators: X1-access to clean fuels and technologies for cooking ( $\%$ of population); X2-access to electricity in rural areas (\% of rural population); X3-agricultural methane emissions (\% of total); $\mathrm{X} 4$-agricultural nitrous oxide emissions (\% of total); $\mathrm{X} 5$-arable land (\% of land area); $\mathrm{X} 6$ - cereal yield ( $\mathrm{kg}$ per hectare); $\mathrm{X} 7-\mathrm{CO}_{2}$ emissions (metric tons per capita); $\mathrm{X} 8$ - electric power transmission and distribution losses (\% of output); $\mathrm{X} 9$-electricity production from renewable sources, excluding hydroelectric (\% of total); $\mathrm{X} 10$ - fertilizer consumption (kilograms per hectare of arable land); X11—forest area (\% of land area); X12-renewable electricity output (\% of total electricity output). The summative statistics for the set of dependent and independent variables are in Table 2.

Table 2. Summative statistics for the set of variables.

\begin{tabular}{cccccc}
\hline Variable & Obs & Mean & Std. Dev. & Min & Max \\
\hline FSI & 448 & 1.295 & 0.565 & 0.16 & 2.25 \\
X1 & 476 & 82.774 & 16.484 & 38.07 & 100.00 \\
X2 & 476 & 99.724 & 0.519 & 95.68 & 100.00 \\
X3 & 237 & 36.122 & 16.434 & 0.00 & 75.29 \\
X4 & 237 & 63.263 & 15.924 & 0.00 & 87.68 \\
X5 & 464 & 23.172 & 15.259 & 0.58 & 56.23 \\
X6 & 464 & 3310.283 & 1250.055 & 804.10 & 6742.3 \\
X7 & 465 & 5.642 & 3.669 & 0.29 & 17.31 \\
X8 & 471 & 13.835 & 7.341 & 1.82 & 72.90 \\
X9 & 471 & 1.553 & 3.677 & 0.00 & 29.99 \\
X10 & 364 & 95.155 & 85.911 & 0.84 & 495.23 \\
X11 & 476 & 29.539 & 17.141 & 1.23 & 62.12 \\
X12 & 476 & 29.985 & 30.526 & 0.00 & 100.00 \\
\hline
\end{tabular}

Notes: X1—access to clean fuels and technologies for cooking (\% of population); X2-access to electricity in rural areas (\% of rural population); $\mathrm{X} 3$-agricultural methane emissions ( $\%$ of total); $\mathrm{X} 4$-agricultural nitrous oxide emissions ( $\%$ of total); $\mathrm{X} 5$ - arable land ( $\%$ of land area); $\mathrm{X} 6$ - cereal yield ( $\mathrm{kg}$ per hectare); $\mathrm{X} 7-\mathrm{CO}_{2}$ emissions (metric tons per capita); $\mathrm{X} 8$ - electric power transmission and distribution losses (\% of output); $\mathrm{X} 9$-electricity production from renewable sources, excluding hydroelectric ( $\%$ of total); $\mathrm{X} 10$ - fertilizer consumption (kilograms per hectare of arable land); X11—forest area (\% of land area); X12-renewable electricity output (\% of total electricity output); Obs—amount of observations; Std. Dev.-Standard deviation.

Based on the results presented in Table 2, it should be noted that the number of observations differs for some variables. Nevertheless, the panel is strongly balanced, which allows us to get reliable and significant empirical research results. 


\section{Results}

Taking into account weight coefficients (Table 3), the FSI was constructed with the PCA approach. It is also worth noting that the calculated FSI is quite representative. Its comparison with the Global Food Security Index for those 13 countries, which are matched in both samples (Belarus, Kazakhstan, Poland, Hungary, Poland, Hungary, Poland, Hungary, Russia, Serbia, Slovakia, Tajikistan, Ukraine, and Uzbekistan) for the years 2012-2016, revealed a correlation of $90.20 \%$. Consequently, the FSI allows the characterization of the same trends as those displayed by the Global Food Security Index.

Table 3. Weight coefficients of indicators of Food Security Index.

\begin{tabular}{cccccc}
\hline Indicator & Eigenvalue & Indicator & Eigenvalue & Indicator & Eigenvalue \\
\hline ADESA & 0.2571 & Under & 0.2779 & FoodSup & -0.0198 \\
FoodProd & 0.2452 & FoodDef & 0.2266 & ImWater & 0.2247 \\
CRT & -0.2904 & Cereals & 0.1765 & Sanit & 0.0920 \\
Protein & 0.2994 & Irrig & -0.2673 & Obesity & -0.2855 \\
AnProt & 0.2761 & ImEx & 0.1203 & Anemia & 0.1908 \\
Railway & 0.2126 & PolStab & 0.2416 & & \\
GDPpc & 0.2834 & FPV & 0.1295 & & \\
\hline
\end{tabular}

Analysis of the FSI level in 2016 shows that the highest level of food security is in the Czech Republic (2.25 from 2.39), and the lowest is in Tajikistan (0.16). It is also worth noting that such countries as Albania, Armenia, Azerbaijan, Bosnia and Herzegovina, Georgia, Kyrgyz Republic, Macedonia, Moldova, Serbia, Tajikistan, Turkmenistan, Ukraine, and Uzbekistan have less-than-average levels of national food security. The rest of the countries have higher-than-average levels of national food security. In terms of the characteristics of the dynamics of the FSI level, it might be highlighted that Azerbaijan (566.19\%), Tajikistan (520.97\%), Uzbekistan (182.79\%), Armenia (178.68\%), Turkmenistan (97.80\%), Georgia (83.93\%), and Albania (74.63\%) have the best growth dynamics in comparison with 2001, while for the other countries, the growth rate fluctuates in almost the same range (about 31.66\%).

The next step is the identification of the relationship between the relevant environmental determinants and the FSI. It is based on the panel data regression analysis (PMG estimator). Practically, it was implemented with the help of the "xtpmg" add-on of the Stata software. The results of the regression analysis are given in Table 4.

Therefore, the following conclusions can be made. The vast majority of the environmental factors have a statistically significant long-term impact on countries' food security (significant at the $10 \%$, $5 \%$, or $1 \%$ level). Environmental determinants that have no statistically significant impact on the FSI level in the long-term perspective are as follows: Agricultural methane emissions (\% of total emissions) (X3); agricultural nitrous oxide emissions (\% of total emissions) (X4); cereal yield (kg per hectare) (X6); electric power transmission and distribution losses (\% of output) (X8). Thus, the absence of a statistically significant impact of the growth of greenhouse gas emissions by agricultural enterprises on the level of countries' food security is mostly explained by the intensified efforts of the world community on the reduction of such emissions (according to the Kyoto Protocol, countries are obliged to reduce greenhouse gas emissions by 2100). Additionally, agro-industrial enterprises provide only $10 \%-12 \%$ of the total emissions, while transport, industrial, construction, and energy enterprises have a greater impact on the ecosystem. The reduction in the net carbon dioxide emissions of the agro-industrial sector was largely explained by the decline of deforestation and the increase in forest plantations.

However, the increase of carbon dioxide emissions per capita from all sources of pollution (X7) remains a strong factor of the negative impact on countries' food security in the long-run perspective. Namely, an increase of this independent variable by a point results in a decrease of country food security level by 0.0886 (or $3.71 \%$ of the maximum possible FSI value). 
Table 4. Results of identifying short- and long-run coefficients of environmental factors' influence on the FSI.

\begin{tabular}{|c|c|c|c|c|}
\hline \multirow{2}{*}{ Variable } & Coefficient & Std. Deviation & $\mathbf{Z}$ & $P>|z|$ \\
\hline & \multicolumn{4}{|c|}{ Long-Run Perspective } \\
\hline $\mathrm{X} 1$ & 0.0105 & 0.0076 & 1.38 & 0.168 \\
\hline $\mathrm{X} 2$ & 0.0811 & 0.0513 & 1.58 & 0.114 \\
\hline $\mathrm{X} 3$ & -0.0055 & 0.0127 & -0.43 & 0.667 \\
\hline $\mathrm{X} 4$ & 0.0041 & 0.0050 & 0.82 & 0.410 \\
\hline $\mathrm{X} 5$ & 0.0285 & 0.0175 & 1.62 & $0.104 *$ \\
\hline $\mathrm{X} 6$ & 0.0000 & 0.0000 & 0.87 & 0.384 \\
\hline $\mathrm{X} 7$ & -0.0886 & 0.0248 & 3.57 & $0.000 * * *$ \\
\hline $\mathrm{X} 8$ & 0.0028 & 0.0019 & 1.40 & 0.161 \\
\hline X9 & -0.0262 & 0.0168 & -1.56 & 0.218 \\
\hline $\mathrm{X} 10$ & 0.0020 & 0.0009 & 2.23 & $0.026 * *$ \\
\hline $\mathrm{X} 11$ & 0.0948 & 0.0561 & 1.69 & $0.091 *$ \\
\hline \multirow[t]{2}{*}{$\mathrm{X} 12$} & 0.0154 & 0.0054 & 2.86 & $0.004^{* * *}$ \\
\hline & \multicolumn{4}{|c|}{ Short-Run Perspective } \\
\hline $\mathrm{X} 1$ & -0.0134 & 0.0180 & -0.74 & 0.457 \\
\hline $\mathrm{X} 2$ & -0.0101 & 0.0074 & -1.36 & 0.173 \\
\hline $\mathrm{X} 3$ & -0.0109 & 0.0041 & -2.86 & $0.007^{* * *}$ \\
\hline $\mathrm{X} 4$ & 0.0001 & 0.0007 & 0.12 & 0.906 \\
\hline $\mathrm{X} 5$ & -0.0024 & 0.0049 & -0.48 & 0.629 \\
\hline $\mathrm{X} 6$ & $-4.86 \times 10^{-6}$ & $5.20 \times 10^{-6}$ & -0.93 & 0.350 \\
\hline $\mathrm{X} 7$ & -0.0190 & 0.0082 & -2.31 & 0.021 ** \\
\hline $\mathrm{X} 8$ & -0.0001 & 0.0004 & -0.31 & 0.755 \\
\hline X9 & 0.0181 & 0.0043 & 4.26 & $0.000^{* * *}$ \\
\hline $\mathrm{X} 10$ & -0.0003 & 0.0003 & -0.91 & 0.364 \\
\hline $\mathrm{X} 11$ & 0.0514 & 0.0619 & 0.83 & 0.406 \\
\hline $\mathrm{X} 12$ & -0.0021 & 0.0010 & -2.08 & 0.038 ** \\
\hline Cons & -3.6307 & 1.2189 & -2.98 & $0.003^{* * *}$ \\
\hline $\mathrm{ec}$ & -0.2920 & 0.0863 & -3.38 & $0.001^{* * *}$ \\
\hline Countries & 28 & 28 & 28 & 28 \\
\hline Observations & 476 & 476 & 476 & 476 \\
\hline
\end{tabular}

Notes: X1-access to clean fuels and technologies for cooking (\% of population); X2-access to electricity in rural areas (\% of rural population); X3-agricultural methane emissions ( $\%$ of total); X4-agricultural nitrous oxide emissions (\% of total); $\mathrm{X} 5$ - arable land (\% of land area); $\mathrm{X} 6$ - cereal yield (kg per hectare); $\mathrm{X} 7-\mathrm{CO}_{2}$ emissions (metric tons per capita); X8 - electric power transmission and distribution losses (\% of output); X9-electricity production from renewable sources, excluding hydroelectric ( $\%$ of total); $\mathrm{X} 10$-fertilizer consumption (kilograms per hectare of arable land); X11 - forest area (\% of land area); X12-renewable electricity output (\% of total electricity output); ${ }^{*}$-significance at $10 \%$ level; ${ }^{* *}$ - significance at $5 \%$ level; ${ }^{* *}$ - significance at $1 \%$ level.

In turn, some factors have a positive impact on the countries' food security, such as:

- Access to clean fuels and technologies for cooking (\% of population) (X1) —an increase of the environmental factor by a point results in strengthening of a country's food security by 0.0105 (or $0.43 \%$ of the maximum possible FSI value);

- $\quad$ Access to electricity in rural areas (\% of rural population) (X2) - an increase of the environmental factor by a point results in strengthening of a country's food security by 0.0811 (or $3.39 \%$ of the maximum possible FSI value), which means that further electrification of rural areas using environmentally friendly technologies should be a priority direction of public policy.

This statement is also confirmed by a positive and statistically significant impact of expanding renewable electricity output (\% of total electricity output) (X12) on the country's food security in the long-run perspective. Namely, its increase by a point leads to strengthening of a country's food security by 0.0154 (or $0.64 \%$ of the maximum possible FSI value). Experts note [67-69] that the expansion of land for growing biofuel plants might have some negative consequences. It leads to the elimination of the land from the process of food production and may harm a country's food security. Consequently, 
this damage might not be offset by the positive environmental impact of using biofuels instead of traditional fuels.

In addition, the statistical significance of the long-term effects of arable land growth (X5) and forest area growth (X11) was confirmed at the $10 \%$ level. Particularly, an increase by a point of one of these particular environmental factors (X5 and X11) results in an increase in a country's food security by 0.0285 and 0.0948 , respectively. Such a trend is quite natural, since the expansion of arable land will increase the volume of food products. However, such a scenario can have negative consequences and requires a well-thought-out and scientifically grounded approach. In particular, an intensive approach to the agricultural sector's development is preferable. It helps to ensure an increase of agricultural production without large-scale use of additional land resources. It is also equally important to use the most environmentally friendly tools for increasing agribusiness productivity and yields. While there is no widespread expansion of an intensive model of agricultural management, extensive technologies still do not lose their relevance. This is also confirmed by the statistically significant impact of the indicator "fertilizer consumption (kilograms per hectare of arable land)" (X10) on a country's food security (at the $5 \%$ level). Its increase by a point results in the FSI increase by $0.0020(0.08 \%$ of maximum FSI value).

It is worth noting that most of the short-run coefficients are not statistically significant. However, the variables "agricultural methane emissions (\% of total)" (X3) and " $\mathrm{CO}_{2}$ emissions (metric tons per capita)" (X7) have a statistically significant negative impact on the food security index at the $1 \%$ and $5 \%$ levels, respectively. In addition, the positive impact of growth in electricity production from renewable sources is confirmed (both without hydroelectric power-variable X9 and with hydroelectric power-variable X12).

However, in most cases, the particular environmental factors are statistically significant only in short or long run. Consequently, we cannot compare statistically significant results with insignificant ones. Hence, we mainly focused only on the analysis and practical implications of only statistically significant research results. Nonetheless, it is worth noting that the increase in renewable electricity output (\% of total electricity output) (X12) has a positive long-term but negative short-term influence on a country's food security. These findings might be partially explained by the specificity of the sample of countries. Namely, most of 28 post-socialistic countries have triggered more intensive economic, environmental, and technological development only for the last three decades. That is the main reason for the absence of a highly productive network of renewable energy stations. Consequently, the expansion of renewable electricity output leads to an immediate negative impact on a country's food security because of the partial elimination of land and water resources from foodstuff production and the worsening of its quality. Otherwise, in the long run, renewable energy outcompetes traditional energy production, which is more harmful to the environment and countries' food security. Familiar trends were also mentioned in the FAO report "Impacts of Bioenergy on Food Security" [70].

In turn, the increase of $\mathrm{CO}_{2}$ emissions negatively influences a country's food security both in the short and long run. However, the scale and significance of this factor's effect become more influential in the long-term perspective.

\section{Discussion}

Aggregation of these empirical research results aimed at the identification of the influence of environmental (ecological) factors on a country's food security in short- and long-run perspectives allows the confirmation of trends and cohesions identified by other scientists. Specifically, Sola et al. [71] analyzed 132 articles about the influence of access to clean fuels and technologies for cooking on food security measures. Researchers mentioned that, in general, most of the scientists argued that this factor has a positive impact on food security and nutrition. However, there are no numerous empirical pieces of evidence of it. However, our research results allow us to quantitatively clarify such an impact: An increase of the factor by a point results in the strengthening of a country's food security by 0.0105 
in the long run. Moreover, the FAO [72] also actively supports the idea that access to clean fuels leads to better nutrition and less environmental damage.

In addition, our empirical results about the impact of access to electricity in rural areas on food security also correlate with the FAO's findings. Namely, in publication [72], it is mentioned that access to electricity is crucial for a country's food security because electricity is necessary at each stage of foodstuff production. Moreover, access to electricity in rural areas might become a driver of agricultural productivity, efficiency, and food security.

In turn, Wambua, Omoke, and Telesia [73] found empirical pieces of evidence that lack of arable lands and other familiar resources are preconditions of food insecurity in Kenya. Mbuthia, Kioli, and Wanjala [74] highlighted the importance of the other resource factors. Namely, they revealed that the prohibition of cutting trees (forest areas) has a positive influence on household food security. Thereby, our research results form empirical evidence of the relationships that were previously identified at a theoretical level.

Moreover, Wambua, Omoke, and Telesia [73] also revealed that using animal manure or industrial fertilizers allows an increase in agricultural crops. Hence, the authors pointed out that households using fertilizers for agricultural issues did not face the problem of food insecurity even in periods of unfavorable weather and climate conditions (based on 66 households' self-assessment). In our research, the hypothesis about the long-run positive impact of fertilizer consumption on a country's food security measures was also confirmed.

In the research, it was revealed that $\mathrm{CO}_{2}$ emissions have a negative influence on a country's food security, as was also highlighted in other research by Sibanda and Ndlela [54], Dkhili and Dhiab [55], Mačaitytè and Virbašiūtė [56], and Odermatt [57].

Finally, empirical findings about the positive influence of renewable energy output on a country's food security were also proved by other scientists' and international organizations' reports, such as the International Renewable Energy Agency (IRENA) [75]. Namely, it is noted in the report that the increase of renewable energy has crucial importance because of several reasons:

- $\quad$ Electricity itself plays an important role in households' everyday life and agriculture business activity, while it is necessary for foodstuff production, storing, and distribution processes;

- Renewable energy and electricity allow the decrease of consumption of fossil fuels, both for private and business purposes;

- $\quad$ Substitution of traditional electricity production with renewable electricity production might help to solve some environmental problems, especially in terms of reduction of greenhouse gas emission;

- $\quad$ Renewable energy's prevalence in comparison with traditional energy sources is more fit for the Sustainable Development Goals, especially in terms of Goal \#7: "Ensure access to affordable, reliable, sustainable and modern energy for all".

In terms of the practical implications of the empirical research results, they might become a background for the development of states' economic, social, and environmental policies in order to ensure countries' food security. Moreover, it also might be useful for the identification of the strategic and operational priorities of public policy.

In terms of further research perspectives, it might be noted that certain environmental determinants may be relevant to the general level of food security, but may not have a statistically significant effect on its components. Therefore, it is also important to identify specific environmental stimulants and inhibitors in terms of ensuring food availability, food access, food stability, and food utilization.

\section{Conclusions}

Thus, it can be concluded that this empirical research aimed at the identification of factors affecting countries' food security in short- and long-run perspectives allows us to confirm previous empirical research results and theoretical findings (especially about the influence of $\mathrm{CO}_{2}$ emissions, sufficiency of 
arable lands, forest areas, and other natural resources, access to electricity, and use of fertilizers). On the other hand, results that were revealed allowed us to obtain empirical evidence and quantitatively clarify the kinds of relationships that were identified mostly on a theoretical level (about influence of access to clean fuels and technologies for cooking).

Therefore, taking into account the results obtained regarding the impact of environmental determinants on countries' food security in short- and long-run perspectives for the 28 former socialist countries, the following can be noted:

- The main operational target in terms of ensuring a country's food security might be an intensification of efforts in reducing greenhouse gas emissions (both methane and carbon dioxide), as well as the reorientation towards the production and consumption of electricity from renewable sources rather than traditional ones, which are more destructive to the ecosystem (in countries where the use of alternative energy sources is limited, a possible solution of the problem may be reducing the number of cogeneration and nuclear power plants in favor of hydroelectric power plants);

- Among the key vectors of mitigating the long-run risks of deterioration of a country's food security can be mentioned the following: Intensification of efforts to reduce carbon dioxide emissions not only in the agricultural sector, but also in the industrial sector; continuation of rural electrification and the provision of environmentally friendly fuels and electricity sources to the population, with the reorientation from traditional sources of energy production towards alternative ones; growth of arable land (or more effective usage of the existing ones) and increasing forest areas, while moving to intensive rather than extensive agricultural management (using fewer resources in order to ensure bigger yields).

Consideration of these proposals might become a basis for the development of state policies in the field of ensuring national food security.

Despite the fact that the obtained empirical results correlate with previous empirical findings, and that, on their basis, some practical recommendations that might be used by governmental authorities while ensuring country food security were developed, there are some limitations of this research, such as: (1) The sample of Countries consists of only 28 post-socialist countries, so expansion of the sample of countries might help to get more comprehensive, complex, and reliable results; (2) other than the expansion of the country sample, it might be valuable to realize cluster analysis and specify recommendations for certain clusters; (3) as the Global Food Security Index, which is considered as a unified proxy of countries' food security, covers the period starting from 2012, it is too small for reliable empirical results; thus, despite constructing our own index, a better option may be the use of the methodology of the Global Food Security Index in order to get more reliable assessments.

Moreover, this research was aimed at identification of specific environmental determinants that influence a country's food security in short- or long-run perspectives, but in order to develop efficient public policy in terms of ensuring country food security, lags of postponed impact of environmental determinants on the FSI might be specified.

Author Contributions: Conceptualization, A.V. and N.S.; methodology, N.S.; software, A.V. and G.M.; formal analysis, investigation, and resources, A.V. and G.M.; writing-original draft preparation, N.S. and T.O.; writing-review and editing, A.V.; visualization, N.S. and T.O.; supervision, A.V. All authors have read and agreed to the published version of the manuscript.

Funding: This research received no external funding.

Conflicts of Interest: The authors declare no conflict of interest.

\section{References}

1. Sustainable Development Goals. Available online: https://sustainabledevelopment.un.org/?menu=1300 (accessed on 18 January 2020). 
2. Food Insecurity: When People Live with Hunger and Fear Starvation. The State of the Food Insecurity in the World 2000. Available online: http://www.fao.org/FOCUS/E/SOFI00/img/sofirep-e.pdf (accessed on 18 January 2020).

3. The State of Food Security and Nutrition in the World 2019-Safeguarding Against Economic Slowdowns and Downturns. Available online: http://www.fao.org/3/ca5162en/ca5162en.pdf (accessed on 18 January 2020).

4. Food and Agriculture Organization of the United Nations. Available online: http://fao.org (accessed on 18 January 2020).

5. Musová, Z.; Musa, H.; Ludhova, L. Environmentally responsible purchasing in Slovakia. Econ. Sociol. 2018, 11, 289-305. [CrossRef]

6. Dwikuncoro, R.A.; Ratajczak, S. Analysis of green activities impact on purchase intention. Pol. J. Manag. Stud. 2019, 20, 159-167. [CrossRef]

7. Vasa, L. Economic coherences between food consumption and income conditions in the Hungarian households. Ann. Agrar. Sci. 2005, 1, 228-232.

8. Jakubowska, D.; Radzymińska, M. Health and environmental attitudes and values in food choices: A comparative study for Poland and Czech Republic. Oeconomia Copernic. 2019, 10, 433-452. [CrossRef]

9. Dabija, D.C.; Bejan, B.M.; Dinu, V. How sustainability oriented is generation z in retail? A literature review. Transform. Bus. Econ. 2019, 18, 140-156.

10. Gadeikienè, A.; Dovalienė, A.; Grase, A.; Banytè, J. Sustainable Consumption Behaviour Spill-Over from Workplace to Private Life: Conceptual Framework. Pol. J. Manag. Stud. 2019, 19, 142-154.

11. Arslan, Y. Exploring the Effects of Consumers' Nutritional Knowledge and Information Interest on the Acceptance of Artificial Sweetener Usage in Soft Drinks. Mark. Manag. Innov. 2019, 3, 33-44. [CrossRef]

12. Olasiuk, H.; Bhardwaj, U. An Exploration of Issues Affecting Consumer Purchase Decisions towards Eco-friendly Brands. Mark. Manag. Innov. 2019, 2, 173-184. [CrossRef]

13. Ahmad, J. Analyzing the Employee Satisfaction and Demand vs Fulfillment of the Food and Beverage Sector in Bangladesh. Bus. Ethics Leadersh. 2018, 2, 74-83. [CrossRef]

14. Morkūnas, M.; Volkov, A.; Pazienza, P. How Resistant is the Agricultural Sector? Economic Resilience Exploited. Econ. Sociol. 2018, 11, 321-332. [CrossRef]

15. Morkūnas, M.; Volkov, A.; Bilan, Y.; Raišienè, A.G. The role of government in forming agricultural policy: Economic resilience measuring index exploited. Adm. Si Manag. Public 2018, 31, 111-131. [CrossRef]

16. Tomchuk, O.; Lepetan, I.; Zdyrko, N.; Vasa, L. Environmental activities of agricultural enterprises: Accounting and analytical support. Econ. Ann. XXI 2018, 169, 77-83. [CrossRef]

17. Handayani, R.; Wahyudi, S.; Suharnomo, S. The effects of corporate social responsibility on manufacturing industry performance: The mediating role of social collaboration and green innovation. Bus. Theory Pract. 2017, 18, 152-159. [CrossRef]

18. Mikhaylova, A.; Mikhaylov, A.; Savchina, O.; Plotnikova, A. Innovation landscape of the Baltic region. Adm. Manag. Public 2019, 33, 165-180. [CrossRef]

19. Akhtar, P. Drivers of Green Supply Chain Initiatives and their Impact on Economic Performance of Firms: Evidence from Pakistan's Manufacturing Sector. J. Compet. 2019, 11, 5-18. [CrossRef]

20. Kheyfets, B.A.; Chernova, V.Y. Sustainable agriculture in Russia: Research on the dynamics of innovation activity and labor productivity. Entrep. Sustain. 2019, 7, 814-824. [CrossRef]

21. Stjepanović, S.; Tomić, D.; Škare, M. Green GDP: An analyses for developing and developed countries. E A M: Ekon. A Manag. 2019, 22, 4-17. [CrossRef]

22. Cismas, L.M.; Miculescu, A.; Negrut, L.; Negrut, V.; Otil, M.D.; Vadasan, I. Social Capital, Social Responsibility, Economic Behavior and Sustainable Economic Development-An Analysis of Romania's Situation. Transform. Bus. Econ. 2019, 18, 605-628.

23. Jayasundera, M. Economic development of Ceylon Tea Industry in Sri Lanka. Financ. Mark. Inst. Risks 2019, 3, 131-135. [CrossRef]

24. Harold, N.Y. Econometric analysis of long and short-run effects of exports on economic growth in Cameroon (1980-2016). Financ. Mark. Inst. Risks 2018, 2, 50-57. [CrossRef]

25. Haninun, H.; Lindrianasari, L.; Denziana, A. The effect of environmental performance and disclosure on financial performance. Int. J. Trade Glob. Mark. 2018, 11, 138. [CrossRef]

26. Ortikov, A.; Smutka, L.; Benešová, I. Competitiveness of Uzbek agrarian foreign trade-different regional trade blocs and the most significant trade partners. J. Int. Stud. 2019, 12, 177-194. [CrossRef] [PubMed] 
27. Shuquan, H. The Impact of Trade on Environmental Quality: A Business Ethics Perspective and Evidence from China. Bus. Ethics Leadersh. 2019, 3, 43-48. [CrossRef]

28. Smutka, L.; Maitah, M.; Svatoš, M. Policy impacts on the EU-Russian trade performance: The case of agri-food trade. J. Int. Stud. 2019, 12, 82-98. [CrossRef] [PubMed]

29. Falkowski, K. Trade interdependence between Russia vs. the European Union and China within the context of the competitiveness of the Russian economy. Equilib. Q. J. Econ. Econ. Policy 2018, 13, 667-687. [CrossRef]

30. Kadochnikov, S.M.; Fedyunina, A.A. Explaining the performance of Russian export: What role does the soft and hard infrastructure play? Int. J. Econ. Policy Emerg. Econ. 2018, 11, 541-559. [CrossRef]

31. Krajnakova, E.; Navickas, V.; Kontautiene, R. Effect of macroeconomic business environment on the development of corporate social responsibility in Baltic Countries and Slovakia. Oeconomia Copernic. 2018, 9 , 477-492. [CrossRef]

32. Grenčíková, A.; Bilan, Y.; Samusevych, Y.; Vysochyna, A. Drivers and Inhibitors of Entrepreneurship Development in Central and Eastern European Countries. In Proceedings of the 33rd International Business Information Management Association Conference, IBIMA 2019: Education Excellence and Innovation Management through Vision, Granada, Spain, 10-11 April 2019; Volume 2019, pp. 2536-2547.

33. Bilan, Y.; Lyeonov, S.; Vasylieva, T. and Samusevych, Y. Does tax competition for capital define entrepreneurship trends in Eastern Europe? Online J. Model. New Eur. 2018, 27, 34-66. [CrossRef]

34. Bilan, Y.; Vasilyeva, T.; Lyeonov, S.; Bagmet, K. Institutional complementarity for social and economic development. Bus. Theory Pract. 2019, 20, 103-115. [CrossRef]

35. Bilan, Y.; Raišienè, A.G.; Vasilyeva, T.; Lyulyov, O.; Pimonenko, T. Public Governance efficiency and macroeconomic stability: Examining convergence of social and political determinants. Public Policy Adm. 2019, 18, 241-255.

36. Bilan, Y.; Vasilyeva, T.; Lyulyov, O.; Pimonenko, T. EU vector of Ukraine development: Linking between macroeconomic stability and social progress. Int. J. Bus. Soc. 2019, 20, 433-450.

37. Lyulyov, O.; Pimonenko, T.; Stoyanets, N.; Letunovska, N. Sustainable development of agricultural sector: Democratic profile impact among developing countries. Res. World Econ. 2019, 10, 97-105. [CrossRef]

38. Akhmadeev, R.; Redkin, A.; Glubokova, N.; Bykanova, O.; Malakhova, L.; Rogov, A. Agro-industrial cluster: Supporting the food security of the developing market economy. Entrep. Sustain. Issues 2019, 7, 1149-1170. [CrossRef]

39. Bhandari, M.P. Sustainable Development: Is This Paradigm The Remedy of All Challenges? Does Its Goals Capture The Essence of Real Development and Sustainability? With Reference to Discourses, Creativeness, Boundaries and Institutional Architecture. Socioecon. Chall. 2019, 3, 97-128. [CrossRef]

40. Bello, H.S.; Galadima, I.S.; Jibrin, A.-M.A. Appraisal of the Salam Islamic Mode of Financing Agribusiness and Agriculture among Rural Farmers in Bauchi State of Nigeria. Socioecon. Chall. 2018, 2, 56-62. [CrossRef]

41. Sokolenko, L.F.; Tiutiunyk, I.V.; Leus, D.V. Ecological and economic security assessment in the system of regional environmental management: A case study of Ukraine. Int. J. Ecol. Dev. 2017, 32, 27-35.

42. Lizińska, W.; Marks-Bielska, R.; Babuchowska, K. Intervention on the agricultural land market in relation to the end of the transitional period for purchasing agricultural land by foreigners. Equilib. Q. J. Econ. Econ. Policy 2017, 12, 171-183. [CrossRef]

43. Vacca, A.; Onishi, H. Transparency and privacy in environmental matters. Int. J. Econ. Policy Emerg. Econ. 2018, 11, 333-343. [CrossRef]

44. Kostyuchenko, N.; Petrushenko, Y.; Smolennikov, D.; Danko, Y. Community-based approach to local development as a basis for sustainable agriculture: Experience from Ukraine. Int. J. Agric. Resour. Gov. Ecol. 2015, 11, 178-189. [CrossRef]

45. Popp, J.; Oláh, J.; Kiss, A.; Lakner, Z. Food security perspectives in Sub-Saharan Africa. Amfiteatru Econ. 2019, 21, 361-376. [CrossRef]

46. Vasylyeva, T.A.; Pryymenko, S.A. Environmental economic assessment of energy resources in the context of Ukraine's energy security. Actual Probl. Econ. 2014, 160, 252-260.

47. Mekhum, W. Sustainable development facets: Role of renewable energy production, consumption and research and development expenditure. J. Secur. Sustain. Issues 2020, 9, 252-263. [CrossRef]

48. Lu, Z.; Gozgor, G.; Lau, C.K.M.; Paramati, S.R. The dynamic impacts of renewable energy and tourism investments on international tourism: Evidence from the G20 countries. J. Bus. Econ. Manag. 2019, 20, 1102-1120. [CrossRef] 
49. Androniceanu, A.; Popescu, C.R. An Inclusive Model for an Effective Development of the Renewable Energies Public Sector. Adm. Manag. Public 2017, 28, 81-96.

50. Lyeonov, S.; Pimonenko, T.; Bilan, Y.; Štreimikienè, D.; Mentel, G. Assessment of Green Investments' Impact on Sustainable Development: Linking Gross Domestic Product Per Capita, Greenhouse Gas Emissions and Renewable Energy. Energies 2019, 12, 3891. [CrossRef]

51. Abdimomynova, I.; Kolpak, E.; Doskaliyeva, B.; Stepanova, D.; Prasolov, V. Agricultural Diversification in Low- And Middle-Income Countries: Impact on Food Security. Montenegrin J. Econ. 2019, 15, 167-178. [CrossRef]

52. Mentel, G.; Vasilyeva, T.; Samusevych, Y.; Pryymenko, S. Regional differentiation of electricity prices: Social-equitable approach. Int. J. Environ. Technol. Manag. 2018, 21, 354-372. [CrossRef]

53. Aitkazina, M.A.; Nurmaganbet, E.; Syrlybekkyzy, S.; Koibakova, S.; Zhidebayeva, A.E.; Aubakirov, M.Z. Threats to sustainable development due to increase of greenhouse gas emissions in a key sector. J. Secur. Sustain. Issues 2019, 9, 227-240. [CrossRef]

54. Sibanda, M.; Ndlela, H. The link between carbon emissions, agricultural output and industrial output: Evidence from South Africa. J. Bus. Econ. Manag. 2020, 21, 301-316. [CrossRef]

55. Dkhili, H.; Dhiab, L.B. Management of Environmental Performance and Impact of the Carbon Dioxide Emissions $\left(\mathrm{CO}_{2}\right)$ on the Economic Growth in the GCC Countries. Mark. Manag. Innov. 2019, 4, 252-268. [CrossRef]

56. Mačaitytè, I.; Virbašiūtè, G. Volkswagen Emission Scandal and Corporate Social Responsibility-A Case Study. Bus. Ethics Leadersh. 2018, 2, 6-13. [CrossRef]

57. Odermatt, C.C. Clean coal project: Carbon certificate pricing. Int. J. Trade Glob. Mark. 2018, 11, 149-159. [CrossRef]

58. Vasylieva, N. Ukrainian Agricultural Contribution to the World Food Security: Economic Problems and Prospects. Montenegrin J. Econ. 2018, 14, 215-224. [CrossRef]

59. Aliyas, I.M.; Ismail, E.Y.; Alhadeedy, M.A.H. Evaluation of Applications of Sustainable Agricultural Development in Iraq. Socioecon. Chall. 2018, 2, 75-80. [CrossRef]

60. Bilan, Y.; Lyeonov, S.; Stoyanets, N.; Vysochyna, A. The impact of environmental determinants of sustainable agriculture on country food security. Int. J. Environ. Technol. Manag. 2018, 21, 289-305. [CrossRef]

61. The World Bank DataBank. Available online: http://databank.worldbank.org/data/home.aspx (accessed on 18 January 2020).

62. UNEP. Environmental Data Explorer; UNEP: Geneva, Switzerland, 2020; Available online: http://geodata.grid. unep.ch/results.php (accessed on 18 January 2020).

63. FAOSTAT. Available online: http://fao.org/faostat/en/ (accessed on 18 January 2020).

64. Beiragh, R.G.; Alizadeh, R.; Kaleibari, S.S.; Cavallaro, F.; Zolfani, S.H.; Bausys, R.; Mardani, A. An integrated multi-criteria decision-making model for sustainability performance assessment for insurance companies. Sustainability 2020, 12, 789. [CrossRef]

65. Pesaran, M.H.; Shin, Y.; Smith, R.P. Pooled mean group estimation of dynamic heterogeneous panels. J. Am. Stat. Assoc. 1999, 94, 621-634. [CrossRef]

66. Blackburne, E.F.; Frank, M.W. Estimation of nonstationary heterogeneous panels. Stata J. 2007, 7, 197-208. [CrossRef]

67. Summary for Policymakers. Climate Change 2014: Mitigation of Climate Change. Contribution of Working Group III to the Fifth Assessment Report of the Intergovernmental Panel on Climate Change; Edenhofer, O., Pichs-Madruga, R., Sokona, Y., Farahani, E., Kadner, S., Seyboth, K., Adler, A., Baum, I., Brunner, S., Eickemeier, P., et al., Eds.; Cambridge University Press: Cambridge, UK; New York, NY, USA, 2014; Available online: https://www.ipcc.ch/site/assets/uploads/2018/02/ipcc_wg3_ar5_full.pdf (accessed on 18 January 2020).

68. Sipos, G.; Urbányi, B.; Vasa, L.; Kriszt, B. Application of by-products of bioethanol production in feeding, environmental and feeding safety concerns of utilization. Cereal Res. Commun. 2007, 35, 1065-1068. [CrossRef]

69. Mesterházy, A.; Oláh, J.; Popp, J. Losses in the grain supply chain: Causes and solutions. Sustainability 2020, 12, 2342. [CrossRef]

70. Impacts of Bioenergy on Food Security-Guidance for Assessment and Response at National and Project Levels. Available online: http://www.fao.org/3/i2599e/i2599e00.pdf (accessed on 18 January 2020).

71. Sola, P.; Ochieng, C.; Yila, J.; Iiyama, M. Links between energy access and food security in sub Saharan Africa: An exploratory review. Food Secur. 2016, 8, 635-642. [CrossRef] 
72. Energy-Smart Food at FAO: An Overview. Available online: http://www.fao.org/3/an913e/an913e.pdf (accessed on 18 January 2020).

73. Wambua, B.N.; Omoke, K.J.; Telesia, M.M. Effects of Socio-Economic Factors on Food Security Situation in Kenyan Dry lands Ecosystem. Asian J. Agric. Food Sci. 2014, 2, 52-59.

74. Mbuthia, K.W.; Kioli, F.N.; Wanjala, K.B. Environmental Determinants to Household Food Security in Kyangwithya West Location of Kitui County. J. Food Secur. 2017, 5, 129-133. [CrossRef]

75. IRENA. Renewable Energy in the Water, Energy \& Food Nexus. Abu Dhabi, UAE, 2015. Available online: https://www.irena.org/documentdownloads/publications/irena_water_energy_food_nexus_2015.pdf (accessed on 18 January 2020).

(C) 2020 by the authors. Licensee MDPI, Basel, Switzerland. This article is an open access article distributed under the terms and conditions of the Creative Commons Attribution (CC BY) license (http://creativecommons.org/licenses/by/4.0/). 


\title{
Review
}

\section{The Challenge of Feeding the World}

\author{
Dániel Fróna ${ }^{1,2, *}$, János Szenderák ${ }^{1,2}$ and Mónika Harangi-Rákos ${ }^{2}$ \\ 1 Karoly Ihrig Doctoral School of Management and Business, University of Debrecen, \\ 4032 Debrecen, Hungary; szenderak.janos@econ.unideb.hu \\ 2 Institute of Sectoral Economics and Methodology, University of Debrecen, 4032 Debrecen, Hungary; \\ rakos.monika@econ.unideb.hu \\ * Correspondence: frona.daniel@econ.unideb.hu
}

Received: 12 September 2019; Accepted: 17 October 2019; Published: 20 October 2019

\begin{abstract}
The aim of the present research is to provide a comprehensive review about the current challenges related to food security and hidden hunger. Issues are presented according to major factors, such as growing population, changing dietary habits, water efficiency, climate change and volatile food prices. These factors were compiled from reports of major international organizations and from relevant scientific articles on the subject. Collecting the results and presenting them in an accessible manner may provide new insight for interested parties. Accessibility of data is extremely important, since food security and its drivers form a closely interconnected but extremely complex network, which requires coordinated problem solving to resolve issues. According to the results, the demand for growing agricultural products has been partly met by increasing cultivated land in recent decades. At the same time, there is serious competition for existing agricultural areas, which further limits the extension of agricultural land in addition to the natural constraints of land availability. Agricultural production needs to expand faster than population growth without further damage to the environment. The driving force behind development is sustainable intensive farming, which means the more effective utilization of agricultural land and water resources. Current global trends in food consumption are unsustainable, analyzed in terms of either public health, environmental impacts or socio-economic costs. The growing population should strive for sustainable food consumption, as social, environmental and health impacts are very important in this respect as well. To this end, the benefits of consuming foods that are less harmful to the environment during production are also to be emphasized in the scope of consumption policy and education related to nutrition as opposed to other food types, the production of which causes a major demand for raw materials.
\end{abstract}

Keywords: nutrition; agriculture; food security; hidden hunger

\section{Introduction}

Currently, one of the most important challenges to achieve food security is the intensification of global food production. Most surveys and research efforts in agriculture focus on crop production. However, these analyses do not take into account the instability of yield over time or the variability and reliability of cereal production over the years [1]. As the global population continues to grow, agricultural production must also keep pace with it. Over the upcoming 40 years, agricultural emissions will increase by approximately $60 \%$ so that humanity can be supplied with food in appropriate quantity and quality. Various studies predict strong population growth within 30 years [2]. According to Röös et al. (2017) that number will be approximately 9-11 billion by 2050 [3] but the number is disproportionate in terms of territorial distribution as it is mostly based on urbanized environments [4]. Concerns about food production are not unfounded. Scientific and technological innovations beat Malthus' predictions in 1798 over the long run and increasing food production has met with the increasing food demand of the growing population. To continue to prove Malthus wrong in the future 
will require serious efforts, especially in terms of agricultural livestock production [5]. If current global processes continue and population growth tendencies remain unchanged, another 2.4 billion people will live in developing countries by 2050 (in South Asia and Sub-Saharan Africa, the population is expected to grow steadily). The size of urbanized areas is expected to increase threefold between 2000 and 2030 [6]. In these regions, agriculture is of outstanding national economic importance. In total, $75 \%$ of the world's poorest people live in rural areas, where agriculture is their most important foundation of subsistence [7]. Nevertheless, on average, over $20 \%$ of the population living in rural areas is suffering from food supply security problems [8]. Satisfying the demand requires increased productivity, structural changes in the livestock sector and the need to increase animal products [9]. According to forecasts, the average daily intake per capita is projected to exceed 3000 kcal globally by 2050 to reach $3500 \mathrm{kcal}$ in developed countries and to exceed $2500 \mathrm{kcal}$ even in the poorest sub-Saharan areas [10].

The demand for food, feed and crops with high fiber content is constantly increasing. So, there is increasing pressure on the already "impoverished" arable land and freshwater resources. The size and proportion of land used to produce food and feed depend largely on the evolution of global eating habits and the achievable average yields. The production of raw materials for the Western diet (involving high meat, dairy and egg consumption), which is becoming more widespread in the world, poses serious environmental challenges [11]. In addition to the competition between food and feed production, the increasing utilization of biomass also has a significant impact on land use and water management. The global food sector is heavily dependent on fossil fuels. Therefore, the volatility of energy markets might have a significant direct impact on food prices and an indirect impact on the security of food supply [7].

The issues presented above have been under intensive research for several decades, surrounded by disputes in many cases. Different drives of food supply and security form a complex network, with strongly interconnected factors. The complexity of this network poses a major challenge for interested parties and requires close cooperation between parties to resolve the issues. Despite the overwhelming scientific results, some of the related areas are discussed based on emotion and by taking a subjective approach. Synthesizing scientific results and presenting them in an accessible manner may provide novel insight for related parties. This research is a comprehensive review about these issues and the possible solutions.

\section{Materials and Methods}

The overall objective of this paper is to provide comprehensive research about the topic, with the processing of international and relevant literature in a literature study. Food security, nutrition and livelihood security is connected at the global and national level as well. Thereby, they are affected with the risk of so-called "shocks" such as climate disasters (drought, flood, etc.), human conflict (such as war, radical protests, etc.), pests and diseases (such as invasive species, etc.). Multi-sectoral cooperation is essential because most of the studies have shown that only a few countries have achieved fast economic growth without preceding agricultural growth. The development of food production systems is based on agricultural diversification, the conservation of water sources and efficient land usage while biodiversity is being preserved.

Qualitative research is suitable for exploring results and situations from previous relevant research and comparing with our research. However, methodological examination regarding the data analysis process is limited, but there are no systematic rules for analyzing qualitative data. Of course, there must be a logical structure or a framework behind the analysis. Computer-assisted search engines make qualitative data analysis more efficient and faster. Qualitative research often provides results, insights and concepts rather than data analysis methods to assess hypotheses or theories. The economic impact of food security is analyzed by various, relevant studies, but there is a close relationship between the environmental and social effects (like water and soil management, climate change, energy security). In addition, upon preparing the study a combination of the following terms was applied during the 
search for relevant studies: food security, agriculture, population growth, food and environmental safety, food demand, yield trends, change in land use, biofuels, sustainability requirements, and mitigation of climate change. These relevant studies were mostly analyzed from Google Scholar, AgEconSearch, EconBiz.de and Scopus. The literature review is based on recent, relevant studies between 2005 and 2019. In every case, the latest database of the World Bank [12] and Food and Agriculture Organization of the United Nations (FAO) [13] was analyzed during the creation of this study. In some cases, the databases have been merged, e.g., for the exchange of currencies, the harmonization of units of measurement, the frequency of communication. These circumstances were harmonized with each other, so that there was no need to "beautify" the database. Based on these databases, we covered some of the major related results to gain insight into the complexity of these processes. Graphic representations can help readers to better understand the results. Data from the previously mentioned databases were analyzed by $\mathrm{R}$ Studio. This program supports the graphic appearance of the analyzed data. Comparing the results is difficult, since most of the results can be viewed as crude approximations of the future developments. We rather focus on the trends related to food security.

\section{Results and Discussion}

\subsection{Land Use}

In recent decades, the demand for growing agricultural products has been partly met by increasing cultivated land [14]. However, in the future, the efficiency of agricultural production and specific yields must be increased, since there is serious competition for existing agricultural areas. Various relevant studies outline an increasingly gloomy prospect, namely that increasing yields will not be able to meet the demands for raw materials [15-17]. Nowadays, the increase in agricultural performance is mainly due to the cultivation of new areas, which is hardly sustainable in the long term. Consequently, new areas must be incorporated into agricultural production. Agricultural production needs to expand faster than population growth and this objective needs to be achieved in a sustainable way without further damage to the environment. The driving force behind development is sustainable intensive farming, which means the even more effective utilization of agricultural land and water resources [18].

Urbanization takes away an increasing amount of agricultural land and puts pressure on current land use and biodiversity as well [19]. According to estimations, the growing food demand will require approximately $320-850$ million hectares of agricultural land additionally by 2050 . The demand for additional agricultural land is limited by the changes in future dietary habits, which will mainly be influenced by socio-economic developments in developing countries. Depending on these changes, consumption will be shifted towards food sources of animal origin by 2050 due to improving welfare.

Moreover, this will cause a major change in land use as well, since the demand for feed crops will increase [20]. In addition, future yields based partly on the introduction of new plant varieties and improved agronomic practices will determine how much arable land will be needed. The requirement to reduce greenhouse gas emissions originating from agriculture will inevitably limit further land allocations [21]. At the same time, it should also be taken into account that the reduction of greenhouse gas emissions in agriculture depends largely on the attitude of producers as they are the ones who are directly affected by the effects of climate change. Farmers who believe in climate change and its anthropogenic or man-made nature are much more open to reducing greenhouse gas emissions but, at the same time, farmers are often more easily able to adapt to changing circumstances than to reduce emissions of harmful substances [22].

\subsection{Population}

It is beyond dispute that population growth is among the main drivers of global changes (notice in Figure 1). In approximately 10,000 B.C., agriculture began to develop with a global population of approximately 2.4 million people [23]. At the beginning of our chronology, Earth's population was 
188 million. As a result of the industrial revolution and the parallel development of health care and medicine, a major change occurred. By the end of the 1800s, the global population reached or already exceeded one billion people [24]. Currently, China alone has a population of 1.4 billion people [25]. The next major period was the 1930s when global population exceeded 2 billion people (when maize hybrids began to spread) (Figure 1). Due to the achievements of the Green Revolution, the global population doubled to over 3 billion (1960). It has been established that the global population grew from 1.65 billion to 6 billion during the 20th century. In 1970, there were nearly half as many people in the world as today [26]. By the middle of the 20th century, annual global population growth rose to $2.1 \%(1962)$, which is the highest annual growth rate in history. Nowadays, the growth rate has fallen to $1.2 \%$, which is less than 80 million people annually. According to forecasts, the annual growth rate will decline to $0.1 \%$ by 2100 [27].

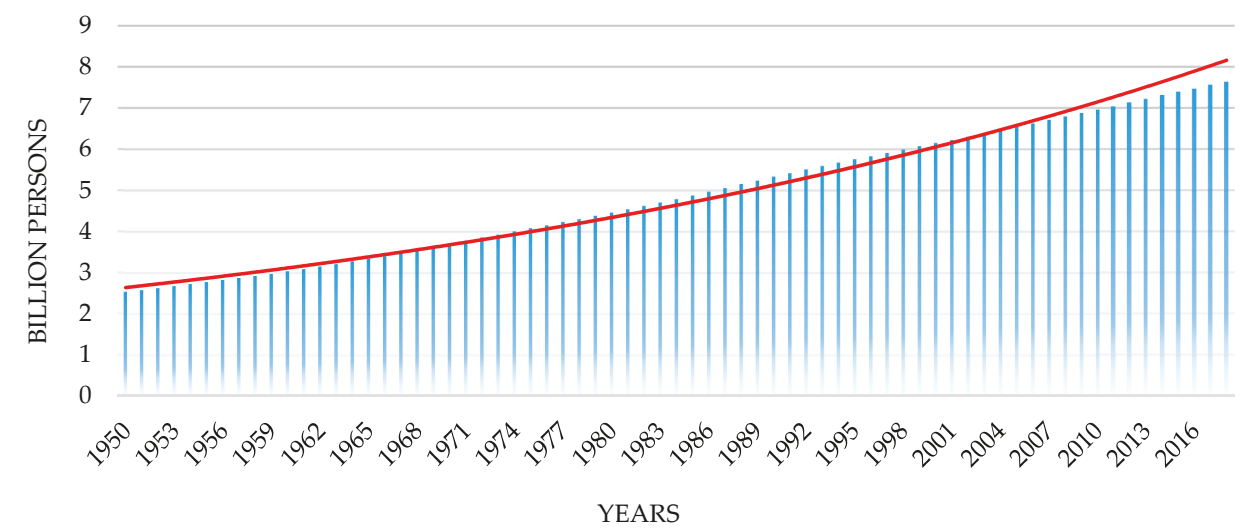

Figure 1. Global population growth. (Source: Own calculation and editing based on the database of FAO, 2019) [13].

Population growth in itself does not completely explain the changes in food consumption. While the volume of food consumption is dependent on the size of the population, quality of the consumed food is dependent on the average household income. According to Figure 2, there is no apparent connection between the (log of the) population and the (log of) GDP per capita, which means that independently from the population of the given countries, the GDP per capita may vary freely. At the same time, a higher GDP is more likely to be associated with a low share of agricultural added value. At the bottom of the graph, African countries possess a very high agricultural share in the GDP, while Europe at the top of the graph is very much the opposite with a high GDP per capita and a low share of agriculture (Figure 2). 


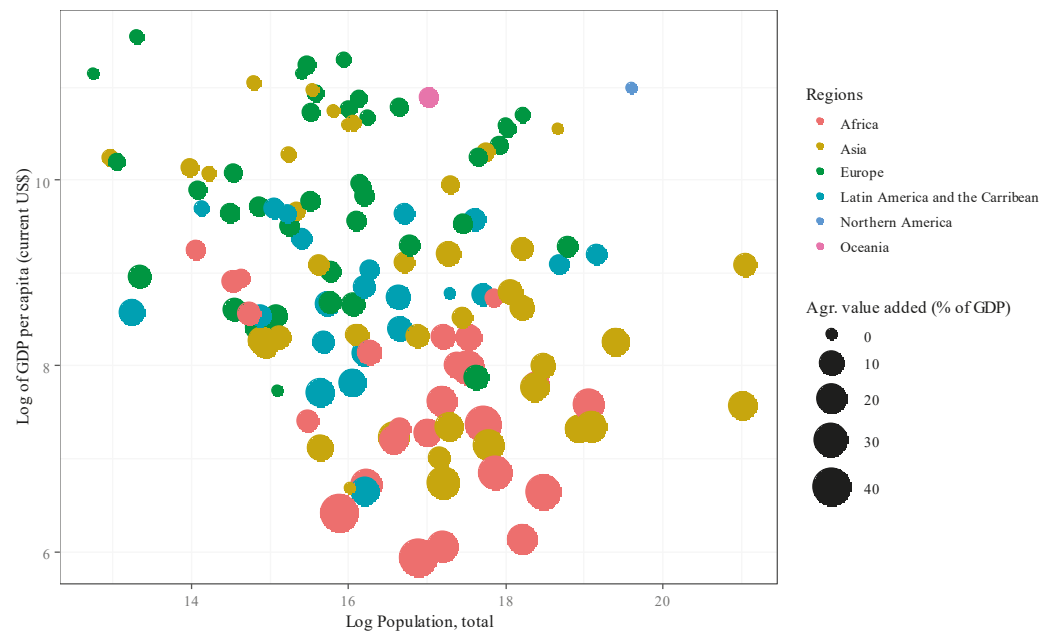

Figure 2. The connection among the population-GDP per capita and agriculture, 2017a. (Source: Own calculation and editing based on the database of the World Bank, 2019) [12].

Figure 3 shows the connection between the share of agriculture (as value added in \% of GDP) and the GDP per capita. GDP per capita is measured in current US\$, plotted in logarithmic form. As the GDP per capita increases in a given country of the world, the share of agriculture decreases quickly. Generally, African countries (red color) have the highest share of agriculture in GDP among the regions, with over $30 \%$ or even more in some cases. However, at the same time, the value of GDP per capita is very moderate. Asian and African countries have a relatively low GDP per capita but high share of agriculture in GDP. The values of Asian countries are extremely diverse. At the same time, European and North American countries typically have a high GDP per capita, while the share of agriculture is only a few percent. The share of agriculture is much lower in Latin America, Oceania, Northern America and especially in Europe, mostly under 5\% of the GDP. At the same time, GDP per capita is the highest among the countries. The graph indicates that African and Asian countries are still very much dependent on agriculture, as they take a high share of the GDP (denoted by red and orange).

In Figure 4, a similar methodology-based editing can be noticed. It deals with the connections between energy consumption, agriculture and the GDP per capita. With these elements, the latest database is from 2013. It also indicates the regions with different colors and the GDP per capita value in US dollars. The " $\mathrm{X}$ " axis represents the energy usage (in $\mathrm{kg}$ of oil equivalent per capita) and the " $\mathrm{Y}$ " axis represents the share of agriculture in the GDP. It can be read that energy use per capita is very low in the case of Africa-the value is well under $2500 \mathrm{~kg}$ of oil equivalent per capita. A correlation also can be discovered between the agricultural share in the GDP and energy usage. In regions, where the share of agriculture in GDP is high (over $20 \%$ ), there is a low value energy use per capita (under $2500 \mathrm{~kg}$ of oil equivalent per capita). In general, as a country became more industrialized, energy demand increased rapidly and, at the same time, the share of agriculture in the GDP quickly took a downturn. It can be concluded that countries with a high consumption of energy have much higher living standards in terms of the GDP per capita compared to countries with low energy consumption.

It is also worth noticing that the relationship is not linear. Below the $2500 \mathrm{~kg}$ of oil equivalent per capita consumption, a small increase in the energy use comes with a rapid decrease in agricultural share in the GDP. Above this level, no further change is expected. According to the regional distribution, Africa shows a lower level of energy consumption and the share of Asia varies between the lowest levels and the highest levels of oil consumption. 


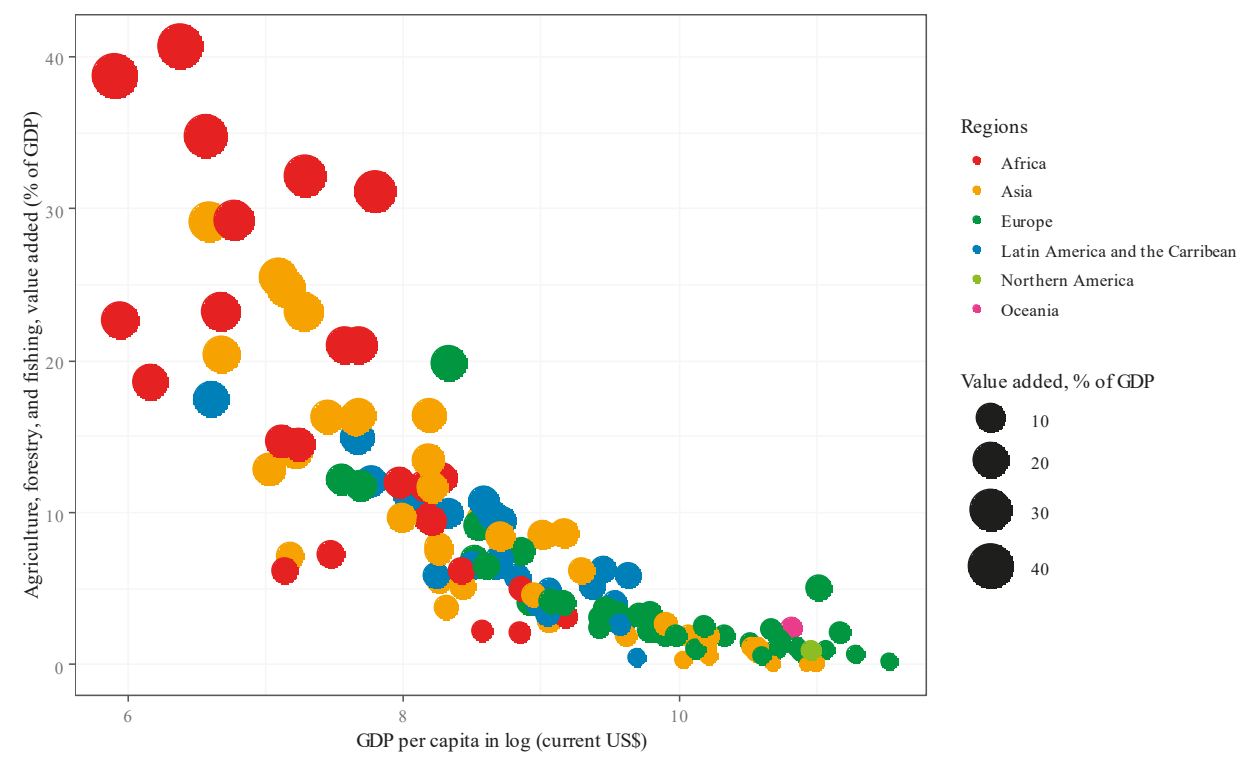

Figure 3. The relationship between GDP per capita and the share of agriculture in GDP, 2016. (Source: Own calculation and editing based on the database of the World Bank, 2019) [12].

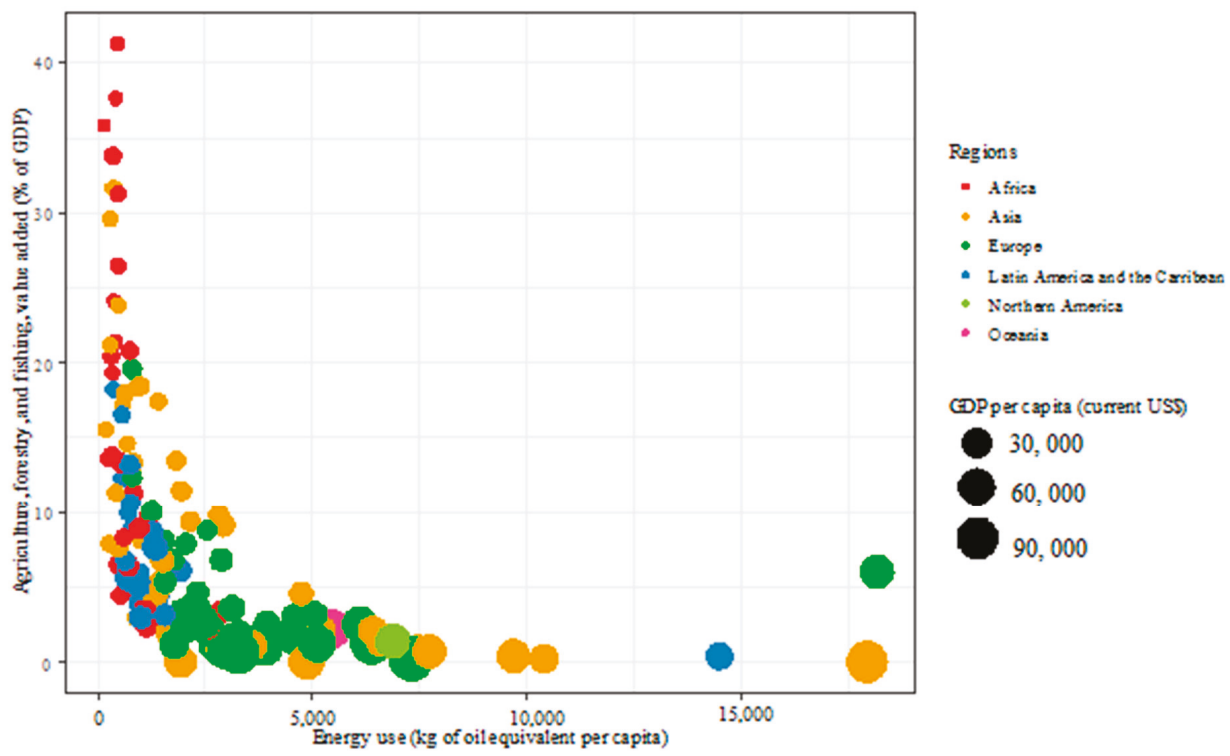

Figure 4. The main connections between energy consumption, agriculture and the GDP per capita, 2013. (Source: Own calculation and editing based on the database of the World Bank, 2019) [12].

\subsection{Crop Biology}

Crop production and harvest research have traditionally been limited to studies on the physiology and genetics of plants, the creation of new plant varieties, the development of new agricultural chemicals and the development of better agronomic methods [28]. Such research is necessary and 
there is an increasing number of global initiatives, which are aimed at the achievement of higher cereal yields [29]. Similarly, reducing the yield gap is also a keen research topic and objective, since it is becoming more and more justifiable for many crops to increase yields. Genetic enhancements are likely to be the potential solutions for achieving maximum yields for plants of key importance. There is considerable potential for improvement in yields and flexibility in the so-called "orphan crops". These crops have not been genetically modified yet and they are not traded on an international level. Consequently, less attention is focused on them in terms of their agricultural utilization. As they receive less research attention, breeding technology of "orphan crops" is lagging behind modern technology (e.g., millet, cowpea, manioc, etc.) [30]. On the other hand, agricultural research is increasingly driven by problems of a wider scope, such as the expected decline in yields due to climate change and severe weather events [31]. In addition to problems elicited by weather, the focus of research is on the emission of greenhouse gases and the pollution of water associated with the production of nitrogen-based fertilizers [32-34].

Similarly, research on pests and diseases is important as they are also major risk factors in the case of yield differentials and, due to the effects of climate change and efforts to conserve biodiversity, they are considered as urgent factors [35]. Due to the concerns about soil degradation discussed above, all agricultural practices related to conservation should be applied for the sake of yield improvements, such as tillage and other measures such as the conservation of crop residues and the application of crop rotations [36]. In order for agriculture to meet the emerging challenges it faces, new scientific discoveries should be adapted into practice as soon as possible. In addition, closer cooperation between farmers and scientists is required to integrate new developments appropriately into developments that complement agricultural practices [37]. Nevertheless, the use of genetically modified plants still sets off contradictions among researchers. The debate is mainly present between representatives of natural science and social science; however, it must be resolved in order for the reasons of aversions towards technologies to become understood [38]. Especially, as the latest technological advancements, for example, the application of genome editing in agriculture-and indirectly in food production-might exceed the significance of current GMO crop production [39]. GMO crops can play a radically different role in certain markets: while they have been present in the US since the mid-1990s [40], their distribution in other countries is strictly prohibited.

\subsection{Reasons of Changing Eating Habits}

Consumption patterns are constantly shifting towards products of animal origin and dairy products that contain higher value added, which results in the increasing demand for the production of feed crops. This process is already typical as, between 1960 and 2010, global arable land per capita decreased from 0.45 to 0.25 hectares and by 2050, it is expected to shrink to less than 0.20 hectares [41]. Approximately $66 \%$ of agricultural land is currently used by livestock farming in the European Union as well. This ratio is $40 \%$ on a global scale and is expected to rise further by 2050 [41]. According to the data above, dietary change will have a more prominent impact on land use than population growth. The problems mentioned above could be addressed by putting emphasis on wider cultural changes, which focuses on the necessity for coordinated actions of government and political activities, industry, communities, family and society. Recognizing the social needs and attitudes of consumer behavior, a number of research studies analyzing dietary changes are published, which increasingly reveal the routine nature of consumer habits and the institutions and infrastructure supporting them [42-44]. Initiatives aimed at the promotion of healthier and more sustainable patterns of consumption should address the social and technical systems that are able to respond to changing consumer habits. According to certain research activities, the decision-making process for choosing a diet might force consumers to face various ethical challenges [45]. For example, consumer preferences for organic food (with respect to health or sustainability) or the need for locally produced food (minimizing the so-called "food miles"). Obviously, these preferences greatly influence the decision-making process of consumers 
in relation to the choice of diet [42]. In addition, it should be emphasized that the sustainability of the food supply could be significantly improved even by the reduction of food losses [46].

The growing population should strive for sustainable food consumption, as social, environmental and health impacts are very important in this respect as well. To this end, the benefits of consuming foods that are less harmful to the environment during production are also to be emphasized in the scope of consumption policy and education related to nutrition as opposed to other food types, the production of which causes a major raw material demand [47]. In several countries—at primary schools—lunch break is a basic place of the learning process, where students learn about hygiene, healthy eating habits and/or recycling waste. Acquiring knowledge about healthy eating and recycling waste is fundamental at a young age [48]. Current global trends in food consumption are unsustainable, analyzed in terms of either public health, environmental impacts or socio-economic costs [49]. On different geographic scales, there are clear correlations between the socio-economic situation and the intake of high-quality food and the resulting health outcomes. The change in production structure is caused by the increase in the number of people with higher incomes in low- and medium-income countries. Primarily, this induces a change in consumption habits through the increasing consumption of meat, fruit and vegetables compared to different kinds of cereals [50]. The fact that the seasonal consumption of fruit and vegetables completely disappears is a particularly interesting development. From this point of view, transportation can be a critical factor of environmental impact. Currently, a person eats an average of $42 \mathrm{~kg}$ of meat annually, which is expected to rise to $52 \mathrm{~kg}$ by 2050, and 1.5 billion new consumers will appear on the market [27]. The growing share of poultry meat among other kinds of meat should be mentioned here. Due to changing eating habits, more and more people consume chicken meat. It can be produced relatively quickly, it is relatively cheaper, and it is not prohibited by religions.

The focus of research is increasingly shifted towards the relationship between nutrition and food production, especially the problems caused by climate change, increasing population and urbanization. As an example, many studies on Africa have been published [51,52], which have pointed out that there is a need for intervention at a social level to modify nutrition habits and to avoid malnutrition. Areas that are different in terms of public health so far are likely to become even more diversified, as low-income countries in particular find it more difficult to adapt to the consequences of climate change, food shortages and water shortage, as well as to the associated socio-demographic changes and the resulting dietary modifications [53]. Subsequent research activities and their practical implementation should address the impact of dietary changes on the natural environment and the impact of environmental changes on all components of food safety [20].

The integrated approach of agri-food research draws attention to the impact of social and political conflicts on health and malnutrition. Changes occurring in the environment might aggravate malnutrition by limiting the ability to produce food products. Extreme weather events (for example drought and floods) might contribute to the volatile change in food prices, which in extreme cases might result in serious problems, in the form of riots or the further increase in the proportion of famine [54].

\subsection{Links between Nutrients and "Hidden Hunger"}

There is a detectable positive change in the reduction process of global famine. However, despite progress, the world is still far from a sustainable food safety system. Obesity is a phenomenon that exists nearly in parallel with famine and malnutrition. Nearly 800 million people are chronically underfed in terms of energy intake, while 2 billion people suffer from micronutrient deficit, but at the same time 1.9 billion people are overweight or obese [55,56].

People suffering from hidden hunger typically consume food items with high calorie but low nutrient content, which can easily lead to obesity (although not necessarily). This also proves that famine and obesity, as well as under- and overnutrition occur in parallel at a global scale. This means the inadequate consumption of sufficient vitamins, minerals and trace elements. Therefore, it is 
interesting that overnutrition (in calories) may be associated with malnutrition (micronutrient). It will be a great challenge for the future to produce food of not only sufficient quantity but quality as well. As a summary of the above, three phenomena appear as contradictions but parallel to each other: malnutrition, overnutrition, and hidden hunger. These three forms of nutritional problems are also referred to as the "triple burden" of malnutrition [57]. This triple effect contributes to the reduction of physical and cognitive human development, the loss of productivity, sensitivity to infectious and chronic diseases and aging [58].

Micronutrient-deficient nutrition is a global phenomenon that may affect certain social groups, such as those over the age of 65 even in the most advanced countries [60]. Reduction of the various forms of malnutrition requires better food policy and targeted nutrition-related interventions. In Africa and Asia, urban populations are growing at a high rate, which may lead to a further decrease in per capita nutrients (an average reduction of 36\% in Africa, 30\% in Asia) (Figure 5). A possible solution for slowing down the process might be nutrient reuse. In contrast, average per capita amount of nutrients in Europe will decrease by $10 \%$, but a steady decline in population numbers is also expected here [61]. Obviously, these analyses are limited by certain factors as they do not take into account, for example, the size of the city or changes that have occurred in terms of land use. By 2030, urban expansion will require an additional $2 \%$ of the available global land, but local effects might be more significant in the life of individual cities, affecting reuse opportunities and making adaptive decisions [8].

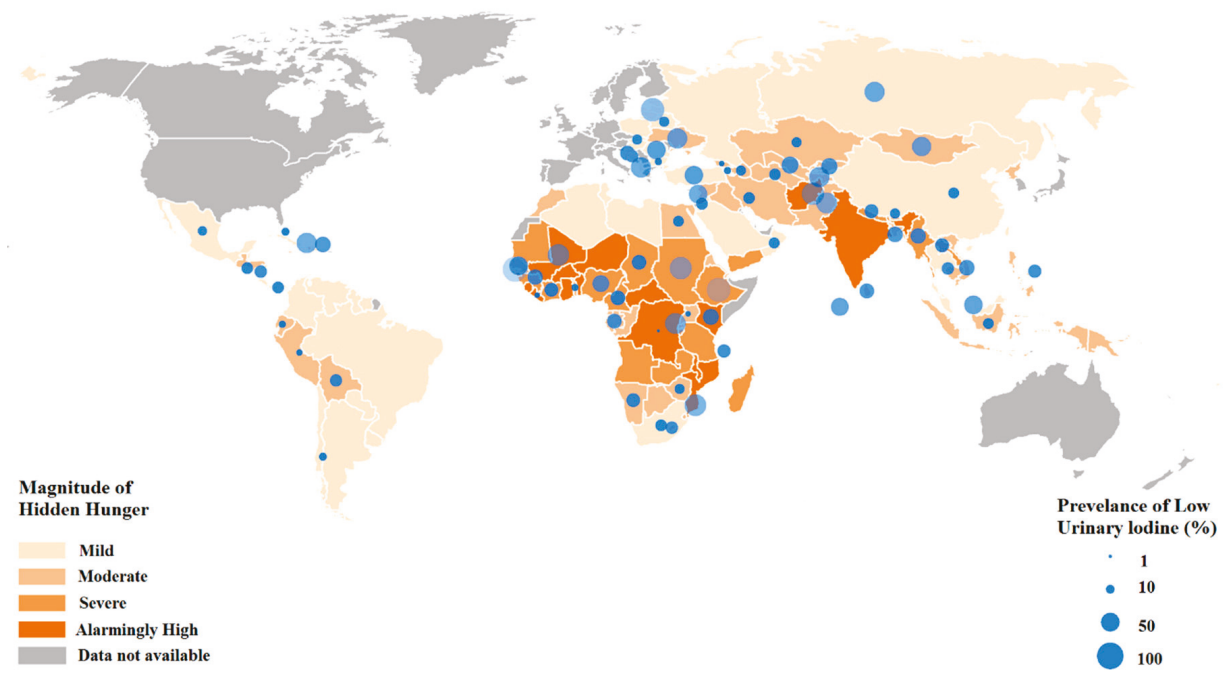

Figure 5. Map of hidden hunger. (Source: Muthayya et. al. (2013) [59]).

\subsection{Climate Change and Water}

According to estimations, climate change has already reduced global crop yields of maize and wheat by $3.8 \%$ and 5.5\% respectively and researchers are warning that further decline in productivity is expected as temperature changes exceed critical physiological thresholds [62]. The progressively extreme climate change increases production risk and puts an increasing burden on the subsistence of agricultural producers. Climate change also poses a threat to the food supply of both rural and urban populations. Extreme climatic events have a long-term negative impact, since exposure to risk and increasing uncertainty affect the introduction of effective economic innovations. Consequently, the number of low-risk but low-yield activities begins to increase [31]. Agricultural activity also contributes to warming the planet. Total carbon dioxide emissions from agriculture in 2010 were equal to 5.2-5.8 gigatons of $\mathrm{CO}_{2}$ equivalent annually, representing approximately $10 \%-12 \%$ of 
global anthropogenic emissions [63]. Agricultural categories with the highest level of emission are fermentation, manure, synthetic fertilizer and biomass combustion. Considering that there will be a need for further increases in agricultural production, the emission of harmful substances is also expected to increase. The main source of planned emission growth is the application of conventional agricultural techniques (as opposed to precision farming) that will result in the further, severe damage of the ecosystem, such as further water and soil pollution [64]. Some recent publications discuss the impact of climate change on yields, especially for the most important crops, such as wheat, maize, rice and soybean [65-69], which means that scientific processing of the topic is ongoing.

Currently, $97.5 \%$ of Earth's water resources are saltwater and only $2.5 \%$ is freshwater, $69 \%$ of which are glaciers and persistent snow, $30.7 \%$ groundwater, and $0.3 \%$ in the form of lakes and rivers [41]. There is some similarity between freshwater resources and land in terms of their availability. If we look at both factors on a global level, they are available in sufficient quantities, but the distribution is very uneven. This is also illustrated by the fact that there are huge differences between countries in the same regions, but even within countries. Demand for water is expected to increase by $100 \%$ by 2050, which can be attributed to population growth, urbanization and the effects of climate change [70]. As the urban population grows, household and industrial water consumption are expected to double. Climate change implies a greater chance of more extreme weather phenomena, because of which water consumption of crop production might increase considerably [70].

Humanity consumes the most water in the course of food production and global production of cereals. Due to increasing food production, water resources from the rivers and groundwater are primarily used for the irrigation of cultivated crops. Most irrigation systems usually provide more water to plants than they actually require [71]. Improving living standards, changing food preferences and the increasing demand for goods require a higher amount of water consumption. At the same time, more than 650 million people- especially south of the Sahara-have no access to drinking water of adequate quality. The current situation is further exasperated by the fact that 2.4 billion people do not have modern wastewater management [72]. The United Nations Organization puts special emphasis on the issue of sewage disposal.

This is also well illustrated by the fact that the 6th element of the Sustainable Development Goals is clean and sanitary water. Ensuring appropriate management and sustainable treatment of water resources is essential for our future.

Climate change is a global phenomenon, but developing countries are in greater danger. In addition, the problems posed by urbanization, increasing water shortage and technological backwardness are the most important challenges to be addressed. Rural areas should have access to the fundamental services of the 21st century, such as public utilities, health care, electrification, education, etc. This is important for the improvement in the living conditions of the population living here [63].

\subsection{China's Food Supply}

Inputs (fertilizer, water) and their impact on the environment are vital elements of food production (mostly cereal). According to surveys, the global center of nitrogen fertilizer utilization was in Western Europe and the US in the 1960s but was relocated to East Asia, especially to China by the beginning of the 21st century [73]. In the last century, China faced a number of food shortages. In the course of one of them, a quota system was introduced (1955-1993) followed by a land contract reform (1981) that was implemented. Total cereal production increased by $74 \%$, from 354 million tons in 1982 to 618 million tons by 2017, which exceeded the rate of population growth [74]. Currently, China feeds $20 \%$ of the global population on $7 \%$ of the total agricultural land. In order to maintain this performance, China has paid a high price. The use of chemical fertilizers has tripled in the last three decades. Excessive and inefficient use achieved $32 \%$ efficiency compared to a global average of $55 \%$. China's water supply is in a similar situation since, apart from low-efficiency utilization and poor-quality quantitative distribution across the country, it is also uneven. China's available water supply per person is only $2050 \mathrm{~m}^{3}$, which is $25 \%$ of the global average. In North China, where only a low amount of water is available, 
a large volume of underground water is used for agricultural purposes. Therefore, it is of utmost importance for China to proactively investigate how food security can be achieved through the balance of resource management, environmental protection and sustainable agricultural development [74-76]. In 2015, the one-child policy was abolished; families are now allowed to have a second child. However, many people choose not to have more children because they cannot afford the high costs of their upbringing. Thus, according to demographic estimations, the two-child policy will result in only 2-4 million additional people in China annually for the next 10 years. The accelerated growth of China in terms of urban population as compared to rural areas continues to affect food consumption [77]. In 2016, China's urbanization rate rose to $57 \%$ and it might increase to $65 \%$ by 2025 and to $80 \%$ by 2050. However, it should be noted that in the east (China, India), a significant part of the population is concentrated because it is often impossible to live outside these areas (e.g., deserts, high mountains, and jungles). In light of these statistical data, they need to find a solution for further safe and healthy food supply [78].

\subsection{Food Prices and Food Security}

Changes in food prices fundamentally affect the quantity and quality of food available to an individual. In developing countries, where a high proportion of household income is spent on food, changes in food prices are a critical factor. In these areas, relatively moderated price changes can also have a significant impact on food security. The past few decades have been marked by rising food prices and rising price volatility. These market events require the collective cooperation of the countries concerned in order to mitigate the adverse effects of price changes. Swinnen and Squicciarini (2012) drew attention to the contradictory messages being transmitted by the parties involved in the food safety debate. These messages do not always correctly convey the true effect of high or even low food prices [79].

While the food price boom dates back at least to the 1970s, rising food prices (in nominal terms) in 2007/08 renewed the attention of the policy makers and market analysts to the so-called "commodity boom" again. Not only the price levels, but the higher variability became a concern as well [80]. As Baffes and Haniotis (2016) noted, that the reversal of the downward trend in food prices seen until 2000 has already had consequences for food security in developing countries [81]. The main sources of the price boom between 2000 and 2007 was the increased commodity demand induced by the global economic growth, the dollar depreciation and the changes in the stock to use ratio, according to Timmer (2008) [82]. However, these sources provided an inadequate explanation for the sudden increase in the prices. Additional factors were the growing demand for biofuels (where food crops are the input materials, especially maize), unfavorable weather events, plant diseases and the changes in trade policy. In some cases, panic and hoarding and further speculation has some effect as well [80]. According to the United Nations Conference on Trade and Development (UNCTAD) (2011) study, agricultural prices are more vulnerable to fluctuations by their nature. These effects will require a more efficient risk distribution mechanism among the markets, which would strengthen the safety net related to food price changes. Increased price fluctuation has an adverse effect on developing countries, since there is a high share of rural households with low household income, that often rely heavily on self-produced agriculture commodity products [83].

Oil price changes (and in general, energy price changes) became a crucial factor as well. The effect of oil prices is twofold. Firstly, high oil prices would increase the demand for alternative energy sources, such as biofuel. These changes, in turn, will increase the demand for input materials, which can change the allocation between food, feed and fuel. Second, higher oil prices lead to higher production costs, which decreases the supply of food in the long run [84]. In general, the cost of energy is approximately 10 per cent of the agricultural production, according to the World Bank (2016) estimates, which means that agriculture and its related sectors are highly energy intensive. In developing countries, production technologies and transportation are inefficient. Thus, energy price changes can have serious effects. A significant number of studies have shown a stronger impact of energy prices on 
agricultural prices and a closer integration of the two markets [85-88]. These studies have found a stronger connection between the energy and the agricultural market after the global economic and financial crisis. Among the results, there was apparent support for possible non-linear effects, increased spillover mechanisms and long-term relations (cointegration). At the same time, the root of the price developments is the fundamental market mechanism, as supply and demand. As Timmer (2008) noted, the long-term question is whether supply can keep up with demand generated by rapid economic growth. While the possibility existed in recent decades and supply could keep up with demand, this time, it is compounded by the scarcity of high-quality, accessible agricultural area, stagnation in yields seen over decades, and rising costs of basic inputs. As research results are often lagging behind in this field, the only possibility is to increase yields until new agricultural technologies emerge. The most effective solution to high food prices is therefore to stimulate an increase in agricultural output. Combining the effect of climate change and water scarcity, the problem requires a quick and efficient solution.

In the wealthiest countries, the concentration of retail trade and the increasing complexity of food businesses, as well as the extended impact of supply chains, play a role of key importance. In poorer countries, many of the listed effects can be overcome. However, according to researchers, cooperation along the supply chain is less effective $[89,90]$. In addition to cooperation between chain members, traceability is also very important in modern agriculture. The implementation of technological innovations is essential in food supply chains from farm to plate [89].

Cooperation along the supply chain is particularly important in developed countries because food retail is highly concentrated and, in many countries, there are numerous companies with a very strong bargaining position with suppliers and they therefore often push down purchasing prices. Lower profit ratios and higher volumes from more limited suppliers encourage lower prices and increase the number of sales, creating a vicious circle of addiction [91].

Additional income generated by the rising prices of agricultural products and food, therefore, does not reach producers in most of the cases, who are consequently able to introduce production-related innovation only from fewer resources [92]. The share of supermarket-type stores in food retail has become increasingly significant on a global scale in recent decades. Companies dealing with food retail often employ suppliers to ensure a continuous supply of certain product types, which may further increase the exposure of producers in the supply chain [93].

\section{Conclusions}

Growing population and changing dietary habits, with the intensifying demand for food with higher value added in developing countries are expected to increase food demand by $60 \%$ by 2050 . In addition, unprecedented developments are taking place, especially in areas where the demand for fossil resources has traditionally been very low. Agricultural production can only be intensified with the increasing use of fertilizers. Thus, the efficiency of fertilizer usage needs to be improved. Almost all developed and developing countries have accepted the need to increase agricultural productivity and efficiency. The sustainable production of more food for human consumption requires technology that makes better application of limited resources, including land, water and fertilizer. Traditional agricultural production is not sustainable economically or environmentally. The question is whether the existing knowledge on agro-ecological practices is able to achieve the rate of yield that is required to feed the growing population. Without answering the question, a substantial investment is needed in research and innovation. In addition to food security, food stability is also important, and the most important issue here is predictability.

Food production requires a fundamental transformation in order to preserve the ecological conditions of the planet and to avoid the associated health risks. The key to the solution is so diverse that it is essential to integrate and renew the relevant branches of science. This includes, for example, molecular and taxonomic biology, food science and medicine, agronomy, ecology, earth science, computer science and nature biology. Long-term, interdisciplinary human health studies need to 
be further integrated in order to achieve a higher standard and compatibility of sustainable food production. Globally, sustainable development goals require an industrial and scientific revolution. Food production, affected human population growth and the global ecological challenges it generates, will play a crucial role in the future of the Earth.

Climate change and extreme negative weather conditions are key drivers of global famine and food insecurity. They have a negative impact on livelihood and all aspects of food security (accessibility, stability, etc.) and contribute to other malnutrition related to childcare and nutrition. Due to the growing energy and food demand, it has become evident that greenhouse gas emissions, especially carbon dioxide, have an impact on the global climate. There is a growing demand for suitable land, where food production, feed production, energy crops and urbanization are in competition. These problems are further exacerbated by the gradual change in soil productivity caused by climate change (erosion, water stress, increasing soil salinity, etc.). The health of the soil is also crucial during agricultural production because healthy crops can only be produced on soils in good conditions. Producing crops that meet the high criteria of healthy foods requires soil in good conditions. That means the farmers have to pay attention to the health status of the soil during agricultural production and plant seeds or use fertilizers which do not harm the soil. However, the change in indirect land use may also increase greenhouse gas emissions. Precision plant breeding is a good solution to increase crop production and yields. Farmers always have to pay attention to saving biodiversity. Increasing yields by starting agricultural production on new lands cannot be a solution anymore in order to save the available natural resources. This is due to the fact that crop production has shifted to previously unused land, which can lead to the transformation of forests and savannah. Such land use change will damage biodiversity and increase greenhouse gas emissions. The science of global climate change indicates that, as a result of the increasing level of greenhouse gases, the Earth as a whole has a general warming trend. While natural resources have an impact on greenhouse gas concentrations over time, global scientific consensus indicates that human resources for greenhouse gases also contribute to global climate change. The risk of food insecurity and malnutrition is greater today, especially in low-income regions, which are more exposed and sensitive to climate change.

Technological innovations may allow mankind to increase food production in a sustainable way to meet the reasonable needs. The use of smart devices including smartphones, other IT tools and different applications of precision and automatized agriculture can help farmers to increase the efficiency of agriculture. The spread of smart IT devices can help the spread of precision and automatized agriculture as well as more agriculture employees will have knowledge about these technological solutions. When professional agricultural users start to introduce new smart solutions in the operation of agricultural companies, they can count on the IT knowledge of their workforce; however, during the self-evaluation of employee knowledge, managers always have to pay attention to the Dunning-Kruger effect [94]. The above effect means that less educated workforce usually overestimates their knowledge-and this circumstance is totally typical in the case of IT knowledge in the agricultural sector [95]. Ultimately, the issue of food security applies to people as well as to finite resources. There is no simple or easy solution to sustainably feed nine billion people, especially with consumption habits becoming non-sustainable. Hopefully the scientific and technological innovation is going to help to defeat this challenge. Sustainable food production can only be achieved by reducing greenhouse gas emissions and reducing water usage. This growth must be achieved without further environmental damage. Sustainable intensification might be a way to ensure the necessary-and not overestimated-scale of production while mitigating environmental impacts. We must avoid further reducing our biodiversity for the easy profit of food production, not only because biodiversity provides numerous public goods that humankind relies on, but also because we have no right to deprive the future generation of the economic and cultural benefits. These challenges together represent the crucial problem that needs to be solved. To solve this crucial problem, we need a social revolution that breaks down the barriers between science and agriculture related to food production. The goal is not only to 
maximize productivity but also to optimize the results of production, environmental protection and social justice (fairness of food distribution) in a much more complex way.

According to the results, instead of the inclusion of additional agricultural area, further improved yields and food management will be necessary to provide sufficient amounts of additional food. This will require more efficient water and energy management as well as improvements in waste management. Due to the growing population and changing dietary habits, food supply (especially the animal protein-related consumption) is expected to increase the pressure on the environment. A higher share of plant-based consumption may help to reduce this pressure, but it is expected only in the developed areas with a relatively high GDP per capita. Climate change is the slowest changing component of the food supply, but its impact is felt globally. The right perception of climate change can have a serious impact on improving food security. Despite the overwhelming scientific evidence, there is often skepticism and emotional overtones in the debate surrounding climate change. However, effective solutions to problems require a united and cooperative approach. Coordinated restrictions on agricultural trade are essential in times of high and volatile food prices, which was often hampered by ad-hoc and unadvised trade restrictions in individual countries in the past. Higher food price volatility has become a feature of the liberalized agricultural market in the last decade. As price volatility cannot be reduced, the aim should be to spread and hedge the associated risks properly. Efficient future markets and different types of insurance could be useful tools to tackle these issues. Taking these factors into account is particularly important, since inadequate food supply is likely to lead to food-related riots and social unrest, which, in addition to their economic and social impact, have ethical and political implications as well.

Author Contributions: Conceptualization, D.F. and J.S.; Methodology, J.S and D.F.; Software, J.S.; Writing—original draft preparation, D.F.; J.S.; M.H.-R.; Writing—review and editing, D.F.; J.S.; M.H.-R.; Visualization, D.F; J.S..; Supervision, M.H.-R.

Funding: This work/publication is supported by the Debrecen Venture Catapult Program, EFOP-3.6.1-16-2016-00022 project. This project is co-financed by the European Union and the European Social Fund.

Conflicts of Interest: The authors declare no conflict of interest

\section{References}

1. Knapp, S.; van der Heijden, M.G.A. A global meta-analysis of yield stability in organic and conservation agriculture. Nat. Commun. 2018, 9, 3632. [CrossRef] [PubMed]

2. Hofstra, N.; Vermeulen, L.C. Impacts of population growth, urbanisation and sanitation changes on global human Cryptosporidium emissions to surface water. Int. J. Hyg. Environ. Health 2016, 219, 599-605. [CrossRef] [PubMed]

3. Röös, E.; Bajželj, B.; Smith, P.; Patel, M.; Little, D.; Garnett, T. Greedy or needy? Land use and climate impacts of food in 2050 under different livestock futures. Glob. Environ. Chang. 2017, 47, 1-12. [CrossRef]

4. Kummu, M.; De Moel, H.; Salvucci, G.; Viviroli, D.; Ward, P.J.; Varis, O. Over the hills and further away from coast: Global geospatial patterns of human and environment over the 20th-21st centuries. Environ. Res. Lett. 2016, 11, 034010. [CrossRef]

5. Smith, P. Malthus is still wrong: We can feed a world of 9-10 billion, but only by reducing food demand. Proc. Nutr. Soc. 2015, 74, 187-190. [CrossRef]

6. d'Amour, C.B.; Reitsma, F.; Baiocchi, G.; Barthel, S.; Güneralp, B.; Erb, K.-H.; Haberl, H.; Creutzig, F.; Seto, K.C. Future urban land expansion and implications for global croplands. Proc. Natl. Acad. Sci. USA 2017, 114, 8939-8944. [CrossRef]

7. Popp, J.; Lakner, Z.; Harangi-Rakos, M.; Fari, M. The effect of bioenergy expansion: Food, energy, and environment. Renew. Sustain. Energy Rev. 2014, 32, 559-578. [CrossRef]

8. Wheeler, T.; Von Braun, J. Climate change impacts on global food security. Science 2013, 341, 508-513. [CrossRef]

9. Riggs, P.K.; Fields, M.J.; Cross, H.R. Food and Nutrient Security for a Growing Population; Oxford University Press US: Oxford, MS, USA, 2018. 
10. Alexandratos, N.; Bruinsma, J. World Agriculture towards 2030/2050: The 2012 Revision; ESA Working Paper; FAO: Rome, Italy, 2012.

11. Westhoek, H.; Lesschen, J.P.; Rood, T.; Wagner, S.; De Marco, A.; Murphy-Bokern, D.; Leip, A.; van Grinsven, H.; Sutton, M.A.; Oenema, O. Food choices, health and environment: Effects of cutting Europe's meat and dairy intake. Glob. Environ. Chang. 2014, 26, 196-205. [CrossRef]

12. The World Bank Homepage. Available online: https://databank.worldbank.org/home.aspx (accessed on 22 January 2019).

13. Database of Food and Agriculture Organization of the United Nations. Available online: http://www.fao.org/ faostat/en/\#data (accessed on 18 January 2019).

14. Boserup, E. The Conditions of Agricultural Growth: The Economics of Agrarian Change under Population Pressure; Routledge: London, UK, 2017. [CrossRef]

15. Davis, K.F.; Gephart, J.A.; Emery, K.A.; Leach, A.M.; Galloway, J.N.; D'Odorico, P. Meeting future food demand with current agricultural resources. Glob. Environ. Chang. 2016, 39, 125-132. [CrossRef]

16. Crist, E.; Mora, C.; Engelman, R. The interaction of human population, food production, and biodiversity protection. Science 2017, 356, 260-264. [CrossRef] [PubMed]

17. McLaughlin, D.; Kinzelbach, W. Food security and sustainable resource management. Water Resour. Res. 2015, 51, 4966-4985. [CrossRef]

18. Ramankutty, N.; Mehrabi, Z.; Waha, K.; Jarvis, L.; Kremen, C.; Herrero, M.; Rieseberg, L.H. Trends in global agricultural land use: Implications for environmental health and food security. Annu. Rev. Plant Biol. 2018, 69, 789-815. [CrossRef] [PubMed]

19. Blum, W.E. Functions of soil for society and the environment. Rev. Environ. Sci. Bio/Technol. 2005, 4, 75-79. [CrossRef]

20. Tilman, D.; Clark, M. Global diets link environmental sustainability and human health. Nature 2014, 515, 518. [CrossRef]

21. Godfray, H. The challenge of feeding 9-10 billion people equitably and sustainably. J. Agric. Sci. 2014, 152, 2-8. [CrossRef]

22. Arbuckle, J.G., Jr.; Morton, L.W.; Hobbs, J. Understanding farmer perspectives on climate change adaptation and mitigation: The roles of trust in sources of climate information, climate change beliefs, and perceived risk. Environ. Behav. 2015, 47, 205-234. [CrossRef]

23. WORLDOMETERS. Current World Population. 2019. Available online: https://www.worldometers.info/ world-population/ (accessed on 7 January 2019).

24. Our World in Data. World Population over the Last 12,000 Years and UN Projection until 2100. 2018. Available online: https://ourworldindata.org/world-population-growth (accessed on 8 December 2018).

25. UN. World Population Prospects. 2019. Available online: https://population.un.org/wpp/Publications/Files/ WPP2019_Highlights.pdf (accessed on 8 June 2019).

26. WORLDOMETERS. Current World Population. 2018. Available online: https://www.worldometers.info/ world-population/world-population-by-year/ (accessed on 8 December 2018).

27. FAO. The Future of Food and Agriculture-Trends and Challenges. 2017. Available online: http://www.fao. org/3/a-i6583e.pdf (accessed on 8 December 2018).

28. Murchie, E.; Pinto, M.; Horton, P. Agriculture and the new challenges for photosynthesis research. New Phytol. 2009, 181, 532-552. [CrossRef]

29. Furbank, R.T.; Quick, W.P.; Sirault, X.R. Improving photosynthesis and yield potential in cereal crops by targeted genetic manipulation: Prospects, progress and challenges. Field Crop. Res. 2015, 182, 19-29. [CrossRef]

30. Foley, J.A.; Ramankutty, N.; Brauman, K.A.; Cassidy, E.S.; Gerber, J.S.; Johnston, M.; Mueller, N.D.; O'Connell, C.; Ray, D.K.; West, P.C.; et al. Solutions for a cultivated planet. Nature 2011, 478, 337. [CrossRef]

31. Lesk, C.; Rowhani, P.; Ramankutty, N. Influence of extreme weather disasters on global crop production. Nature 2016, 529, 84. [CrossRef] [PubMed]

32. Zhang, X.; Davidson, E.A.; Mauzerall, D.L.; Searchinger, T.D.; Dumas, P.; Shen, Y. Managing nitrogen for sustainable development. Nature 2015, 528, 51. [CrossRef] [PubMed]

33. Goucher, L.; Bruce, R.; Cameron, D.D.; Koh, S.L.; Horton, P. The environmental impact of fertilizer embodied in a wheat-to-bread supply chain. Nat. Plants 2017, 3, 17012. [CrossRef] [PubMed] 
34. Dawson, C.J.; Hilton, J. Fertiliser availability in a resource-limited world: Production and recycling of nitrogen and phosphorus. Food Policy 2011, 36, S14-S22. [CrossRef]

35. Lamberth, C.; Jeanmart, S.; Luksch, T.; Plant, A. Current challenges and trends in the discovery of agrochemicals. Science 2013, 341, 742-746. [CrossRef]

36. Pittelkow, C.M.; Liang, X.; Linquist, B.A.; Van Groenigen, K.J.; Lee, J.; Lundy, M.E.; Van Gestel, N.; Six, J.; Venterea, R.T.; Van Kessel, C. Productivity limits and potentials of the principles of conservation agriculture. Nature 2015, 517, 365. [CrossRef]

37. Woolf, S.H. The meaning of translational research and why it matters. JAMA 2008, 299, 211-213. [CrossRef]

38. Jacobsen, S.-E.; Sørensen, M.; Pedersen, S.M.; Weiner, J. Feeding the world: Genetically modified crops versus agricultural biodiversity. Agron. Sustain. Dev. 2013, 33, 651-662. [CrossRef]

39. Hefferon, K.L.; Herring, R.J. The End of the GMO? Genome Editing, Gene Drives and New Frontiers of Plant Technology. Journal 2017, 7, 1-32.

40. Fairfield-Sonn, J.W. Political Economy of GMO Foods. J. Manag. Policy Pract. 2016, 17, 1.

41. FAO. The State of Food Security \& Nutrition around the World 2018; FAO: Rome, Italy, 2018.

42. Jackson, P.; Ward, N.; Russell, P. Moral economies of food and geographies of responsibility. Trans. Inst. Br. Geogr. 2009, 34, 12-24. [CrossRef]

43. Warde, A. Consumption and theories of practice. J. Consum. Cult. 2005, 5, 131-153. [CrossRef]

44. Delormier, T.; Frohlich, K.L.; Potvin, L. Food and eating as social practice-understanding eating patterns as social phenomena and implications for public health. Sociol. Health Illn. 2009, 31, 215-228. [CrossRef] [PubMed]

45. Watson, M.; Meah, A. Food, waste and safety: Negotiating conflicting social anxieties into the practices of domestic provisioning. Sociol. Rev. 2012, 60, 102-120. [CrossRef]

46. West, P.C.; Gerber, J.S.; Engstrom, P.M.; Mueller, N.D.; Brauman, K.A.; Carlson, K.M.; Cassidy, E.S.; Johnston, M.; MacDonald, G.K.; Ray, D.K. Leverage points for improving global food security and the environment. Science 2014, 345, 325-328. [CrossRef]

47. Clark, M.; Tilman, D. Comparative analysis of environmental impacts of agricultural production systems, agricultural input efficiency, and food choice. Environ. Res. Lett. 2017, 12, 064016. [CrossRef]

48. OECD. Education at a Glance 2018; OECD: Paris, France, 2018. [CrossRef]

49. Blanchard, J.L.; Watson, R.A.; Fulton, E.A.; Cottrell, R.S.; Nash, K.L.; Bryndum-Buchholz, A.; Büchner, M.; Carozza, D.A.; Cheung, W.W.L.; Elliott, J.; et al. Linked sustainability challenges and trade-offs among fisheries, aquaculture and agriculture. Nat. Ecol. Evol. 2017, 1, 1240-1249. [CrossRef]

50. Cole, M.B.; Augustin, M.A.; Robertson, M.J.; Manners, J.M. The science of food security. NPJ Sci. Food 2018, 2, 14. [CrossRef]

51. Gustafsson, J.; Cederberg, C.; Sonesson, U.; Emanuelsson, A. The Methodology of the FAO Study: Global Food Losses and Food Waste-Extent, Causes and Prevention-FAO, 2011; SIK Institutet för livsmedel och bioteknik: Boras, Sweden, 2013.

52. Tirado, M.; Hunnes, D.; Cohen, M.; Lartey, A. Climate change and nutrition in Africa. J. Hunger Environ. Nutr. 2015, 10, 22-46. [CrossRef]

53. Holdsworth, M.; Kruger, A.; Nago, E.; Lachat, C.; Mamiro, P.; Smit, K.; Garimoi-Orach, C.; Kameli, Y.; Roberfroid, D.; Kolsteren, P. African stakeholders' views of research options to improve nutritional status in sub-Saharan Africa. Health Policy Plan. 2014, 30, 863-874. [CrossRef]

54. Godfray, H.C.J.; Beddington, J.R.; Crute, I.R.; Haddad, L.; Lawrence, D.; Muir, J.F.; Pretty, J.; Robinson, S.; Thomas, S.M.; Toulmin, C. Food security: The challenge of feeding 9 billion people. Science 2010, 327, 1185383. [CrossRef] [PubMed]

55. McGuire, S.; FAO; IFAD; WFP. The State of Food Insecurity in the World 2015: Meeting the 2015 International Hunger Targets: Taking Stock of Uneven Progress; FAO: Rome, Italy, 2015. [CrossRef]

56. Haddad, L.; Achadi, E.; Bendech, M.A.; Ahuja, A.; Bhatia, K.; Bhutta, Z.; Blössner, M.; Borghi, E.; Colecraft, E.; de Onis, M.; et al. The Global Nutrition Report 2014: Actions and Accountability to Accelerate the World's Progress on Nutrition. J. Nutr. 2015, 145, 663-671. [CrossRef] [PubMed] 
57. Hengeveld, L.M.; Wijnhoven, H.A.; Olthof, M.R.; Brouwer, I.A.; Harris, T.B.; Kritchevsky, S.B.; Newman, A.B.; Visser, M.; Study, H.A. Prospective associations of poor diet quality with long-term incidence of protein-energy malnutrition in community-dwelling older adults: The Health, Aging, and Body Composition (Health ABC) Study. Am. J. Clin. Nutr. 2018, 107, 155-164. [CrossRef] [PubMed]

58. Lim, S.S.; Vos, T.; Flaxman, A.D.; Danaei, G.; Shibuya, K.; Adair-Rohani, H.; AlMazroa, M.A.; Amann, M.; Anderson, H.R.; Andrews, K.G. A comparative risk assessment of burden of disease and injury attributable to 67 risk factors and risk factor clusters in 21 regions, 1990-2010: A systematic analysis for the Global Burden of Disease Study 2010. Lancet 2012, 380, 2224-2260. [CrossRef]

59. Muthayya, S.; Rah, J.H.; Sugimoto, J.D.; Roos, F.F.; Kraemer, K.; Black, R.E. The global hidden hunger indices and maps: An advocacy tool for action. PLoS ONE 2013, 8, e67860. [CrossRef]

60. Eggersdorfer, M.; Akobundu, U.; Bailey, R.L.; Shlisky, J.; Beaudreault, A.R.; Bergeron, G.; Blancato, R.B.; Blumberg, J.B.; Bourassa, M.W.; Gomes, F. Hidden Hunger: Solutions for America's Aging Populations. Nutrients 2018, 10, 9. [CrossRef]

61. Trimmer, J.T.; Guest, J.S. Recirculation of human-derived nutrients from cities to agriculture across six continents. Nat. Sustain. 2018, 1, 427-435. [CrossRef]

62. Lobell, D.B.; Schlenker, W.; Costa-Roberts, J. Climate trends and global crop production since 1980. Science 2011, 333, 1204531. [CrossRef]

63. Diaz, D.; Moore, F. Quantifying the economic risks of climate change. Nat. Clim. Chang. 2017, 7, 774. [CrossRef]

64. Fróna, D. Globális kihívások a mez̋ogazdaságban. Int. J. Eng. Manag. Sci. 2018, 3, 195-205. [CrossRef]

65. Scialabba, N.E.-H.; Müller-Lindenlauf, M. Organic agriculture and climate change. Renew. Agric. Food Syst. 2010, 25, 158-169. [CrossRef]

66. Müller, C.; Robertson, R.D. Projecting future crop productivity for global economic modeling. Agric. Econ. 2014, 45, 37-50. [CrossRef]

67. Müller, C.; Bondeau, A.; Popp, A.; Waha, K.; Fader, M. Climate change impacts on agricultural yields. 2010. Available online: https://openknowledge.worldbank.org/handle/10986/9065?locale-attribute=en (accessed on 8 December 2018).

68. Challinor, A.J.; Watson, J.; Lobell, D.; Howden, S.; Smith, D.; Chhetri, N. A meta-analysis of crop yield under climate change and adaptation. Nat. Clim. Chang. 2014, 4, 287. [CrossRef]

69. Asseng, S.; Ewert, F.; Martre, P.; Rötter, R.P.; Lobell, D.; Cammarano, D.; Kimball, B.; Ottman, M.; Wall, G.; White, J.W. Rising temperatures reduce global wheat production. Nat. Clim. Chang. 2015, 5, 143. [CrossRef]

70. EASAC. Opportunities and Challenges for Research on Food and Nutrition Security and Agriculture in Europe; EASAC: Halle, Germany, 2017.

71. Lane, A.; Norton, M.; Ryan, S. Water Resources: A New Water Architecture; John Wiley \& Sons: Hoboken, NJ, USA, 2017.

72. WHO. Progress on Sanitation and Drinking Water: 2015 Update and MDG Assessment; World Health Organization: Geneva, Switzerland, 2015.

73. Lu, C.; Tian, H. Global nitrogen and phosphorus fertilizer use for agriculture production in the past half century: Shifted hot spots and nutrient imbalance. Earth Syst. Sci. Data 2017, 9, 181-192. [CrossRef]

74. Cui, K.; Shoemaker, S.P. A look at food security in China. NPJ Sci. Food 2018, 2, 4. [CrossRef] [PubMed]

75. Qin, Y.; Zhang, X. The road to specialization in agricultural production: Evidence from rural China. World Dev. 2016, 77, 1-16. [CrossRef]

76. Kang, S.; Hao, X.; Du, T.; Tong, L.; Su, X.; Lu, H.; Li, X.; Huo, Z.; Li, S.; Ding, R. Improving agricultural water productivity to ensure food security in China under changing environment: From research to practice. Agric. Water Manag. 2017, 179, 5-17. [CrossRef]

77. Carter, C.A.; Zhong, F.; Zhu, J. Advances in Chinese agriculture and its global implications. Appl. Econ. Perspect. Policy 2012, 34, 1-36. [CrossRef]

78. Guan, X.; Wei, H.; Lu, S.; Dai, Q.; Su, H. Assessment on the urbanization strategy in China: Achievements, challenges and reflections. Habitat Int. 2018, 71, 97-109. [CrossRef]

79. Swinnen, J.; Squicciarini, P. Mixed messages on prices and food security. Science 2012, 335, 405-406. [CrossRef] [PubMed] 
80. Calvo-Gonzalez, O.; Shankar, R.; Trezzi, R. Are Commodity Prices More Volatile Now? A Long-Run Perspective; The World Bank: Washington, DC, USA, 2010.

81. Baffes, J.; Haniotis, T. What explains agricultural price movements? J. Agric. Econ. 2016, 67, 706-721. [CrossRef]

82. Timmer, C.P. Causes of High Food Prices; ADB Economics Working Paper Series; ADB Economics: Manila, Philippines, 2008.

83. Imf, O.; Unctad, W. Price Volatility in Food and Agricultural Markets: Policy Responses; FAO: Roma, Italy, 2011.

84. Hochman, G.; Rajagopal, D.; Timilsina, G.; Zilberman, D. Quantifying the causes of the global food commodity price crisis. Biomass Bioenergy 2014, 68, 106-114. [CrossRef]

85. Serra, T.; Zilberman, D. Biofuel-related price transmission literature: A review. Energy Econ. 2013, 37, $141-151$. [CrossRef]

86. Kristoufek, L.; Janda, K.; Zilberman, D. Correlations between biofuels and related commodities before and during the food crisis: A taxonomy perspective. Energy Econ. 2012, 34, 1380-1391. [CrossRef]

87. Kristoufek, L.; Janda, K.; Zilberman, D. Regime-dependent topological properties of biofuels networks. Eur. Phys. J. B 2013, 86, 40. [CrossRef]

88. Gilbert, C.L. How to understand high food prices. J. Agric. Econ. 2010, 61, 398-425. [CrossRef]

89. Opara, L.U. Traceability in agriculture and food supply chain: A review of basic concepts, technological implications, and future prospects. J. Food Agric. Environ. 2003, 1, 101-106.

90. Behzadi, G.; O'Sullivan, M.J.; Olsen, T.L.; Zhang, A. Agribusiness supply chain risk management: A review of quantitative decision models. Omega 2018, 79, 21-42. [CrossRef]

91. Horton, P.; Koh, L.; Guang, V.S. An integrated theoretical framework to enhance resource efficiency, sustainability and human health in agri-food systems. J. Clean. Prod. 2016, 120, 164-169. [CrossRef]

92. Farkasné Fekete, M.; Balyi, Z.; Szúcs, I. Az agrárgazdaság hatékonyságának néhány sajátos aspektusa. Gazdálkodás Sci. J. Agric. Econ. 2014, 58, 564-594.

93. Du, X.; Lu, L.; Reardon, T.; Zilberman, D. Economics of agricultural supply chain design: A portfolio selection approach. Am. J. Agric. Econ. 2016, 98, 1377-1388. [CrossRef]

94. Dunning, D.; Johnson, K.; Ehrlinger, J.; Kruger, J. Why people fail to recognize their own incompetence. Curr. Dir. Psychol. Sci. 2003, 12, 83-87. [CrossRef]

95. Cavicchi, C.; Vagnoni, E. Intellectual capital in support of farm businesses' strategic management: A case study. J. Intellect. Cap. 2018, 19, 692-711. [CrossRef] 


\title{
Losses in the Grain Supply Chain: Causes and Solutions
}

\author{
Ákos Mesterházy ${ }^{1}$, Judit Oláh ${ }^{2,3, *}$ and József Popp ${ }^{3,4}$ \\ 1 Cereal Research Non-Profit Ltd., 6701 Szeged, Hungary; akos.mesterhazy@gabonakutato.hu \\ 2 Faculty of Economics and Business, University of Debrecen, 4032 Debrecen, Hungary \\ 3 Faculty of Economic and Management Sciences, TRADE Research Entity, North-West University, \\ Vanderbijlpark 1900, South Africa; Popp.Jozsef@gtk.szie.hu \\ 4 Faculty of Economics and Social Sciences, Szent István University, 2100 Gödölő, Hungary \\ * Correspondence: olah.judit@econ.unideb.hu; Tel.: +36-2028-69085
}

Received: 27 February 2020; Accepted: 16 March 2020; Published: 17 March 2020

\begin{abstract}
Global grain production needs a significant increase in output in the coming decades in order to cover the food and feed consumption needs of mankind. As sustainability is the key factor in production, the authors investigate global grain production, the losses along the value chain, and future solutions. Global wheat, maize, rice, and soybean production peaked at 2.102 million tons (mt) of harvested grain in 2018. Pre-harvest losses due to diseases, animal pests, weeds, and abiotic stresses and harvest destroy yearly amount to about $35 \%$ of the total possible biological product of $3.153 \mathrm{mt}$, with $1051.5 \mathrm{mt}$ being lost before harvest. The losses during harvest and storage through toxin contamination are responsible for $690 \mathrm{mt}$, with a total of $1.741 \mathrm{mt}$ or $83 \%$ of the total newly stored grain. Limited cooperation can be experienced between scientific research, plant breeding, plant protection, agronomy, and society, and in addition, their interdependence is badly understood. Plant breeding can help to reduce a significant part of field loss up to $300 \mathrm{mt}$ (diseases, toxins, water and heat stress) and up to $220 \mathrm{mt}$ during storage (toxin contamination). The direct and indirect impact of pest management on production lead to huge grain losses. The main task is to reduce grain losses during production and storage and consumption. Better harvest and storage conditions could prevent losses of $420 \mathrm{mt}$. The education of farmers by adopting the vocational school system is a key issue in the prevention of grain loss. In addition, extension services should be created to demonstrate farmers crop management in practice. A $50 \%$ reduction of grain loss and waste along the value chain seems to be achievable for the feeding $3-4$ billion more people in a sustainable way without raising genetic yields of crop cultivars.
\end{abstract}

Keywords: preharvest losses; postharvest losses; prevention of losses; plant breeding solution; sustainability

\section{Introduction}

Grain production is the basis of global food security and is indispensable for feeding the world. In 1798 , Malthus argued that the global population increases more rapidly than global food supply until war, disease, or famine reduces the number of people [1]. The failure thus far of Malthus's prediction has not prevented others from promoting similar scenarios in more recent decades. For example, Paddock [2] forecasted a worldwide famine by 1975 and stated that within the short-term, it would be impossible to feed the population. Ehrlich and Ehrlich [3] predicted worldwide famine in the 1970s and 1980s due to overpopulation and urged action to control population growth. Just like Malthus [1] and Paddock [2], Ehrlich and Ehrlich [3] failed to appreciate the creativity of humanity. Romer [4] highlighted that a sustainable economy may be introduced in the future. Therefore, the green revolution introduced agricultural technologies that resulted in a doubling of grain production globally. 
More than 50 years have passed since the predictions of Paddock and Ehrlich, but mass starvation has not become widespread, although the number of undernourished and malnourished people has risen.

Nevertheless, many of Ehrlich and Ehrlich's [3] arguments related to resource scarcity appear to be close to reality because there are physical limits on natural resources. This has led Diamond [5] and other experts to shift the blame from "population" to "consumption." Fifty years ago, a growing population was highlighted as the main challenge facing humanity. Today, what really matters is people's consumption and production, which creates a resource problem. The principal challenge today is not population but total world consumption-namely, the product of local population times the local per capita consumption rate and it is not even consumption itself that is the major issue-only irresponsible and excessive waste, for which efficiency is the solution. The rational use of natural resources is the only way to avoid the global collapse of food, energy, and environmental security. Now we must take another step forward. We hypothesize that the problem is deeper and needs an even wider consideration to find more effective solutions or ways that will lead us towards a significant improvement.

1962 was the year of peak population growth, with a growth rate of $2.1 \%$. Subsequently, population growth slowed to $1.1 \%$ by 2015 . Global population will continue to grow until 2100; however, the rate of growth is expected to fall gradually to $0.1 \%$ annually [6]. The world's population reached 7.8 billion in 2020 and is projected to increase to 11.2 billion by 2100 (Figure 1). Can it realistically cover its grain needs?

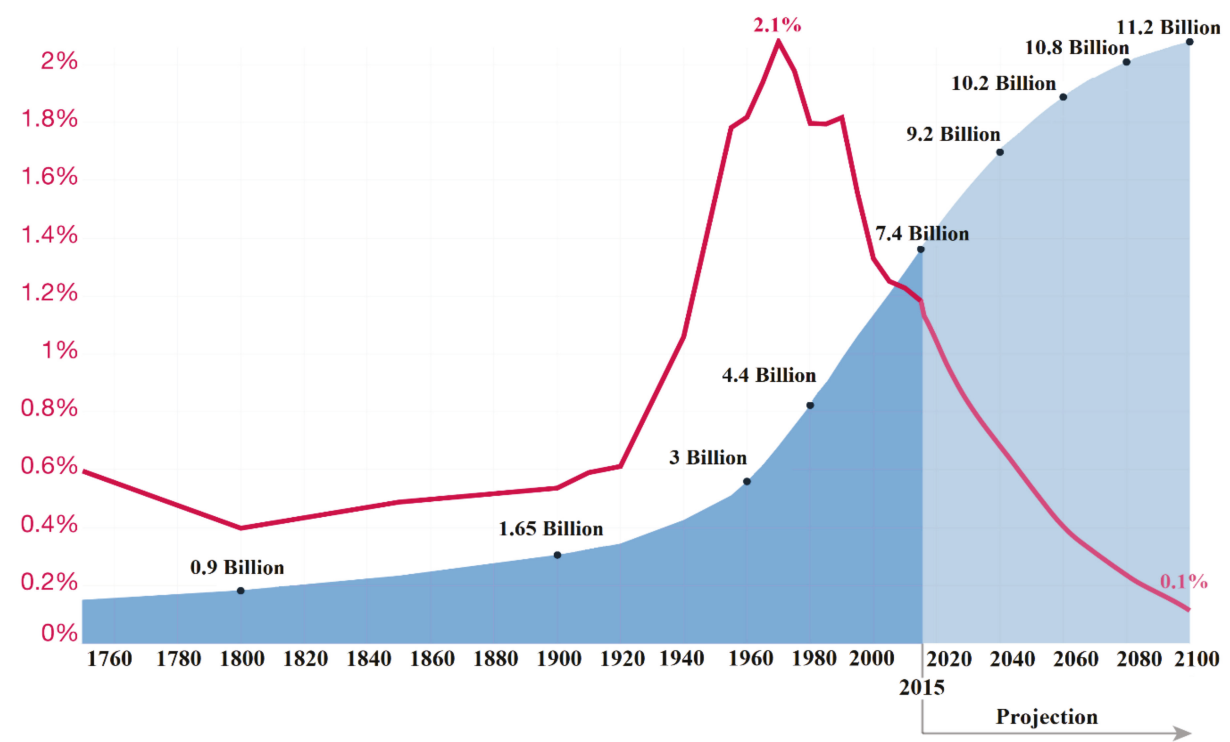

Figure 1. World population and growth rate, 1750-2015, and projections until 2100. Source: Roser and Ortiz-Ospina [7].

The goal of this study is to summarize losses along the grain value chain and identify more effective solutions. The problems at the pre-harvest and storage stages combined with mycotoxin contamination represent a very strong limitation, leading to huge losses of grains. This paper first presents the literature review on food loss (FL) and food waste (FW), followed by global grain production and losses along the grain chain including field, storage, mycotoxin contamination losses and consumer waste, a discussion of the role of integrated pest management, plant breeding, and agronomy in grain production and the implications for the future supply of grain for food and feed. Overall, this study 
explains the complexity of the grain value chain in order to make decisions on how best to prevent grain losses across the supply chain.

\section{Literature Review}

The world's population is predicted to reach 9.8 billion by 2050 and this will require an increase of $70 \%$ in food availability [6]. FL may occur due to technical limitations, such as a lack of proper storage facilities, infrastructure, packaging etc. [8]. FW is generated after the food is spoiled or expires due to poor stock management or neglect. FL takes place during the production, post-harvest, and processing stages, while food waste typically occurs at the retail and consumer levels. FL and FW can be evaluated and measured in different ways. There are several definitions of FL and FW taking into consideration pre-harvest and/or post-harvest stages, the use and destination of food, the edible part of food products, or the nutritional value of FL and FW [9]. The inclusion of pre-harvest stages to quantify food loss is essential because the pre-harvest management stage can increase the quantity and quality of tomatoes along the value chain [10]. FL and FW have negative food-security, economic, and environmental impacts. FL and FW represent the natural resources (water, land, energy) used to produce food. Reducing loss and waste throughout the food supply chain is an effective solution to mitigate the GHG emissions of agriculture and improve global food and nutrition security [8].

In 2011, the FAO estimated that annually around one-third of food produced is lost or wasted globally, which amounts to about 1.3 billion tons per year [11]. The 2030 Agenda for Sustainable Development (target 12.3) calls for halving per capita global FW at retail and consumer levels. FW represents a waste of resources (land, water, energy, soil, seeds, pesticides, etc.) used in its production; furthermore, it contributes to increasing GHG emissions. FL originates from decisions and actions by food suppliers in the value chain, excluding retailers, food service providers and consumers, while FW occurs from decisions by retailers, food service providers and consumers [12].

The global population will grow from its current 7.8 billion in 2020 to 9.8 billion in 2050 and global food demand is estimated to increase by at least $50 \%$, but demand for protein rich products may grow even faster [6]. Closing the food gap requires a decreasing rate of growth in demand by cutting FL and FW, reducing GHG emissions from agriculture, shifting the meat-based diets of high meat consumers towards a plant-based diet, innovation and a voluntary reduction of the birth rate in Africa [13]. According to BCG the annual FL and FW has reached 1.6 billion tons, worth ca. $\$ 1.2$ trillion USD, and by 2030 these figures may go up to 2.1 billion tons, worth about $\$ 1.5$ trillion USD [14]. Food lost or wasted annually accounts for one-third of global food production and $8 \%$ of global greenhouse gas emissions, while over 800 million people worldwide suffer from malnutrition. FL or FW along the food chain is most striking at the beginning and the end, namely in the production and transportation stage in developing regions, while it is more typical in the retail and consumption stage in developed countries. All stakeholders across the value chain can play a crucial role in food loss and waste reduction [15].

In North America (the US, Canada, and Mexico), annual FL and FW amount to 168 million tons. There are several opportunities to address FL and FW in North America including multi-stakeholder collaboration, standardized data labels, improved cold chain management, and processing and packaging innovation [16-18]. During processing, waste is generated by inadequate infrastructure and machinery, contamination, trimming and cutting problems, confusing date labels, food safety issues and cold chain problems [16-18]. About 40\% of the annual US food supply is lost and wasted, so action is required across the food supply chain, with collaboration among agencies, businesses, and communities. The United States Government Accountability Office identified three key areas - limited data and lack of awareness about food loss and waste, and limited infrastructure - which should be addressed to cut FL and FW. In 2015, the US announced a goal to reduce national FL and FW by half by 2030 [19].

FL and FW accounted for approximately $20 \%$ of food produced in the EU with a value of $€ 143$ billion in 2015 [20]. Household expenditure on food indicates how food is valued in different 
countries. Household income spent on food in the EU is low as a proportion of income, on average $13 \%$. By contrast, in several African countries, almost $50 \%$ of income is spent on food. The share of FW in Europe was a few percent in the 1930s but has increased sharply since then to current global levels where one-third of food produced is lost or wasted. The relatively cheap food in the EU gives little economic incentive for consumers to avoid waste. In addition to FW, plastic waste is also a major economic, environmental, and social challenge. The overwhelming majority of plastic packaging is used only once. In the food supply chains, materials, including packaging, should be reduced, reused, and recycled in the framework of the circular economy [21].

According to a market study, up to $10 \%$ of food waste generated annually in the EU is linked to date marking; however, the market survey showed a high level of compliance. The authors conclude that FW linked to date marking can be reduced with a clear and legible date mark and consumers can make the distinction between "use by" (indicator of safety) and "best before" (indicator of quality). Nevertheless, significant FW prevention in relation to date labelling can be achieved in the dairy, fresh juices, chilled meat and fish supply chain [22]. Misinterpretation of food date labels is one of the key factors leading to FW. Date labels on food in the USA show a large variety of forms such as "use by," "best before," "sell by," and "enjoy by" dates, which are poorly understood by consumers. This paper makes recommendations on changes to the date labelling system in the USA and addresses actions needed to clarify the issue [23].

A survey conducted in Italy showed three key factors defining the extent of household FW, namely socio-demographic characteristics (household income spent on food), food shopping patterns and consumer behavior. More education and information are needed for the prevention of household FW [24]. Another study identified measures to combat FW along the food value chain in the metropolitan region of Barcelona and stressed the relevance of more research, since stakeholders oppose the introduction of new regulations and policies. Future research on the impact of new regulation including strong FW prevention measures is needed to reach a consensus and willingness among stakeholders of the food supply chain to implement new policies [25].

Conrad et al. [26] analyzed the link between FW, diet quality, nutrient waste and sustainability in the US. Higher quality diets lead to higher FW associated with greater amounts of wasted irrigation water and pesticides but less cropland waste due to the increasing consumption of fruits and vegetables included in higher quality diets, which have lower cropland and higher input needs compared to other crops. The results of the study show that simultaneously improving diet quality and reducing FW is a complex issue. Fanelli [27] found similarities in the structure of the food supply in relation to the quantity of animal-based products. The environmental impact of agriculture depends mainly on the structures of the food supply and agricultural practices applied in the different Member States of the EU. Consequently, large differences can be detected in the food supply of animal-based products and the GHG emissions intensity of the livestock sector. The farming system applied in the Member States should be based on the impact of agricultural practices on the environment to achieve a balance between livestock production and the intensity of GHG emissions. Furthermore, Fanelli [28] investigated the impact of agricultural activities on the environment in the Member States of the EU. She came to the conclusion that several Member States have similar production methods with a high impact on the environment; however, Mediterranean and northern Member States use traditional production methods including livestock grazing. Production methods with a high impact on the environment must be directed towards sustainable intensification.

The prevention of FW has become a global issue. In order to achieve this goal in developing countries a higher budget is needed for education, training and communication, technology implementation, and better infrastructure. Collaboration and dialogue between stakeholders along the food supply chain is crucial. Furthermore, data collection and comparable figures for different countries are needed, as well [29]. Ishangulyyev et al. [30] emphasized that FL and FW are complicated issues involving multi-stakeholders along the food supply chain; therefore, more research, collaboration, 
and awareness is needed for the prevention of FL and FW. Authors focus on awareness of the impacts of FL and FW leading to changing consumer attitudes and behaviors.

In China, Gao [19] reported an annual loss of $7.9 \mathrm{mt}$ for rice, wheat, and maize, but with advanced storage management, this can be reduced substantially. In India, the annual losses are estimated at 12-16 mt; however, losses are much higher at traditional farms, where $60-70 \%$ of the harvested grain is kept in short term storage facilities [31]. According to estimates by the FAO, in India the general FL and FW is around $40 \%$, but for cereals 30\% [32]. In the developing countries almost all pre-harvest and and post-harvest operations are conducted manually, therefore post-harvest loss accounts for $15 \%$ in the field, 13-20\% during processing, and 15-25\% during storage [33]. Smallholder farmers generally use conventional grain storage facilities, which are not effective against insects and mold. The replacement of these traditional storage structure with improved storage systems will maintain crop quality, reduce grain losses and food insecurity [34]. Up to $50-60 \%$ of cereal grains are lost during storage due to the traditional storage structures. Modern storage structures can reduce these losses up to $98 \%$, thereby increasing food security [35]. In Jordan, the total loss and waste along the wheat supply chain amounts to $34 \%$ associated with significant of losses of natural resources. Among postharvest losses, consumer waste ranks first, accounting for $13 \%$ [36].

\section{Materials and Methods}

Several methodological approaches can be used to identify household FW. Multivariate statistical techniques (descriptive statistics, principal component analysis, and hierarchical cluster analysis) were conducted to study the similarities and differences-namely the links between the structure of the food supply and the impact of agricultural practices on the environment between EU Member States [25]. Another study performed an exploratory online survey using a questionnaire adapted for studies on FW [24]. Furthermore, multivariate analyses was carried out for a comparative analysis of the environmental characteristics of the EU Member States with different agricultural systems [26].

The causes and prevention of losses along the grain supply chain is shown, based on the review of relevant literature and combining results from relevant studies and global models. Various combinations of the following terms were used to search in various papers: preharvest losses, postharvest losses, prevention of losses, plant breeding solution, sustainability. The literature on food security is already substantial; however, grain losses across the supply chain have not been addressed in detail. Furthermore, there is a lack of available publications relating to the causes of preharvest and postharvest grain losses. In addition, we also conducted supplementary searches by examining bibliographies of articles for additional references. The references of the paper mainly cover the period 2001 to 2019. References might differ in their focus on potential or realized FL and FW, their use of different baselines for comparisons, and other background conditions.

The FAO, OECD, International Grains Council, EU, and many other institutions publish serial data on grain production, use, trade, and prices. Other international sources issue estimates or data on grain losses before and after harvest. However, these data and information have not been aggregated and combined to make comparisons in order to calculate the benefits and trade-offs of grain production and losses at a global level. Data on food security related to production and losses have not been embedded into a global perspective. This paper attempts to combine all information collected to obtain a clear picture on the issue, which may serve the interests of multi-stakeholders along the grain supply chain. Other losses in the grain supply chain-losses in the conversion of feed into animal products, processing losses and over-consumption-have not been included in the calculation of grain losses and waste, and soybean losses and waste have also been excluded from our calculation.

\section{Global Grain Production}

Worldwide, wheat, maize, and rice are the most important cereal grains, and soybean is the major oilseed grain. The production volume and projected yield growth of grains are closely related to food security. The consumption of grains is projected to exceed supply, while supply is expected to grow 
at a higher rate than demand in the midterm (Table 1). Borlaug [37] also reported an increase in the deficit of grain production compared to consumption, primarily in developing countries. According to the forecast of the International International Grains Council [38], yield increase is expected to grow from $0.8 \%$ to $1.5 \%$ annually from $2013 / 2018$ to $2020 / 2024$.

On the other hand, the increase in consumption is projected to decrease from $2.1 \%$ to $1.0 \%$ on average in the same period. So, the gap between the supply and demand of grains is shrinking leading to a decreasing accumulated deficit of about 155 million tons ( $\mathrm{mt}$ ) between production and consumption over the period of 2017/2018-2023/2024. The consequence of the downward trend in supply is a fall in the carry-over stock level from 29\% to 21\% between 2017/2018 and 2023/2024, making supply in critical years more problematic. However, data on supply and demand between years may vary strongly. Grain prices are expected to be higher than in past years in both real and nominal terms due to shrinking stock levels. This means that a robust increase in production cannot be expected; therefore, we should investigate how to feed the global population and livestock. The yearly change for the next years $(\mathrm{y} / \mathrm{y})$ is projected at $1.5 \%$ for production, $1.0 \%$ for consumption and $1.5 \%$ for exports accompanied by a slow decrease of carryover stocks. For this reason, much greater attention must be given to losses along the food chain.

Table 1. Forecast for global grain production (wheat, corn, rice and soybean), 2017/2018-2023/2024 (million tons).

\begin{tabular}{|c|c|c|c|c|c|c|c|c|c|}
\hline Total Grains & $17 / 18$ & $18 / 19$ & $19 / 20$ & $20 / 21$ & $21 / 22$ & $22 / 23$ & $23 / 24$ & $\begin{array}{c}5 y \\
\text { Average } \\
2013 / 2018\end{array}$ & $\begin{array}{c}\text { y/y } \\
\text { Change, \% } \\
2020 / 2024\end{array}$ \\
\hline Consumption $(\mathrm{M} \mathrm{t})$ & 2.107 & 2.137 & 2.156 & 2.179 & 2.201 & 2.226 & 2.249 & $2.1 \%$ & $1.0 \%$ \\
\hline Exports (Jul/Jun, M t) & 367 & 368 & 371 & 377 & 383 & 390 & 396 & $5.5 \%$ & $1.5 \%$ \\
\hline Stocks to use ratio, $\%$ & $29 \%$ & $26 \%$ & $25 \%$ & $23 \%$ & $22 \%$ & $21 \%$ & $21 \%$ & & \\
\hline
\end{tabular}

Source: International Grains Council [38]

On the production side, further substantial increases in yield will be constrained. Obviously, technology, plant breeding, improving agronomy, and new production methods will resolve this phenomenon to a certain extent. Higher yielding cultivars are on the market, but their effect on yield is only moderate as the genetic capacity of these cultivars is just partly exploited. Without making long-term predictions of the global grain supply the problem described above must be approached from a different perspective. We have to focus on causes and solutions of food and feed losses along the grain supply chain.

\section{Losses along the Grain Chain}

The reduction of grain losses by biotic factors (pests, pathogens and weeds) is a major challenge for food supply [39]. In addition to pre-harvest losses, the losses occurring during transport, pre-processing, storage, processing, packaging, marketing and plate waste are also substantial (Figure 2). Reduction of losses results in a higher revenue than an increase in genetic yield ability [40]. Globally, an average of $35 \%$ of potential crop yield is lost to pre-harvest pests [41]. In addition to pre-harvest losses, the losses occurring during transport, pre-processing, storage, processing, packaging, marketing, and plate waste are also substantial [39]. By reducing FL and FW, food security combined with resource efficiency can be enhanced. In 2011 the European Commission set targets to halve the disposal of edible FW by 2020, and in 2012, the European Parliament also issued a resolution to halve FW by 2025 and designated 2014 as the "European Year against Food Waste" [42,43]. The problem is that the EC targeted only edible FW excluding other forms of waste, for example in feeding. 


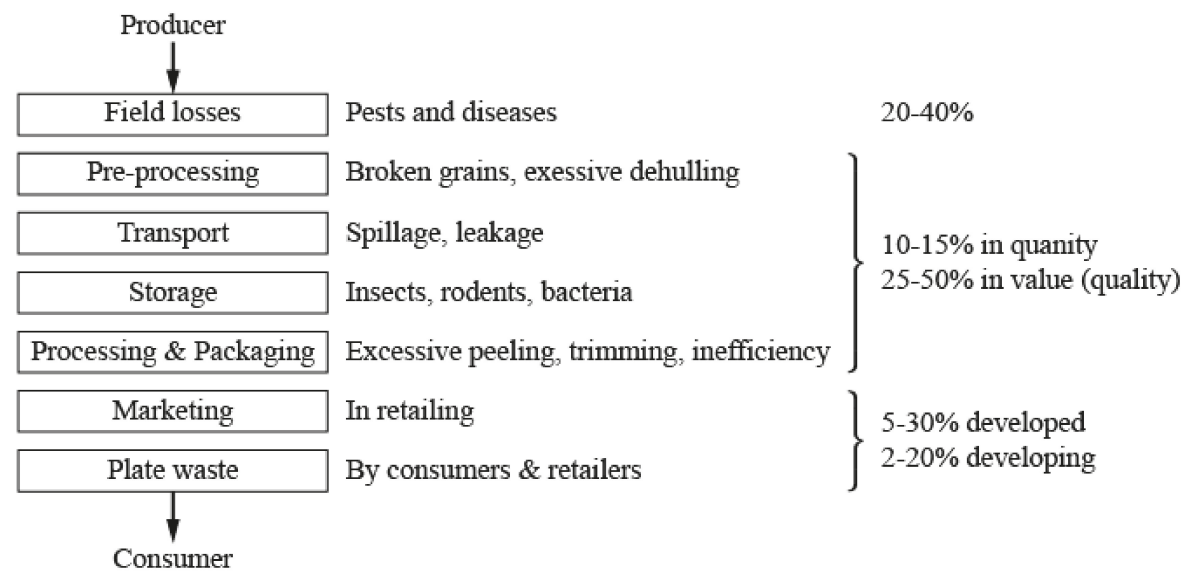

Figure 2. Losses along the food chain. Source: International Water Management Institute [44].

Each stage of the grain value chain is a source of grain losses and waste, each with a different loss ratio. The problem needs a multidisciplinary approach $[45,46]$, but in spite of efforts we are far from the solution. Therefore, our goal was to summarize losses along the grain value chain and identify more effective solutions. The increasing loss and waste of grains reduce food security and also negatively affect sustainable development (natural resources, environment and human health) $[47,48]$. In addition to the actual loss and waste, resource inputs, e.g. arable land, irrigated water, fertilizer and energy, are also lost and wasted Gustavsson et al. [11] contributing to higher cost for a unit of really consumed product.

In 2018, global grain production accounted for 2.102 million tons [38]. The data we used for losses are based on estimates in the literature. However, the different sources produce comparable numbers. We used the lower estimates for increased reliability. It is well known that the loss expressed in monetary term is very high at lower quality or high toxin contamination even the amount of losses does not change much. For example, toxin contamination can cause $100 \%$ income loss at minimal yield reduction. Approximately one-third of potential crop yield is lost to pre-harvest pests, pathogens and weeds. The theoretical yield would account for $3.153 \mathrm{mt}$ per annum and pre-harvest losses amounts to 1.051 million $\mathrm{mt}$. Grain losses at harvest are estimated at $3 \%$ or $60 \mathrm{mt}$ annually, with wide regional variations between small and large farms. Total pre-harvest and harvesting losses account for about $1.110 \mathrm{mt}$ per year. In addition, $420 \mathrm{mt}$ of grains are lost during storage, 210 million tons due to field mycotoxin contamination (excluding consumer's waste of $286 \mathrm{mt}$ annually (Table 2). It can be concluded that one third of the possible yield is lost before harvest, another $20 \%$ is wasted due to storage and mycotoxin contamination, and only one third of the grain total production potential is really consumed, including consumer waste of around $10 \%$ ). 
Table 2. Losses of grains along the full value chain in 2018 (million tons).

\begin{tabular}{cccc}
\hline Items & Million Metric Tons & \% to Total Capacity & \% to Harvest \\
\hline Total production capacity & 3.153 & 100.00 & \\
Total harvested yield & 2.102 & 66.67 & 100.00 \\
Losses due to biotic and abiotic factors & 1.051 & 33.33 & 50.00 \\
Harvest losses (cc 3\%) & 60 & 1.90 & 2.85 \\
Storage losses & 421 & 13.35 & 20.03 \\
Field mycotoxin contamination & 210 & 6.67 & 9.99 \\
Consumer's waste & 286 & 9.07 & 13.61 \\
Total loss & 2.028 & 64.32 & 96.50 \\
Total grain consumed & 1125 & 35.68 & 0.00 \\
\hline
\end{tabular}

Source: Authors' own calculation based on the production data of International Grains Council [38].

\subsection{Field (Pre-Harvest) Losses}

Yield losses caused by pests, pathogens, and weeds are major challenges to crop production. Increased use of plant protection increased crop harvests from $42 \%$ of the theoretical worldwide yield in 1965 to $70 \%$ of the theoretical yield by 1990; however, at least 30\% of the theoretical yield was still being lost due to ineffective pest-management methods applied in several regions of the world. Without plant protection, $70 \%$ of crop yields could have been lost to pests [41]. Actual losses were estimated at $26-30 \%$ for soybean and wheat, and $35 \%$, and $40 \%$ for maize and rice, respectively [40]. Cramer [49] estimated crop losses of around 28\% due to all pests in North and Central America. Russel (1978) cited over 50\% yield losses caused by pests, pathogens and weeds worldwide. Schumann and D'Arcy [50] estimated the loss of yield caused by all pests at some $20 \%$ despite the billions of dollars spent on plant protection. According to Ubrizsy [51], in the 1960s mean yield loss for all crops caused by pests, pathogens and weeds stood at $15-20 \%$ and $25-30 \%$, respectively. Actual losses were estimated at $36 \%$ for wheat and 38\% for maize on average during the period 1950-1960 excluding yield loss caused by abiotic factors (temperature, humidity, rain, floods, etc.).

It is well known that plants would not survive a crisis-level water shortage because under a certain level of precipitation plants cannot cope with water stress. In Hungary, yield sensitivity to droughts show that maize and wheat yield reduction may reach up to $50 \%$ in drought seasons. The effects of drought play a large role in damage to crops, depending on soil quality. Drought conditions can have a moderate impact on good soil or a profound impact on sand. The yield loss in drought and dry seasons reaches one-third on average. Beyond the $35 \%$ loss due to biotic factors, we did not count extra losses for abiotic losses, as in drought years, diseases, insects, and weeds normally cause significantly less damage. The authors aimed to make a conservative estimate that is close to reality. Aflatoxin is an exception in draught and hot years, but in yield reduction it is not important.

\subsection{Integrated Crop Management}

Integrated crop management (ICM) is an environmentally sensitive and economically viable production system by using the latest available techniques to produce high quality food in an efficient manner [52]. Reductions in pest control costs and in the use of pesticide in ICM programs can be achieved by introducing populations of natural enemies, variety selection, applying alternative pesticides, etc. For farmers, the main benefit of ICM is still a reduction in pesticide use, although most programs still rely heavily on pesticides [39]. The main task of ICM is not to decrease pesticide costs but it contributes to the production of healthy food. The present production level is a consequence of contemporary pesticide use, but the losses that could not be prevented show that a significant development is necessary.

Bajwa and Kogan [53] listed 67 definitions for integrated pest management but did not mention resistance to pests. Ehler [54] focused on integrated pest management but also mentioned integrated 
pesticide management because it is not the pests themselves, but rather the use of pesticides, that should be better managed in order to reduce the occurrence of pests.

Kumar and Shivay [55] took a step forward by combining pest management with seedling establishment and nutrient management. Vanlauwe et al. [56] highlighted integrated soil fertility management, focusing on the efficiency of fertilizer use. Bottrell [57] reported on integrated pest management, while Barzman et al. [58] summarized the most important principles with the objective of optimizing the use of pesticides but did not mention resistance as a possible influencing agent, only considering pesticide reduction.

Lehoczki-Krsjak et al. [59], Mesterhazy and Bartok [60], Mesterházy [61], Mesterházy [62], Mesterházy et al. [63], Mesterházy et al. [64], and Mesterházy et al. [65] were among the first to indicate the decisive role of the resistance level increasing the effect of fungicides against Fusarium head blight in wheat. Actually, the resistance level regulates the fungicide effect. Lamichhane et al. [66] stressed the role of resistance in sustainable and low-input agricultural systems and the role of breeding cultivars with the resistance traits required for organic production. Nevertheless, in a wider context we need to integrate plant breeding, water management, and storage conditions with an emphasis on the fungi that normally cause less grain loss. It is possible to keep the whole production process under control by the introduction of Intelligent Field Crop Management (ICM).

\subsection{Storage Losses}

Storage plays a central role in the grain supply chain. Grain storage losses are affected by several factors, including direct and indirect losses. Direct losses are related to the physical loss of grains, and indirect losses occur due to loss in quality and nutrition [35]. Storage losses can be classified into biotic factors (insect, pests, rodents, fungi) and abiotic factors (temperature, humidity, rain). Moisture content and temperature affects storage life. For example, storage molds spread rapidly at higher temperatures and humidity. Damage and losses caused by insects and rodents can refer to physical deterioration (e.g., holes in the grain) and quality (value) loss. Huge direct and indirect storage losses are reported in developing countries. Jayas [67] estimated losses as low as 1-2\% in developed countries using metal silos compared to $20-50 \%$ in developing countries where grains are generally stored by family farms in traditional storage structures. According to Manandhar et al. [34] in most developing countries up to $80 \%$ of cereals are produced by small family farms where grain losses can go up to $15 \%$ in the field, $13-20 \%$ during processing, and 15-25\% during storage, giving total losses of $43-60 \%$. Grain losses in storage account for 10 to $20 \%$ of stored products, as a result of damage caused by insects [68]. By calculating an average storage loss and damage of up to $20 \%$ of stored grain worldwide, approximately $420 \mathrm{mt}$ of grains are lost during storage annually.

The storage and handling methods should minimize losses. Before storage the grain must be cleaned and contaminants (dust, insects, straw, chaff, weed seeds, etc.) removed. Furthermore, test for toxins is mandatory before storage and grains of low, medium and high contamination level must be stored separately from each other. Critical physiological factors (moisture content and temperature) affect the storability of crops because high moisture content and heat cause fungal and insect problems, therefore humidity temperature and $\mathrm{CO}_{2}$ control is highly important. Introducing best practices for handling and storage is a cheaper solution compared to the loss of grains during storage.

\subsection{Mycotoxin Contamination}

Mycotoxins are toxic chemicals unsuitable for animal feed and human consumption. High concentrations of aflatoxin can pose a serious health risk both to humans and livestock. A significant concentration of toxin levels is frequently measured even during harvest, leading to the need for control measures, both pre- and post-harvest. The most important source of the mycotoxin problem is the generally high susceptibility of the grain crops. Large toxin epidemics in the fields are always consequences of an epidemic. WHO estimated that $25 \%$ of the world's crops are contaminated by mycotoxins excluding considerable preharvest losses [69]. Up to $25-40 \%$ of global 
cereal grains are contaminated by the mycotoxins produced by fungi Kumar et al. [70]. Dowling [71] reported, based on UNO and FAO data, that $25 \%$ of the world grain crop is significantly contaminated by mycotoxins.

McMullen et al. [72] reported that due to nearly yearly epidemics in the USA the acreage of wheat was reduced from 29 million ha (1992) to 21.4 million ha (2010). The same numbers for barley are 2.9 and 1.0 million ha. This is normally not taken into consideration. The high toxin contamination of harvested yield caused additional quality loss and a reduction in prices of 50-90\%. The yield and quality losses amounted to billions of dollars. Similar losses were also recorded in epidemic years in Canada, Europe, and China. Maize is a more complicated problem. Szabo et al. [73] estimated losses in maize in 2014 at about 300 million dollars, with nearly no yield reduction. The contaminated grain (deoxynivalenol, zearalenone, fumonisins) decreased the price of harvested grain by about \$32 USD/t or $25 \%$, while the rest of the loss was attributed to animal husbandry by lower weight gain, sexual disorders, higher death rates, cost of toxin bindings and antibiotics, etc.

This means that yield loss on its own does not show the significance of the problem. The damage caused by toxins during storage represents about $10 \%$ yearly loss at a conservative estimation and removes $210 \mathrm{mt}$ of grain per annum globally. This amount represents stored grains and does not include the infected and light grain part in small grains blown out by the combine at harvest, which cannot be measured, but exists. Due to toxin regulations the human population is well protected in the developed world, but this is not the case in many countries where animal husbandry the situation is similar-contaminated grains are normally used in animal husbandry In small grains cleaning systems, optical selection of infected grains can reduce toxin levels, but the cost is relatively high equivalent to a yield loss of $10-20 \%$. In maize, however, such effective methods are in experimental phase. Most of the toxins are of field origin detectable at harvest, but bad storage conditions can cause significant increases. In order to minimize grain losses, fungi formation must be addressed during storage.

\subsection{Consumer Waste}

Plate waste of food is as high as 5-20\%. In developing countries, FL and FW including plate waste is higher than in developed countries. FL and FW depend on technology and on consumer behavior. 1.3 billion tons of food or $1 / 3$ of all food produced for human consumption is lost or wasted from harvest to consumption annually, without accounting for losses in livestock production worldwide $[11,74]$. Carrying out evidence-based FL and FW calculations still presents an open challenge. In estimating FW, the most critical research gap is related to the lack of a clear definition of FW and a harmonized FW accounting methodology [75]. In developed countries, consumers throw away $286 \mathrm{mt}$ of cereal products [76]. Just taking into consideration maize, wheat, and rice, at least $200 \mathrm{mt}$ of cereals are wasted by consumers per annum globally (soybean loss and waste is not included).

\subsection{Breeding Versus Food Losses}

Research has clarified that resistance is the most important toxin regulator $[61,62,65,77,78]$. However, large resistance differences occur, in wheat Fusarium head blight deoxynivalenol concentration varied between $5 \mathrm{mg} / \mathrm{kg}$ and $400 \mathrm{mg} / \mathrm{kg}$ at the higher epidemic pressure in 2001-2002 [78]. According to literature sources there is no effective means for solving toxin contamination before harvest Jans et al. [79] stressing the preharvest prevention of disease and toxin by resistance. This is a problem as this also inhibits breeding activity and creates difficulties for stakeholders. The results of the wide international literature do not support this view. Ten- to 20 -fold resistance differences also exist in toxin response; therefore, this problem should be exploited.

Resistance also influences further fungicide efficiency and improves the predisposition of plants to previous crops with high pathogen population [80]. Disease and toxin forecasts will be better when resistance levels are considered [81]. Zorn et al. [82] indicated that ploughing was as effective a way to reduce deoxynivalenol (DON) as planting a more resistant variety, and in other diseases the experiences are similar. Breeding for adaptation to different soil and climatic conditions is essential. 
Tolerance to acidic soils is also a breeding problem among many others. Minimum tillage and organic production needs plants that are highly resistant against the most important diseases, as in these cases the disease pressure can be significantly higher as effective fungicide are forbidden to use. Resistance to biotic and abiotic factors brings a direct and significant improvement to yield, quality stability and adaptation. Breeding for more efficient fertilizer use in order to improve the photosynthetic activity, adaptation etc. of the plants has also its place. The main problem is that the extensive knowledge available in the scientific community suffers from a bottleneck effect when it should be applied in plant breeding. Most breeding firms are small, with 1-2 breeders for a plant or less, and they lack any laboratory background or support from trained scientists. This is true also for European family companies. The large firms concentrate on high yields but often neglect food safety and other problems, so varieties with high yields often produce severe financial losses.

Unsatisfactory breeding efforts contribute to $210 \mathrm{mt}$ loss due to toxin contaminated grains. Much of the storage microbes are of field origin, so lack of resistance might be partly responsible for storage losses. The devastating effect of storage microbes is characteristic when storage conditions are bad, however, most of the losses could be prevented by advanced storage technology. Storage microbes cause about $50 \%$ of storage loss, i.e. 210 million $\mathrm{mt}$ of grain per annum; therefore, mycotoxins of field and storage origin are treated separately because they need to be treated using different approaches.

\subsection{Agronomy}

The keys to the green revolution, whose father was the Nobel laurate Norman Borlaug, were improved seeds, especially the short straw lodging resistant wheat varieties giving higher yields due to a better harvest index and resistance to diseases such as rust. The breeding program was led by Norman Borlaug and supported by inputs (chemicals and fertilizer) and irrigation water [83]. The green revolution spread in all developing and developed regions and helped more than one billion people to survive. The key factor was to find a connection between breeding and agronomy that helped to exploit the greater abilities of the new varieties. This is essentially an update the basic ideas of the Green revolution by Baranski [83] adapted to present needs and balancing the negative effects of climate change.

Breeding for more yield resulted in increasing nitrogen and water dependence. We can mention possible shortage in phosphorus and potassium. Today, several breeding companies are focusing on shorter season crops, less water use, and gene editing, among other things. There is an improving efficiency of utilization of nitrogen, potassium, phosphorus, but insufficient supply of microelements is also a growing problem. The decoupling of nitrogen from yield dependence is another central research area. Nevertheless, breeding for higher yields still has priority. Wang et al. [84] summarized the possibilities for wheat, but similar patterns exist also for other crops. Pest management is also relevant in agronomy to protect grain against pests, pathogens, and weeds. Effective disease control is indispensable in epidemic years. However, the contemporary storage needs also pesticides for insect control and specific fungicides against diseases.

\section{Discussion}

In order to explain the possible shortage of food globally, Malthus [1] warned about overpopulation. He did not take into consideration the fact that more food required could be produced due to scientific and technological development. The forecasted mass starvation has so far not become a reality. Diamond [5] blamed consumption, especially overconsumption in the developed world. The present global food production is not sustainable and accompanied by huge losses and wastes along the value chain. For this reason, agricultural production needs a reorganization with specific local solutions for particular regions.

Half of total losses occur before the process of harvesting begins representing $1051.5 \mathrm{mt}$ annually. This makes production per unit more expensive. Among the causes of crop losses, the bottleneck effect between basic, applied research, and breeding must be highlighted, which means that most of the 
available existing knowledge does not reach, for example, those involved in breeding, plant protection, agronomy, etc. Consequently, the effectiveness of the combination and utilization of the knowledge adapted for local and regional breeding, agronomy, etc. is very poor and the results are embarrassing. More knowledge is needed about the interrelations between disease resistance, yield ability, and the efficacy of pesticides and agronomy responses at cultivar level to develop the optimum mix of different procedures for each region and field. At least two third of grain field losses, namely $700 \mathrm{mt}$, are related to biotic stresses. Plant breeding is supposed to be responsible for about a third of this amount $(233 \mathrm{mt})$. However, it is impossible to breed for resistance against 200 diseases of a crop. Plants are generally treated for the 4-5 most important diseases by farms; therefore, resistance and pesticide treatments should be combined. For the rest of the losses (roughly $500 \mathrm{mt}$ ) correct pest management and agronomy measures combined are needed. Suggestions made by Lamichhane et al. [66] for organic culture are also necessary for conventional plant production. Near Szeged (southern Hungary), Mesterházy et al. [64] and Mesterházy et al. [65] reorganized the crop structure and fungicide program and tillage for wheat. Without any additional cost, the wheat yield became much healthier (fewer toxins and leaf diseases), and a $4-5 \%$ yield increase could be achieved on about 2000 ha of wheat.

Grain production is expected to expand well below the growth rates of the last decades. Yield increase will not be sufficient to achieve global food security. The potential increase in maize, wheat, rice and soybean yields will be less than $10 \%$ in the next five years, resulting at the most in 220 million $\mathrm{mt}$ of extra yields. Comparing the projected extra yields of grains for the next five years, with the annual losses and waste of about $980 \mathrm{mt}$ excluding pre-harvest losses, it becomes apparent that reducing food loss and waste can help to enhance food security more efficiently then yield increase can. The slowdown in global annual yield growth is the main challenge facing global food security. Maize, rice, wheat, and soybean together produce about $64 \%$ of global agricultural calories (of this maize, rice, and wheat $57 \%$ ) and decreasing yield gains in these crops will have serious implications for the global grain supply chain [85]. Grain yields are affected by both biophysical and socioeconomic factors worldwide leading to increased yield variability in the future. Climate-change-related heat stress, scarcity of water for irrigation, depletion of soil fertility and salinization, soil erosion, pest and disease build-up and a lack of capital will have a greater impact on yield development than the genetic improvement of grain cultivars. In Europe, yields are affected by climate change in several EU member states.

Moreover, agricultural subsidies are tied to the reduction of environmental burden and agricultural inputs, leading to yield stagnation. For this reason, the reduction of loss and waste is the most important factor in achieving food security with a much larger impact on the grain supply for food and feed than higher yielding crops. Breeding for yield stability and resistance combined with advanced pest management strategies, improved agronomy and storage could reduce grain losses and waste by at least $50 \%$ and meet the demand for grain for an additional 3-4 billion people globally.

At least two third of the field losses namely $700 \mathrm{mt}$ are related to biotic stresses. Plant breeding is supposed to be responsible for about a third of this amount $(233 \mathrm{mt})$. However, it is impossible to breed for resistance against 200 diseases of a crop. Plants are generally treated for the $4-5$ most important diseases by farms; therefore, resistance and pesticide treatments should be combined. For the rest of the losses (roughly $500 \mathrm{mt}$ ), both correct pest management and agronomy measures are needed.

\section{Conclusions}

Increasing global population and decreasing natural resources associated with growing FL and FW have resulted in an unprecedented challenge. Transforming a wasteful food supply chain into a sustainable food solution needs collaboration between researchers and multi-stakeholders in the food supply system. This conclusion is in line with several studies $[16,19,29,30]$. We have to understand the key drivers causing FL and FW across the food supply chain and find solutions for reducing these losses and waste. The field of FL and FW lacks appropriate metrics used to calculate benefits and trade-offs. Stakeholders in the food supply chain have incomplete data about how much FL and FW is 
generated or the total costs of its management to make these comparisons. This outcome is supported by other reviews as well $[9,10]$.

The results show that cumulating harvesting, storage and toxins losses along the grain supply chain may reach up to $690 \mathrm{mt}$ annually, excluding the $1.051 \mathrm{mt}$ of pre-harvest losses. Besides pre-harvest losses, the highest rates of loss are associated with storage and mycotoxin contamination. Breeding, cultivation, plant protection, harvesting, storage, handling, and transportation practices play key roles in the efficiency of the grain supply chain. Grain loss in the future depends on technology and the workforce. In addition, consumer waste is based on consumer behavior and food waste management.

At present, a significant increase in global grain production only by the introduction of new higher yielding varieties is not possible. What are the limitations? Interestingly, it is not the shortage of inputs, such as fertilizers, chemicals, etc., that plays an important role in restricting increases in the yield and quality of cereals. The shortage of water is an acute problem on one side, with research on the other. Cooperation among those involved in breeding to increase yield, to improve resistance to biotic and abiotic stresses and agronomy is poor, as these fields largely work separately from each other and their positive innovative effects are not utilized to the extent that could be possible. Special problems occur in the field of toxigenic fungi. However, in recent decades screening and genetic methods have been used to increase resistance levels. The problems at the harvest and storage stages represent a very strong limitation, leading to losses of several hundred million tons of grains. In many regions of the globe poor infrastructure is also a strong limiting factor, inhibiting the application of modern logistics, installations, machines etc. The lack of special education is a very strong limiting factor causing very high losses before and after harvest. This conclusion is consistent with previous studies [24,29,30].

How do we prevent a significantly higher amount of loss? Plant breeding must consider closely global needs and local activity in order to reach the highest adaptation of the cultivars bred, because cultivars have to resist to different challenges of both biotic and abiotic stresses. We face a special problem in stresses such as drought, heat, toxic fungi, and leaf spots that inherit mostly polygenic traits and so breeding is more complicated than in the case of monogenic traits. We should be aware that each crop has about 200 pathogens, of which 4-5 can be treated in a breeding program, indicating the need for chemical control when a new disease appears in the field. A much higher resistance is needed against toxigenic fungi; therefore, crop production must be much better adapted to local conditions. The finding is in line with previous literature [28].

About 20 years ago, we spoke about integrated crop management to reduce pesticide use. Today, Intelligent Field Crop Management is spreading. It is necessary to evaluate for each field the optimal mix of variety, agronomy, pesticide application, irrigation, and previous crop selection to ensure maximum possible yield by using necessary pesticides. Harvest and storage management should be modernized. The current best available technologies reduce loss during storage by $2-3 \%$ without quality reduction. This outcome is in accordance with the studies published by $[8,19,34,35]$.

In order to prevent grain loss farmers should be educated globally; the extension service in the US can be an example to follow. Demonstration farms can show farmers how intelligent field crop management works in practice. The vocational school system should also be adopted to meet these new challenges. The production method used in developed countries should also be applied in the developing world. Developed countries also face new problems, including the ecological crisis, therefore new solutions are needed through global action and scientific innovation. Local agricultural development programs can solve local problems, but international organizations must support and harmonize the global and local network.

Agriculture is a capital and knowledge-intensive sector, so huge agricultural investments must be made in the next few decades to meet the challenges of the growing yield demand for grain, and at the same time to maintain a sustainable environment. Therefore, reducing global losses and waste along the grain supply chain is the most effective way to increase global food and nutrition security. This needs long term thinking and not short run profit at a maximum level. For this reason, national 
and global regulations, investment and scientific policies are preconditions to provide reasonable and sustainable solutions for the future; however, the largest task is to change the way we think.

Author Contributions: Á.M. and J.P. conceived and designed the experiments. Á.M. and J.P. contributed analysis tools. Á.M., J.O. and J.P. wrote the paper. All authors have read and agreed to the published version of the manuscript.

Funding: This research received no external funding.

Acknowledgments: The authors are indebted to the projects MycoRed FP7 (KBBE-2007-2-5-05 (2009-2012), GOP 1.1.1.-11-2012-0159 EU-HU (2012-2013), GINOP-2.2.1-15-2016-00021 (2016-2020) and TUDFO/5157/2019/ITM for financial support. This research was supported by the ÚNKP-19-4-DE-147 New National Excellence Program of the Ministry for Innovation and Technology and by the János Bolyai Research Scholarship of the Hungarian Academy of Sciences.

Conflicts of Interest: Authors declare that there is no conflict of interest.

\section{References}

1. Malthus, T.R. An Essay on the Principle of Population as it Affects the Future Improvement of Society, with Remarks on the Speculations of Mr. Goodwin, M. Condorcet and Other Writers, 1st ed.; J. Johnson in St Paul's Church-yard: London, UK, 1798.

2. Paddock, W. Famine-975! America's Decision: Who Will Survive? Little, Brown and Company: Boston, MA, USA, 1967.

3. Ehrlich, P.R.; Ehrlich, A.H. The Population Bomb Revisited. Electron. J. Sustain. Dev. 2009, 1, 63-71.

4. Romer, P.M. Two strategies for economic development: Using ideas and producing ideas. World Bank Econ. Rev. 1992, 6, 63-91. [CrossRef]

5. Diamond, J. Collapse: How Societies Choose to Fail or Succeed; Viking Penguin/Allen Lane: New York, NY, USA; London, UK, 2005.

6. United Nations. World Population Prospects: The 2017 Revision; United Nations, Department of Economic and Social Affairs, Population Division: New York, NY, USA, 2017. Available online: https://www.un.org/ development/desa/publications/world-population-prospects-the-2017-revision.html (accessed on 15 January 2020).

7. Roser, M.; Ortiz-Ospina, E. World Population Growth, Our World in Data. 2017. Available online: https://ourworldindata.org/world-population-growth (accessed on 15 January 2020).

8. Food and Agriculture Organization of the United Nations. Global Initiative on Food Loss and Waste Reduction; Food and Agriculture Organization of the United Nations: Rome, Italy, 2015; pp. 1-8. Available online: http://www.fao.org/3/a-i4068e.pdf (accessed on 20 February 2020).

9. Chaboud, G.; Daviron, B. Food losses and waste: Navigating the inconsistencies. Glob. Food Secur. 2017, 12, 1-7. [CrossRef]

10. Chaboud, G. Assessing food losses and waste with a methodological framework: Insights from a case study. Resources. Conserv. Recycl. 2017, 125, 188-197. [CrossRef]

11. Gustavsson, J.; Cederberg, C.; Sonesson, U.; van Otterdijk, R.; Meybeck, A. Global Food Losses and Food Waste: Extent Causes and Prevention; Food and Agriculture Organization of the United Nations (FAO): Rome, Italy, 2011; pp. 1-37. Available online: http://www.fao.org/3/mb060e/mb060e.pdf (accessed on 20 February 2020).

12. United Nations Transforming Our World. The 2030 Agenda for Sustainable Development; A/70/L.1; United Nations, General Assembly: New York, NY, USA, 2015; pp. 1-35. Available online: https://www.un.org/ga/ search/view_doc.asp?symbol=A/RES/70/1\&Lang=E (accessed on 20 February 2020).

13. Searchinger, T.; Waite, R.; Hanson, C.; Ranganathan, J.; Dumas, P.; Matthews, E. Creating a Sustainable Food Future: A Menu of Solutions to Feed Nearly 10 Billion People by 2050; World Resources Institute: Washington, DC, USA, 2019; pp. 1-556. Available online: https://reliefweb.int/report/world/world-resources-report-creatingsustainable-food-future-menu-solutions-feed-nearly-10 (accessed on 20 February 2020).

14. BCG Food and Agriculture Organization of the United Nations. Global Food Losses and Food Waste; BCG FLOW Model. 2015 Findings, in 2015 Dollars; FAOSTAT Database: Boston, MA, USA, 2018. Available online: https:/www.consulting.us/news/860/global-food-wastage-could-hit-21-billion-tons-by-2030-instaggering-crisis (accessed on 20 February 2020). 
15. Hegnsholt, E.; Unnikrishnan, S.; Pollmann-Larsen, M.; Askelsdottir, B.; Gerard, M. Tackling the 1.6-Billion-Ton Food Loss and Waste Crisis; The Boston Consulting Group in Collaboration with Food Nation and State of Green: Boston, MA, USA, 2018. Available online: https://www.consulting.us/news/860/global-food-wastagecould-hit-21-billion-tons-by-2030-in-staggering-crisis (accessed on 20 February 2020).

16. CEC Technical Report. Quantifying Food Loss and Waste and its Impacts; Commission for Environmental Cooperation: Montreal, QC, Canada, 2019; pp. 1-129. Available online: http://www3.cec.org/islandora/en/ item/11813-technical-report-quantifying-food-loss-and-waste-and-its-impacts (accessed on 20 February 2020).

17. Popp, J.; Kiss, A.; Oláh, J.; Máté, D.; Bai, A.; Lakner, Z. Network analysis for the improvement of food safety in the international honey trade. Amfiteatr. Econ. 2018, 20, 84-98. [CrossRef]

18. Popp, J.; Olah, J.; Fari, M.; Balogh, P.; Lakner, Z. The GM-regulation game-The case of Hungary. Int. Food Agribus. Manag. Rev. 2018, 21, 945-968. [CrossRef]

19. Gao, D. Food Loss and Waste; Building on Existing Federal Efforts Could Help to Achieve National Reduction Goal; GAO-19-391 United States Government Accountability Office: Washington, DC, USA, 2019; pp. 1-47. Available online: https://www.gao.gov/assets/gao-19-391.pdf (accessed on 20 February 2020).

20. European Commission. Frequently Asked Questions: Reducing Food Waste in the EU; European Commisison: Brussels, Belgium, 2019; pp. 1-5. Available online: https://ec.europa.eu/food/sites/food/files/safety/docs/fs_ eu-actions_fwm_qa-fight-food-waste.pdf (accessed on 20 February 2020).

21. Schweitzer, J.; Gionfra, S.; Pantzar, M.; Mottershead, D.; Watkins, E.; Petsinaris, F.; Ten Brink, P.; Ptak, E.; Lacey, C.; Janssens, C. Unwrapped: How Throwaway Plastic Is Failing to Solve Europe's Food Waste Problem (and What We Need to Do Instead); Institute for European Environmental Policy: Brussels, Belgium, 2018; pp. 1-28. Available online: http://www.foeeurope.org/sites/default/files/materials_and_waste/2018/unwrapped_-_ throwaway_plastic_failing_to_solve_europes_food_waste_problem.pdf (accessed on 20 February 2020).

22. European Commsission. Market Study on Date Marking and Other Information Provided on Food Labels and Food Waste Prevention, Final Report, Written by ICF in Association with Anthesis, Brook Lyndhurst, and WRAP January 2018; Directorate-General for Health and Food Safety: Brussels, Belgium, 2018; pp. 1-100. Available online: https://ec.europa.eu/food/sites/food/files/safety/docs/fw_lib_srp_date-marking.pdf (accessed on 14 March 2020).

23. Leib, E.B.; Gunders, D.; Ferro, J.; Nielsen, A.; Nosek, G.; Qu, J. The Dating Game: How Confusing Food Date Labels Lead to Food Waste in America; National Resources Defense Council: New York, NY, USA, 2013; pp. 1-61. Available online: https://cpb-us-e1.wpmucdn.com/blogs.uoregon.edu/dist/a/3266/files/2013/10/dating-gamereport-1m6z9a3.pdf (accessed on 20 February 2020).

24. Fanelli, R.M. Using causal maps to analyse the major root causes of household food waste: Results of a survey among people from Central and Southern Italy. Sustainability 2019, 11, 1183. [CrossRef]

25. Diaz-Ruiz, R.; Costa-Font, M.; López-i-Gelats, F.; Gil, J.M. Food waste prevention along the food supply chain: A multi-actor approach to identify effective solutions. Resour. Conserv. Recycl. 2019, 149, 249-260. [CrossRef]

26. Conrad, Z.; Niles, M.T.; Neher, D.A.; Roy, E.D.; Tichenor, N.E.; Jahns, L. Relationship between food waste, diet quality, and environmental sustainability. PLoS ONE 2018, 13, e0195405. [CrossRef]

27. Fanelli, R.M. The interactions between the structure of the food supply and the impact of livestock production on the environment. A multivariate analysis for understanding the differences and the analogies across European Union countries. Qual. Acc. Success 2018, 19, 131-139.

28. Fanelli, R.M. The (un) sustainability of the land use practices and agricultural production in EU countries. Int. J. Environ. Stud. 2019, 76, 273-294. [CrossRef]

29. Swedish International Agricultural Network Initiative. Reducing Food Waste Across Global Food Chains; Policy Brief: Stockholm, Sweden, 2017; pp. 1-4. Available online: https://www.siani.se/wp-content/uploads/2017/ 10/policy_brief.pdf (accessed on 20 February 2020).

30. Ishangulyyev, R.; Kim, S.; Lee, S.H. Understanding Food Loss and Waste-Why Are We Losing and Wasting Food? Foods 2019, 8, 297. [CrossRef] [PubMed]

31. Nagpal, M.; Kumar, A. Grain losses in India and government policies. Qual. Assur. Saf. Crop. Foods 2012, 4, 143. [CrossRef] 
32. National Academy of Agricultural Sciences. National Academy of Agricultural Sciences Saving the Harvest: Reducing the Food Loss and Waste; Policy Brief No.5; National Academy of Agricultural Sciences: New Delhi, India, 2019; pp. 1-10. Available online: http://naasindia.org/documents/Saving\%20the\%20Harvest.pdf (accessed on 20 February 2020).

33. Abass, A.B.; Ndunguru, G.; Mamiro, P.; Alenkhe, B.; Mlingi, N.; Bekunda, M. Post-harvest food losses in a maize-based farming system of semi-arid savannah area of Tanzania. J. Stored Prod. Res. 2014, 57, 49-57. [CrossRef]

34. Manandhar, A.; Milindi, P.; Shah, A. An overview of the post-harvest grain storage practices of smallholder farmers in developing countries. Agriculture 2018, 8, 57. [CrossRef]

35. Kumar, D.; Kalita, P. Reducing postharvest losses during storage of grain crops to strengthen food security in developing countries. Foods 2017, 6, 8. [CrossRef]

36. Khader, B.F.Y.; Yigezu, Y.A.; Duwayri, M.A.; Nianed, A.A.; Shideed, K. Where in the value chain are we losing the most food? The case of wheat in Jordan. Food Secur. 2019, 11, 1009-1027. [CrossRef]

37. Borlaug, N. Increasing and Stabilizing Food Production. In Plant Breeding II; Frey, K.J., Ed.; Iowa State University Press: Ames, IA, USA, 1979; pp. 467-492.

38. International Grains Council. International Grains Council Grain Market Report Five-Year Baseline Projections of Supply and Demand for Wheat, Maize (Corn), Rice and Soyabeans to 2023/24 March 2019; International Grains Council: London, UK, 2019; pp. 1-4. Available online: http://www.igc.int/en/downloads/gmrsummary/ gmrsumme.pdf (accessed on 15 January 2020).

39. Popp, J.; Pető, K.; Nagy, P. Pesticide productivity and food security. A review. Agron. Sustain. Dev. 2013, 33, 243-255. [CrossRef]

40. Oerke, E.-C.; Dehne, H.-W. Safeguarding production-losses in major crops and the role of crop protection. Crop Prot. 2004, 23, 275-285. [CrossRef]

41. Oerke, E. Crop losses to pests. J. Agric. Sci. 2006, 144, 31-43. [CrossRef]

42. European Commission. European Commission Roadmap to a Resource Efficient Europe COM(2011) 571; European Commission: Brussels, Belgium, 2011. Available online: https://www.eea.europa.eu/policy-documents/com2011-571-roadmap-to (accessed on 10 January 2020).

43. European Commission. European Parliament EP Parliament Calls for Urgent Measures to Halve Food Wastage in the EU-Plenary Sessions; European Commission: Brussels, Belgium, 2020. Available online: https://www.europarl.europa.eu/news/en/press-room/20120118IPR35648/parliament-callsfor-urgent-measures-to-halve-food-wastage-in-the-eu (accessed on 10 January 2020).

44. International Water Management Institute. Water for Food, Water for Life: A Comprehensive Assessment of Water Management in Agriculture; International Water Management Institute: London, UK, 2007; pp. 1-645. Available online: http://www.iwmi.cgiar.org/assessment/Publications/books.htm (accessed on 15 January 2020).

45. Leslie, J.; Logrieco, A. Mycotoxin Reduction in Grain Chains; Wiley Blackwell: Hoboken, NJ, USA, 2014.

46. Logrieco, A.; Visconti, A. An Introduction to the MycoRed Project. In Mycotoxin Reduction in Grain Chains; Leslie, J., Logrieco, A., Eds.; Wiley Blackwell: Hoboken, NJ, USA, 2014; pp. 1-7.

47. Godfrey, H.; Beddington, J.; Crute, I.; Haddad, L.; Lawrence, D.; Muir, J.; Pretty, J.; Robinson, S.; Thomas, S.; Toulmin, C. The Challenge of Feeding 9 Billion People. Science 2010, 12, 812-818. [CrossRef] [PubMed]

48. Kummu, M.; De Moel, H.; Porkka, M.; Siebert, S.; Varis, O.; Ward, P.J. Lost food, wasted resources: Global food supply chain losses and their impacts on freshwater, cropland, and fertiliser use. Sci. Total Environ. 2012, 438, 477-489. [CrossRef] [PubMed]

49. Cramer, H.-H. Plant protection and world crop production. Bayer Pflanzenschutz-Nachr. 1967, $20,1-524$.

50. Schumann, G.; D’Arcy, C. Essential Plant Pathology; APS Press: Sao Paulo, MN, USA, 2006.

51. Ubrizsy, G. Növényvédelmi Enciklopédia I. Általános Növényvédelem-Szántóföldi Növényvédelem-Encyclopedia of Plant Protection, Volume 1. General Plant Protection-Protection of Field Crops; Mezőgazdasági Kiadó-Agr Publ House: Budapest, Hungary, 1968.

52. Bradley, B.D.; Christodoulou, M.; Caspari, C.; Di Luc, P. Integrated Crop Managements Systems in the EU. Amended Final Report for European Commission DG Environment; Agra CEAS Consulting: Ashford, UK, 2002; pp. 1-141. Available online: https://ec.europa.eu/environment/agriculture/pdf/icm_finalreport.pdf (accessed on 14 March 2020). 
53. Bajwa, W.I.; Kogan, M. Compendium of IPM Definitions (CID)—What is IPM and how is it defined in the Worldwide Literature. IPPC Publ. 2002, 998, 1-14.

54. Ehler, L. Perspective Integrated pest management (IPM): Definition, historical development and implementation, and the other IPM Pest Management. Science 2006, 62, 787-789.

55. Kumar, D.; Shivay, Y. Modern Concepts in Agriculture, Integrated Crop Management; Indian Agricultural Research Institute: New Delhi, India, 2008; pp. 1-30. Available online: https://www.researchgate.net/publication/ 237569012 (accessed on 15 January 2020).

56. Vanlauwe, B.; Bationo, A.; Chianu, J.; Giller, K.E.; Merckx, R.; Mokwunye, U.; Ohiokpehai, O.; Pypers, P.; Tabo, R.; Shepherd, K.D. Integrated soil fertility management: Operational definition and consequences for implementation and dissemination. Outlook Agric. 2010, 39, 17-24. [CrossRef]

57. Bottrell, D. Ntegrated Pest Management. Record Number: 19810584265; United States Government Printing Office: Washington, DC, USA, 1979; pp. 1-120.

58. Barzman, M.; Bàrberi, P.; Birch, A.N.E.; Boonekamp, P.; Dachbrodt-Saaydeh, S.; Graf, B.; Hommel, B.; Jensen, J.E.; Kiss, J.; Kudsk, P. Eight principles of integrated pest management. Agron. Sustain. Dev. 2015, 35, 1199-1215. [CrossRef]

59. Lehoczki-Krsjak, S.; Varga, M.; Mesterházy, Á. Distribution of prothioconazole and tebuconazole between wheat ears and flag leaves following fungicide spraying with different nozzle types at flowering. Pest Manag. Sci. 2015, 71, 105-113. [CrossRef]

60. Mesterhazy, A.; Bartok, T. Control of Fusarium head blight of wheat by fungicides and its effect on the toxin contamination of the grains. Pflanzenschutz-Nachr. Bayer 1996, 49, 181-198.

61. Mesterházy, Á. Breeding Wheat for Fusarium Head Blight Resistance in Europe. In Fusarium Head Blight of Wheat and Barley; Bushnell, W., Ed.; APS Press: Sao Paulo, MN, USA, 2003; pp. 211-240.

62. Mesterházy, Á. Control of Fusarium Head Blight of Wheat by Fungicides. In Fusarium Head Blight of Wheat and Barley; Leonard, K., Bushnell, W., Eds.; APS Press: Sao Paulo, MN, USA, 2003; pp. 363-380.

63. Mesterházy, Á.; Tóth, B.; Varga, M.; Bartók, T.; Szabó-Hevér, Á.; Farády, L.; Lehoczki-Krsjak, S. Role of fungicides, application of nozzle types, and the resistance level of wheat varieties in the control of Fusarium head blight and deoxynivalenol. Toxins 2011, 3, 1453-1483. [CrossRef] [PubMed]

64. Mesterházy, Á.; Varga, M.; György, A.; Lehoczki-Krsjak, S.; Tóth, B. The role of adapted and non-adapted resistance sources in breeding resistance of winter wheat to Fusarium head blight and deoxynivalenol contamination. World Mycotoxin J. 2018, 11, 539-557. [CrossRef]

65. Mesterházy, Á.; Varga, M.; Tóth, B.; Kotai, C.; Bartók, T.; Véha, A.; Ács, K.; Vágvölgyi, C.; Lehoczki-Krsjak, S. Reduction of deoxynivalenol (DON) contamination by improved fungicide use in wheat. Part 1 . Dependence on epidemic severity and resistance level in small plot tests with artificial inoculation. Eur. J. Plant Pathol. 2018, 151, 39-55. [CrossRef]

66. Lamichhane, J.R.; Arseniuk, E.; Boonekamp, P.; Czembor, J.; Decroocq, V.; Enjalbert, J.; Finckh, M.R.; Korbin, M.; Koppel, M.; Kudsk, P. Advocating a need for suitable breeding approaches to boost integrated pest management: A European perspective. Pest Manag. Sci. 2018, 74, 1219-1227. [CrossRef] [PubMed]

67. Jayas, D.S. Storing grains for food security and sustainability. Agric. Res. 2012, 1, 21-24. [CrossRef]

68. Philip, T.; Throne, J. Biorational approaches for managing stored-product insect. Annu. Rev. Entomol. 2010, 55, 375-397. [CrossRef]

69. World Health Organisation. Aflatoxins, REF. No.: WHO/NHM/FOS/RAM/18; World Health Organisation, Department of Food Safety and Zoonoses: Geneva, Switzerland, 2018; pp. 1-5. Available online: https: //www.who.int/foodsafety/FSDigest_Aflatoxins_EN.pdf (accessed on 20 February 2020).

70. Kumar, R.; Mishra, A.K.; Dubey, N.; Tripathi, Y. Evaluation of Chenopodium ambrosioides oil as a potential source of antifungal, antiaflatoxigenic and antioxidant activity. Int. J. Food Microbiol. 2007, 115, 159-164. [CrossRef]

71. Dowling, T. Fumonisin and its toxic effects. Cereal Foods World 1997, 42, 13-15.

72. McMullen, M.; Jones, R.; Gallenberg, D. Scab of wheat and barley: A re-emerging disease of devastating impact. Plant Dis. 1997, 81, 1340-1348. [CrossRef]

73. Szabo, B.; Toth, B.; Toth Toldine, E.; Varga, M.; Kovacs, N.; Varga, J.; Kocsube, S.; Palagyi, A.; Bagi, F.; Budakov, D. A New Concept to Secure Food Safety Standards against Fusarium Species and Aspergillus Flavus and Their Toxins in Maize. Toxins 2018, 10, 372. [CrossRef] 
74. Alexander, P.; Brown, C.; Arneth, A.; Finnigan, J.; Moran, D.; Rounsevell, M.D. Losses, inefficiencies and waste in the global food system. Agric. Syst. 2017, 153, 190-200. [CrossRef]

75. Caldeira, C.; Caldeira, C.; Sara, C.; Serenella, S. Food Waste Accounting: Methodologies, Challenges and Opportunities. JRC109202; 9279778889; Publications Office of the European Union: Brussels, Belgium, 2017.

76. Food and Agriculture Organization of the United Nations. Food Loss and Waste Facts; Food and Agriculture Organisation of the United Nations: Rome, Italy, 2019. Available online: http://www.fao.org/3/a-i4807e.pdf (accessed on 10 January 2020).

77. Mesterházy, Á. Breeding for Resistance against FHB in Wheat. In Mycotoxin Reduction in Grain Chains: A Practical Guide; Logrieco, A.F., Visconti, A., Eds.; Blackwell-Wiley: Hoboken, NJ, USA, 2014; pp. 189-208.

78. Mesterházy, A.; Lehoczki-Krsjak, S.; Varga, M.; Szabó-Hevér, Á.; Tóth, B.; Lemmens, M. Breeding for FHB Resistance via Fusarium Damaged Kernels and Deoxynivalenol Accumulation as Well as Inoculation Methods in Winter Wheat. Agric. Sci. 2015, 6, 970-1002.

79. Jans, D.; Pedrosa, K.; Schatzmayr, D.; Bertin, G.; Grenier, B. Mycotoxin Reduction in Animal Diets. In Mycotoxin Reduction in Grain Chains; Logrieco, A.F., Visconti, A., Eds.; Wiley: Oxford, UK, 2014; pp. 101-110.

80. Edwards, S.G.; Jennings, P. Impact of agronomic factors on Fusarium mycotoxins in harvested wheat. Food Addit. Contam. Part A 2018, 35, 2443-2454. [CrossRef] [PubMed]

81. Cowger, C.; Weisz, R.; Arellano, C.; Murphy, P. Profitability of integrated management of Fusarium head blight in North Carolina winter wheat. Phytopathology 2016, 106, 814-823. [CrossRef] [PubMed]

82. Zorn, A.; Musa, T.; Lips, M. Costs of preventive agronomic measures to reduce deoxynivalenol in wheat. J. Agric. Sci. 2017, 155, 1033-1044. [CrossRef]

83. Baranski, M.R. Wide adaptation of Green Revolution wheat: International roots and the Indian context of a new plant breeding ideal, 1960-1970. Stud. Hist. Philos. Sci. Part C 2015, 50, 41-50. [CrossRef]

84. Wang, J.; Vanga, S.K.; Saxena, R.; Orsat, V.; Raghavan, V. Effect of climate change on the yield of cereal crops: A review. Climate 2018, 6, 41. [CrossRef]

85. Tilman, D.; Balzer, C.; Hill, J.; Befort, B.L. Global food demand and the sustainable intensification of agriculture. Proc. Natl. Acad. Sci. USA 2011, 108, 20260-20264. [CrossRef]

(C) 2020 by the authors. Licensee MDPI, Basel, Switzerland. This article is an open access article distributed under the terms and conditions of the Creative Commons Attribution (CC BY) license (http://creativecommons.org/licenses/by/4.0/). 

MDPI

St. Alban-Anlage 66

4052 Basel

Switzerland

Tel. +41616837734

Fax +4161302 8918

www.mdpi.com

Sustainability Editorial Office

E-mail: sustainability@mdpi.com www.mdpi.com/journal/sustainability

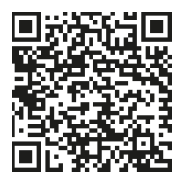



MDPI

St. Alban-Anlage 66

4052 Basel

Switzerland

Tel: +41 616837734

Fax: +41 613028918 